\title{
Flood of April 2-4, 2005, Delaware River Main Stem from Port Jervis, New York, to Cinnaminson, New Jersey
}

By Timothy J. Reed and Amy R. Protz

Prepared in cooperation with the

Federal Emergency Management Agency

Scientific Investigations Report 2007-5067 


\title{
U.S. Department of the Interior DIRK KEMPTHORNE, Secretary
}

\author{
U.S. Geological Survey \\ Mark D. Myers, Director
}

U.S. Geological Survey, Reston, Virginia 2007

For product and ordering information:

World Wide Web: http://www.usgs.gov/pubprod

Telephone: 1-888-ASK-USGS

For more information on the USGS — the Federal source for science about the Earth,

its natural and living resources, natural hazards, and the environment:

World Wide Web: http://www.usgs.gov

Telephone: 1-888-ASK-USGS

Suggested citation:

Reed, T.J., and Protz, A.R., 2007, Flood of April 2-4, 2005, Delaware River main stem from Port Jervis, New York, to Cinnaminson, New Jersey: U.S. Geological Survey Scientific Investigations Report 2007-5067, 157 p.

Any use of trade, product, or firm names is for descriptive purposes only and does not imply endorsement by the U.S. Government. Use of company names is for identification purposes only and does not imply responsibility.

Although this report is in the public domain, permission must be secured from the individual copyright owners to reproduce any copyrighted material contained within this report. 


\section{Contents}

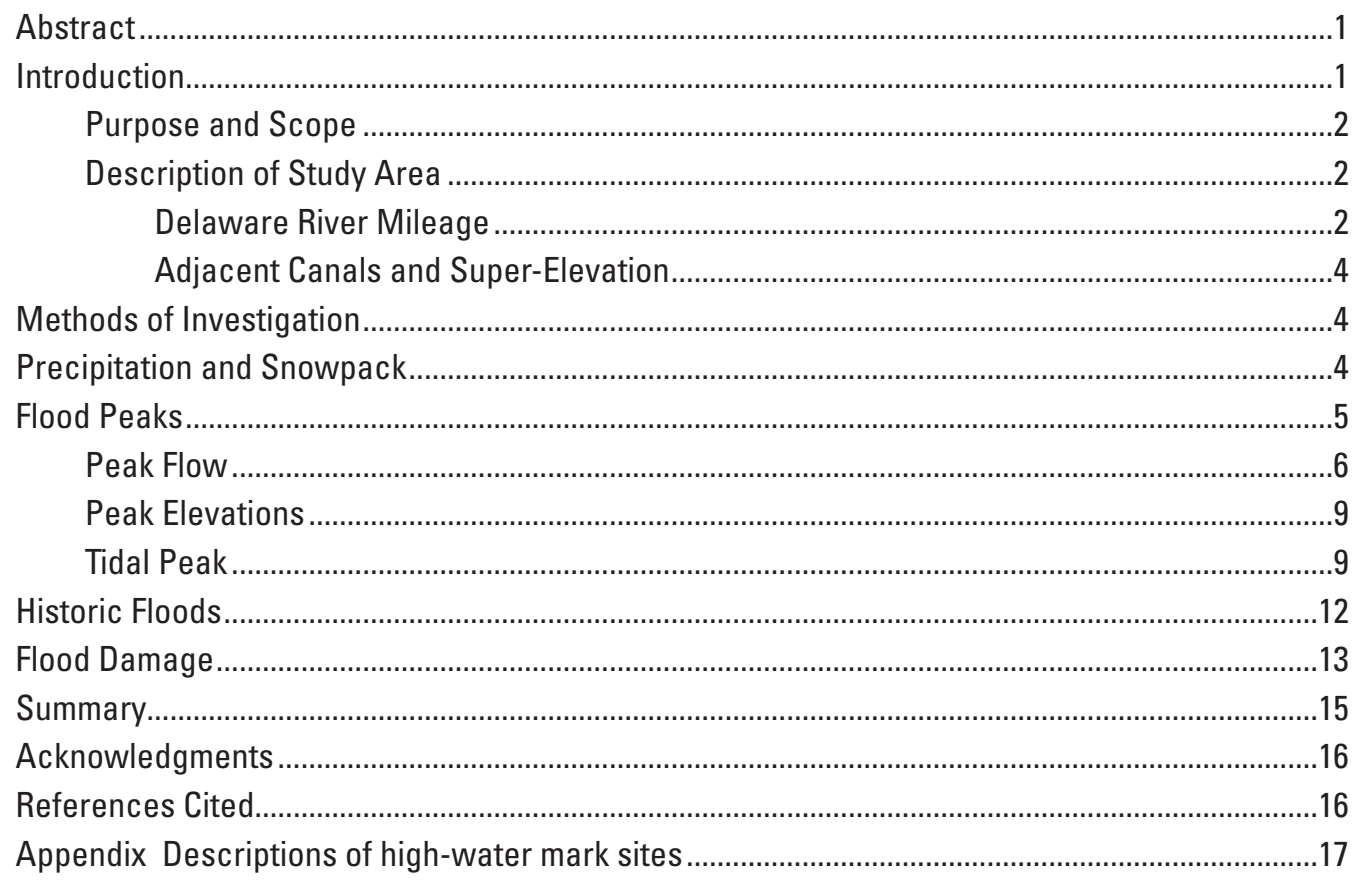

\section{Figures}

1-3. Maps Showing-

1. Locations of study sites and selected U.S. Geological Survey streamflow-gaging stations in the Delaware River Basin chosen for the April 2-4, 2005 flood study .....3

2. Water equivalent of snowpack prior to March rainfall event, and after March 2829 and April 2-4, 2005, rainfall events

3. Total combined rainfall during March 28 to April 4, 2005, in and around the Delaware River Valley.

4-7. Graphs Showing-

4. Hydrographs showing streamflow at six continuous-record streamflow-gaging stations on the Delaware River, March 20 to April 15, 2005

5. Delaware River peak elevations at U.S. Geological Survey (USGS) streamflowgaging stations and high-water mark sites, April 2-4, 2005.

6. Hydrographs showing tide cycles on the Delaware River at Burlington, New Jersey, and stream elevations on the Delaware River at Trenton, New Jersey, March 28 to April 5, 2005

7. Annual peak discharges for the Delaware River at (a) Port Jervis, New York, and (b) Trenton, New Jersey, for the respective periods of record. 


\section{Tables}

1. Characteristics of survey monuments on record with the National Geodetic Survey (NGS) that were incorporated into the Differential Global Positioning System (DGPS) used for determining peak flood elevations of the April 2-4, 2005, Delaware River flood

2. Results of accuracy check for selected U.S. Geological Survey (USGS) temporary benchmark (reference mark) elevations of April 2-4, 2005, flood on the Delaware River, using two independent occupations of the Differential Global Positioning System (DGPS)

3. Total rainfall at selected sites within the Delaware River Basin, April 2 to 4, 2005, and March 28 to April 4, 2005

4. Summary of flood peaks at U.S. Geological Survey streamflow-gaging stations on the Delaware River and selected tributaries, April 2-4, 2005.

5. Historic peak discharges at U.S. Geological Survey streamflow-gaging stations on the

Delaware River between Port Jervis, New York, and Trenton, New Jersey... 
Conversion Factors and Datums

\begin{tabular}{|c|c|c|}
\hline Multiply & By & To obtain \\
\hline \multicolumn{3}{|c|}{ Length } \\
\hline inch (in.) & 2.54 & centimeter $(\mathrm{cm})$ \\
\hline inch (in.) & 25.4 & millimeter (mm) \\
\hline foot $(\mathrm{ft})$ & 0.3048 & meter $(\mathrm{m})$ \\
\hline mile (mi) & 1.609 & kilometer $(\mathrm{km})$ \\
\hline \multicolumn{3}{|c|}{ Area } \\
\hline square mile $\left(\mathrm{mi}^{2}\right)$ & 259.0 & hectare (ha) \\
\hline square mile $\left(\mathrm{mi}^{2}\right)$ & 2.590 & square kilometer $\left(\mathrm{km}^{2}\right)$ \\
\hline \multicolumn{3}{|c|}{ Volume } \\
\hline cubic foot $\left(\mathrm{ft}^{3}\right)$ & 28.32 & cubic decimeter $\left(\mathrm{dm}^{3}\right)$ \\
\hline cubic foot $\left(\mathrm{ft}^{3}\right)$ & 0.02832 & cubic meter $\left(\mathrm{m}^{3}\right)$ \\
\hline \multicolumn{3}{|c|}{ Flow rate } \\
\hline foot per second $(\mathrm{ft} / \mathrm{s})$ & 0.3048 & meter per second $(\mathrm{m} / \mathrm{s})$ \\
\hline cubic foot per second $\left(\mathrm{ft}^{3} / \mathrm{s}\right)$ & 0.02832 & cubic meter per second $\left(\mathrm{m}^{3} / \mathrm{s}\right)$ \\
\hline $\begin{array}{l}\text { cubic foot per second per square mile } \\
{\left[\left(\mathrm{ft}^{3} / \mathrm{s}\right) / \mathrm{mi}^{2}\right]}\end{array}$ & 0.01093 & $\begin{array}{l}\text { cubic meter per second per square } \\
\text { kilometer }\left[\left(\mathrm{m}^{3} / \mathrm{s}\right) / \mathrm{km}^{2}\right]\end{array}$ \\
\hline million gallons per day (Mgal/d) & 0.04381 & cubic meter per second $\left(\mathrm{m}^{3} / \mathrm{s}\right)$ \\
\hline
\end{tabular}

Vertical coordinate information is referenced to the North American Vertical Datum of 1988

(NAVD 88), unless otherwise noted.

Horizontal coordinate information is referenced to the North American Datum of 1983 (NAD 83). 



\title{
Flood of April 2-4, 2005, Delaware River Main Stem from Port Jervis, New York, to Cinnaminson, New Jersey
}

\author{
By Timothy J. Reed and Amy R. Protz
}

\section{Abstract}

Several conditions, including saturated soils, snowmelt, and heavy rains, caused flooding on the Delaware River on April 2-4, 2005. The event occurred 50 years after the historic 1955 Delaware River flood, and only six months after a smaller but equally notable flood on September 18-19, 2004. The Delaware River flooded for a third time in 22 months in June, 2006. The peak flows and elevations of the 2005 flood were similar to those on June 28-29, 2006. The following report describes the April 2-4, 2005, Delaware River flood, and includes the associated precipitation amounts, peak flows and elevations, and flood frequencies. A comparison of historic Delaware River floods also is presented. The appendix of the report contains detailed information for 156 high-water mark elevations obtained on the main stem of the Delaware River from Port Jervis, New York, to Cinnaminson, New Jersey, for the April 2-4, 2005 flood.

The April 2005 event originated with frequent precipitation from December 2004 to March 2005 which saturated the soils in the upper Delaware River Basin. The cold winter froze some of the soils and left a snowpack at higher elevations equivalent to as much as 10 inches of water in some areas. Temperatures rose above freezing, and heavy rains averaging 1 to 3 inches on March 27, 2005, melted some of the snow, causing the Delaware River to rise; however, peak elevations were still 2 to 7 feet below flood stage. Another round of rainfall averaging 2-5 inches in the basin on April 2, 2005, melted the remaining snowpack. The combination of snowmelt and runoff from the two storms produced flood conditions along the main stem of the Delaware River.

Flood frequencies of flows at selected tributaries to the Delaware River did not exceed the 35-year recurrence intervals. The Delaware River main stem peak-flow recurrence intervals ranged from 40 to 80 years; flows were approximately 20 percent less than those from the peak of record in 1955. Peak elevations exceeded National Weather Service flood stages defined at continuous-record streamflow-gaging stations by 5 to 7 feet, but were on average 3 to 5 feet lower than the peak of record in August 1955. Peak elevations determined at 48 sites along the main stem of the Delaware River defined the flood profile between the gaging stations. The peak elevation in the tide-effected portion of the Delaware (downstream of Trenton, New Jersey), occurred on April 2, 2 days before the riverine peak, as a result of water pushed into the bay by a low-pressure system situated just off the coast.

Every county located along the main stem of the Delaware River was declared a Federal disaster area. Property damage estimates in Pennsylvania, New York, and New Jersey exceeded \$200 million.

\section{Introduction}

Historic flooding occurred in New York, New Jersey, and Pennsylvania, on the main stem of the Delaware River on April 2-4, 2005. Several factors combined to create the high-water conditions only 6 months after Hurricane Ivan caused flooding on the east coast in September 2004. Other basins surrounding the Delaware River Basin also experienced high-water conditions on April 2-4, 2005; however, this report focuses on the Delaware River main stem adjacent to New Jersey and includes only a general overview of selected tributaries. Information on conditions for tributaries to the Delaware River and surrounding basins can be found at the U.S. Geological Survey web site http://water.usgs.gov/.

Precipitation was near or above average in the Delaware River Basin for 5 months prior to March 2005, saturating soils in the area. A cold winter left a sizable snowpack on top of frozen soils. Rain fell on March 28, 2005, and melted a part of the snowpack. The combined precipitation and snowmelt drained to the Delaware River, which rose more than 15 feet at Riegelsville, New Jersey. The Delaware River receded on March 30, 2005, without causing serious flooding. However, widespread, heavy rain fell on the saturated soils throughout the Delaware River Basin Saturday and Sunday, April 2 and 3,2005 . As a result of the additional rainfall and snowmelt, a flood crest moved down the Delaware River, causing damage 
to bridges, homes, businesses, and the canals on both the New Jersey and Pennsylvania river banks.

On April 19, 2005, President George W. Bush had declared Federal disaster status for all counties along the main stem of the Delaware River in Pennsylvania, New York, and New Jersey, as far downstream as Trenton, New Jersey. Several bridges across the Delaware River between New Jersey and Pennsylvania were damaged; extensive damage to the Washington Crossing Bridge led to its closing for several weeks until repairs could be made.

In accordance with the National Flood Insurance Act of 1968 and the Flood Disaster Protection Act of 1973, the Federal Emergency Management Agency (FEMA) conducts Flood Insurance Studies to identify flood hazards in states, counties, and communities nationwide. The U.S Geological Survey (USGS), as part of its cooperative agreement with FEMA, documents flood stages and flows at USGS continuous-record streamflow-gaging stations along the Delaware River. The U.S. Geological Survey (USGS) documented the April 2-4, 2005, Delaware River flood on the world wide web at $h t t p: / /$ nj.usgs.gov on a near realtime basis using readings from the USGS streamflow-gaging stations along the Delaware River in New York, New Jersey, and Pennsylvania. Additional flood data and attributes of the April 2-4, 2005, event were collected and documented in cooperation with FEMA.

To supplement streamflow information from the existing USGS gaging stations, a section of the Delaware River main stem between Port Jervis, New York, and Cinnaminson, New Jersey, was selected for investigation of flood peak elevations (fig. 1). Study sites were established at 48 locations along the selected reach: 32 sites on the New Jersey bank, and 16 sites on the Pennsylvania bank. At each of the sites, multiple high-water marks were flagged with various visible and recoverable markers. Detailed written descriptions of the flood marks and digital photographs were obtained. The elevations of the high-water marks were then determined by Differential Global Positioning System (DGPS) and conventional leveling techniques.

While the data in this report was being compiled, yet another flood occurred on the Delaware River on June 28-29, 2006. The magnitude of the 2006 flood was similar to the 2005 flood. The 2006 flood is not thoroughly documented here, but is noted for its significance, as it was the third flood to occur on the Delaware River in 22 months. Peak discharges for 2006 flood are included in tables and figures herein. More information about 2006 flood peaks can be obtained from the New York, Pennsylvania, and New Jersey Water Science Centers of the U.S. Geological Survey.

\section{Purpose and Scope}

The purpose of this report is to document flood conditions along a 145-mile reach of the Delaware River. This report lists precipitation amounts, peak flows and elevations, and flood frequencies associated with the April 2-4, 2005, flood. Peak stages and flows at six USGS continuous-record streamflow-gaging stations on the Delaware River and nine selected tributaries to the Delaware River, as well as the peak elevation at one USGS continuous-record tide gaging station on the Delaware River are presented in tables and figures. An overview of past floods on the Delaware River is also included. The elevations, detailed descriptions, photographs, and maps of sites for 156 high-water marks are included in the appendix at the back of the report.

\section{Description of Study Area}

The Delaware River main stem is the longest un-dammed river east of the Mississippi, extending 330 miles from the confluence of its East and West branches at Hancock, New York, to the mouth of the Delaware Bay. The river is fed by more than 200 tributaries; the largest are the Schuylkill and Lehigh Rivers in Pennsylvania. Water from 12,765 $\mathrm{mi}^{2}$ of land in Pennsylvania, New York, New Jersey, and Delaware drains or discharges into the Delaware River. The water in the basin is used for drinking and industrial use by approximately 5 percent of the nation's population (Delaware River Basin Commission, 2006a).

Because the drainage area is relatively large, an intense, widespread, or prolonged steady rain event is necessary to cause flooding in the Delaware River Basin. The basin can convey flows from smaller, isolated showers easily. Because the headwaters of the basin form in the Catskill and Pocono Mountains, additional runoff from snowmelt can increase the effect of any widespread rainfall in the area.

The study of the April 2-4, 2005, Delaware River flood was conducted on the 145-mile section of the main stem of the Delaware River beginning near the intersection of the New Jersey, Pennsylvania, and New York borders at Port Jervis, New York, downstream to Cinnaminson, New Jersey. The tidal effect on the Delaware River generally begins south of Trenton, New Jersey. Five of the 48 high-water mark sites in this report are in the tide-affected part of the reach.

\section{Delaware River Mileage}

River miles are displayed on the appendix maps showing the locations of the selected sites along the Delaware River to reference the location of documented flood peaks. The U.S. Army Corps of Engineers developed a Delaware River mileage system for stream location and identification in 1956. Revisions to the mileage were made by the Delaware River Basin Commission (DRBC) in 1988 (Delaware River Basin Commission, 1988).

The river mileage begins at zero at the intersection of a line between Cape May Lighthouse, New Jersey, and the tip of Cape Henlopen, Delaware, at the centerline of the navigation channel. River miles increase in the upstream direction. A total of 159 high-water mark elevations were documented between 


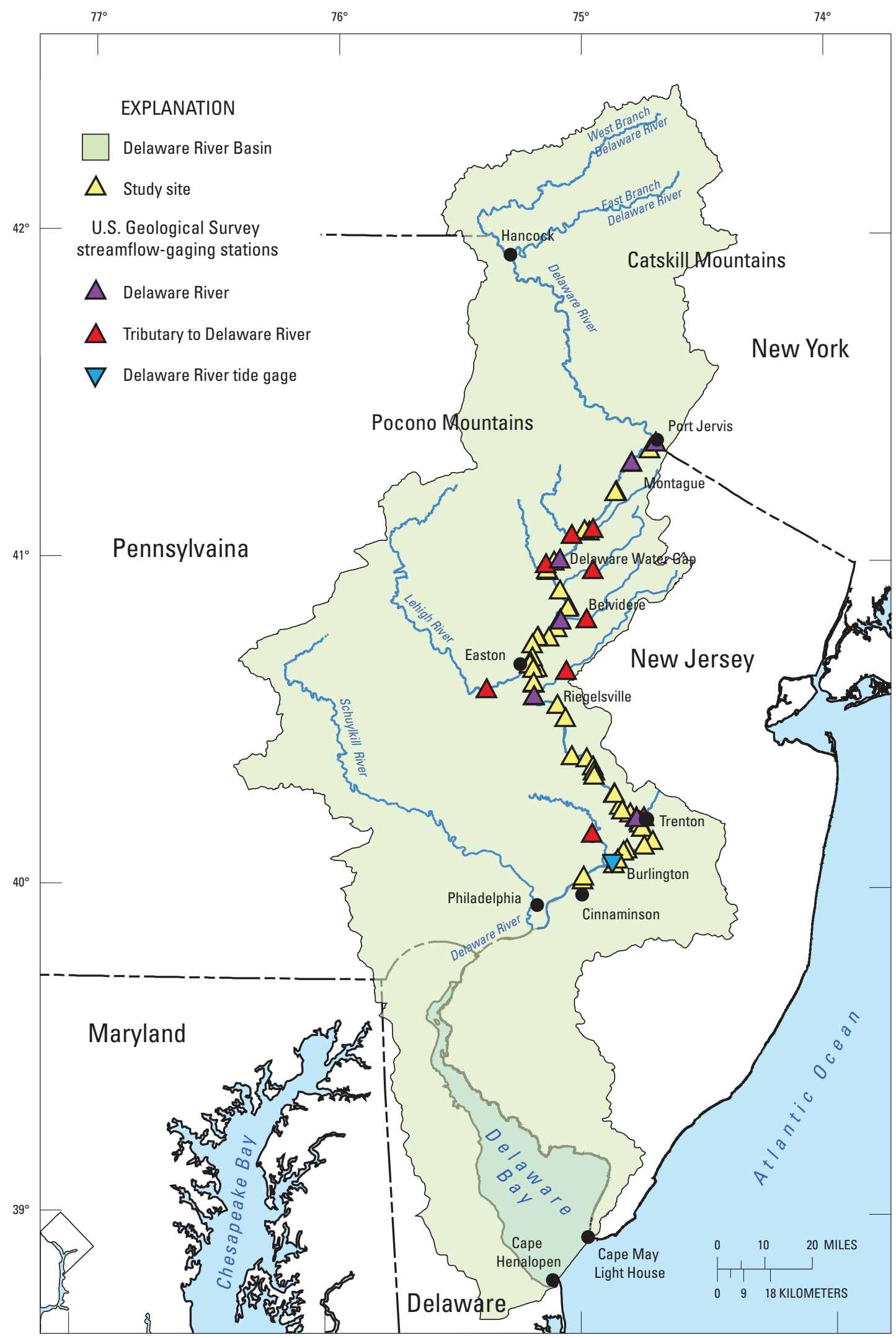

Figure 1. Locations of study sites and selected U.S. Geological Survey streamflow-gaging stations in the Delaware River Basin chosen for the April 2-4, 2005 flood study. 
river mile 255 at Port Jervis, NY, and river mile 110 at Cinnaminson, NJ, for the April 2005 flood.

\section{Adjacent Canals and Super-Elevation}

The Delaware and Raritan Canal (in New Jersey) and the Delaware Canal (in Pennsylvania) run parallel to the Delaware River. Water in the canals can be perched above or sit below the elevation of water in the river as a result of factors such as high embankments between the two, the effect of dams and gates on the canal, and differing channel elevations. During a high-water event, the Delaware River and the canals will merge over the floodplain at various points, depending on the magnitude of the flood. At other points, surface-water elevations of the river will still differ from those of the canals. Judgment was used to identify and include high-water marks that are representative of flood peak elevations of the Delaware River only.

At high velocities, as water flows around a bend in the channel of a river, the water level can become super-elevated on the outside of the curve with respect to the mean elevation across the river. As a result, the water levels on the opposite bank might be lower than expected. Elevations of high-water marks are presented as found for each specific location and are not corrected for any possible super-elevation. An attempt was made to establish study sites on both sides of the Delaware River at any given point in order to record the true elevation or stage on both banks.

\section{Methods of Investigation}

The elevations of the 156 high-water marks were determined by a combination of Differential Global Positioning System (DGPS) leveling and conventional leveling. The DGPS leveling involved establishing a base station receiver over survey monuments documented by the National Geodetic Survey (NGS) (National Geodetic Survey, 2005). As the base station received information from satellites that were within radio range, USGS survey crews set reference marks near or on the high-water marks along the Delaware River. These reference marks are metal washers stamped with "USGS" for ease of identification, and are set in sidewalks, roadways, or parking lots. A rover Global Positioning System (GPS) receiver supported by a bipod stand was placed on the reference mark to receive information from the satellites that were within radio range at the same time as the base station. The simultaneous readings from the static base station and the rover GPS units then were entered into software which plotted the locations and elevations of the USGS reference marks in relation to the NGS survey monuments.

Elevations of the NGS survey monuments as determined by DGPS were compared to the published elevation of that benchmark; the differences in elevations typically were within $0.10 \mathrm{ft}$ (table 1). It was assumed that the accuracy of the USGS reference marks set with the rover DGPS also is about 0.10 $\mathrm{ft}$. This assumption was tested at several sites by performing conventional levels from random USGS reference marks set by DGPS to nearby published benchmarks. The difference between the elevation of the published benchmark and the elevation of the same benchmark as determined by conventional leveling from the USGS reference marks was about $0.10 \mathrm{ft}$.

Another method of quality assuring the accuracy of the DGPS levels was to determine the elevation of a random selection of USGS reference marks with two independent DGPS occupations. A selection of USGS reference marks that had their elevations determined by DGPS were tested again by the DGPS the following day. This was done at 14 study sites, 7 in New Jersey and 7 in Pennsylvania. Of these 14 sites, the difference between the independent occupations for the USGS reference marks as determined by DGPS ranged from $0.02 \mathrm{ft}$ to $0.28 \mathrm{ft}$ (table 2). Of the 14 independent occupations, 6 reference marks had a difference of $0.10 \mathrm{ft}$ or less, 7 were between the range of 0.11 and $0.20 \mathrm{ft}$, and 1 had a $0.28 \mathrm{ft}$ difference.

Once the USGS reference mark was established at each study site and its elevation determined, third-order conventional leveling techniques as described in Kennedy (1990) were implemented. An engineer's level and level rod were used to determine the elevation of each high-water mark based on the established reference marks.

The elevations of the high-water marks were originally surveyed in feet above North American Vertical Datum of 1988 (NAVD 88). These elevations were then adjusted to feet above National Geodetic Vertical Datum of 1929 (NGVD 29), and published as such, whereas the reference mark elevations are presented using NAVD 88. The high-water mark elevations were converted for ease of comparison to the historical peaks at continuous-record streamflow-gaging stations in the area, which use NGVD 29. The conversion of the high-water mark datum was performed with the software VERTCON, available from the National Geodetic Survey (2006). The program computes the modeled difference in orthometric height between NAVD 88 and NGVD 29 for a given location specified by latitude and longitude.

\section{Precipitation and Snowpack}

Light precipitation began to fall in the evening of March 27,2005 , caused by a low pressure system that traveled along the Gulf Coast States (National Climatic Data Center, 2006). The low-pressure system moved slowly eastward, drawing moisture from the Gulf of Mexico and the Atlantic Ocean. A secondary low pressure system developed over North Carolina and moved up the eastern coast bringing heavier rain during the afternoon and evening hours of March 28. One to 3 inches of rain fell over a widespread area in and around the Delaware River Basin.

In the months prior to the March rainfall, a substantial snowpack had accumulated in the Pocono and Catskill 
Table 1. Characteristics of survey monuments on record with the National Geodetic Survey (NGS) that were incorporated into the Differential Global Positioning System (DGPS) used for determining peak flood elevations of the April 2-4, 2005, Delaware River flood.

[PID, Permanent Identifier; NAD 83, North American Datum of 1983; NAVD 88, North American Vertical Datum of 1988]

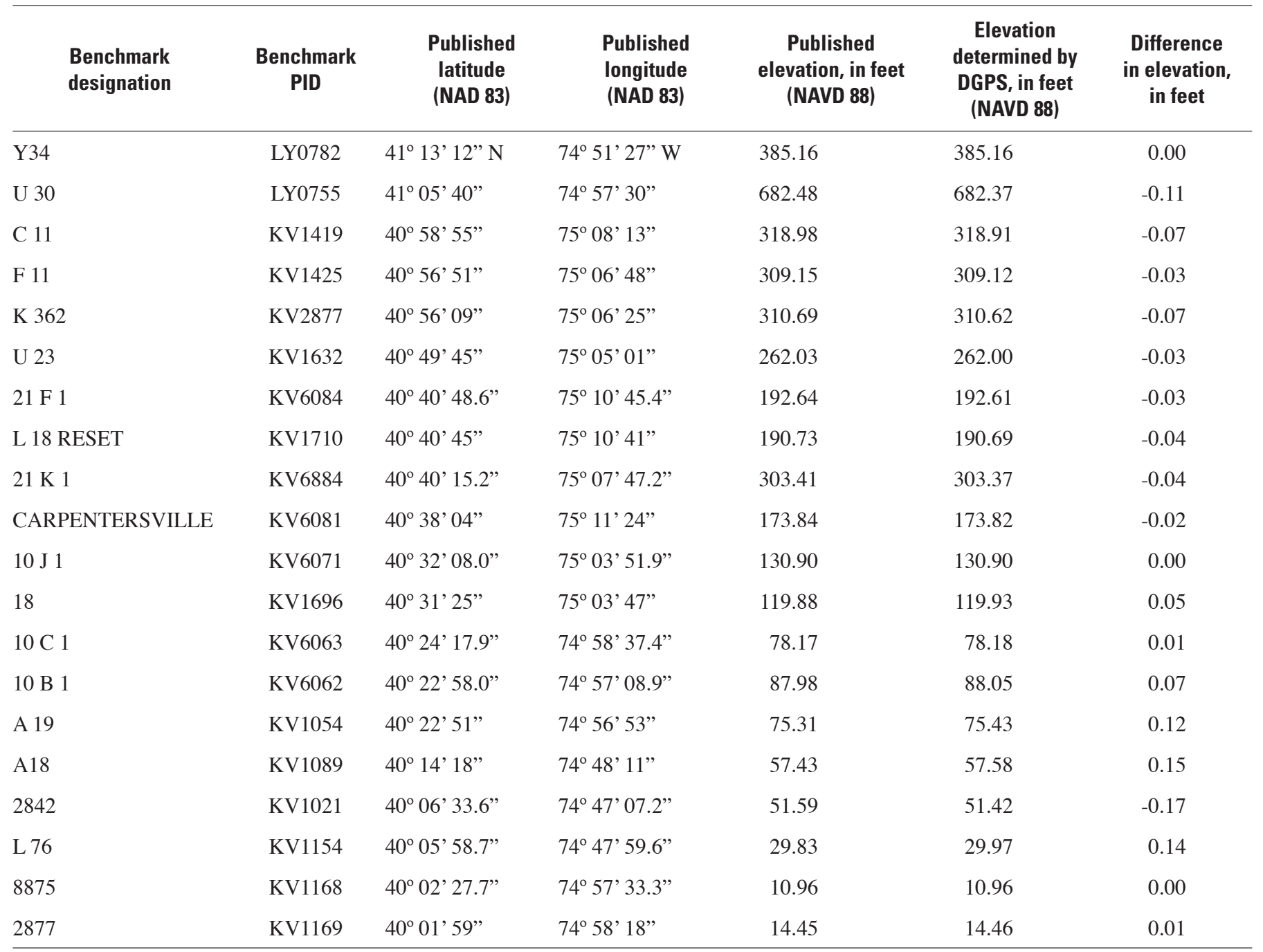

Mountains. The water equivalency of the snow was as much as 10 inches in some isolated areas (fig. 2) (National Weather Service, 2005). From radar imagery, it appears that after the late March rain most of the snow in the lower elevations had melted, adding to the runoff from precipitation in the area. Warmer temperatures in the days following the rain continued to melt the snow, maintaining high river levels; however, snow was still present at higher elevations.

The Delaware River was receding from the combined rainfall and snowmelt of late March when another low pressure system traveled north from the southern Gulf Coast States and eventually produced an additional 2 to 5 inches of rain in the Delaware River Basin during April 2-4, 2005. The rain and warmer temperatures melted the remaining snow in the mountains, and the Delaware River began to rise a second time. Within the basin, the maximum combined total rainfall reported by the National Weather Service for March 28 to April 4, 2005, was 8.20 inches in Tobyhanna, Pennsylvania (table 3 ). The average combined rainfall from the two storms in the basin ranged from 4 to 8 inches (fig. 3 ).

The rainfall amounts for each individual rain event were not substantial. Because the two storms occurred within days of each other, the rain fell on saturated soils, and combined with substantial runoff from melted snow, the net effect was substantial flooding for the Delaware River.

\section{Flood Peaks}

Peak flows determined at the Delaware River stream gages included in this report ranged from 18 to 29 percent less than the peak of record, which occurred in 1955. Peak 
Table 2. Results of accuracy check for selected U.S. Geological Survey (USGS) temporary benchmark (reference mark) elevations of April 2-4, 2005, flood on the Delaware River, using two independent occupations of the Differential Global Positioning System (DGPS).

[NAVD 88, North American Vertical Datum of 1988]

\begin{tabular}{lcccc}
\hline Site & $\begin{array}{c}\text { USGS Temporary } \\
\text { benchmark } \\
\text { (reference mark) }\end{array}$ & $\begin{array}{c}\text { First DGPS elevation } \\
\text { (feet above NAVD 88) }\end{array}$ & $\begin{array}{c}\text { Second DGPS elevation } \\
\text { (feet above NAVD 88) }\end{array}$ & $\begin{array}{c}\text { Difference of } \\
\text { elevations } \\
\text { (feet) }\end{array}$ \\
\hline NJ 6 & USGS TBM 332 & 278.84 & 278.66 & 0.19 \\
NJ 8 & USGS TBM 120 & 234.76 & 234.69 & 0.07 \\
NJ 10 & USGS TBM 222 & 228.30 & 228.32 & -0.03 \\
NJ 11 & USGS TBM 308 & 189.02 & 188.97 & 0.05 \\
NJ 15 & USGS TBM 212 & 160.42 & 160.25 & 0.17 \\
NJ 16 & USGS TBM 208 & 136.79 & 136.68 & 0.11 \\
NJ 29 & USGS TBM 103 & 9.58 & 9.48 & 0.10 \\
PA 1 & USGS TBM 360 & 414.73 & 414.62 & 0.11 \\
PA 5 & USGS TBM 240 & 316.60 & 316.54 & 0.06 \\
PA 6 & USGS TBM 140 & 313.78 & 313.90 & -0.12 \\
PA 14 & USGS TBM 116 & 183.47 & 183.44 & 0.02 \\
PA 15 & USGS TBM 306 & 183.14 & 182.87 & 0.28 \\
PA 27 & USGS TBM 107 & 35.18 & 35.37 & -0.20 \\
PA 31 & USGS TBM 703 & 16.10 & 15.93 & 0.17 \\
\hline
\end{tabular}

elevations at USGS streamflow-gaging stations were several feet lower than the 1955 peak of record. High-water marks documented between the existing USGS streamflow-gaging stations were used to define the flood profile along the reach.

Tributaries to the Delaware River did not experience significant flooding except for backwater effects from the Delaware River at the mouths of the streams. A tidal peak occurred on the Delaware River downstream from Trenton, New Jersey, 2 days prior to the peak flow caused by the precipitation and snowmelt.

\section{Peak Flow}

The initial rise in streamflow from the March runoff caused the Delaware River to reach a preliminary peak flow on March 29-30, 2005 (fig. 4). The recession of that peak was slowed slightly by additional snowmelt as temperatures became warmer. The flow had decreased by 50 percent in 3 days, but was still from 300 to 360 percent greater than the monthly mean March flow when the second rainfall began on April 2. The resulting second peak on April 2-4 more than doubled the first, as the basin was vulnerable to any additional rainfall.

Recurrence intervals of peak flows determined on the Delaware River during April 2-4, 2005, ranged from 40 to 80 years, meaning that flows of this magnitude have a 2.5 percent $(1 / 40)$ to 1.2 percent $(1 / 80)$ probability of occurring in any given year (table 4). Frequency was computed using the log-
Pearson Type III flood frequency analysis (U.S. Interagency Advisory Committee on Water Data, 1982). Variation in flood frequency along a river reach can occur for several reasons, including differing contributions of inflows entering at various points along the main stem of a river.

Peak flows for the Delaware River at Port Jervis, New York, and at Montague, New Jersey, were associated with recurrence intervals of 40 and 60 years, respectively. Recurrence intervals at the downstream sites, Belvidere and Riegelsville, New Jersey, were 65 and 80 years, respectively. There are no substantial inflows to the Delaware River below Riegelsville, as reflected in the relatively small increase in drainage area. The peak flow at the farthest downstream streamflow-gaging station at Trenton, New Jersey, indicated a flood frequency of 45 years. During both peaks, flow increased as it traveled downstream until Riegelsville, after which it attenuated some before reaching Trenton.

Tributaries to the Delaware River experienced peak flows with recurrence intervals of as much as 20 years, with the exception of the Lehigh River, which experienced a 35-year recurrence interval (table 4). The Lehigh River, the largest tributary within the study area, enters the Delaware River approximately 8 miles upstream from Riegelsville, New Jersey. Two Army Corps of Engineers flood-control reservoirs reduce peak flows on the Lehigh River; however, the subbasin did receive the most rainfall during the event. 

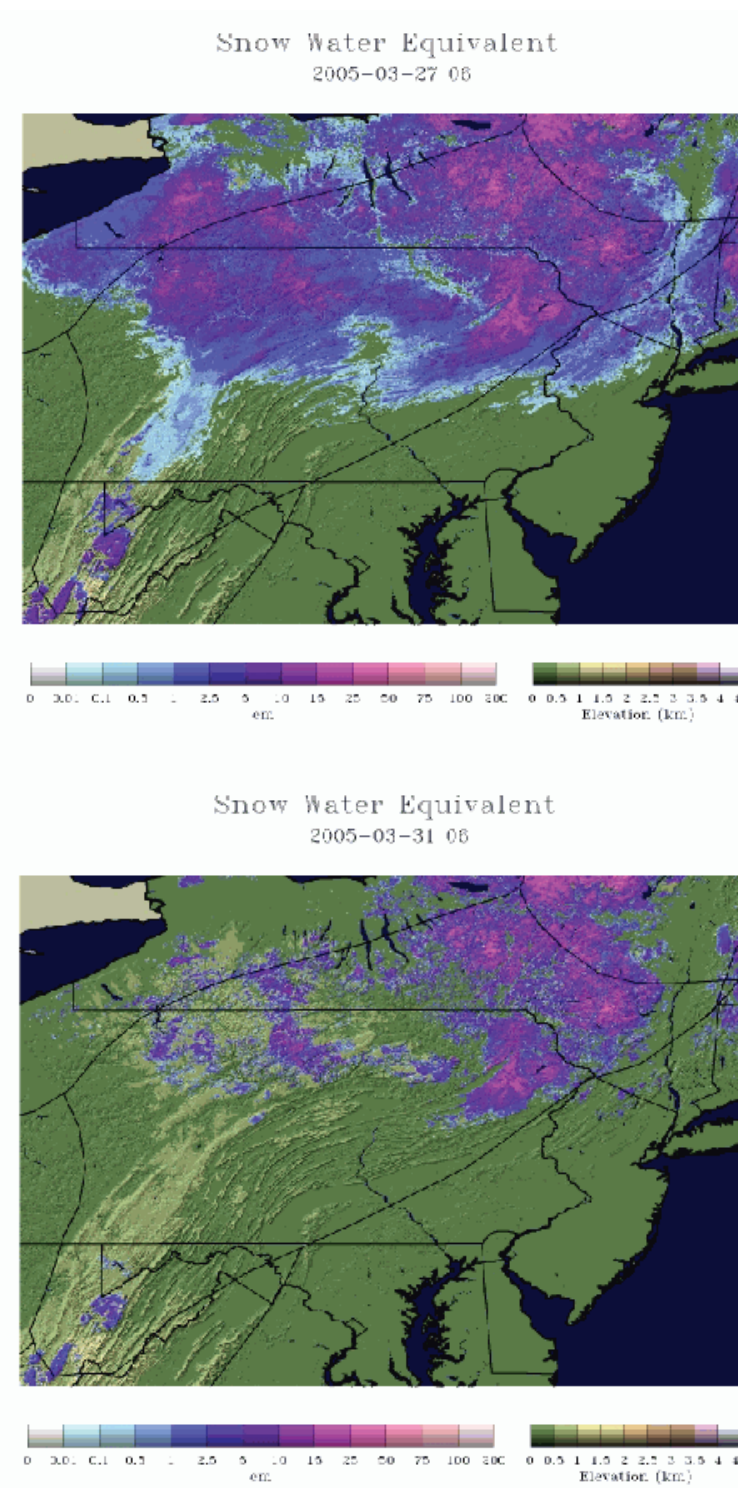

Snow Water Equivalent $2005-04-0 e$ ob
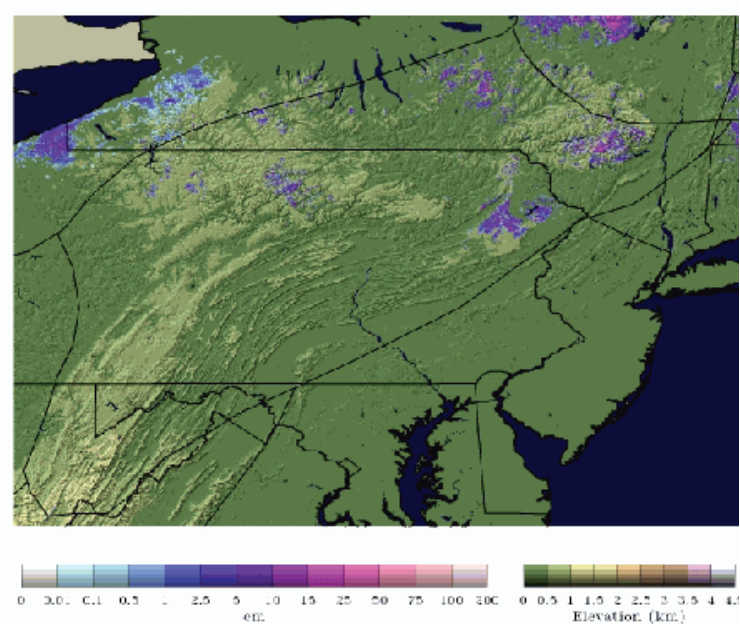

Figure 2. Water equivalent of snowpack prior to March rainfall event, and after March 28-29 and April 2-4, 2005, rainfall events. (Figures provided by the National Weather Service. [cm, centimeters; km, kilometers])

Table 3. Total rainfall at selected sites within the Delaware River Basin, April 2 to 4, 2005, and March 28 to April 4, 2005.

[Data provided by the National Weather Service.]

\begin{tabular}{lcc}
\hline \multicolumn{1}{c}{$\begin{array}{c}\text { Municipality } \\
\text { and state }\end{array}$} & $\begin{array}{c}\text { Total rainfall, } \\
\text { April 2 to 4, 2005 } \\
\text { (inches) }\end{array}$ & $\begin{array}{c}\text { Total rainfall, } \\
\text { March 28 to } \\
\text { April 4, 2005 } \\
\text { (inches) }\end{array}$ \\
\hline Tobyhanna, PA & 5.60 & 8.20 \\
Mount Pocono, PA & 5.45 & 7.80 \\
Blakeslee, PA & 4.66 & 7.49 \\
Roscoe, NY & 4.20 & 7.30 \\
Palm, PA & 4.30 & 6.80 \\
Columbia, NJ & 4.20 & 6.80 \\
Matamoras, PA & 3.70 & 6.75 \\
Callicoon, NY & 3.61 & 6.61 \\
Greentown, PA & 3.90 & 6.40 \\
Bethlehem, PA & 4.26 & 6.33 \\
Montague, NJ & 3.50 & 6.33 \\
Hawley, PA & 3.27 & 6.06 \\
Andover, NJ & 3.81 & 6.01 \\
Fishs Eddy, NY & 3.79 & 5.88 \\
Allentown, PA & 3.67 & 5.61 \\
Honesdale, PA & 2.96 & 5.46 \\
Doylestown, PA & 3.24 & 4.92 \\
Riegelsville, NJ & 2.89 & 4.91 \\
Trenton, NJ & 2.20 & 3.90 \\
\hline
\end{tabular}




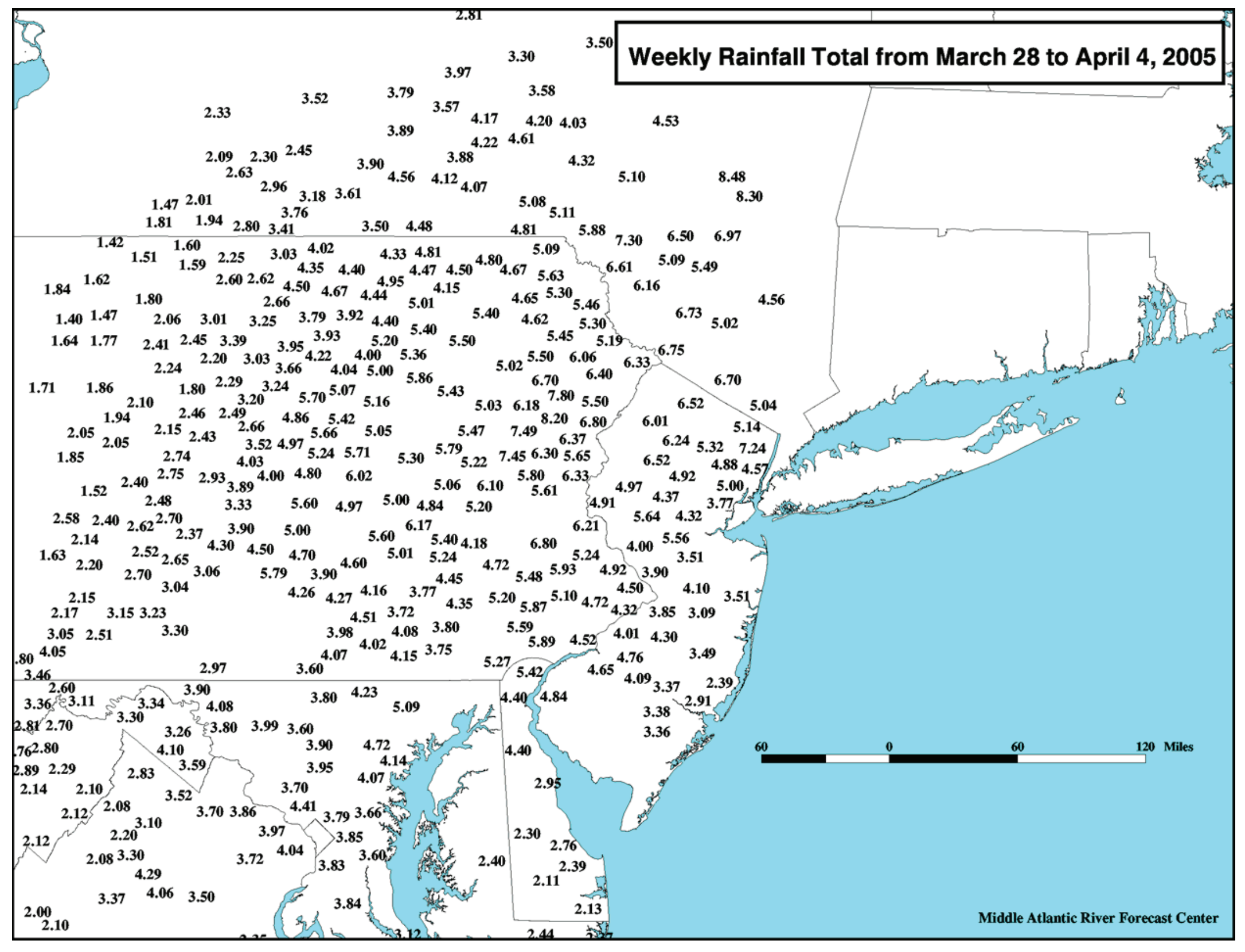

Figure 3. Total combined rainfall during March 28 to April 4, 2005, in and around the Delaware River Valley. (Figure provided by National Weather Service.) 


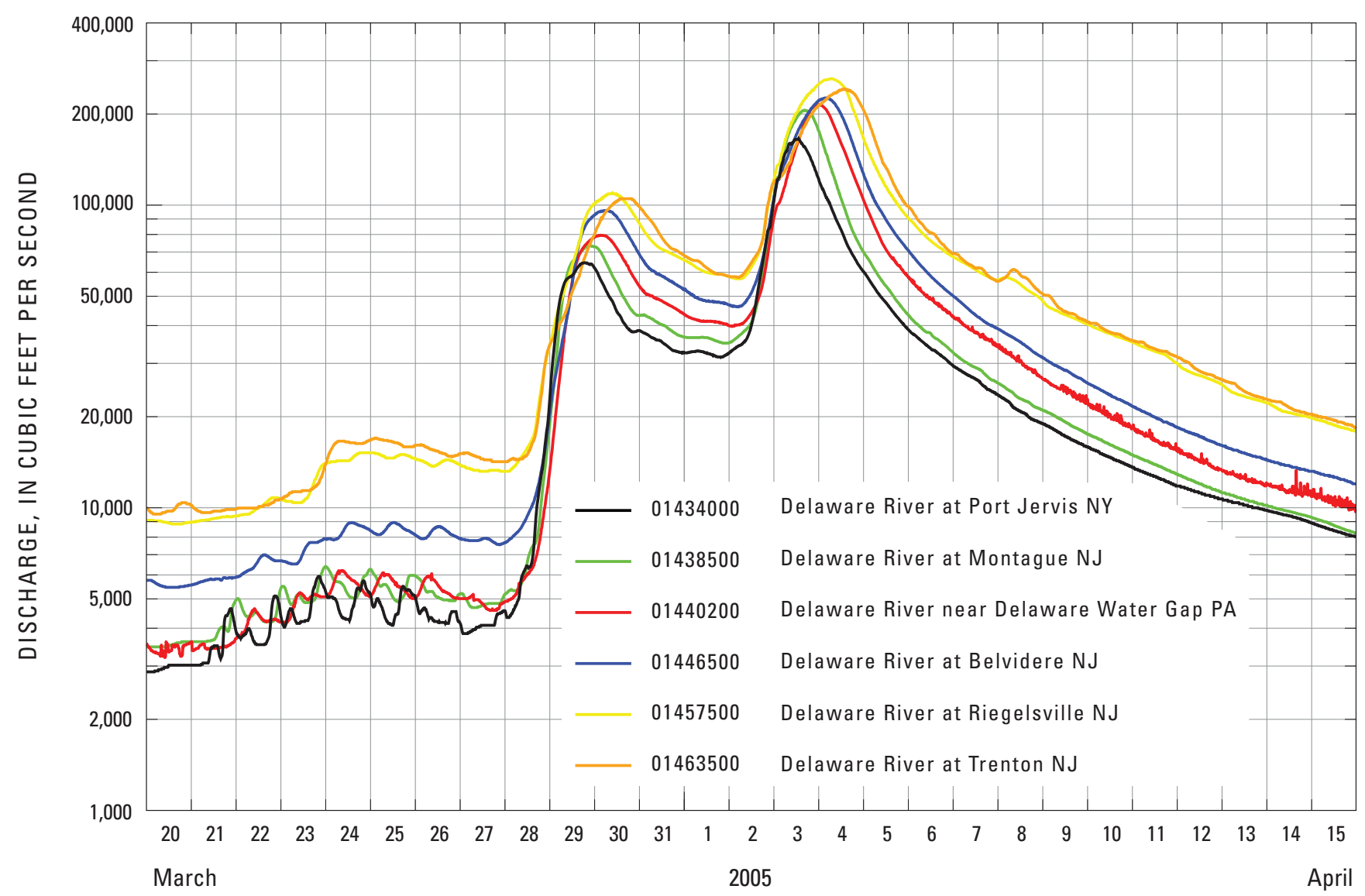

Figure 4. Hydrographs showing streamflow at six continuous-record streamflow-gaging stations on the Delaware River, March 20 to April 15, 2005.

\section{Peak Elevations}

Peak elevations at the six Delaware River streamflowgaging stations were 3 to $5 \mathrm{ft}$ lower than the period of record maximum that occurred in 1955 (table 4). In addition to the flood elevations recorded at the existing Delaware River streamflow-gaging stations, 159 peak elevations were determined at 48 sites along 145 miles of the river between Port Jervis, New York, and Cinnaminson, New Jersey. Elevations are reported in feet above National Geodetic Vertical Datum of 1929.

The initial peak from the March 28-29 rainfall raised the Delaware River to within 2 to $7 \mathrm{ft}$ of flood stage, as determined at continuous-record streamflow-gaging stations in the reach. The second peak which occurred after additional rainfall on April 2-4 exceeded flood stage by 5 to $7 \mathrm{ft}$. Peak flood elevations began at $435.9 \mathrm{ft}$ at the Port Jervis, New York, streamflow-gaging station, and decreased to $8.6 \mathrm{ft}$ at Cinnaminson, New Jersey. River elevations fell fairly steadily along the reach, reflecting the characteristics of the Delaware River Valley. At approximately 2 miles below Trenton, flood elevations became static (fig. 5). Tidal effect on the Delaware River generally occurs downstream from Trenton. The slope of the riverbed in the tidal reach is relatively flat and the channel is wider where the river is tide affected.

\section{Tidal Peak}

The peak elevation in the tidal part of the Delaware River occurred almost two days before the riverine flood peak (fig. 6). At the USGS continuous-record tide gaging station Delaware River at Burlington, a peak of $8.65 \mathrm{ft}$ was recorded on April 2, 2005, at 21:21 hours, Eastern Daylight Time (EDT). The Delaware River at Trenton streamflow-gaging station, which is 16 miles upstream from the Burlington tide gaging station, recorded a peak of $25.33 \mathrm{ft}$ on April 4, 2005, at 14:30 hours, EDT.

According to the National Climatic Data Center, minor tidal flooding occurred as early as March 29, 2005, because higher than normal astronomical tides resulted from the full moon (National Climatic Data Center, 2006). Onshore flow was produced by a low pressure system that formed along the Gulf Coast States. Water was pushed into the Delaware Bay by a counterclockwise circulation around the low pressure system. Wind gusts of up to 40 miles per hour from the southeast were recorded at the New Jersey shore, which may have 
Table 4. Summary of flood peaks at U.S. Geological Survey streamflow-gaging stations on the Delaware River and selected tributaries, April 2-4, 2005.

[ $\mathrm{mi}^{2}$, square miles; $\mathrm{ft}^{3} / \mathrm{s}$, cubic feet per second; ft, feet; NGVD 29, National Geodetic Vertical Datum of 1929; NA, not available; >, greater than; <, less than]

\begin{tabular}{|c|c|c|c|c|c|c|c|c|c|c|c|c|}
\hline $\begin{array}{c}\text { U.S. } \\
\text { Geological } \\
\text { Survey } \\
\text { station } \\
\text { number }\end{array}$ & Station name & $\begin{array}{c}\text { Years } \\
\text { of peak } \\
\text { record }\end{array}$ & $\begin{array}{c}\text { Distance } \\
\text { above } \\
\text { mouth of } \\
\text { Delaware } \\
\text { Bay (miles) }\end{array}$ & $\begin{array}{c}\text { Drainage } \\
\text { area } \\
\left(\mathrm{mi}^{2}\right)\end{array}$ & Remarks & Date & $\begin{array}{c}\text { Peak } \\
\text { discharge } \\
\left(\mathrm{ft}^{3} / \mathrm{s}\right)\end{array}$ & $\begin{array}{c}\text { Peak } \\
\text { discharge per } \\
\text { square mile } \\
\left(\mathrm{ft}^{3} / \mathrm{s} / \mathrm{mi}^{2}\right)\end{array}$ & $\begin{array}{c}\text { Gage } \\
\text { height } \\
\text { (ft) }\end{array}$ & $\begin{array}{l}\text { Elevation, } \\
\text { above } \\
\text { NGVD } 29\end{array}$ & $\begin{array}{c}\text { Time } \\
\text { (Eastern } \\
\text { daylight) }\end{array}$ & $\begin{array}{c}\text { Recurrence } \\
\text { interval } \\
\text { (years) }\end{array}$ \\
\hline \multirow{2}{*}{01434000} & \multirow{2}{*}{$\begin{array}{l}\text { Delaware River at } \\
\text { Port Jervis, NY }\end{array}$} & \multirow{2}{*}{102} & \multirow{2}{*}{255} & \multirow{2}{*}{3,070} & $\begin{array}{l}\text { Peak of } \\
\text { record }\end{array}$ & $8 / 19 / 1955$ & 233,000 & 75.9 & 23.91 & 439.26 & NA & $>100$ \\
\hline & & & & & $\begin{array}{l}\text { Flood } \\
\text { peak }\end{array}$ & $4 / 03 / 2005$ & 166,000 & 54.1 & 20.52 & 435.88 & 1315 & 40 \\
\hline \multirow{2}{*}{01438500} & \multirow{2}{*}{$\begin{array}{l}\text { Delaware River at } \\
\text { Montague, NJ }\end{array}$} & \multirow{2}{*}{71} & \multirow{2}{*}{246} & \multirow{2}{*}{3,480} & $\begin{array}{l}\text { Peak of } \\
\text { record }\end{array}$ & 8/19/1955 & 250,000 & 71.8 & 35.15 & 405.08 & NA & $>100$ \\
\hline & & & & & $\begin{array}{l}\text { Flood } \\
\text { peak }\end{array}$ & 4/03/2005 & 206,000 & 59.2 & 31.69 & 401.62 & 1615 & 60 \\
\hline \multirow{2}{*}{01439500} & \multirow{2}{*}{$\begin{array}{c}\text { Bush Kill at } \\
\text { Shoemakers, PA }\end{array}$} & \multirow{2}{*}{88} & \multirow{2}{*}{ NA } & \multirow{2}{*}{117} & $\begin{array}{l}\text { Peak of } \\
\text { record }\end{array}$ & 8/19/1955 & 23,400 & 200 & 13.95 & 435.08 & NA & $>100$ \\
\hline & & & & & $\begin{array}{l}\text { Flood } \\
\text { peak }\end{array}$ & $4 / 03 / 2005$ & 5,670 & 48.5 & 7.51 & 428.64 & NA & 20 \\
\hline \multirow{2}{*}{01440000} & \multirow{2}{*}{$\begin{array}{l}\text { Flat Brook near } \\
\text { Flat brookville, } \mathrm{NJ}\end{array}$} & \multirow{2}{*}{81} & \multirow{2}{*}{ NA } & \multirow{2}{*}{64.0} & $\begin{array}{l}\text { Peak of } \\
\text { record }\end{array}$ & 8/19/1955 & 9,560 & 149 & 12.58 & 360.31 & NA & $>100$ \\
\hline & & & & & $\begin{array}{l}\text { Flood } \\
\text { peak }\end{array}$ & 4/03/2005 & 2,880 & 45.0 & 7.25 & 354.98 & 0700 & 7 \\
\hline \multirow{2}{*}{01440200} & \multirow{2}{*}{$\begin{array}{c}\text { Delaware River } \\
\text { near Delaware } \\
\text { Water Gap, PA }\end{array}$} & \multirow{2}{*}{36} & \multirow{2}{*}{216} & \multirow{2}{*}{3,850} & $\begin{array}{l}\text { Peak of } \\
\text { record }\end{array}$ & 8/19/1955 & 260,000 & 67.5 & 37.40 & 331.04 & NA & $>100$ \\
\hline & & & & & $\begin{array}{l}\text { Flood } \\
\text { peak }\end{array}$ & $4 / 03 / 2005$ & 215,000 & 55.8 & 33.25 & 326.89 & 2300 & 55 \\
\hline \multirow{2}{*}{01442500} & \multirow{2}{*}{$\begin{array}{l}\text { Brodhead Creek at } \\
\text { Minisink Hills, PA }\end{array}$} & \multirow{2}{*}{46} & \multirow{2}{*}{ NA } & \multirow{2}{*}{259} & $\begin{array}{l}\text { Peak of } \\
\text { record }\end{array}$ & 8/19/1955 & 68,800 & 266 & NA & NA & NA & $>100$ \\
\hline & & & & & $\begin{array}{l}\text { Flood } \\
\text { peak }\end{array}$ & $4 / 03 / 2005$ & 25,900 & 100 & $14.16^{1}$ & 316.00 & NA & 20 \\
\hline \multirow{2}{*}{01443500} & Paulins Kill at & 81 & NA & 126 & $\begin{array}{l}\text { Peak of } \\
\text { record }\end{array}$ & 8/19/1955 & 8,750 & 69.4 & 11.12 & 346.98 & NA & $>100$ \\
\hline & Blairstown, NJ & 81 & NA & 126 & $\begin{array}{l}\text { Flood } \\
\text { peak }\end{array}$ & $4 / 03 / 2005$ & 3,550 & 28.2 & 7.38 & 343.24 & 0715 & 13 \\
\hline & Pequest River at & & & & $\begin{array}{l}\text { Peak of } \\
\text { record }\end{array}$ & 1/25/1979 & $2,130^{2}$ & 20.1 & 5.97 & 404.75 & NA & 70 \\
\hline 01445500 & Pequest, NJ & 53 & NA & 106 & $\begin{array}{l}\text { Flood } \\
\text { peak }\end{array}$ & 4/03/2005 & $1,520^{2}$ & 14.3 & 5.09 & 403.87 & 0500 & 8 \\
\hline & Delaware River at & & & & $\begin{array}{l}\text { Peak of } \\
\text { record }\end{array}$ & 8/19/1955 & 273,000 & 60.2 & 30.21 & 256.64 & NA & $>100$ \\
\hline 01446500 & Belvidere, $\mathrm{NJ}$ & 84 & 199 & 4,535 & $\begin{array}{l}\text { Flood } \\
\text { peak }\end{array}$ & $4 / 04 / 2005$ & 226,000 & 49.8 & 27.22 & 253.67 & 0330 & 65 \\
\hline 01453000 & Lehigh River at & 37 & NA & 1270 & $\begin{array}{l}\text { Peak of } \\
\text { record }\end{array}$ & $5 / 23 / 1942$ & 92,000 & 71.9 & 25.90 & 236.84 & NA & $>100$ \\
\hline 01455000 & Bethlehem, PA & 37 & NA & 1,219 & $\begin{array}{l}\text { Flood } \\
\text { peak }\end{array}$ & 4/03/2005 & $56,700^{3}$ & 44.3 & 19.70 & 230.64 & NA & 35 \\
\hline 01457000 & Musconetcong River & 86 & NA & 141 & $\begin{array}{l}\text { Peak of } \\
\text { record }\end{array}$ & 1/25/1979 & 7,200 & 51.1 & 8.50 & 283.33 & NA & 80 \\
\hline $0145 / 000$ & near Bloomsbury, NJ & 80 & NA & 141 & $\begin{array}{l}\text { Flood } \\
\text { peak }\end{array}$ & 4/03/2005 & 3,230 & 22.9 & 6.25 & 281.08 & 0345 & 6 \\
\hline
\end{tabular}


Table 4. Summary of flood peaks at U.S. Geological Survey streamflow-gaging stations on the Delaware River and selected tributaries, April 2-4, 2005.-Continued [mi², square miles; fts/s, cubic feet per second; ft, feet; NGVD 29, National Geodetic Vertical Datum of 1929; NA, not available; >, greater than; <, less than]

\begin{tabular}{|c|c|c|c|c|c|c|c|c|c|c|c|c|}
\hline $\begin{array}{c}\text { U.S. } \\
\text { Geological } \\
\text { Survey } \\
\text { station } \\
\text { number }\end{array}$ & Station name & $\begin{array}{l}\text { Years } \\
\text { of peak } \\
\text { record }\end{array}$ & $\begin{array}{c}\text { Distance } \\
\text { above } \\
\text { mouth of } \\
\text { Delaware } \\
\text { Bay (miles) }\end{array}$ & $\begin{array}{l}\text { Drainage } \\
\text { area } \\
\left(\mathrm{mi}^{2}\right)\end{array}$ & Remarks & Date & $\begin{array}{c}\text { Peak } \\
\text { discharge } \\
\left(\mathrm{ft}^{3} / \mathrm{s}\right)\end{array}$ & $\begin{array}{c}\text { Peak } \\
\text { discharge per } \\
\text { square mile } \\
\left(\mathrm{ft}^{3} / \mathrm{s} / \mathrm{mi}^{2}\right)\end{array}$ & $\begin{array}{c}\text { Gage } \\
\text { height } \\
\text { (ft) }\end{array}$ & $\begin{array}{l}\text { Elevation, } \\
\text { above } \\
\text { NGVD } 29\end{array}$ & $\begin{array}{c}\text { Time } \\
\text { (Eastern } \\
\text { daylight) }\end{array}$ & $\begin{array}{c}\text { Recurrence } \\
\text { interval } \\
\text { (years) }\end{array}$ \\
\hline \multirow{2}{*}{01457500} & \multirow{2}{*}{$\begin{array}{c}\text { Delaware River at } \\
\text { Riegelsville, NJ }\end{array}$} & \multirow{2}{*}{100} & \multirow{2}{*}{175} & \multirow{2}{*}{6,328} & $\begin{array}{l}\text { Peak of } \\
\text { record }\end{array}$ & $8 / 19 / 1955$ & 340,000 & 53.7 & 38.85 & 163.97 & NA & $>100$ \\
\hline & & & & & $\begin{array}{l}\text { Flood } \\
\text { peak }\end{array}$ & $4 / 04 / 2005$ & 262,000 & 41.4 & 34.07 & 159.19 & 0700 & 80 \\
\hline \multirow{2}{*}{01463500} & \multirow{2}{*}{$\begin{array}{l}\text { Delaware River at } \\
\text { Trenton, NJ }\end{array}$} & \multirow{2}{*}{103} & \multirow{2}{*}{134} & \multirow{2}{*}{6,780} & $\begin{array}{l}\text { Peak of } \\
\text { record }\end{array}$ & $8 / 20 / 1955$ & 329,000 & 48.5 & $28.60^{4}$ & 28.60 & NA & $>100$ \\
\hline & & & & & $\begin{array}{l}\text { Flood } \\
\text { peak }\end{array}$ & $4 / 04 / 2005$ & 242,000 & 35.7 & 25.33 & 25.33 & 1430 & 45 \\
\hline \multirow{2}{*}{01464000} & \multirow{2}{*}{$\begin{array}{l}\text { Assunpink Creek at } \\
\text { Trenton, NJ }\end{array}$} & \multirow[b]{2}{*}{38} & \multirow{2}{*}{ NA } & \multirow{2}{*}{90.6} & $\begin{array}{l}\text { Peak of } \\
\text { record }\end{array}$ & 7/21/1975 & 5,450 & 60.2 & 14.61 & 39.37 & NA & $>100$ \\
\hline & & & & & $\begin{array}{l}\text { Flood } \\
\text { peak }\end{array}$ & $4 / 02 / 2005$ & 1,670 & 18.4 & 8.62 & 33.38 & 2230 & 4 \\
\hline \multirow{2}{*}{01465500} & \multirow{2}{*}{$\begin{array}{c}\text { Neshaminy Creek } \\
\text { near Langhorne, PA }\end{array}$} & \multirow{2}{*}{64} & \multirow{2}{*}{ NA } & \multirow{2}{*}{210} & $\begin{array}{l}\text { Peak of } \\
\text { record }\end{array}$ & $8 / 19 / 1955$ & 49,300 & 234 & 22.84 & 63.41 & NA & $>100$ \\
\hline & & & & & $\begin{array}{l}\text { Flood } \\
\text { peak }\end{array}$ & $4 / 03 / 2005$ & 14,000 & 66.7 & 12.87 & 53.44 & NA & $<10$ \\
\hline
\end{tabular}

${ }^{1}$ Gage heights (and stream elevations) at this site are affected by backwater from the Delaware River.

${ }^{2}$ From 1958 through 1960, approximately 10 miles of the Pequest River from Long Bridge, New Jersey, to below Vienna, New Jersey, was dredged and realigned by the U.S. Soil and Conservation Service. This work may have affected peak discharges at this stream gage.

${ }^{3}$ Discharge is affected by regulation. Flood frequency is based on period with regulation, 1961-1997.

${ }^{4}$ Maximum known elevation, 30.6 feet above NGVD 29 (gage datum), March 8, 1904, from floodmark due to ice jam. 


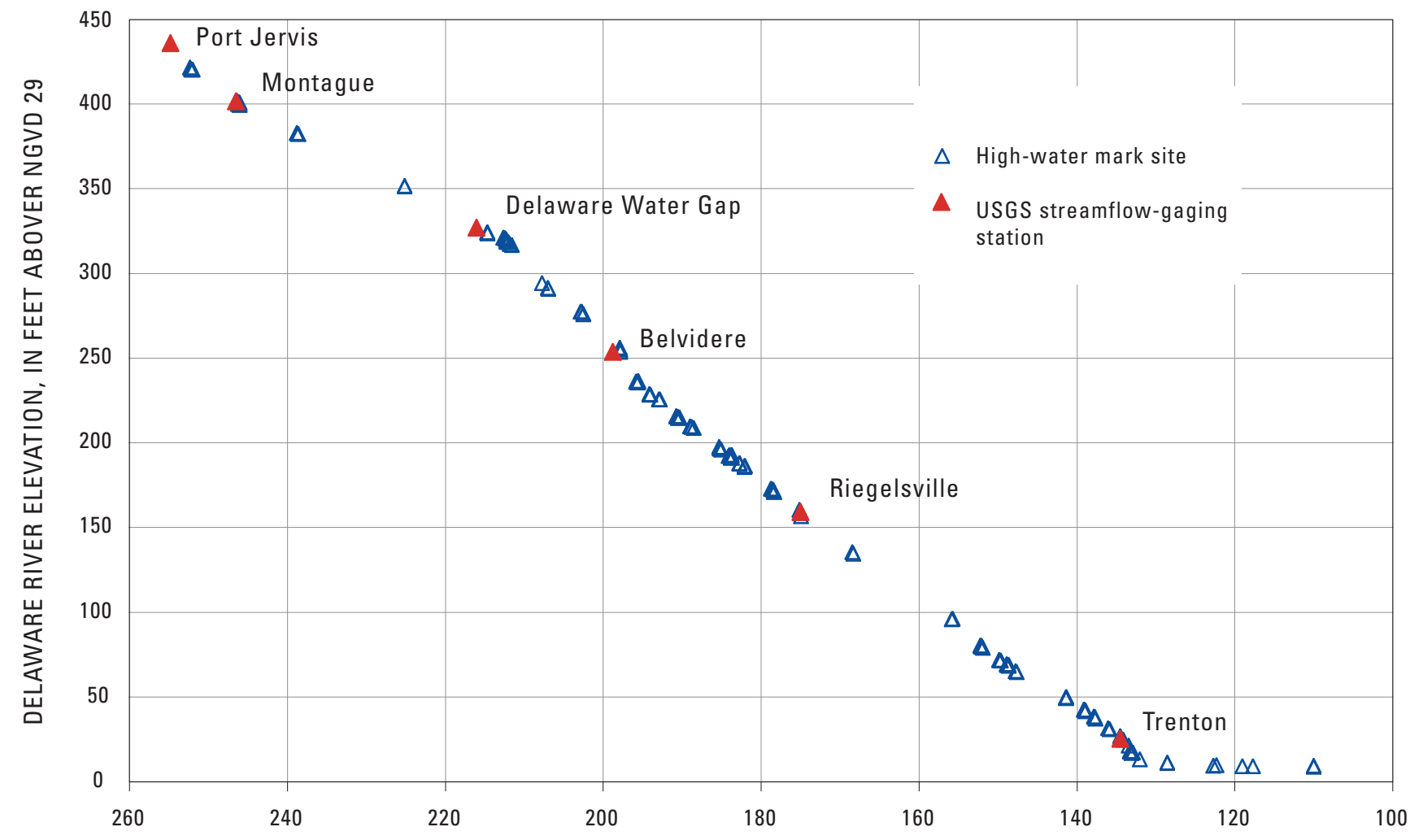

DISTANCE ABOVE MOUTH OF DELAWARE BAY, IN MILES

Figure 5. Delaware River peak elevations at U.S. Geological Survey (USGS) streamflow-gaging stations and high-water mark sites, April 2-4, 2005.

contributed to higher tides in the Delaware Bay. The higher than normal tides, combined with the initial March rainfall, produced a tidal peak prior to the riverine peak.

\section{Historic Floods}

Annual peak discharges for the period of record at the continuous streamflow-gaging stations on the Delaware River at Port Jervis, New York, and Trenton, New Jersey, are shown in figure 7. The figure is a good visual indicator of the peak discharges for the history of these two gaging stations that are near the boundaries of the study area. Peak discharges of flood events documented since 1902 in Delaware River study area are listed in table 5 .

The August 1955 flood was by far the highest recorded on the Delaware River. It was somewhat similar to, but much more extreme than, the 2005 flood. The 1955 flood also was caused by two rainfall events that occurred within days of each other. In 1955 on August 12 Hurricane Connie and on August 17 Hurricane Diane made landfall in North Carolina. Both made their way north through the eastern states (Bogart, 1960). The maximum recorded rainfall in the Delaware River Basin for each of the hurricanes was more than 9 and
11 inches, respectively. The combined maximum rainfall was almost 4 times that which fell March 28 to April 4, 2005. However, as this event occurred in August, there was no additional runoff due to snowmelt. Within the study area, peak elevations ranged from 3.3 to 4.8 feet higher than the 2005 flood.

A flood on the Delaware River in October 1903 was caused by the remnants of a tropical storm that came ashore in the Atlantic City area (Ludlum, 1983). Rain began to fall on October 7, continued, and became heavier on October 8-9. Within the study area, peak elevations ranged from 1.4 to 3.8 feet higher than the 2005 flood. Five months later, in March of 1904, flow in the Delaware River was slowed by an ice jam at Trenton, causing the river to rise 2 feet above the 1955 flood peak. The March 1904 elevation is the highest recorded river elevation at Trenton.

A flood in March 1936 was the most similar to the 2005 flood, as it also resulted from two rainstorms combined with snowmelt. The water content of the snow for the 1936 flood ranged from 5 to 8 inches, and combined maximum measured rainfall during March 11-22, 1936, at Mount Pocono, Pennsylvania, was approximately 8.7 inches (Ludlum, 1983). Within the study area, peak elevations ranged from 0.9 to 3.2 feet lower than the 2005 flood. 


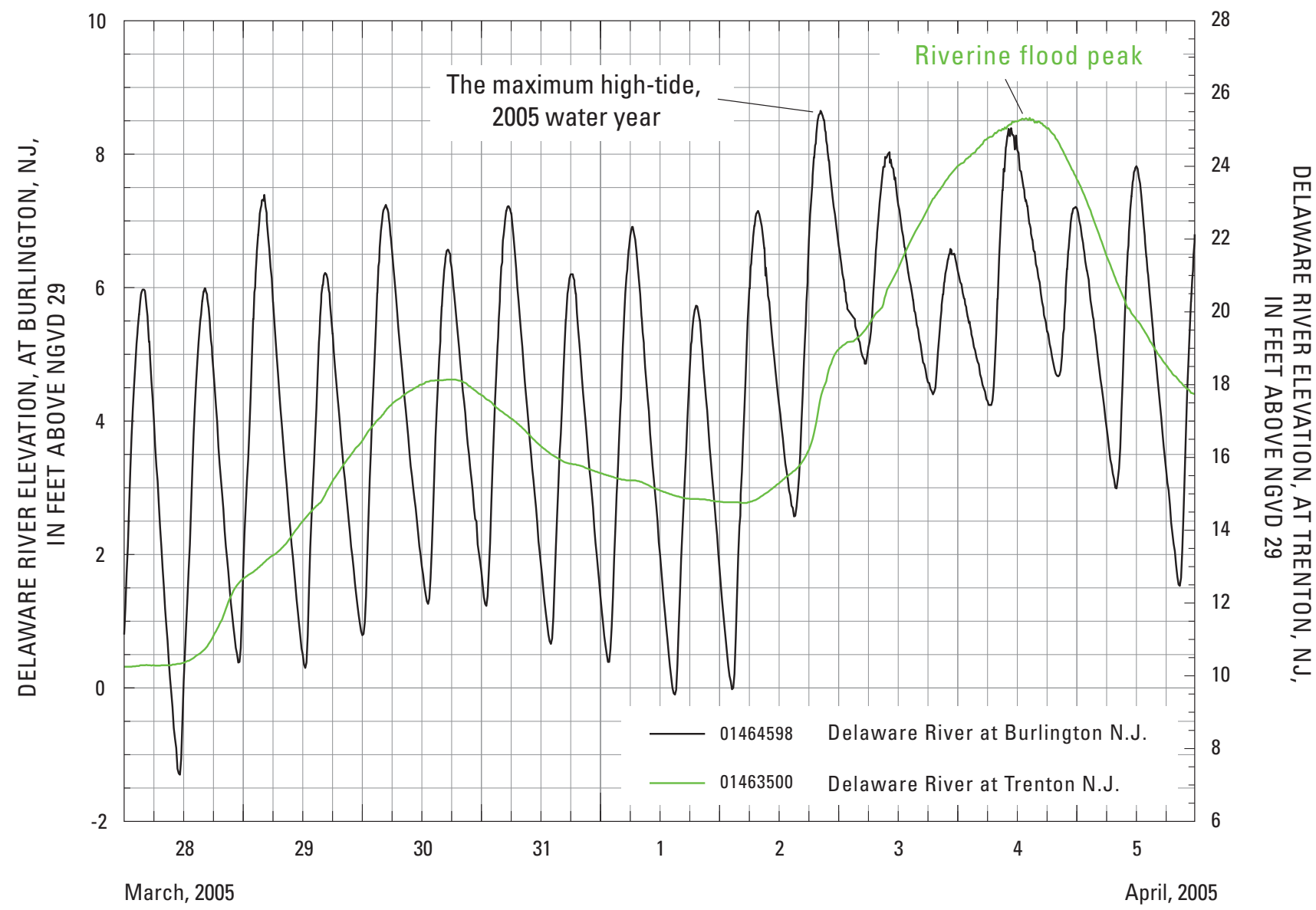

Figure 6. Hydrographs showing tide cycles on the Delaware River at Burlington, New Jersey, and stream elevations on the Delaware River at Trenton, New Jersey, March 28 to April 5, 2005. (NGVD 29, National Geodetic Vertical Datum of 1929)

The April 2005 flood occurred just 6 months after the remnants of Hurricane Ivan made a path through the eastern states. Soils were saturated prior to the residual rain of Hurricane Ivan, as the result of showers in the area that brought approximately 2 inches of rain to the Delaware River Basin on September 9-10, 2004. The remnants of Ivan then brought an additional 4 to 6 inches of rain on September 17-18. Peak flow at Trenton was about 20 percent less than the 2005 flood. Peak elevations from the 2004 flood ranged from 1.0 to 3.3 feet lower than those of April 2005, but nevertheless caused considerable damage throughout the basin.

In June 2006, fifteen months after the April 2005 flood, the Delaware River flooded again after varying amounts rain fell across the region every day from June 23 to June 28, with the heaviest precipitation occurring on June 27. Rainfall totals of more than 12 inches were recorded during the 7-day period in the headwaters of the basin in New York. The peak flows and elevations of the 2006 flood were similar to the 2005 flood. Preliminary data show that at Montague and Delaware Water Gap, New Jersey, the flood crest was approximately 0.5 and 0.6 feet higher than the 2005 flood. At Belvidere, New Jersey, both flood crests were about the same. Further down- stream, at Riegelsville and Trenton, New Jersey, the 2006 flood crest was approximately 0.4 and 0.2 feet lower than the 2005 flood.

Additional data on historic flood peaks for the Delaware River (and other rivers in New Jersey) can be obtained from http://nj.usgs.gov/.

\section{Flood Damage}

On April 15, 2005, President George W. Bush ordered disaster aid for flood damages in eastern Pennsylvania in response to the April 2-4 flood. On April 19, 2005, he declared disaster area status for New Jersey and New York. All twelve counties located along the Delaware River main stem became eligible for Federal aid (Federal Emergency Management Agency, 2006).

Property damage was estimated to be more than $\$ 200$ million for 17 counties which are either partially or completely in the Delaware River Basin (Delaware River Basin Commission, 2006b). New York and New Jersey each received approx- 

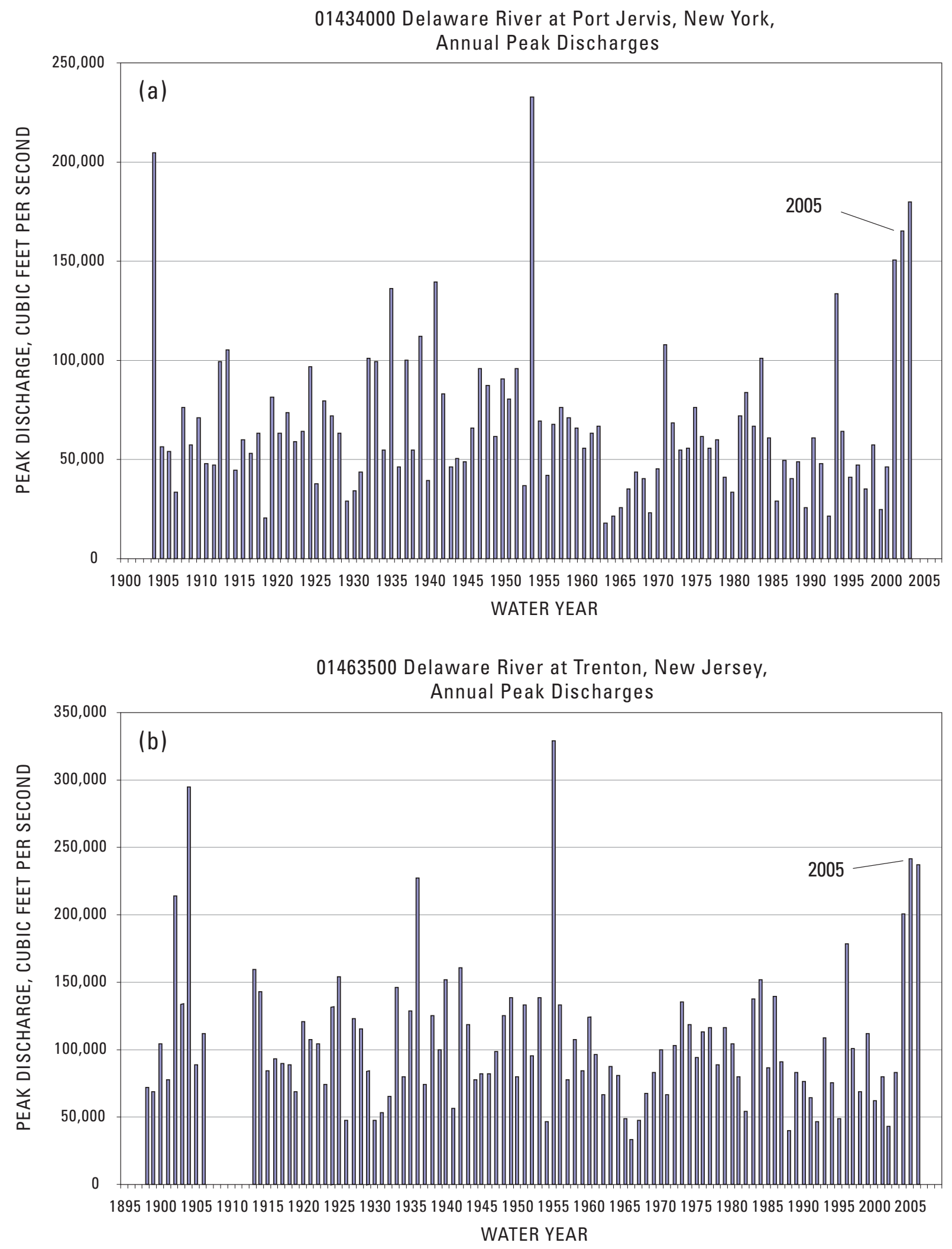

Figure 7. Annual peak discharges for the Delaware River at (a) Port Jervis, New York, and (b) Trenton, New Jersey for the respective periods of record. (Water year is defined as 12-month period from October 1 through September 30, and is designated by the calendar year in which it ends. Thus, the year ending September 30, 2002, is called the "2002 water year.") 
Table 5. Historic peak discharges at U.S. Geological Survey streamflow-gaging stations on the Delaware River between Port Jervis, New York, and Trenton, New Jersey.

$\left[\mathrm{mi}^{2}\right.$, square miles; $\mathrm{ft}^{3} / \mathrm{s}$, cubic feet per second; e, estimated; ---, no data]

\begin{tabular}{|c|c|c|c|c|c|c|c|c|c|}
\hline \multirow{2}{*}{$\begin{array}{c}\text { U.S. } \\
\text { Geological } \\
\text { Survey } \\
\text { station } \\
\text { number }\end{array}$} & \multirow{2}{*}{ Station name } & \multirow{2}{*}{$\begin{array}{l}\text { Drainage } \\
\text { Area }\left(\mathrm{mi}^{2}\right)\end{array}$} & \multicolumn{7}{|c|}{ Peak discharge $\left(\mathrm{ft}^{3} / \mathrm{s}\right)$} \\
\hline & & & $\begin{array}{c}\text { March } \\
1902\end{array}$ & $\begin{array}{c}\text { October } \\
1903\end{array}$ & $\begin{array}{c}\text { March } \\
1936\end{array}$ & $\begin{array}{c}\text { August } \\
1955\end{array}$ & $\begin{array}{c}\text { September } \\
2004\end{array}$ & $\begin{array}{l}\text { April } \\
2005\end{array}$ & $\begin{array}{l}\text { June } \\
2006\end{array}$ \\
\hline 01434000 & $\begin{array}{l}\text { Delaware River } \\
\text { at Port Jervis, } \\
\text { NY }\end{array}$ & 3,070 & --- & 205,000 & --- & 233,000 & 151,000 & 166,000 & 189,000 \\
\hline 01438500 & $\begin{array}{c}\text { Delaware River } \\
\text { at Montague, } \\
\text { NJ }\end{array}$ & 3,480 & --- & --- & 164,500 & 250,000 & 168,000 & 206,000 & 212,000 \\
\hline 01440200 & $\begin{array}{c}\text { Delaware River } \\
\text { near Delawar } \\
\text { Water Gap, PA }\end{array}$ & 3,850 & --- & --- & --- & 260,000 & 176,000 & 215,000 & 225,000 \\
\hline 01457500 & $\begin{array}{c}\text { Delaware River } \\
\text { at Riegelsville, } \\
\text { NJ }\end{array}$ & 6,328 & --- & 275,000 & 237,000 & 340,000 & 216,000 & 262,000 & 254,000 \\
\hline 01463500 & $\begin{array}{l}\text { Delaware River } \\
\text { at Trenton, NJ }\end{array}$ & 6,780 & 214,000 & $\mathrm{e} 295,000$ & 227,000 & 329,000 & 201,000 & 242,000 & 237,000 \\
\hline
\end{tabular}

imately 20 percent of the total damages, and Pennsylvania received 60 percent. Damage to bridges across the Delaware River was estimated at $\$ 1.5$ million, causing several bridges to be temporarily closed. The longest closure and greatest damage was to the Washington Crossing Bridge, which is approximately 5 miles upstream from Trenton (Appendix, site NJ 22) (National Climatic Data Center, 2005).

\section{Summary}

During the Delaware River flood of April 2-4, 2005, peak flow recurrence intervals ranged from 40 to 80 years. This flood was the result of a typical spring occurrence of heavy rain and snowmelt, but was of a magnitude that could not be contained within the banks of the Delaware River.

Rainfall from two storms totaling more than 8 inches occurred within 5 days of each other and combined with snowmelt to produce the flood. The initial rainfall on March 28-29, 2005, saturated soils in the Delaware River Basin, leaving the watershed at risk of flooding. Runoff from a second rainfall on
April 2-4, 2005, generated a flood crest that exceeded several previously documented floods along the Delaware River.

Four of the six current USGS streamflow-gaging stations on the Delaware River have documented flood peaks dating back more than 100 years. The flows from the April 2005 flood rank from second to forth highest on record in the study area, depending on the location along the reach. Peak flows were approximately 20 percent less than the peak of record in 1955; peak elevations were 3 to $5 \mathrm{ft}$ lower than the 1955 flood.

In the days leading up to and during the flood, tides in the Delaware Bay were higher than normal. The recent full moon, a counterclockwise circulation around a low pressure system, and high offshore winds helped to push water into the bay. The initial runoff from the March 28-29 precipitation converged with the above average tide to produce a peak elevation in the bay on April 2, prior to the flood peak at Trenton on April 4.

Area residents were still recovering from a smaller but notable flood which occurred on the Delaware River on September 18-19, 2004. Peak flood elevations during the April 2-4, 2005, event were on average more than $2 \mathrm{ft}$ higher than those of the 2004 flood.

Fifteen months after the April 2005 flood, another flood crest of similar magnitude made its way down the Delaware 
Valley on June 28-29, 2006. The greatest rainfall total associated with the flood occurred in New York, in the headwaters of the Delaware River Basin. At points closer to New York, the flood peaks were slightly higher for the 2006 flood compared to April 2005. Downstream from Belvidere, New Jersey, flood peaks were slightly lower than in 2005.

Each of the 2004, 2005, and 2006 floods were the result of significant amounts of precipitation in different circumstances. In 2004, it was the remnants of a tropical storm; 2005 was precipitation combined with snowmelt; 2006 was sporadic heavy rains, followed by a widespread, intense rainfall. Counties along the Delaware River were declared Federal disaster areas for each event. Estimated property damages totaled more than \$200 million for the April 2005 flood alone.

\section{Acknowledgments}

The authors gratefully acknowledge:

Christopher Harney of the Delaware River Joint Toll Bridge Commission for providing additional flood elevations. Paul Weberg and Jon Janowicz of the Federal Emergency Management Agency (Regions II and III, respectively) for their input and counsel.

William S. Banks, Joseph E. Beman, Jonathan J. A. Dillow, Matthew J. Ferrari, Steven M. Fuller, Carrie A. Huitger, Eric M. Lindbloom, Thomas M. Moffett, Chad J. Ostheimer, Brian S. Painter, Bernard N. Sroka, Charles J. Strain, Matthew T. Whitehead, and George L. Zynjuk of the USGS for invaluable field data collection.

The authors also thank Kara M. Watson of the USGS for assistance in developing the site maps and Ruth M. Larkins, USGS, for the editorial review. Exceptional gratitude is owed to Gregory L. Simpson, USGS, for preparing the numerous site maps and photographs for publication.

Appreciation is also noted for Robert D. Schopp, USGS, for technical assistance.

\section{References Cited}

Bogart, D. B., 1960, Floods of August -October 1955, New England to North Carolina; U.S. Geological Survey WaterSupply Paper 1420, 854 p.

Delaware River Basin Commission, 1988, Delaware River stream mileage system, accessed October 25, 2005, at http://www.state.nj.us/drbc/mileage.htm

Delaware River Basin Commission, 2006a, Basin facts, accessed August 8, 2006 at http://www.state.nj.us/drbc/thedrb.htm

Delaware River Basin Commission, 2006b, County-wide reported flood damages in the Delaware River Basin, accessed August 16, 2006 at http://www.state.nj.us/drbc/ Flood_Website/reporteddamages.htm

Federal Emergency Management Agency, 2006, accessed January 4, 2006 at $h t t p: / / w w w . f e m a . g o v / n e w s / d i s a s t e r s$. fema

Kennedy, E. J., 1990, Levels at streamflow gaging stations: U.S. Geological Survey Techniques of Water-Resources Investigations, book 3, chapter A19, $26 \mathrm{p}$.

Ludlum, D. L., 1983, The New Jersey Weather Book: New Brunswick, N.J., Rutgers University Press, 249 p.

National Climatic Data Center, 2005, Storm events, accessed October 6, 2005 at http://www4.ncdc.noaa.gov/cgi-win/ wwcgi.dll?wwEvent Storms

National Climatic Data Center, 2006, Storm events, accessed August 10, 2006 at http://www4.ncdc.noaa.gov/cgi-win/ wwcgi.dll?wwEvent Storms

National Geodetic Survey, 2005, Benchmark datasheets, accessed May 12, 2005 at $h t t p: / / w w w . n g s . n o a a . g o v /$

National Geodetic Survey, 2006, VERTCON - North American Vertical Datum Conversion Utility, accessed January 7 , 2006 at http://www.ngs.noaa.gov/PC_PROD/VERTCON/

National Weather Service, 2005, Interactive snow information, accessed October 25, 2005 at http://www.nohrsc.nws. gov/interactive/html/map.html

U.S. Interagency Advisory Committee on Water Data, 1982, Guidelines for determining flood flow frequency, Bulletin 17-B of the Hydrology Subcommittee: Reston, Va., U.S. Geological Survey, Office of Water data Coordination, $183 \mathrm{p}$. 


\section{Appendix}

\section{Descriptions of high-water mark sites}

- Site maps, listed in downstream order, showing location of 156 high-water marks, survey reference marks, selected USGS streamflow-gaging stations, and mileage along Delaware River, measured upstream from the mouth of the river (table A1).

- Elevations of the high-water marks were converted from North American Vertical Datum of 1988 to National Geodetic Vertical Datum of 1929 using the program VERTCON (http://www.ngs.noaa.gov/PC_ PROD/VERTCON/)

- Photographs and Global Positioning Satellite readings were taken at each high-water mark by USGS field crews.

- All location coordinates are referenced to North American Datum of 1983 (NAD 83) [lat, latitude; long, longitude]

- Additional field notes documenting each high-water mark and each USGS reference mark are on file at the U.S. Geological Survey New Jersey Water Science Center, West Trenton, N.J.

- Several high-water marks were eliminated from the study because they were not distinct. Therefore, the sequence of the high-water mark numbering system is interrupted. 
Table A1. Downstream order of high-water mark sites as presented in the appendix.

\begin{tabular}{|c|c|c|c|c|c|}
\hline \multicolumn{2}{|c|}{ Site identifier } & \multirow[t]{2}{*}{ Location } & \multirow{2}{*}{$\begin{array}{c}\begin{array}{c}\text { Number of } \\
\text { marks at site }\end{array} \\
4\end{array}$} & \multirow{2}{*}{$\begin{array}{c}\begin{array}{c}\text { Distance above } \\
\text { mouth (miles) }\end{array} \\
252\end{array}$} & \multirow{2}{*}{$\begin{array}{r}\text { Page } \\
19\end{array}$} \\
\hline PA 1 & & & & & \\
\hline \multirow[t]{4}{*}{ PA 2} & & New Milford & 7 & 246 & 22 \\
\hline & NJ 1 & Montague & 3 & 246 & 27 \\
\hline & NJ 2 & Dingmans Ferry & 3 & 239 & 30 \\
\hline & NJ 3 & Flatbrookville & 2 & 225 & 33 \\
\hline PA 5 & & Shawnee Island & 3 & 215 & 35 \\
\hline \multirow[t]{4}{*}{ PA 6} & & Delaware Water Gap & 4 & 213 & 38 \\
\hline & NJ 4 & Dunnfield & 7 & 212 & 41 \\
\hline & NJ 5 & Columbia & 3 & 207 & 46 \\
\hline & NJ 6 & Knowlton & 2 & 203 & 49 \\
\hline \multirow[t]{3}{*}{ PA 8} & & Thomas Island & 2 & 203 & 51 \\
\hline & NJ 7 & Belvidere & 4 & 198 & 53 \\
\hline & NJ 8 & Foul Rift & 5 & 196 & 56 \\
\hline \multirow[t]{3}{*}{ PA 9A } & & Mount Pleasant & 3 & 194 & 60 \\
\hline & NJ 9 & Hutchinson & 2 & 193 & 63 \\
\hline & NJ 10 & Brainards & 3 & 191 & 65 \\
\hline PA 10 & & Martins Creek & 3 & 190 & 68 \\
\hline PA 11 & & Sandts Eddy & 3 & 189 & 71 \\
\hline \multirow[t]{2}{*}{ PA 12} & & Easton & 3 & 185 & 74 \\
\hline & NJ 11 & Phillipsburg & 3 & 184 & 77 \\
\hline \multirow[t]{2}{*}{ PA 14} & & Easton & 4 & 184 & 80 \\
\hline & NJ 12 & Phillipsburg & 4 & 184 & 83 \\
\hline \multirow[t]{2}{*}{ PA 15} & & South Easton & 3 & 183 & 86 \\
\hline & NJ 13 & Phillipsburg & 3 & 182 & 89 \\
\hline \multirow[t]{9}{*}{ PA 16} & & Raubsville & 3 & 178 & 92 \\
\hline & NJ 14 & Carpentersville & 3 & 178 & 95 \\
\hline & NJ 15 & Riegelsville & 5 & 175 & 98 \\
\hline & NJ 16 & Milford & 4 & 168 & 102 \\
\hline & NJ 17 & Frenchtown & 4 & 165 & 105 \\
\hline & NJ 18 & Raven Rock & 3 & 156 & 108 \\
\hline & NJ 19 & Stockton & 5 & 152 & 111 \\
\hline & NJ 20 & Lambertville & 4 & 150 & 115 \\
\hline & NJ 21 & Lambertville & 4 & 149 & 118 \\
\hline PA 23 & & New Hope & 4 & 149 & 121 \\
\hline \multirow[t]{3}{*}{ PA 24} & & New Hope & 2 & 148 & 124 \\
\hline & NJ 22 & Washington Crossing & 4 & 141 & 126 \\
\hline & NJ 23 & Scudders Falls & 4 & 139 & 129 \\
\hline \multirow[t]{8}{*}{ PA 27} & & Yardley & 3 & 138 & 132 \\
\hline & NJ 24 & Trenton & 2 & 136 & 135 \\
\hline & NJ 25 & Trenton & 4 & 134 & 137 \\
\hline & NJ 26 & Trenton & 3 & 133 & 140 \\
\hline & NJ 27 & Trenton & 3 & 133 & 143 \\
\hline & NJ 28 & Trenton & 1 & 132 & 146 \\
\hline & NJ 29 & Bordentown & 2 & 128 & 148 \\
\hline & NJ 30 & Florence & 2 & 123 & 150 \\
\hline \multirow[t]{3}{*}{ PA 32} & & Bristol & 1 & 119 & 152 \\
\hline & NJ 31 & Burlington & 1 & 118 & 154 \\
\hline & NJ 32 & Cinnaminson & 2 & 110 & 156 \\
\hline
\end{tabular}




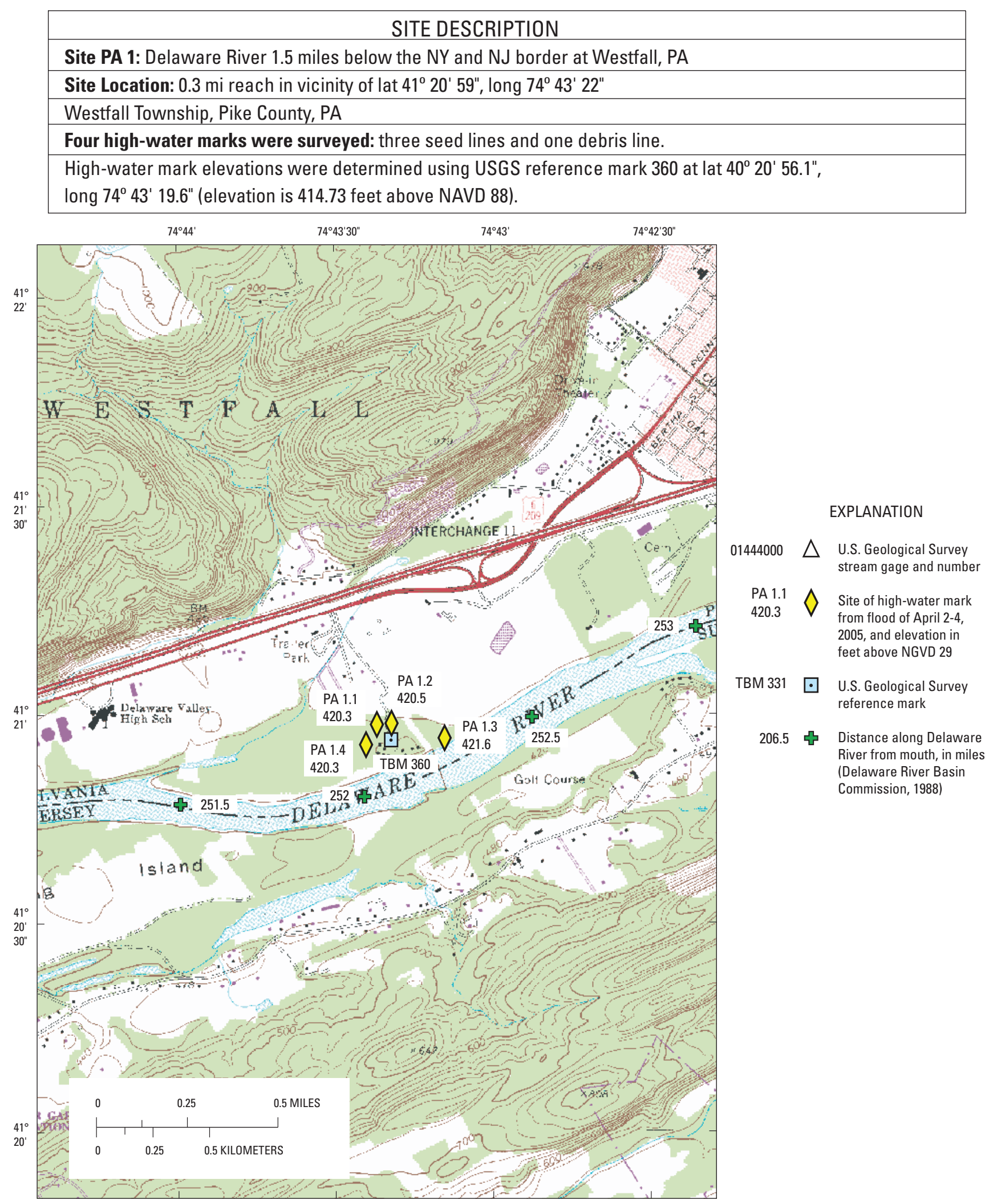

Port Jervis South USGS 7.5' Topographic Quadrangle map showing location of site PA 1, Delaware River 1.5 miles below the NY and NJ border at Westfall, PA. 


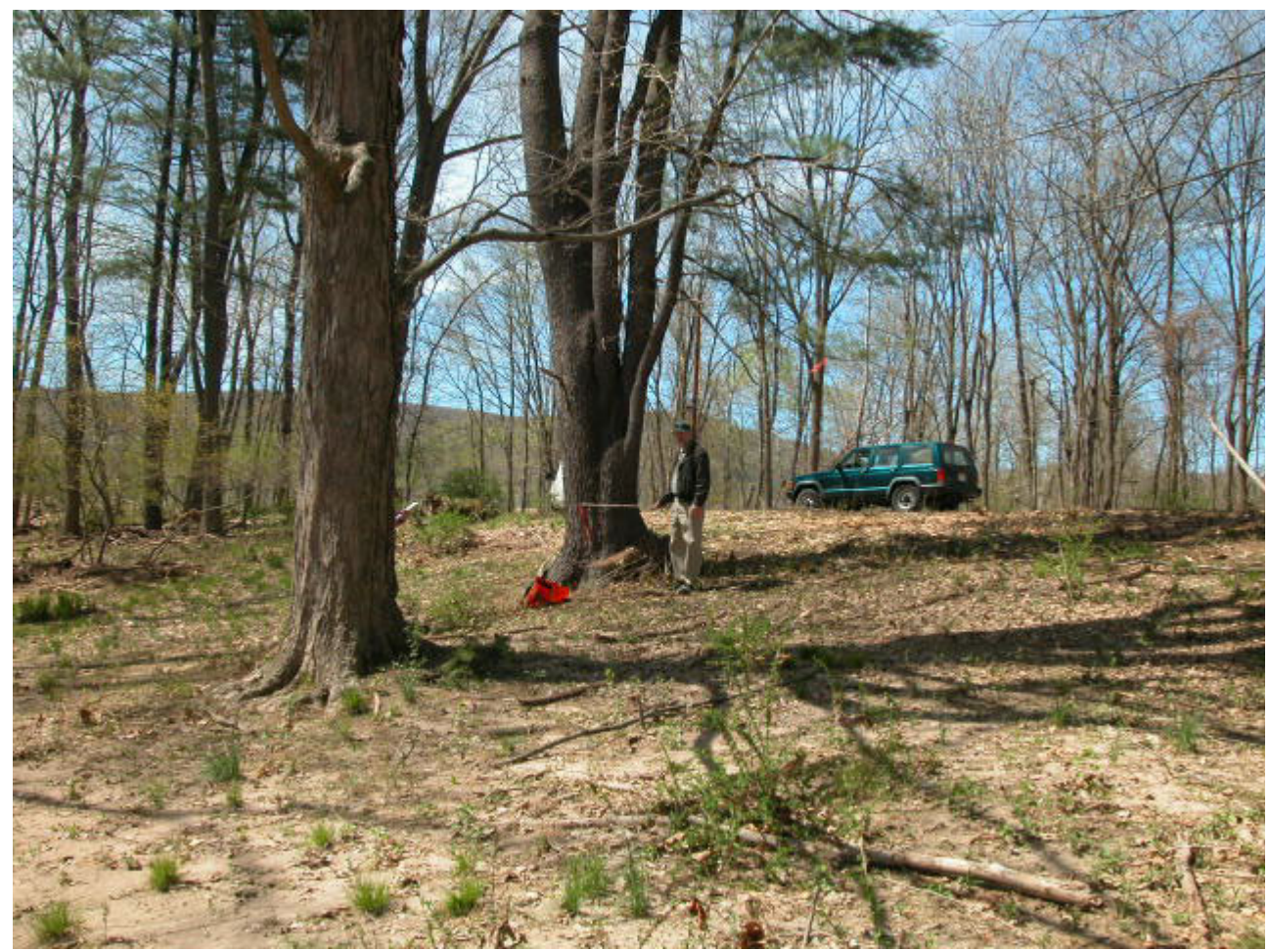

High-water mark PA 1.1 (lat $41^{\circ} 20^{\prime} 59.0^{\prime \prime}$, long $74^{\circ} 43^{\prime} 22.0^{\prime \prime}$ ), at an elevation of 420.3 feet above NGVD 29, is a good seed line on a 3-foot diameter tree, 3.4 feet above the ground, and was marked with a metal USGS washer and nail.

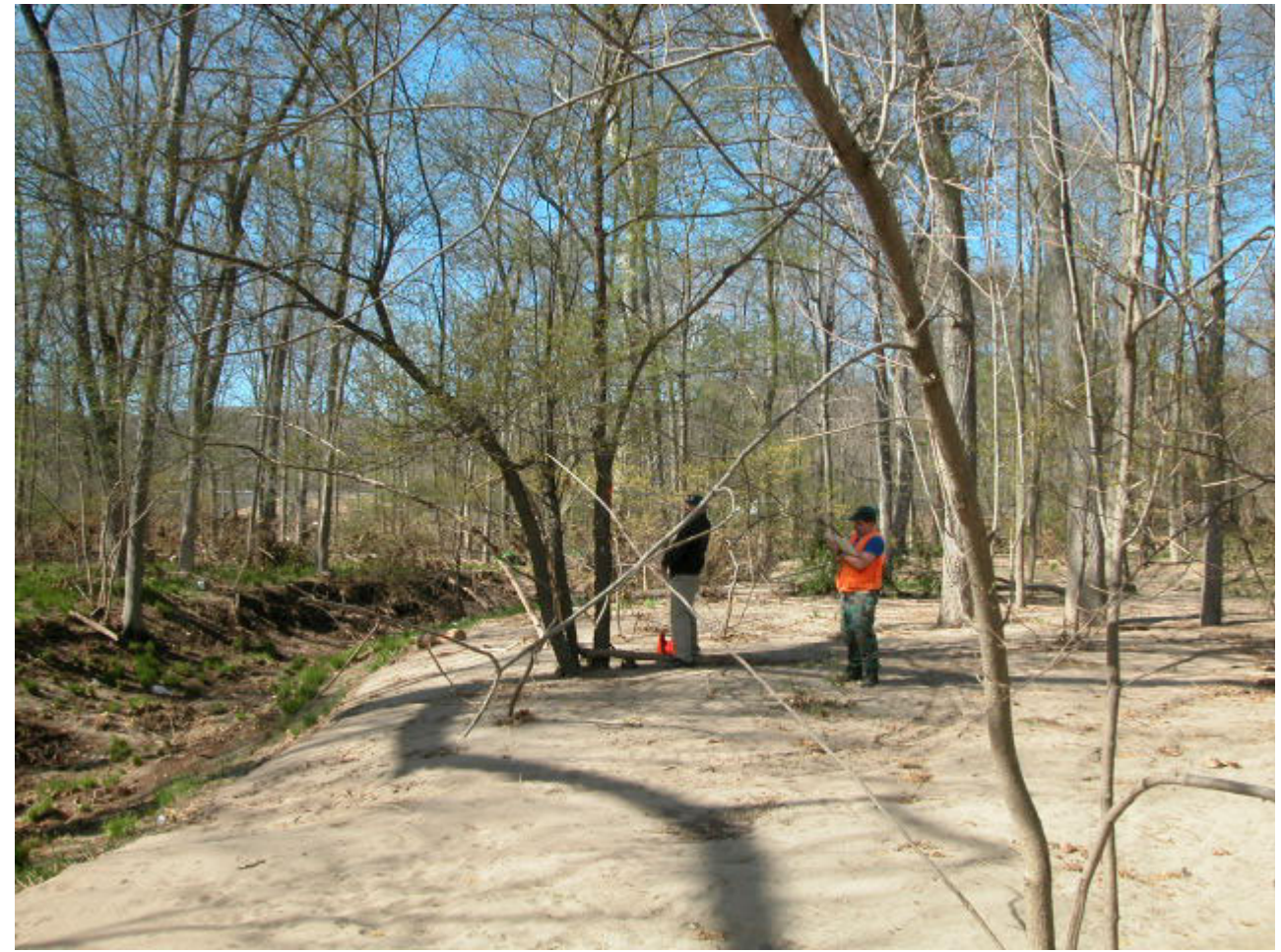

High-water mark PA 1.2 (lat $41^{\circ} 20^{\prime} 59.0^{\prime \prime}$, long $74^{\circ} 43^{\prime} 19.0^{\prime \prime}$ ), at an elevation of 420.5 feet above NGVD 29, is a good seed line on a 3-inch diameter tree, 3.3 feet above the ground, and was marked with a metal USGS washer and nail. 


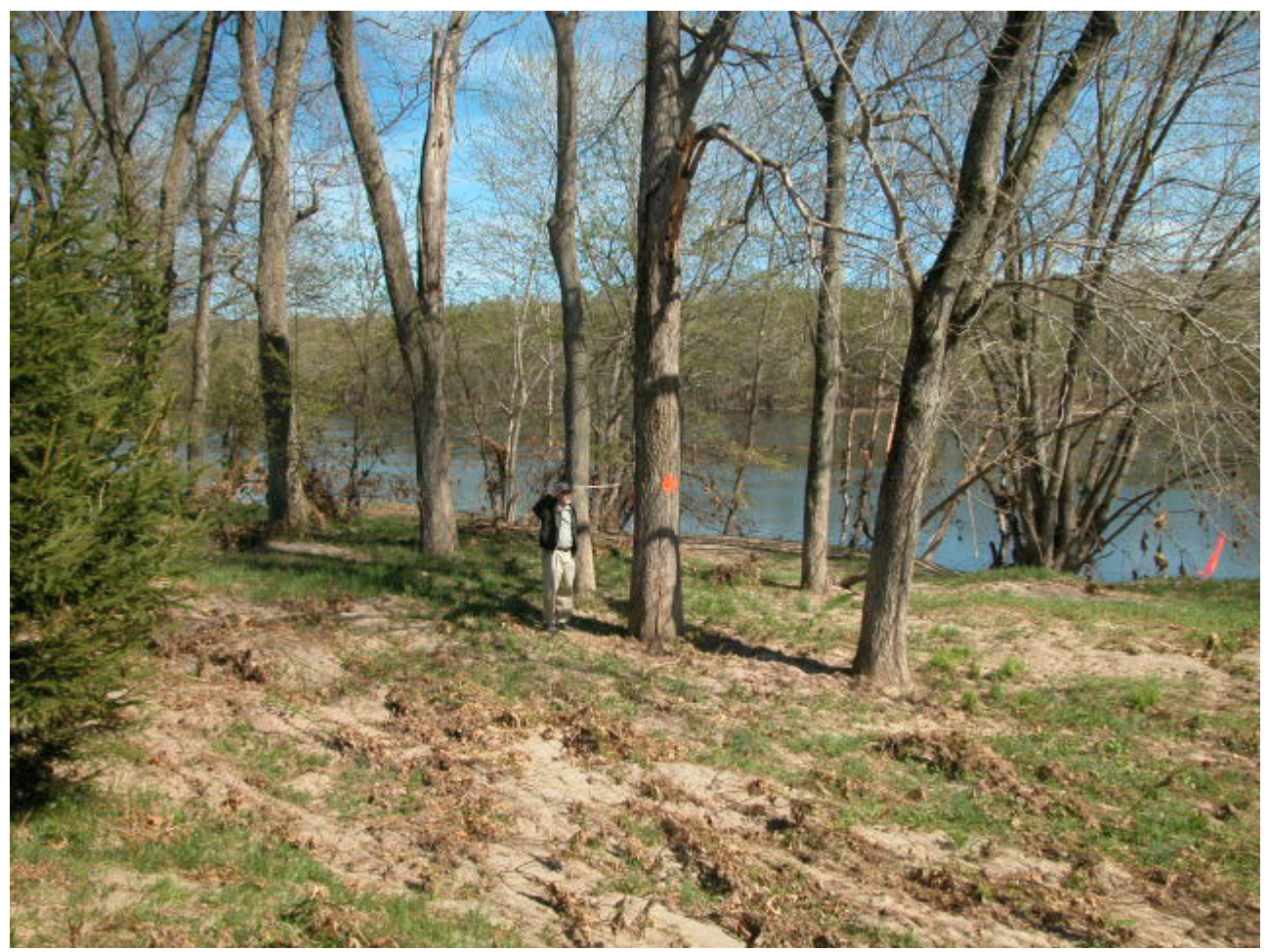

High-water mark PA 1.3 (lat $41^{\circ} 20^{\prime} 57.0^{\prime \prime}$, long $74^{\circ} 43^{\prime} 09.0^{\prime \prime}$ ), at an elevation of 421.6 feet above NGVD 29 , is a poor debris line on a 1.8-foot diameter tree, 6.2 feet above the ground, and was marked with a metal USGS washer and nail.

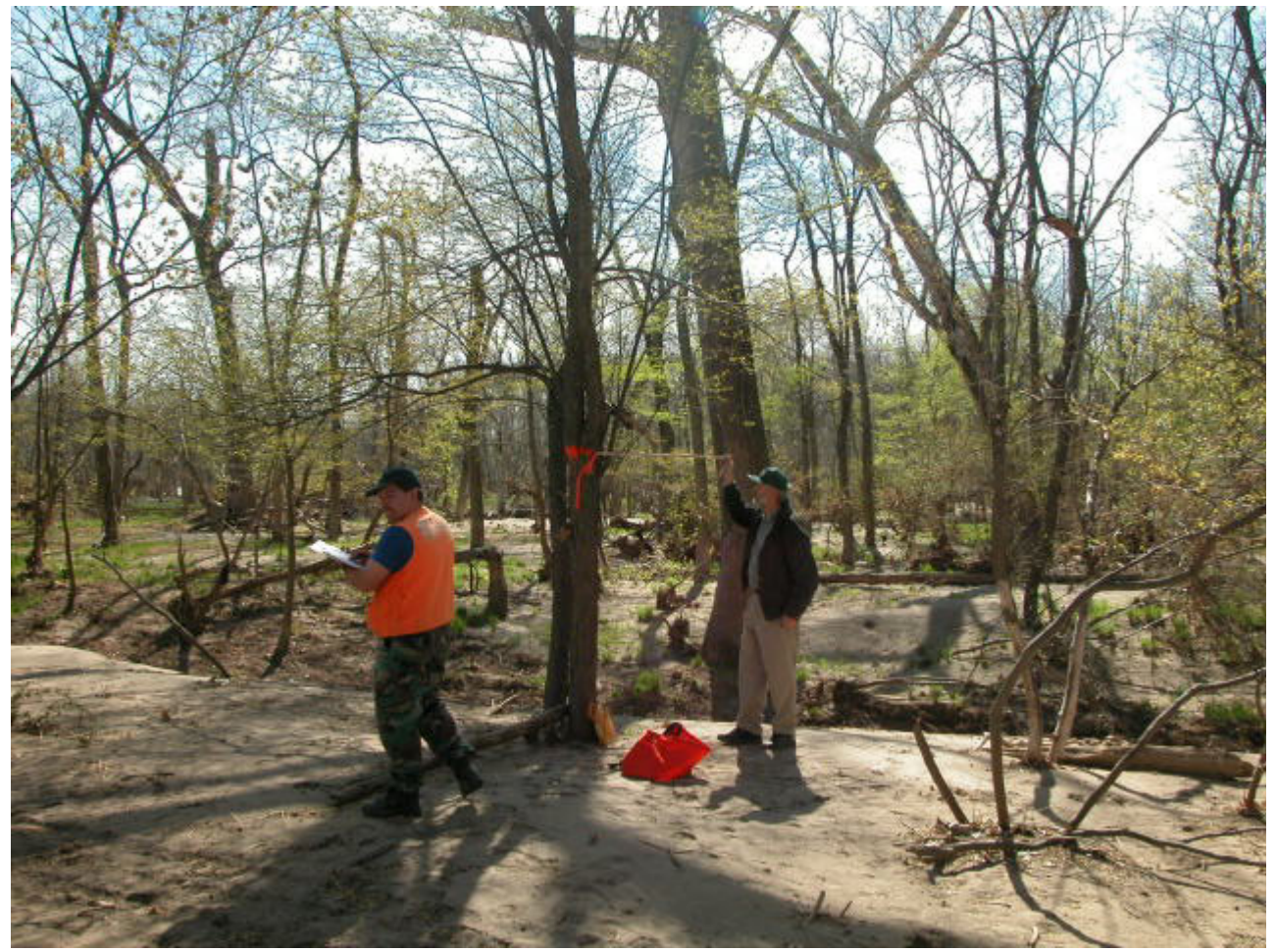

High-water mark PA 1.4 (lat $41^{\circ} 20^{\prime} 56.0^{\prime \prime}$, long $74^{\circ} 43^{\prime} 24.0^{\prime \prime}$ ), at an elevation of 418.8 feet above NGVD 29 , is a good seed line on a 7 -inch diameter tree, 6.4 feet above the ground, and was marked with a metal USGS washer and nail. 


\section{SITE DESCRIPTION}

Site PA 2: Delaware River at New Milford, PA

Site Location: 0.3 mi reach in vicinity of lat $41^{\circ} 18^{\prime} 33^{\prime \prime}$, long $74^{\circ} 47^{\prime} 43^{\prime \prime}$,

Milford Borough, Pike County, PA

Seven high-water marks were surveyed: three mud lines and four seed lines.

High-water mark elevations were determined using USGS reference mark 361 at lat $41^{\circ} 18^{\prime} 37.2^{\prime \prime}$, long $74^{\circ} 47^{\prime} 46.9^{\prime \prime}$ (elevation is 396.53 feet above NAVD 88).

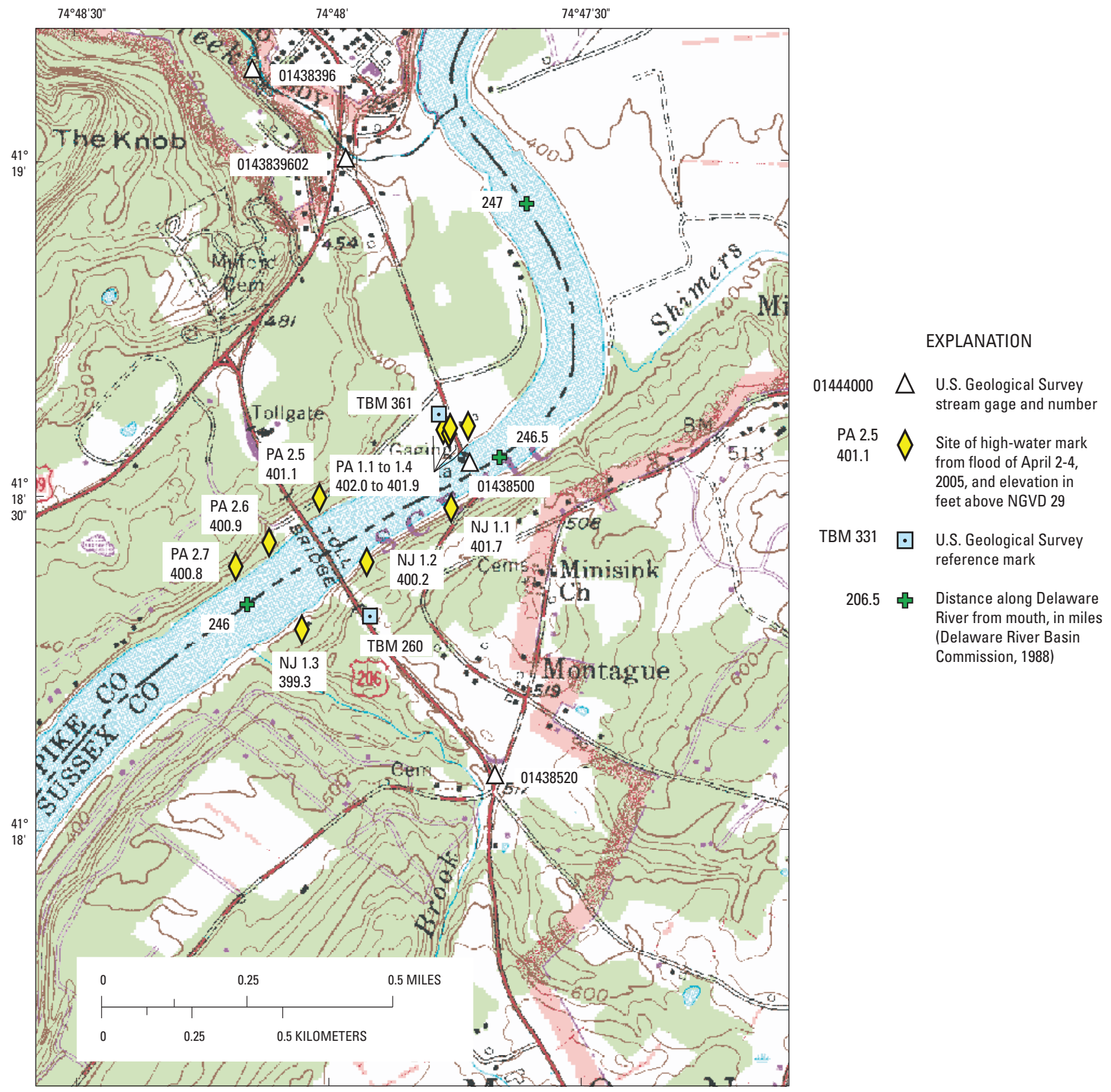

Milford USGS 7.5' Topographic Quadrangle map showing location of site PA 2, Delaware River at New Milford, PA. 


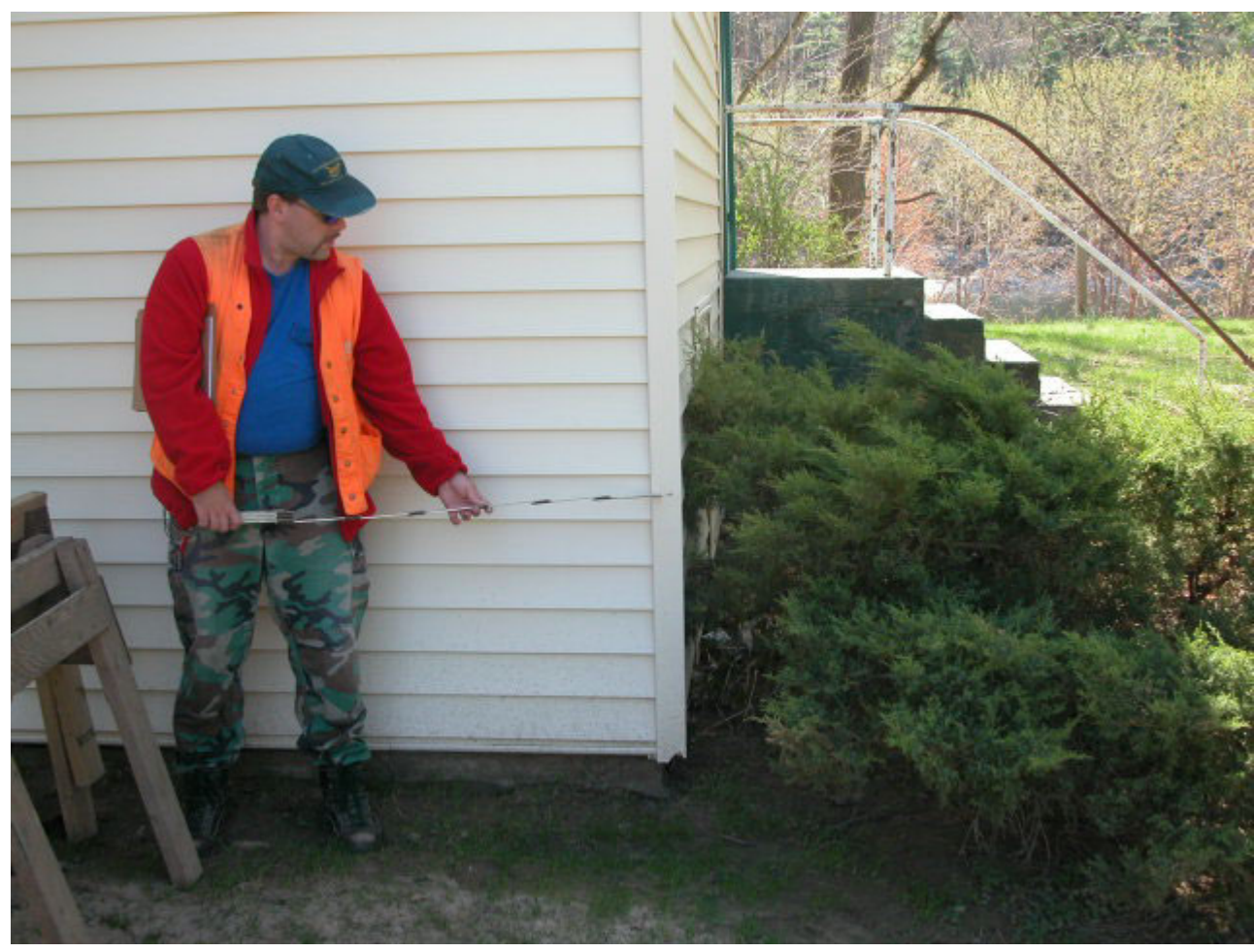

High-water mark PA 2.1 (lat $41^{\circ} 18^{\prime} 36.1^{\prime \prime}$, long $74^{\circ} 47^{\prime} 46.1^{\prime \prime}$ ), at an elevation of 401.8 feet above NGVD 29, is an excellent mud line on a house, 2.6 feet above the ground, 1,400 feet upstream from the US Route 206 bridge, and was marked with a black marker line.

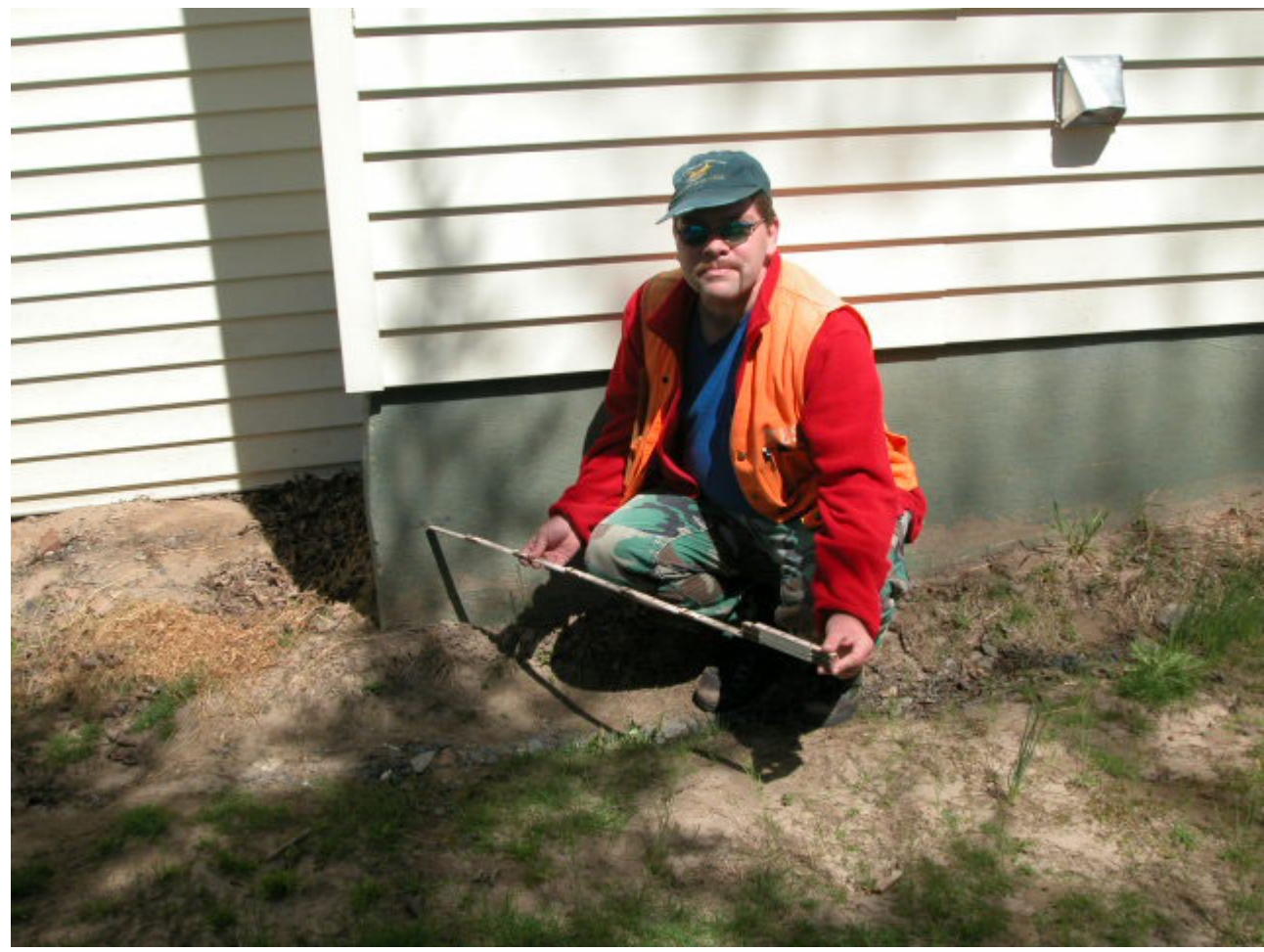

High-water mark PA 2.2 (lat $41^{\circ} 18^{\prime} 35.8^{\prime \prime}$, long $74^{\circ} 47^{\prime} 45.7^{\prime \prime}$ ), at an elevation of 401.9 feet above NGVD 29, is an excellent mud line on a house, 0.8 feet above the ground, 1,400 feet upstream from the US Route 206 bridge, and was marked with a black marker line. 


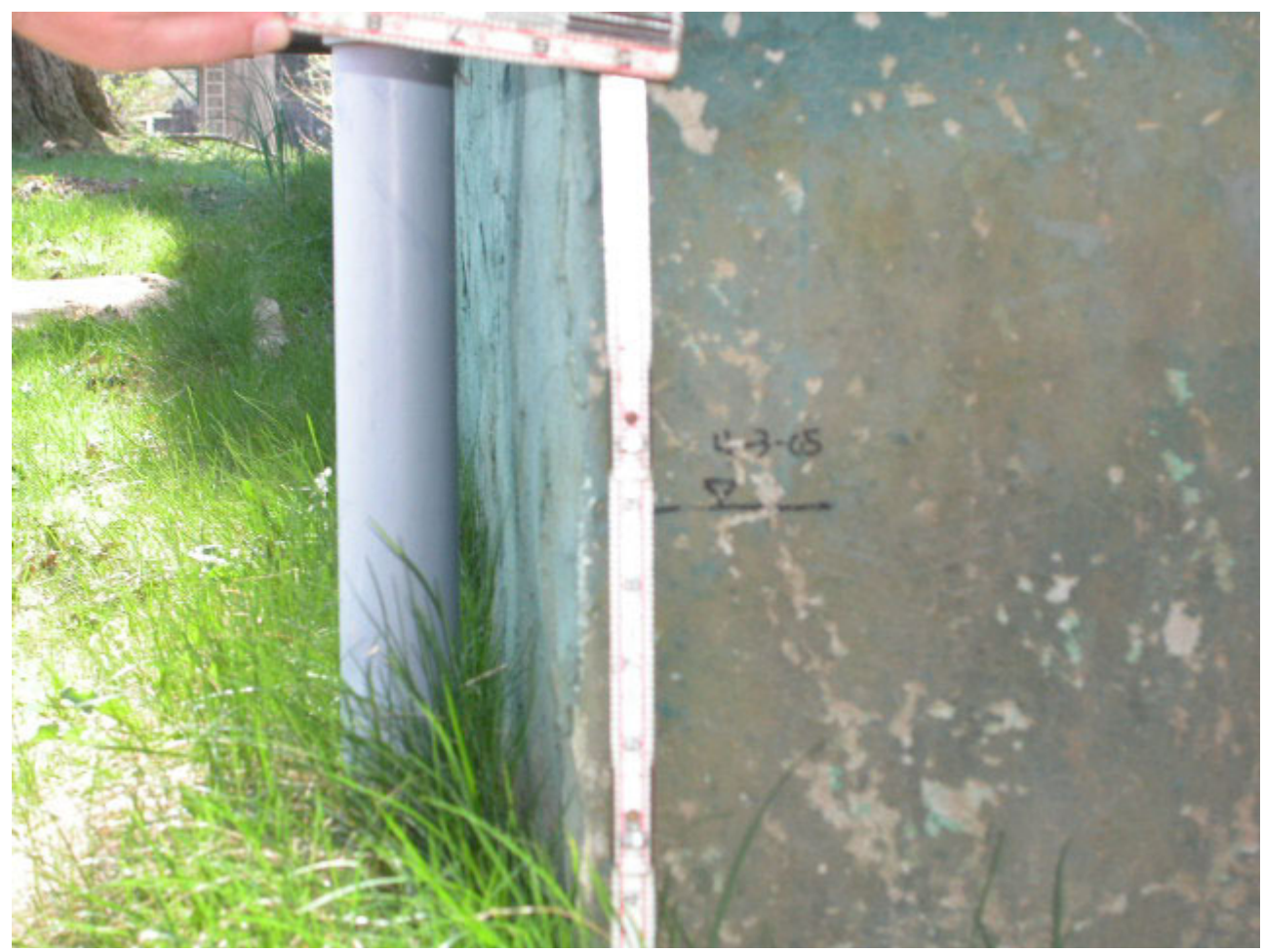

High-water mark PA 2.3 (lat $41^{\circ} 18^{\prime} 36.3^{\prime \prime}$, long $74^{\circ} 47^{\prime} 45.5^{\prime \prime}$ ), at an elevation of 402.0 feet above NGVD 29, is an excellent seed line on a house, 0.9 feet above the ground, 1,400 feet upstream from the US Route 206 bridge, and was marked with a black marker line.

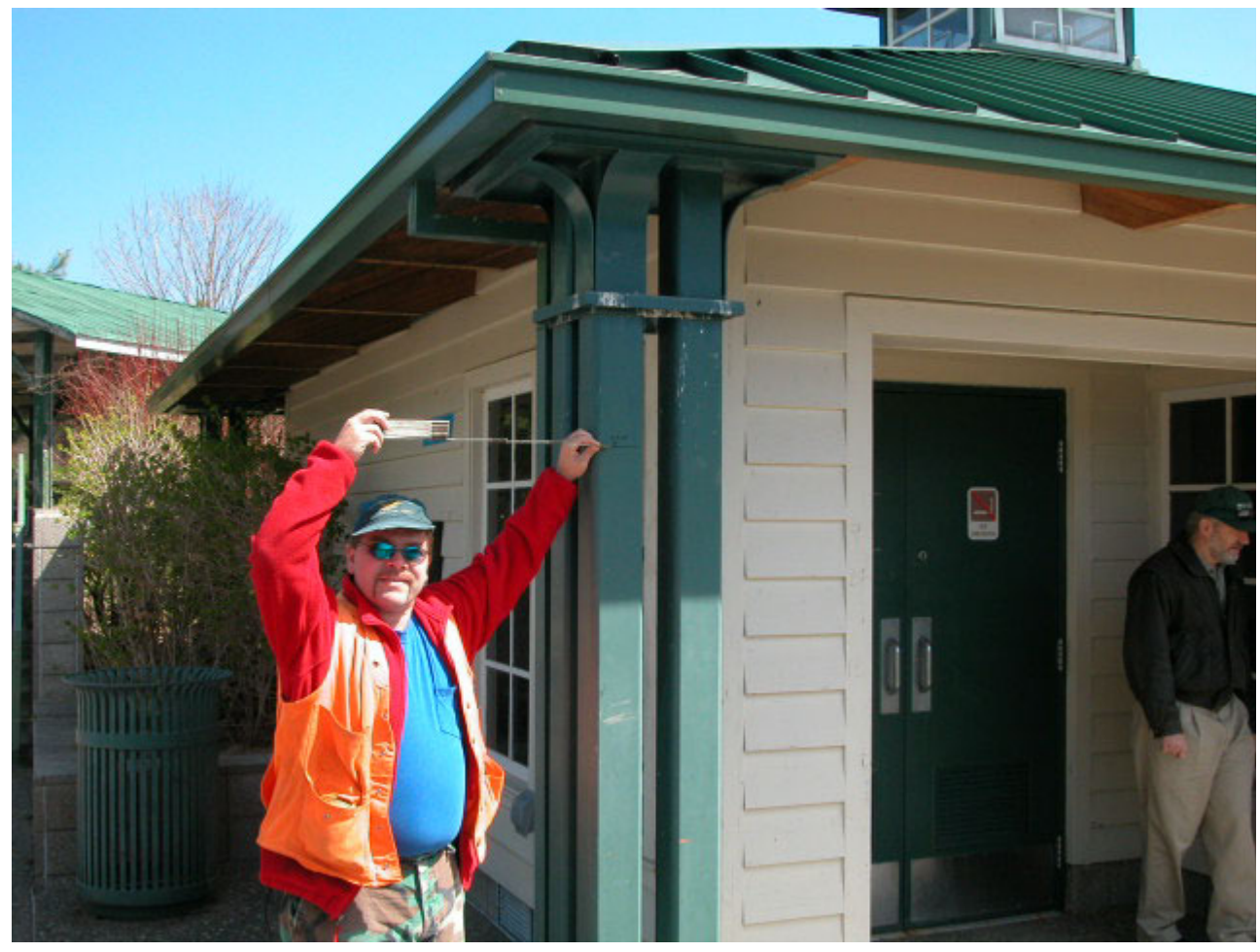

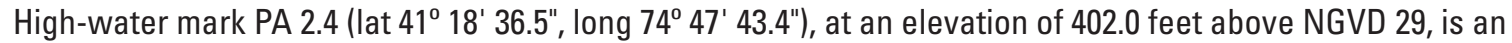
excellent mud line on a first aid building, 5.2 feet above the ground, 1,600 feet upstream from the US Route 206 bridge, and was marked with a black marker line. 


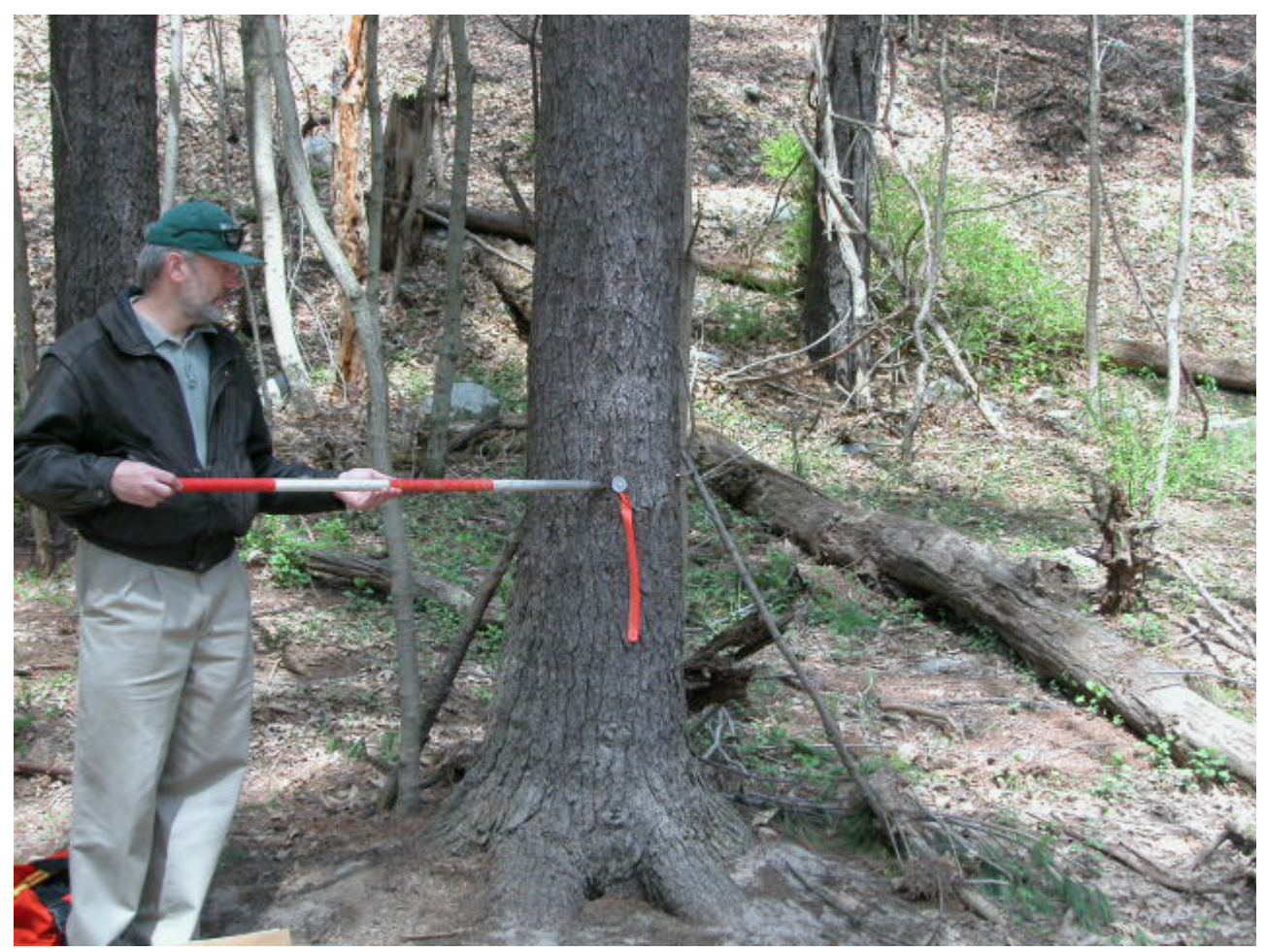

High-water mark PA 2.5 (lat $41^{\circ} 18^{\prime} 30.0^{\prime \prime}$, long $74^{\circ} 48^{\prime} 01.0^{\prime \prime}$ ), at an elevation of 401.1 feet above NGVD 29 , is a good seed line on a 1.2-foot diameter tree, 3.6 feet above the ground, and was marked with a metal USGS washer and nail.

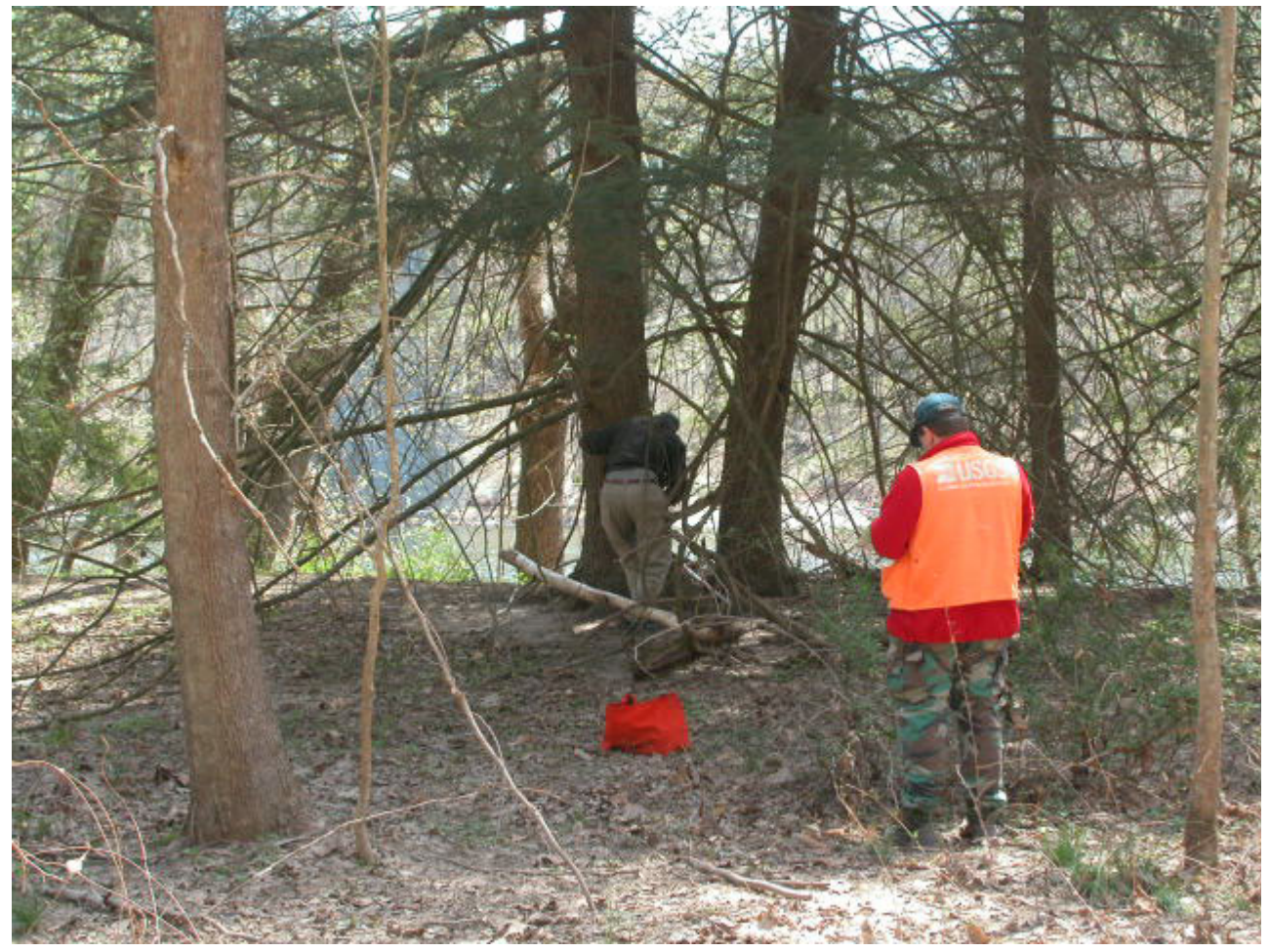

High-water mark PA 2.6 (lat $41^{\circ} 18^{\prime} 26.0^{\prime \prime}$, long $74^{\circ} 48^{\prime} 07.0^{\prime \prime}$ ), at an elevation of 400.9 feet above NGVD 29 , is an excellent seed line on a 1.7-foot diameter tree, 3.4 feet above the ground, and was marked with a metal USGS washer and nail. 


\section{A PHOTOGRAPH OF HIGH-WATER MARK 2.7 is not available}

High-water mark PA 2.7 (lat $41^{\circ} 18^{\prime} 24.0^{\prime \prime}$, long $74^{\circ} 48^{\prime} 11.0^{\prime \prime}$ ), at an elevation of 400.8 feet above NGVD 29 , is an excellent seed line on an 8-inch diameter hemlock tree, 4.5 feet above the ground, and was marked with a metal USGS washer. 


\section{SITE DESCRIPTION}

Site NJ 1: Delaware River at US Route 206 at Montague, NJ

Site Location: 0.4 mi reach in vicinity of lat $41^{\circ} 18^{\prime} 29^{\prime \prime}$, long 74 $47^{\circ} 45^{\prime \prime}$, NAD 1983

Montague Township, Sussex County, NJ

Three high-water marks were surveyed: three seed lines.

High-water-mark elevations were surveyed from USGS Reference Mark 260. USGS Reference

Mark 260 is a metal USGS washer and nail set at lat $41^{\circ} 18^{\prime} 19.1^{\prime \prime}$, long $74^{\circ} 47^{\prime} 55.1^{\prime \prime}$, NAD 1983,

at US Route 206. The elevation of USGS Reference Mark 260 is 490.90 feet above NGVD 1929.

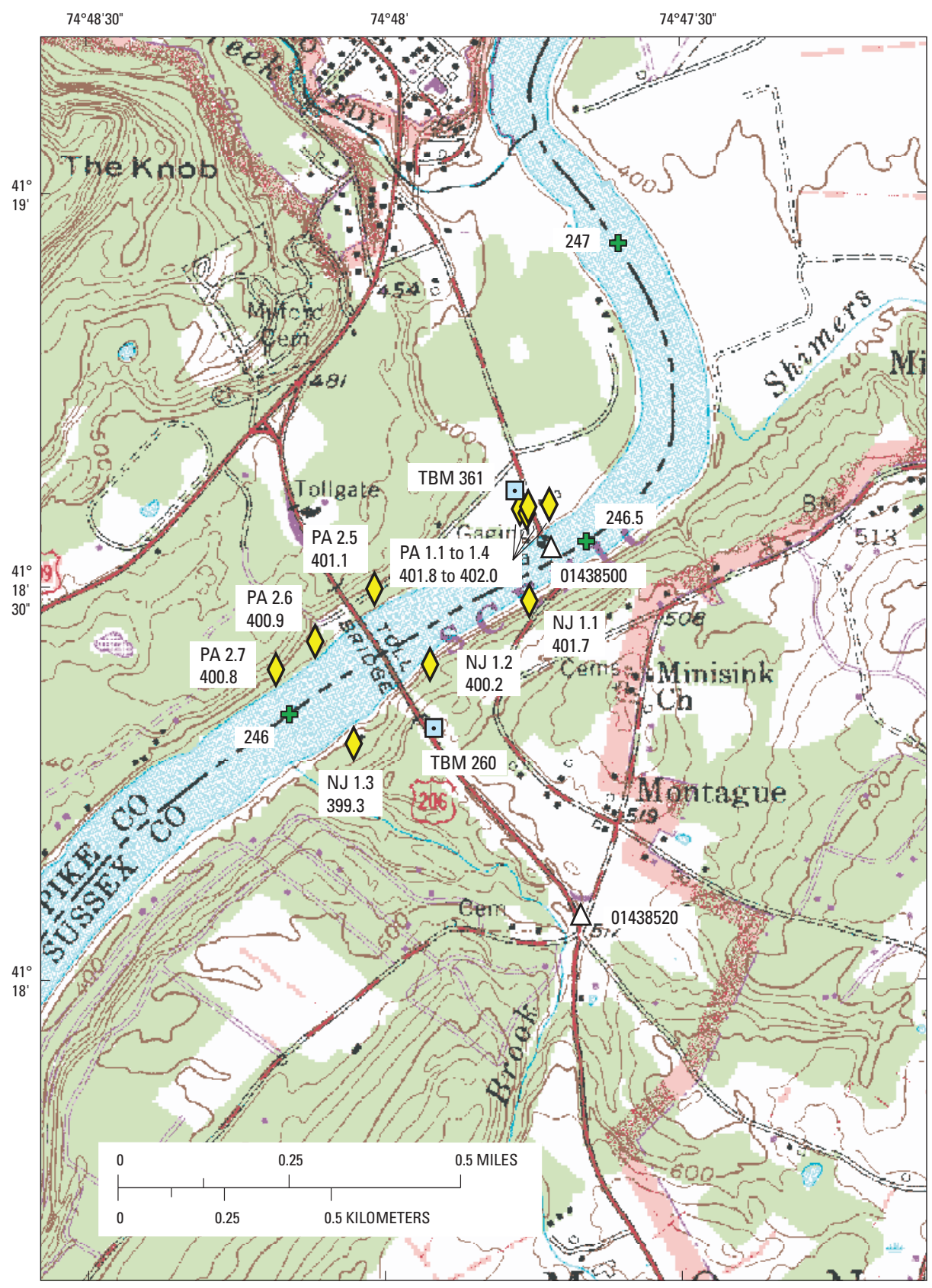

EXPLANATION

$01444000 \triangle \quad$ U.S. Geological Survey stream gage and number

PA 2.5 $\diamond$ Site of high-water mark from flood of April 2-4, 2005, and elevation in feet above NGVD 29

TBM $331 \square \quad$ U.S. Geological Survey reference mark

206.5 Distance along Delaware River from mouth, in miles (Delaware River Basin Commission, 1988)

Milford USGS 7.5' Topographic Quadrangle map showing location of site NJ 1, Delaware River at US Route 206 at Montague, NJ. 


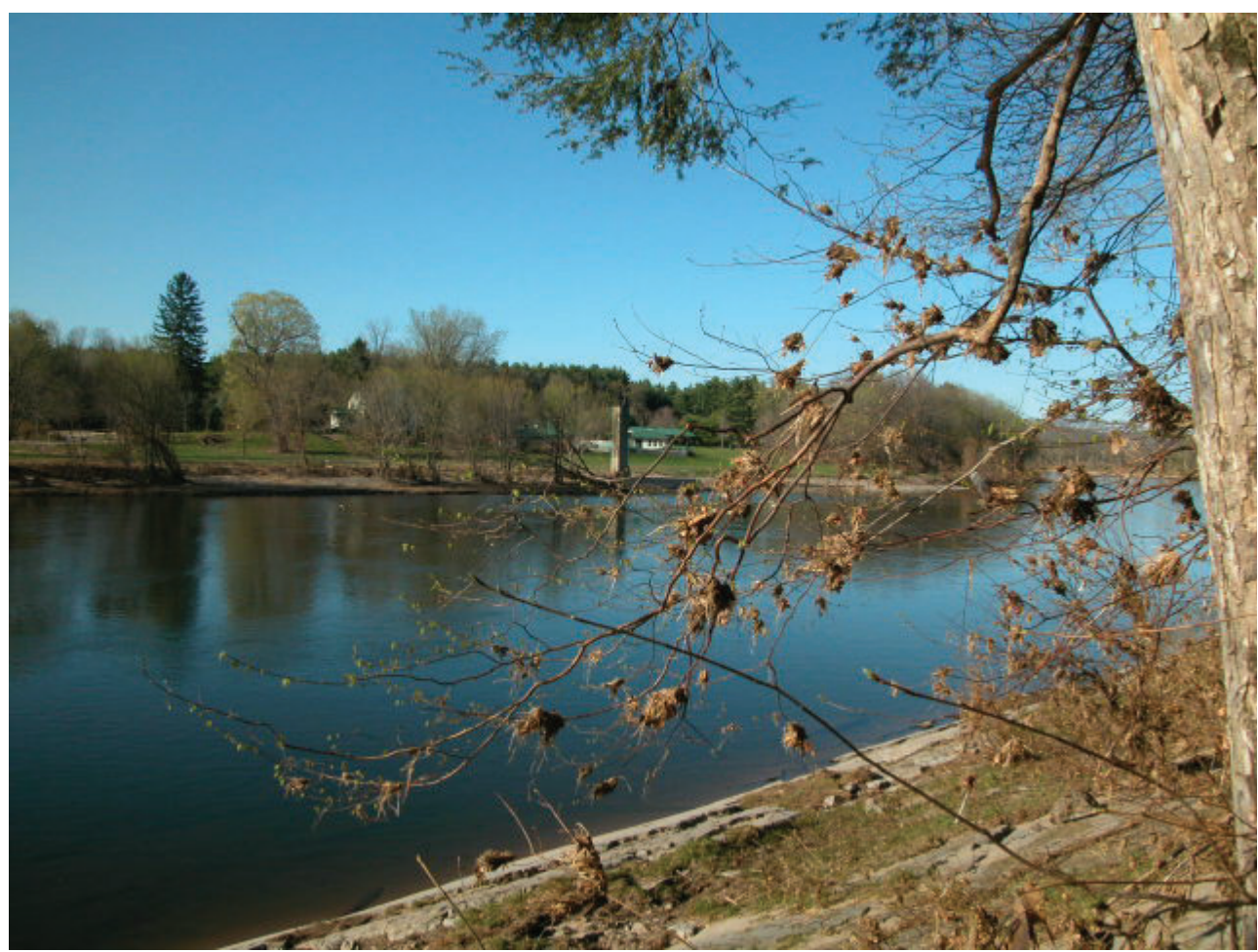

High-water mark NJ 1.1 (lat $41^{\circ} 18^{\prime} 29.2^{\prime \prime}$, long $74^{\circ} 47^{\prime} 45.4^{\prime \prime}$ ), at an elevation of 401.7 feet above NGVD 29, is a fair seed line on a 1-foot diameter tree, 1.2 feet above the ground, 1,200 feet upstream from the US Route 206 bridge, and was marked with a metal USGS washer and nail.

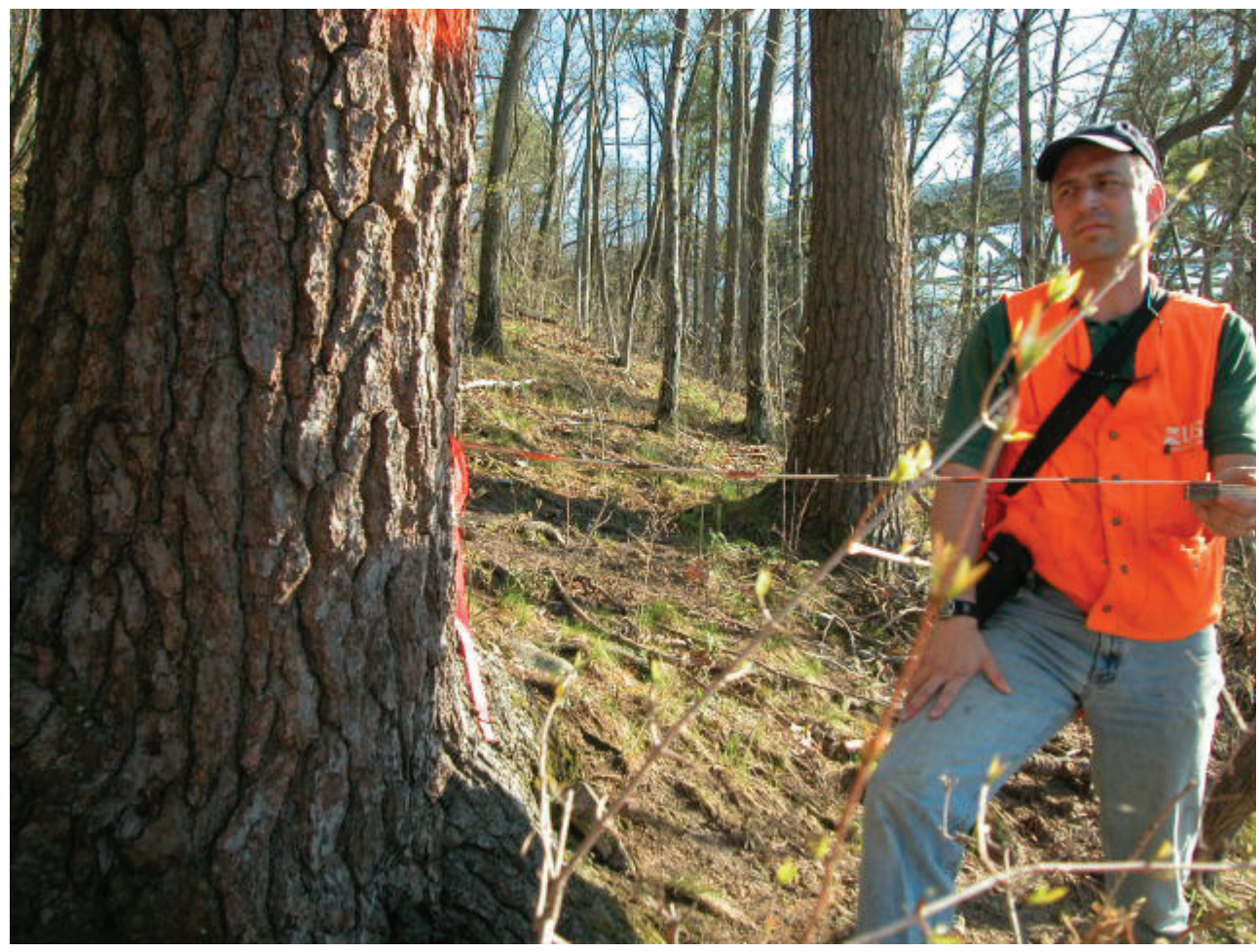

High-water mark NJ 1.2 (lat $41^{\circ} 18^{\prime} 24.3^{\prime \prime}$, long $74^{\circ} 47^{\prime} 55.4^{\prime \prime}$ ), at an elevation of 400.2 feet above NGVD 29, is a fair seed line on a 2-foot diameter tree, 2.8 feet above the ground, 270 feet upstream from the US Route 206 bridge, and was marked with a USGS metal washer and nail. 


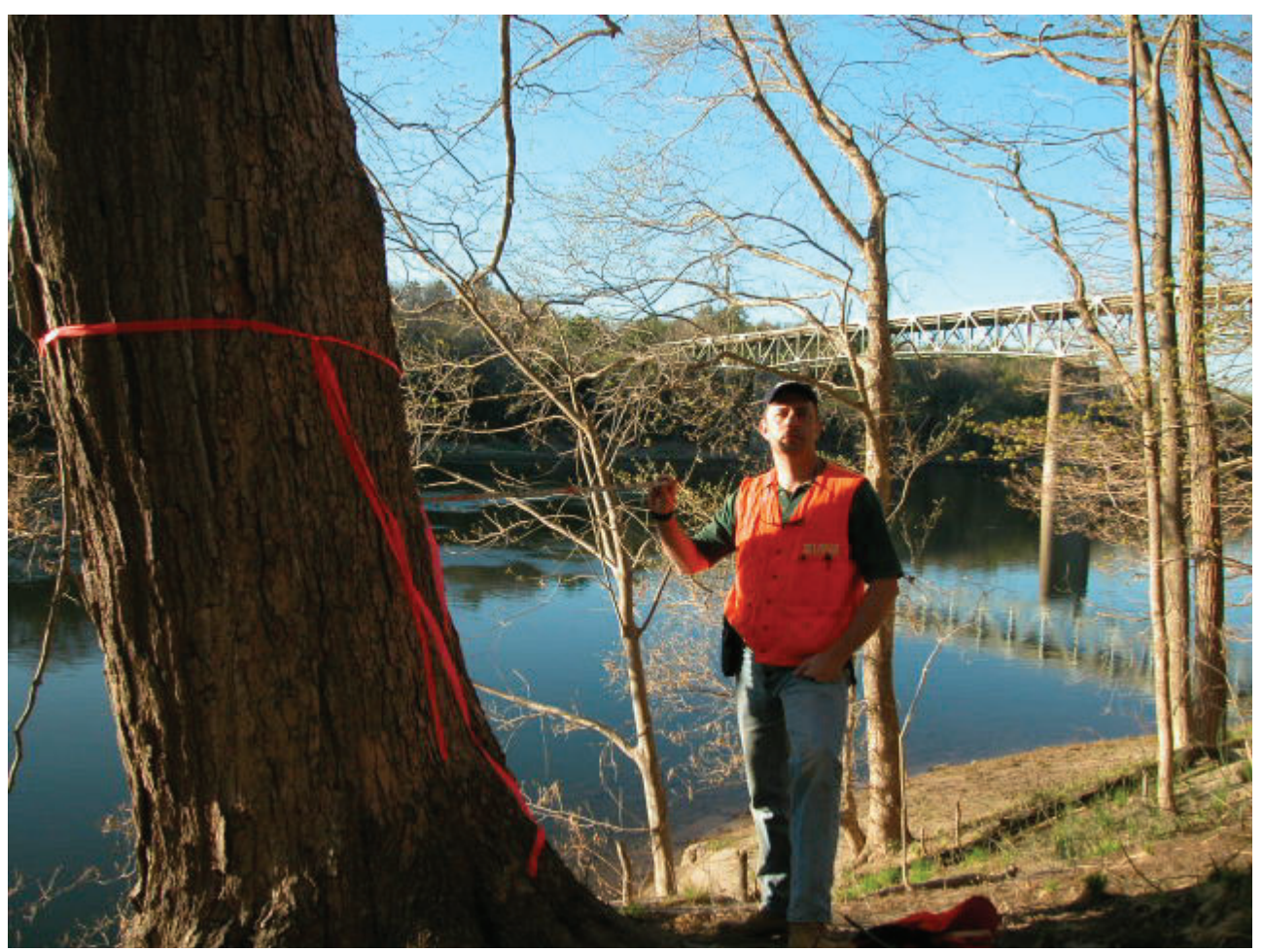

High-water mark NJ 1.3 (lat $41^{\circ} 18^{\prime} 18.3^{\prime \prime}$, long $74^{\circ} 48^{\prime} 03.2^{\prime \prime}$ ) at an elevation of 399.3 feet above NGVD 29 , is a poor seed line on a 3 -foot diameter tree, 5.0 feet above the ground, 500 feet downstream from the US Route 206 bridge, and was marked with a USGS metal washer and nail. 


\section{SITE DESCRIPTION}

Site NJ 2: Delaware River at Dingmans Ferry, NJ

Site Location: 0.4 mi reach in vicinity of lat $41^{\circ} 13^{\prime} 13^{\prime \prime}$, long $74^{\circ} 51^{\prime} 30^{\prime \prime}$

Sandyston Township, Sussex County, NJ

Three high-water marks were surveyed: two seed lines and one wash line.

High-water mark elevations were determined using National Geodetic Survey Benchmark Y 34 at

lat $41^{\circ} 13^{\prime} 12^{\prime \prime}$, long $74^{\circ} 51^{\prime} 27^{\prime \prime}$ (elevation is 385.16 feet above NAVD 88).

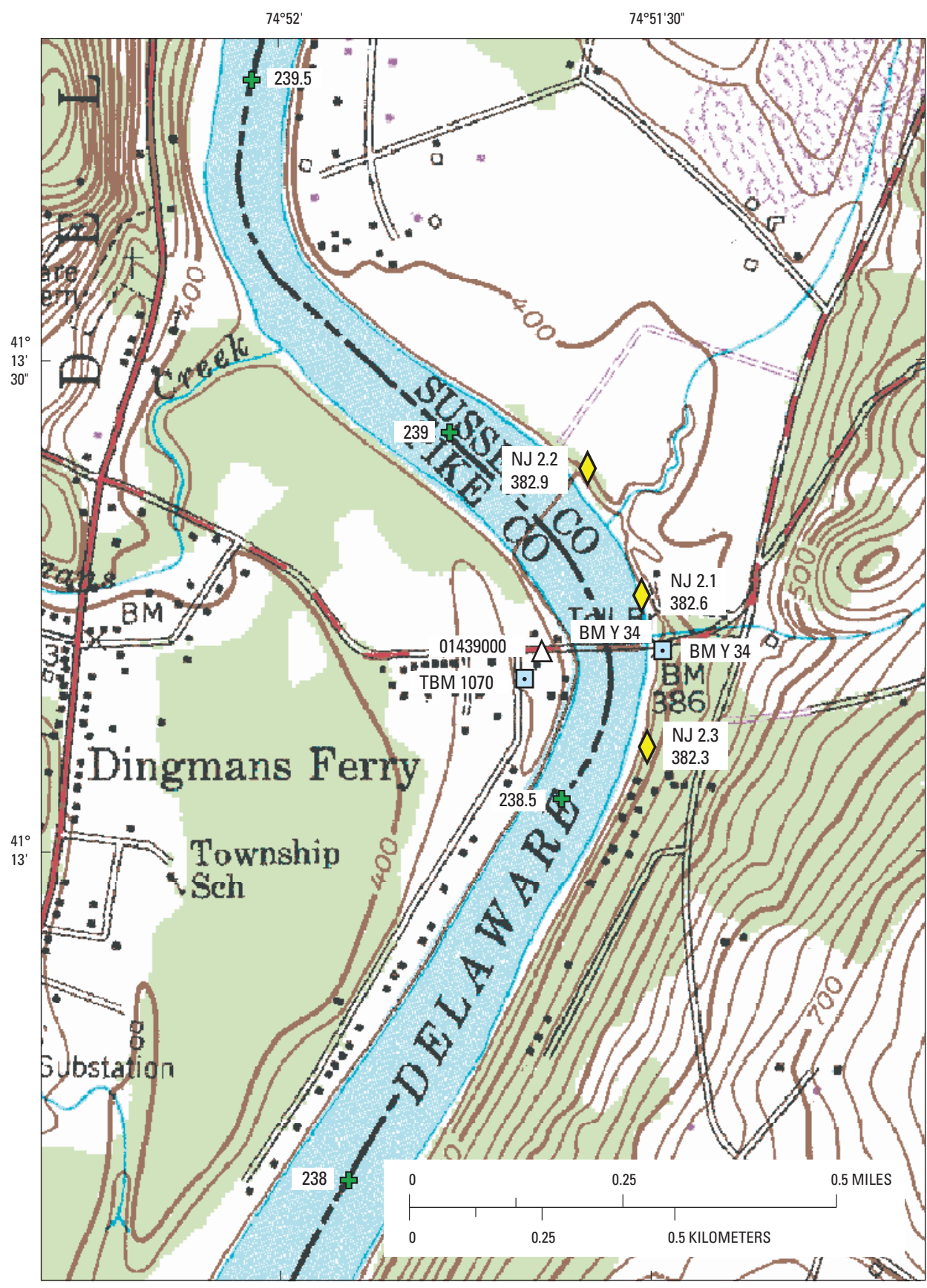

EXPLANATION

$01444000 \triangle \quad$ U.S. Geological Survey stream gage and number

NJ $2.2 \diamond$ Site of high-water mark

382.9 from flood of April 2-4 2005 , and elevation in feet above NGVD 29

TBM $331 \quad$ U.S. Geological Survey reference mark

206.5 Distance along Delaware River from mouth, in miles (Delaware River Basin Commission, 1988)

Culvers Gap USGS 7.5' Topographic Quadrangle map showing location of site NJ 2, Delaware River at Dingmans Ferry, NJ. 


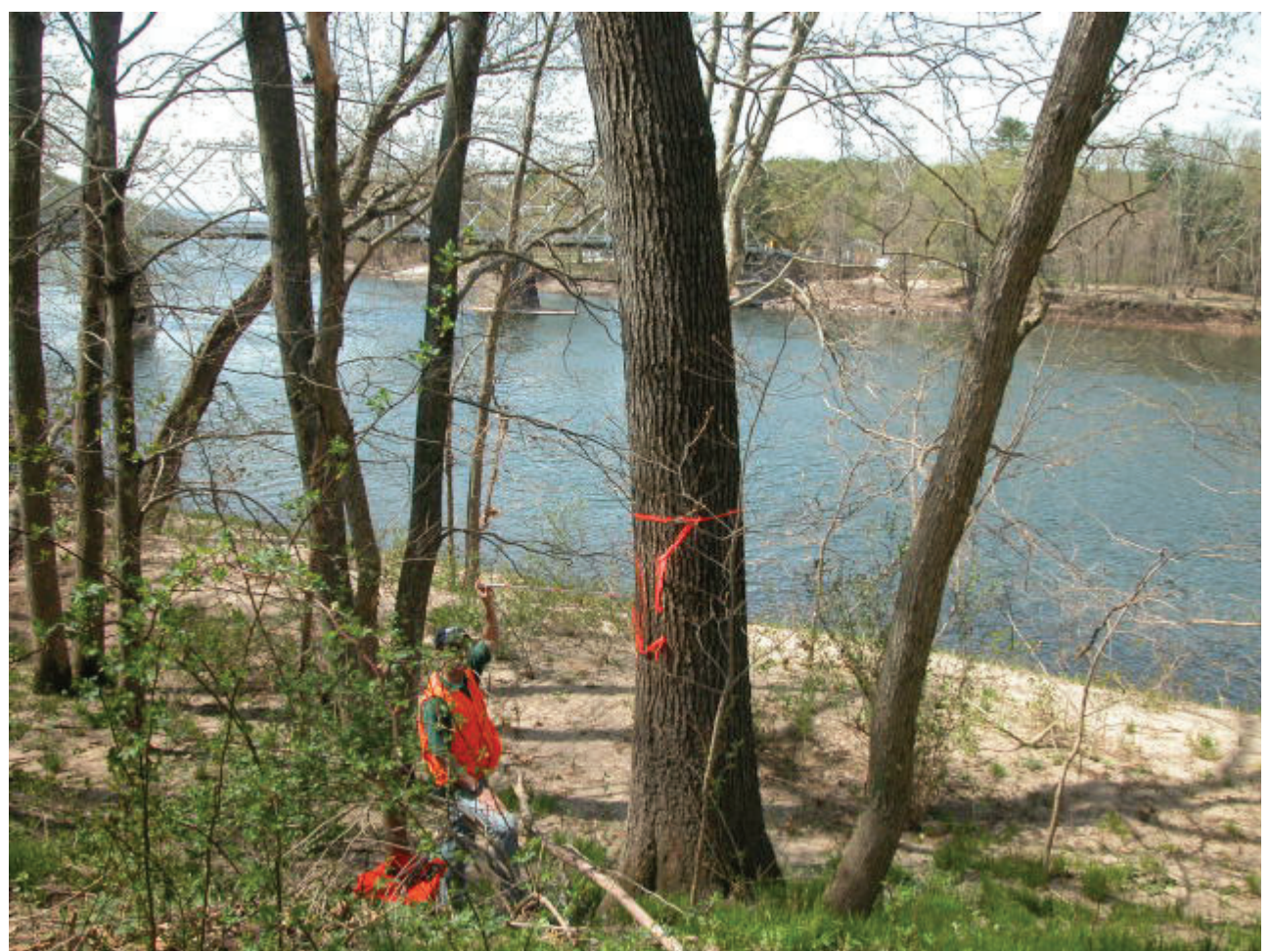

High-water mark NJ 2.1 (lat $41^{\circ} 13^{\prime} 15.9^{\prime \prime}$, long $74^{\circ} 51^{\prime} 30.7^{\prime \prime}$ ), at an elevation of 382.60 feet above NGVD 29 , is an excellent seed line on a 2-foot diameter tree, 6.3 feet above the ground, 400 feet upstream from the Dingmans Ferry bridge, and was marked with a metal USGS washer and nail.

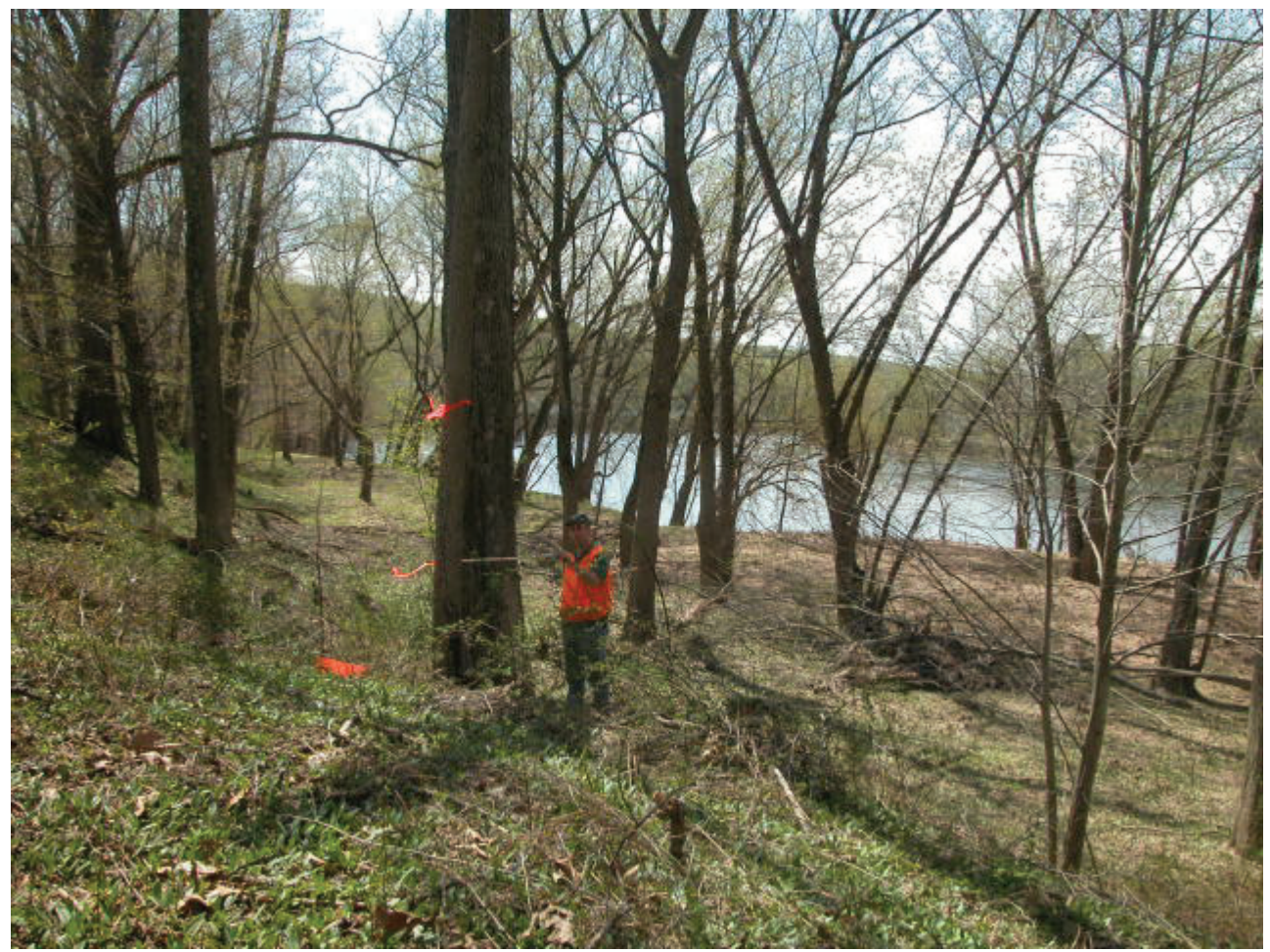

High-water mark NJ 2.2 (lat $41^{\circ} 13^{\prime} 23.6^{\prime \prime}$, long $74^{\circ} 51^{\prime} 35.1^{\prime \prime}$ ), at an elevation of 382.9 feet above NGVD 29 , is a good seed line on a 0.7 -foot diameter tree, 3.5 feet above the ground, 1,200 feet upstream from the Dingmans Ferry bridge, and was marked with a metal USGS washer and nail. 


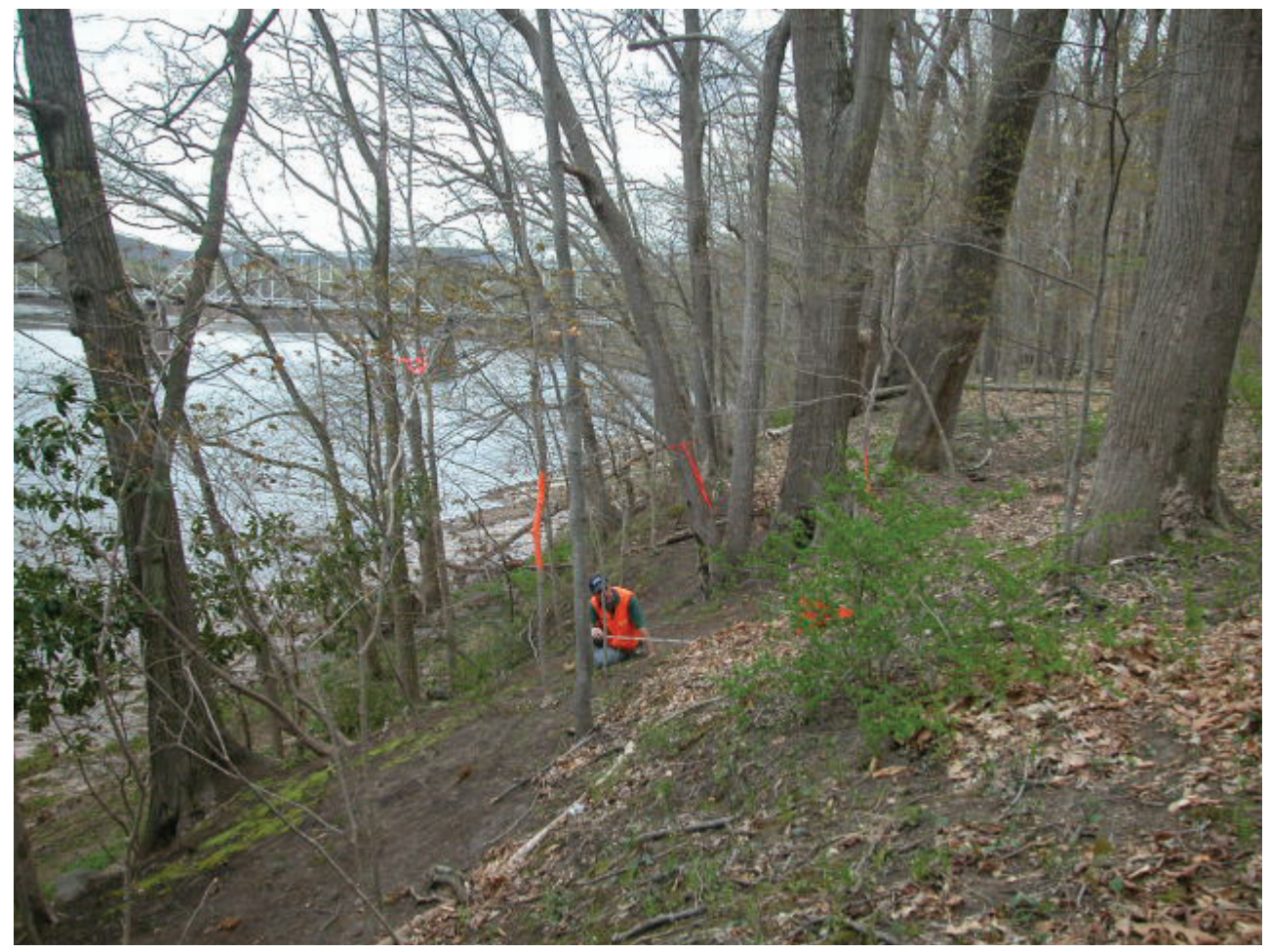

High-water mark NJ 2.3 (lat $41^{\circ} 13^{\prime} 06.6^{\prime \prime}$, long $74^{\circ} 51^{\prime} 30.3^{\prime \prime}$ ), at an elevation of 382.3 feet above NGVD 29 , is a poor wash line on the ground, 600 feet downstream from the Dingmans Ferry bridge, and was marked by painted rebar with orange flagging. 


\section{SITE DESCRIPTION}

Site NJ 3: Delaware River at Flatbrookville, NJ

Site Location: 0.1 mi reach in vicinity of lat $41^{\circ} 05^{\prime} 49^{\prime \prime}$, long $74^{\circ} 58^{\prime} 04^{\prime \prime}$

Walpack Township, Sussex County, NJ

Two high-water marks were surveyed: two seed lines.

High-water mark elevations were determined using USGS reference mark 160 at lat $41^{\circ} 05^{\prime} 47.9^{\prime \prime}$,

long $74^{\circ} 57^{\prime} 58.3^{\prime \prime}$ (elevation is 404.70 feet, NAVD 88) and USGS reference mark 161 at lat $41^{\circ} 05^{\prime}$

$48.9^{\prime \prime}$, long $74^{\circ} 58^{\prime} 08.9^{\prime \prime}$ (elevation is 322.83 feet, NAVD 88).

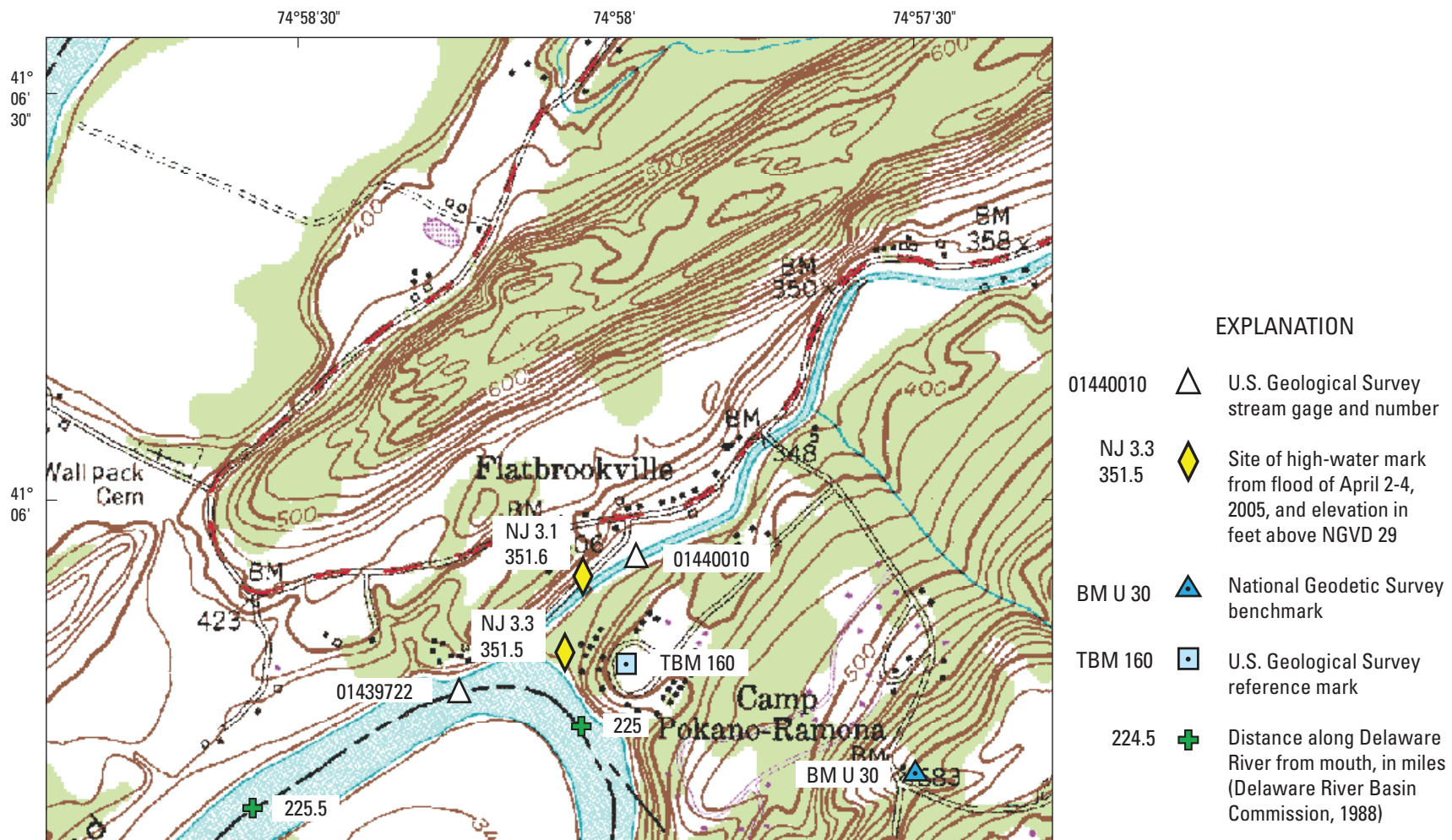

Flatbrookville USGS 7.5' Topographic Quadrangle map showing location of site NJ 3, Delaware River at Flatbrookville, NJ. 


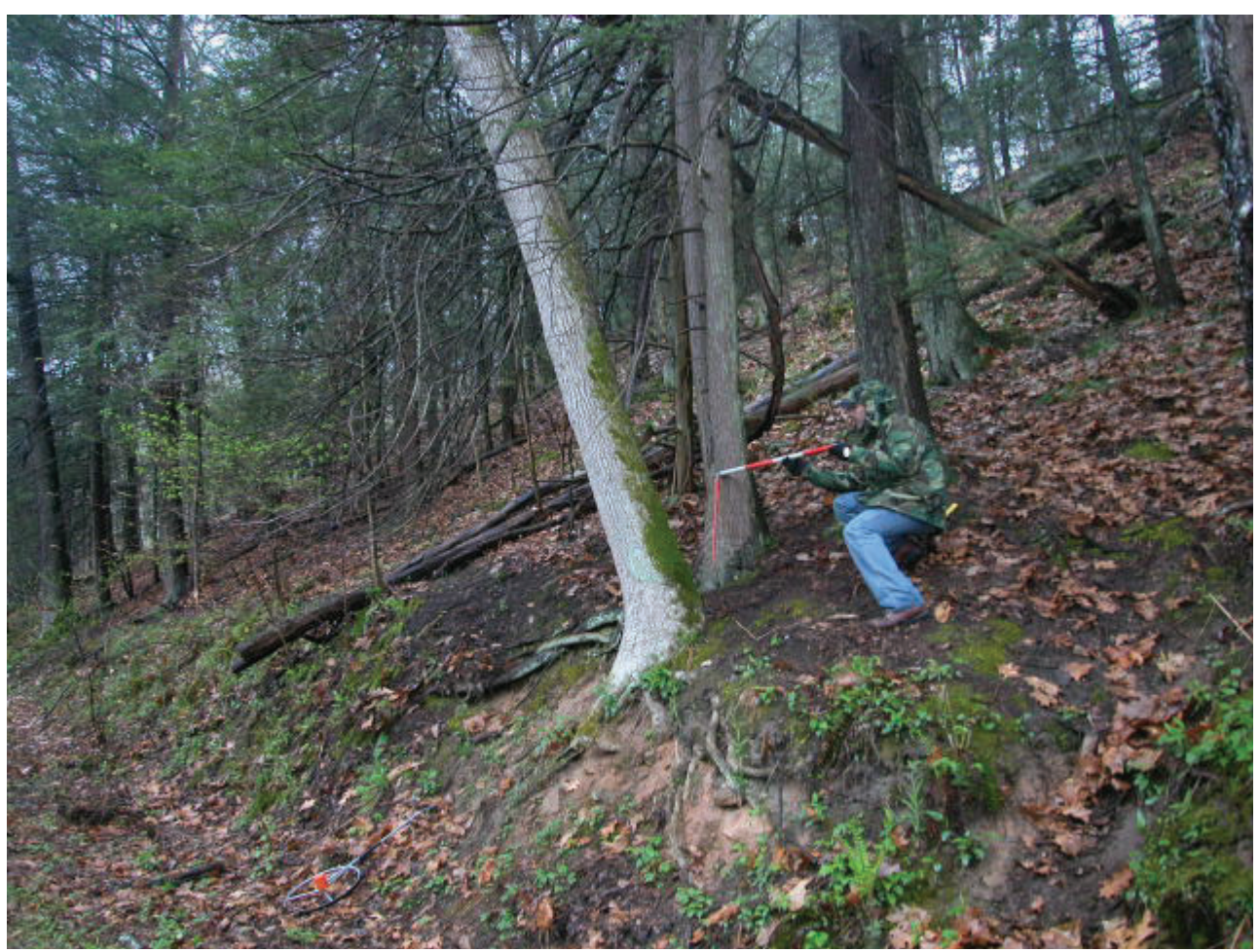

High-water mark NJ 3.1 (lat $41^{\circ} 05^{\prime} 54.6^{\prime \prime}$, long $74^{\circ} 58^{\prime} 02.3^{\prime \prime}$ ), at an elevation of 351.6 feet above NGVD 29 , is a poor seed line on a 1.4-foot diameter tree, 2.6 feet above the ground, on the right bank of Flat Brook, 700 feet upstream from the mouth of Flat Brook, and was marked with a metal USGS washer and nail.

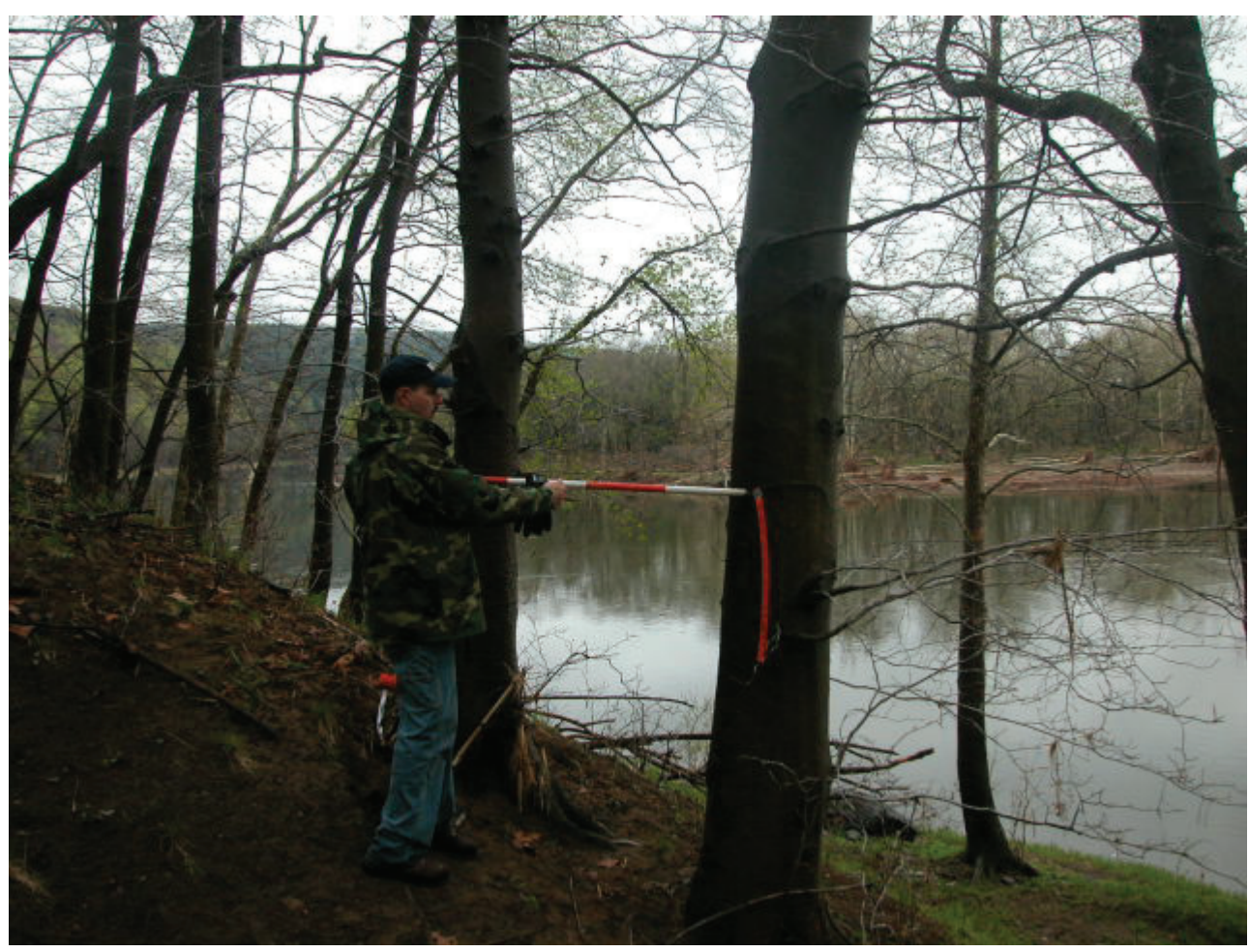

High-water mark NJ 3.3 (lat $41^{\circ} 05^{\prime} 49^{\prime \prime}$, long $74^{\circ} 58^{\prime} 04^{\prime \prime}$ ), at an elevation of 351.5 feet above NGVD 29, is a fair seed line on a 1.3-foot diameter tree, 6 feet above the ground, 400 feet downstream from the mouth of Flat Brook, and was marked with a metal USGS washer and nail. 


\begin{tabular}{|l|}
\hline \multicolumn{1}{|c|}{ SITE DESCRIPTION } \\
\hline Site PA 5: Delaware River at Shawnee Island, PA \\
\hline Site Location: 0.2 mi reach in vicinity of lat $41^{\circ} 00^{\prime} 23^{\prime \prime}$, long $75^{\circ} 06^{\prime} 38^{\prime \prime}$ \\
\hline Smithfield Township, Monroe County, PA \\
\hline Three high-water marks were surveyed: three mud lines. \\
\hline High-water mark elevations were determined using USGS reference mark 240 at lat $41^{\circ} 00^{\prime} 23.7^{\prime \prime}$, \\
long $75^{\circ} 06^{\prime} 35.2^{\prime \prime}$ (elevation is 316.54 feet above NAVD 88 ). \\
\hline
\end{tabular}

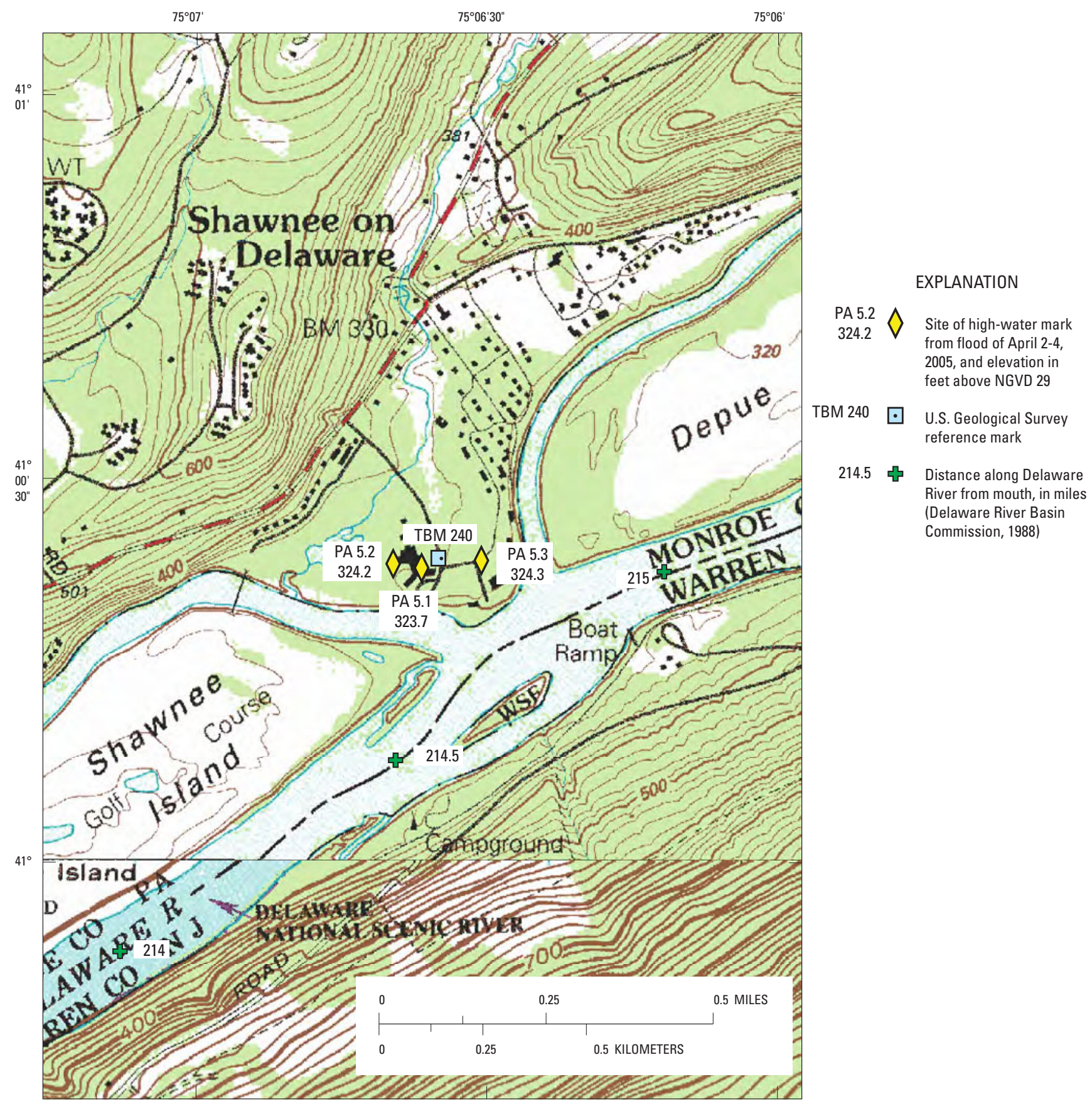

Bushkill USGS 7.5' Topographic Quadrangle map showing location of site PA 5, Delaware River at Shawnee Island, PA. 


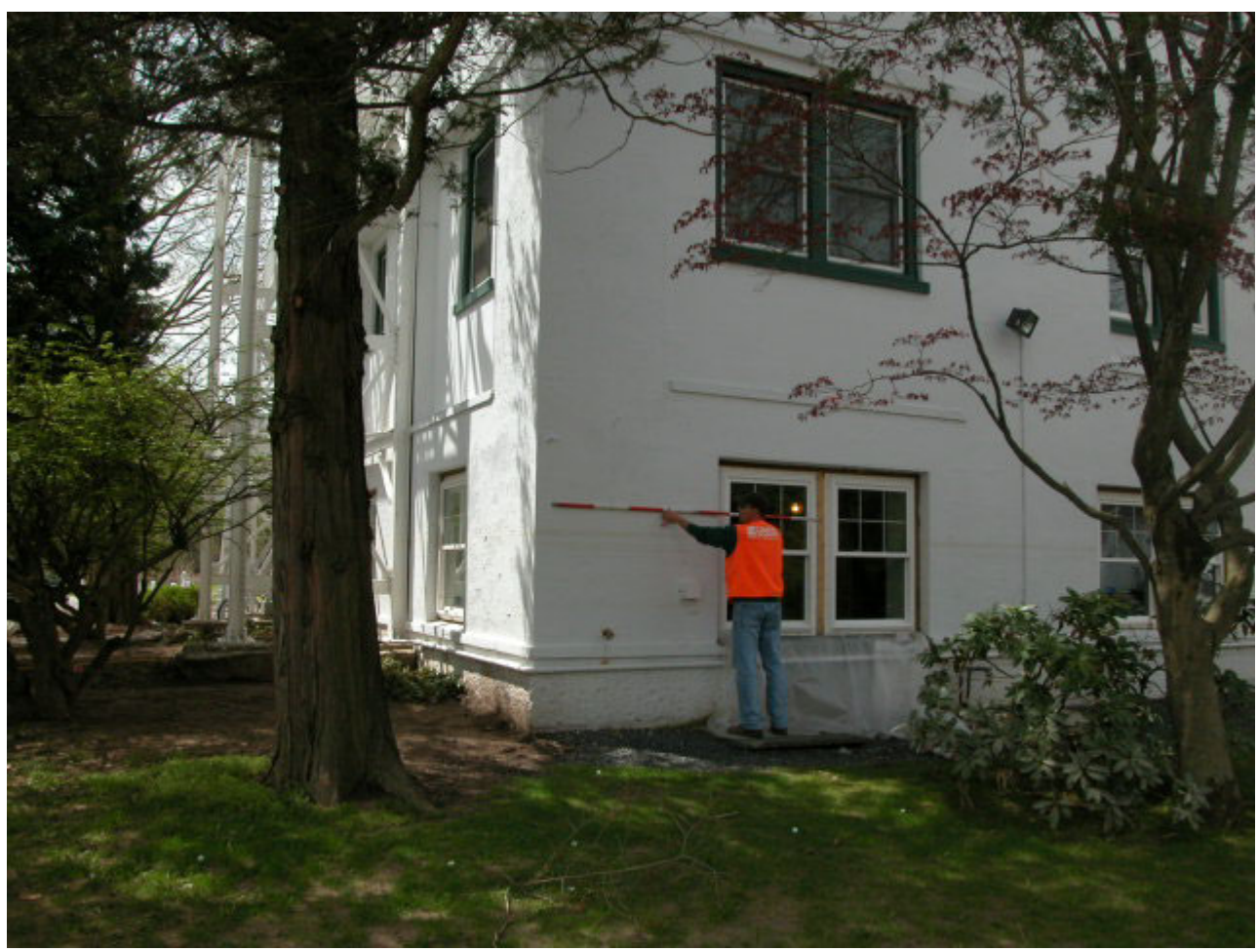

High-water mark PA 5.1 (lat $41^{\circ} 00^{\prime} 23.2^{\prime \prime}$, long $75^{\circ} 06^{\prime} 36.7^{\prime \prime}$ ), at an elevation of 323.7 feet above NGVD 29 , is an excellent mud line on a building (Shawnee Inn), 5.8 feet above the ground, and was marked with a metal USGS washer and nail.

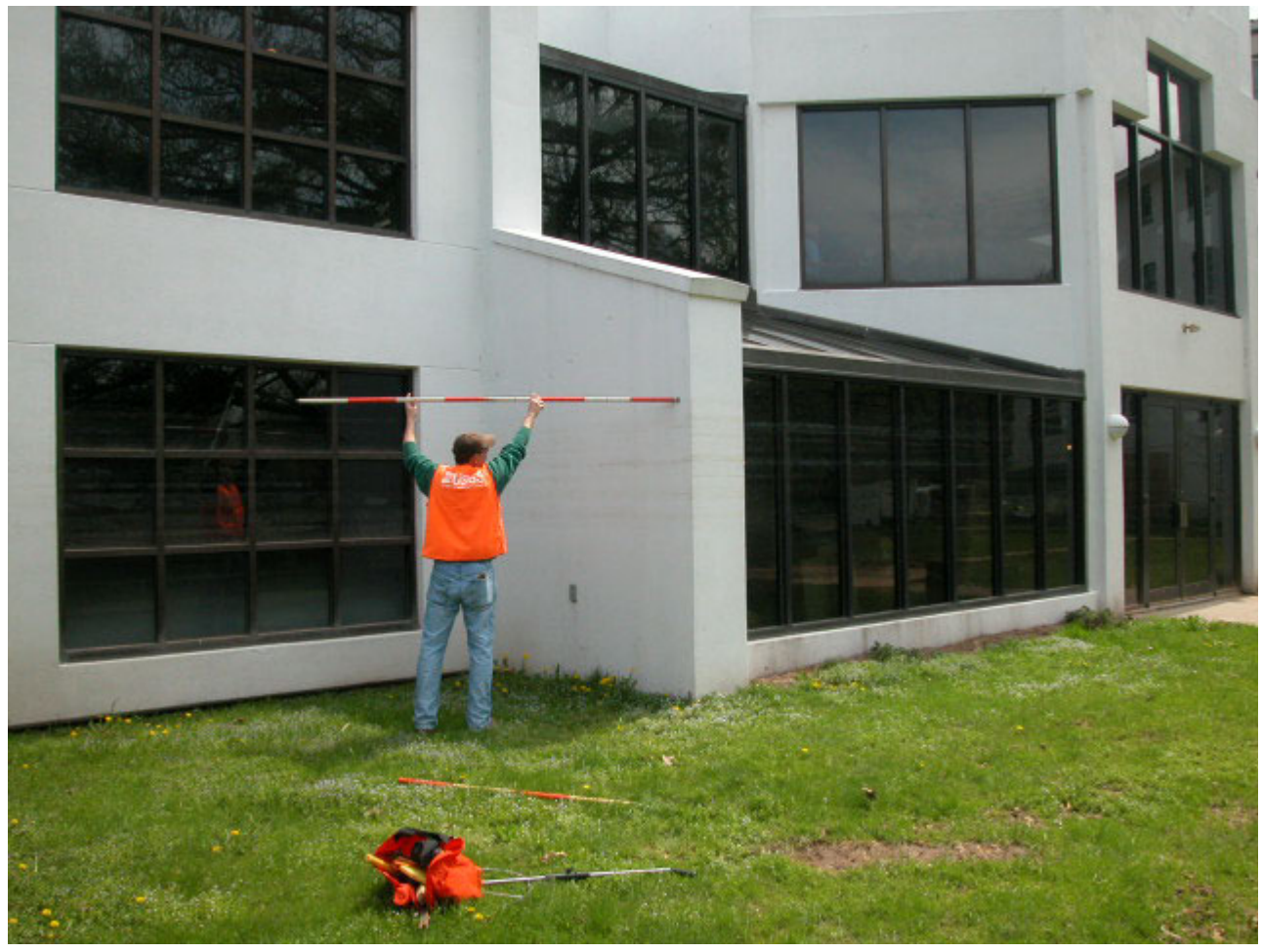

High-water mark PA 5.2 (lat $41^{\circ} 00^{\prime} 23.5^{\prime \prime}$, long $75^{\circ} 06^{\prime} 39.7^{\prime \prime}$ ), at an elevation of 324.2 feet above NGVD 29, is an excellent mud line on a building (Shawnee Inn), 6.8 feet above the ground, and was marked with a metal USGS washer and nail. 


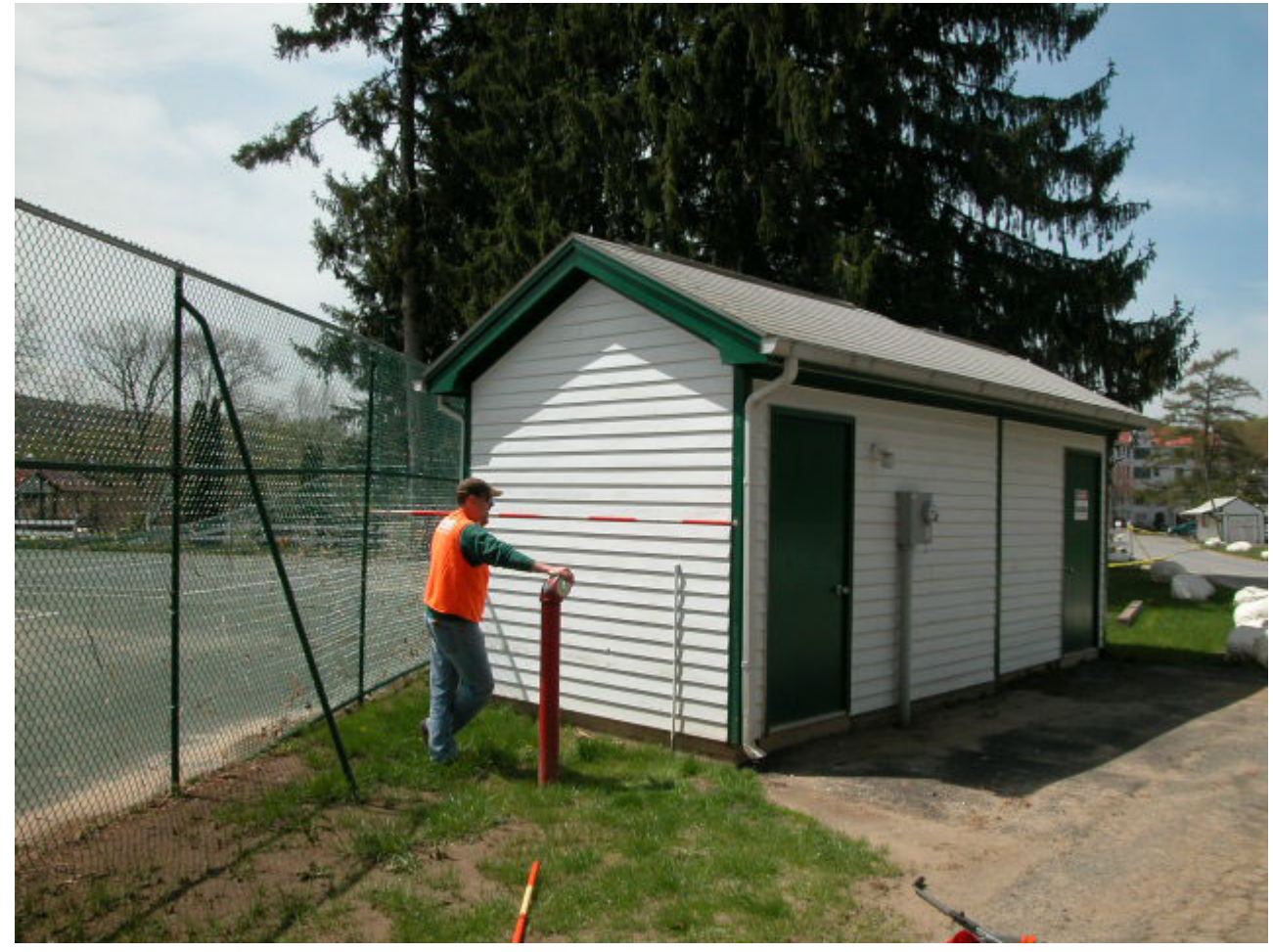

High-water mark PA 5.3 (lat $41^{\circ} 00^{\prime} 23.8^{\prime \prime}$, long $75^{\circ} 06^{\prime} 30.6^{\prime \prime}$ ), at an elevation of 324.3 feet above NGVD 29, is an excellent mud line on a building (pool maintenance shed), 5.2 feet above the ground, near the Shawnee Inn, and was marked with a metal USGS washer and nail. 


\begin{tabular}{|c|}
\hline SITE DESCRIPTION \\
\hline Site PA 6: Delaware River at Delaware Water Gap, PA \\
\hline Site Location: 0.3 mile reach in vicinity of lat $40^{\circ} 58^{\prime} 47^{\prime \prime}$, long $75^{\circ} 08^{\prime} 20^{\prime \prime}$ \\
\hline Smithfield Township, Monroe County, PA \\
\hline Four high-water marks were surveyed: two mud lines, one seed line, and one debris line. \\
\hline $\begin{array}{l}\text { High-water mark elevations were determined using USGS reference mark } 140 \text { at lat } 40^{\circ} 58^{\prime} 58.2^{\prime \prime} \text {, } \\
\text { long } 75^{\circ} 08^{\prime} 12.2^{\prime \prime} \text { (elevation is } 313.90 \text { feet above NAVD } 88 \text { ). }\end{array}$ \\
\hline
\end{tabular}

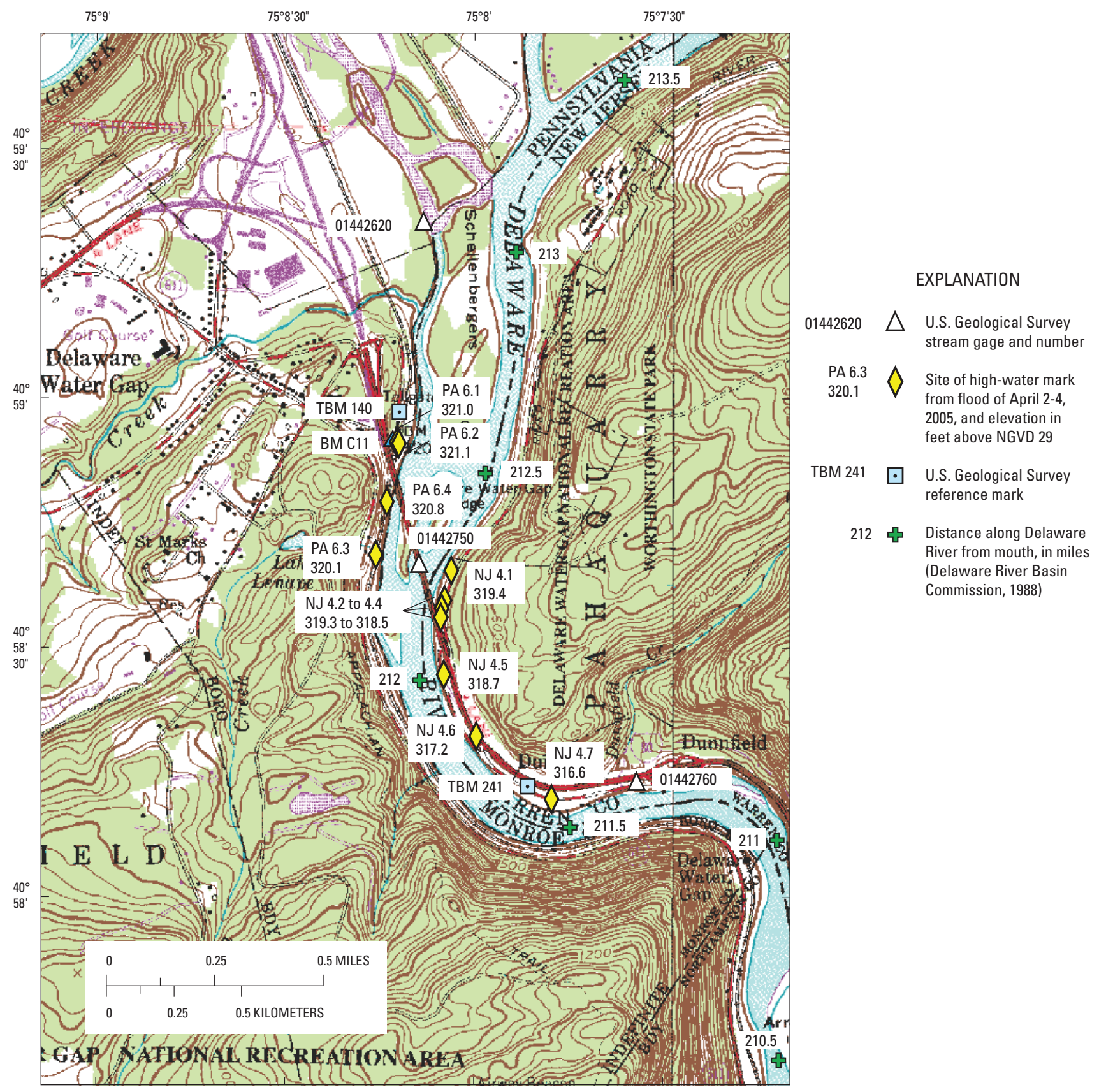

Stroudsburg USGS 7.5' Topographic Quadrangle map showing location of site PA 6, Delaware River at Delaware Water Gap, PA. 


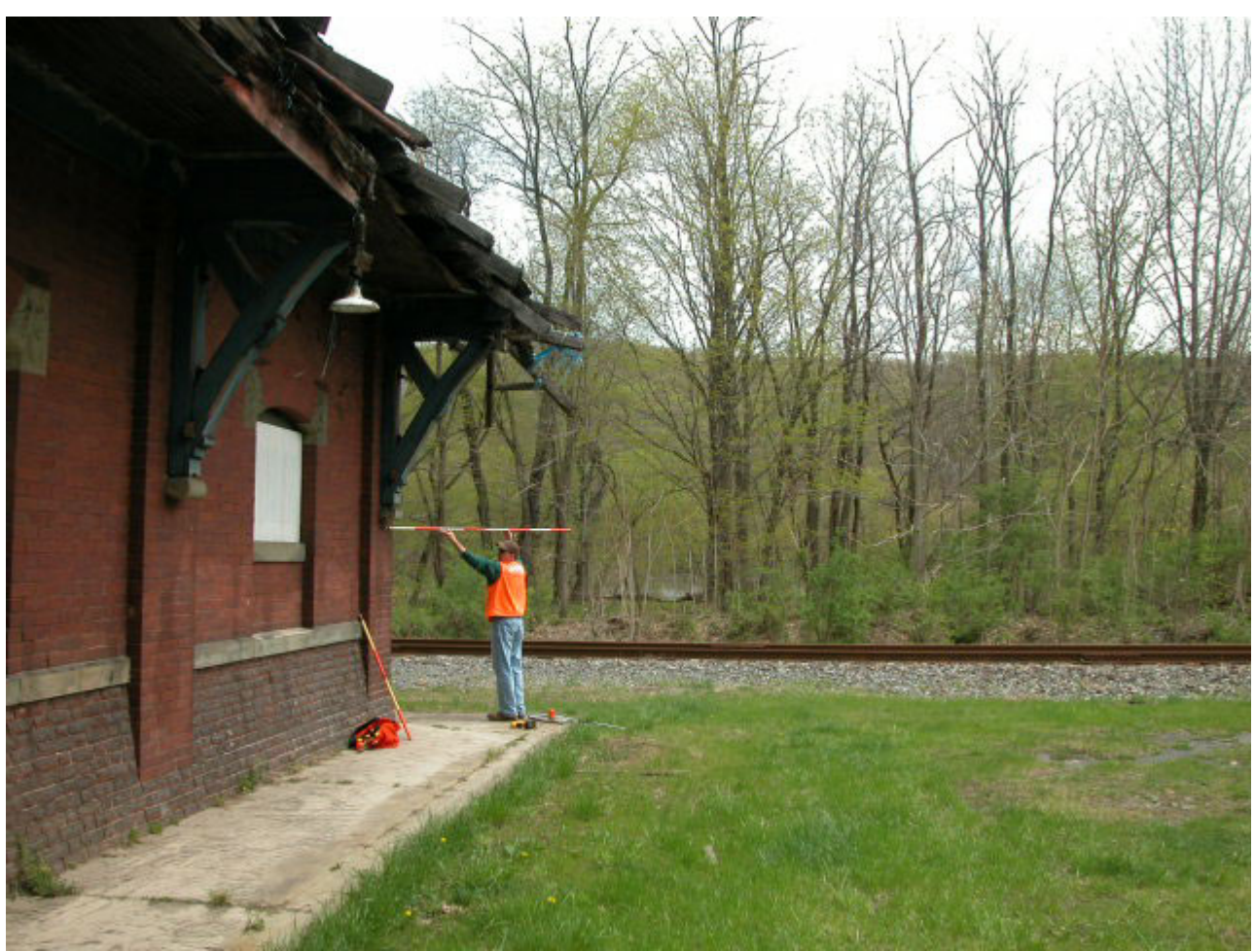

High-water mark PA 6.1 (lat $40^{\circ} 58^{\prime} 55.0^{\prime \prime}$, long $75^{\circ} 08^{\prime} 12.5^{\prime \prime}$ ), at an elevation of 321.0 feet above NGVD 29 , is an excellent mud line on a railroad train station, 6.4 feet above the ground, just upstream from Interstate Route 80 , and was marked with a metal USGS washer and nail.

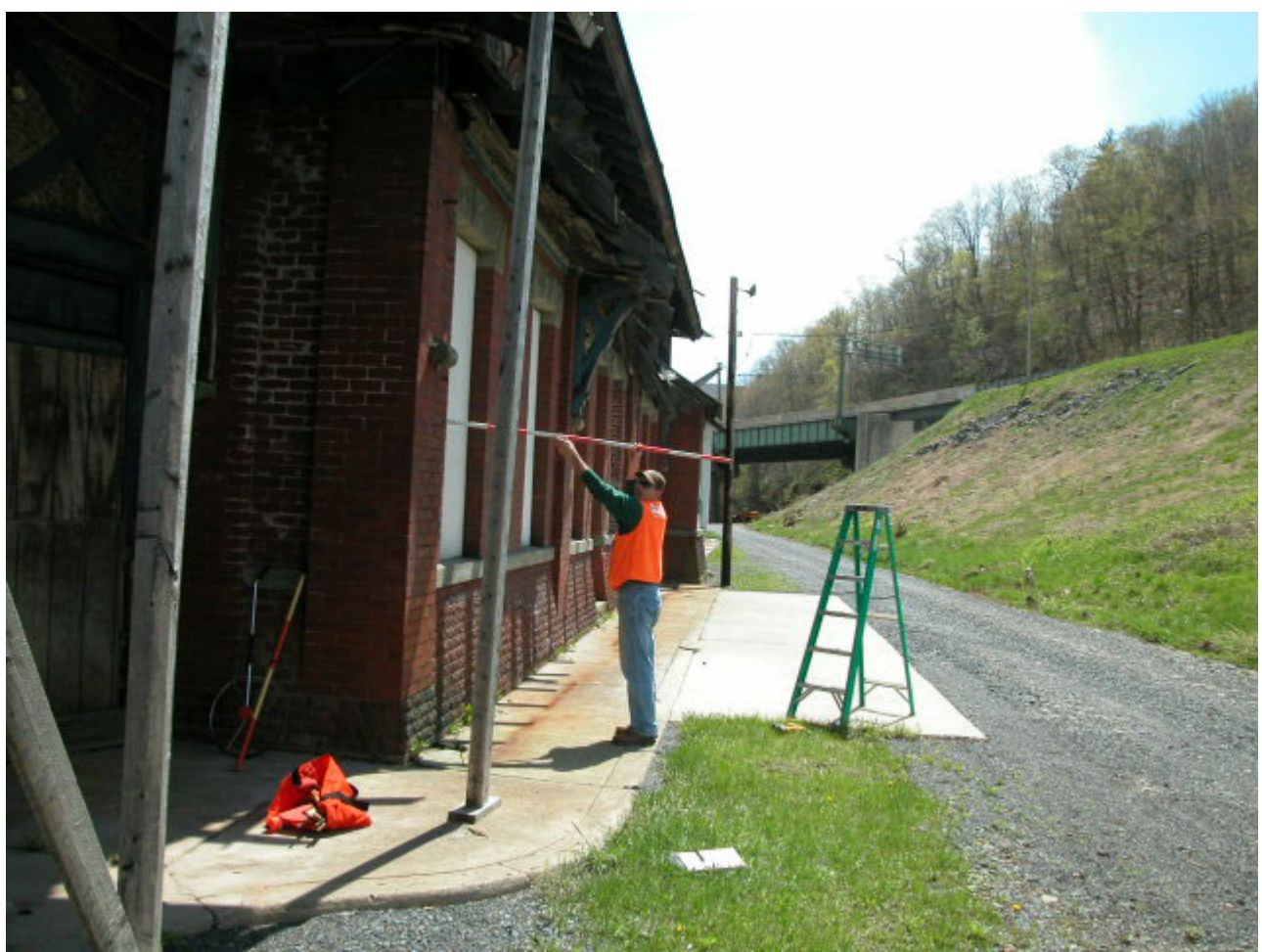

High-water mark PA 6.2 (lat $40^{\circ} 58^{\prime} 56.9^{\prime \prime}$, long $75^{\circ} 08^{\prime} 12.4^{\prime \prime}$ ), at an elevation of 321.1 feet above NGVD 29, is an excellent mud line on a railroad train station, 6.8 feet above the ground, just upstream from Interstate Route 80 , and was marked with a metal USGS washer and nail. 


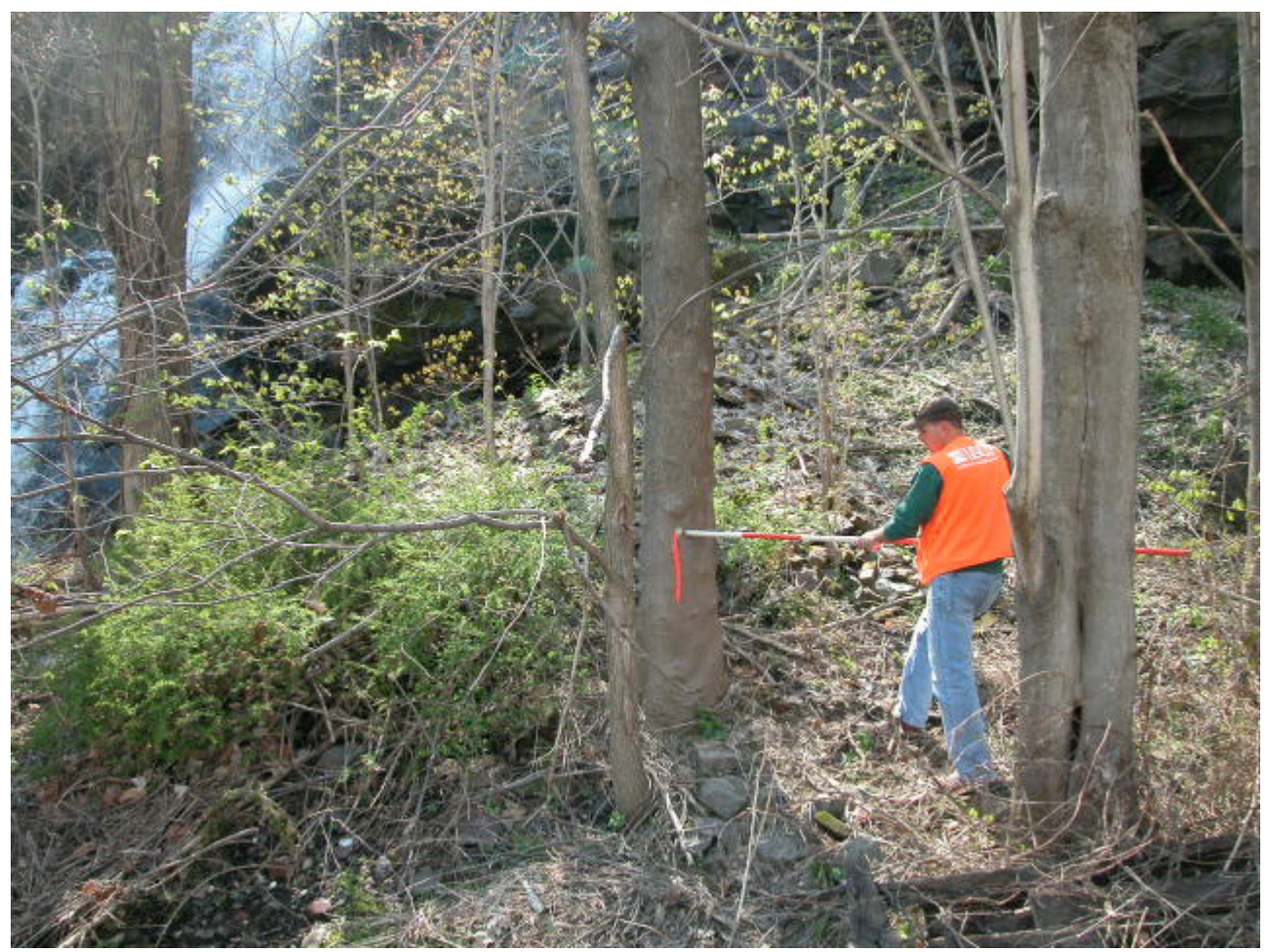

High-water mark PA 6.3 (lat $40^{\circ} 58^{\prime} 41.5^{\prime \prime}$, long $75^{\circ} 08^{\prime} 15.6^{\prime \prime}$ ), at an elevation of 320.1 feet above NGVD 29 , is an unrated debris line on a 1.4-foot diameter tree, 3.5 feet above the ground, 900 feet downstream from Interstate Route 80 , and was marked with a metal USGS washer and nail.

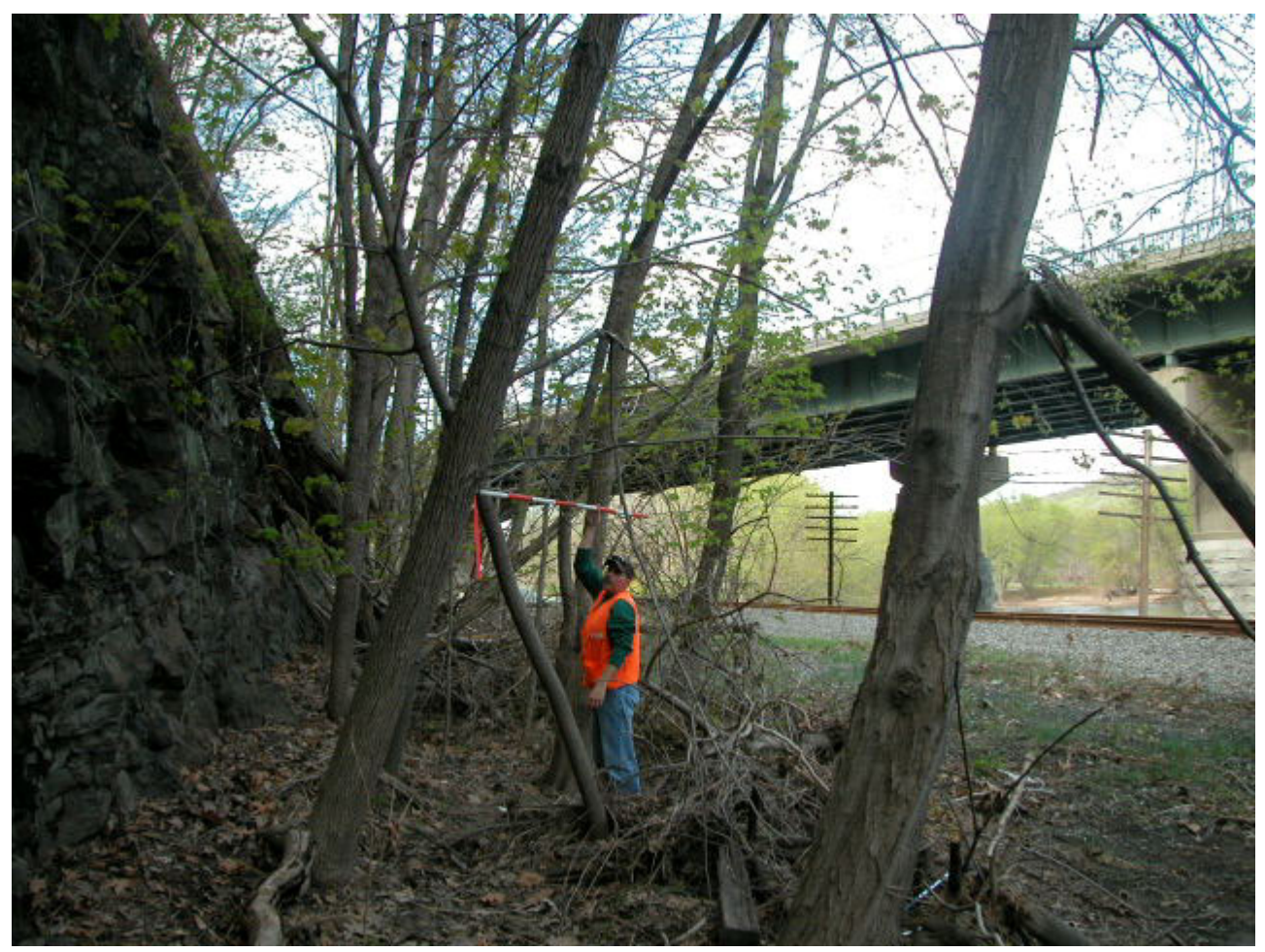

High-water mark PA 6.4 (lat $40^{\circ} 58^{\prime} 47.9^{\prime \prime}$, long $75^{\circ} 08^{\prime} 14.3^{\prime \prime}$ ), at an elevation of 320.8 feet above NGVD 29 , is a good seed line on a 0.8 -foot diameter tree, 7.0 feet above the ground, 265 feet downstream from Interstate Route 80 , and was marked with a metal USGS washer and nail. 


\begin{tabular}{|l|}
\hline \multicolumn{1}{|c|}{ SITE DESCRIPTION } \\
\hline Site NJ 4: 01442750 Delaware River at Dunnfield, NJ \\
\hline Site Location: 0.7 mi reach in vicinity of lat $40^{\circ} 58^{\prime} 27^{\prime \prime}$, long $75^{\circ} 08^{\prime} 05^{\prime \prime}$, \\
\hline Hardwick Township, Warren County, NJ \\
\hline Seven high-water marks were surveyed: six seed lines and one mud line. \\
\hline $\begin{array}{l}\text { High-water mark elevations were determined using USGS reference mark } 241 \text { at lat } 40^{\circ} 58^{\prime} 13.3^{\prime \prime}, \\
\text { long } 75^{\circ} 07^{\prime} 51.8^{\prime \prime} \text { (elevation is } 311.14 \text { feet, NAVD 88). }\end{array}$ \\
\hline
\end{tabular}

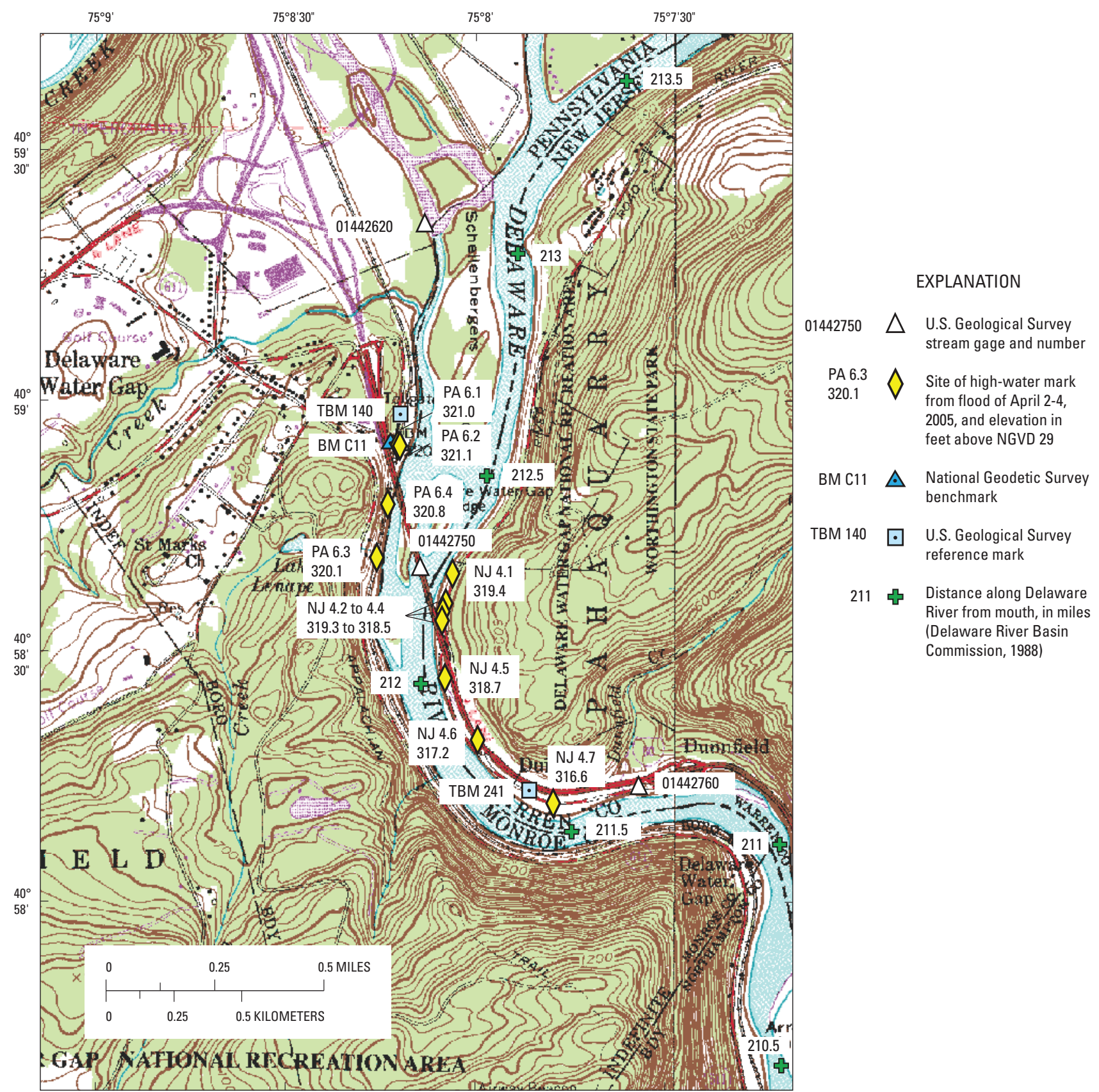

Stroudsburg USGS 7.5' Topographic Quadrangle map showing location of site NJ 4, Delaware River at Dunnfield, NJ. 


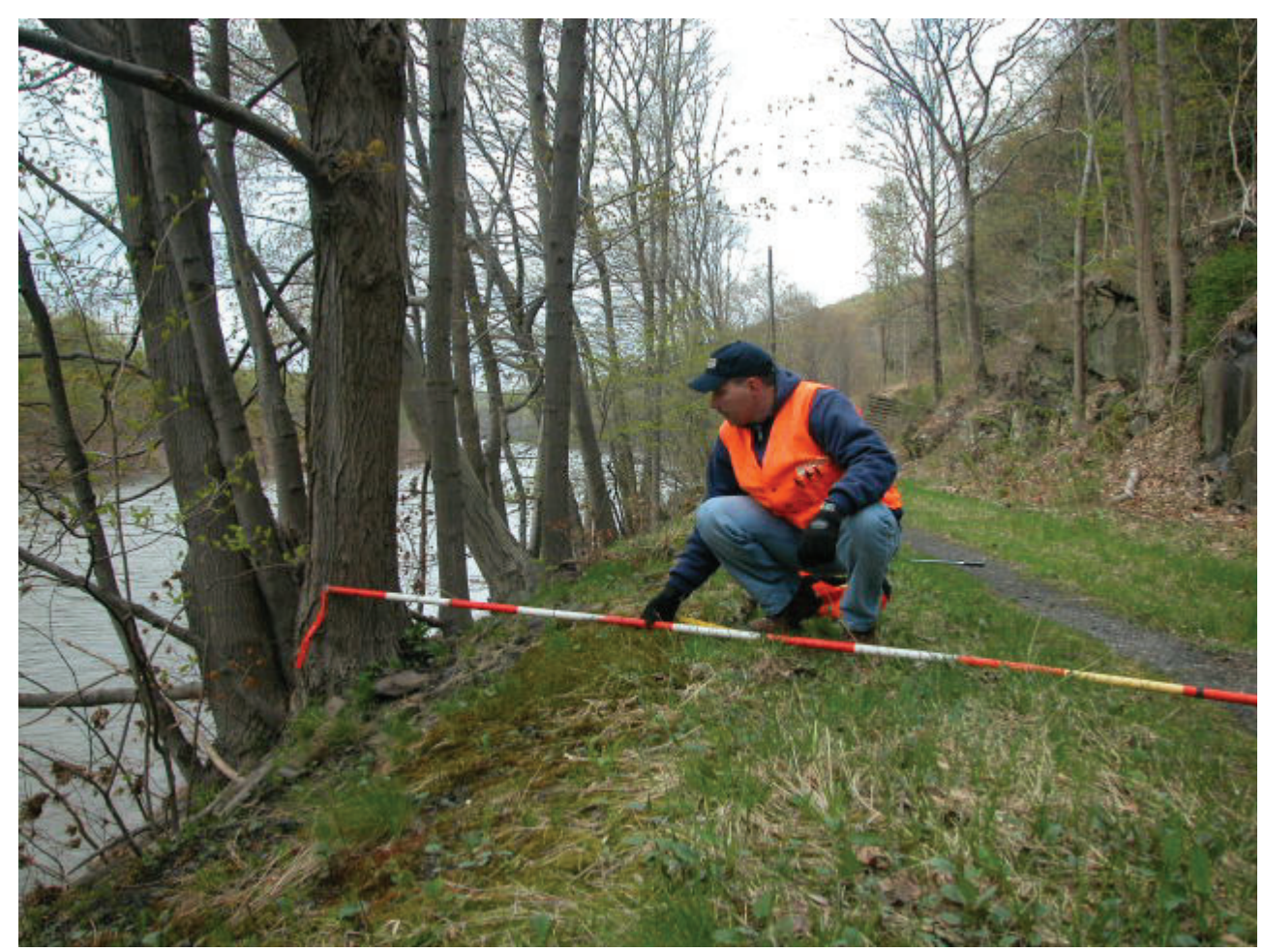

High-water mark NJ 4.1 (lat $40^{\circ} 58^{\prime} 39.5^{\prime \prime}$, long $75^{\circ} 08^{\prime} 04^{\prime \prime}$ ), at an elevation of 319.4 feet above NGVD 29 , is a good seed line on a 1.3-foot diameter tree, 1.0 feet above the ground, 3,220 feet upstream from USGS reference mark 241, and was marked with a metal USGS washer and nail.

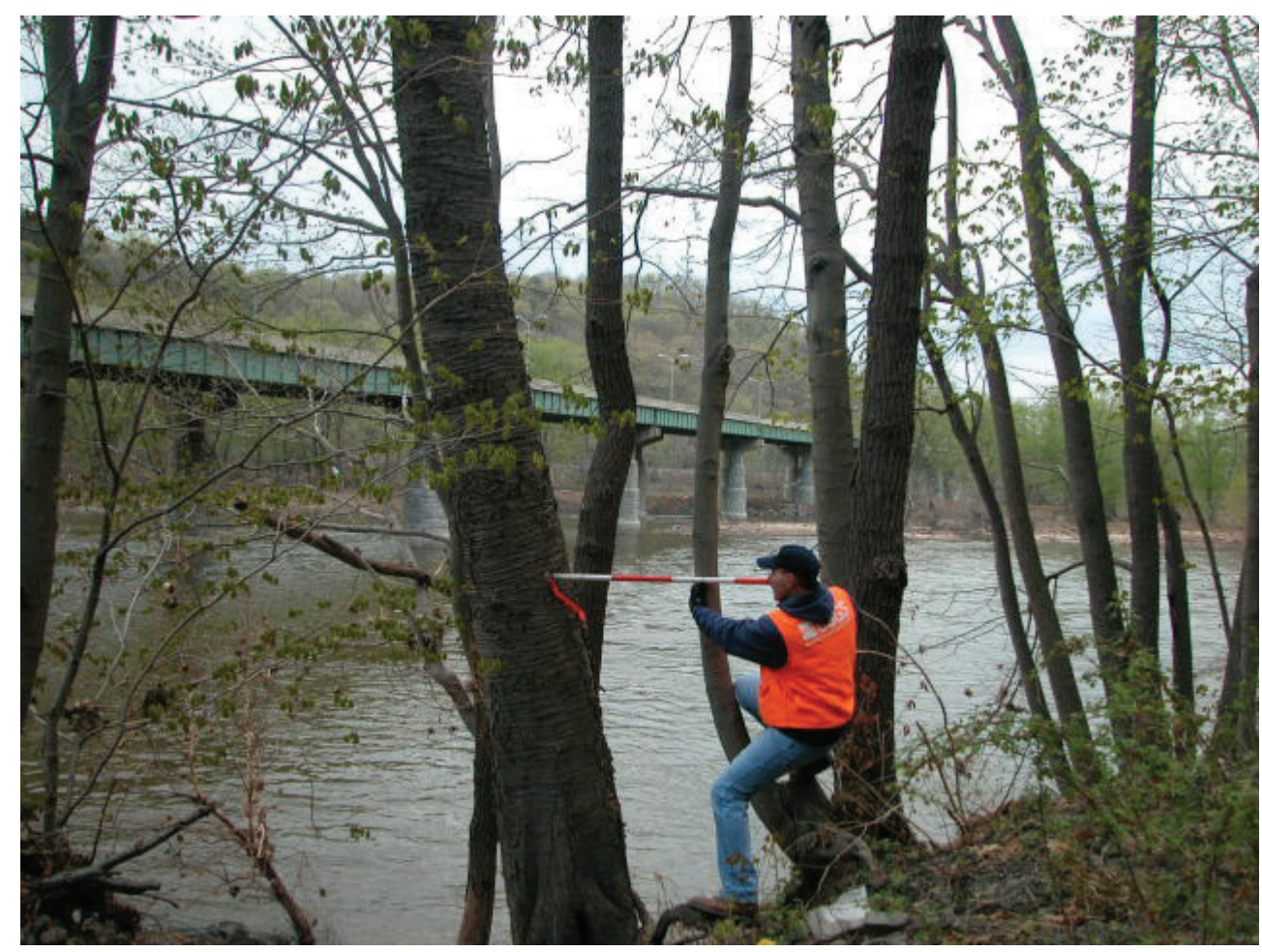

High-water mark NJ 4.2 (lat $40^{\circ} 58^{\prime} 36.0^{\prime \prime}$, long $75^{\circ} 08^{\prime} 05.0^{\prime \prime}$ ), at an elevation of 319.3 feet above NGVD 29 , is a good seed line on a 2-foot diameter tree, 6.5 feet above the ground, 2,900 feet upstream from USGS reference mark 241, and was marked with a metal USGS washer and nail. 


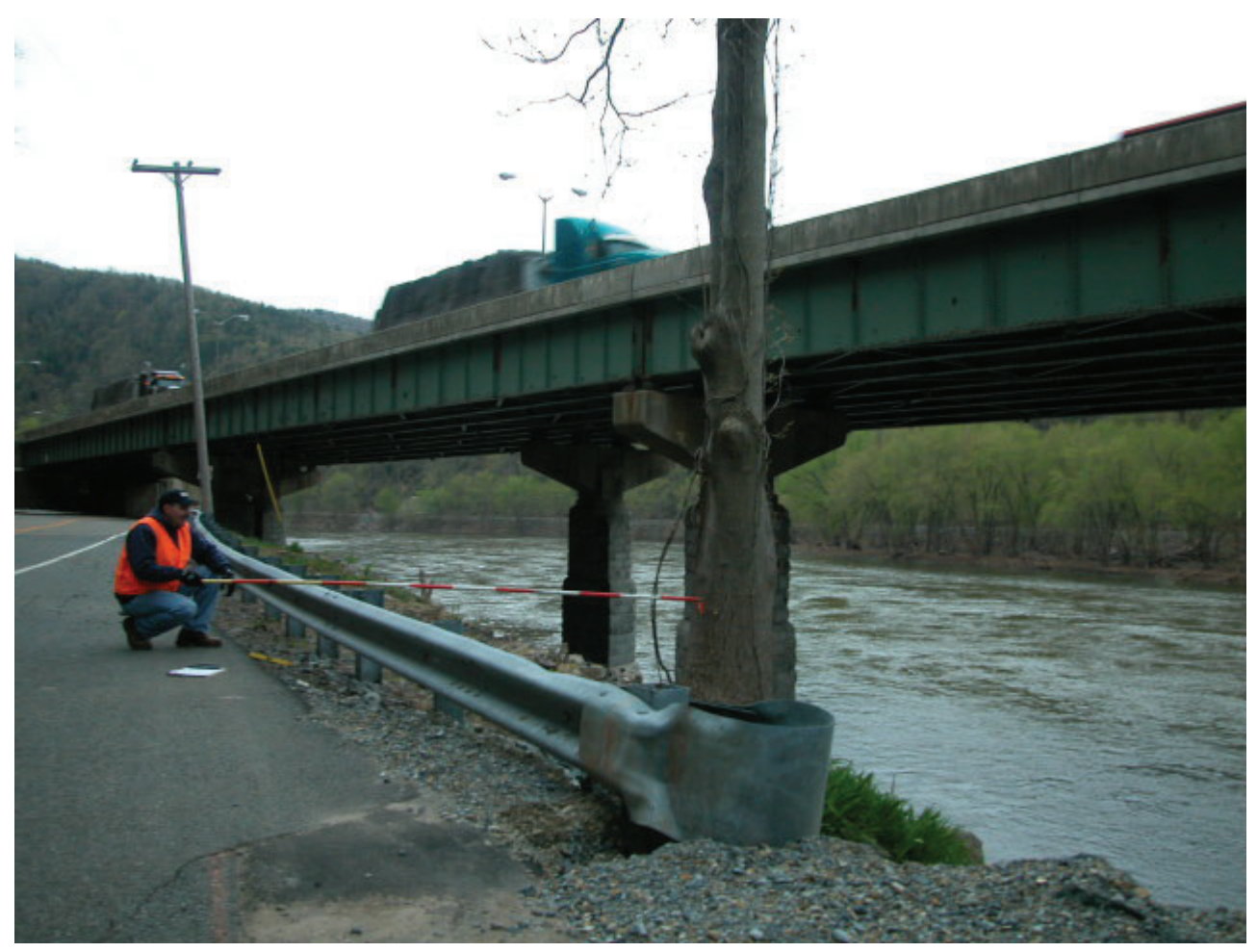

High-water mark NJ 4.3 (lat $40^{\circ} 58^{\prime} 34.0^{\prime \prime}$, long $75^{\circ} 08^{\prime} 05.6^{\prime \prime}$ ), at an elevation of 318.5 feet above NGVD 29 , is a good seed line on a 2-foot diameter tree, 2.6 feet above the ground, 2,550 feet upstream from USGS reference mark 241, and was marked with a metal USGS washer and nail.

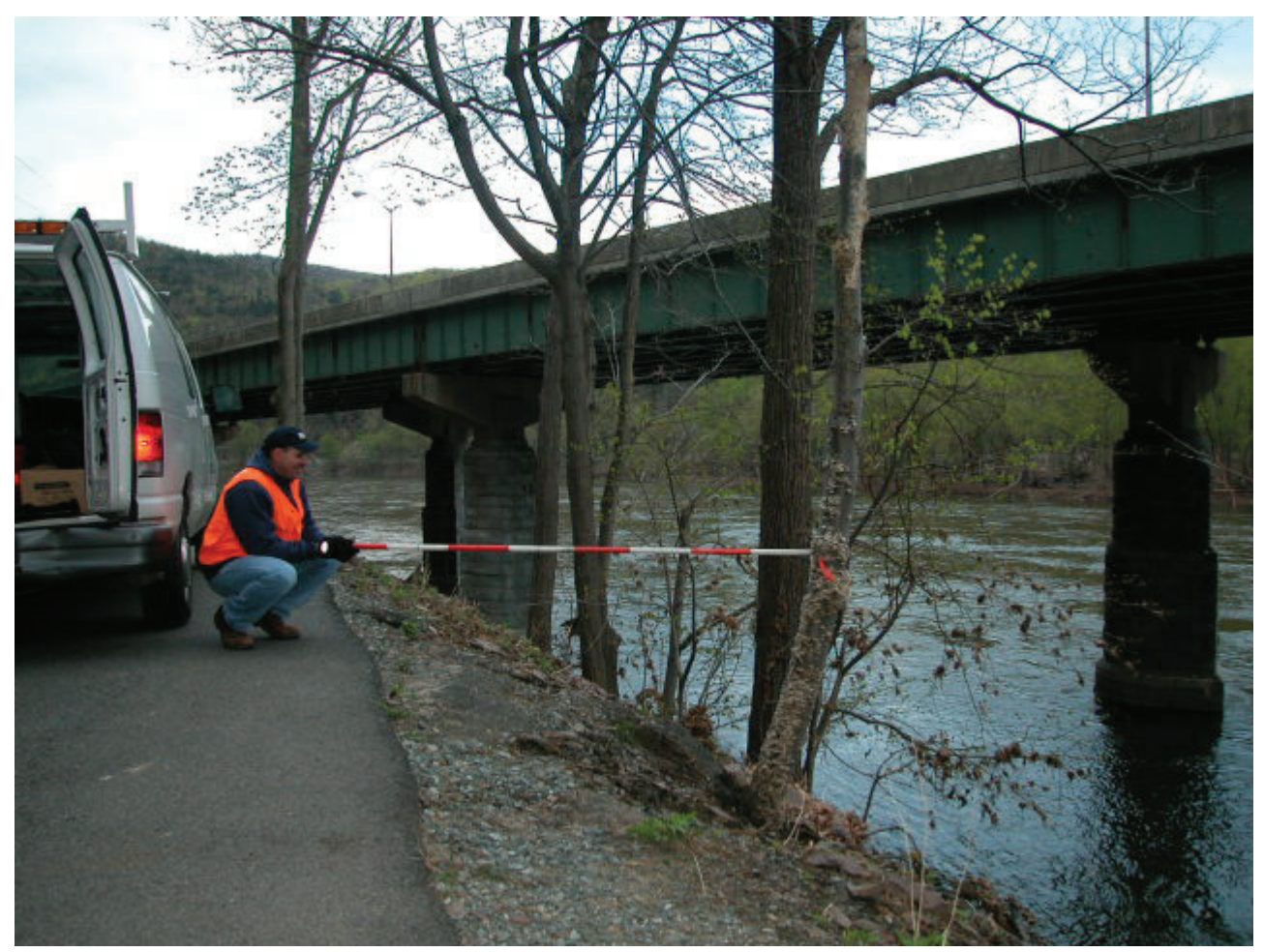

High-water mark NJ 4.4 (lat $40^{\circ} 58^{\prime} 35.0^{\prime \prime}$, long $75^{\circ} 08^{\prime} 05.4^{\prime \prime}$ ), at an elevation of 319.3 feet above NGVD 29 , is a good seed line on a 0.5 -foot diameter tree, 4.5 feet above the ground, 2,650 feet upstream from USGS reference mark 241, and was marked with a metal USGS washer and nail. 


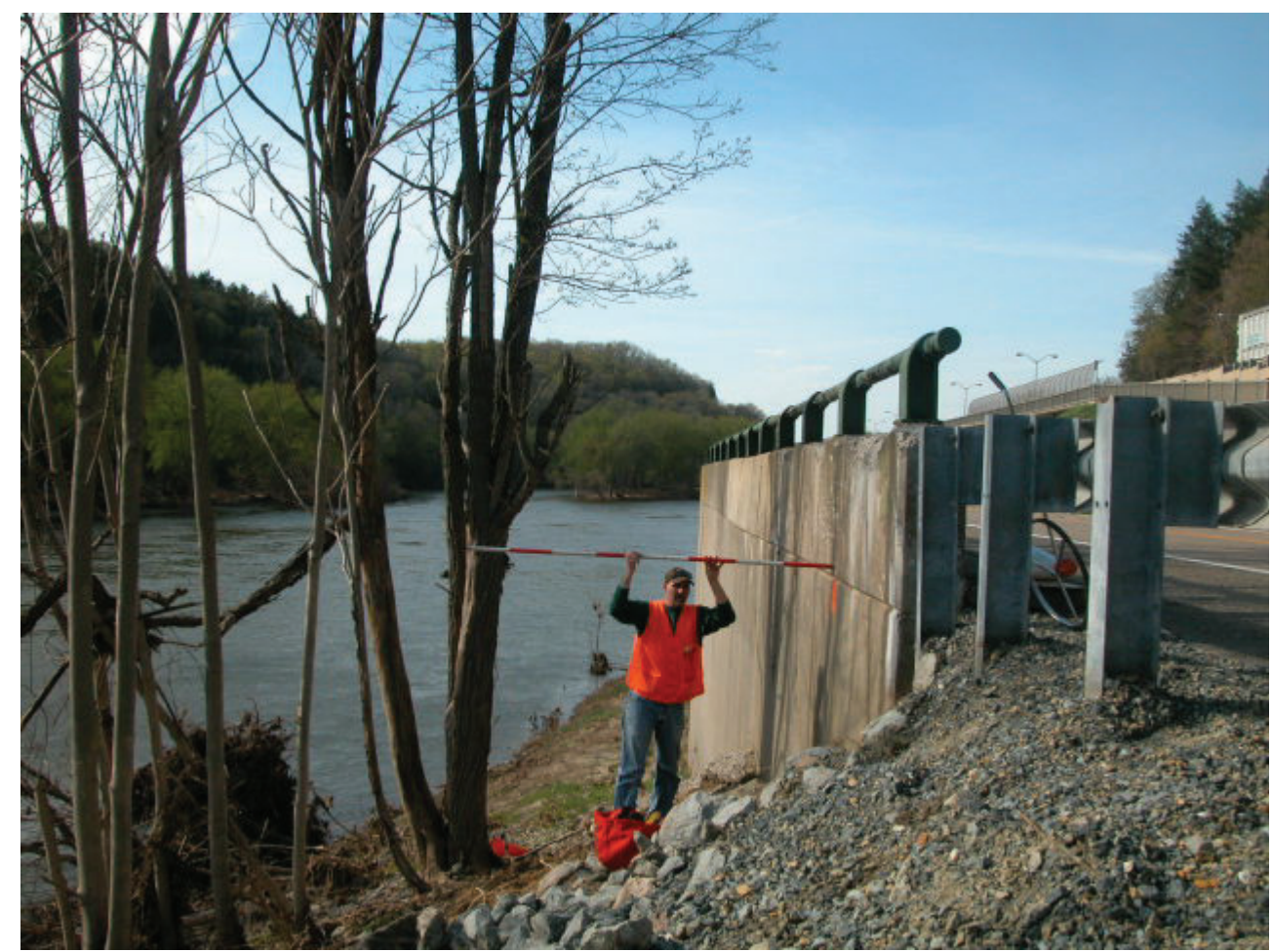

High-water mark NJ 4.5 (lat $40^{\circ} 58^{\prime} 27.2^{\prime \prime}$, long $\left.75^{\circ} 08^{\prime} 05.0^{\prime \prime}\right)$, at an elevation of 318.7 feet above NGVD 29 , is a good seed line on a retaining wall, 5.0 feet above the ground, 1,710 feet upstream from USGS reference mark 241 , and was marked with a drill hole and orange paint.

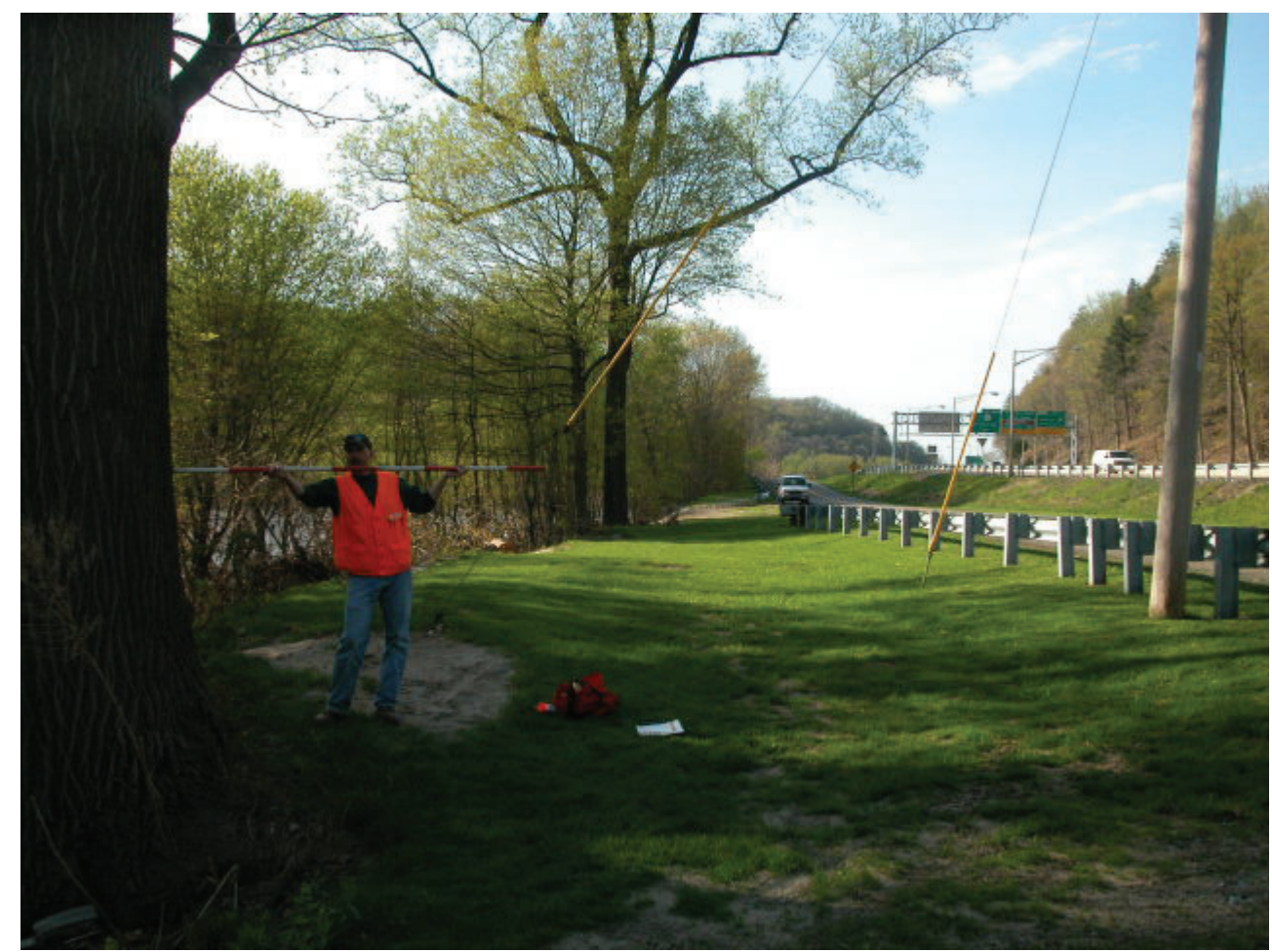

High-water mark NJ 4.6 (lat $40^{\circ} 58^{\prime} 19.8^{\prime \prime}$, long $75^{\circ} 07^{\prime} 59.9^{\prime \prime}$ ), at an elevation of 317.2 feet above NGVD 29 , is a good seed line on a 3.7-foot diameter tree, 5.2 feet above the ground, 860 feet upstream from USGS reference mark 241 , and was marked with a metal USGS washer and nail. 


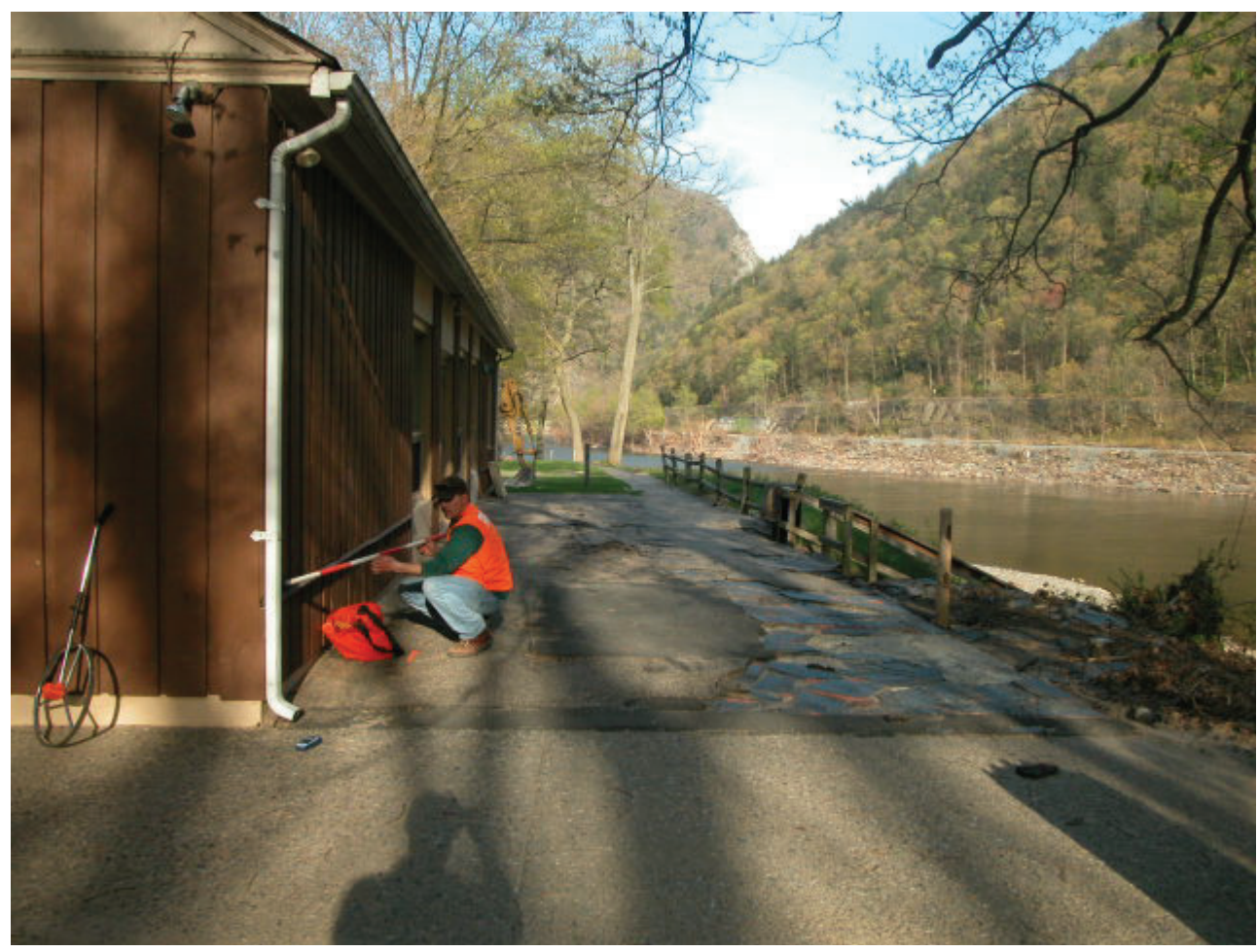

High-water mark NJ 4.7 (lat $40^{\circ} 58^{\prime} 12.0^{\prime \prime}$, long $75^{\circ} 07^{\prime} 48.0^{\prime \prime}$ ), at an elevation of 316.6 feet above NGVD 29 , is an excellent mud line on a building, 2.1 feet above the ground, 320 feet downstream from USGS reference mark 241, and was marked with a metal USGS washer and nail. 


\begin{tabular}{|l|}
\hline \multicolumn{1}{|c|}{ SITE DESCRIPTION } \\
\hline Site NJ 5: Delaware River at Columbia, NJ \\
\hline Site Location: 0.9 mi reach in vicinity of lat $40^{\circ} 55^{\prime} 20^{\prime \prime}$, long $75^{\circ} 05^{\prime} 26^{\prime \prime}$ \\
\hline Knowlton Township, Warren County, NJ \\
\hline Three high-water marks were surveyed: two mud lines and one seed line. \\
\hline High-water mark elevations were determined using USGS reference mark 330 at lat $40^{\circ} 55^{\prime} 05.4^{\prime \prime}$, \\
long $75^{\circ} 05^{\prime} 00.7^{\prime \prime}$ (elevation is 302.14 feet, NAVD 88 ) and from USGS reference mark 331 at lat $40^{\circ}$ \\
$55^{\prime} 30.6^{\prime \prime}$, long $75^{\circ} 05^{\prime} 39.0^{\prime \prime}$ (elevation is 289.10 feet, NAVD 88 ). \\
\hline
\end{tabular}

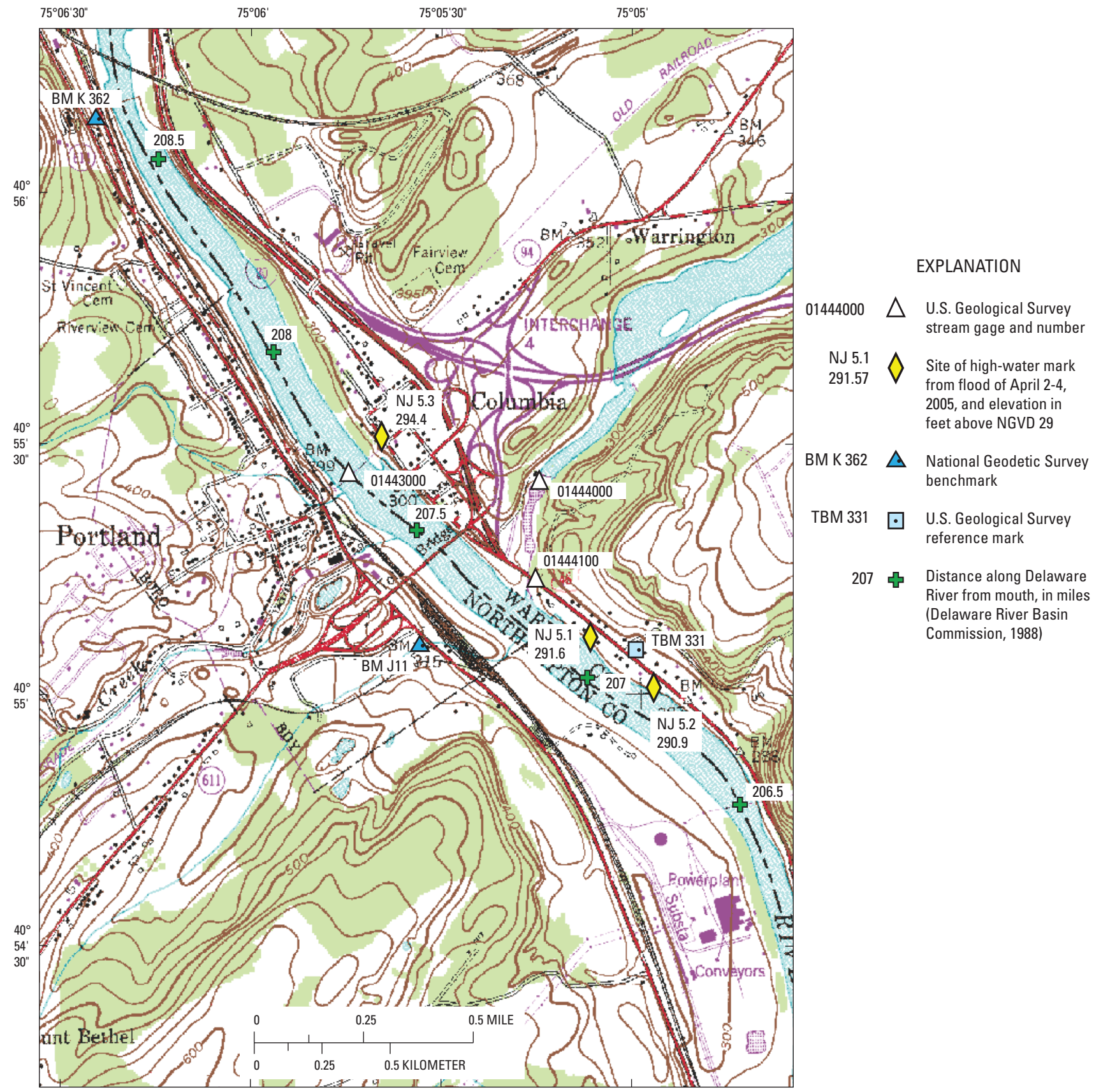

Portland USGS 7.5' Topographic Quadrangle map showing location of site NJ 5, Delaware River at Columbia, NJ. 


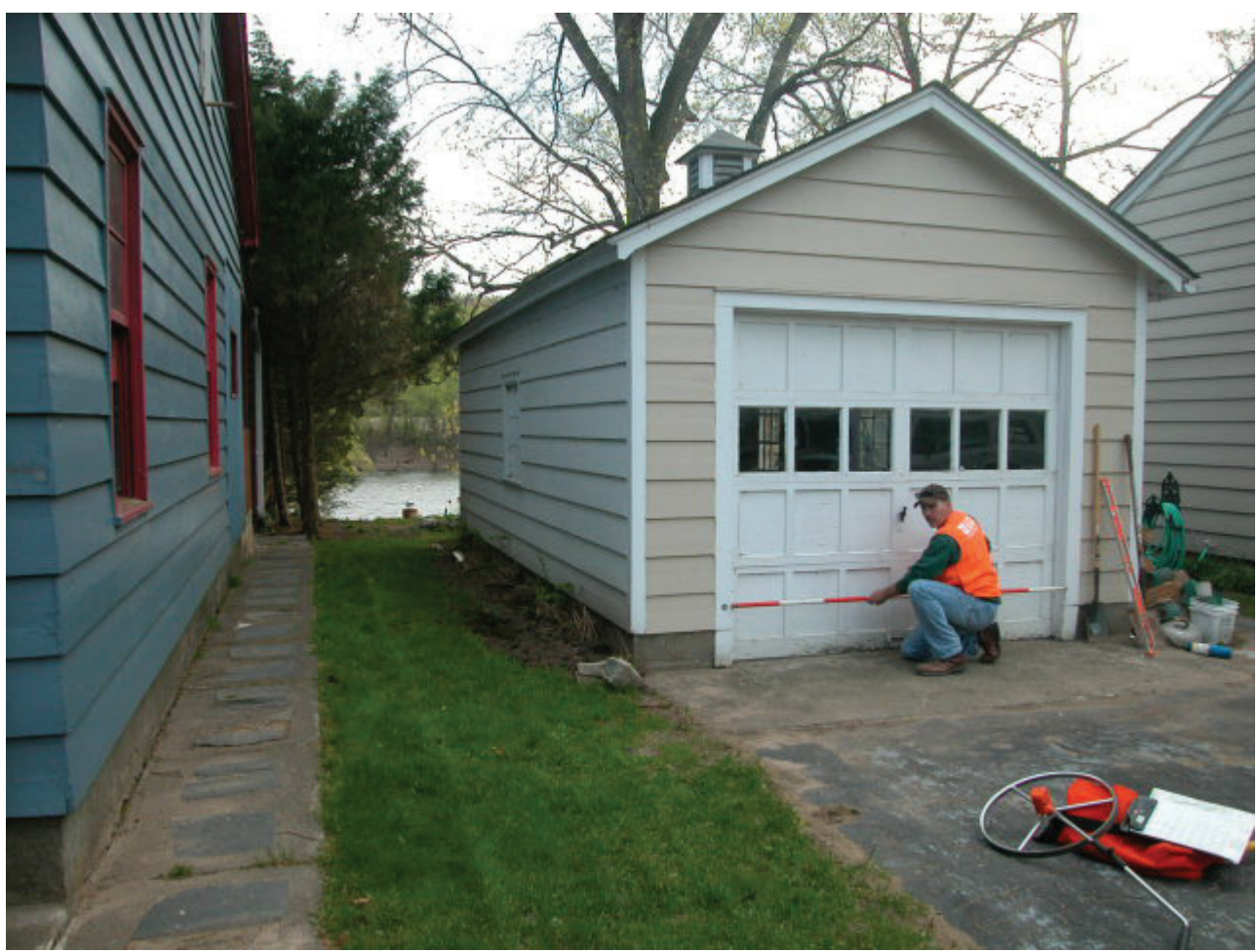

High-water mark NJ 5.1 (lat $40^{\circ} 55^{\prime} 07^{\prime \prime}$, long $75^{\circ} 05^{\prime} 07^{\prime \prime}$ ), at an elevation of 291.6 feet above NGVD 29 , is an excellent mud line on a garage, 1.2 feet above the ground, 2,100 feet downstream from the Columbia-Portland bridge, and was marked with a metal USGS washer and nail.

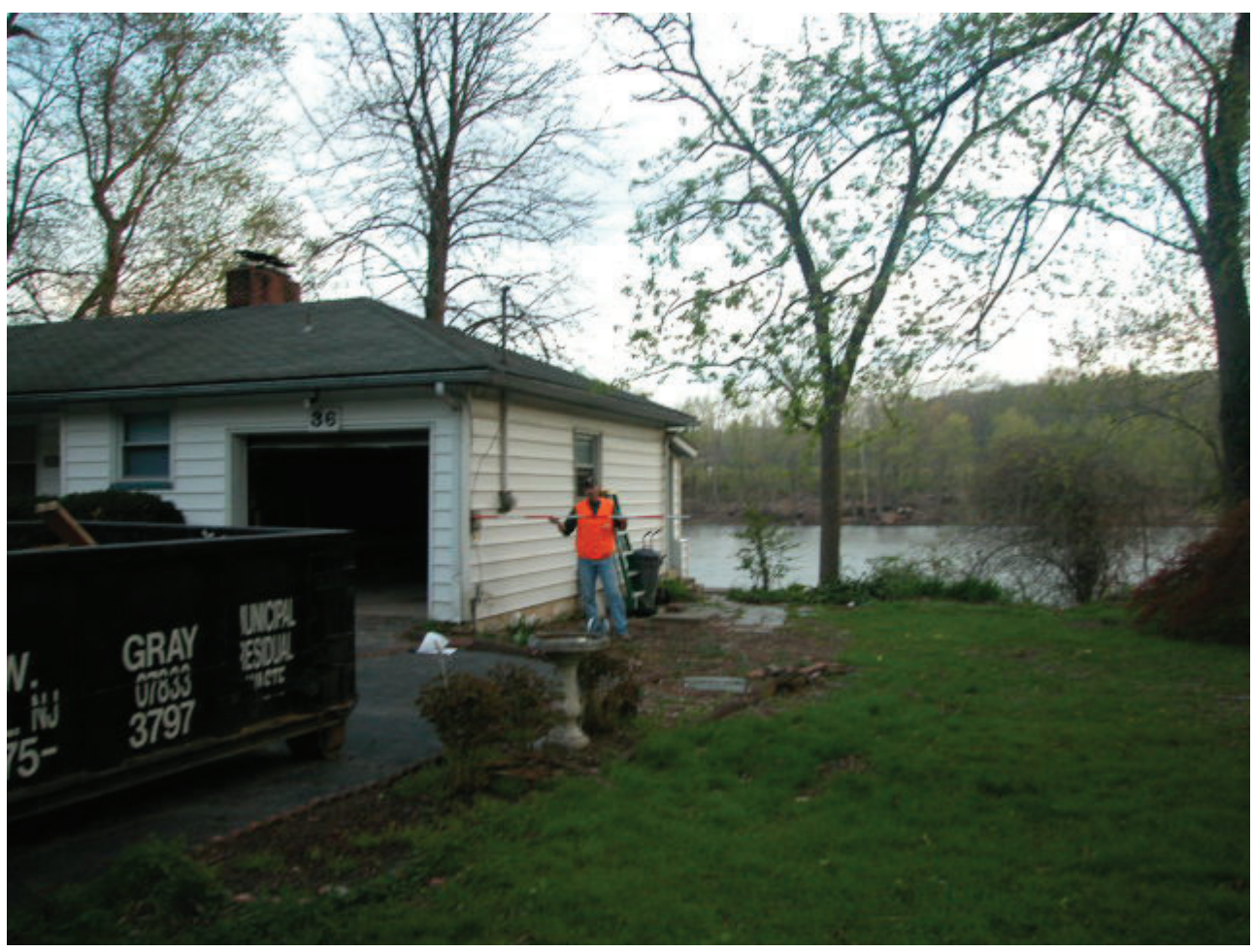

High-water mark NJ 5.2 (lat $40^{\circ} 55^{\prime} 01^{\prime \prime}$, long $75^{\circ} 04^{\prime} 57^{\prime \prime}$ ), at an elevation of 290.9 feet above NGVD 29 , is an excellent mud line on a garage, 4 feet above the ground, 3,000 feet downstream from the Columbia-Portland bridge, and was marked with a black marker line. 


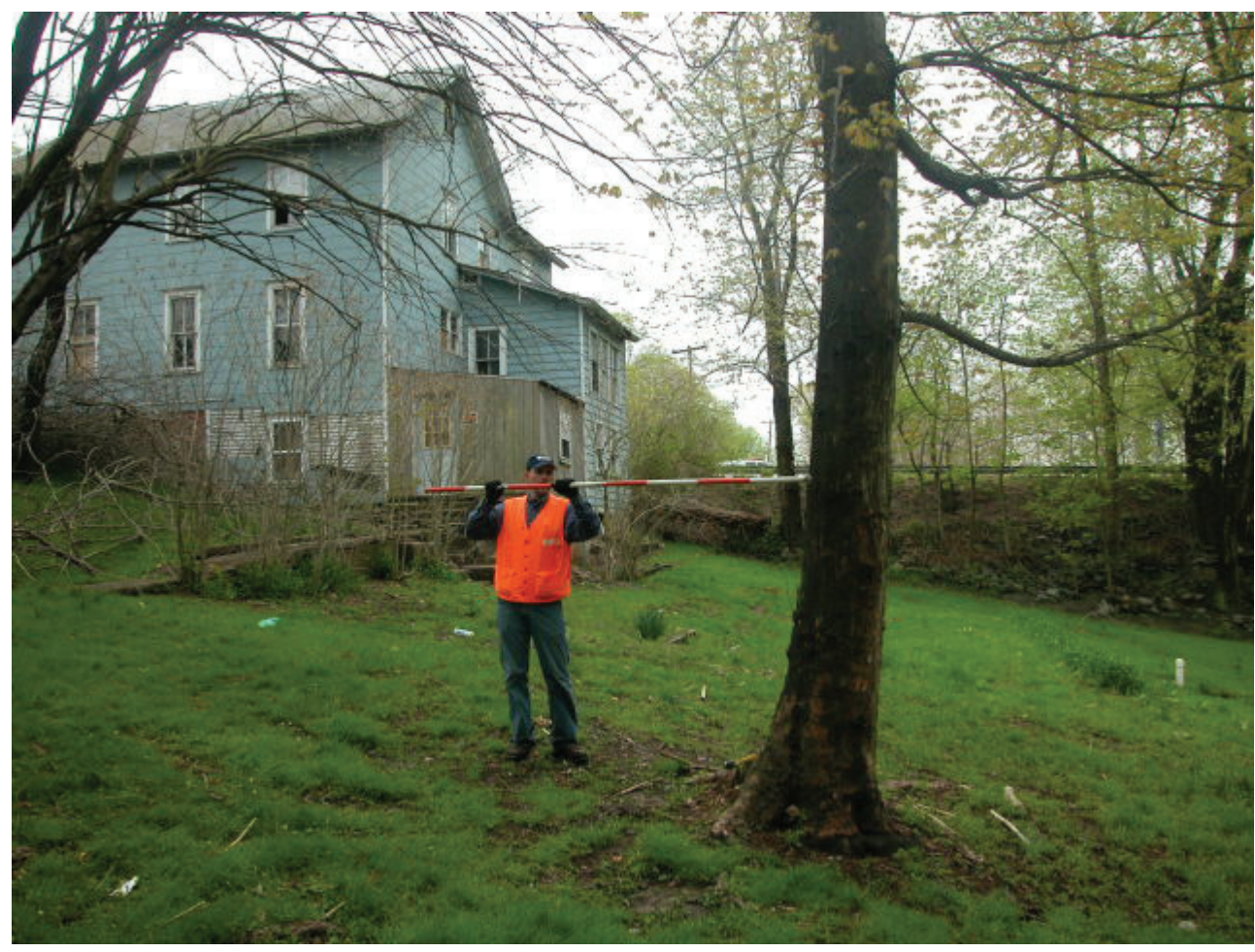

High-water mark NJ 5.3 (lat $40^{\circ} 55^{\prime} 31^{\prime \prime}$, long $75^{\circ} 05^{\prime} 40^{\prime \prime}$ ), at an elevation of 294.4 feet above NGVD 29 , is a good seed line on a 1.4-foot diameter tree, 6 feet above the ground, 1,520 feet upstream from the ColumbiaPortland bridge, and was marked with a metal USGS washer and nail. 


\begin{tabular}{l} 
SITE DESCRIPTION \\
\hline Site NJ 6: Delaware River at Knowlton, NJ \\
\hline Site Location: 0.1 mi reach in vicinity of lat $40^{\circ} 52^{\prime} 08^{\prime \prime}$, long $75^{\circ} 03^{\prime} 01^{\prime \prime}$ \\
\hline Knowlton Township, Warren County, NJ \\
\hline Two high-water marks were surveyed: one debris line and one seed line. \\
\hline High-water mark elevations were determined using USGS reference mark 332 at lat $40^{\circ} 52^{\prime} 08.0^{\prime \prime}$, \\
long $75^{\circ} 03^{\prime} 00.4^{\prime \prime}$ (elevation is 278.84 feet, NAVD 88). \\
\hline
\end{tabular}

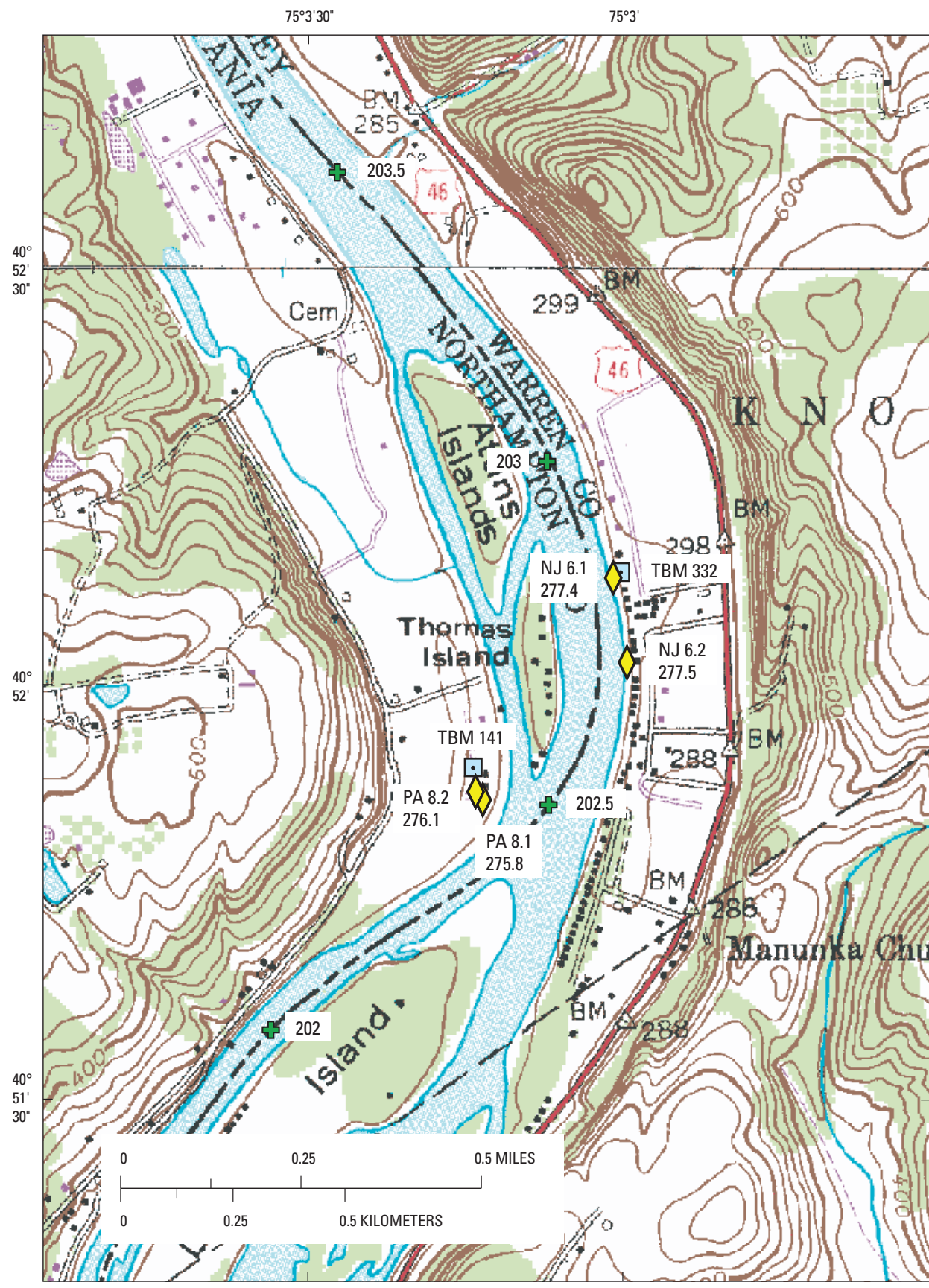

EXPLANATION

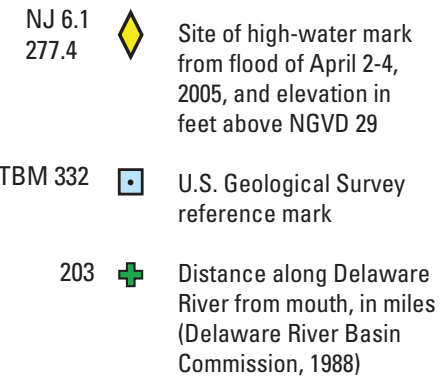

Belvidere USGS 7.5' Topographic Quadrangle map showing location of site NJ 6, Delaware River at Knowlton, NJ. 


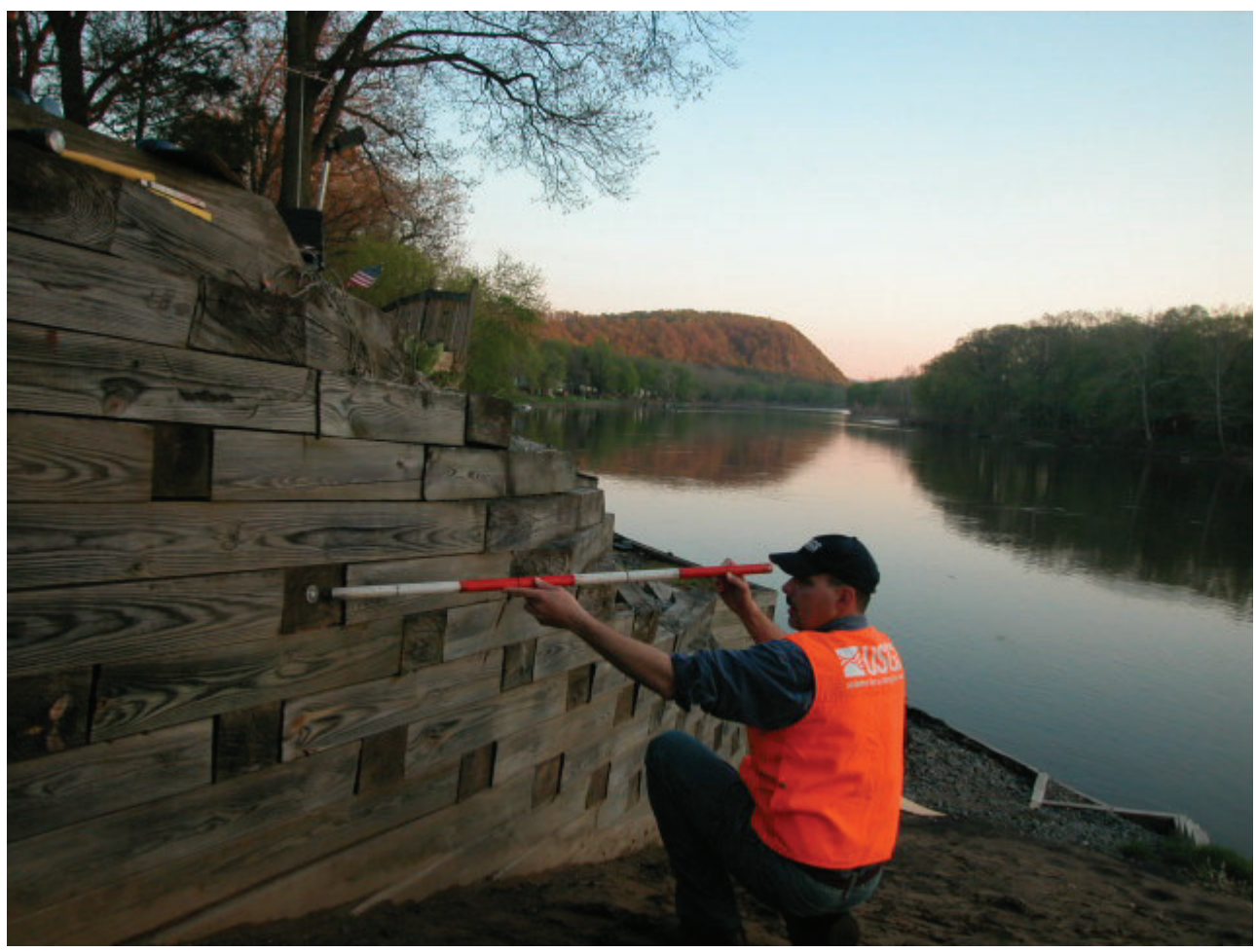

High-water mark NJ 6.1 (lat $40^{\circ} 52^{\prime} 08.0^{\prime \prime}$, long $75^{\circ} 03^{\prime} 01.0^{\prime \prime}$ ), at an elevation of 277.4 feet above NGVD 29 , is a fair debris line on a retaining wall, 2.5 feet above the ground, across from Thomas Island, near Pine Tree Lane, and was marked with a metal USGS washer and nail.

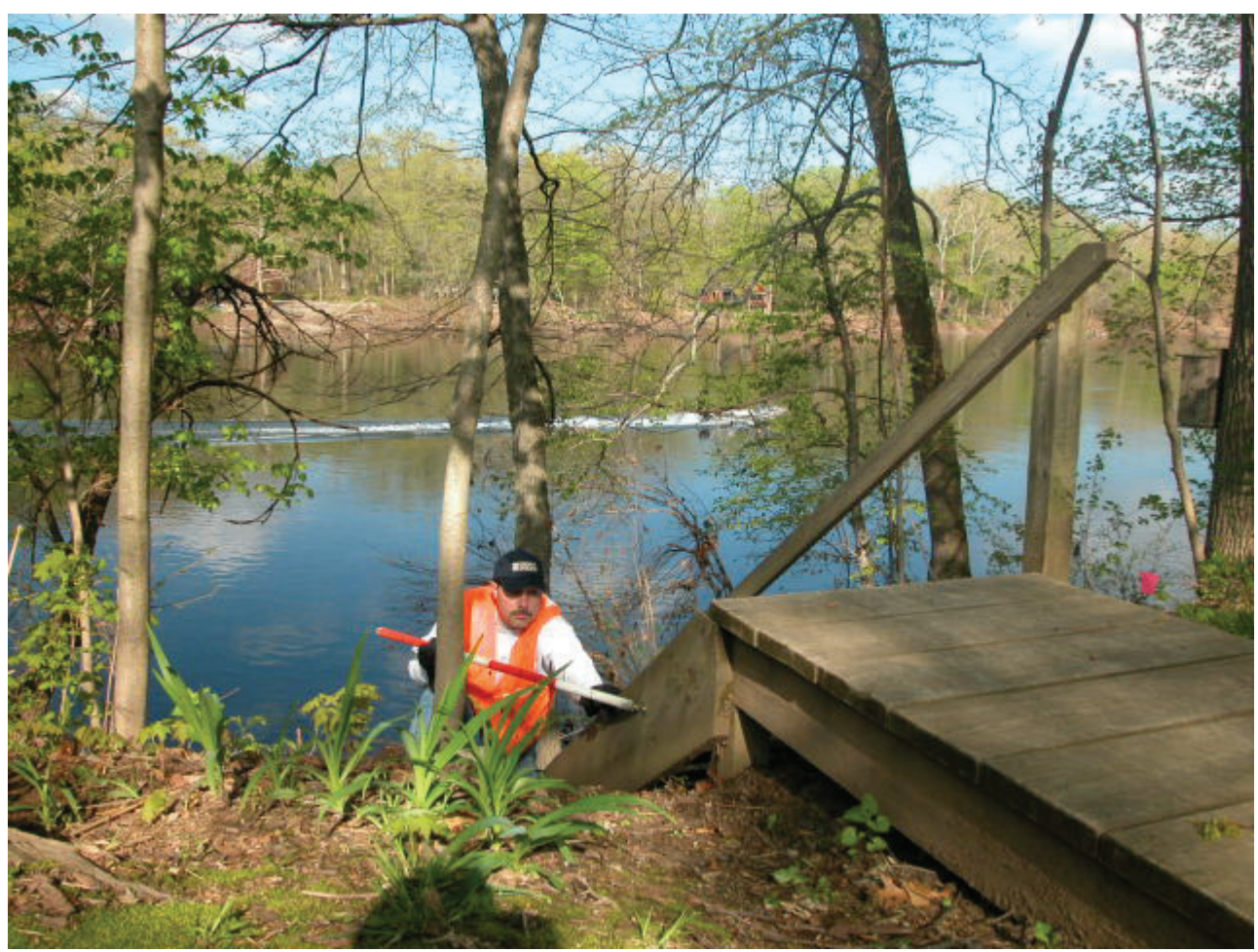

High-water mark NJ 6.2 (lat $40^{\circ} 52^{\prime} 04.0^{\prime \prime}$, long 75 $02^{\prime} 59.8^{\prime \prime}$ ), at an elevation of 277.47 feet above NGVD 29, is a good seed line on steps, 1.0 feet above the ground, across from Thomas Island, near Watergap View Avenue, and was marked with a metal USGS washer and nail. 


\begin{tabular}{|c|}
\hline SITE DESCRIPTION \\
\hline Site PA 8: Delaware River at Thomas Island, PA \\
\hline Site Location: 50 foot reach in vicinity of lat $40^{\circ} 51^{\prime} 52$ ", long $75^{\circ} 03^{\prime} 14^{\prime \prime}$, \\
\hline Upper Mount Bethel Township, Northampton County, PA \\
\hline Two high-water marks were surveyed: one mud line and one seed line. \\
\hline $\begin{array}{l}\text { High-water mark elevations were determined using USGS reference } 141 \text { at lat } 40^{\circ} 51^{\prime} 53.9^{\prime \prime} \text {, } \\
\text { long } 75^{\circ} 03^{\prime} 14.5^{\prime \prime} \text { (elevation is } 272.96 \text { feet above NAVD 88). }\end{array}$ \\
\hline
\end{tabular}

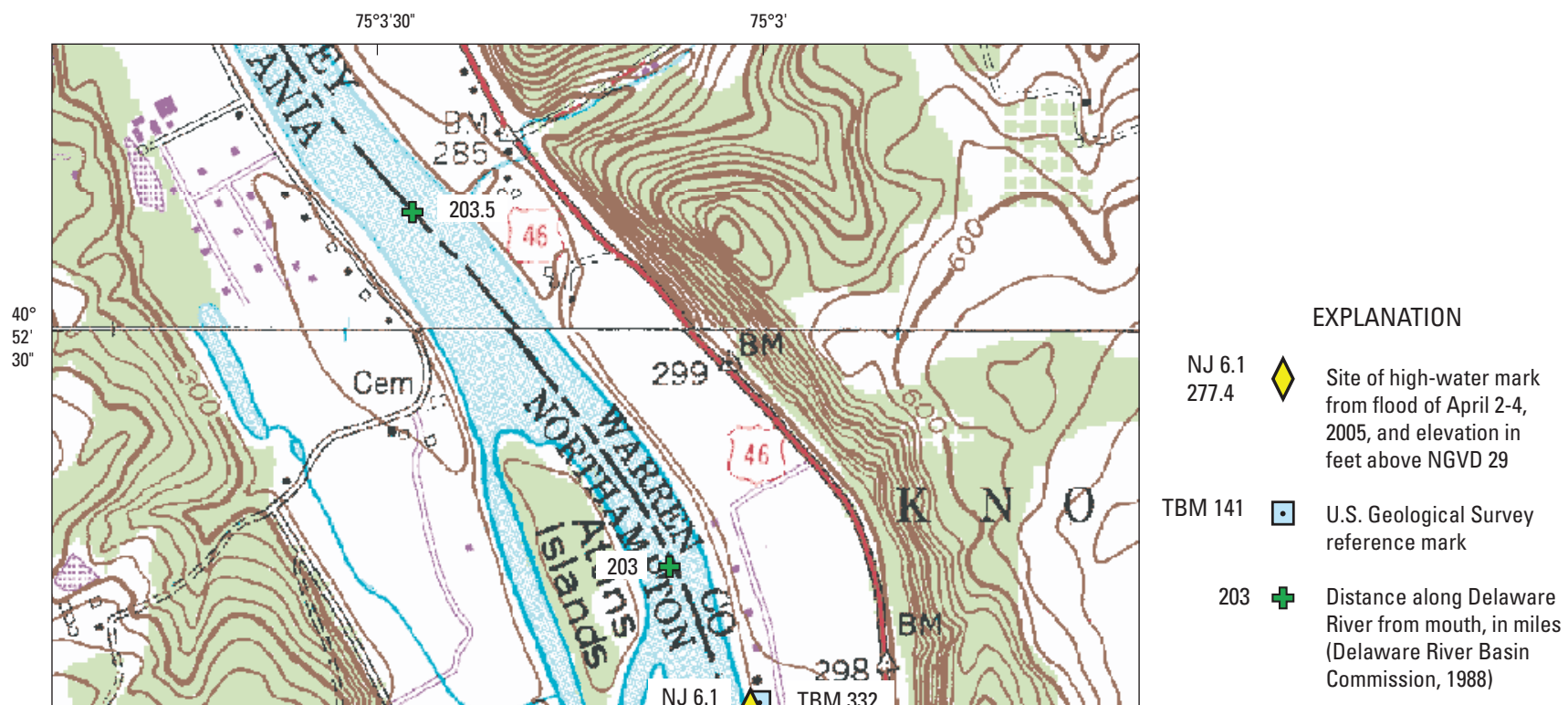

Belvidere USGS 7.5' Topographic Quadrangle map showing location of site PA 8, Delaware River at Thomas Island, PA. 


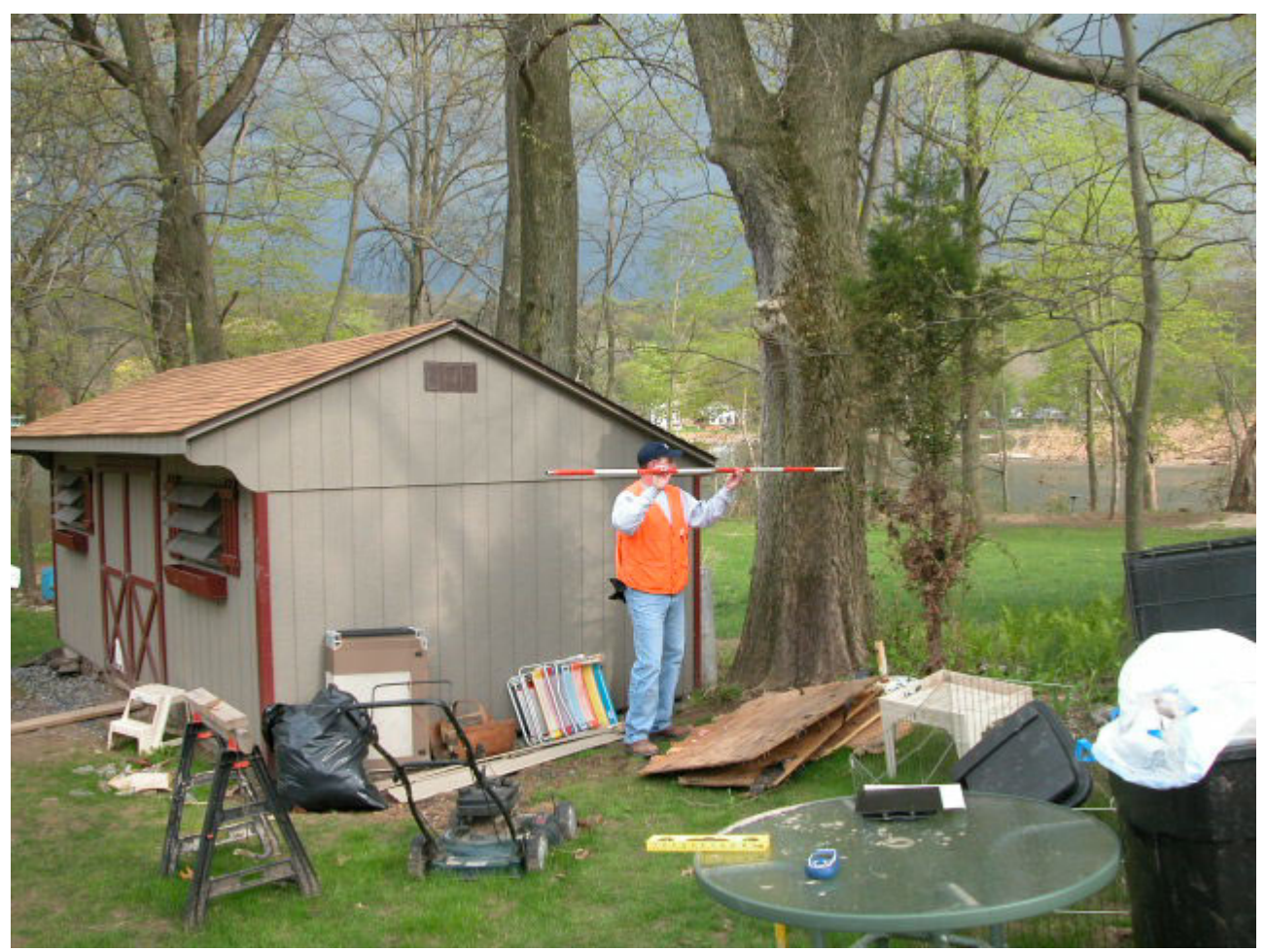

High-water mark PA 8.1 (lat $40^{\circ} 51^{\prime} 52.0^{\prime \prime}$, long $75^{\circ} 03^{\prime} 13.63^{\prime \prime}$ ), at an elevation of 275.8 feet above NGVD 29 , is an excellent mud line on a 2.5-foot diameter tree, 4.3 feet above the ground, at bend in Kovar Lane, and was marked with a metal USGS washer and nail.

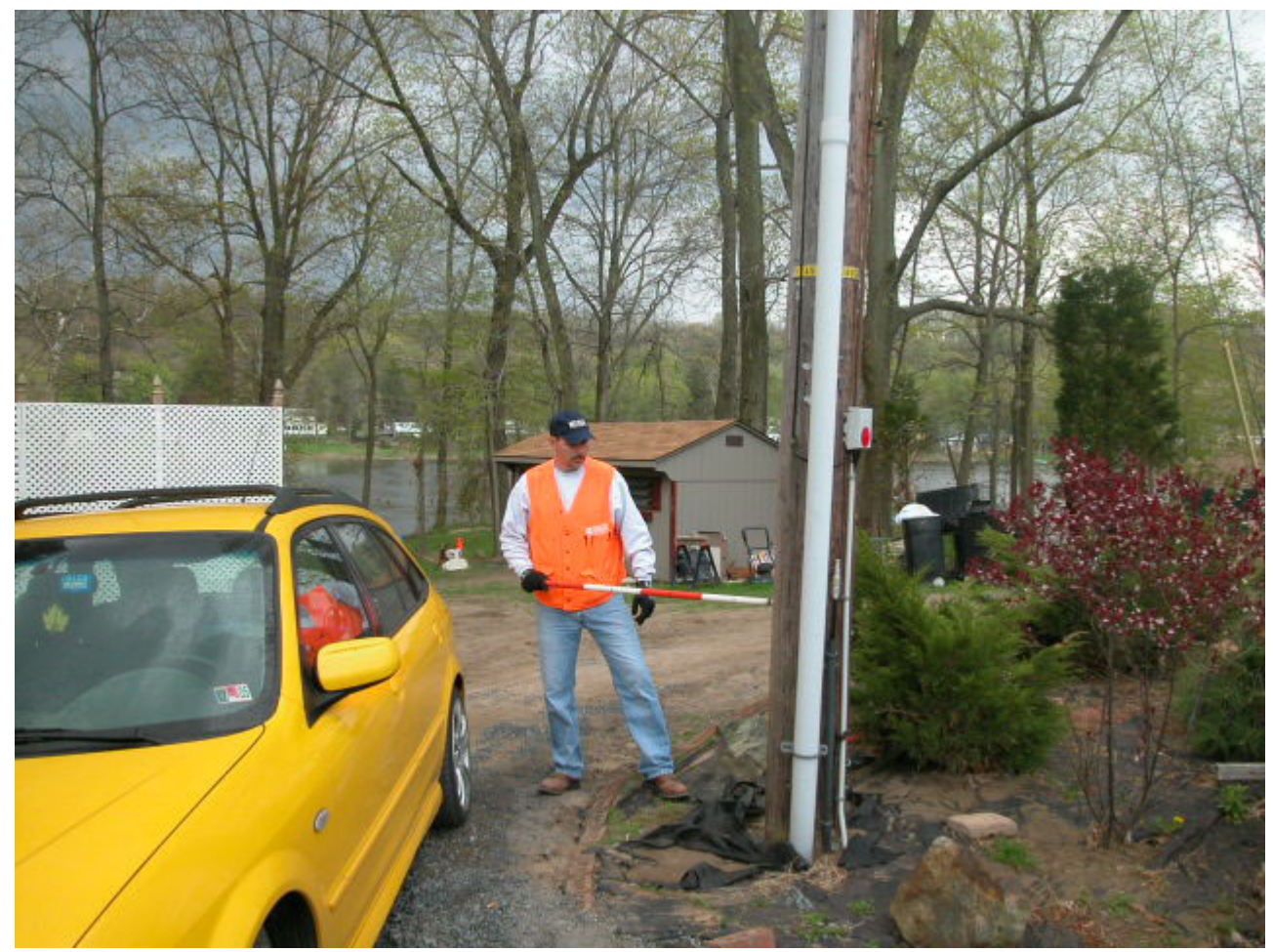

High-water mark PA 8.2 (lat $40^{\circ} 51^{\prime} 52.5^{\prime \prime}$, long $75^{\circ} 03^{\prime} 14.1^{\prime \prime}$ ), at an elevation of 276.1 feet above NGVD 29, is a good seed line on a telephone pole, 3.4 feet above the ground, at bend in Kovar Lane, and was marked with a metal USGS washer and nail. 


\begin{tabular}{|c|}
\hline SITE DESCRIPTION \\
\hline Site NJ 7: 01446500 Delaware River at Belvidere, NJ \\
\hline Site Location: $0.2 \mathrm{mi}$ reach in vicinity of lat $40^{\circ} 49^{\prime} 36^{\prime \prime}$, long $75^{\circ} 04^{\prime} 57^{\prime \prime}$, \\
\hline Belvidere Town, Warren County, NJ \\
\hline Four high-water marks were surveyed: two debris lines and two seed lines. \\
\hline $\begin{array}{l}\text { High-water mark elevations were determined using USGS reference mark } 320 \text { at lat } 40^{\circ} 49^{\prime} 42.2^{\prime \prime} \text {, } \\
\text { long } 75^{\circ} 04^{\prime} 54.3^{\prime \prime} \text { (elevation is } 249.43 \text { feet, NAVD } 88 \text { ) and from USGS reference mark } 321 \text { at } \\
\text { lat } 40^{\circ} 49^{\prime} 48.5^{\prime \prime} \text {, long } 75^{\circ} 05^{\prime} 00.1^{\prime \prime} \text { (elevation is } 273.50 \text { feet, NAVD } 88 \text { ). }\end{array}$ \\
\hline
\end{tabular}

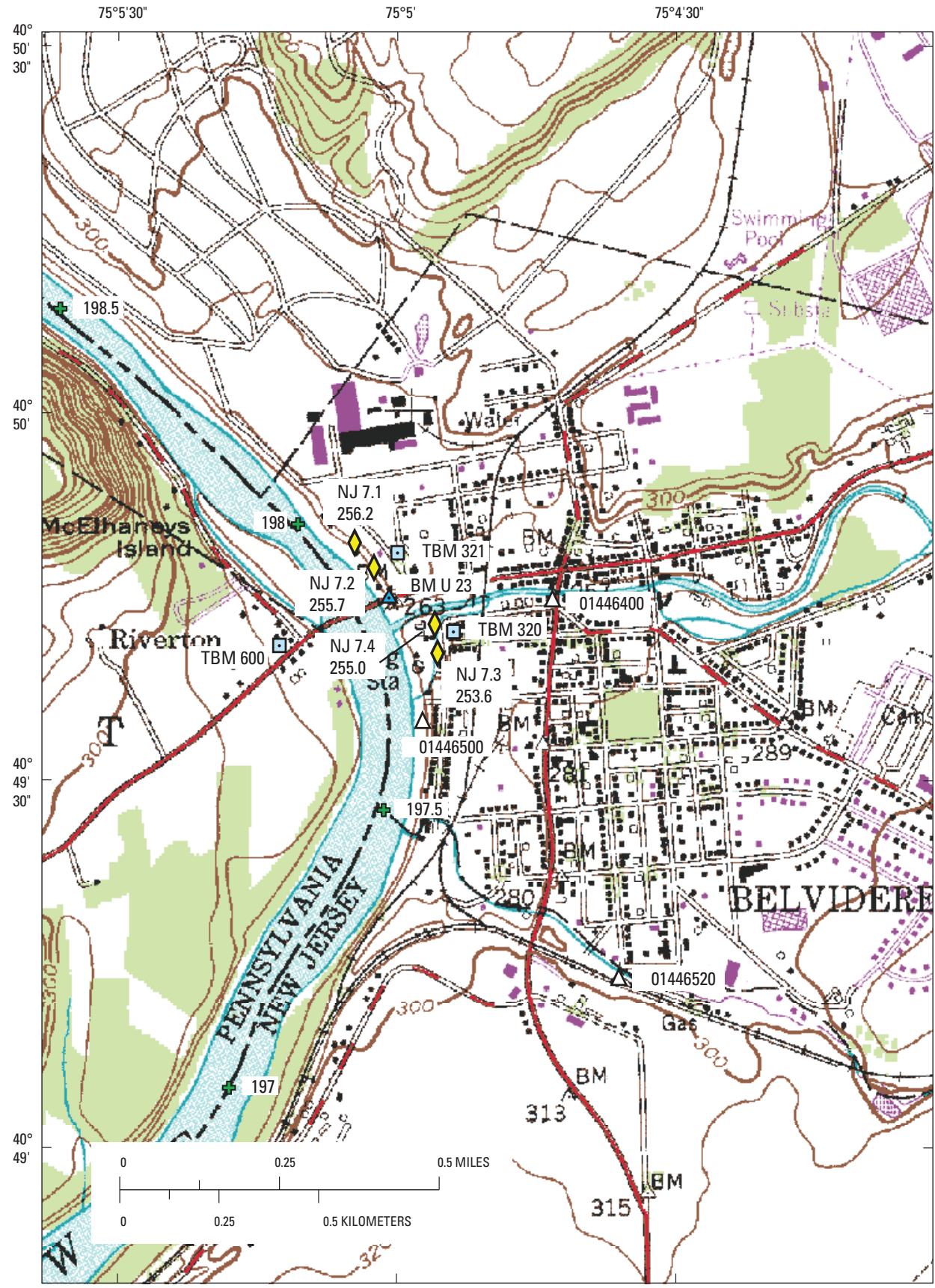

EXPLANATION

$01446500 \triangle$ U.S. Geological Survey stream gage and number

NJ7.3 $\diamond \quad$ Site of high-water mark 253.6 from flood of April 2-4 2005 , and elevation in feet above NGVD 29

BM U $23 \triangle$ National Geodetic Survey benchmark

TBM $321 \square$ U.S. Geological Survey reference mark

197 § Distance along Delaware River from mouth, in miles (Delaware River Basin Commission, 1988)

Belvidere USGS 7.5' Topographic Quadrangle map showing location of site NJ 7, Delaware River at Belvidere, NJ. 


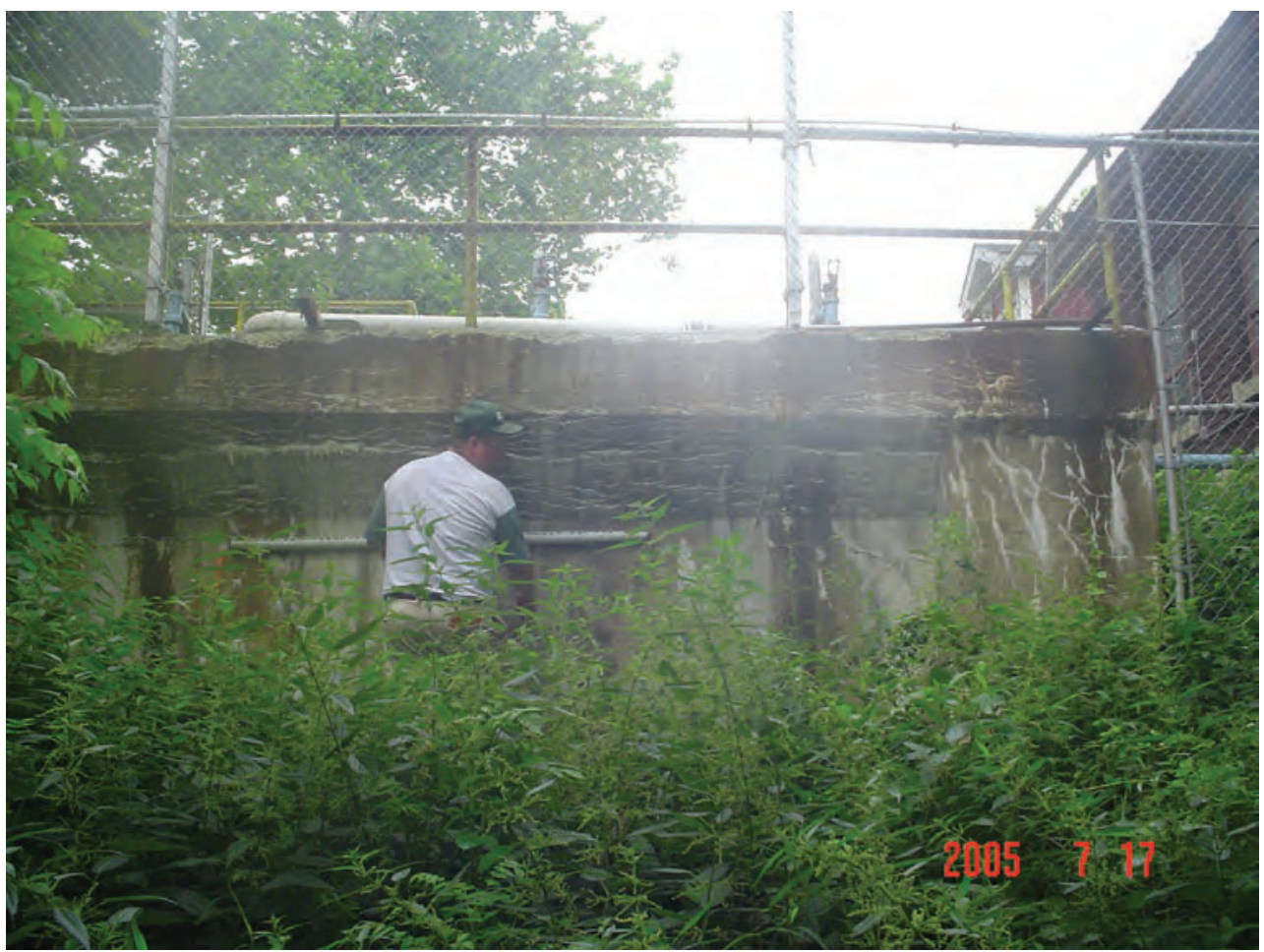

High-water mark NJ 7.1 (lat $40^{\circ} 49^{\prime} 49.5^{\prime \prime}$, long $75^{\circ} 05^{\prime} 04.6^{\prime \prime}$ ), at an elevation of 256.2 feet above NGVD 29 , is a good seed line on a wall, 4 feet above the ground, 500 feet upstream from the Water Street bridge, and was marked with a metal USGS washer and nail.

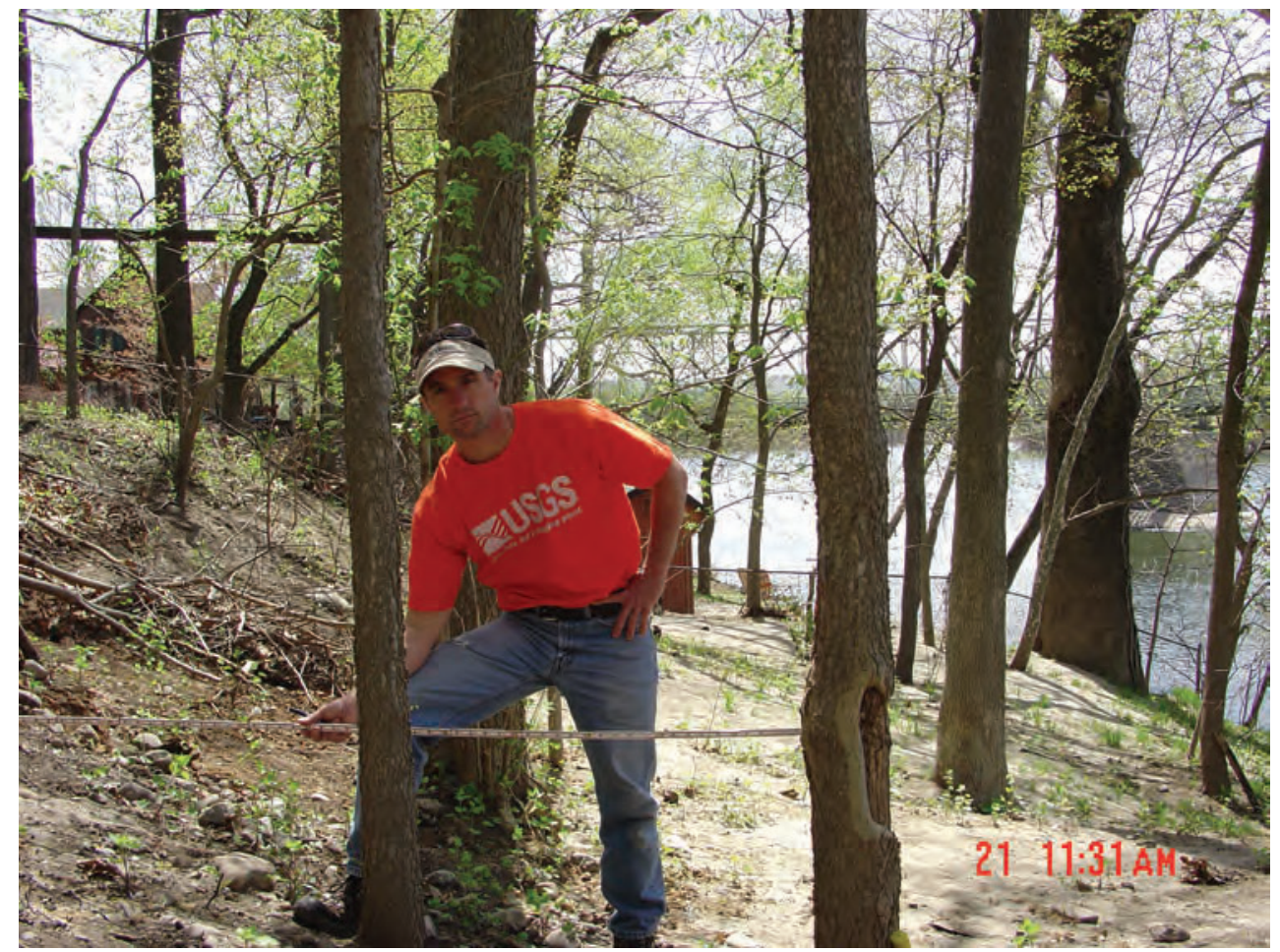

High-water mark NJ 7.2 (lat $40^{\circ} 49^{\prime} 47.5^{\prime \prime}$, long $75^{\circ} 05^{\prime} 02.5^{\prime \prime}$ ), at an elevation of 256.2 feet above NGVD 29 , is a poor debris line on an 8-inch diameter tree, 2.4 feet above the ground, 280 feet upstream from the Water Street bridge, and was marked with a metal USGS washer and nail. 


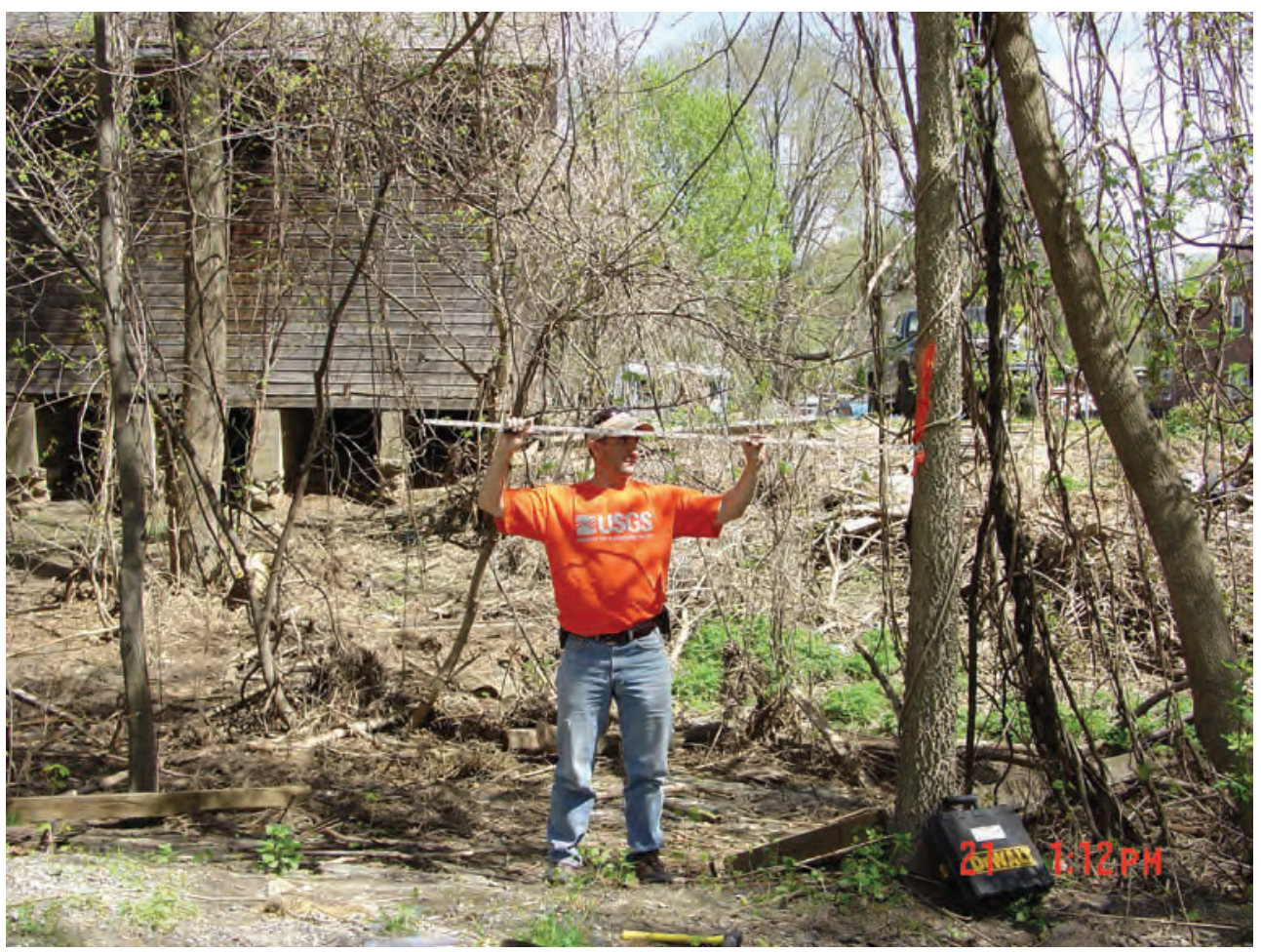

High-water mark NJ 7.3 (lat $40^{\circ} 49^{\prime} 40.7^{\prime \prime}$, long $75^{\circ} 04^{\prime} 55.7^{\prime \prime}$ ), at an elevation of 253.6 feet above NGVD 29 , is a fair debris line on an 10-inch diameter tree, 4.9 feet above the ground, 500 feet downstream from the Water Street bridge, and was marked with a metal USGS washer and nail.

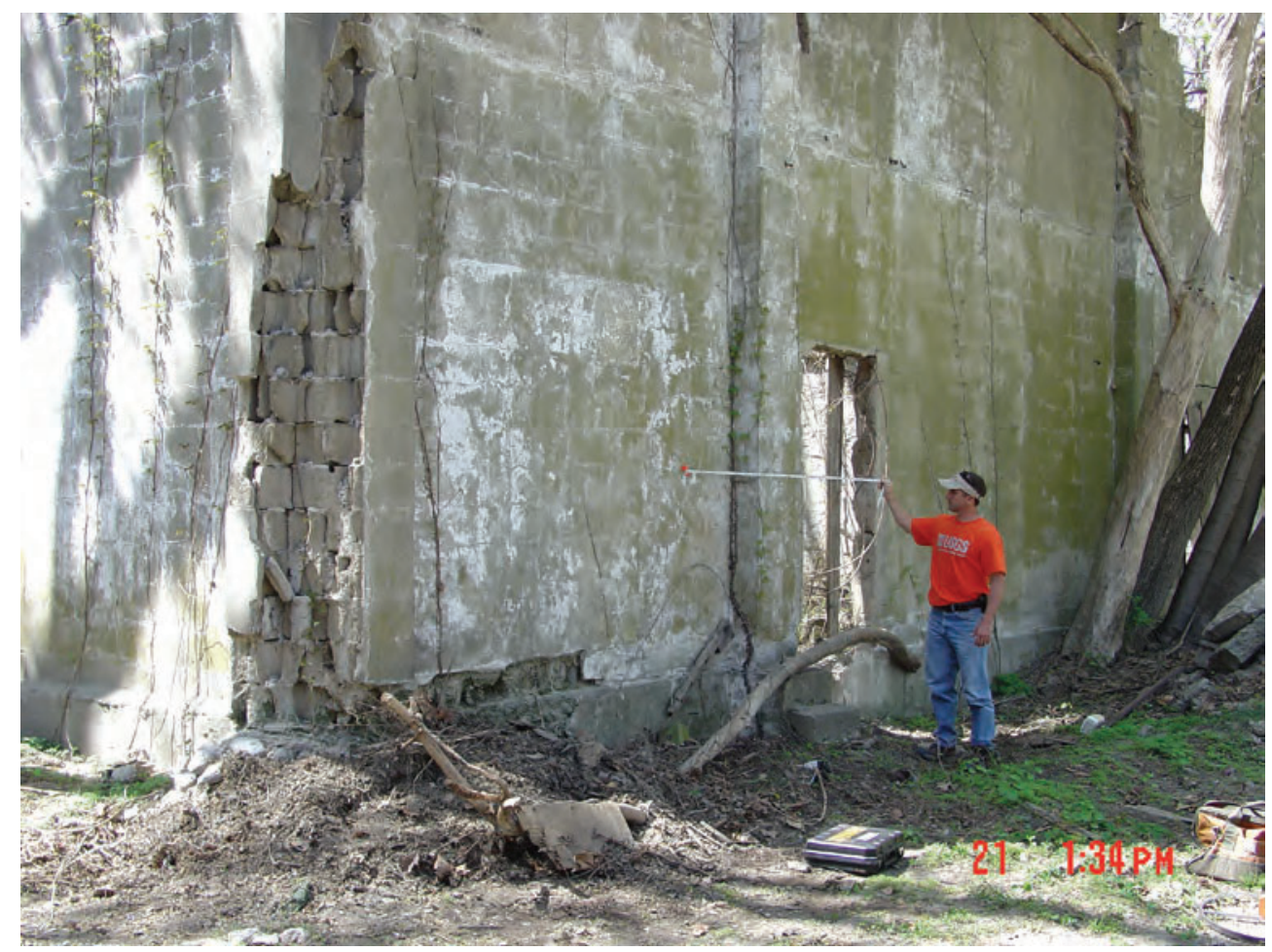

High-water mark NJ 7.4 (lat $40^{\circ} 49^{\prime} 42.8^{\prime \prime}$, long $75^{\circ} 04^{\prime} 55.8^{\prime \prime}$ ), at an elevation of 255.0 feet above NGVD 29 , is a good seed line on an abandoned building, 5.5 feet above the ground, 300 feet downstream from Water Street bridge, and was marked with a metal USGS washer and nail. 


\section{SITE DESCRIPTION}

Site NJ 8: Delaware River at Foul Rift, NJ

Site Location: 0.4 mi reach in vicinity of lat $40^{\circ} 48^{\prime} 06^{\prime \prime}$, long $75^{\circ} 05^{\prime} 53^{\prime \prime}$,

White Township, Warren County, NJ

Five high-water marks were surveyed: three seed lines, one debris line, and one eyewitness description.

High-water mark elevations were determined using USGS reference mark 120 at lat $40^{\circ} 48^{\prime} 07.0^{\prime \prime}$, long $75^{\circ} 05^{\prime} 50.0^{\prime \prime}$ (elevation is 234.69 feet, NAVD 88).

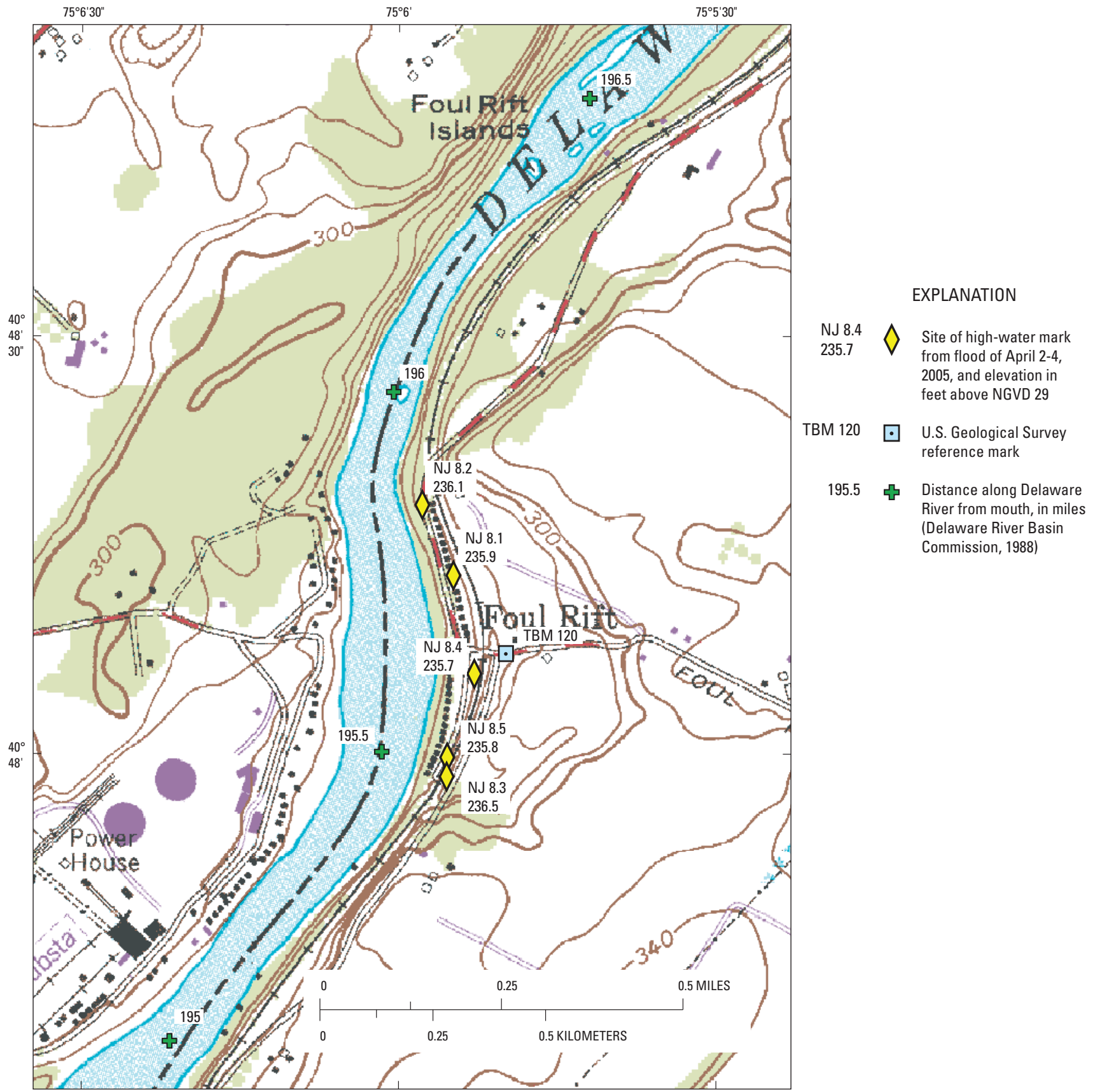

Belvidere USGS 7.5' Topographic Quadrangle map showing location of site NJ 8, Delaware River at Foul Rift, NJ. 


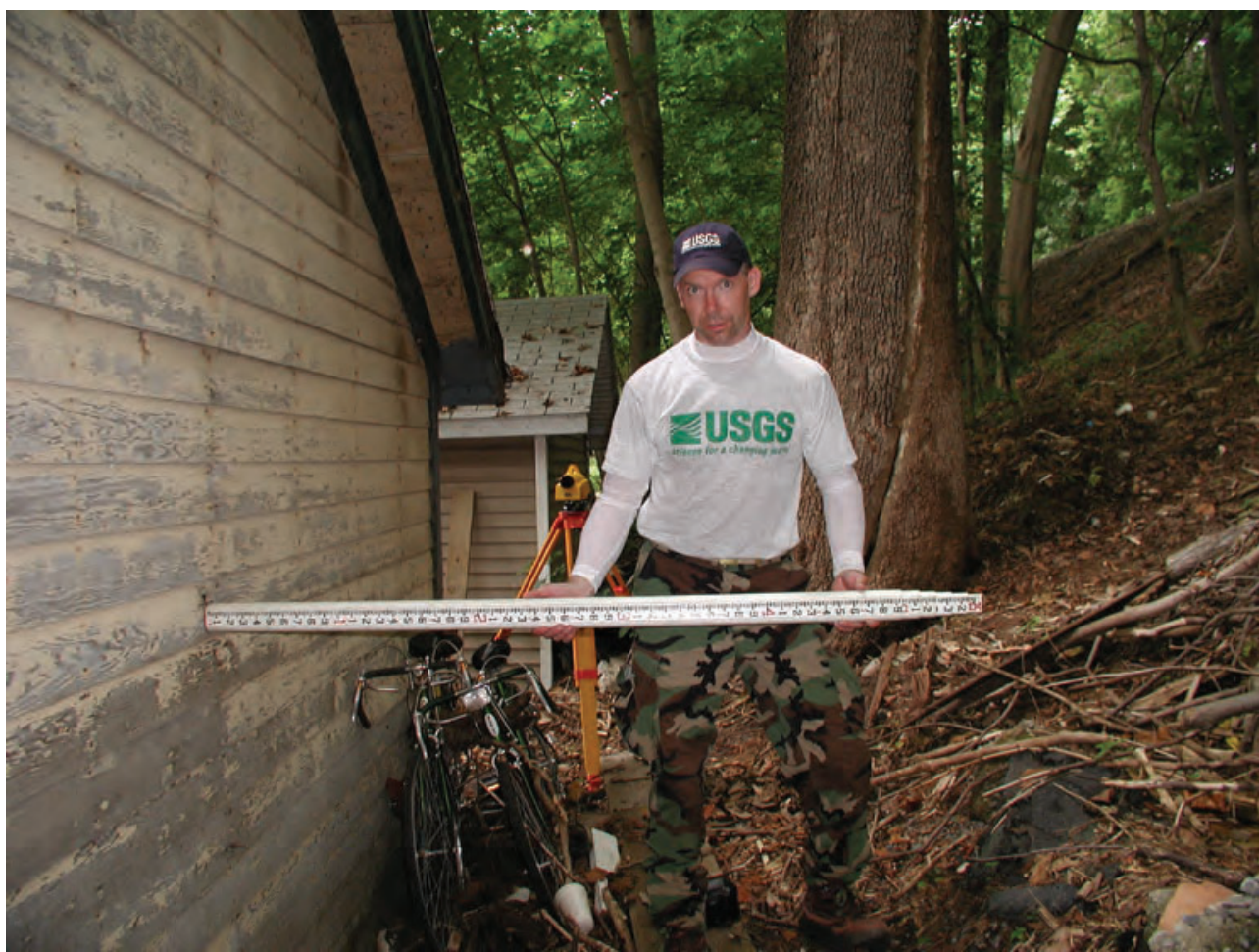

High-water mark NJ 8.1 (lat $40^{\circ} 48^{\prime} 13^{\prime \prime}$, long $75^{\circ} 05^{\prime} 55^{\prime \prime}$ ), at an elevation of 235.9 feet above NGVD 29 , is an excellent seed line on a building, 5 feet above the ground, 590 feet upstream from the intersection of Foul Rift Road and Van Emburgh Court, and was marked with a black marker line.

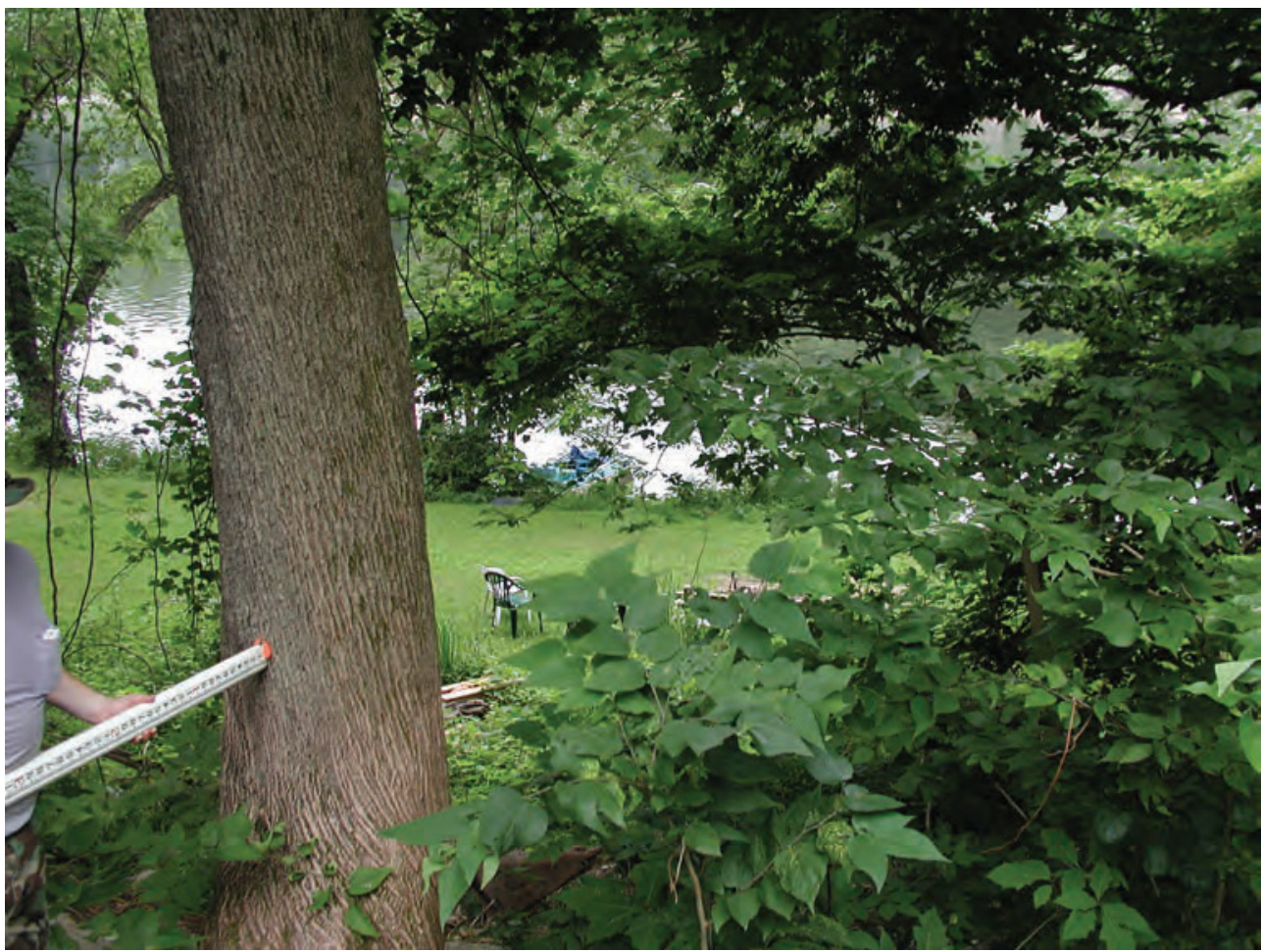

High-water mark NJ 8.2 (lat $40^{\circ} 48^{\prime} 18^{\prime \prime}$, long $75^{\circ} 05^{\prime} 58^{\prime \prime}$ ), at an elevation of 236.1 feet above NGVD 29 , is a good seed line on a 2-foot diameter tree, 3.5 feet above the ground, 1,120 feet upstream from the intersection of Foul Rift Road and Van Emburgh Court, and was marked with a metal USGS washer and nail. 


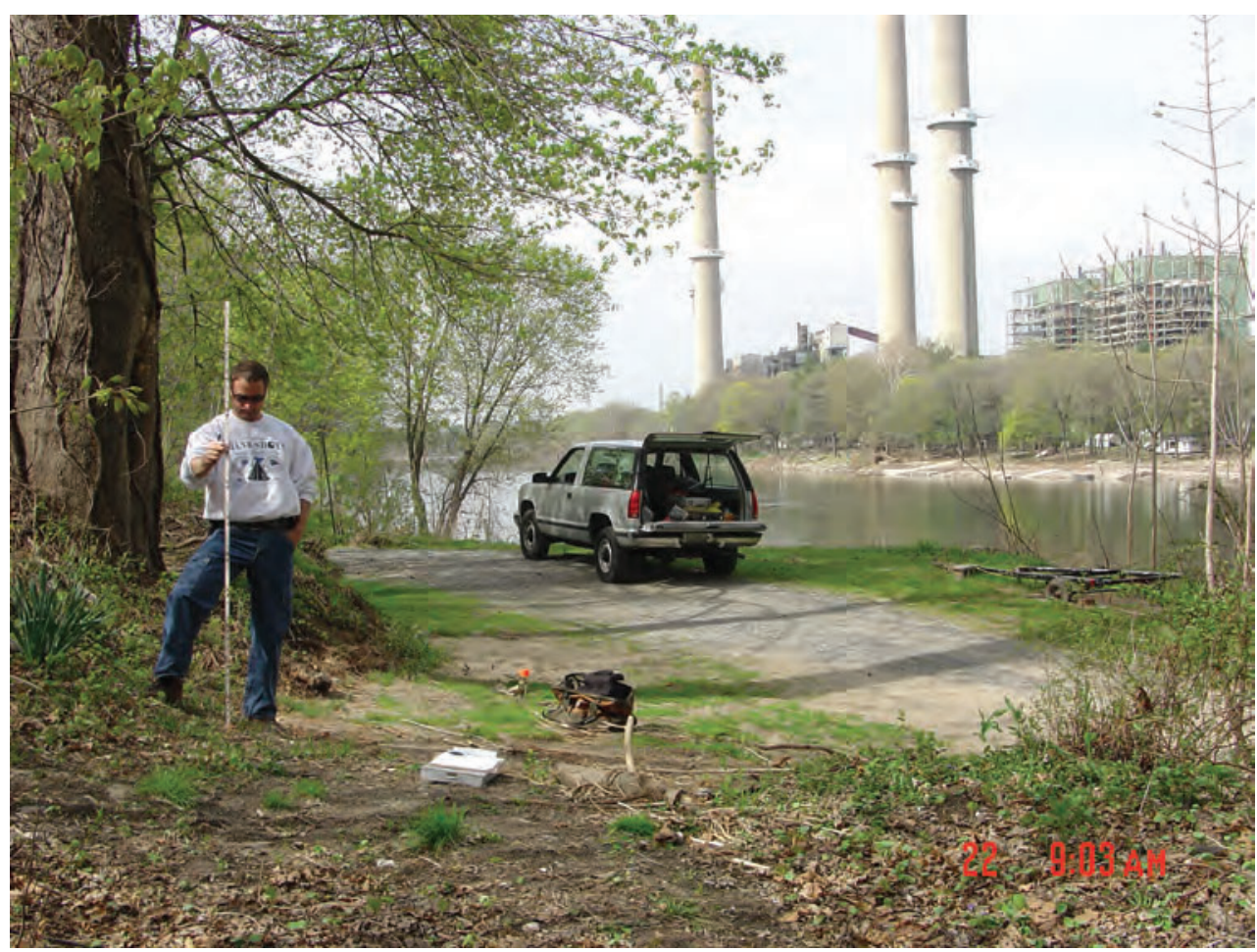

High-water mark NJ 8.3 (lat $40^{\circ} 47^{\prime} 58.7^{\prime \prime}$, long $75^{\circ} 05^{\prime} 55.7^{\prime \prime}$ ), at an elevation of 236.5 feet above NGVD 29, is a good debris line on the ground, 900 feet downstream from the intersection of Foul Rift Road and Van Emburgh Court, and was marked with a metal rebar.

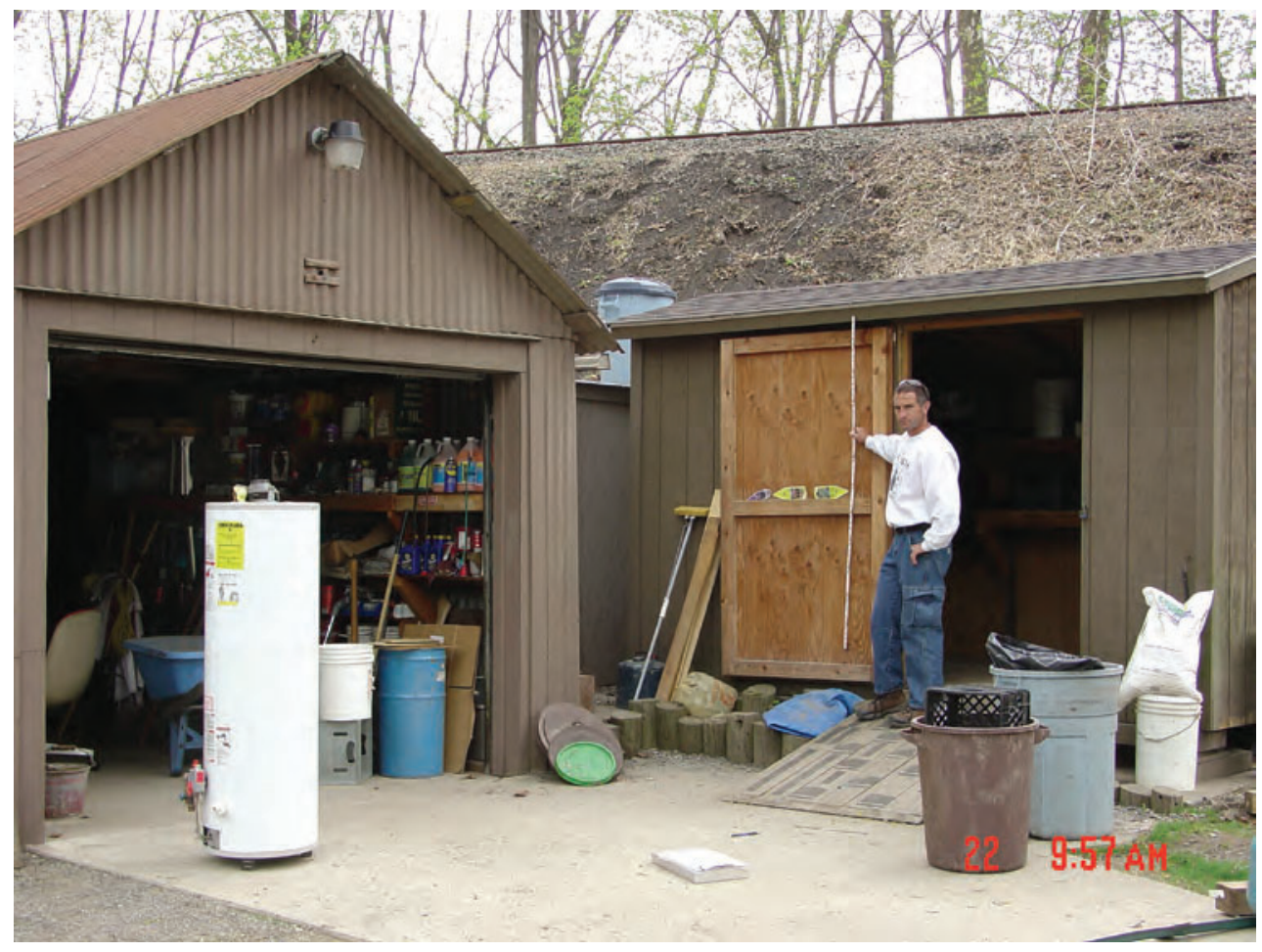

High-water mark NJ 8.4 (lat $40^{\circ} 48^{\prime} 06^{\prime \prime}$, long $75^{\circ} 05^{\prime} 53^{\prime \prime}$ ), at an elevation of 235.7 feet above NGVD 29, is a poor seed line on a shed, 0.6 feet above the shed floor, just downstream from the intersection of Foul Rift Road and Van Emburgh Court, and was marked with a black marker line. 


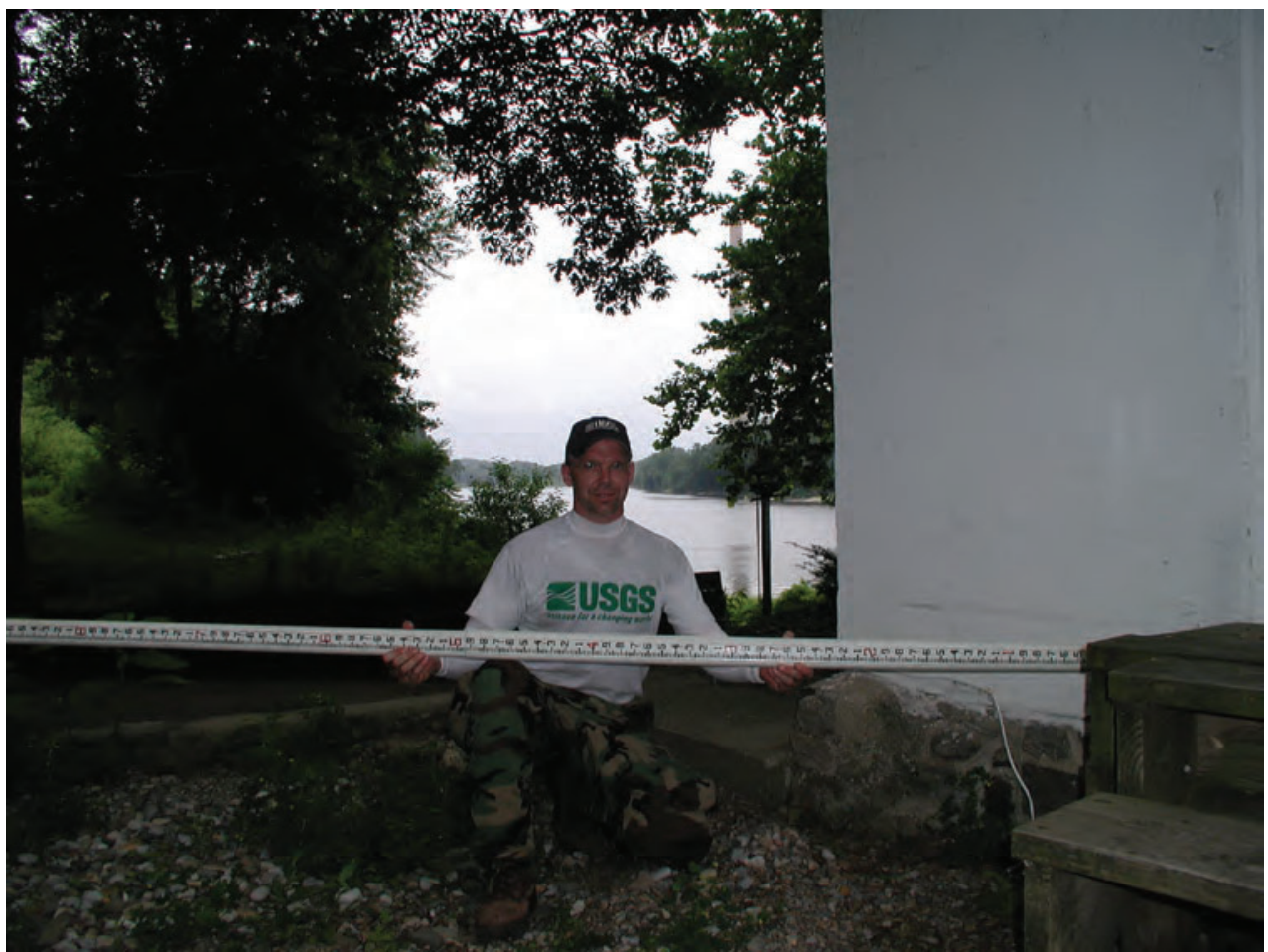

High-water mark NJ 8.5 (lat $40^{\circ} 48^{\prime} 00^{\prime \prime}$, long $75^{\circ} 05^{\prime} 55.5^{\prime \prime}$ ), at an elevation of 235.8 feet above NGVD 29 , is a poor mark on a house (location of mark given by resident), 1.8 feet above the ground, 900 feet downstream from the intersection of Foul Rift Road and Van Emburgh Court, and was marked with a black marker line. 


\begin{tabular}{|c|}
\hline SITE DESCRIPTION \\
\hline Site PA 9A: Delaware River near Mount Pleasant, PA \\
\hline Site Location: 0.1 mile reach in vicinity of lat $40^{\circ} 47^{\prime} 20^{\prime \prime}$, long $75^{\circ} 07^{\prime} 17^{\prime \prime}$ \\
\hline Lower Mount Bethel Township, Northampton County, PA \\
\hline Three high-water marks were surveyed: two mud lines and one seed line. \\
\hline $\begin{array}{l}\text { High-water mark elevations were determined using USGS reference } 142 \text { at lat } 40^{\circ} 47^{\prime} 18.0^{\prime \prime} \text {, } \\
\text { long } 75^{\circ} 07^{\prime} 17.7^{\prime \prime} \text { (elevation is } 205.85 \text { feet above NAVD 88). }\end{array}$ \\
\hline
\end{tabular}

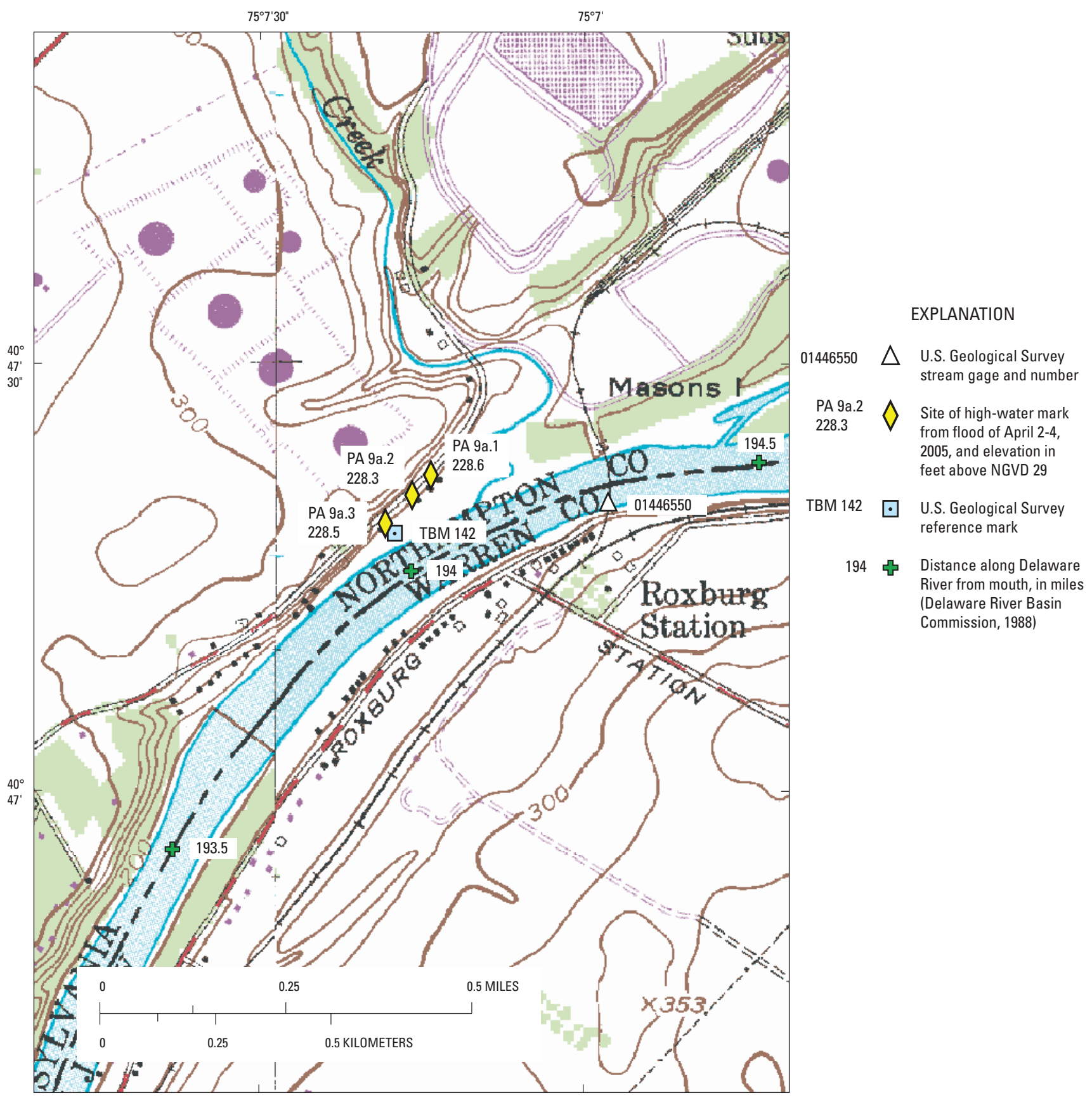

Belvidere USGS 7.5' Topographic Quadrangle map showing location of site PA 9A, Delaware River near Mount Pleasant, PA. 


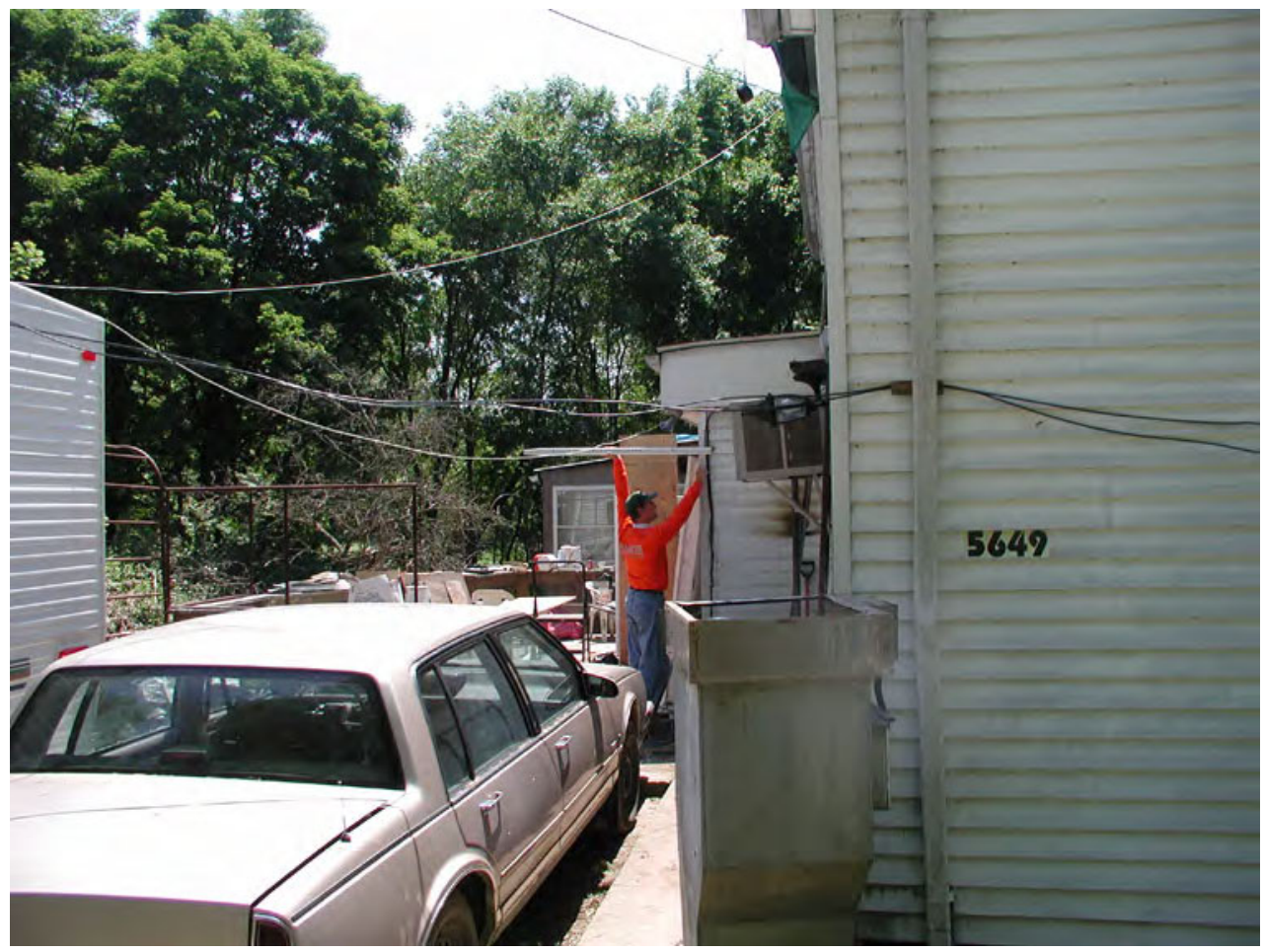

High-water mark PA $9 A .1$ (lat $40^{\circ} 47^{\prime} 22.0^{\prime \prime}$, long $75^{\circ} 07^{\prime} 14.4^{\prime \prime}$ ), at an elevation of 228.6 feet above NGVD 29 , is an excellent mud line on a house on DePues Road, 6.9 feet above the ground, just downstream from Oughoughton Creek, and was marked with a metal USGS washer and nail.

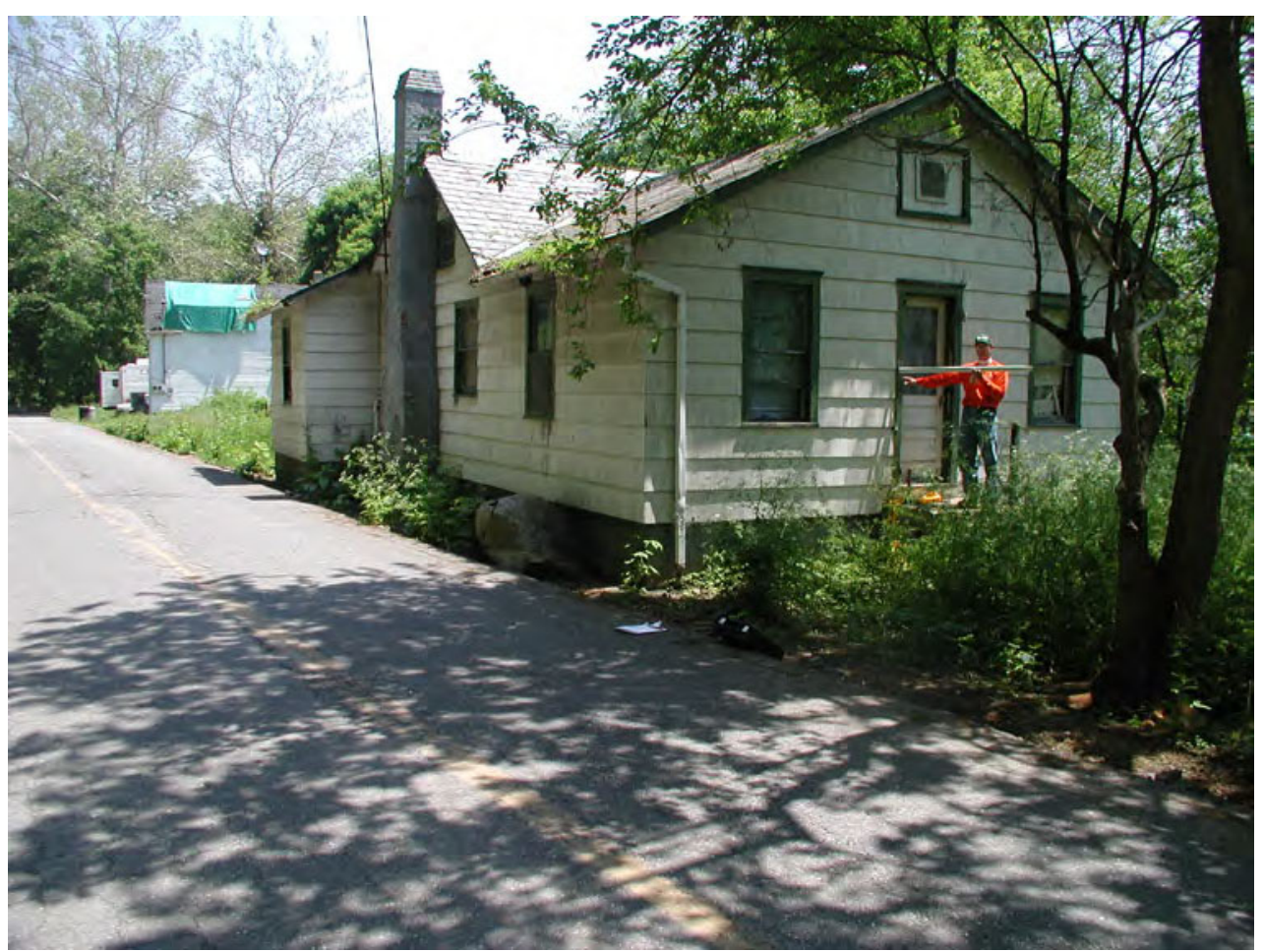

High-water mark PA $9 A .2$ (lat $40^{\circ} 47^{\prime} 20.9^{\prime \prime}$, long $75^{\circ} 07^{\prime} 16.0^{\prime \prime}$ ), at an elevation of 228.3 feet above NGVD 29 , is a good mud line on door of a house on DePues Road, 7.0 feet above the ground, just downstream from Oughoughton Creek, and was marked with a black marker line. 


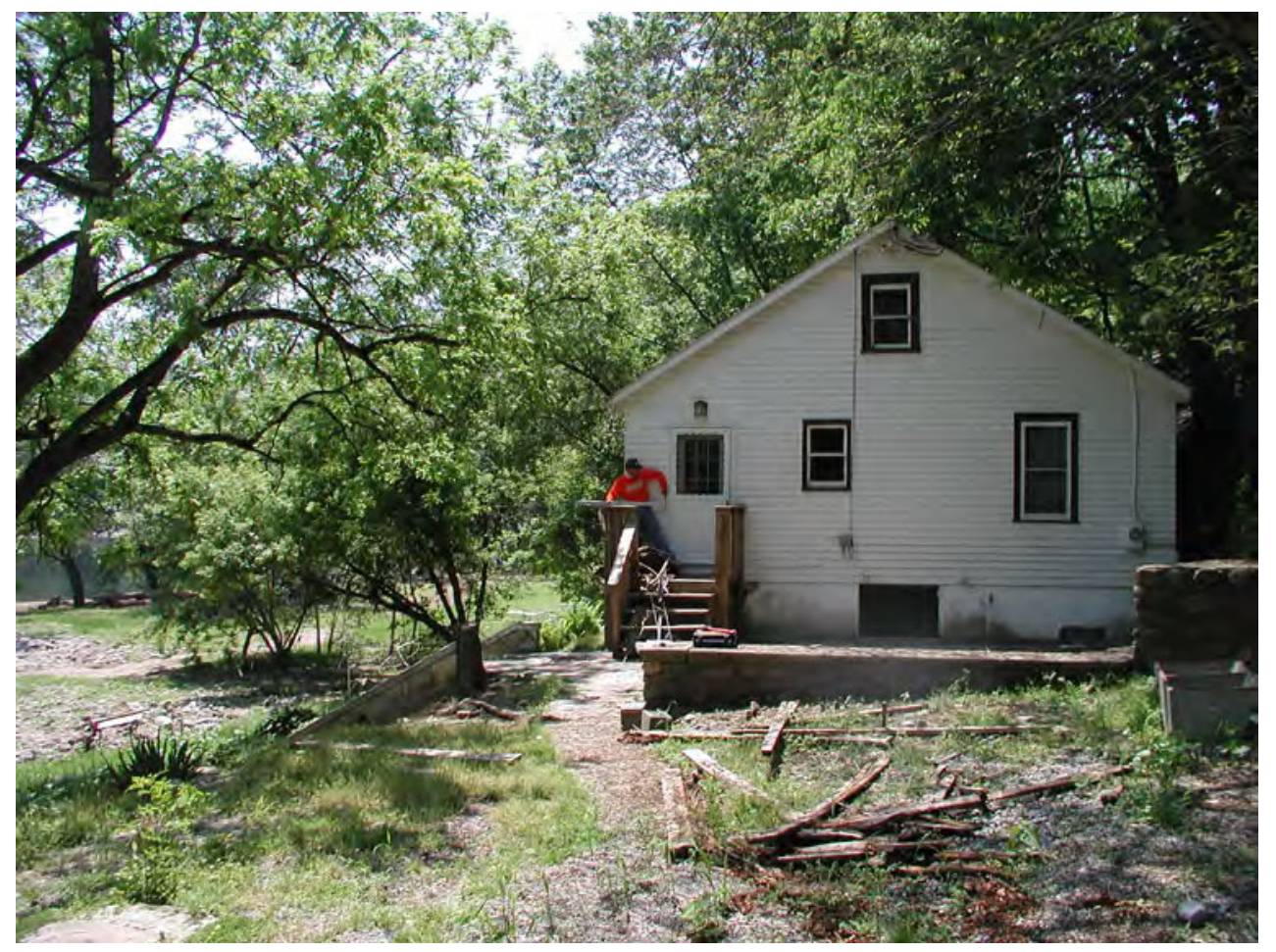

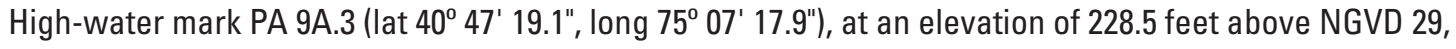
is an excellent seed line on a house on DePues Road, 7.2 feet above the ground, just downstream from Oughoughton Creek, and was marked with a nail (no USGS washer). NOTE: In case house is demolished, mark was transferred to 2-foot diameter tree $39.5 \mathrm{ft}$ northwest of house, and marked with a USGS washer and nail. 


\begin{tabular}{|l|}
\hline \multicolumn{1}{|c|}{ SITE DESCRIPTION } \\
\hline Site NJ 9: Delaware River at Hutchinson, NJ \\
\hline Site Location: 0.1 mi reach in vicinity of lat $40^{\circ} 46^{\prime} 27^{\prime \prime}$, long $75^{\circ} 07^{\prime} 50^{\prime \prime}$ \\
\hline Harmony Township, Warren County, NJ \\
\hline Two high-water marks were surveyed: two mud lines. \\
\hline $\begin{array}{l}\text { High-water mark elevations were determined using USGS reference mark } 322 \text { at lat } 40^{\circ} 46^{\prime} 26.8^{\prime \prime}, \\
\text { long } 75^{\circ} 07^{\prime} 51.9^{\prime \prime} \text { (elevation is } 215.70 \text { feet, NAVD 88). }\end{array}$ \\
\hline
\end{tabular}

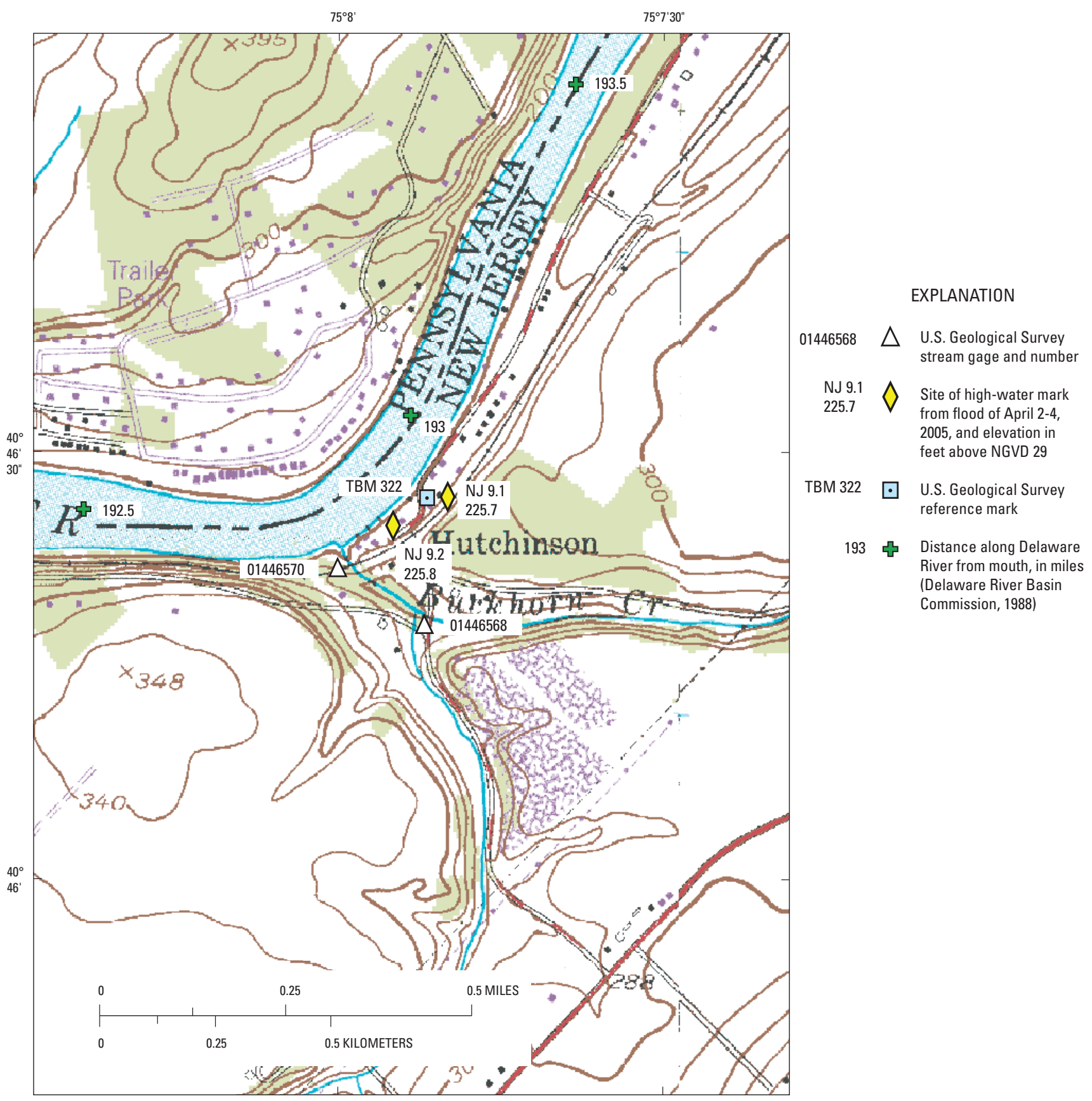

Bangor USGS 7.5' Topographic Quadrangle map showing location of site NJ 9, Delaware River at Hutchinson, NJ. 


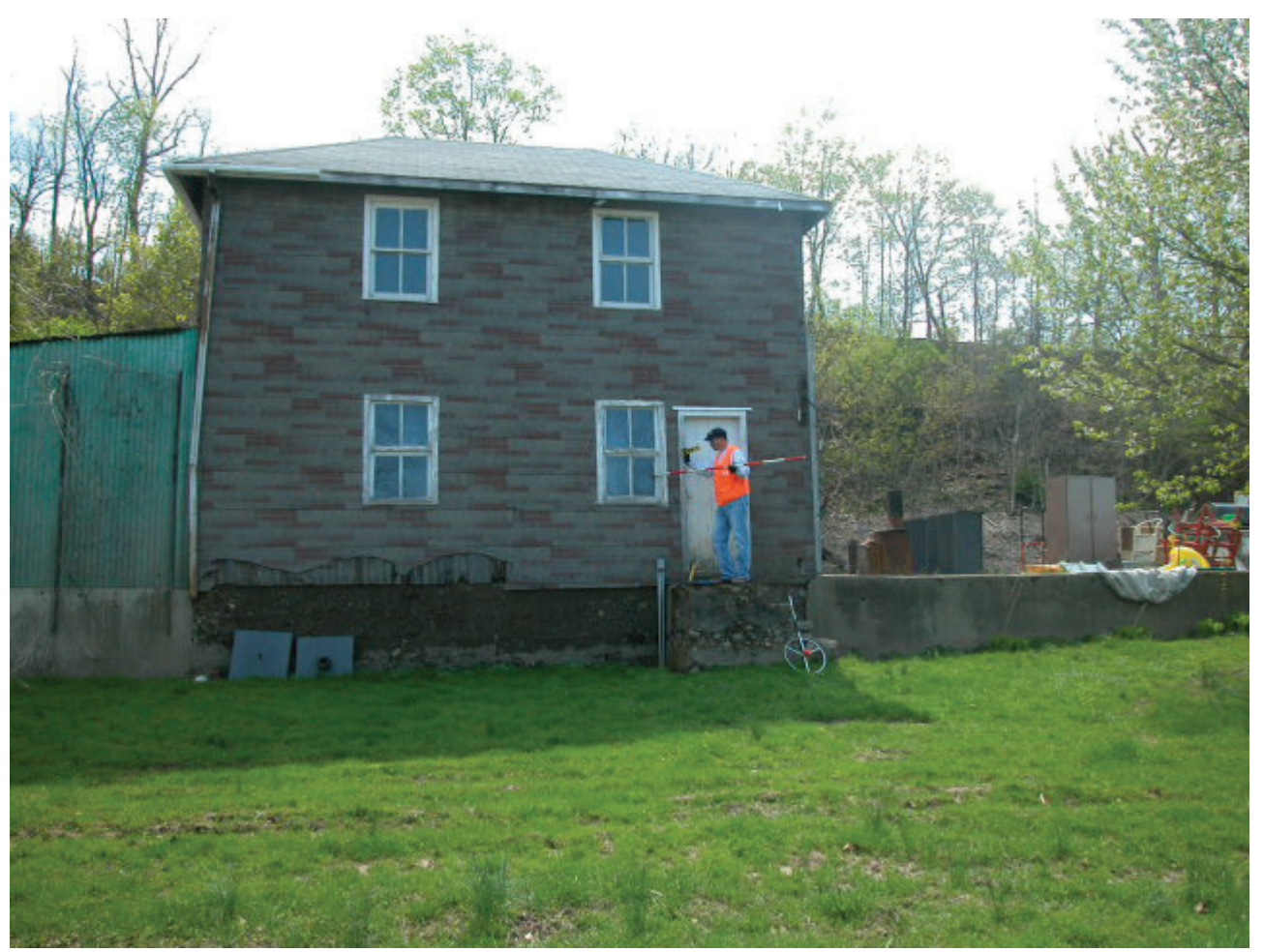

High-water mark NJ 9.1 (lat $40^{\circ} 46^{\prime} 27^{\prime \prime}$, long $75^{\circ} 07^{\prime} 50^{\prime \prime}$ ), at an elevation of 225.7 feet above NGVD 29 , is an excellent mud line on a house, 7.7 feet above the ground, 0.14 miles upstream from Buckhorn Creek, and was marked with a black marker line on window.

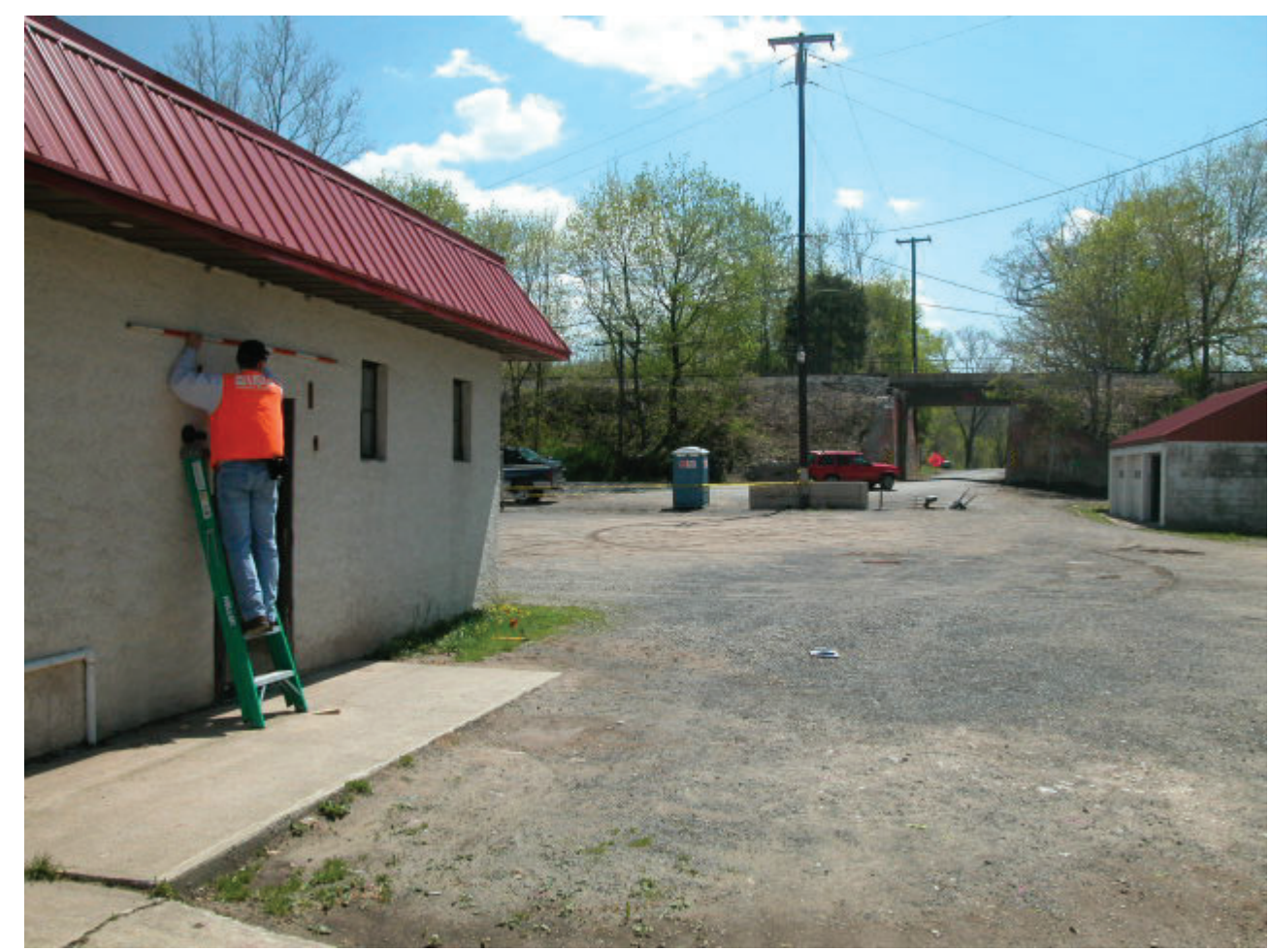

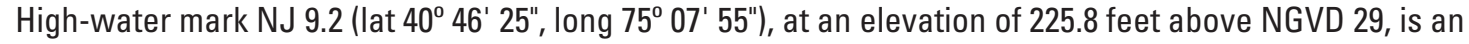
excellent mud line on a building, 8.2 feet above the ground, 0.07 miles upstream from Buckhorn Creek, and was marked with a metal USGS washer and nail. 


\section{SITE DESCRIPTION}

Site NJ 10: Delaware River at Brainards, NJ

Site Location: 0.2 mi reach in vicinity of lat $40^{\circ} 46^{\prime} 33^{\prime \prime}$, long $75^{\circ} 10^{\prime} 18^{\prime \prime}$

Harmony Township, Warren County, NJ

Three high-water marks were surveyed: two mud lines and one seed line.

High-water mark elevations were determined using USGS reference mark 222 at lat $40^{\circ} 46^{\prime} 31.0^{\prime \prime}$,

long $75^{\circ} 10^{\prime} 15.8^{\prime \prime}$ (elevation is 228.30 feet, NAVD 88).

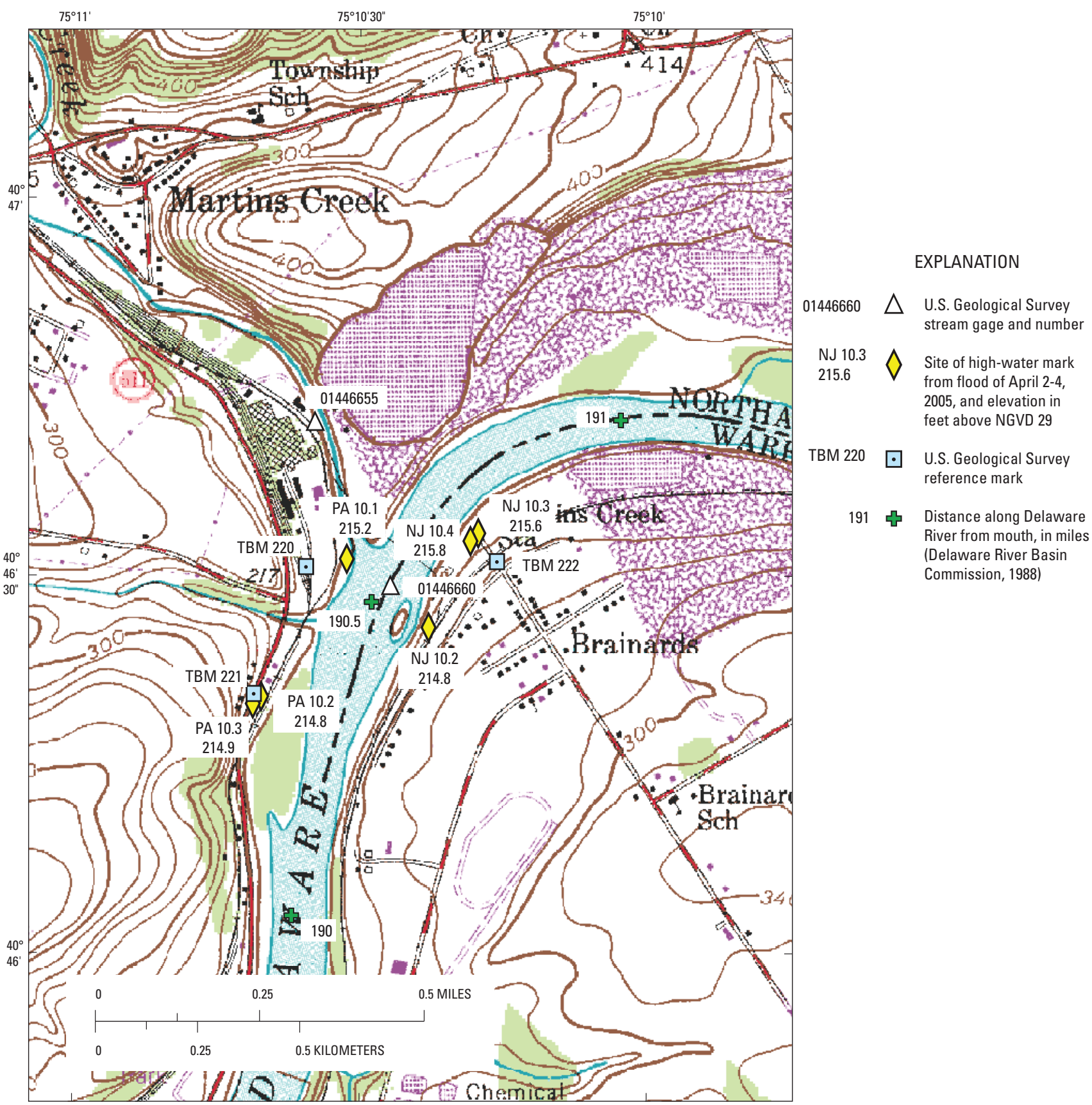

Bangor USGS 7.5' Topographic Quadrangle map showing location of site NJ 10, Delaware River at Brainards, NJ. 


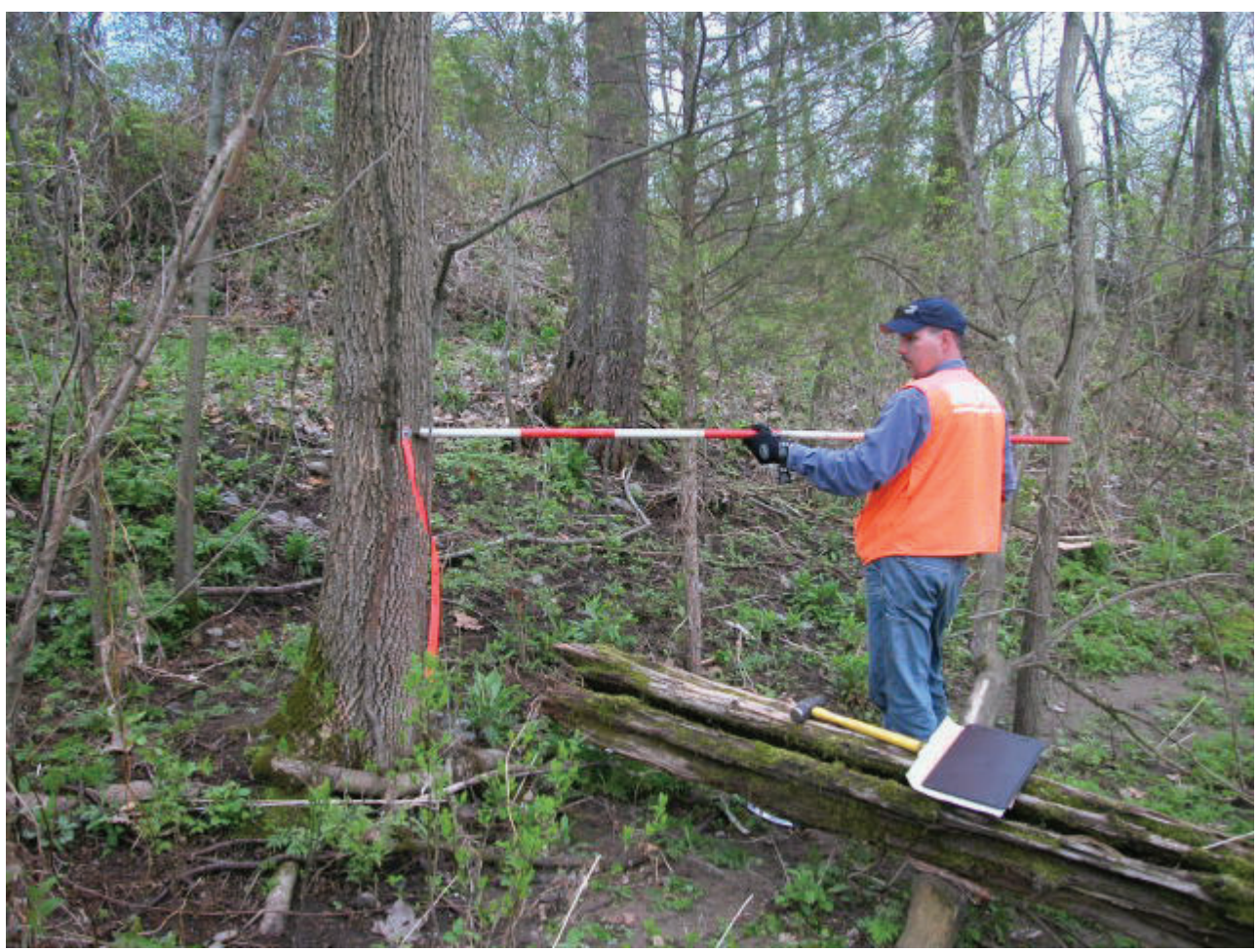

High-water mark NJ 10.2 (lat $40^{\circ} 46^{\prime} 26^{\prime \prime}$, long $75^{\circ} 10^{\prime} 23^{\prime \prime}$ ), at an elevation of 214.8 feet above NGVD 29 , is an excellent seed line on a 1-foot diameter tree, 3.8 feet above the ground, opposite the mouth of Martins Creek, and was marked with a metal USGS washer and nail.

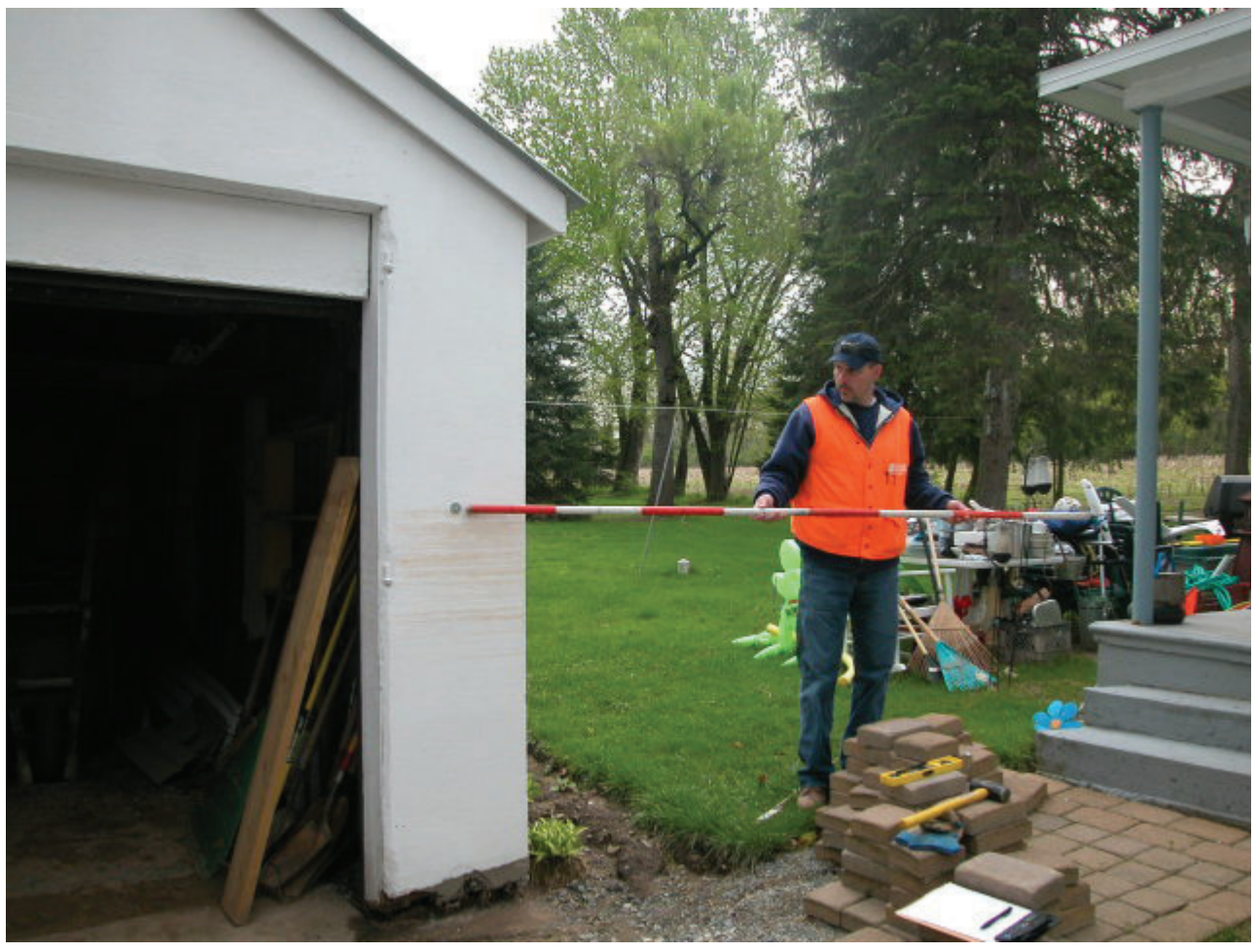

High-water mark NJ 10.3 (lat $40^{\circ} 46^{\prime} 33.5^{\prime \prime}$, long $75^{\circ} 10^{\prime} 17.8^{\prime \prime}$ ), at an elevation of 215.6 feet above NGVD 29, is an excellent mud line on a garage, 4.6 feet above the ground, at the end of Broad Street, and was marked with a metal USGS washer and nail. 


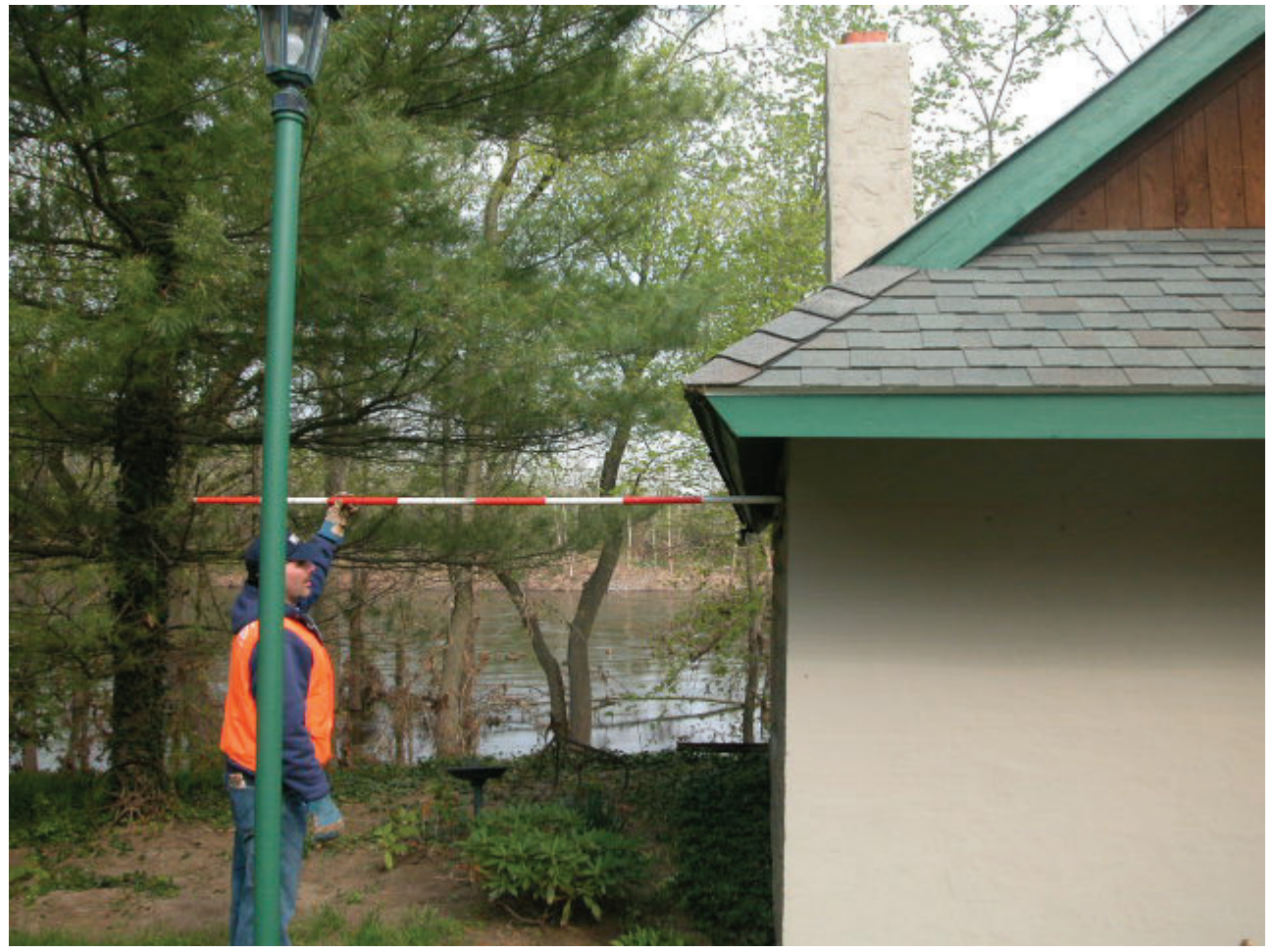

High-water mark NJ 10.4 (lat $40^{\circ} 46^{\prime} 32.9^{\prime \prime}$, long $75^{\circ} 10^{\prime} 18.5^{\prime \prime}$ ), at an elevation of 215.8 feet above NGVD 29 , is an excellent mud line on a garage, 6.7 feet above the ground, at the end of Broad Street, and was marked with a metal USGS washer and nail. 


\begin{tabular}{|c|}
\hline SITE DESCRIPTION \\
\hline Site PA 10: 01446660 Delaware River at Martins Creek, PA \\
\hline Site Location: 0.3 mile reach in vicinity of lat $40^{\circ} 46^{\prime} 26^{\prime \prime}$, long $75^{\circ} 10^{\prime} 37^{\prime \prime}$ \\
\hline Lower Mount Bethel Township, Northampton County, PA \\
\hline Three high-water marks were surveyed: one debris line, one mud line, and one seed line. \\
\hline $\begin{array}{l}\text { High-water mark elevations were determined using USGS reference } 220 \text { at lat } 40^{\circ} 46^{\prime} 30.6^{\prime \prime} \text {, } \\
\text { long } 75^{\circ} 10^{\prime} 35.7^{\prime \prime} \text { (elevation is } 211.73 \text { feet above NAVD } 88 \text { ) and USGS reference } 221 \text { at lat } \\
40^{\circ} 46^{\prime} 20.7^{\prime \prime} \text {, long } 75^{\circ} 10^{\prime} 40.8^{\prime \prime} \text { (elevation is } 210.94 \text { feet above NAVD } 88 \text { ). }\end{array}$ \\
\hline
\end{tabular}

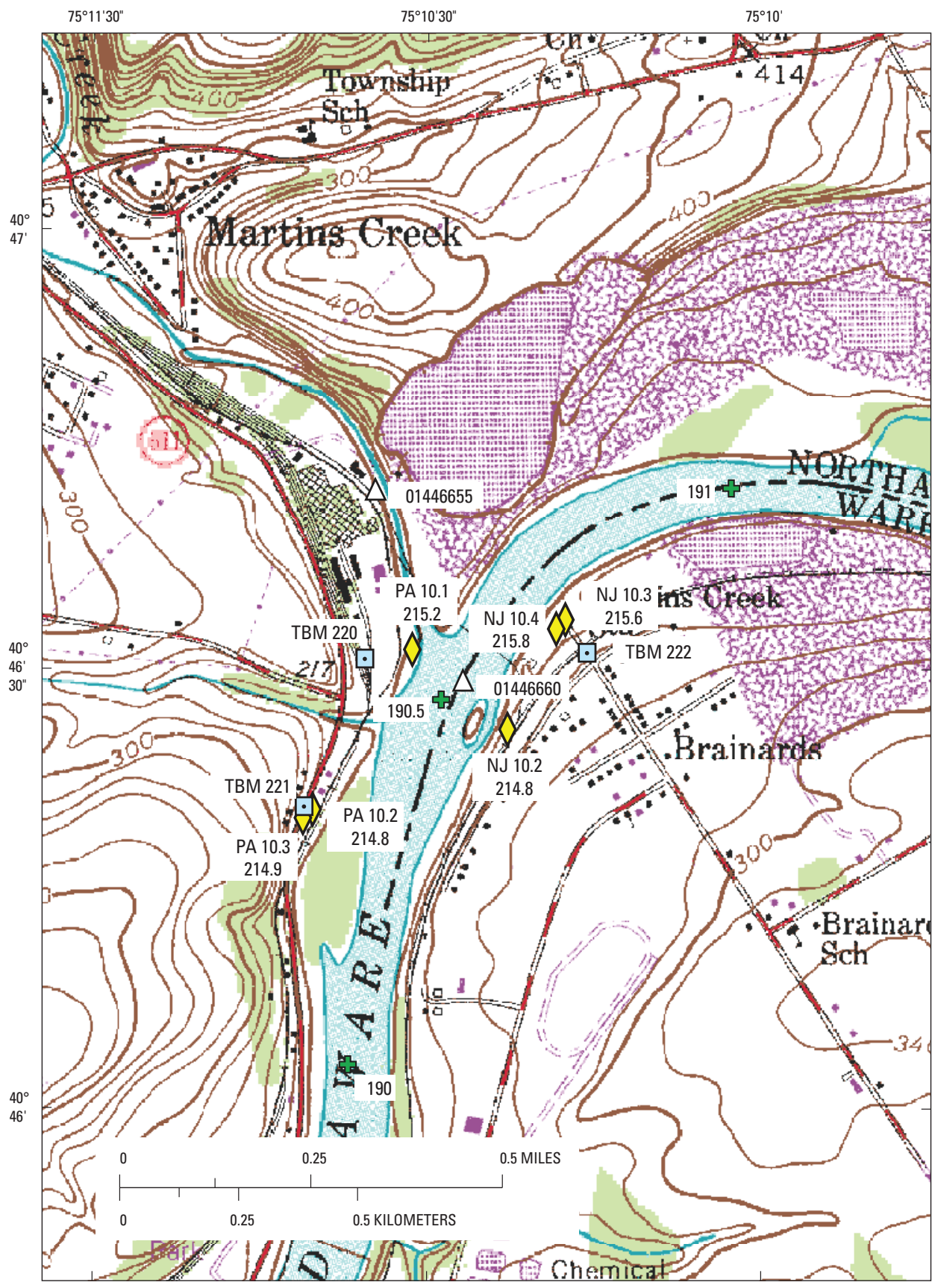

EXPLANATION

$01446655 \triangle$ U.S. Geological Survey stream gage and number

NJ $10.3 \searrow$ Site of high-water mark from flood of April 2-4, 2005 , and elevation in feet above NGVD 29

TBM $221 \square$ U.S. Geological Survey reference mark

191 Distance along Delaware River from mouth, in miles (Delaware River Basin Commission, 1988)

Bangor USGS 7.5' Topographic Quadrangle map showing location of site PA 10, Delaware River at Martins Creek, PA. 


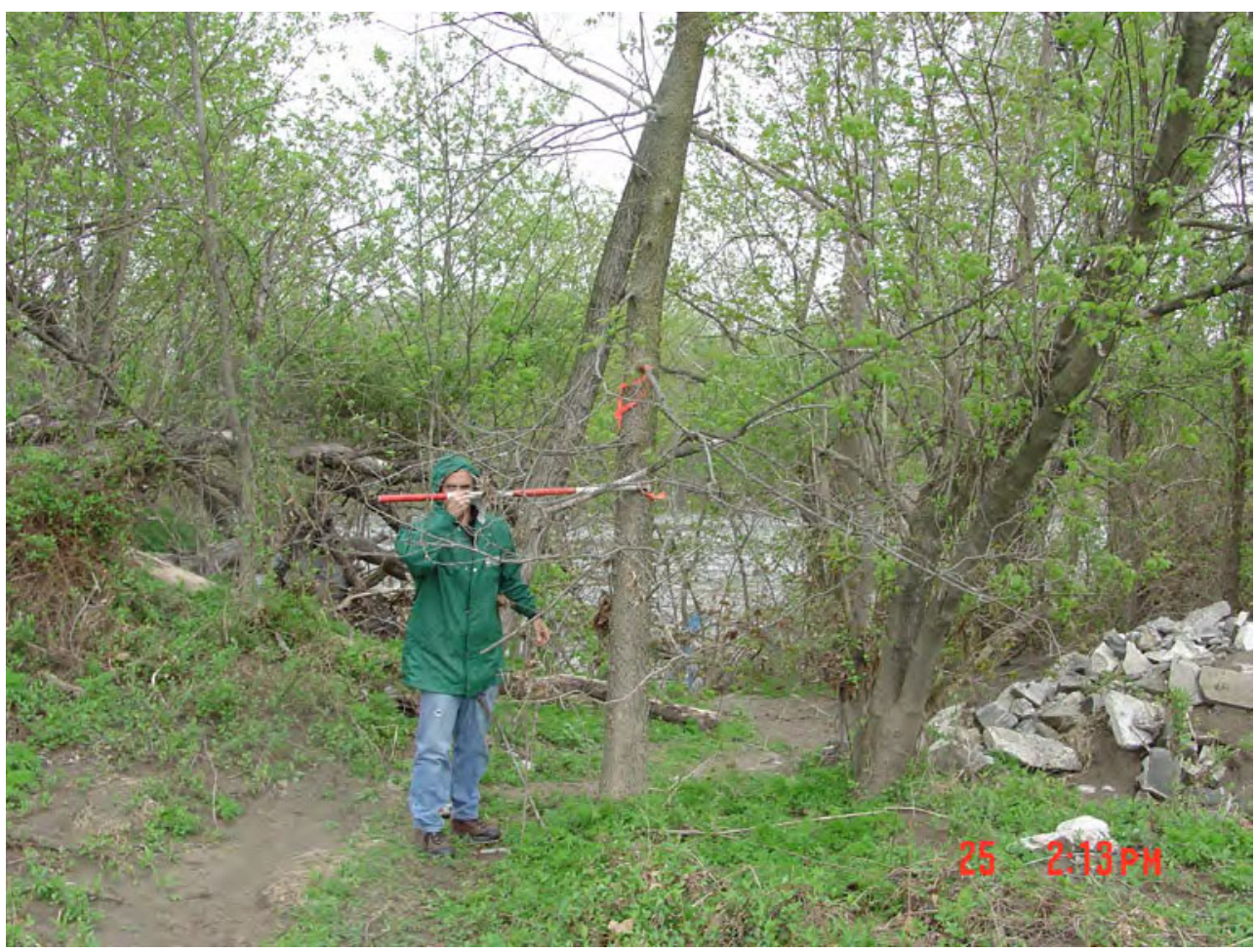

High-water mark PA 10.1 (lat $40^{\circ} 46^{\prime} 31.5^{\prime \prime}$, long $75^{\circ} 10^{\prime} 31.4^{\prime \prime}$ ), at an elevation of 215.2 feet above NGVD 29, is a good debris line on a 6-inch diameter tree, 5.5 feet above the ground, just downstream from Martins Creek, and was marked with a metal USGS washer and nail.

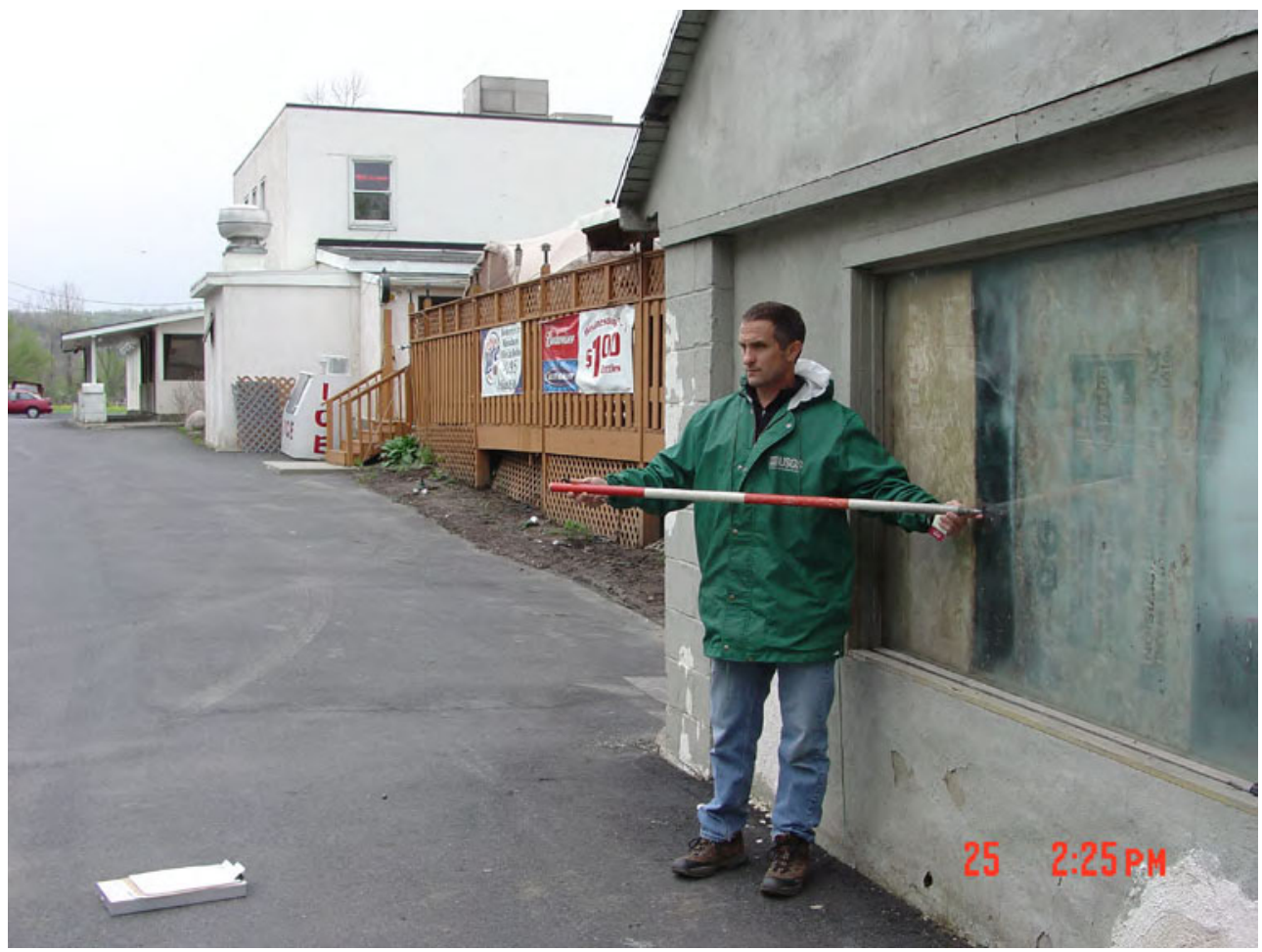

High-water mark PA 10.2 (lat 40 $46^{\prime} 20.7^{\prime \prime}$, long $75^{\circ} 10^{\prime} 40.3^{\prime \prime}$ ), at an elevation of 214.8 feet above NGVD 29, is an excellent seed line on window of building on PA State Route 611, 3.8 feet above the ground, 0.3 miles downstream from Martins Creek, and was marked with a black marker line. 


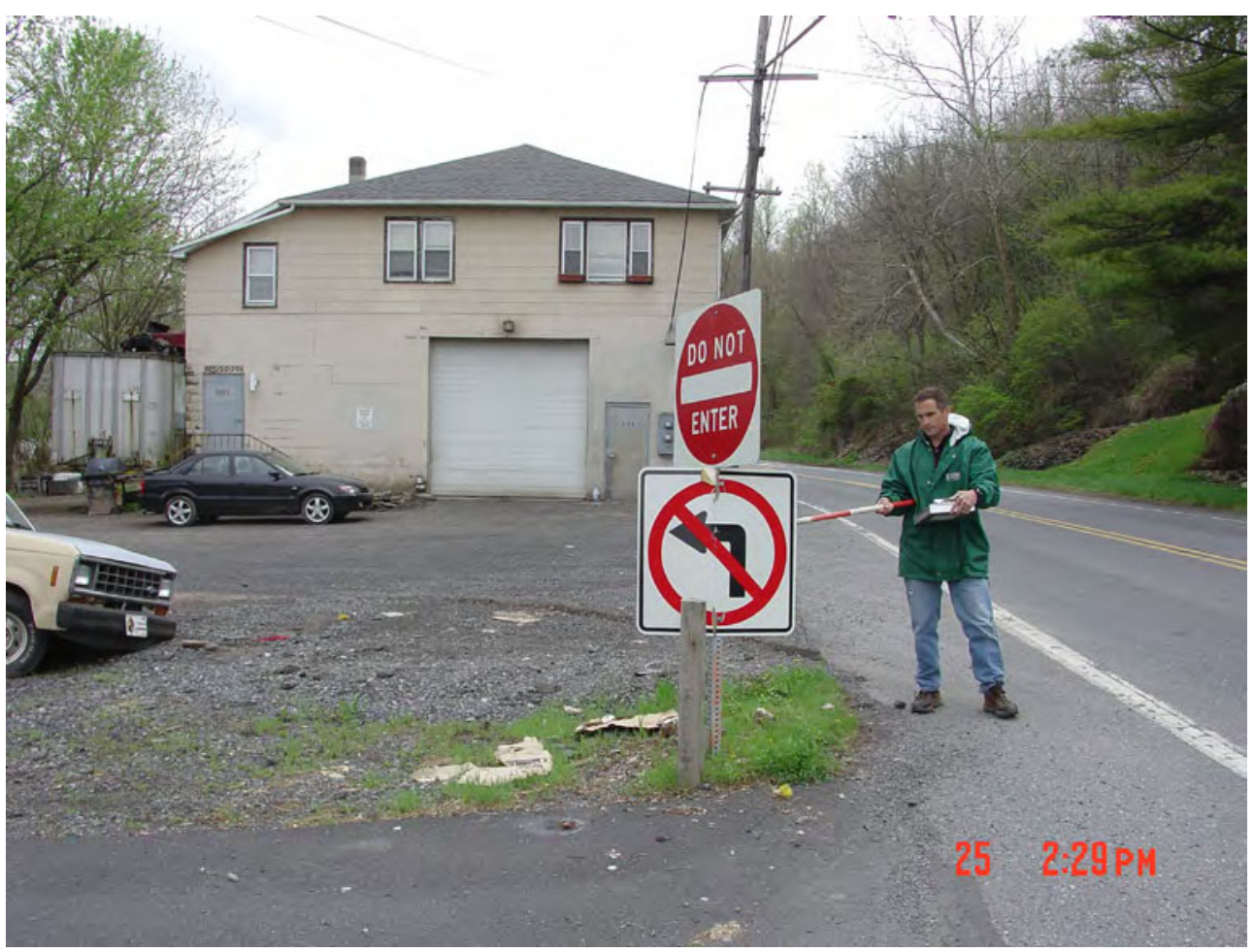

High-water mark PA 10.3 (lat $40^{\circ} 46^{\prime} 20.0^{\prime \prime}$, long $75^{\circ} 10^{\prime} 41.1^{\prime \prime}$ ), at an elevation of 214.9 feet above NGVD 29, is a good mud line on the back of a street sign, 3.4 feet above the ground, 0.3 miles downstream from Martins Creek, and was marked with a black marker line. 


\begin{tabular}{|l|}
\hline \multicolumn{1}{|c|}{ SITE DESCRIPTION } \\
\hline Site PA 11: Delaware River at Sandts Eddy, PA \\
\hline Site Location: 0.5 mile reach in vicinity of lat $40^{\circ} 45^{\prime} 26^{\prime \prime}$, long $75^{\circ} 11^{\prime} 31^{\prime \prime}$ \\
\hline Lower Mount Bethel Township, Northampton County, PA \\
\hline Three high-water marks were surveyed: two mud lines and one seed line . \\
\hline High-water mark elevations were determined using USGS reference 114 at lat $40^{\circ} 45^{\prime} 29.3^{\prime \prime}$, long \\
$75^{\circ} 11^{\prime} 23.1^{\prime \prime}$ (elevation is 203.95 feet above NAVD 88 ).
\end{tabular}

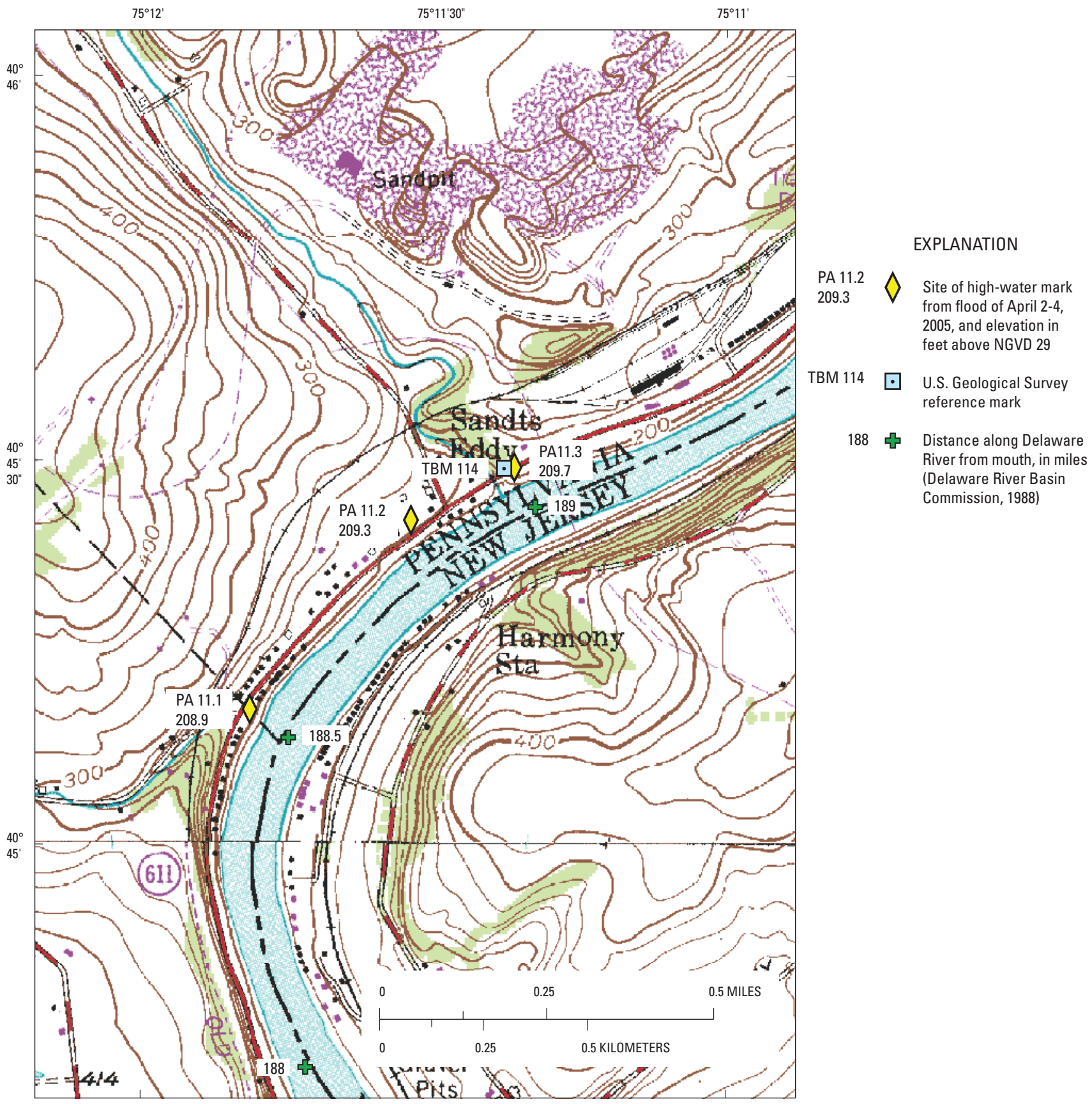

Bangor USGS 7.5' Topographic Quadrangle map showing location of site PA 11, Delaware River at Sandts Eddy, PA. 


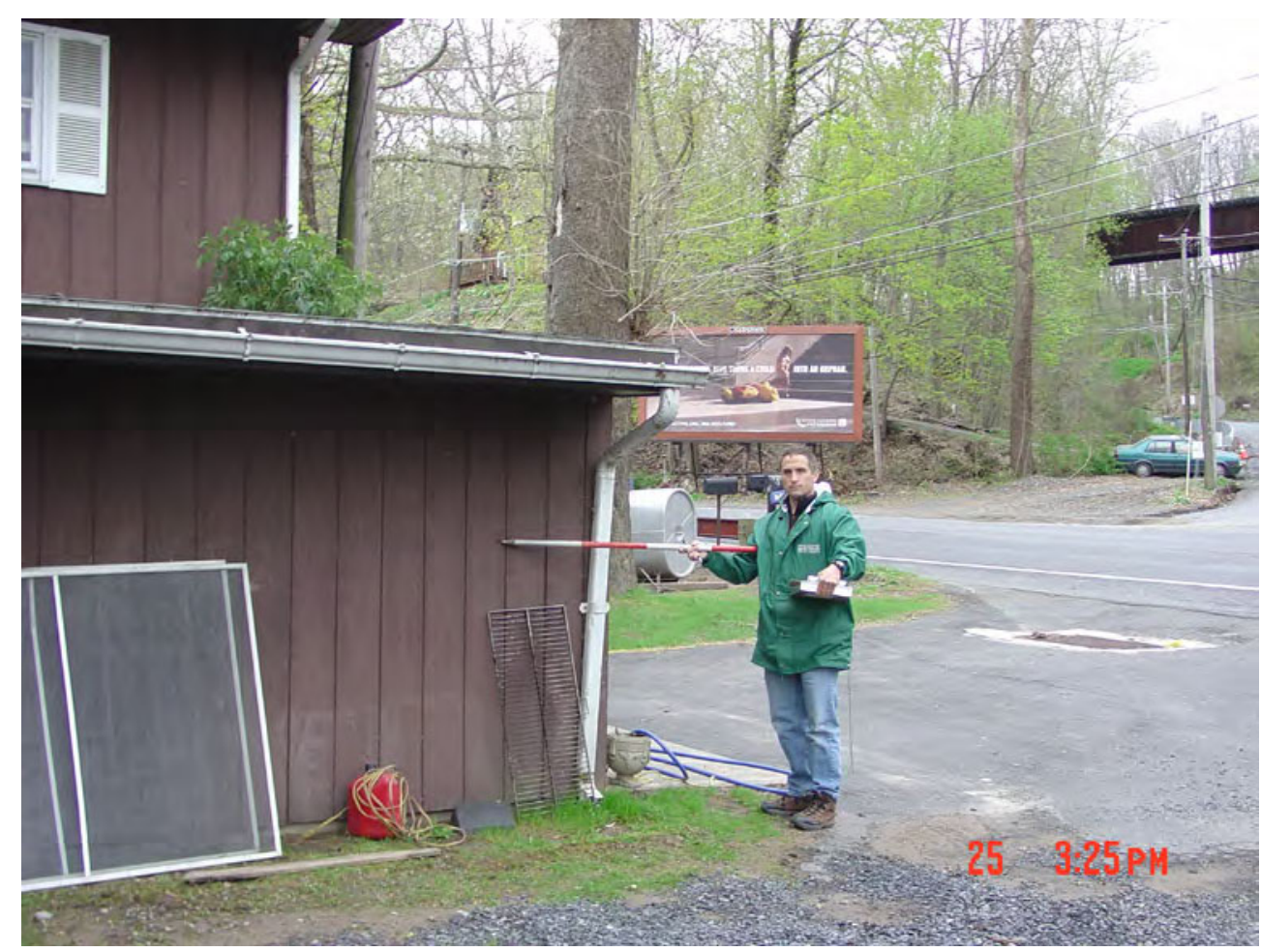

High-water mark PA 11.1 (lat $40^{\circ} 45^{\prime} 10.8^{\prime \prime}$, long $75^{\circ} 11^{\prime} 49^{\prime \prime}$ ), at an elevation of 208.9 feet above NGVD 29 , is an excellent seed line on a building on PA State Route 611, 4.1 feet above the ground, 0.5 -miles downstream from Mud Run, and was marked with a black marker line.

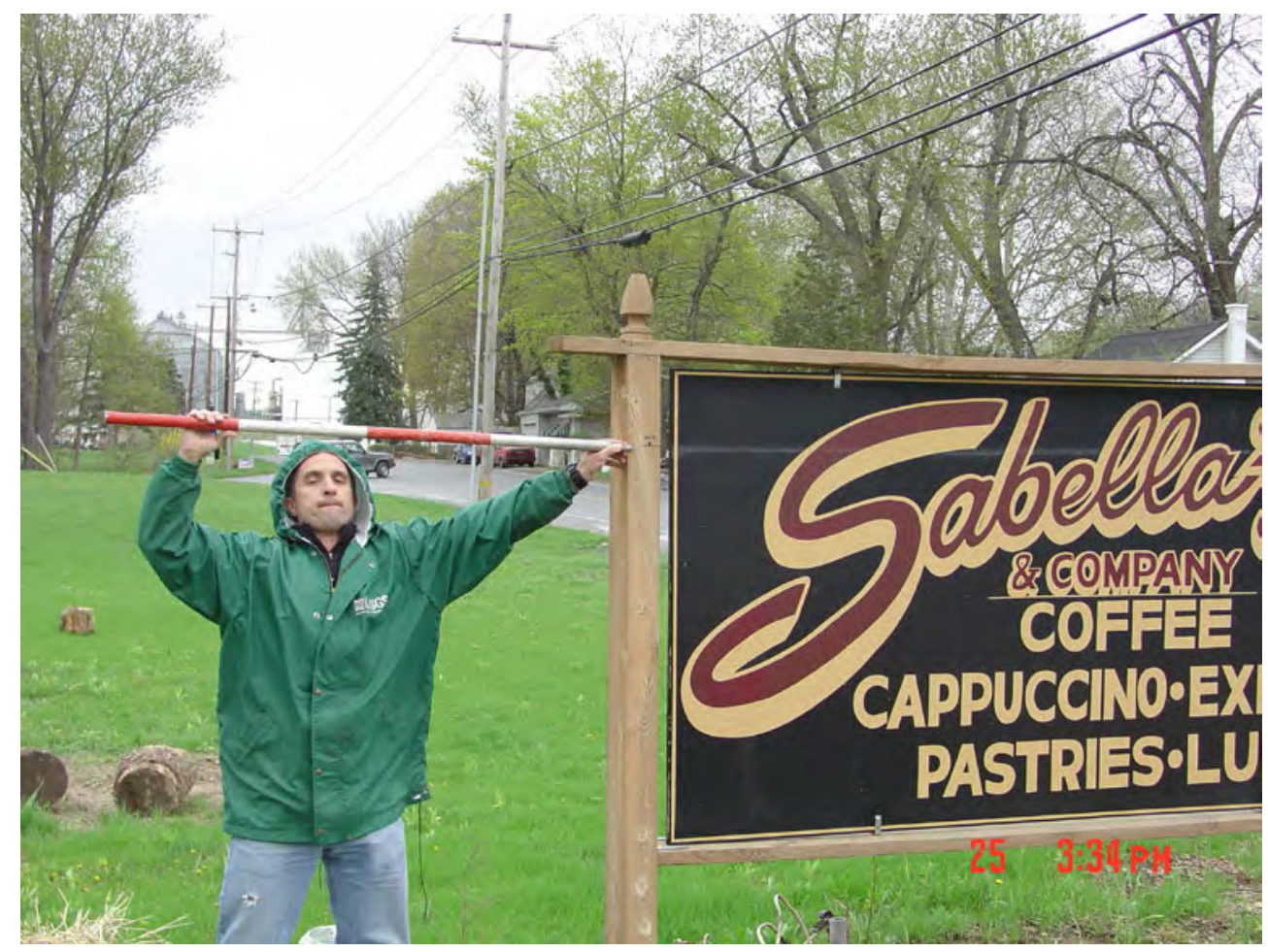

High-water mark PA 11.2 (lat $40^{\circ} 45^{\prime} 25.6^{\prime \prime}$, long $75^{\circ} 11^{\prime} 32.4^{\prime \prime}$ ), at an elevation of 209.3 feet above NGVD 29, is an excellent mud line on a business sign on PA State Route 611, 5.7 feet above the ground, 0.1 miles downstream from Martins Creek, and was marked with a black marker line. 


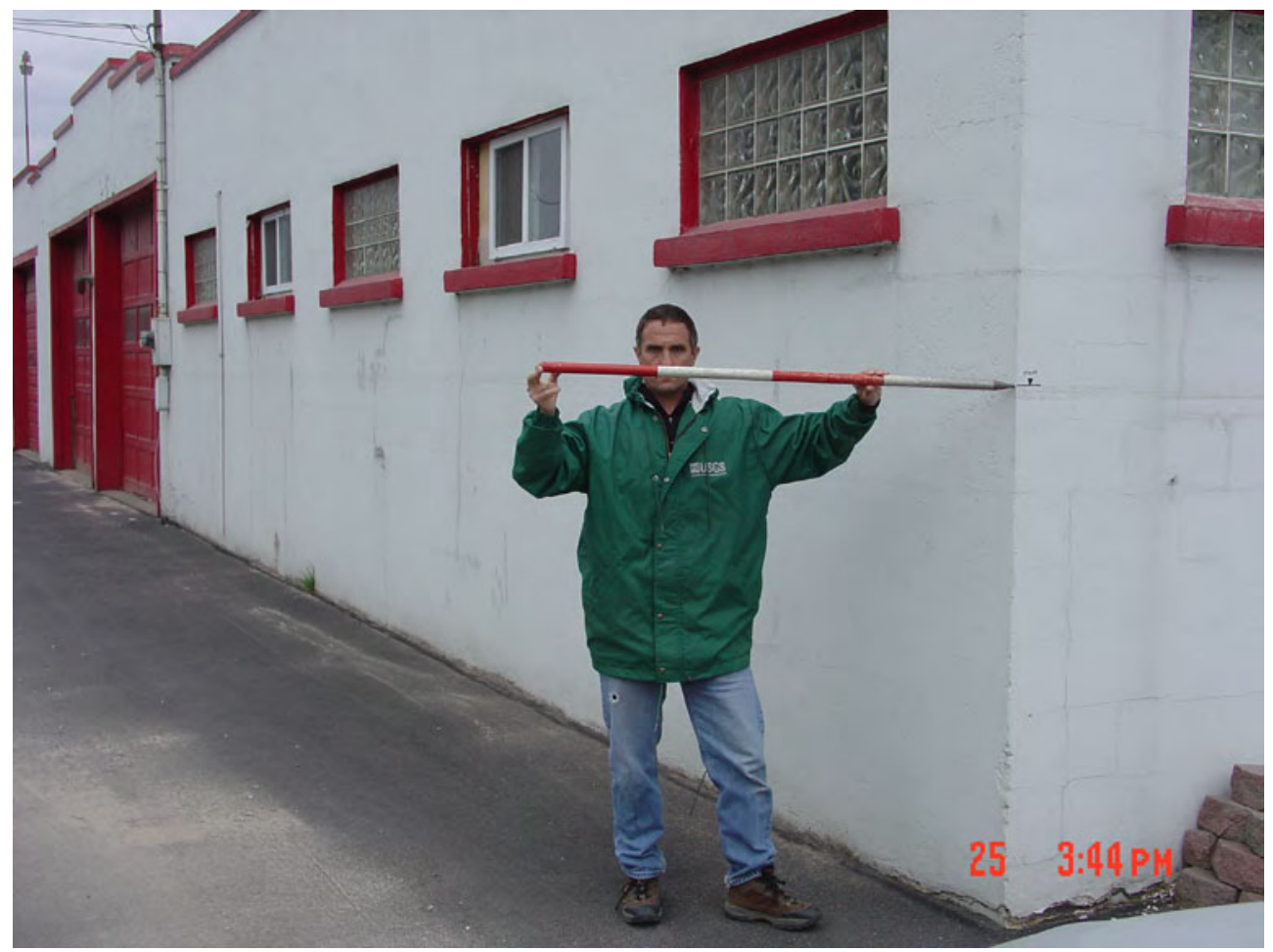

High-water mark PA 11.3 (lat $40^{\circ} 45^{\prime} 29.7^{\prime \prime}$, long $75^{\circ} 11^{\prime} 21.9^{\prime \prime}$ ), at an elevation of 209.7 feet above NGVD 29, is an excellent mud line on a building, 5.0 feet above the ground, 200 feet upstream from Martins Creek, and was marked with a black marker line. 


\section{SITE DESCRIPTION}

Site PA 12: 01446700 Delaware River at Easton, PA

Site Location: 0.3 mile reach in vicinity of lat $40^{\circ} 42^{\prime} 43^{\prime \prime}$, long $75^{\circ} 11^{\prime} 48^{\prime \prime}$

Forks Township, Northampton County, PA

Three high-water marks were surveyed: two mud lines and one seed line.

High-water mark elevations were determined using USGS reference mark 115 at lat $40^{\circ} 42^{\prime} 33.9^{\prime \prime}$, long

$75^{\circ} 11^{\prime} 55.6^{\prime \prime}$ (elevation is 200.48 feet above NAVD 88).

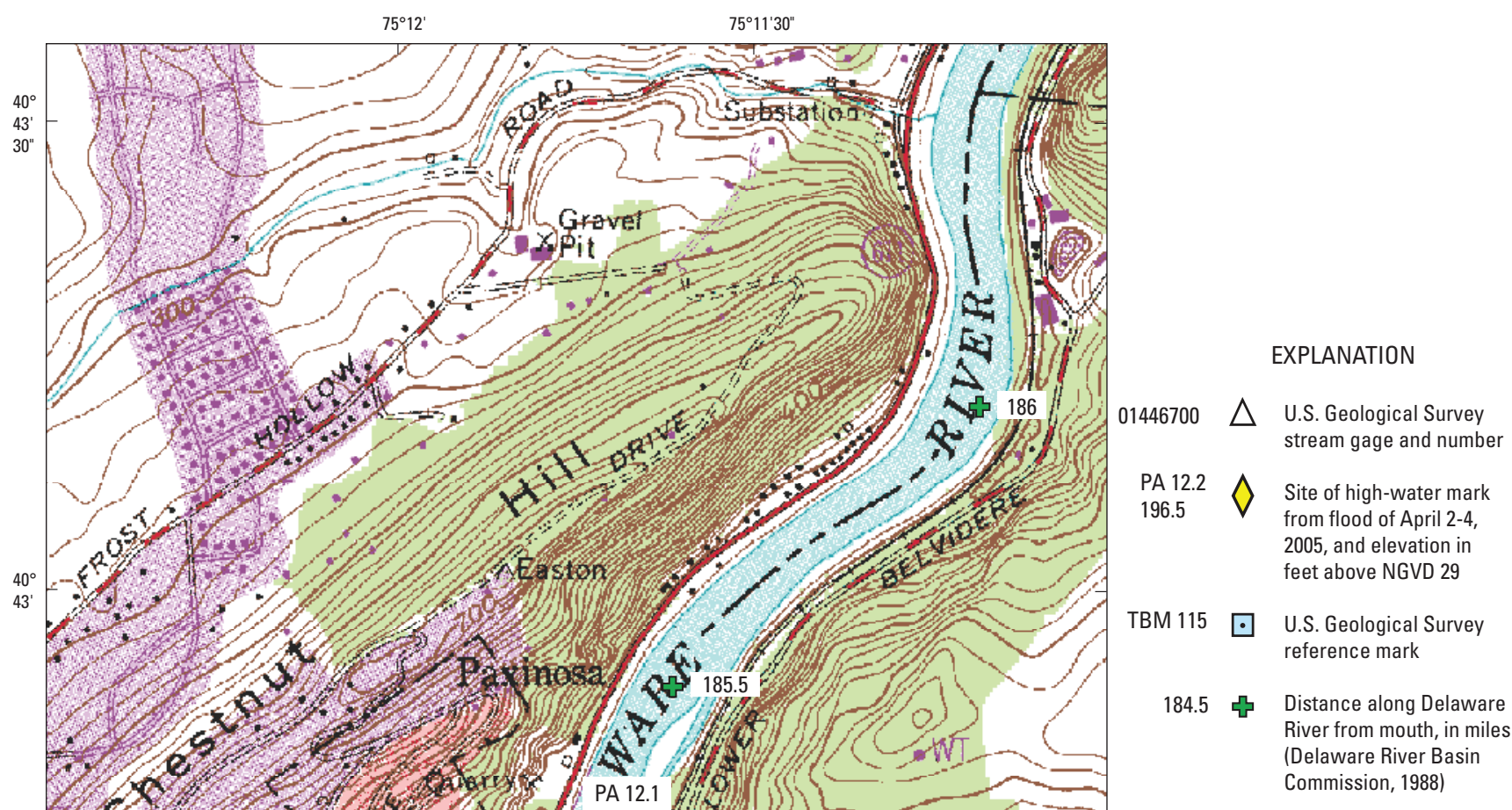

Easton USGS 7.5' Topographic Quadrangle map showing location of site PA 12, Delaware River at Easton, PA. 


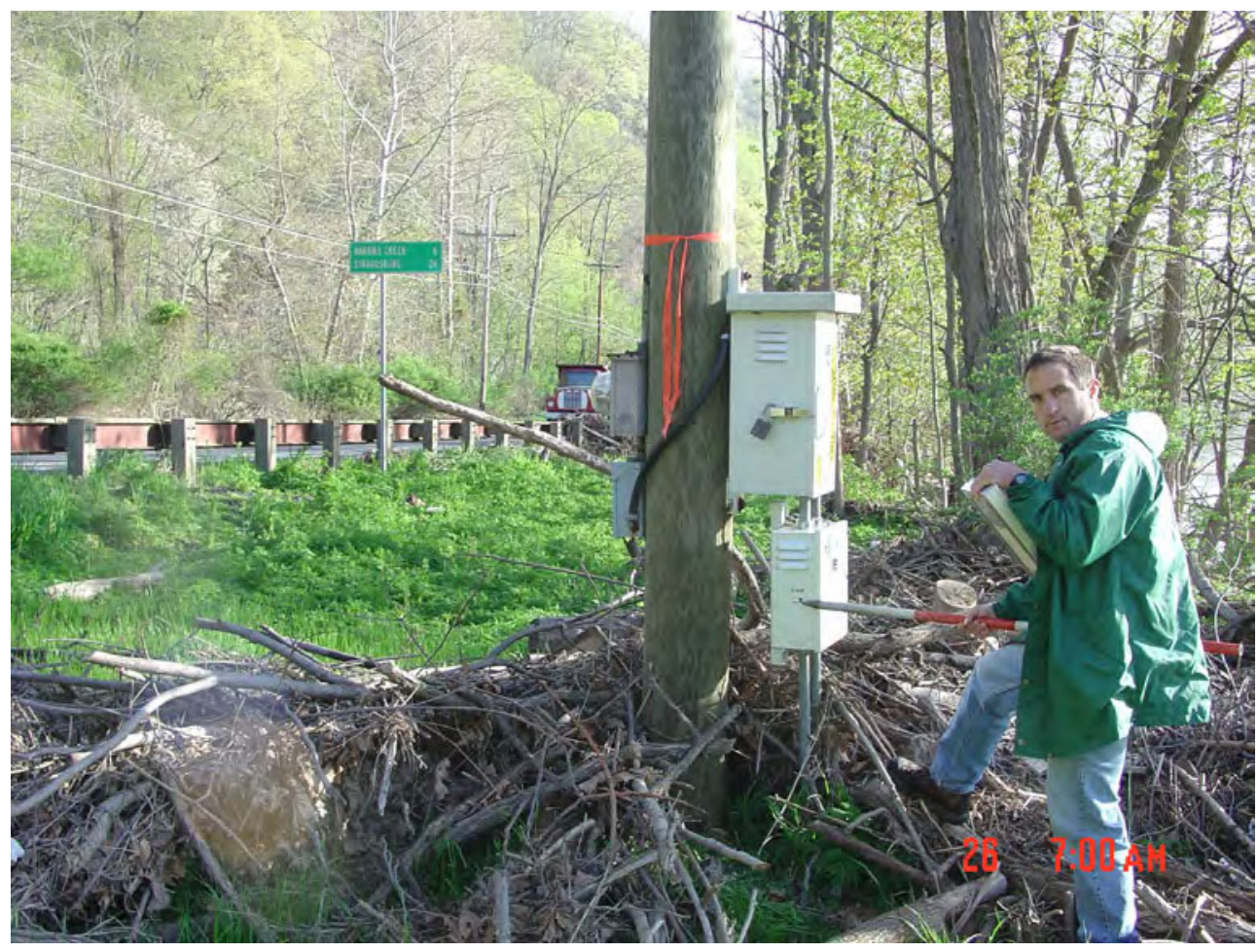

High-water mark PA 12.1 (lat $40^{\circ} 42^{\prime} 44.7^{\prime \prime}$, long $75^{\circ} 11^{\prime} 46.4^{\prime \prime}$ ), at an elevation of 197.6 feet above NGVD 29 , is an excellent mud line on an electric equipment box on a utility pole on PA State Route 611, 2.8 feet above the ground, 1.7 miles upstream from Lehigh River, and was marked with a black marker line.

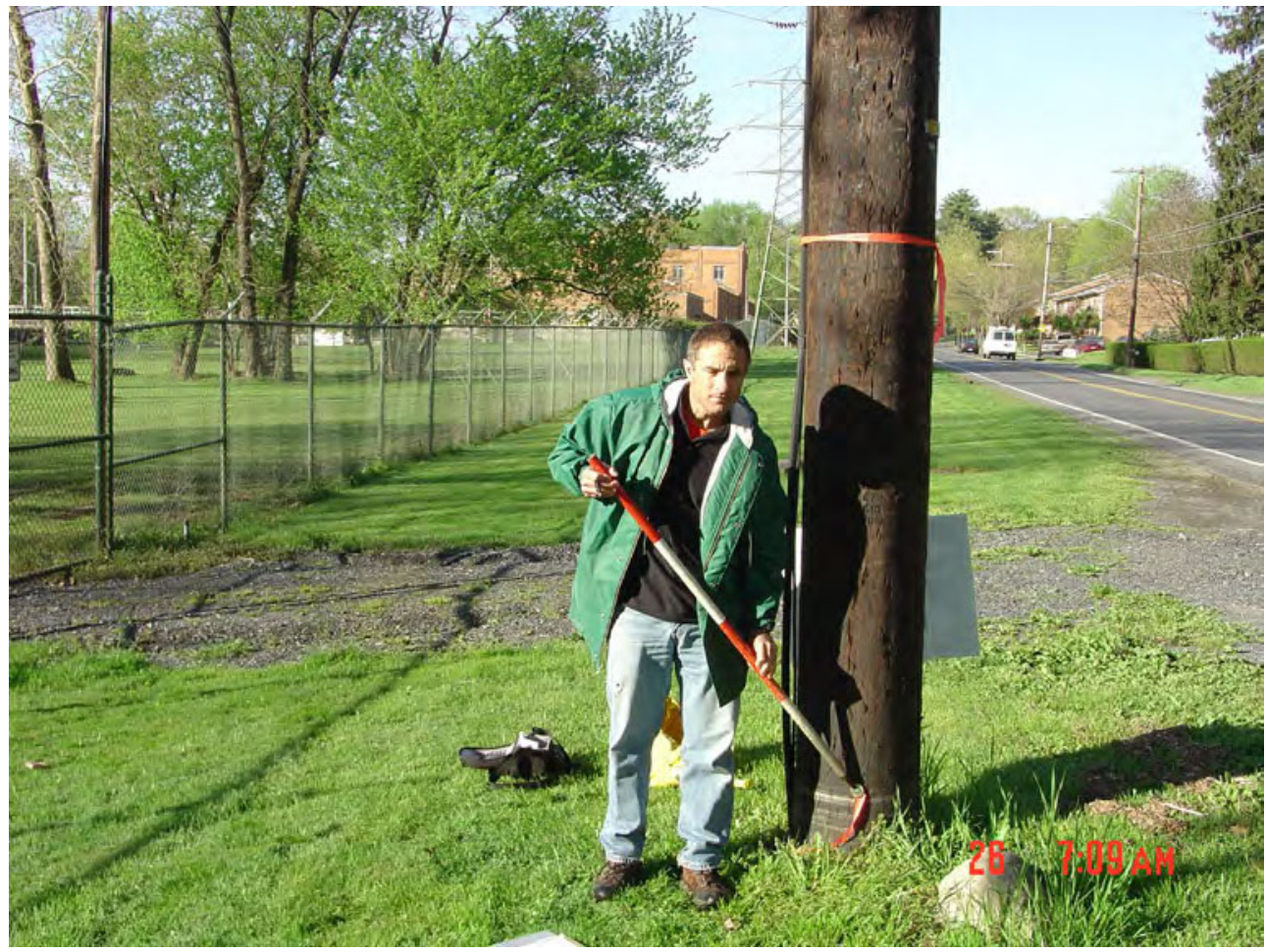

High-water mark PA 12.2 (lat $40^{\circ} 42^{\prime} 41.5^{\prime \prime}$, long $75^{\circ} 11^{\prime} 48.8^{\prime \prime}$ ), at an elevation of 196.5 feet above NGVD 29 , is an excellent mud line on a utility pole on PA State Route 611, 0.9 feet above the ground, 1.6 miles upstream from Lehigh River, and was marked with a metal USGS washer and nail. 


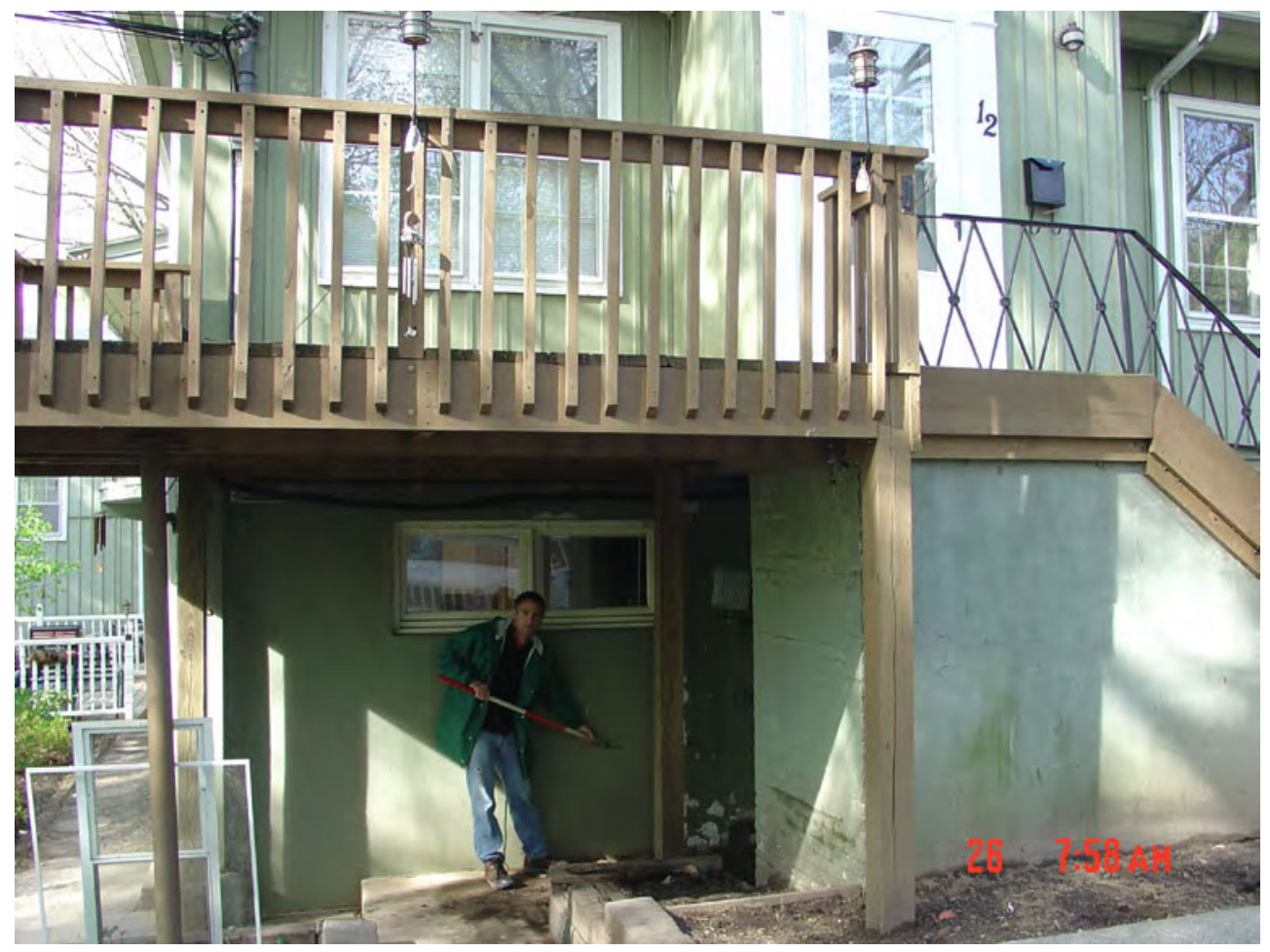

High-water mark PA 12.3 (lat $40^{\circ} 42^{\prime} 31.2^{\prime \prime}$, long $75^{\circ} 11^{\prime} 52.5^{\prime \prime}$ ), at an elevation of 196.1 feet above NGVD 29, is a good seed line on a house on Boileau Avenue, 2.3 feet above the ground, 1.4 miles upstream from Lehigh River, and was marked with a black marker line. 


\begin{tabular}{l} 
SITE DESCRIPTION \\
\hline Site NJ 11: 01446995 Delaware River at US Route 22 at Phillipsburg, NJ \\
\hline Site Location: 0.1 mi reach in vicinity of lat $40^{\circ} 41^{\prime} 40^{\prime \prime}$, long $75^{\circ} 12^{\prime} 09^{\prime \prime}$ \\
\hline Phillipsburg Town, Warren County, NJ \\
\hline Three high-water marks were surveyed: two debris lines and one seed line. \\
High-water mark elevations were determined using USGS reference mark $308 \mathrm{~A}$ at lat $40^{\circ} 41^{\prime} 39.2^{\prime \prime}$, \\
long $75^{\circ} 12^{\prime} 09.3^{\prime \prime}$ (elevation is 188.97 feet above NAVD 88 ). \\
\hline
\end{tabular}

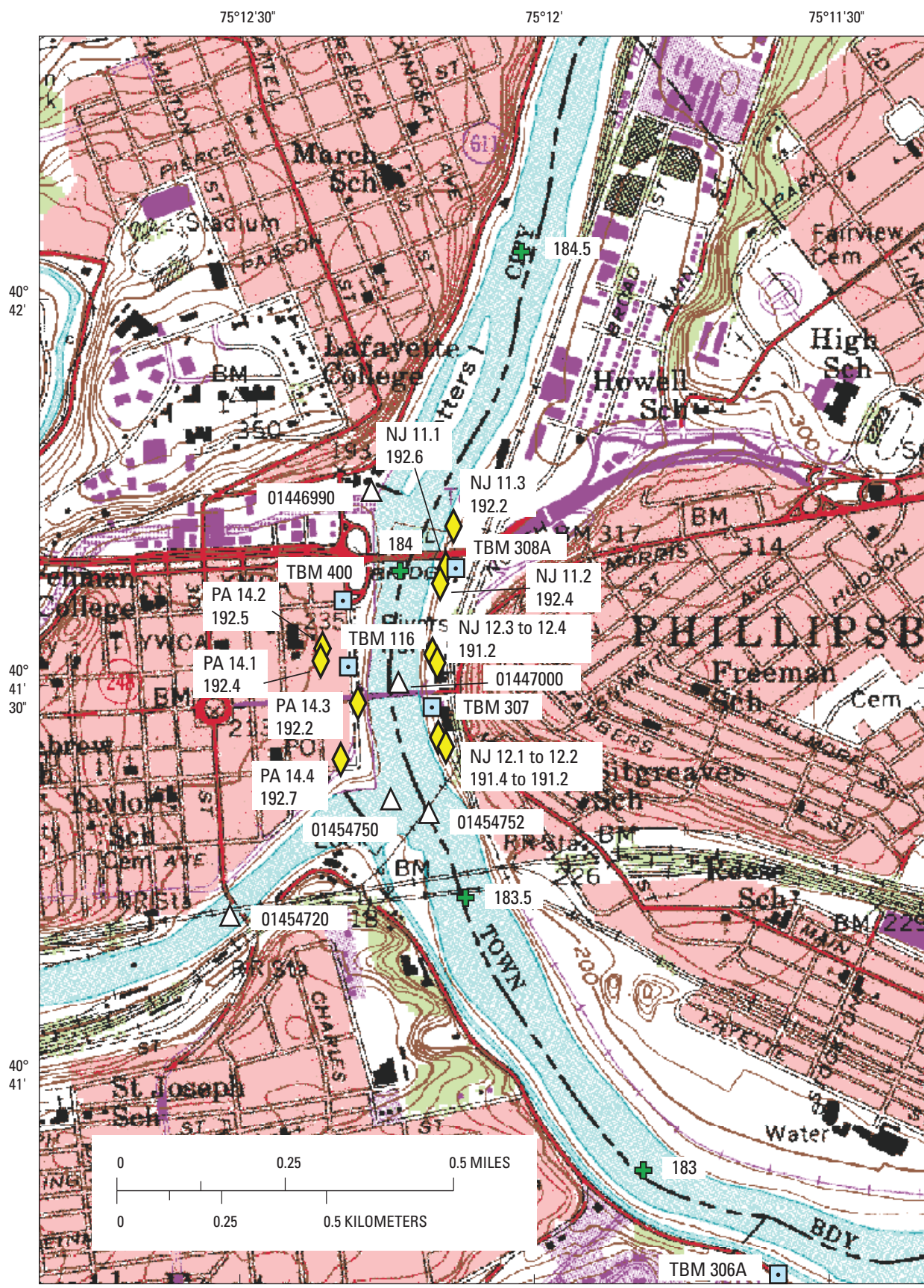

EXPLANATION

$01446990 \triangle \quad$ U.S. Geological Survey stream gage and number

PA $14.3 \bigotimes$ Site of high-water mark

192.2 from flood of April 2-4 2005 , and elevation in feet above NGVD 29

TBM $400 \square \quad$ U.S. Geological Survey reference mark

184 Distance along Delaware River from mouth, in miles (Delaware River Basin Commission, 1988

Easton USGS 7.5' Topographic Quadrangle map showing location of site NJ 11, Delaware River at US Route 22 at Phillipsburg, NJ. 


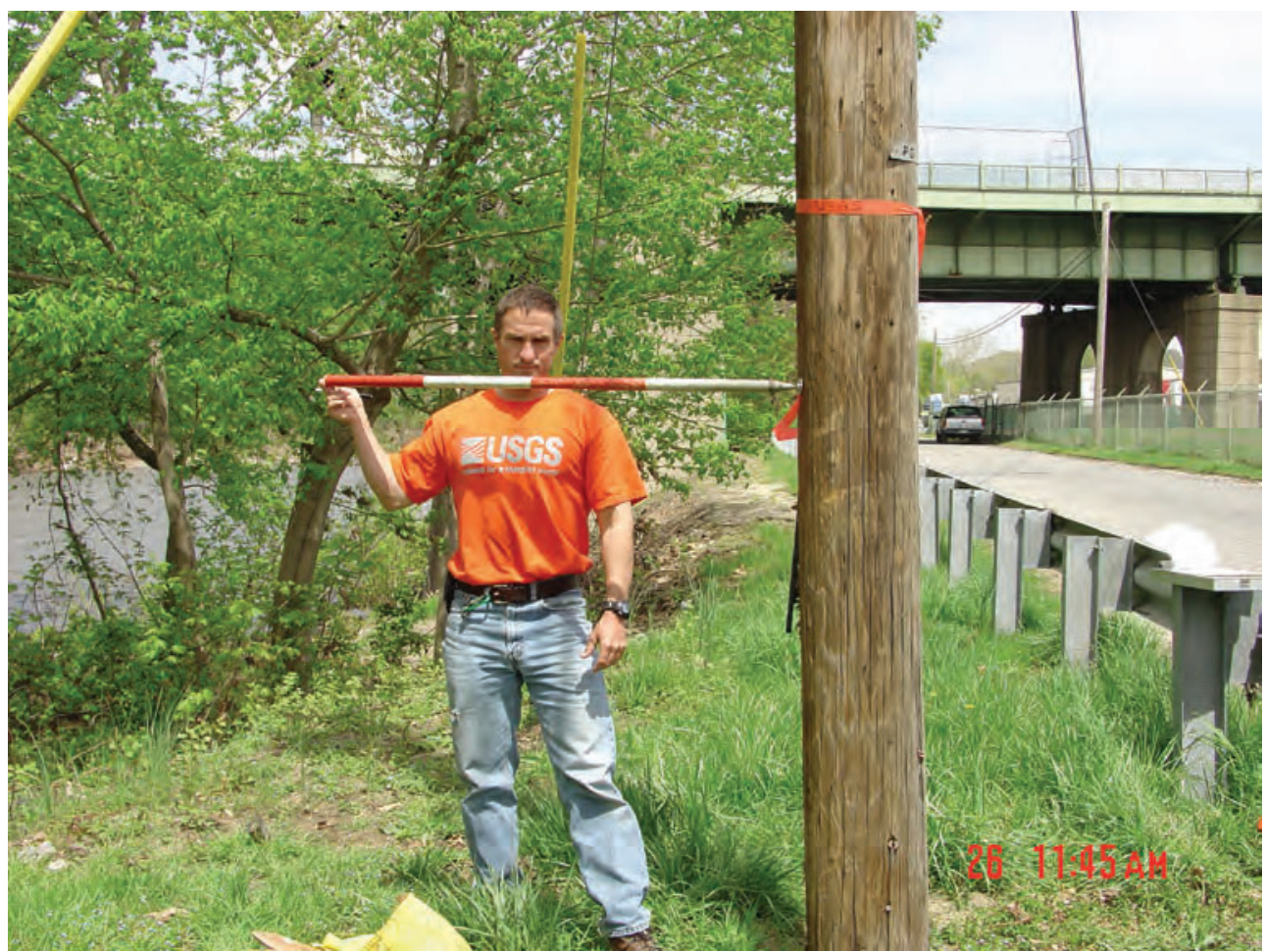

High-water mark NJ 11.1 (lat $40^{\circ} 41^{\prime} 38.3^{\prime \prime}$, long $75^{\circ} 12^{\prime} 09.8^{\prime \prime}$ ), at an elevation of 192.6 feet above NGVD 29, is a good debris line on a utility pole, 4.8 feet above the ground, 183 feet downstream from US Route 22, and was marked with a metal USGS washer and nail.

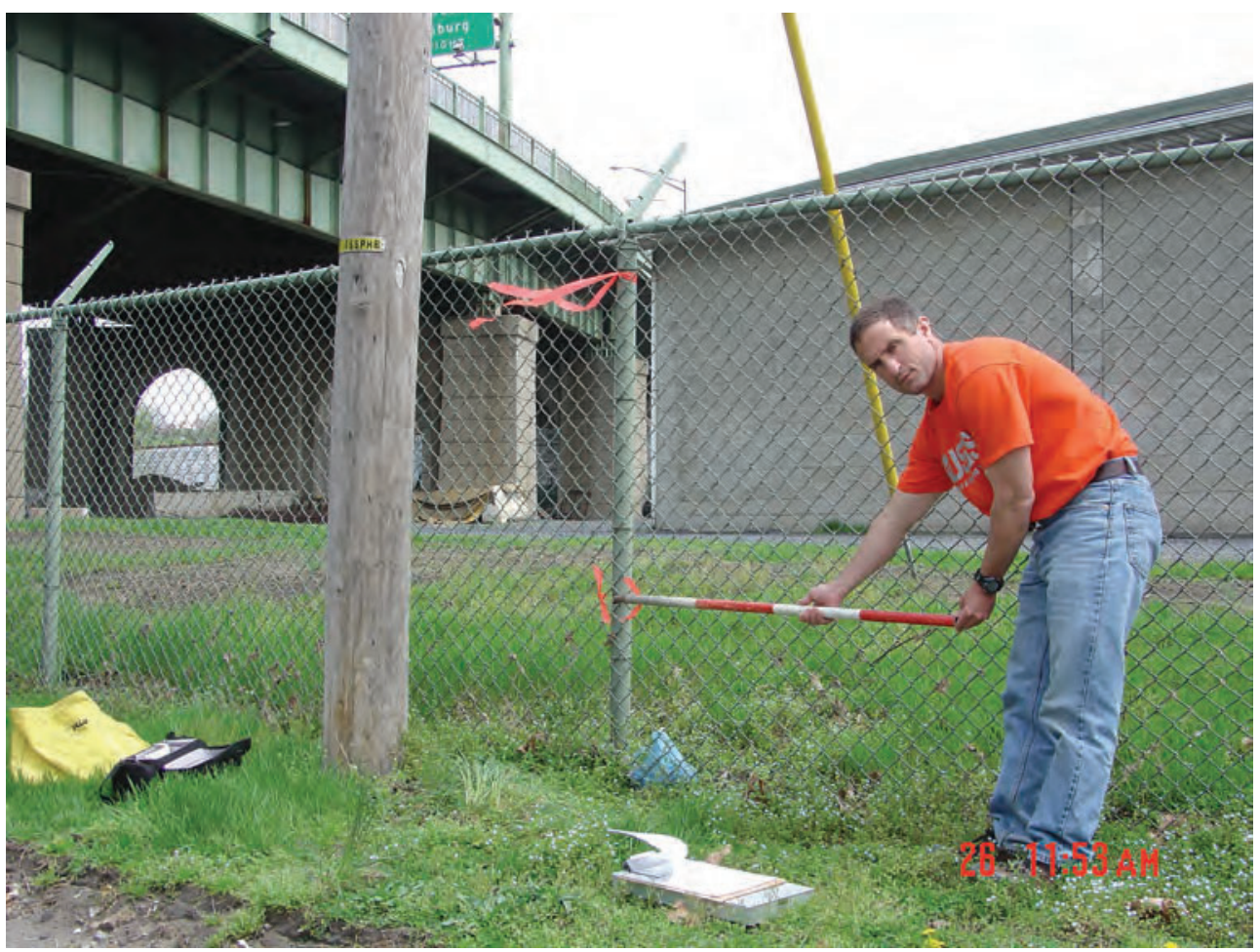

High-water mark NJ 11.2 (lat $40^{\circ} 41^{\prime} 39.6^{\prime \prime}$, long $75^{\circ} 12^{\prime} 09.9^{\prime \prime}$ ), at an elevation of 192.4 feet above NGVD 29, is a fair debris line on a fence, 1.9 feet above the ground, 35 feet downstream from US Route 22, and was marked with a black marker line. 


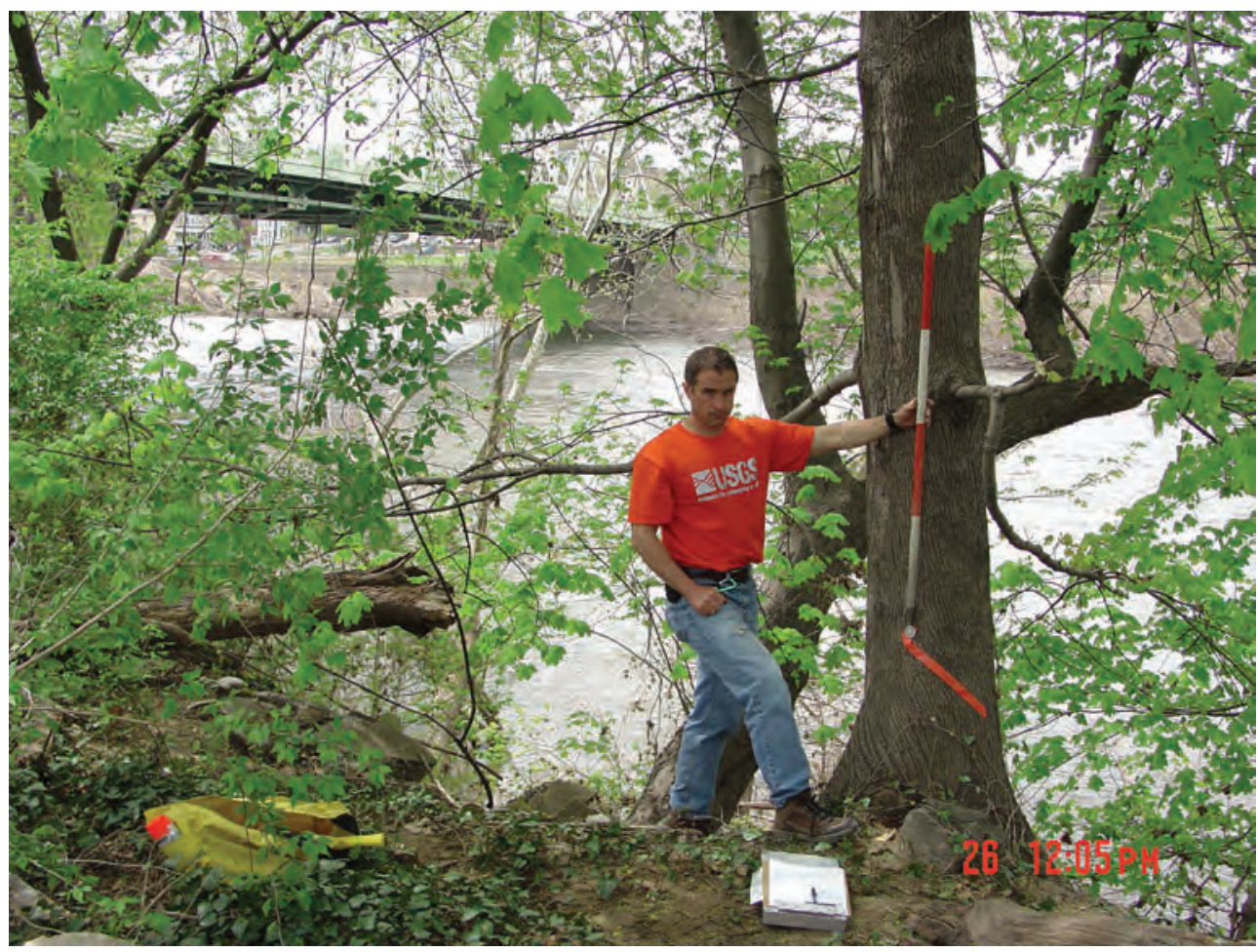

High-water mark NJ 11.3 (lat $40^{\circ} 41^{\prime} 42.7^{\prime \prime}$, long $75^{\circ} 12^{\prime} 08.4^{\prime \prime}$ ), at an elevation of 192.2 feet above NGVD 29 , is a poor seed line on a 1.5-foot diameter tree, 2 feet above the ground, 208 feet upstream from US Route 22, and was marked with a metal USGS washer and nail. 


\begin{tabular}{|l|}
\hline \multicolumn{1}{|c|}{ SITE DESCRIPTION } \\
\hline Site PA 14: 01447000 Delaware River at Northampton Street at Easton, PA \\
\hline Site Location: 0.2 mile reach in vicinity of lat $40^{\circ} 41^{\prime} 29^{\prime \prime}$, long $75^{\circ} 12^{\prime} 18^{\prime \prime}$ \\
\hline City of Easton, Northampton County, PA \\
\hline Four high-water marks were surveyed: three mud lines and one debris line. \\
\hline $\begin{array}{l}\text { High-water mark elevations were determined using USGS reference mark } 116 \text { at lat } 40^{\circ} 41^{\prime} 31.6^{\prime \prime}, \\
\text { long } 75^{\circ} 12^{\prime} 19.3^{\prime \prime} \text { (elevation is } 183.47 \text { feet above NAVD } 88 \text { ). }\end{array}$ \\
\hline
\end{tabular}

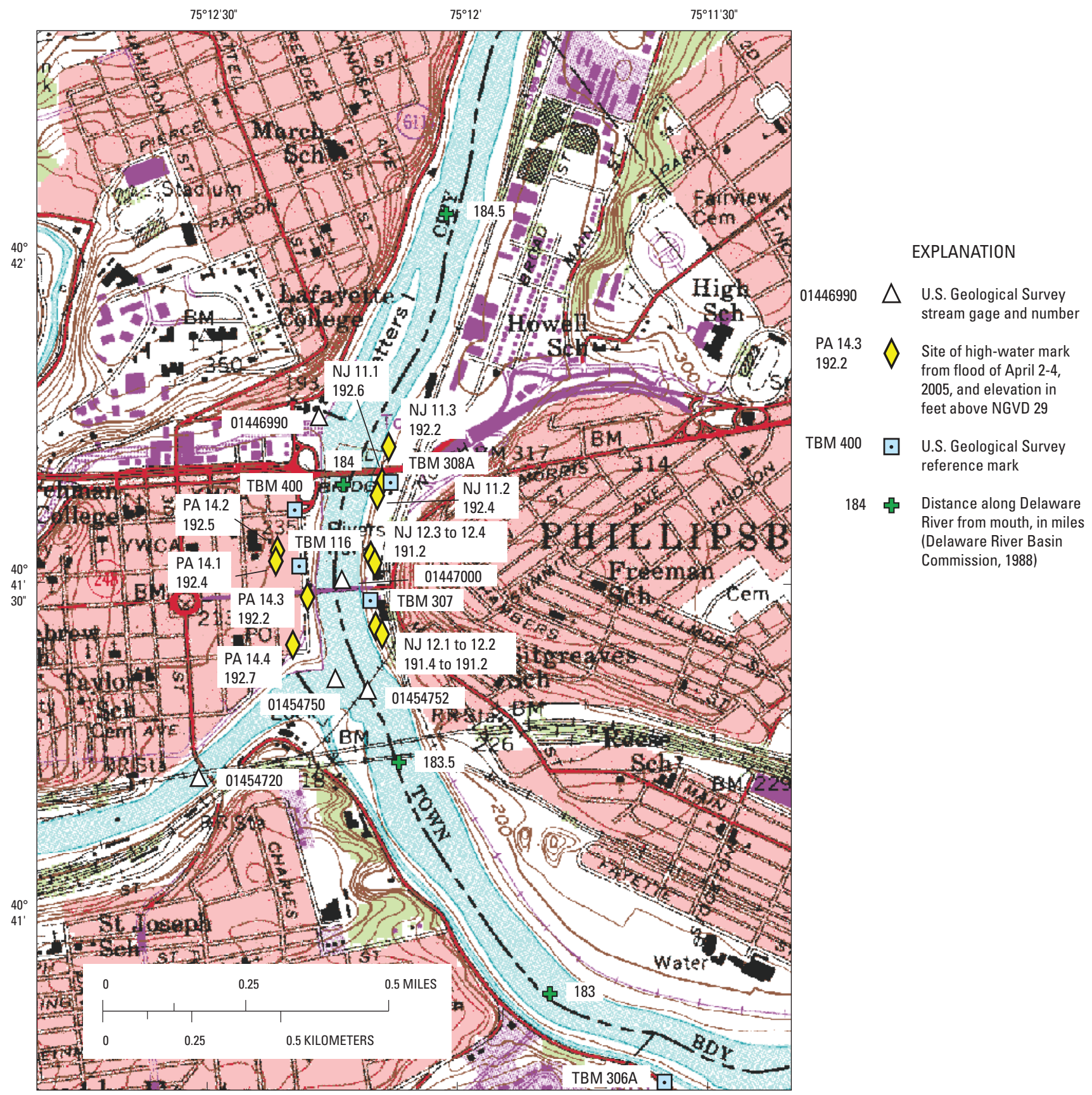

Easton USGS 7.5' Topographic Quadrangle map showing location of site PA 14, Delaware River at Northampton Street at Easton, PA. 


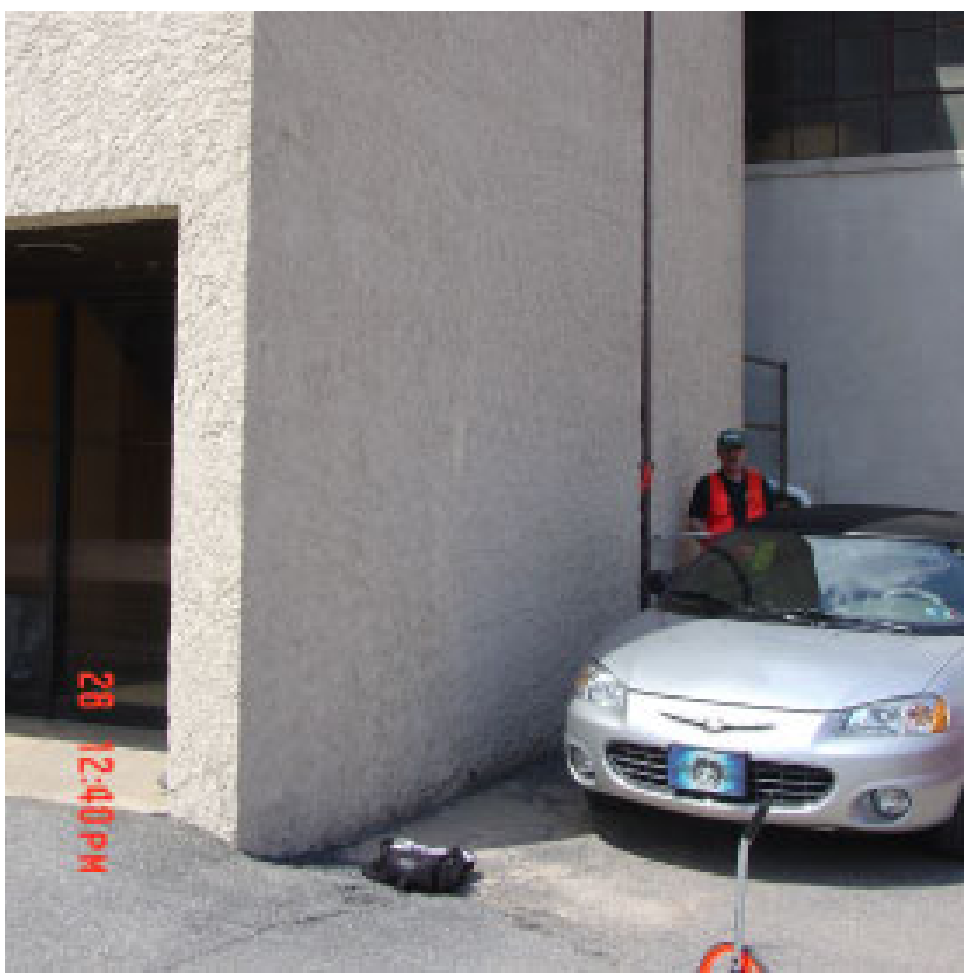

High-water mark PA 14.1 (lat $40^{\circ} 41^{\prime} 32.3^{\prime \prime}$, long $75^{\circ} 12^{\prime} 22.0^{\prime \prime}$ ), at an elevation of 192.4 feet above NGVD 29, is a good mud line on the downspout of building on Larry Holmes Boulevard, 3.6 feet above the ground, 0.2 miles upstream from Lehigh River, and was marked with a black marker line.

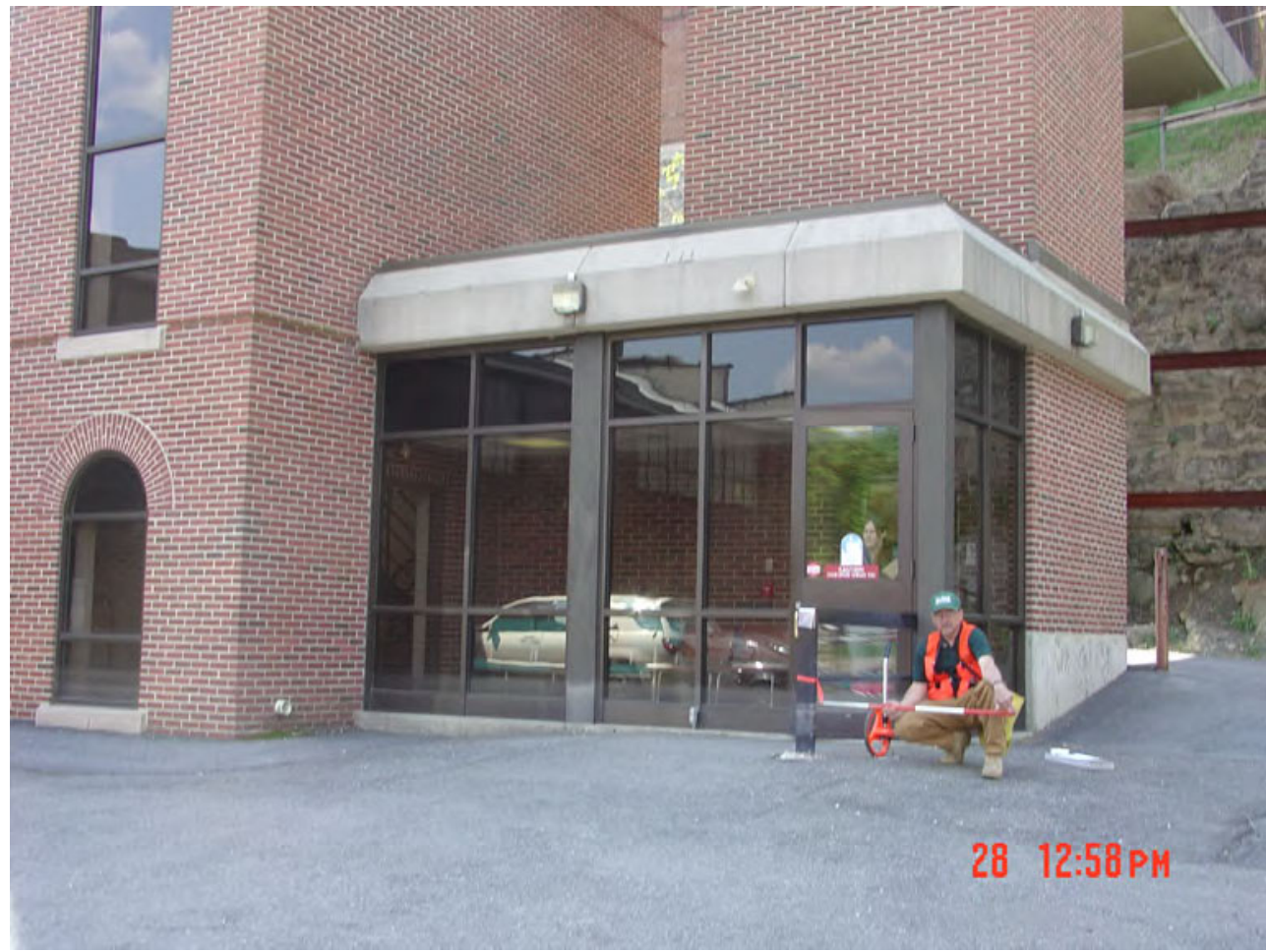

High-water mark PA 14.2 (lat $40^{\circ} 41^{\prime} 33.4^{\prime \prime}$, long $75^{\circ} 12^{\prime} 21.9^{\prime \prime}$ ), at an elevation of 192.5 feet above NGVD 29 , is an excellent mud line on a handrail of a building 1.1 feet above the ground, 0.2 miles upstream from Lehigh River, and was marked with a black marker line. 


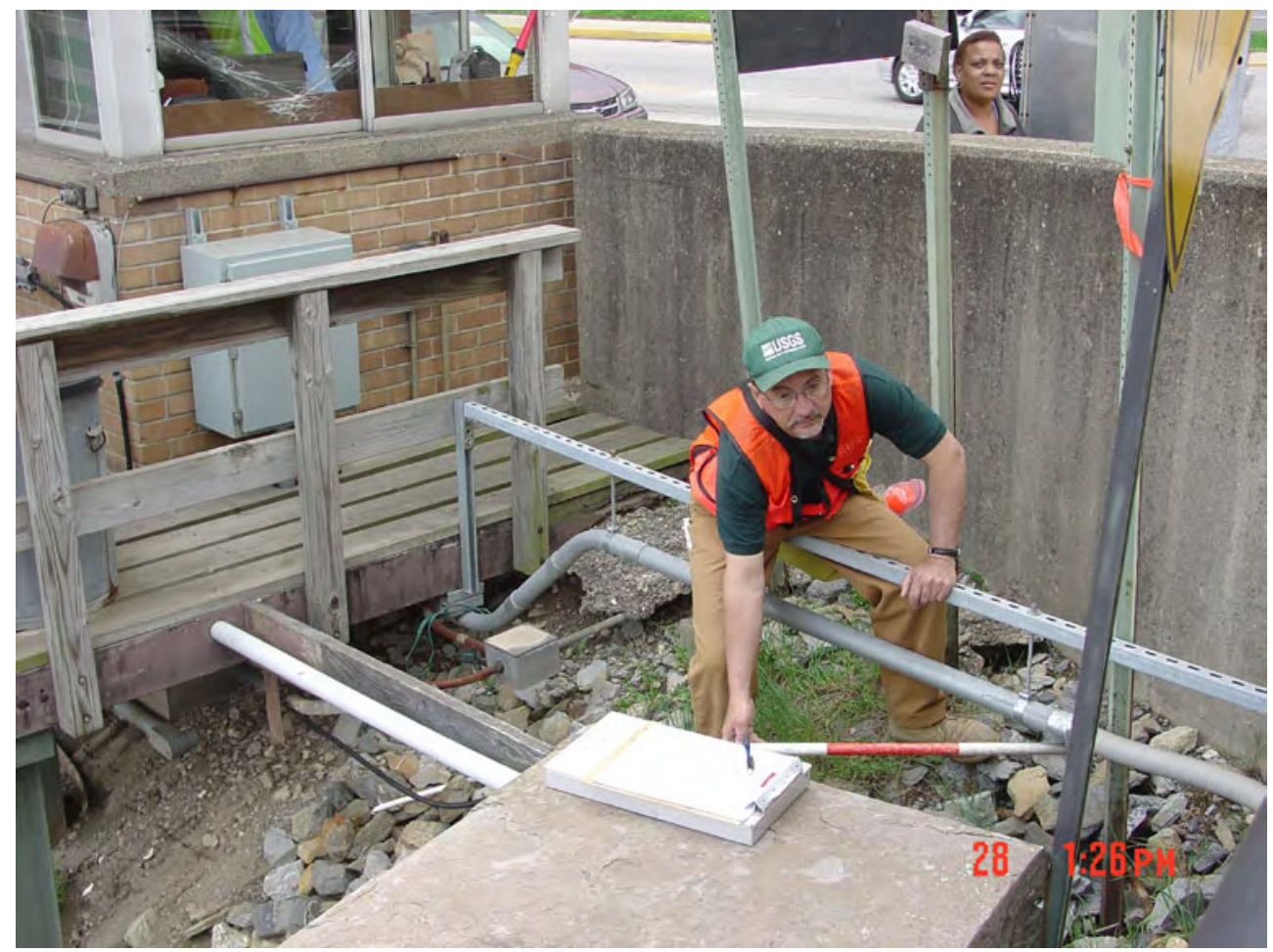

High-water mark PA 14.3 (lat 40 $41^{\prime} 28.9^{\prime \prime}$, long $75^{\circ} 12^{\prime} 18.2^{\prime \prime}$ ), at an elevation of 192.2 feet above NGVD 29 , is a good mud line on a sign post by Southampton Street bridge guard house, 4.3 feet above the ground, 0.1 miles upstream from Lehigh River, and was marked with a black marker line.

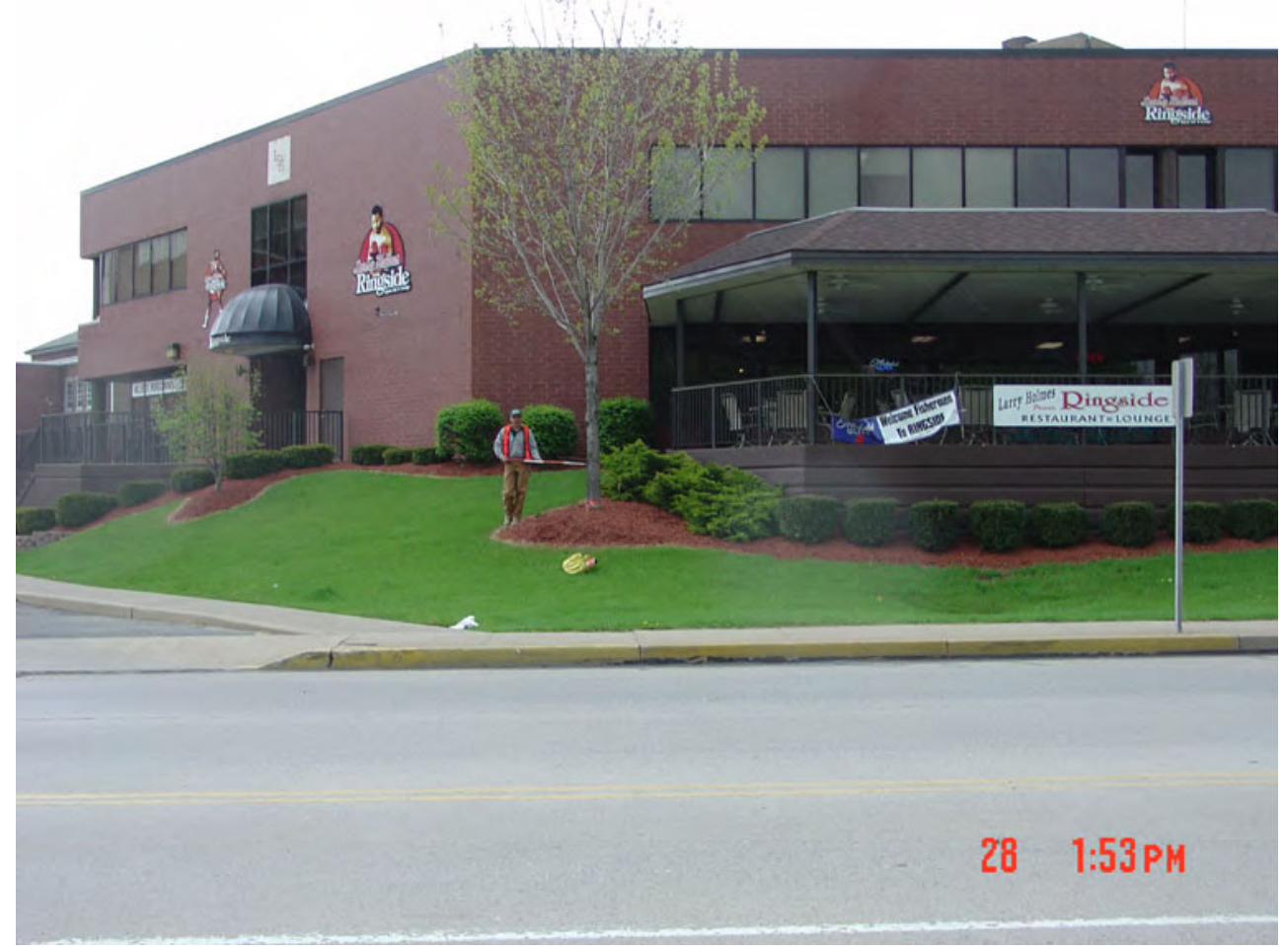

High-water mark PA 14.4 (lat 40 41' 24.6", long 75 $12^{\prime} 20.3^{\prime \prime}$ ), at an elevation of 192.7 feet above NGVD 29, is a good debris line on a 7-inch diameter tree, 2.4 feet above the ground, 250 feet upstream from Lehigh River, and was marked with a black marker line. 


\begin{tabular}{|l|}
\hline \multicolumn{1}{|c|}{ SITE DESCRIPTION } \\
\hline Site NJ 12: Delaware River at Phillipsburg, NJ \\
\hline Site Location: 0.15 mi reach in vicinity of lat $40^{\circ} 41^{\prime} 26^{\prime \prime}$, long $75^{\circ} 12^{\prime} 09^{\prime \prime}$ \\
\hline Phillipsburg Town, Warren County, NJ \\
\hline Four high-water marks were surveyed: three debris lines and one seed line. \\
\hline $\begin{array}{l}\text { High-water mark elevations were determined using USGS reference mark } 307 \text { at lat } 40^{\circ} 41^{\prime} 28.4^{\prime \prime}, \\
\text { long } 75^{\circ} 12^{\prime} 10.6^{\prime \prime} \text { (elevation is } 193.34 \text { feet above NAVD } 88 \text { ). }\end{array}$ \\
\hline
\end{tabular}

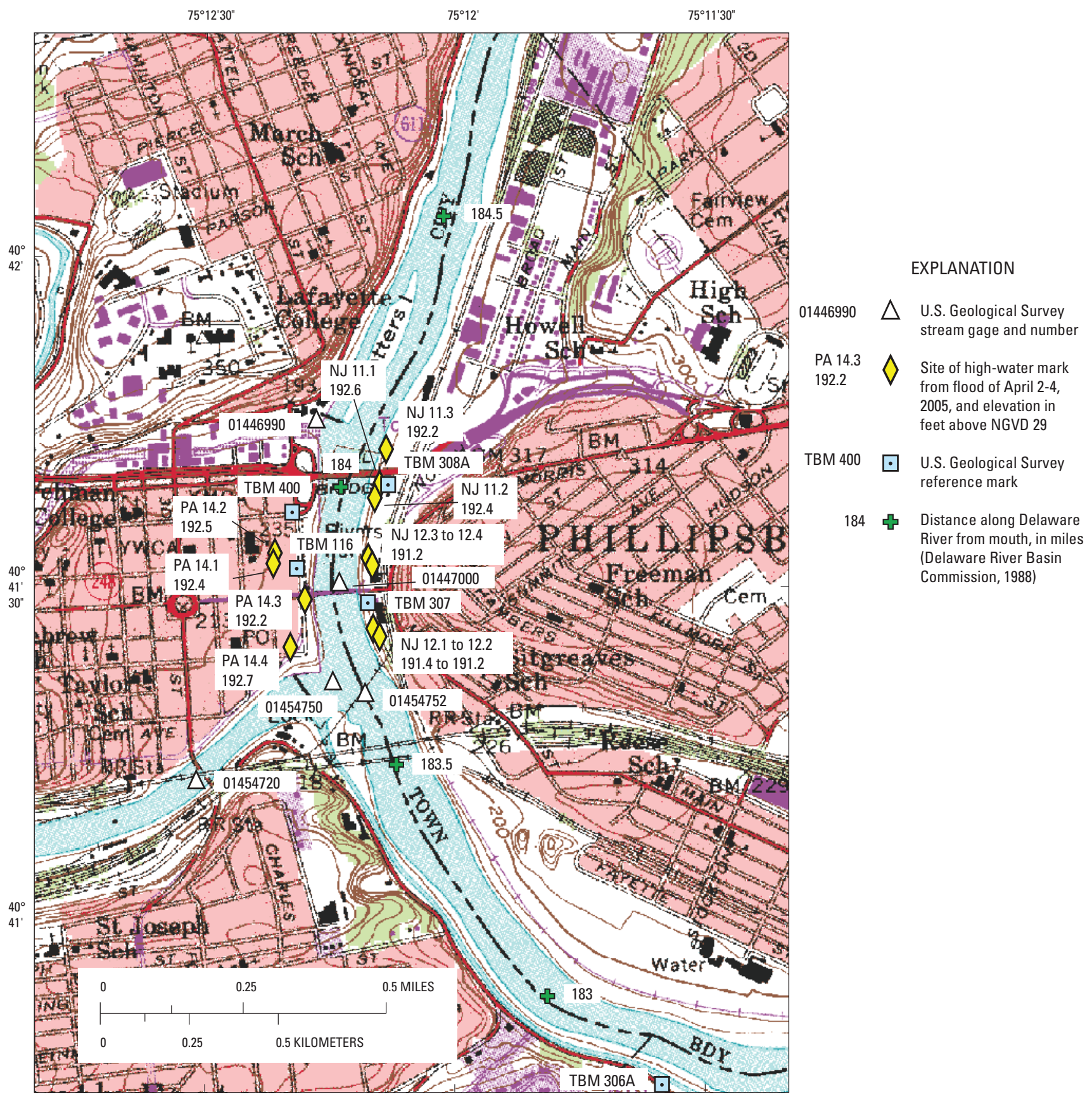

Easton USGS 7.5' Topographic Quadrangle map showing location of site NJ 12, Delaware River at Phillipsburg, NJ. 


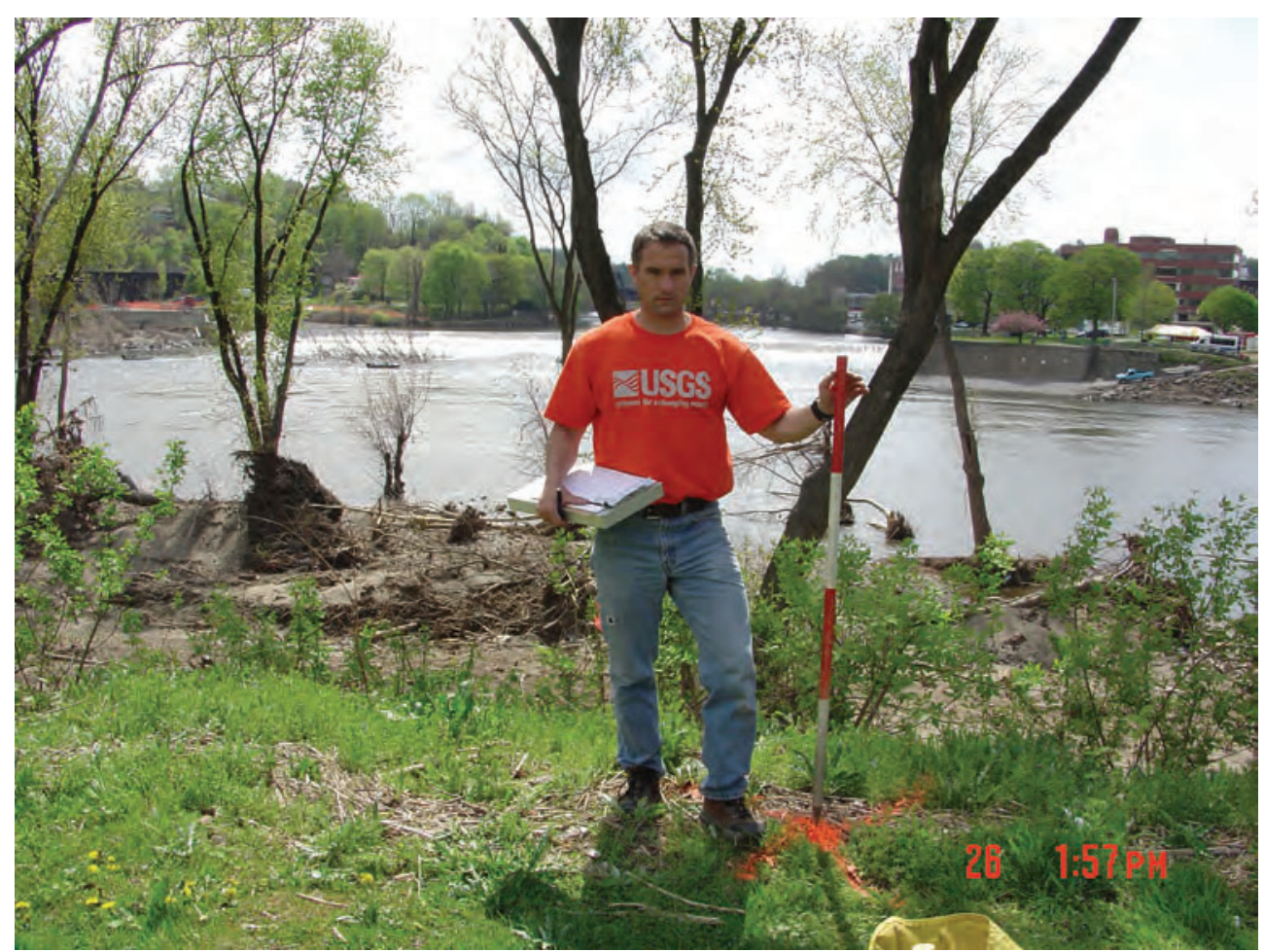

High-water mark NJ 12.1 (lat $40^{\circ} 41^{\prime} 25.5^{\prime \prime}$, long $75^{\circ} 12^{\prime} 09.2^{\prime \prime}$ ), at an elevation of 191.2 feet above NGVD 29 , is a good debris line on the ground, 390 feet downstream from Northampton Street bridge, and was marked with a metal rebar.

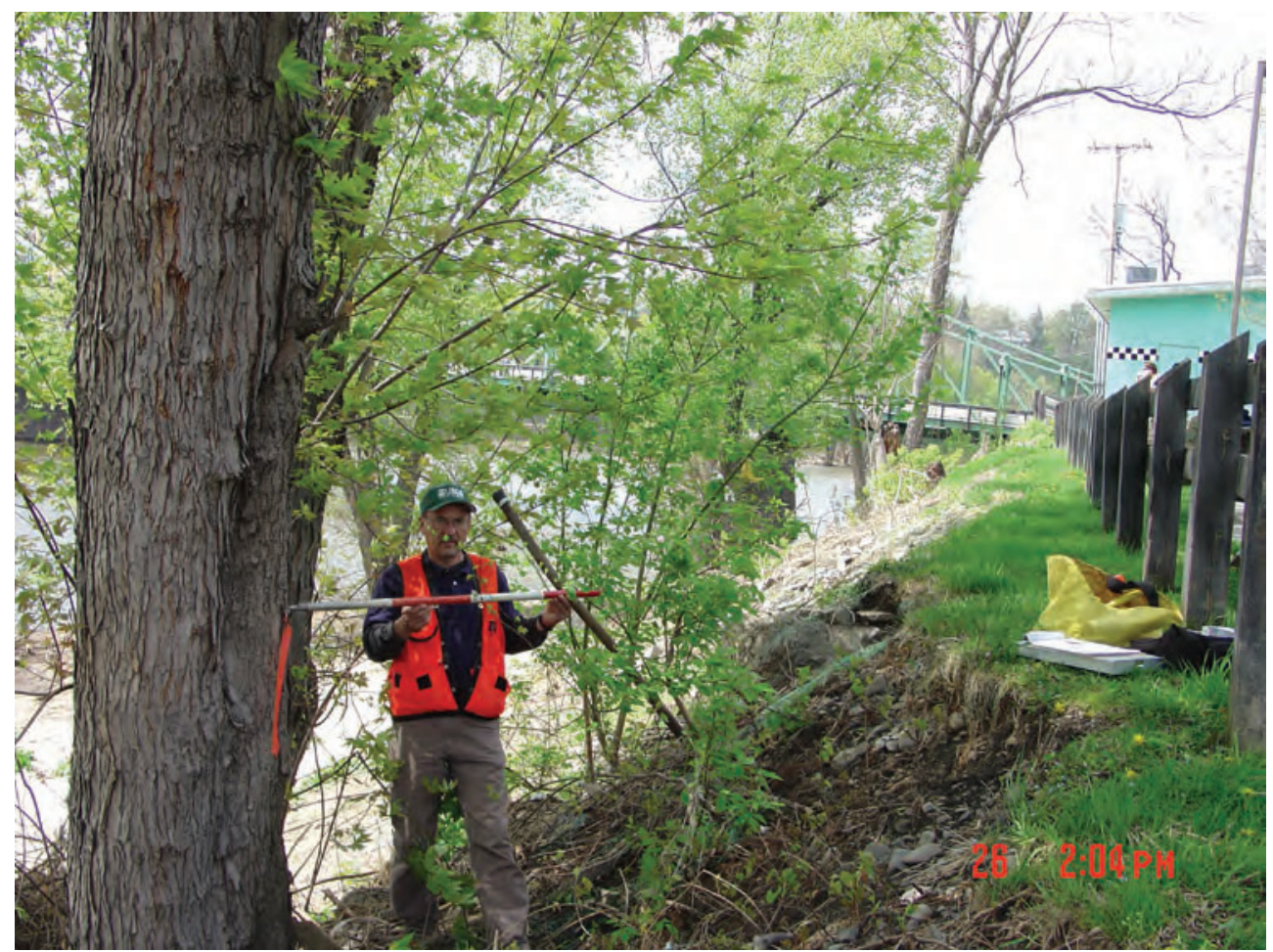

High-water mark NJ 12.2 (lat $40^{\circ} 41^{\prime} 26.2^{\prime \prime}$, long $75^{\circ} 12^{\prime} 09.9^{\prime \prime}$ ), at an elevation of 191.4 feet above NGVD 29, is a fair seed line on a tree, 5.3 feet above the ground, 300 feet downstream from Northampton Street bridge, and was marked with a metal USGS washer and nail. 


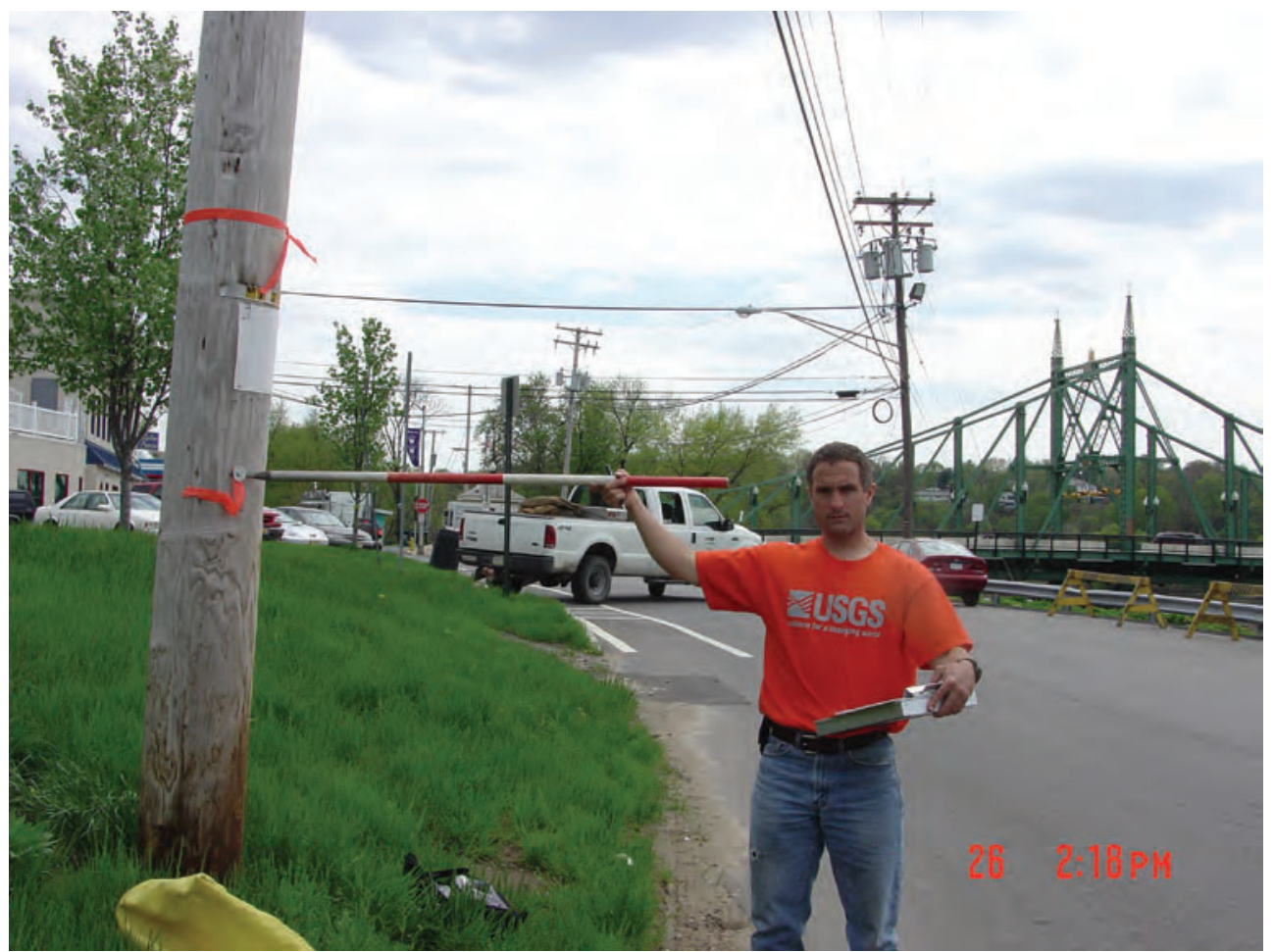

High-water mark NJ 12.3 (lat $40^{\circ} 41^{\prime} 32.7^{\prime \prime}$, long $75^{\circ} 12^{\prime} 10.6^{\prime \prime}$ ), at an elevation of 191.2 feet above NGVD 29 , is a fair debris line on a utility pole, 4.0 feet above the ground, 312 feet upstream from Northampton Street bridge, and was marked with a metal USGS washer and nail.

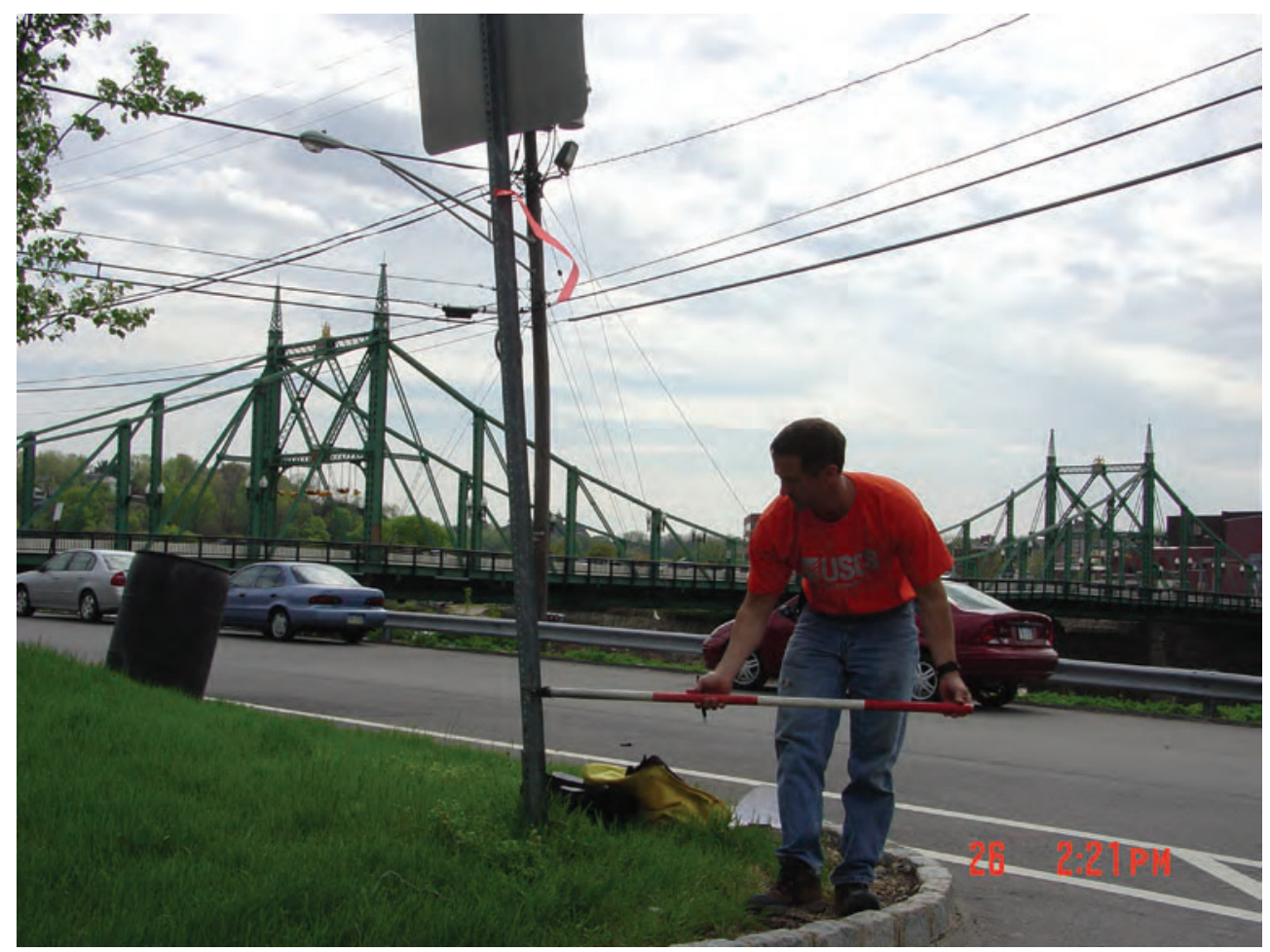

High-water mark NJ 12.4 (lat $40^{\circ} 41^{\prime} 32.1^{\prime \prime}$, long $75^{\circ} 12^{\prime} 10.1^{\prime \prime}$ ), at an elevation of 191.2 feet above NGVD 29 , is a fair debris line on a"DO NOT ENTER" sign post, 1.6 feet above the ground, 230 feet upstream from Northampton Street bridge, and was marked with a black marker line. 


\section{SITE DESCRIPTION}

Site PA 15: Delaware River near South Easton, PA

Site Location: 250 foot reach in vicinity of lat $40^{\circ} 40^{\prime} 43^{\prime \prime}$, long $75^{\circ} 11^{\prime} 35^{\prime \prime}$

Williams Township, Northampton County, PA

Three high-water marks were surveyed: three mud lines.

High-water mark elevations were determined using USGS reference mark 306A at lat $40^{\circ} 40^{\prime} 44.1^{\prime \prime}$,

long $75^{\circ} 11^{\prime} 35.2^{\prime \prime}$ (elevation is 182.87 feet above NAVD 88).

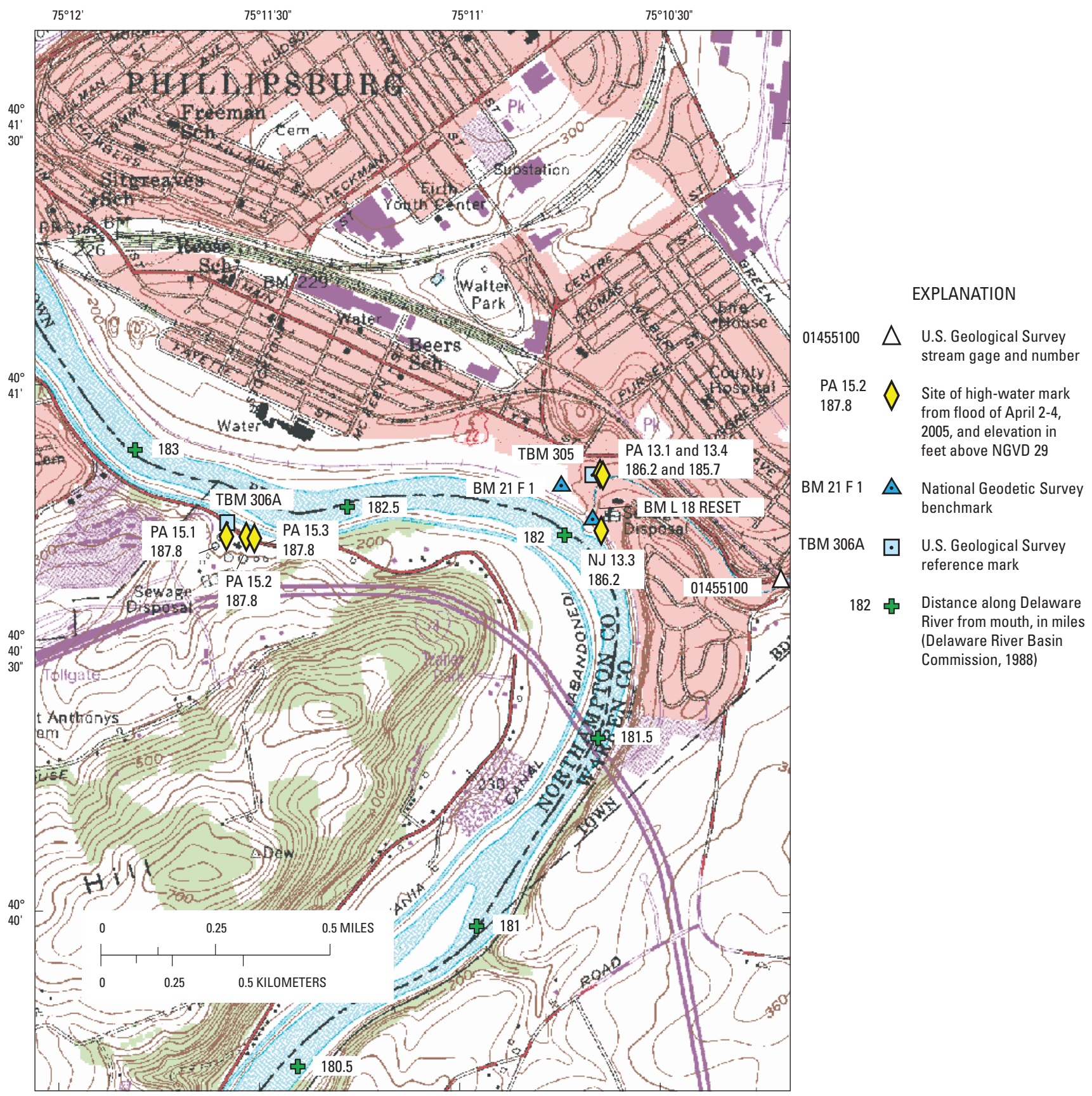

Easton USGS 7.5' Topographic Quadrangle map showing location of site PA 15, Delaware River near South Easton, PA. 


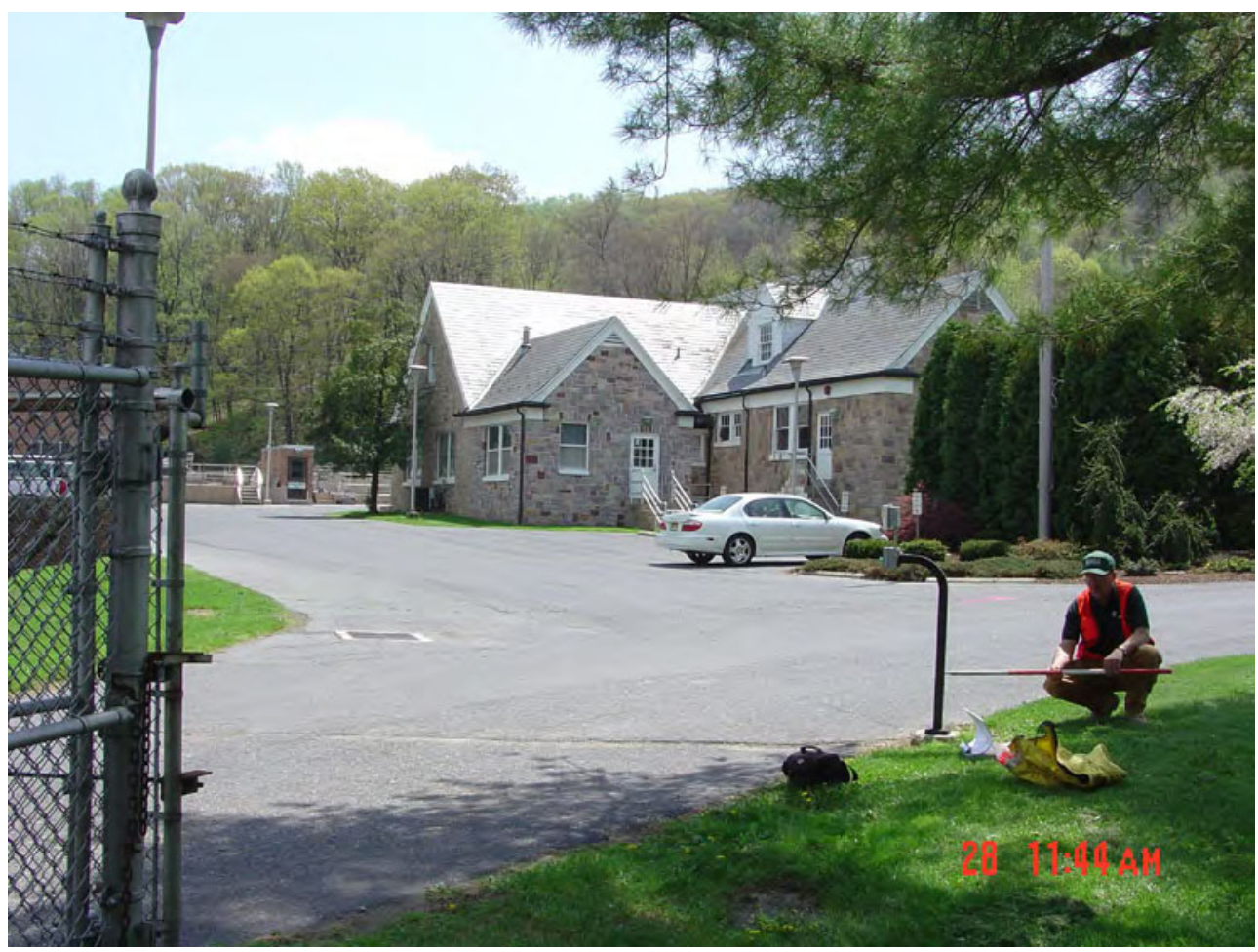

High-water mark PA 15.1 (lat 40 40' 43.2", long $75^{\circ} 11^{\prime} 35.4^{\prime \prime}$ ), at an elevation of 187.8 feet above NGVD 29, is a good mud line on the post for the gate exit control to Easton Area Joint Sewer Authority, 1.6 feet above the ground, 0.9 miles downstream from Lehigh River, and was marked with a black marker line.

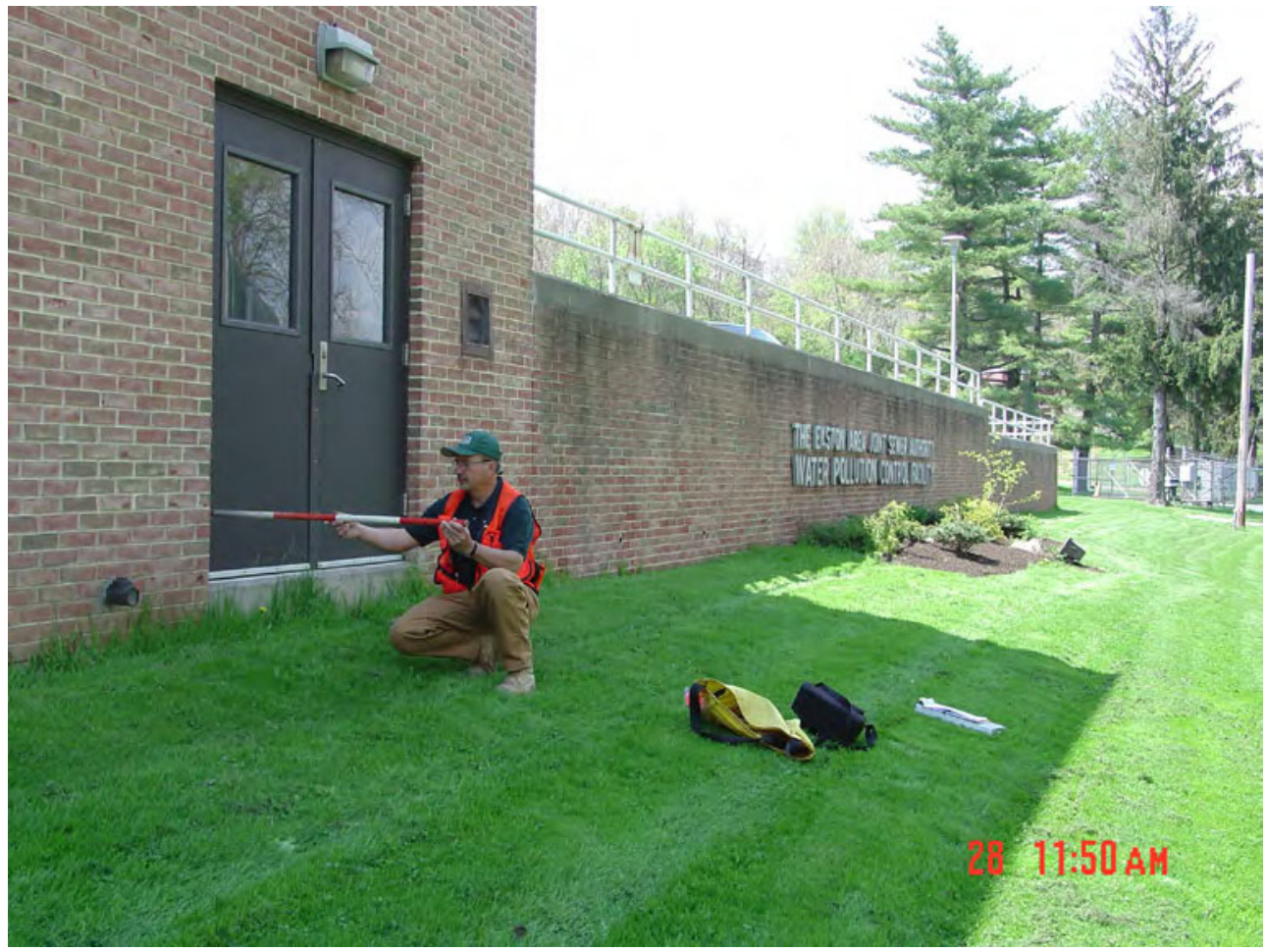

High-water mark PA 15.2 (lat 40 40' 43.0", long $75^{\circ} 11^{\prime} 32.9^{\prime \prime}$ ), at an elevation of 187.8 feet above NGVD 29, is a good mud line on a door of the Easton Area Joint Sewer Authority, 1.0 feet above the door threshold, 1.0 mile downtsream from Lehigh River, and was marked with a black marker line. 


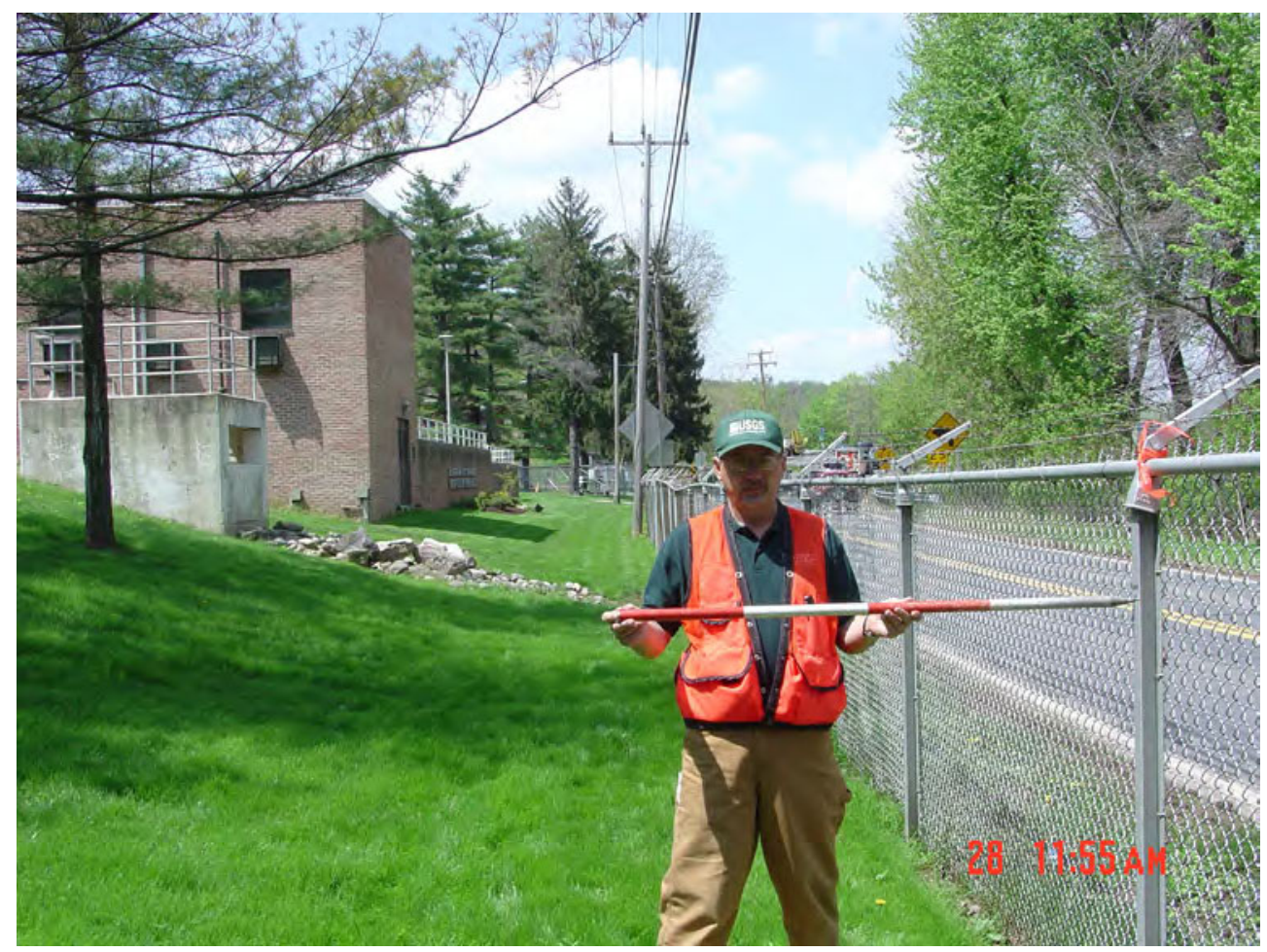

High-water mark PA 15.3 (lat $40^{\circ} 41^{\prime} 42.9^{\prime \prime}$, long $75^{\circ} 11^{\prime} 31.3^{\prime \prime}$ ), at an elevation of 187.8 feet above NGVD 29, is a fair mud line on a fence post on PA State Route 611, 4.5 feet above the ground, 1.0 mile downstream from Lehigh River, and was marked with a black marker line. 


\begin{tabular}{l} 
SITE DESCRIPTION \\
\hline Site NJ 13: Delaware River near Phillipsburg, NJ \\
\hline Site Location: 0.1 mi reach in vicinity of lat $40^{\circ} 40^{\prime} 45^{\prime \prime}$, long $75^{\circ} 10^{\prime} 41^{\prime \prime}$ \\
\hline Phillipsburg Town, Warren County, NJ \\
Three high-water marks were surveyed: two debris lines and one mud line. \\
\hline High-water mark elevations were determined using USGS reference mark 305 at lat $40^{\circ} 40^{\prime} 49.7^{\prime \prime}$, \\
long $75^{\circ} 10^{\prime} 40.8^{\prime \prime}$ (elevation is 176.97 feet above NAVD 88 ). \\
\hline
\end{tabular}

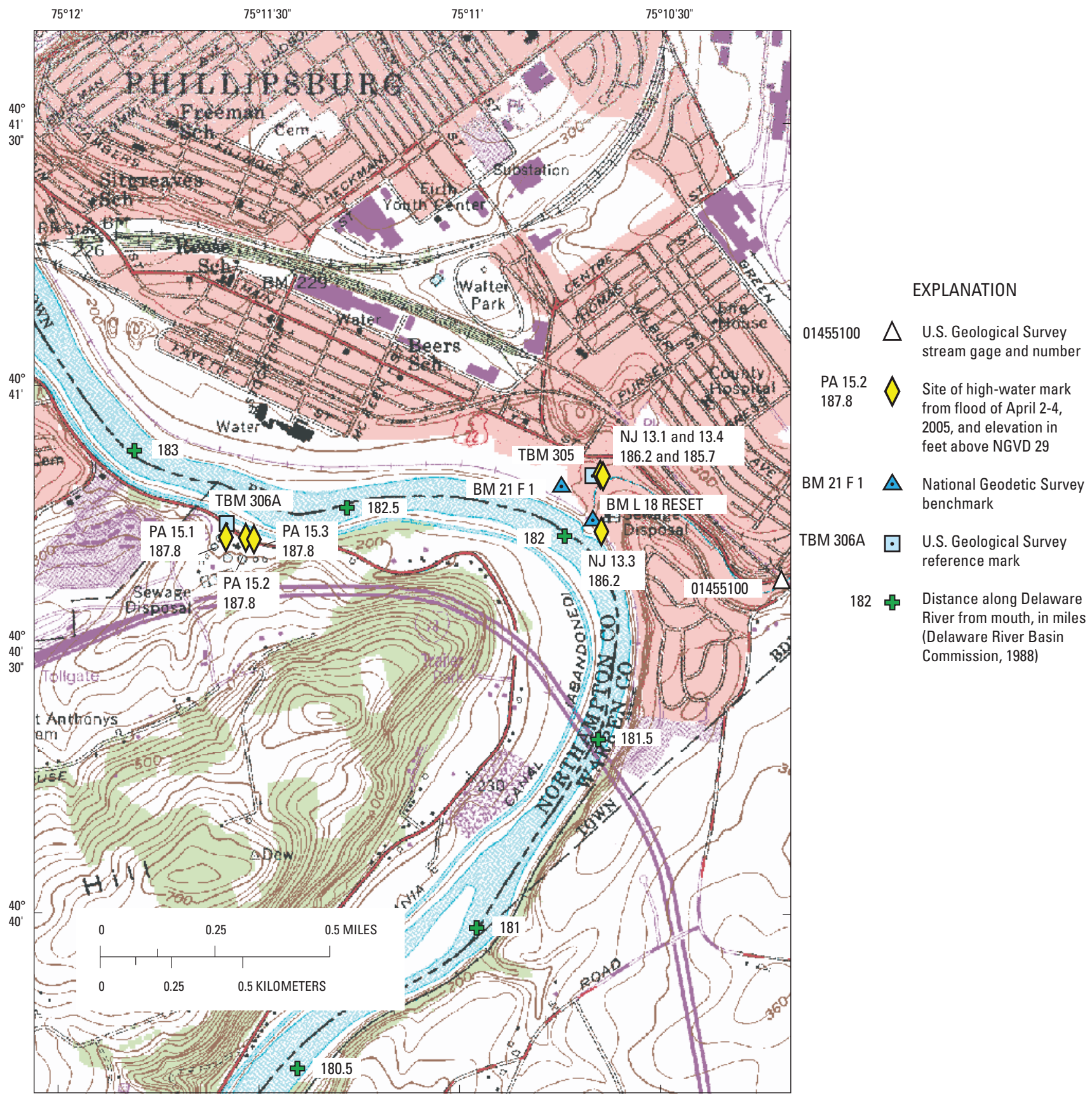

Easton USGS 7.5' Topographic Quadrangle map showing location of site NJ 13, Delaware River near Phillipsburg, NJ. 


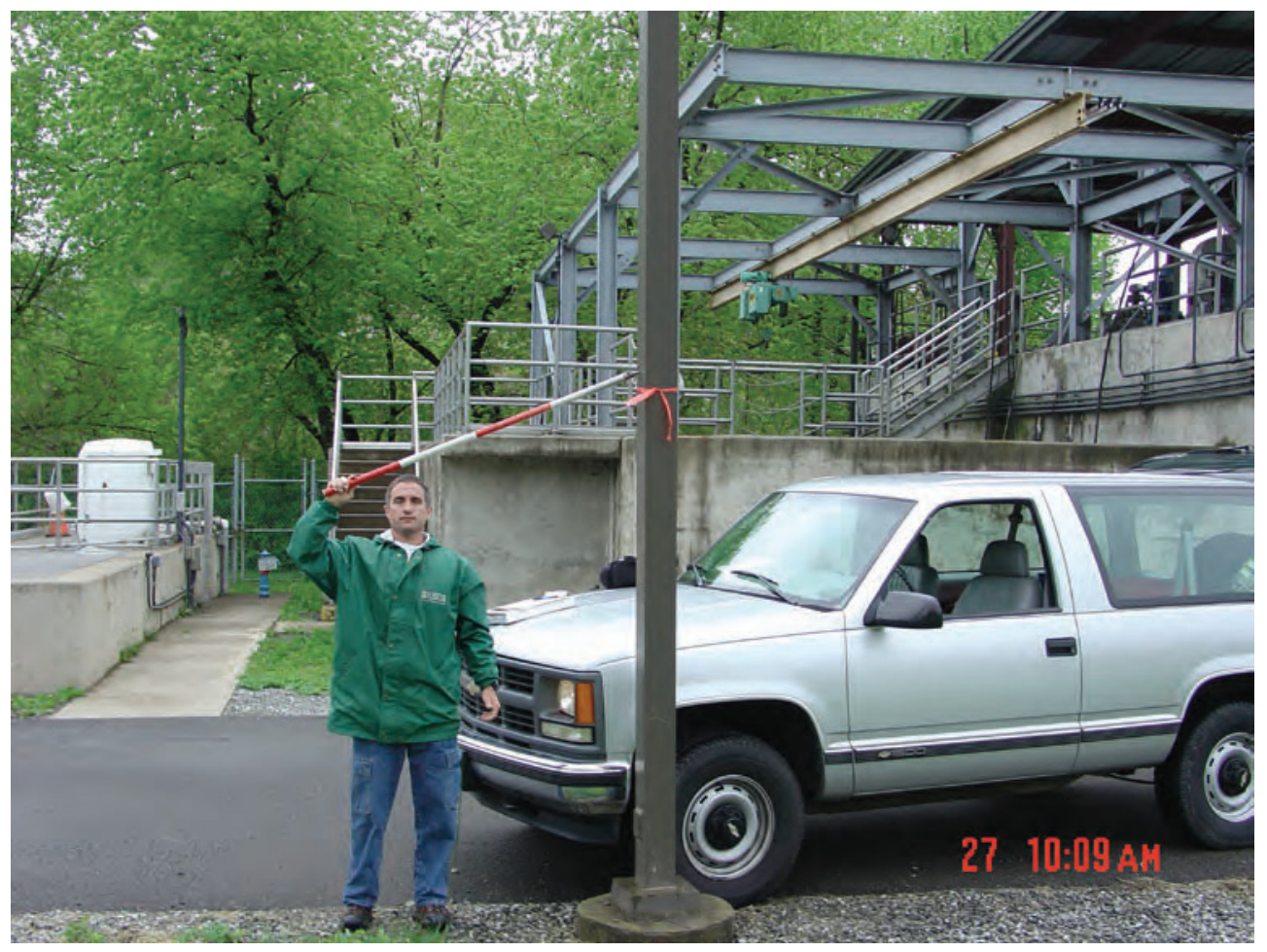

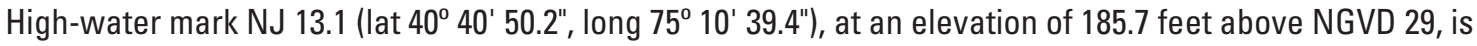
a fair mud line on a light pole in the Phillipsburg Wastewater Treatment Plant, and was marked with a black marker line.

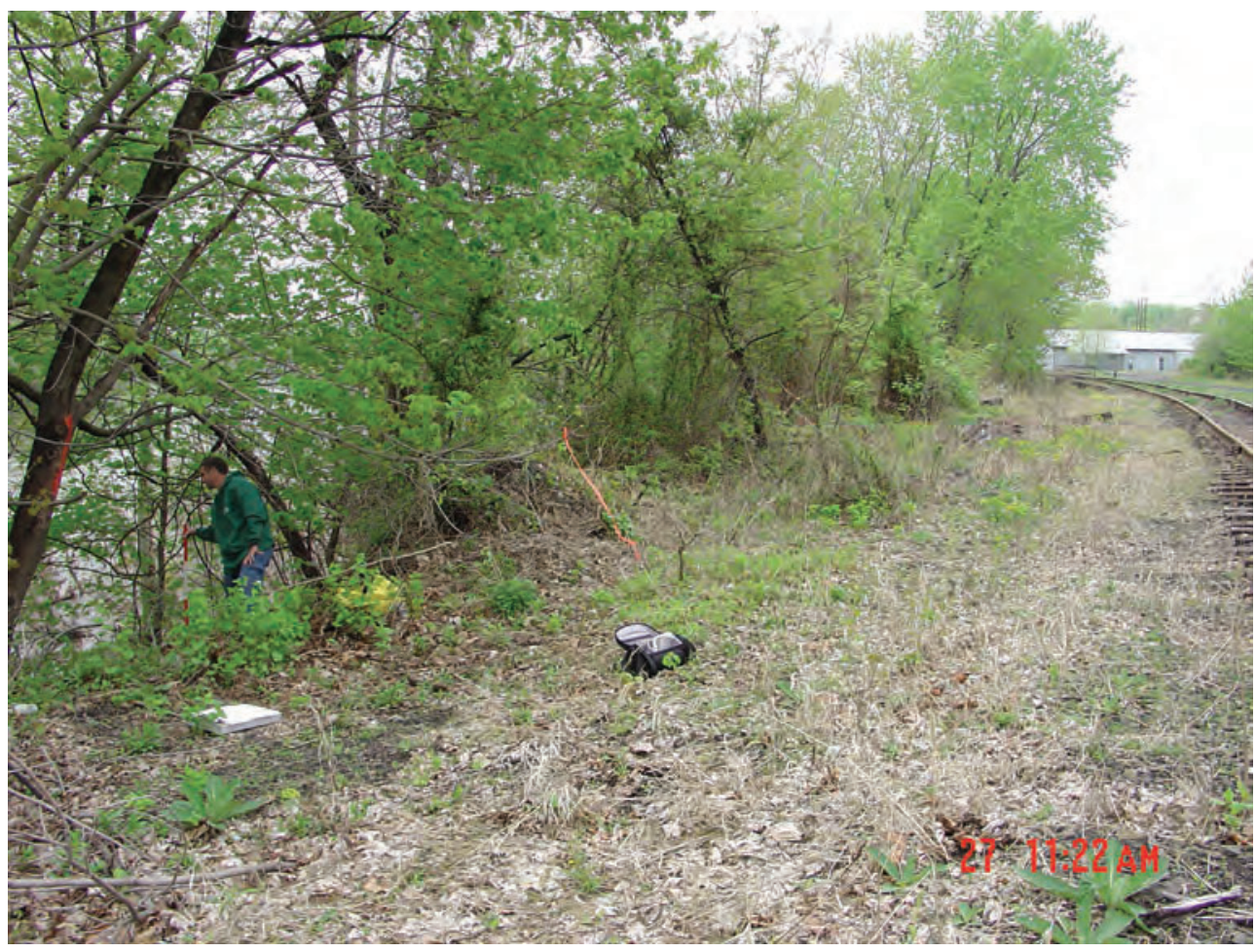

High-water mark NJ 13.3 (lat $40^{\circ} 40^{\prime} 43.9^{\prime \prime}$, long $75^{\circ} 10^{\prime} 39.3^{\prime \prime}$ ), at an elevation of 186.2 feet above NGVD 29 , is a poor debris line on the ground near top of bank, near the mouth of Lopatcong Creek, and was marked with a wooden stake. 


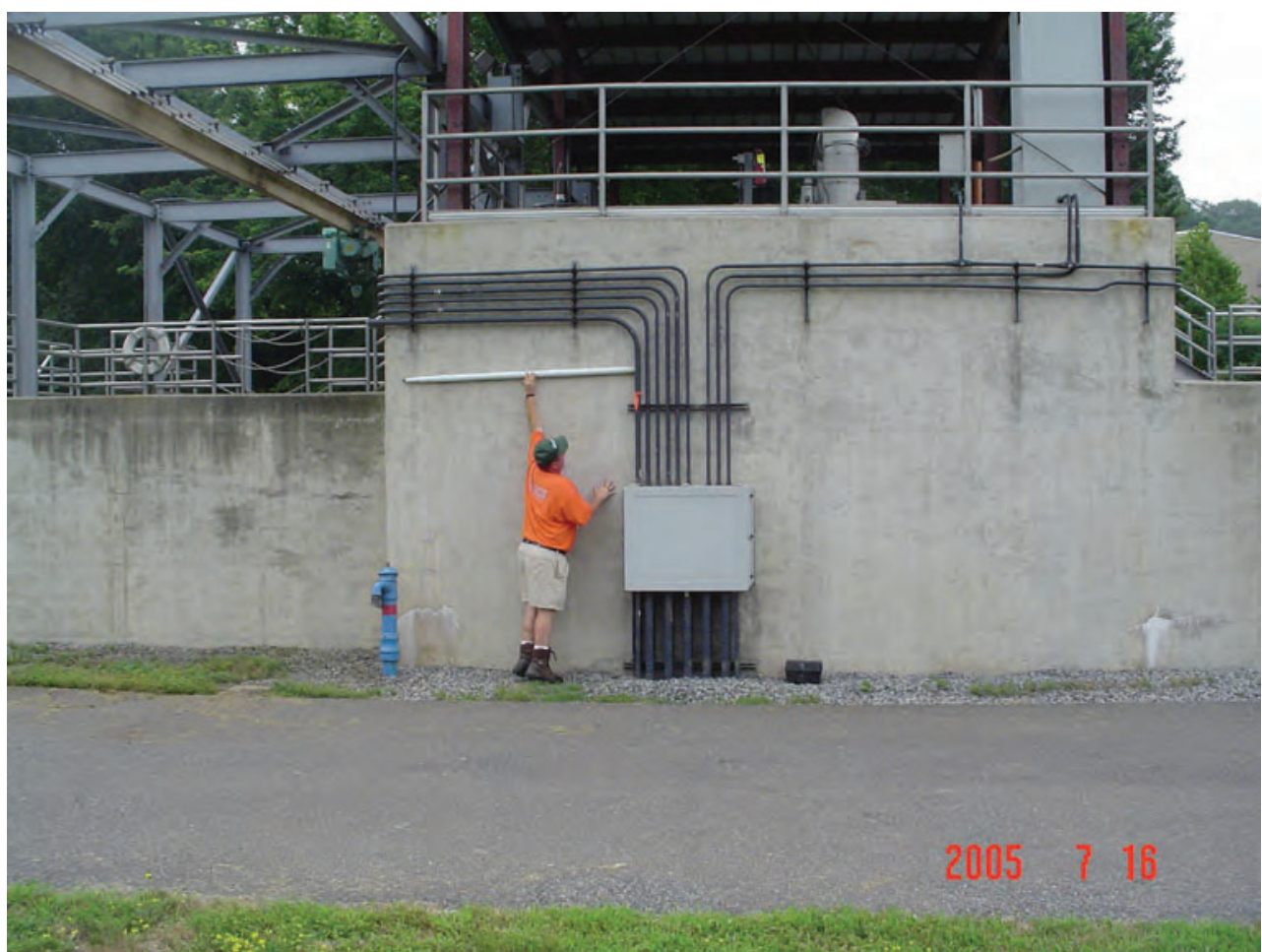

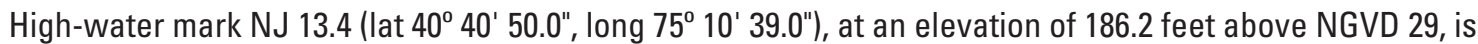
an unrated debris line on a wall in the Phillipsburg Wastewater Treatment Plant, 8 feet above the ground, and was marked with a black marker line. 


\begin{tabular}{|l|}
\hline \multicolumn{1}{|c|}{ SITE DESCRIPTION } \\
\hline Site PA 16: Delaware River at Raubsville, PA \\
\hline Site Location: 0.3 mile reach in vicinity of lat $40^{\circ} 38^{\prime} 10^{\prime \prime}$, long $75^{\circ} 11^{\prime} 35^{\prime \prime}$ \\
\hline Williams Township, Northampton County, PA \\
\hline Three high-water marks were surveyed: two mud lines and one seed line. \\
\hline High-water mark elevations were determined using USGS reference mark 209 at lat $40^{\circ} 38^{\prime} 19.3^{\prime \prime}$, \\
long $75^{\circ} 11^{\prime} 40.8^{\prime \prime}$ (elevation is 187.52 feet above NAVD 88 ) and USGS reference mark 210 at lat \\
$40^{\circ} 38^{\prime} 8.7^{\prime \prime}$, long $75^{\circ} 11^{\prime} 31.6^{\prime \prime}$ (elevation is 167.84 feet above NAVD 88 ). \\
\hline
\end{tabular}

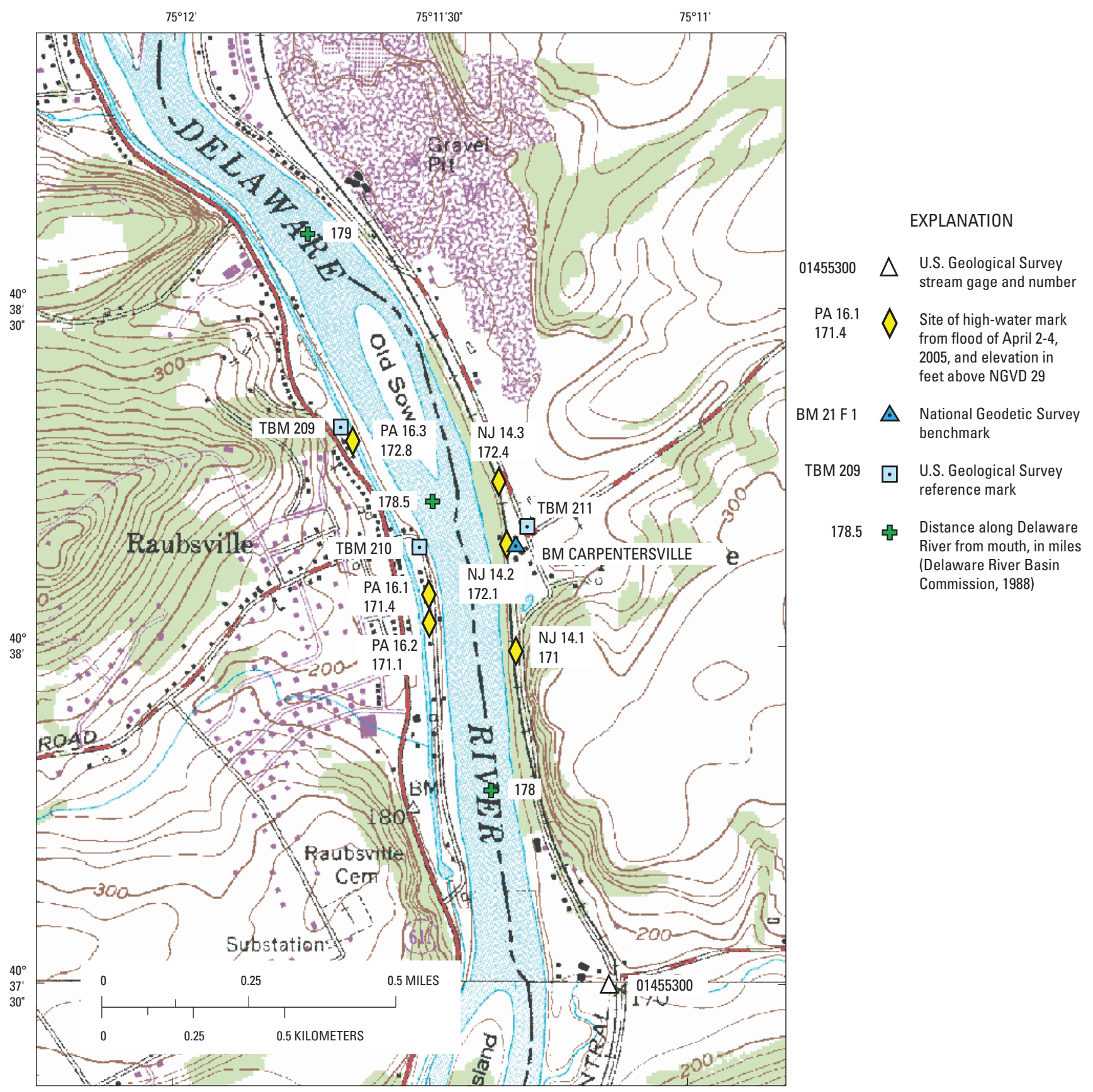

Easton USGS 7.5' Topographic Quadrangle map showing location of site PA 16, Delaware River at Raubsville, PA. 


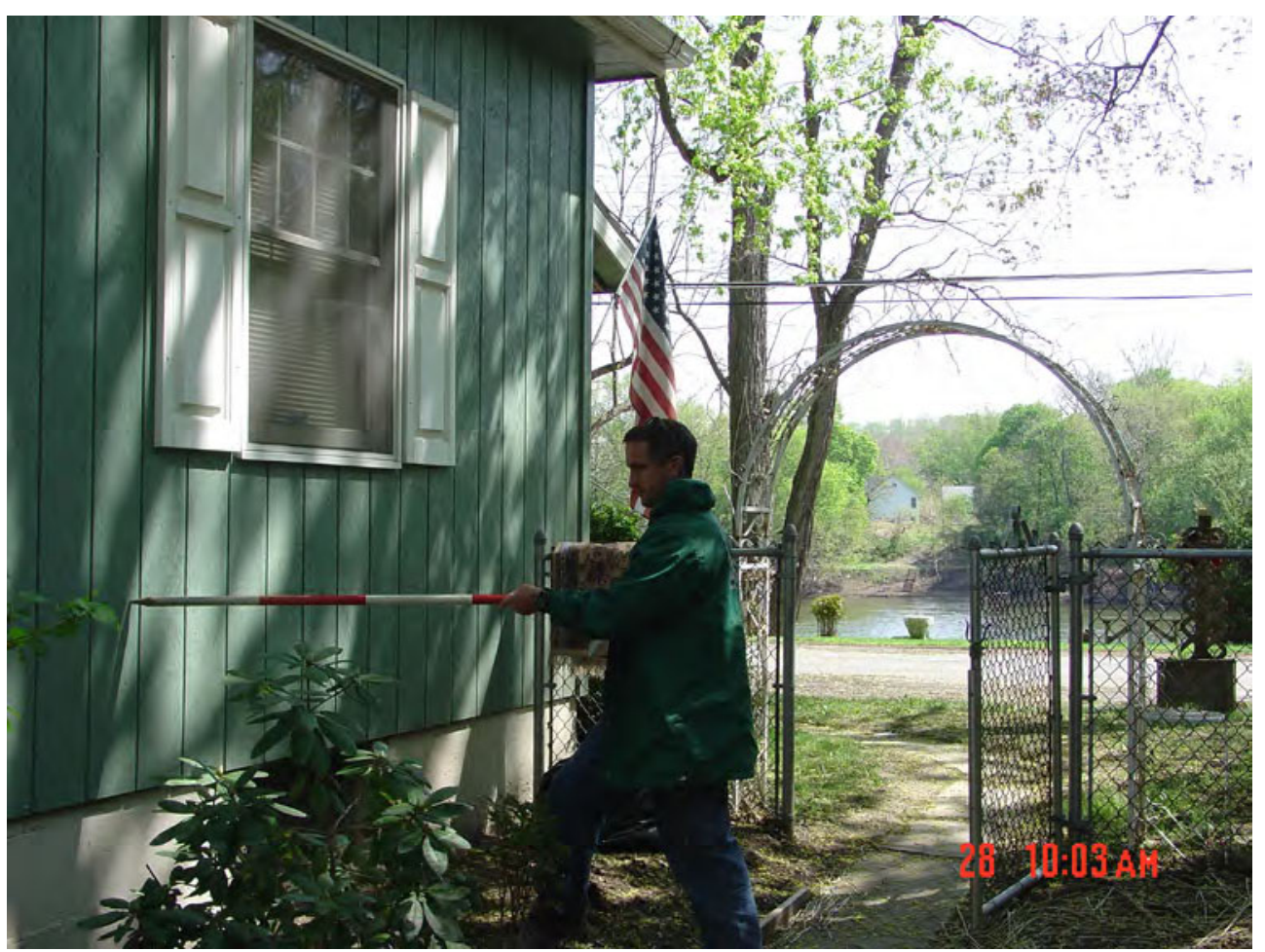

High-water mark PA 16.1 (lat $40^{\circ} 38^{\prime} 4.8^{\prime \prime}$, long $75^{\circ} 11^{\prime} 30.4^{\prime \prime}$ ), at an elevation of 171.4 feet above NGVD 29, is an excellent seed line on a house on Canal Road, 3.8 feet above the ground, 1.6 miles upstream from Frya Run, and was marked with a pencil line.

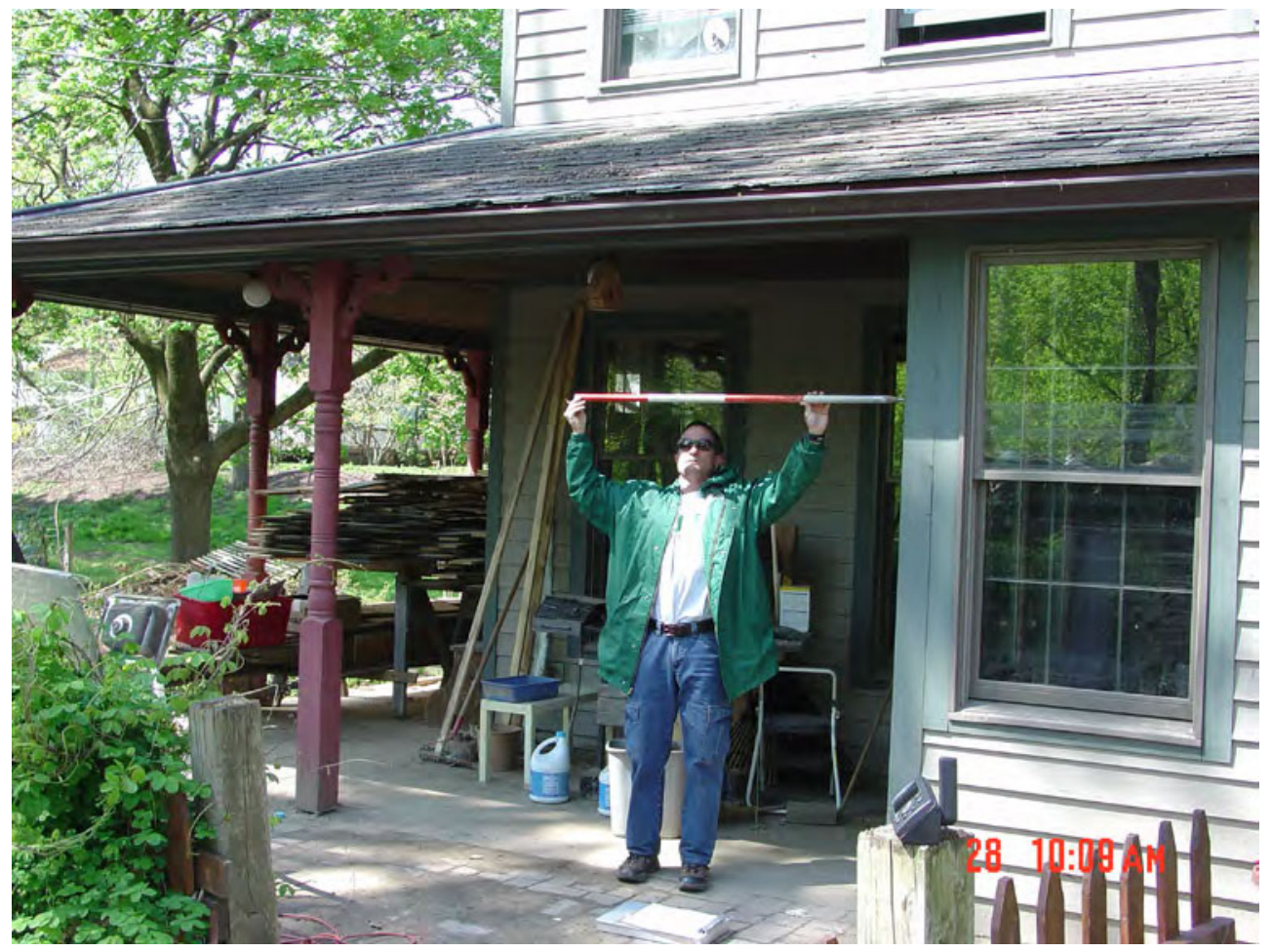

High-water mark PA 16.2 (lat $40^{\circ} 38^{\prime} 2.3^{\prime \prime}$, long $75^{\circ} 11^{\prime} 30.4^{\prime \prime}$ ), at an elevation of 171.1 feet above NGVD 29, is an excellent mud line on a house on Canal Road, 6.0 feet above the ground, 1.6 miles upstream from Frya Run, and was marked with a pencil line. 


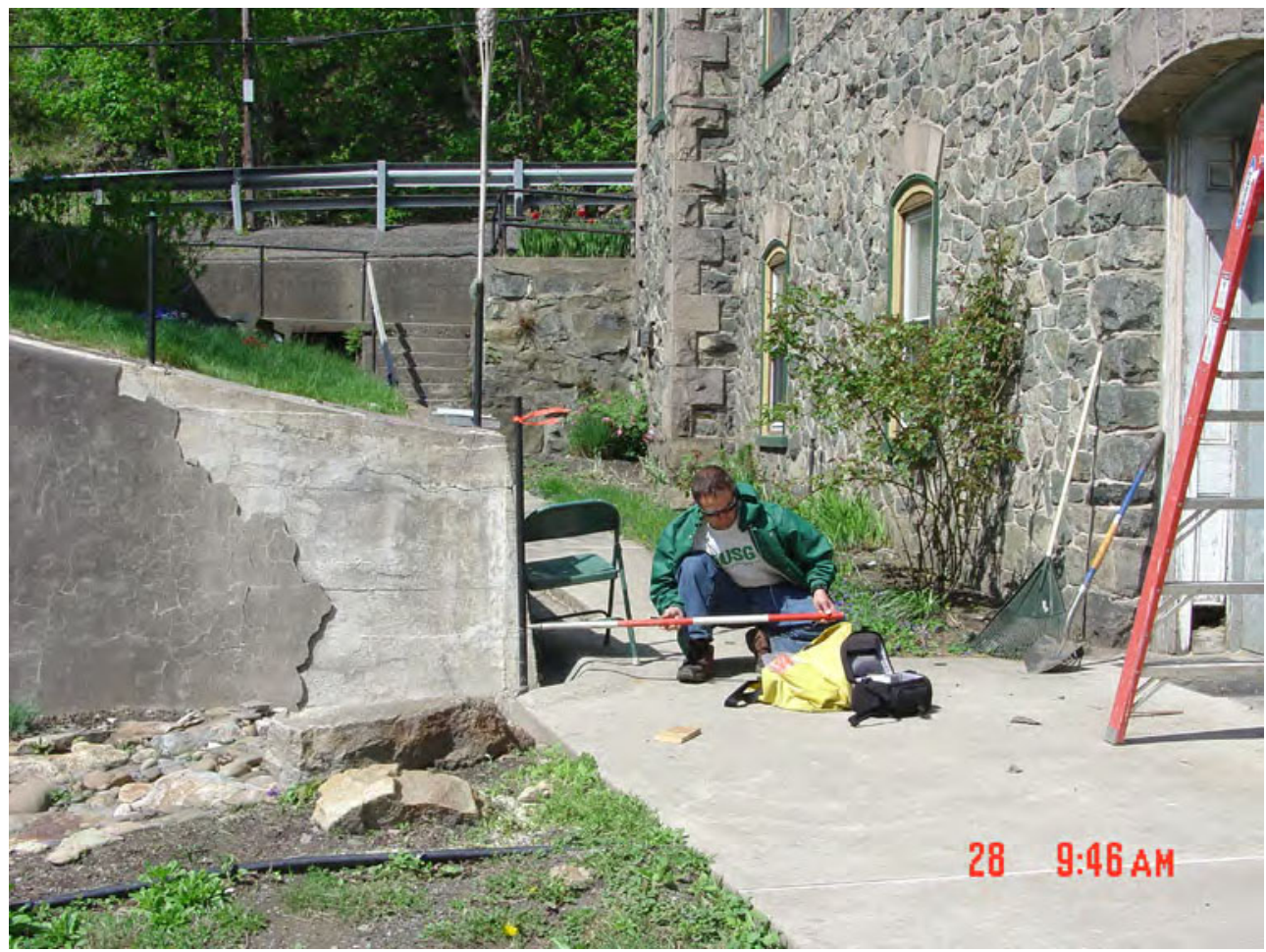

High-water mark PA 16.3 (lat $40^{\circ} 38^{\prime} 18.4^{\prime \prime}$, long $75^{\circ} 11^{\prime} 39.9^{\prime \prime}$ ), at an elevation of 172.8 feet above NGVD 29 , is a good mud line on a metal post next to a church on PA State Route 611, 0.9 feet above the ground, 2.0 miles upstream from Frya Run, and was marked with a black marker line. 


\section{SITE DESCRIPTION}

Site NJ 14: Delaware River at Carpentersville, NJ

Site Location: 0.3 mi reach in vicinity of lat $40^{\circ} 38^{\prime} 09^{\prime \prime}$, long $75^{\circ} 11^{\prime} 21^{\prime \prime}$

Pohatcong Township, Warren County, NJ

Three high-water marks were surveyed: two debris lines and one seed line.

High-water mark elevations were determined using USGS reference mark 211 at lat $40^{\circ} 38^{\prime} 10.6^{\prime \prime}$,

long $75^{\circ} 11^{\prime} 19.0^{\prime \prime}$ (elevation is 169.55 feet above NAVD 88).

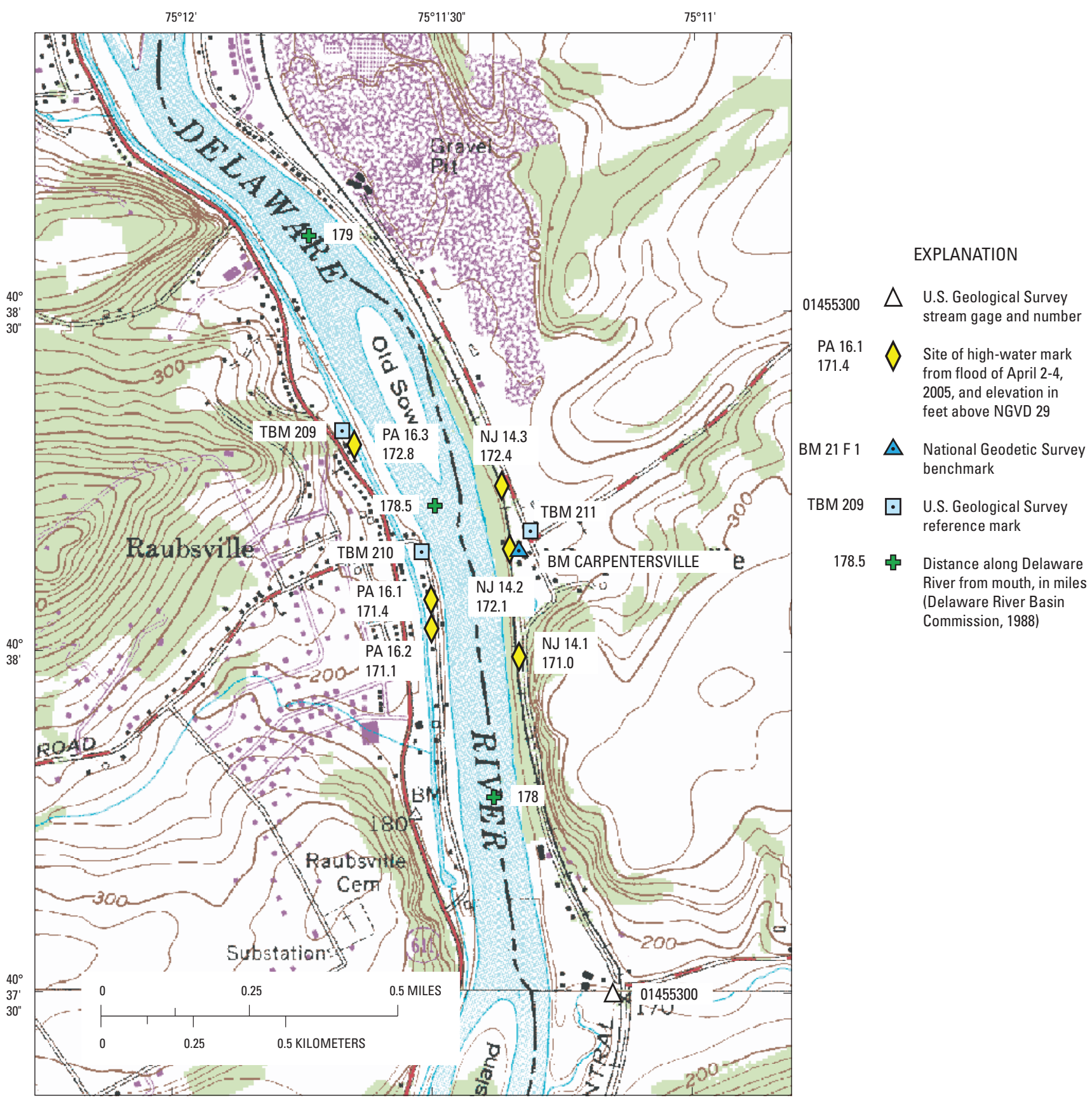

Easton USGS 7.5' Topographic Quadrangle map showing location of site NJ 14, Delaware River at Carpentersville, NJ. 


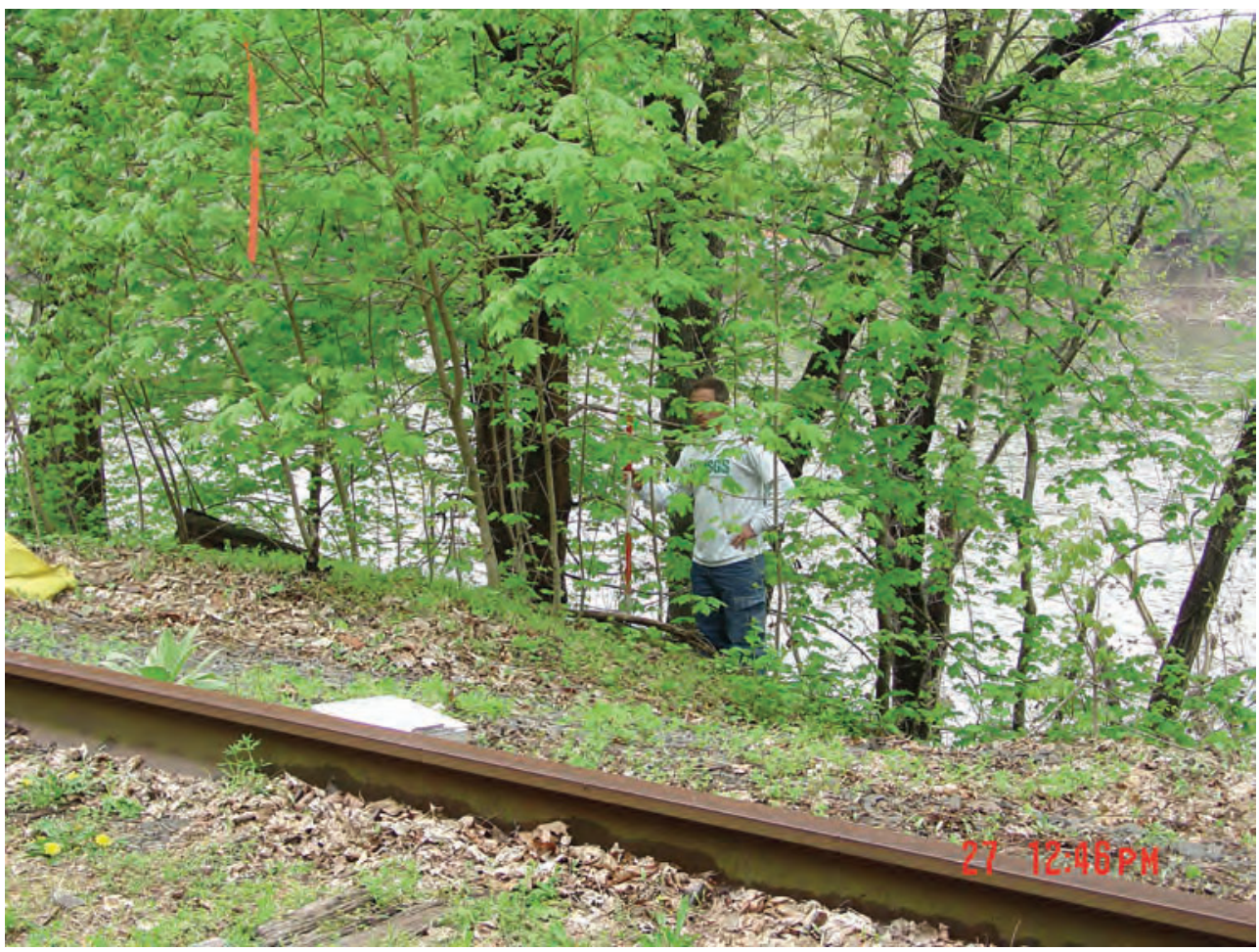

High-water mark NJ 14.1 (lat $40^{\circ} 37^{\prime} 59.9^{\prime \prime}$, long $75^{\circ} 11^{\prime} 20.2^{\prime \prime}$ ), at an elevation of 171.0 feet above NGVD 29, is a fair debris line on the ground, 980 feet downstream from the intersection of Snyders Road and River Road, and was marked with a wooden stake.

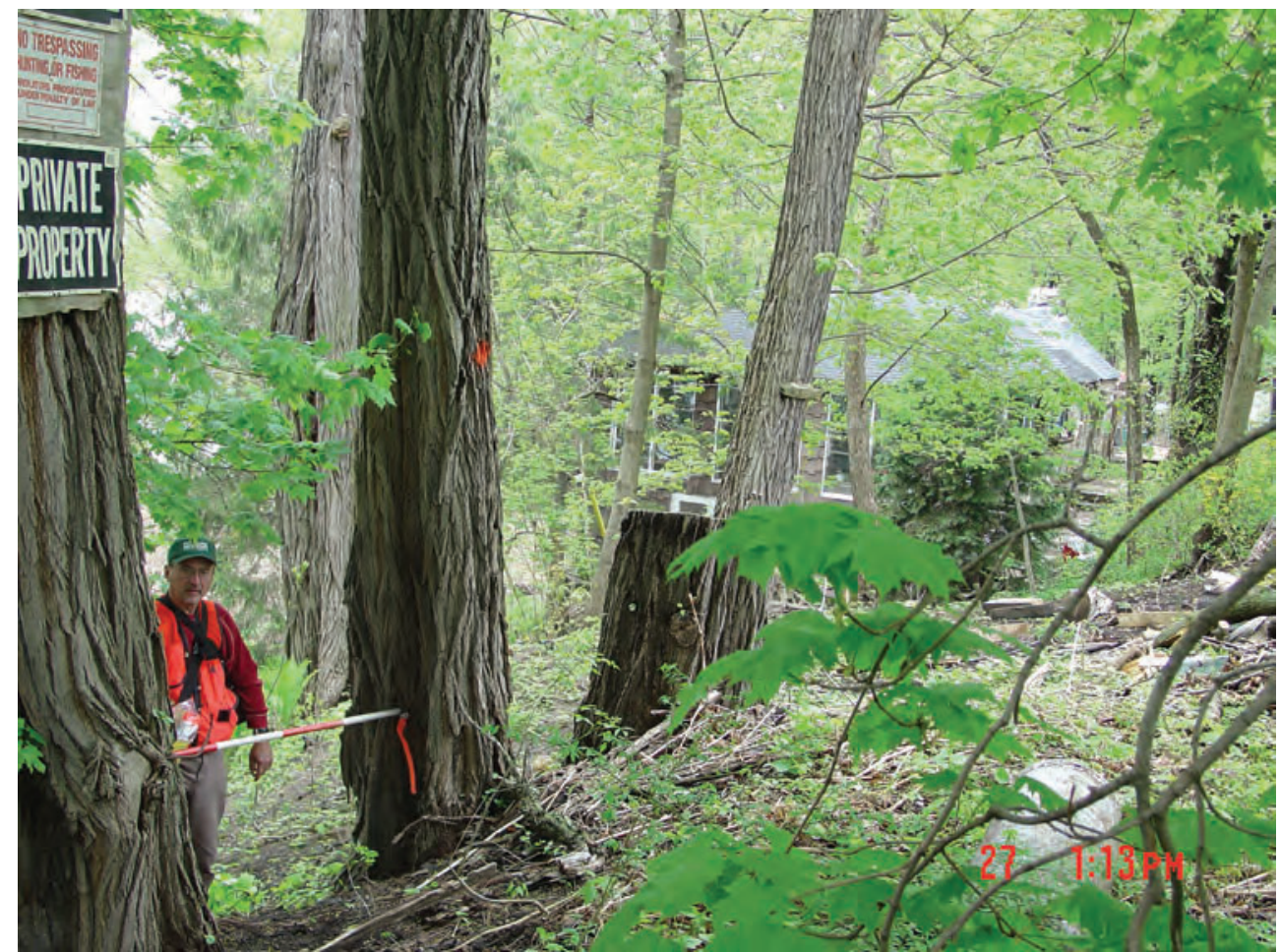

High-water mark NJ 14.2 (lat $40^{\circ} 38^{\prime} 09.2^{\prime \prime}$, long 75 $11^{\prime} 21.4^{\prime \prime}$ ), at an elevation of 172.1 feet above NGVD 29, is a good seed line on a 2-foot diameter tree, 2.2 feet above the ground, near the intersection of Snyders Road and River Road, and was marked with a metal USGS washer and nail. 


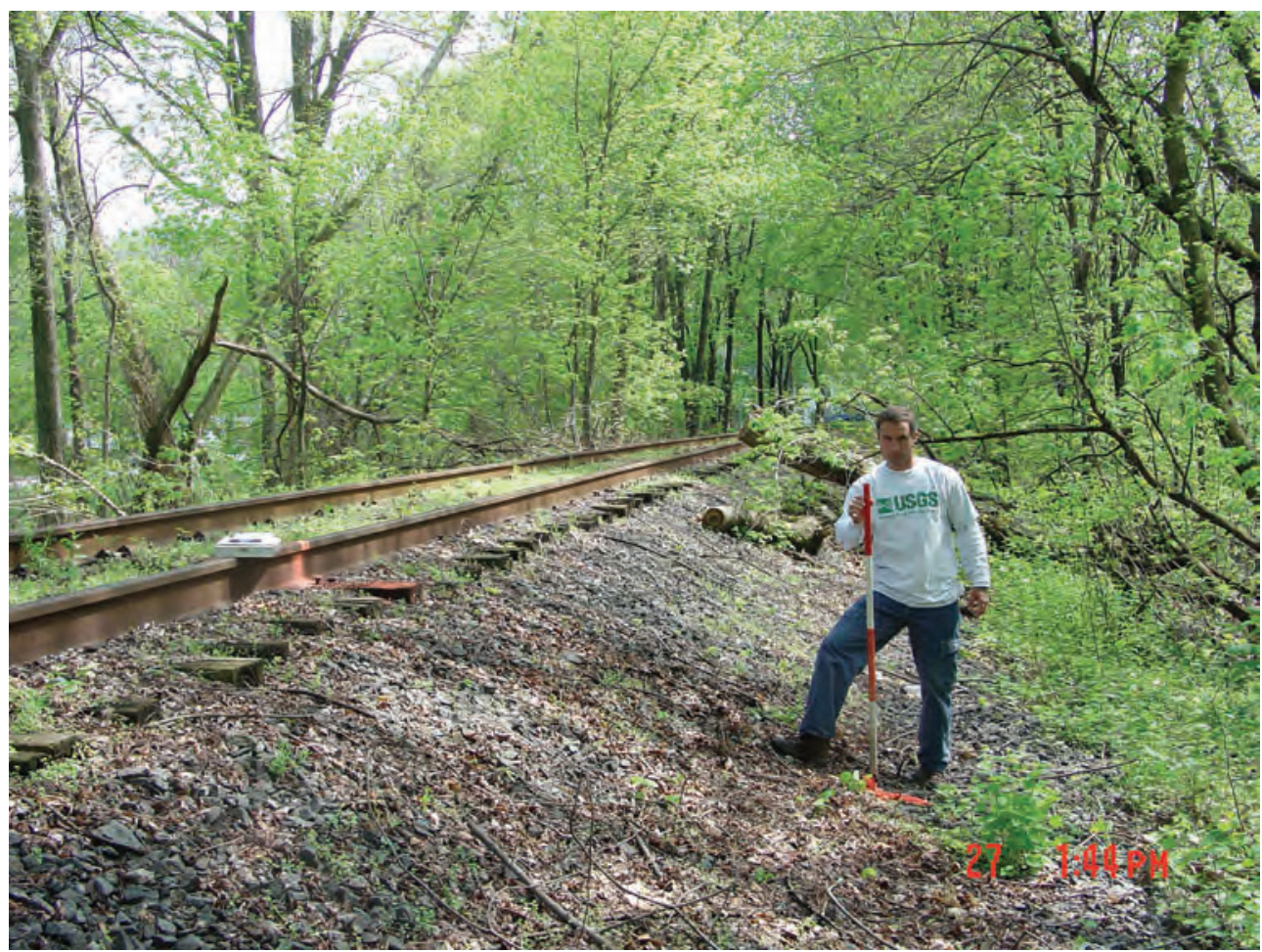

High-water mark NJ 14.3 (lat $40^{\circ} 38^{\prime} 14.7^{\prime \prime}$, long $75^{\circ} 11^{\prime} 22.3^{\prime \prime}$ ), at an elevation of 172.4 feet above NGVD 29 , is a debris line on the bank next to the railroad tracks, 490 feet upstream from the intersection of Snyders Road and River Road, and was marked with a metal rebar. 


\begin{tabular}{|c|}
\hline SITE DESCRIPTION \\
\hline Site NJ 15: 01457500 Delaware River at Riegelsville, NJ \\
\hline Site Location: 0.2 mi reach in vicinity of lat $40^{\circ} 35^{\prime} 41^{\prime \prime}$, long $75^{\circ} 11^{\prime} 24^{\prime \prime}$ \\
\hline Pohatcong Township, Warren County, NJ \\
\hline Five high-water marks were surveyed: three debris lines and two mud lines. \\
\hline $\begin{array}{l}\text { High-water mark elevations were determined using USGS reference mark } 212 \mathrm{~A} \text { at lat } 40^{\circ} 35^{\prime} 40.9^{\prime \prime} \text {, } \\
\text { long } 75^{\circ} 11^{\prime} 22.9^{\prime \prime} \text { (elevation is } 160.25 \text { feet above NAVD 88). }\end{array}$ \\
\hline
\end{tabular}

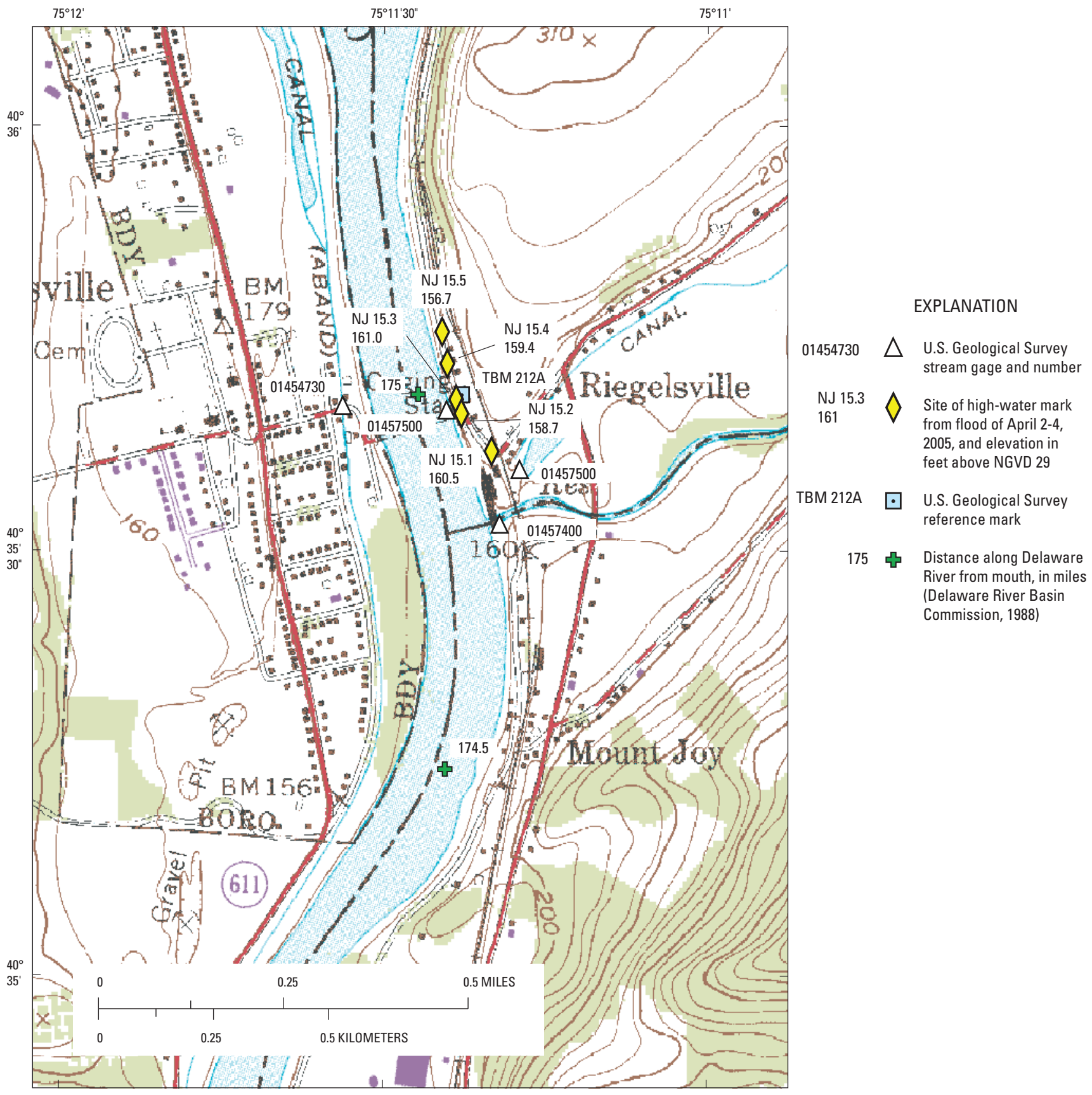

Riegelsville USGS 7.5' Topographic Quadrangle map showing location of site NJ 15, Delaware River at Riegelsville, NJ. 


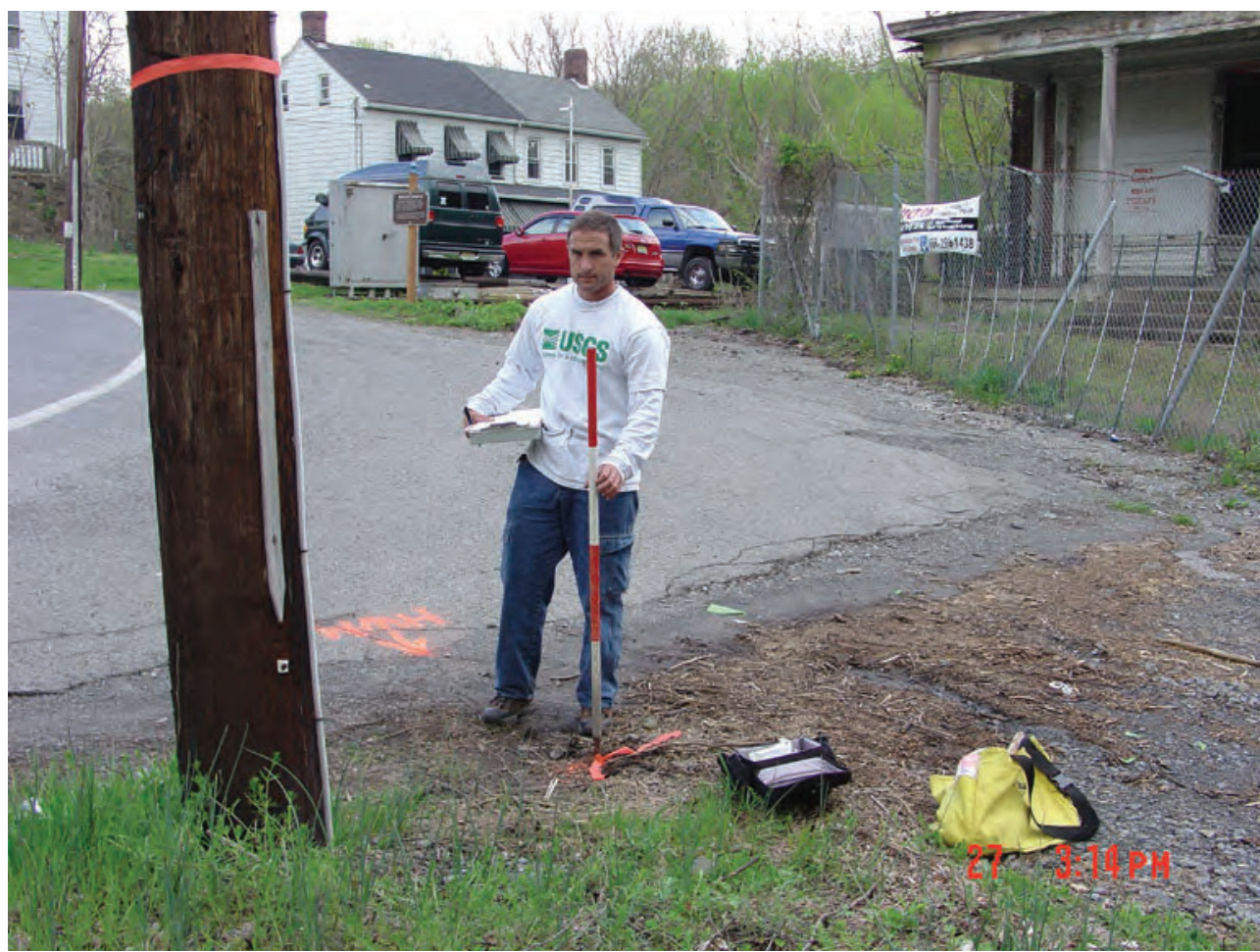

High-water mark NJ 15.1 (lat $40^{\circ} 35^{\prime} 37.3^{\prime \prime}$, long $75^{\circ} 11^{\prime} 20.1^{\prime \prime}$ ), at an elevation of 160.5 feet above NGVD 29 , is a good debris line on the ground, 300 feet downstream from the Riegelsville bridge, and was marked with a metal rebar.

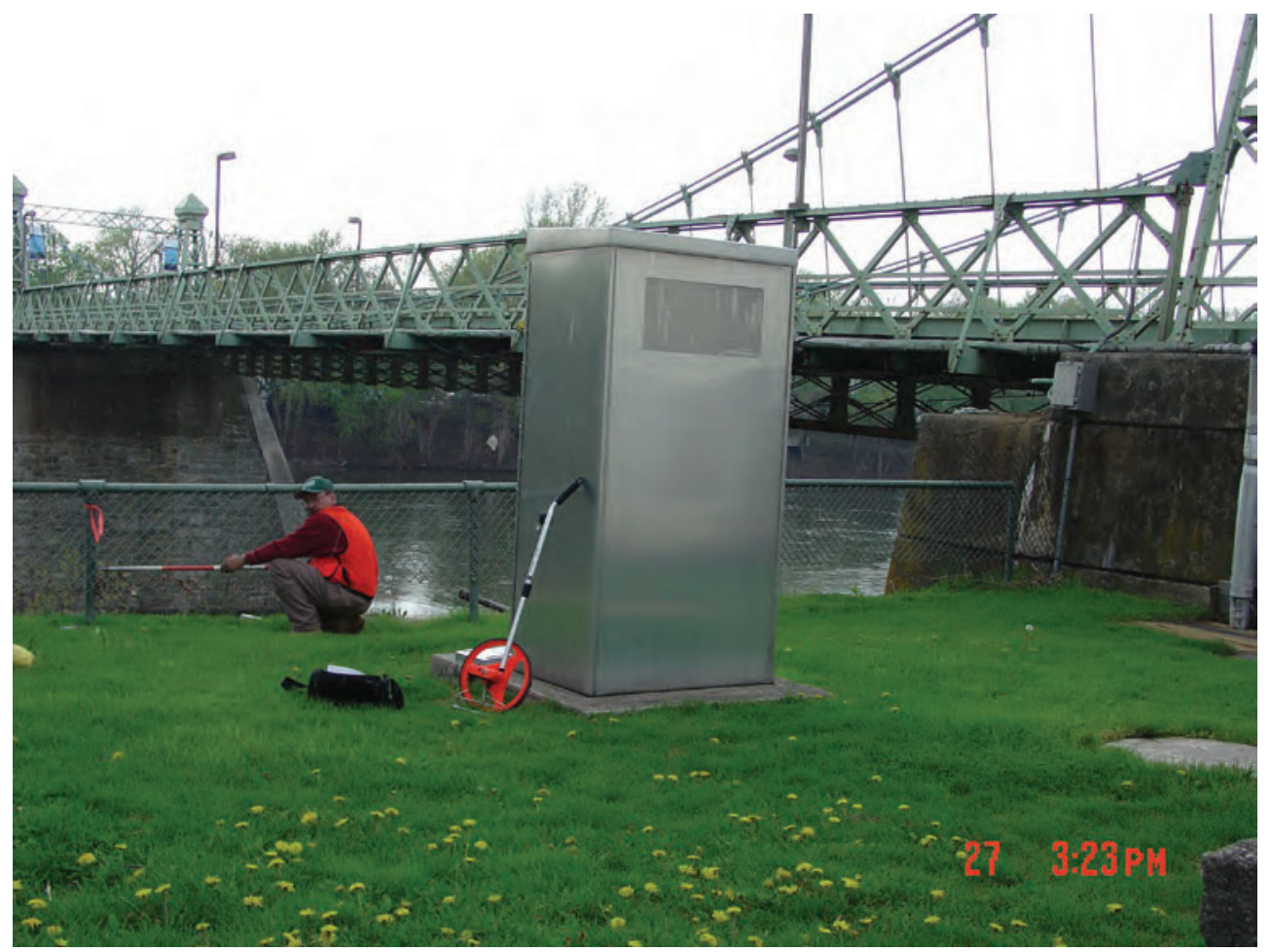

High-water mark NJ 15.2 (lat $40^{\circ} 35^{\prime} 39.9^{\prime \prime}$, long $75^{\circ} 11^{\prime} 23.0^{\prime \prime}$ ), at an elevation of 158.7 feet above NGVD 29, is a good debris line on a chain link fence, 1.2 feet above the ground, near the Delaware River Joint Toll Bridge Commission guard house at the Riegelsville bridge, and was marked with a black marker line. 


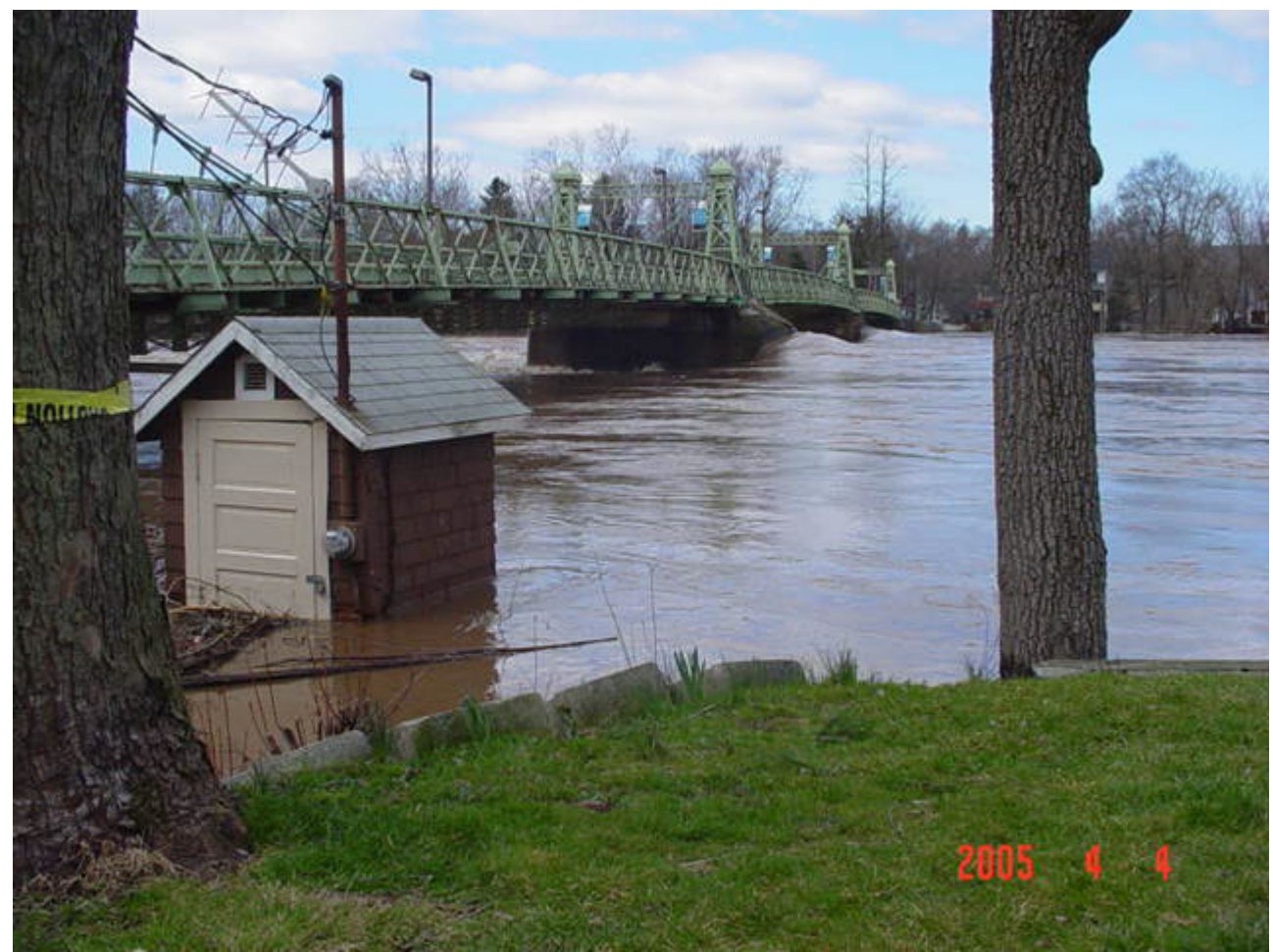

High-water mark NJ 15.3 (lat $40^{\circ} 35^{\prime} 41^{\prime \prime}$, long $75^{\circ} 11^{\prime} 24^{\prime \prime}$ ), at an elevation of 159.1 feet above NGVD 29 , is an excellent debris line on the door of the USGS stream gage house at the Riegelsville bridge, and was marked with a black marker line.

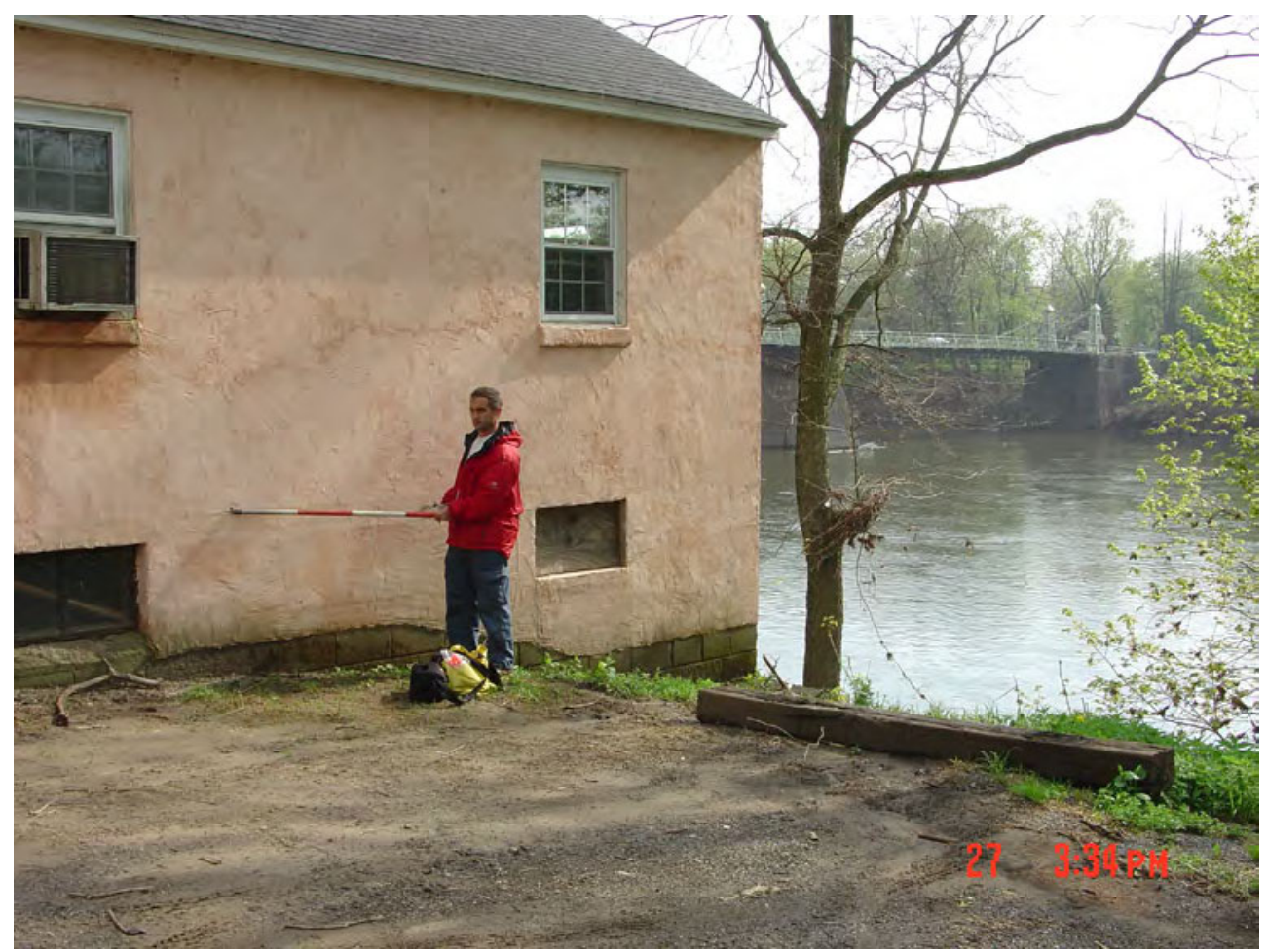

High-water mark NJ 15.4 (lat $40^{\circ} 35^{\prime} 43.5^{\prime \prime}$, long 75 $11^{\prime} 24.2^{\prime \prime}$ ), at an elevation of 159.4 feet above NGVD 29, is an excellent mud line on a house, 3 feet above the ground, 310 feet upstream from the Riegelsville bridge, and was marked with a black marker line. 


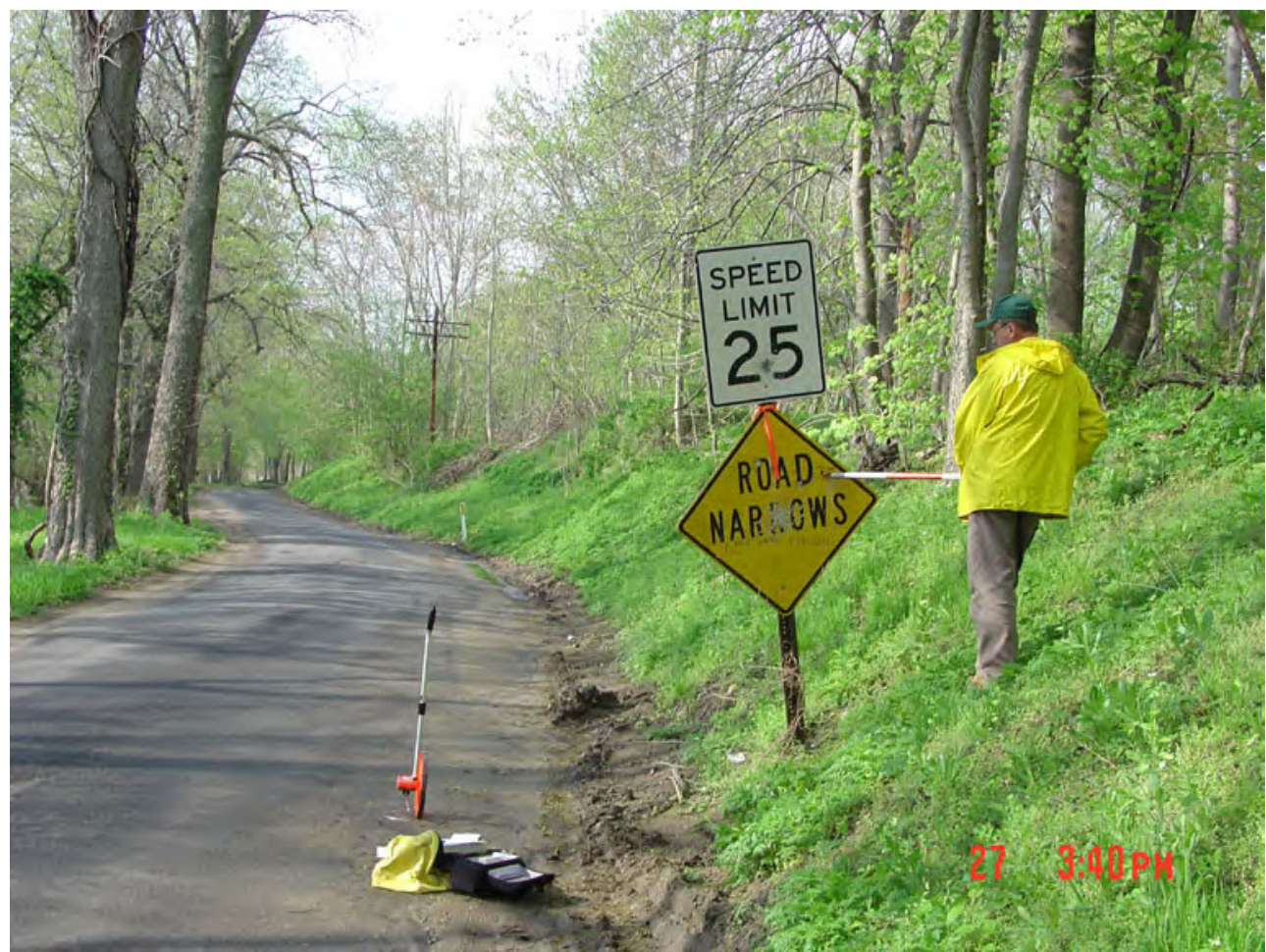

High-water mark NJ 15.5 (lat $40^{\circ} 35^{\prime} 45.7^{\prime \prime}$, long $75^{\circ} 11^{\prime} 24.8^{\prime \prime}$ ), at an elevation of 156.7 feet above NGVD 29 , is an excellent mud line on a"ROAD NARROWS" sign, 4.6 feet above the ground, 560 feet upstream from the Riegelsville bridge, and was marked with a black marker line. 


\begin{tabular}{|c|}
\hline SITE DESCRIPTION \\
\hline Site NJ 16: 01458000 Delaware River at Milford, NJ \\
\hline Site Location: $0.2 \mathrm{mi}$ reach in vicinity of lat $40^{\circ} 33^{\prime} 59^{\prime \prime}$, long $75^{\circ} 05^{\prime} 55^{\prime \prime}$ \\
\hline Milford Borough, Hunterdon County, NJ \\
\hline Four high-water marks were surveyed: two debris lines, one mud line, and one seed line. \\
\hline $\begin{array}{l}\text { High-water mark elevations were determined using USGS reference mark } 208 \text { at lat } 40^{\circ} 34^{\prime} 00.0^{\prime \prime} \text {, } \\
\text { long } 75^{\circ} 05^{\prime} 47.8^{\prime \prime} \text { (elevation is } 136.79 \text { feet above NAVD 88). }\end{array}$ \\
\hline
\end{tabular}

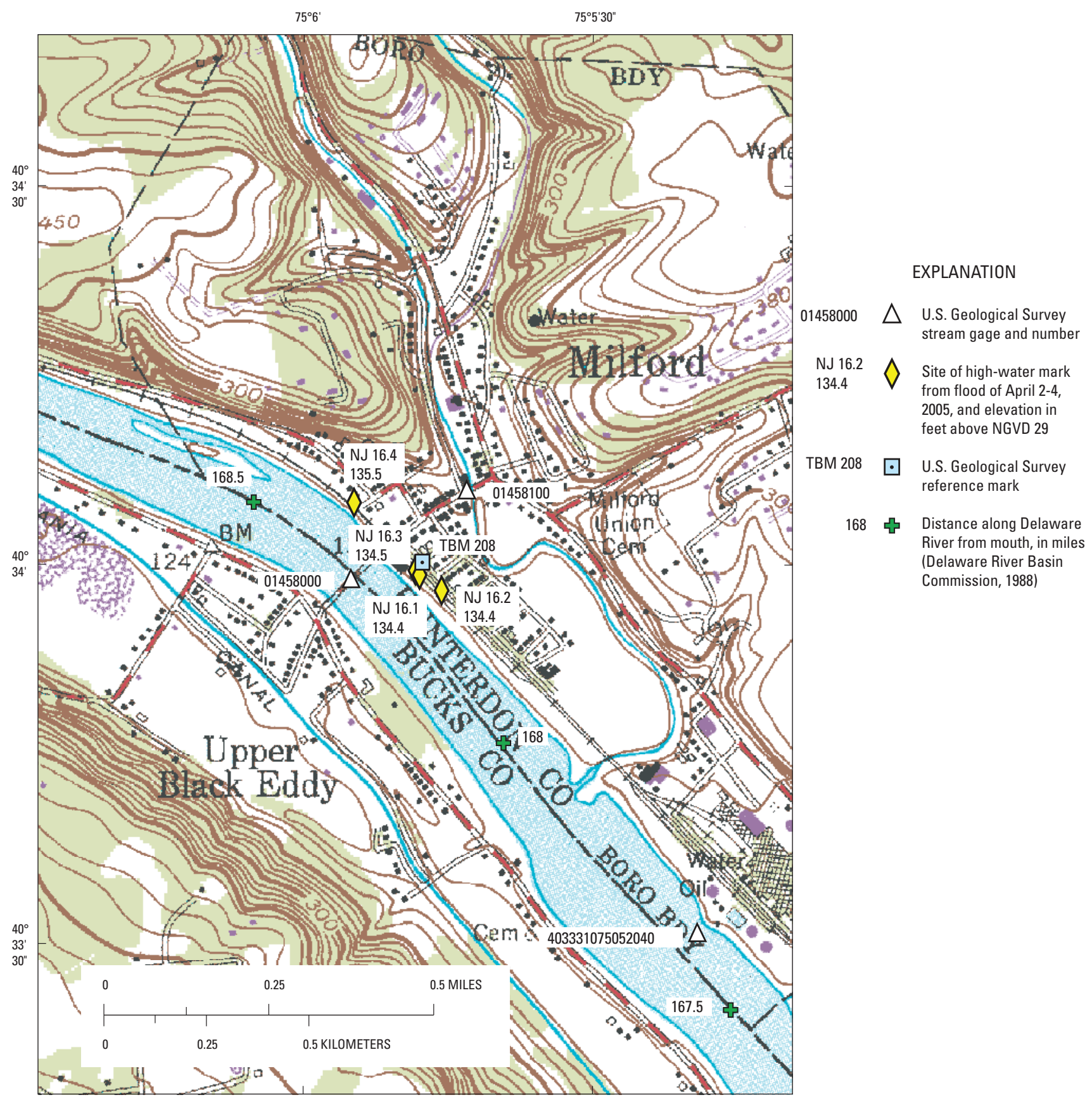

Frenchtown USGS 7.5' Topographic Quadrangle map showing location of site NJ 16, Delaware River at Milford, NJ. 


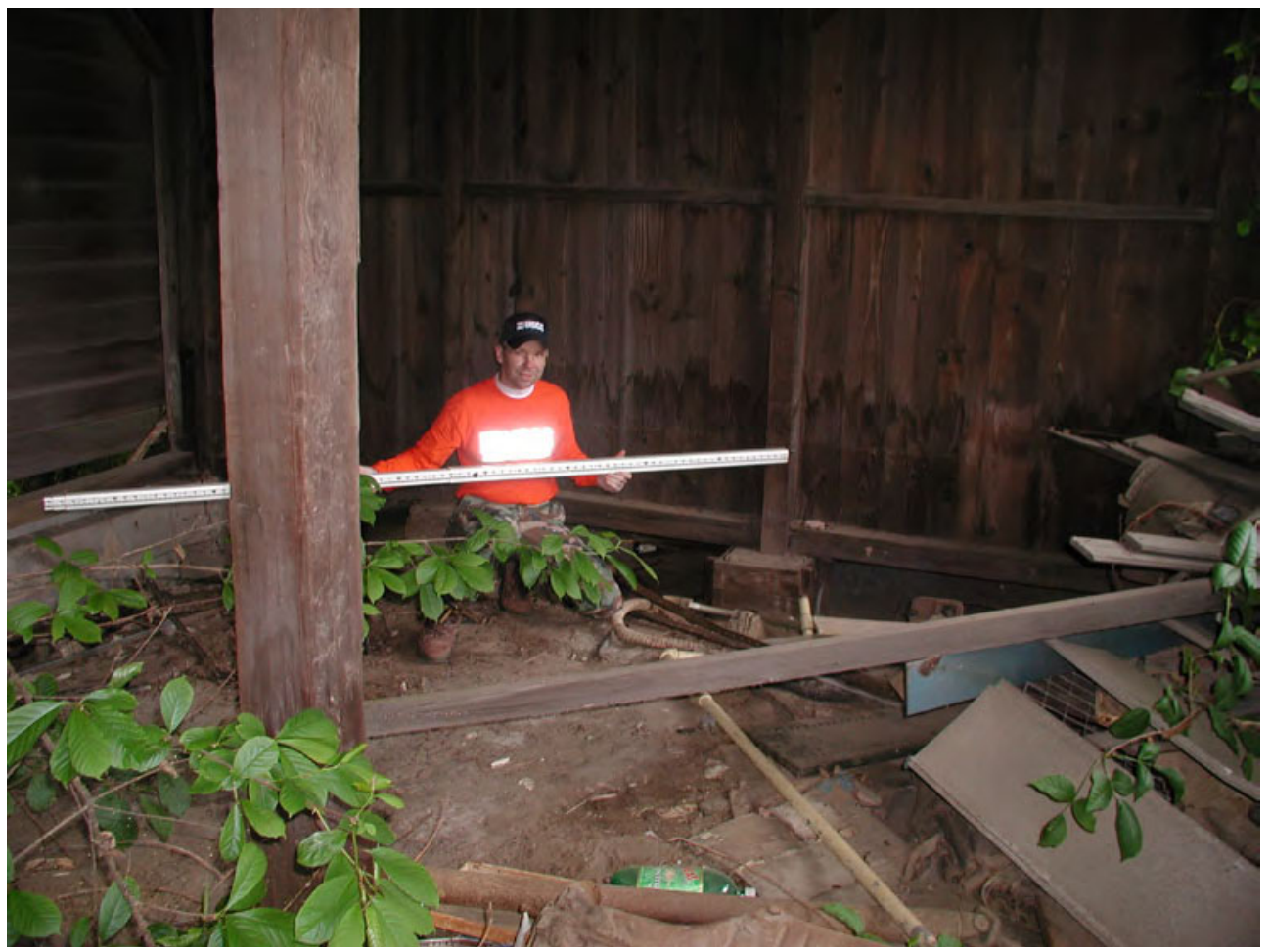

High-water mark NJ 16.1 (lat $40^{\circ} 33^{\prime} 59.3^{\prime \prime}$, long $75^{\circ} 05^{\prime} 48.1^{\prime \prime}$ ), at an elevation of 134.4 feet above NGVD 29 , is a good seed line inside a wooden stable, 300 feet downstream from the Bridge Street bridge, and was marked with a metal USGS washer and nail.

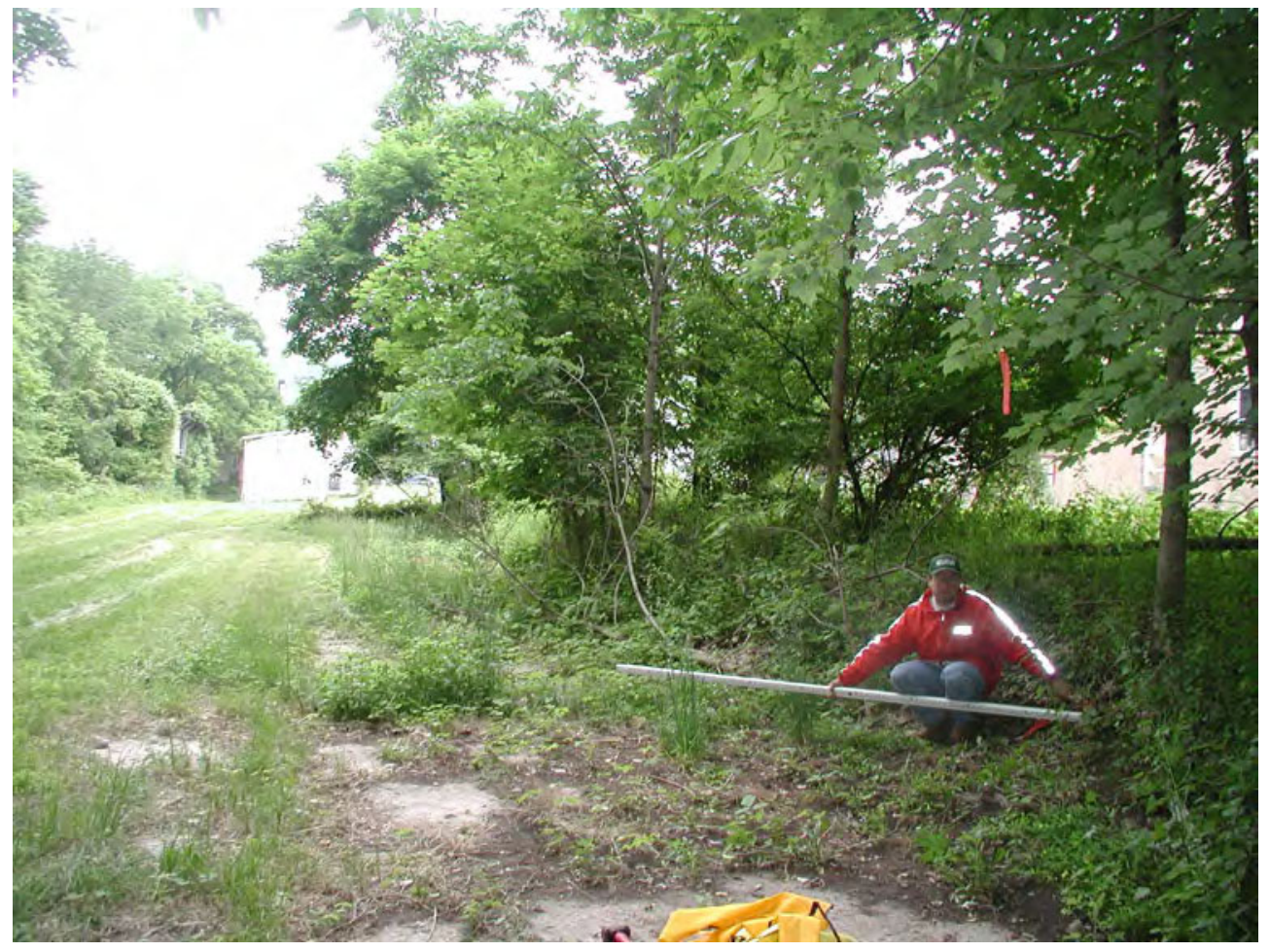

High-water mark NJ 16.2 (lat $40^{\circ} 33^{\prime} 58.1^{\prime \prime}$, long $75^{\circ} 05^{\prime} 45.8^{\prime \prime}$ ), at an elevation of 134.4 feet above NGVD 29, is a good debris line on the ground, 547 feet downstream from the Bridge Street bridge, and was marked with a metal rebar. 


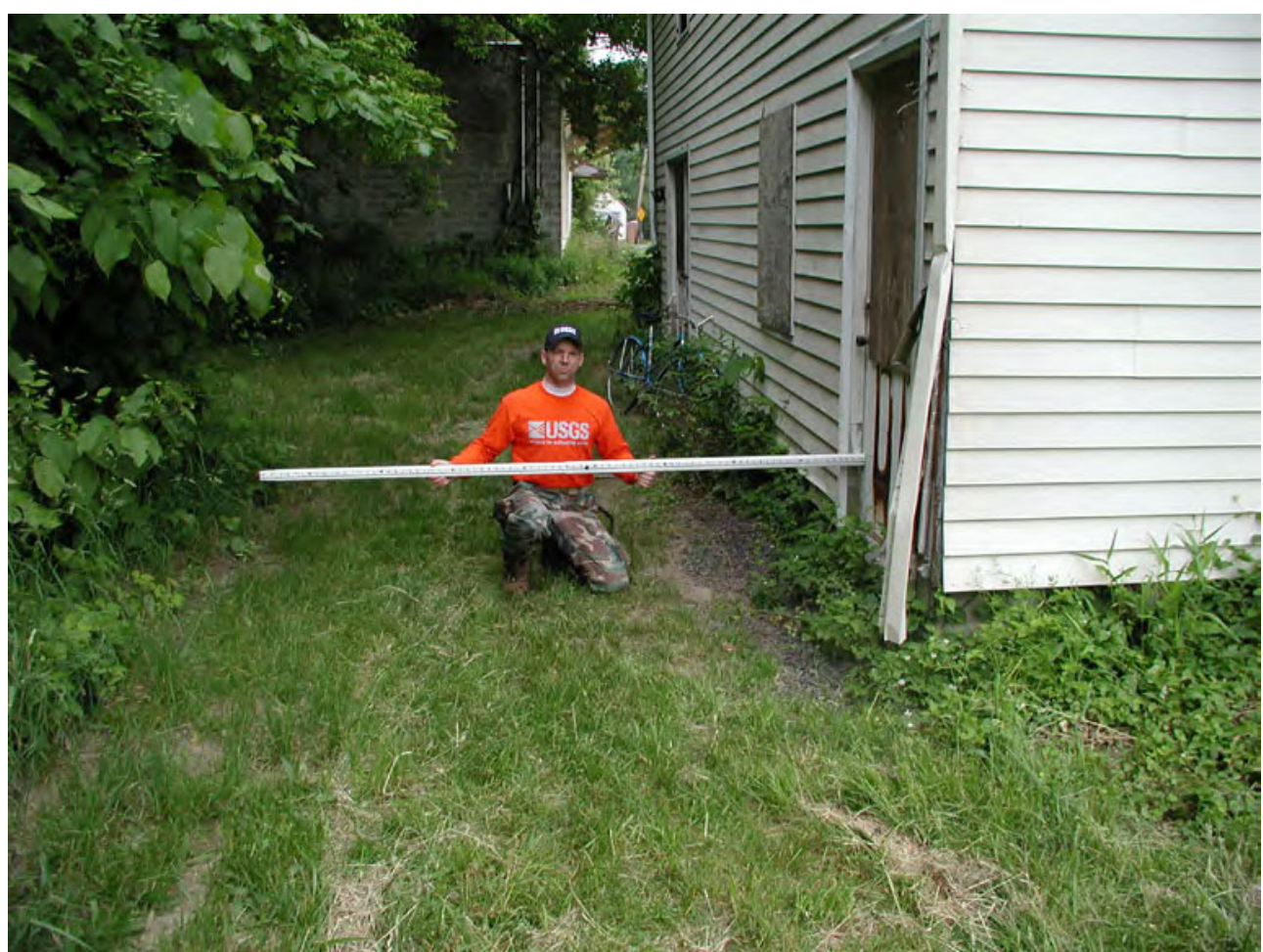

High-water mark NJ 16.3 (lat $40^{\circ} 33^{\prime} 59.8^{\prime \prime}$, long $75^{\circ} 05^{\prime} 48.4^{\prime \prime}$ ), at an elevation of 134.5 feet above NGVD 29 , is an excellent mud line on the door of a house, 2.0 feet above the ground, 290 feet downstream from the Bridge Street bridge, and was marked with a black marker line.

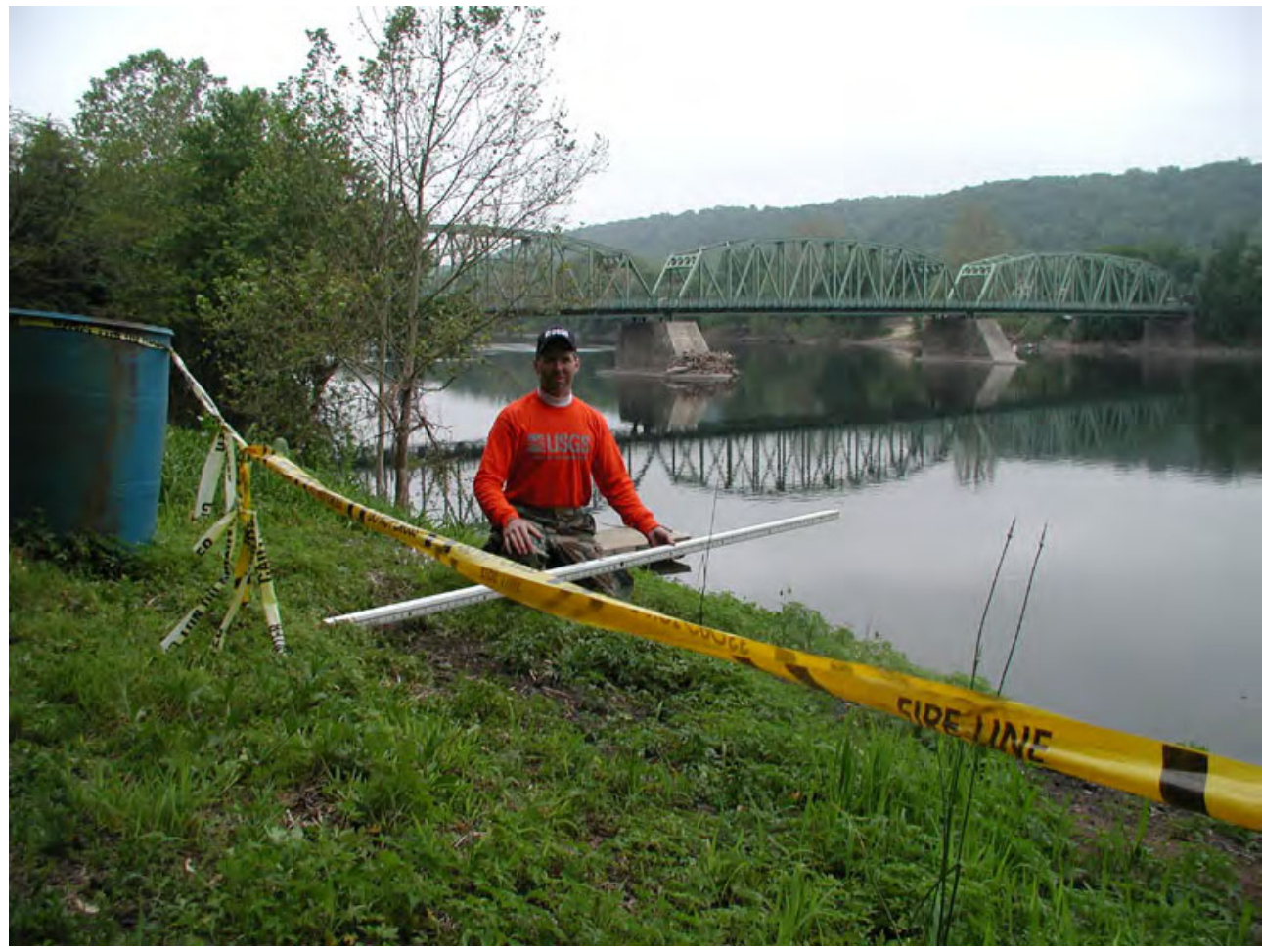

High-water mark NJ 16.4 (lat $40^{\circ} 34^{\prime} 05.1^{\prime \prime}$, long $75^{\circ} 05^{\prime} 54.9^{\prime \prime}$ ), at an elevation of 135.5 feet above NGVD 29, is a good debris line at top of bank, 428 feet upstream from the Bridge Street bridge, and was marked with a wooden stake with a metal USGS washer and nail in the top of the stake. 


\begin{tabular}{l} 
SITE DESCRIPTION \\
\hline Site NJ 17: 01458500 Delaware River at Frenchtown, NJ \\
Site Location: 0.2 mi reach in vicinity of lat $40^{\circ} 33^{\prime} 59^{\prime \prime}$ l long $75^{\circ} 05^{\prime} 55^{\prime \prime}$ \\
\hline Frenchtown Borough, Hunterdon County, NJ \\
Four high-water marks were surveyed: two seed lines, one mud line, and one unknown line. \\
High-water mark elevations were determined using USGS reference mark 113 at lat $40^{\circ} 31^{\prime} 34.9^{\prime \prime}$, \\
long $75^{\circ} 03^{\prime} 46.8^{\prime \prime}$ (elevation is 122.69 feet above NAVD 88).
\end{tabular}

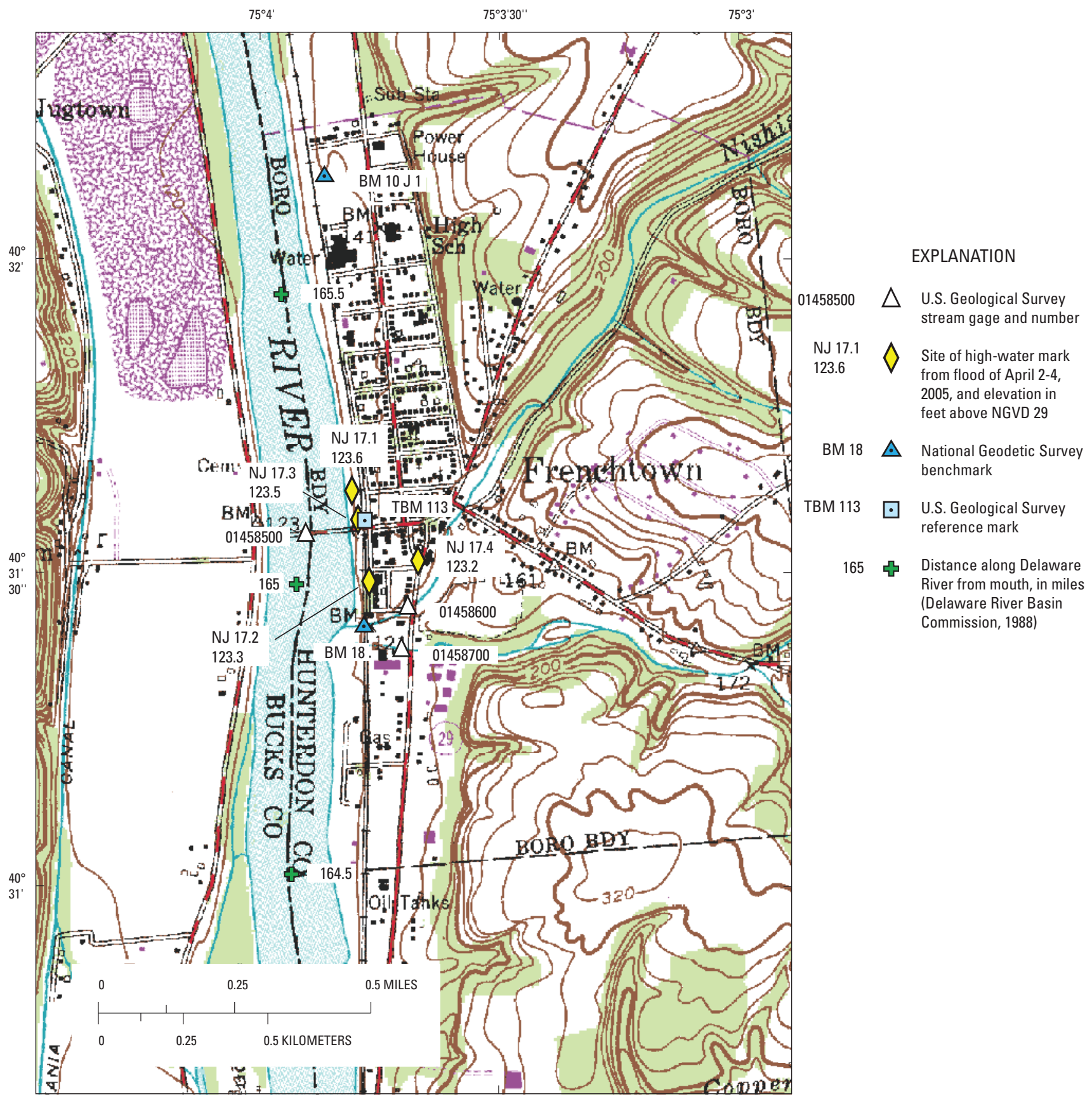

Frenchtown USGS 7.5' Topographic Quadrangle map showing location of site NJ 17, Delaware River at Frenchtown, NJ. 


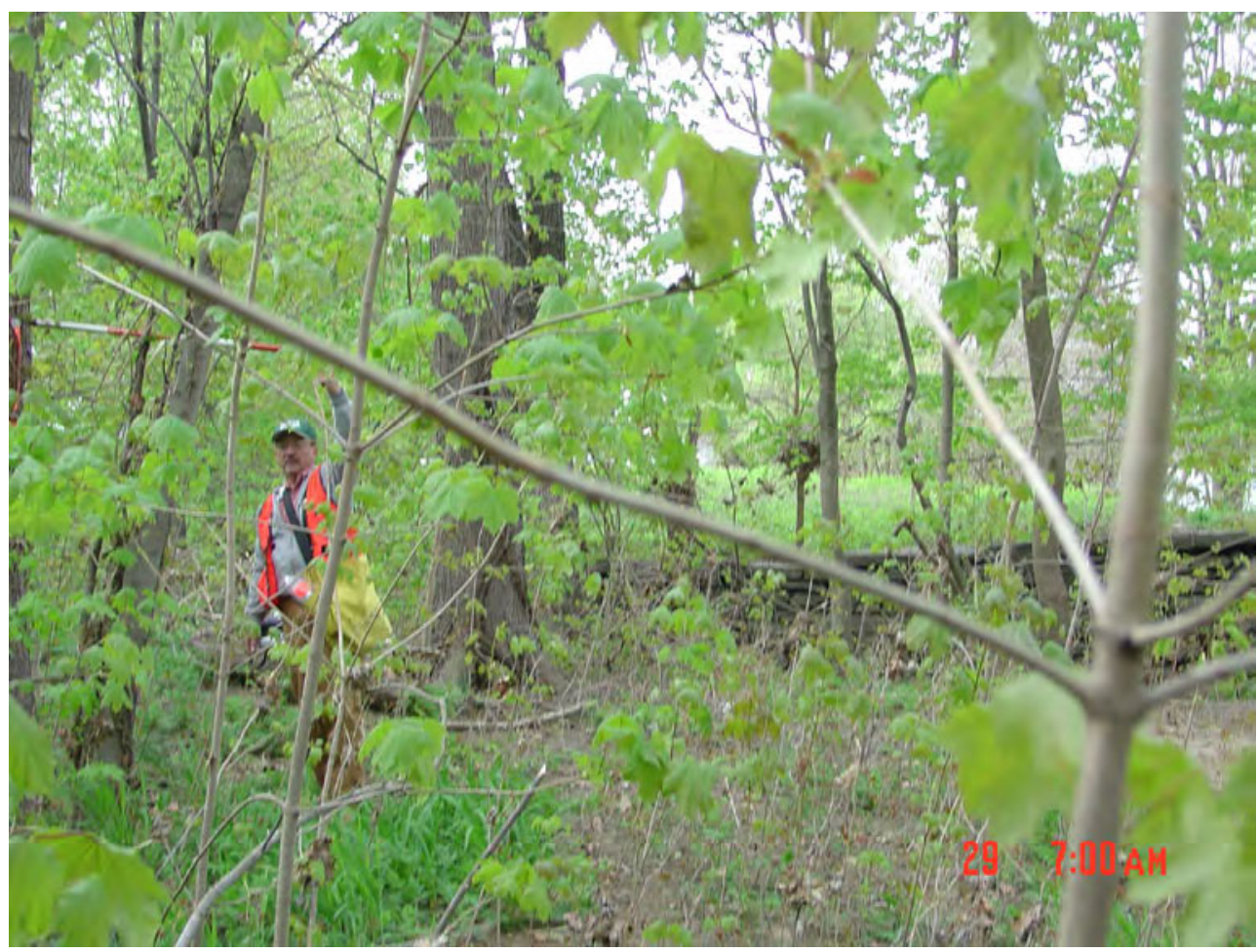

High-water mark NJ 17.1 (lat $40^{\circ} 31^{\prime} 38.1^{\prime \prime}$, long $75^{\circ} 03^{\prime} 48.3^{\prime \prime}$ ), at an elevation of 123.6 feet above NGVD 29, is a fair seed line on a tree, 7 feet above the ground, 340 feet upstream from the Bridge Street bridge, and was marked with a metal USGS washer and nail.

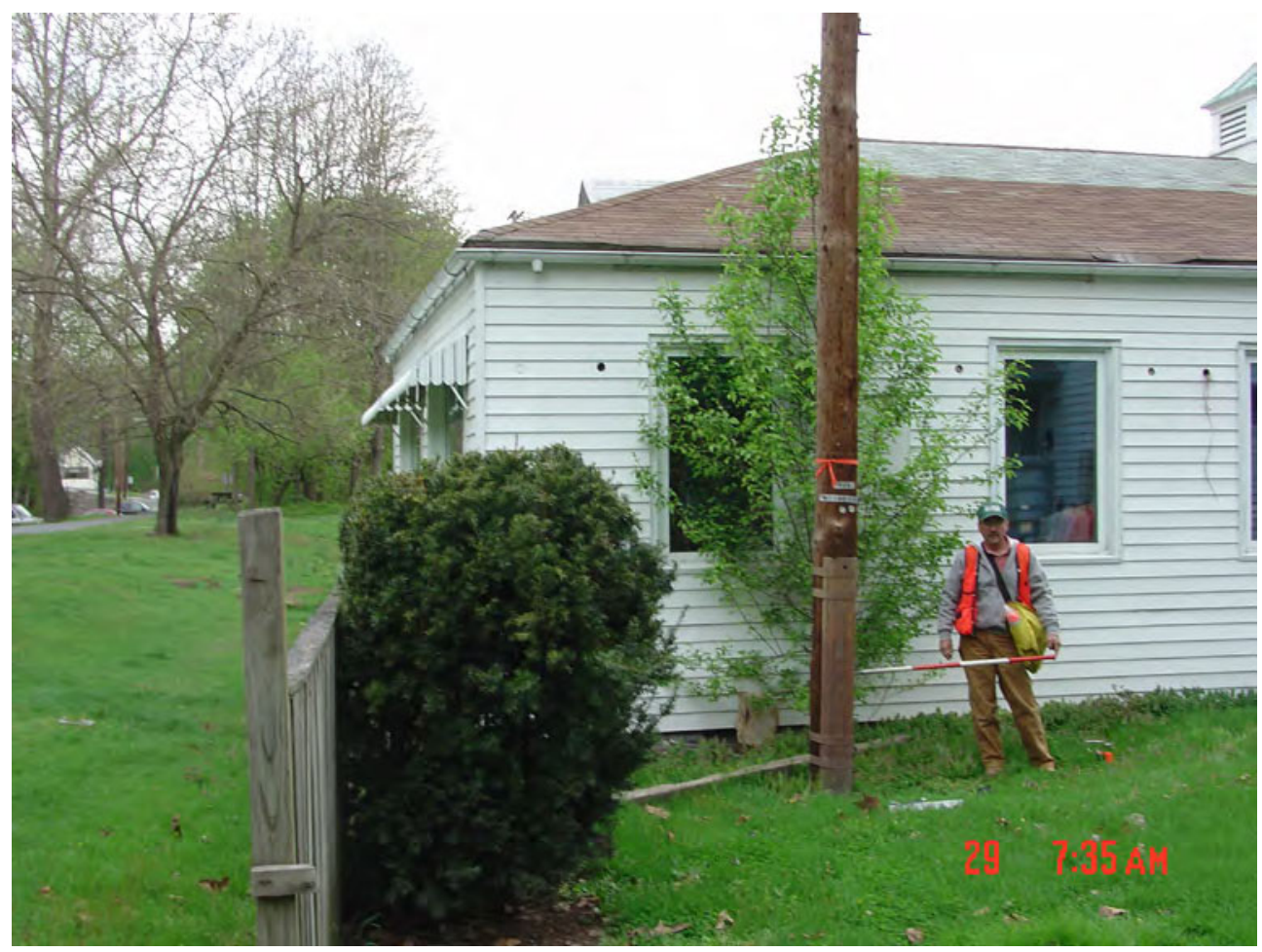

High-water mark NJ 17.2 (lat $40^{\circ} 31^{\prime} 29.4^{\prime \prime}$, long $75^{\circ} 03^{\prime} 46.1^{\prime \prime}$ ), at an elevation of 123.3 feet above NGVD 29, is a fair seed line on a utility pole, 2.6 feet above the ground, 527 feet downstream from the Bridge Street bridge, and was marked with a metal rebar. 


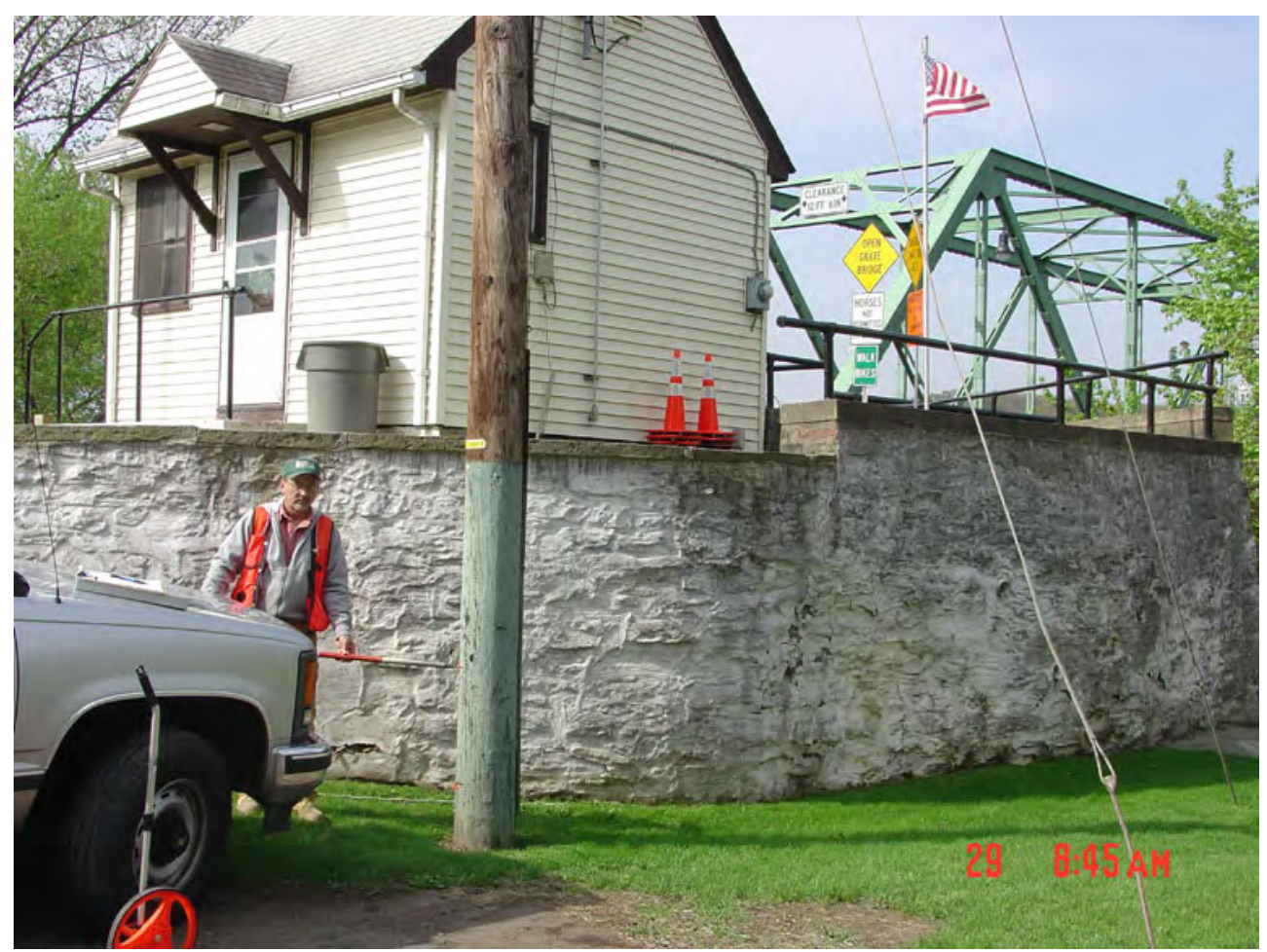

High-water mark NJ 17.3 (lat $40^{\circ} 31^{\prime} 35.3^{\prime \prime}$, long $75^{\circ} 03^{\prime} 47.5^{\prime \prime}$ ), at an elevation of 123.5 feet above NGVD 29 , is a nail with flagging set in a utility pole by unknown party, quality of high-water mark is unknown, 3.0 feet above the ground, several feet upstream from the Bridge Street bridge.

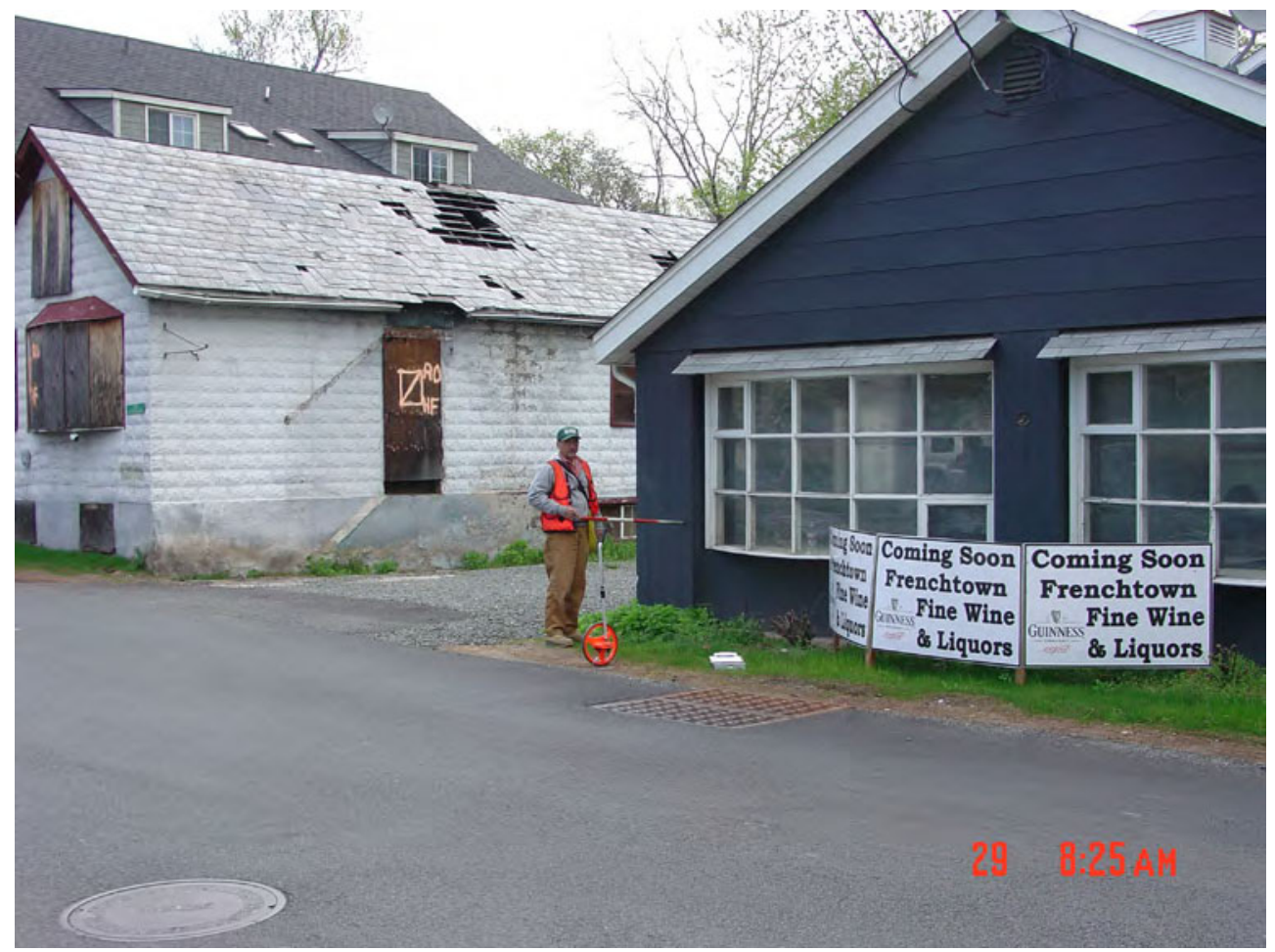

High-water mark NJ 17.4 (lat $40^{\circ} 31^{\prime} 31.3^{\prime \prime}$, long $75^{\circ} 03^{\prime} 40.0^{\prime \prime}$ ), at an elevation of 123.2 feet above NGVD 29 , is an excellent mud line on a building (Front Street Liquor Store), 3.1 feet above the ground, 375 feet downstream from the Bridge Street bridge, and was marked with a black marker line. 


\begin{tabular}{|c|}
\hline SITE DESCRIPTION \\
\hline Site NJ 18: Delaware River at Raven Rock, NJ \\
\hline Site Location: $0.5 \mathrm{mi}$ reach in vicinity of lat $40^{\circ} 24^{\prime} 27^{\prime \prime}$, long $75^{\circ} 02^{\prime} 16^{\prime \prime}$ \\
\hline Delaware Township, Hunterdon County, NJ \\
\hline Three high-water marks were surveyed: two mud lines and one seed line. \\
\hline $\begin{array}{l}\text { High-water mark elevations were determined using USGS reference mark } 112 \text { at lat } 40^{\circ} 24^{\prime} 35.5^{\prime \prime} \text {, } \\
\text { long } 75^{\circ} 02^{\prime} 12.3^{\prime \prime} \text { (elevation is } 93.63 \text { feet above NAVD 88). }\end{array}$ \\
\hline
\end{tabular}

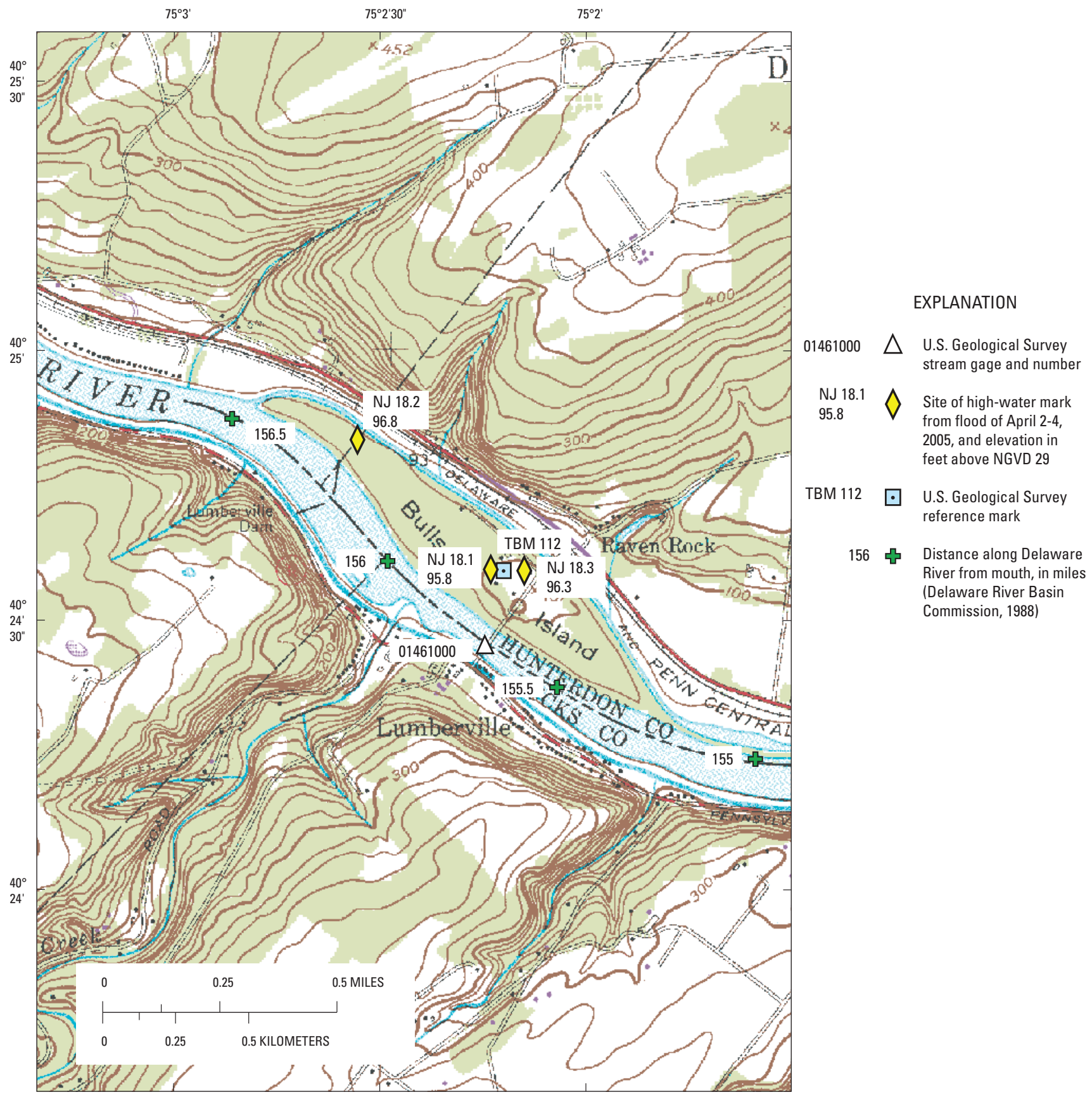

Lumberville USGS 7.5' Topographic Quadrangle map showing location of site NJ 18, Delaware River at Raven Rock, NJ. 


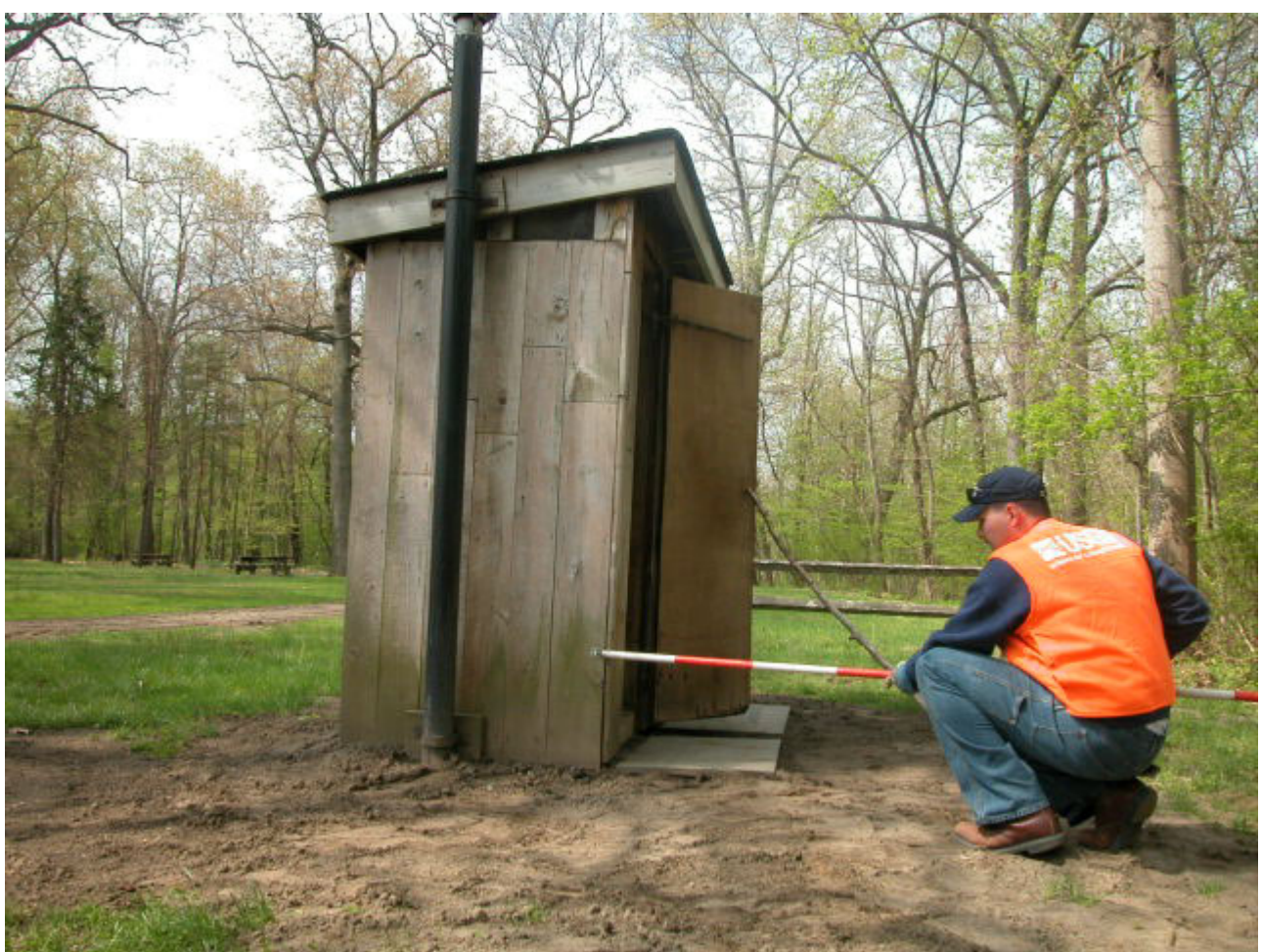

High-water mark NJ 18.1 (lat $40^{\circ} 24^{\prime} 36.1^{\prime \prime}$, long $75^{\circ} 02^{\prime} 14.0^{\prime \prime}$ ), at an elevation of 95.84 feet above NGVD 29, is a good mud line on an outhouse at the Bulls Island Recreation Area, about 1.5 feet above the ground, 490 feet upstream from Quarry Road, and was marked with a metal USGS washer and nail.

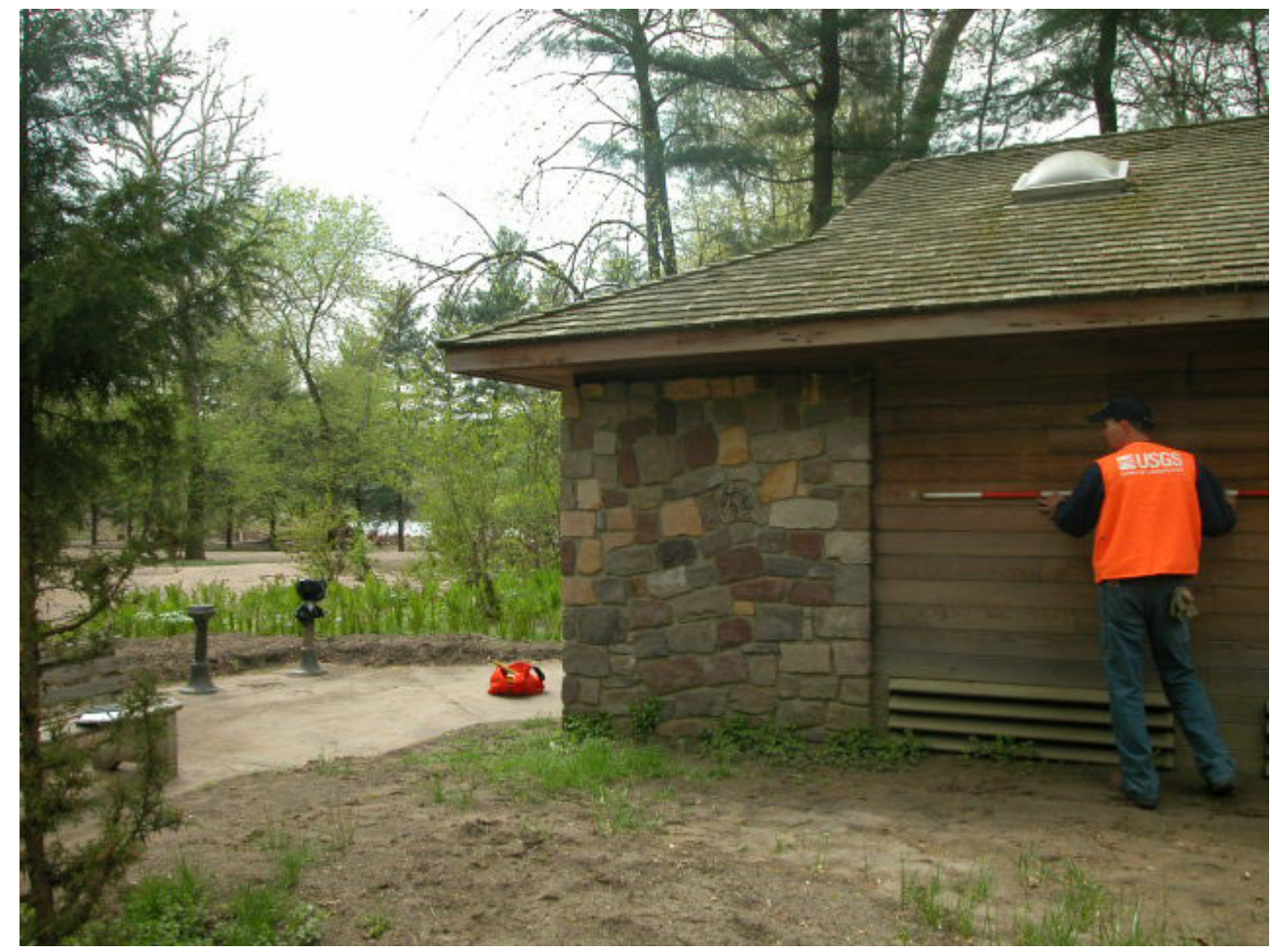

High-water mark NJ 18.2 (lat $40^{\circ} 24^{\prime} 50.4^{\prime \prime}$, long $75^{\circ} 02^{\prime} 33.4^{\prime \prime}$ ), at an elevation of 96.8 feet above NGVD 29 , is a good seed line on a comfort station on Bulls Island, 4.5 feet above the ground, 2,500 feet upstream from Quarry Road, and was marked with a metal USGS washer and nail. 


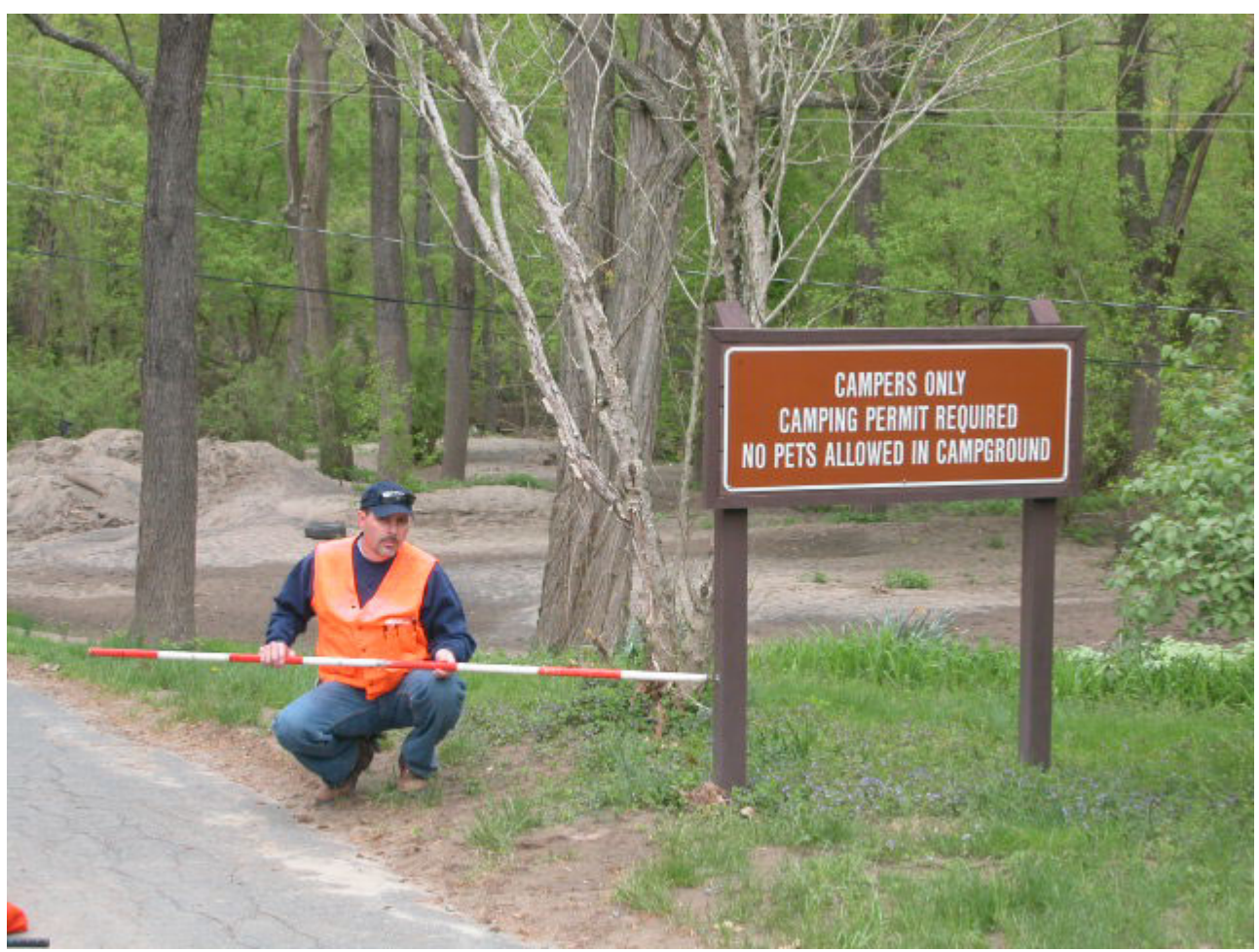

High-water mark NJ 18.3 (lat $40^{\circ} 24^{\prime} 36.0^{\prime \prime}$, long $75^{\circ} 02^{\prime} 09.0^{\prime \prime}$ ), at an elevation of 96.3 feet above NGVD 29 , is a good mud line on the "Campers Only" sign post on Bulls Island, 1.5 feet above the ground, 150 feet upstream from Quarry Road, and was marked with a metal USGS washer and nail. 


\section{SITE DESCRIPTION}

Site NJ 19: 01461500 Delaware River at Stockton, NJ

Site Location: 0.2 mi reach in vicinity of lat $40^{\circ} 24^{\prime} 10^{\prime \prime}$, long $74^{\circ} 58^{\prime} 46^{\prime \prime}$

Stockton Borough, Hunterdon County, NJ

Three high-water marks were surveyed for Delaware River: one debris line, one mud line, and one wash line.

Two high-water marks were surveyed for Delaware and Raritan Canal (adjacent): two mud lines.

High-water mark elevations were determined using National Geodetic Survey benchmark 10C1 at lat $40^{\circ} 24^{\prime} 18^{\prime \prime}$, long $74^{\circ} 58^{\prime} 37^{\prime \prime}$ (elevation is 78.18 feet above NAVD 88 ).

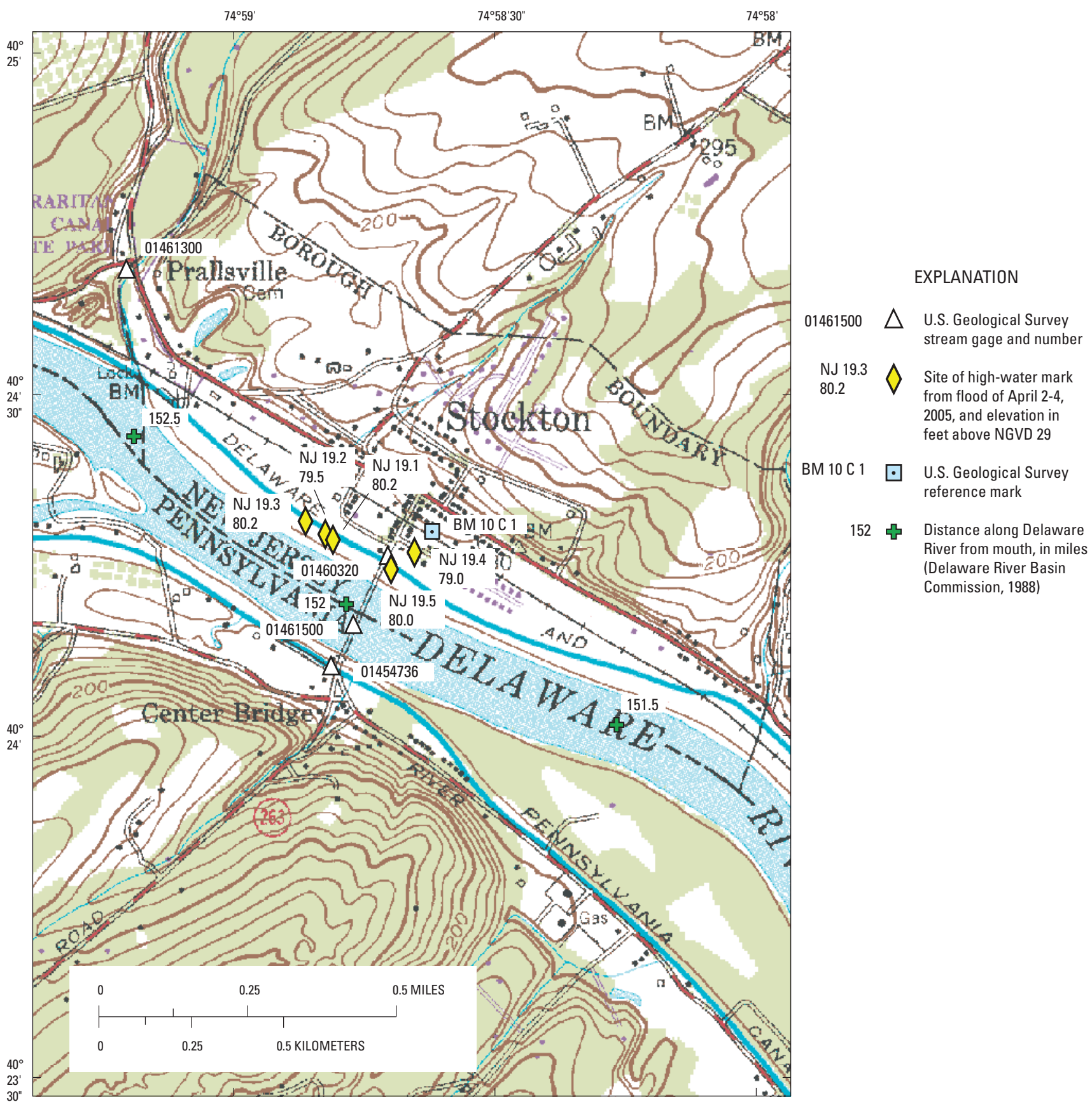

Stockton USGS 7.5' Topographic Quadrangle map showing location of site NJ 19, Delaware River at Stockton, NJ. 


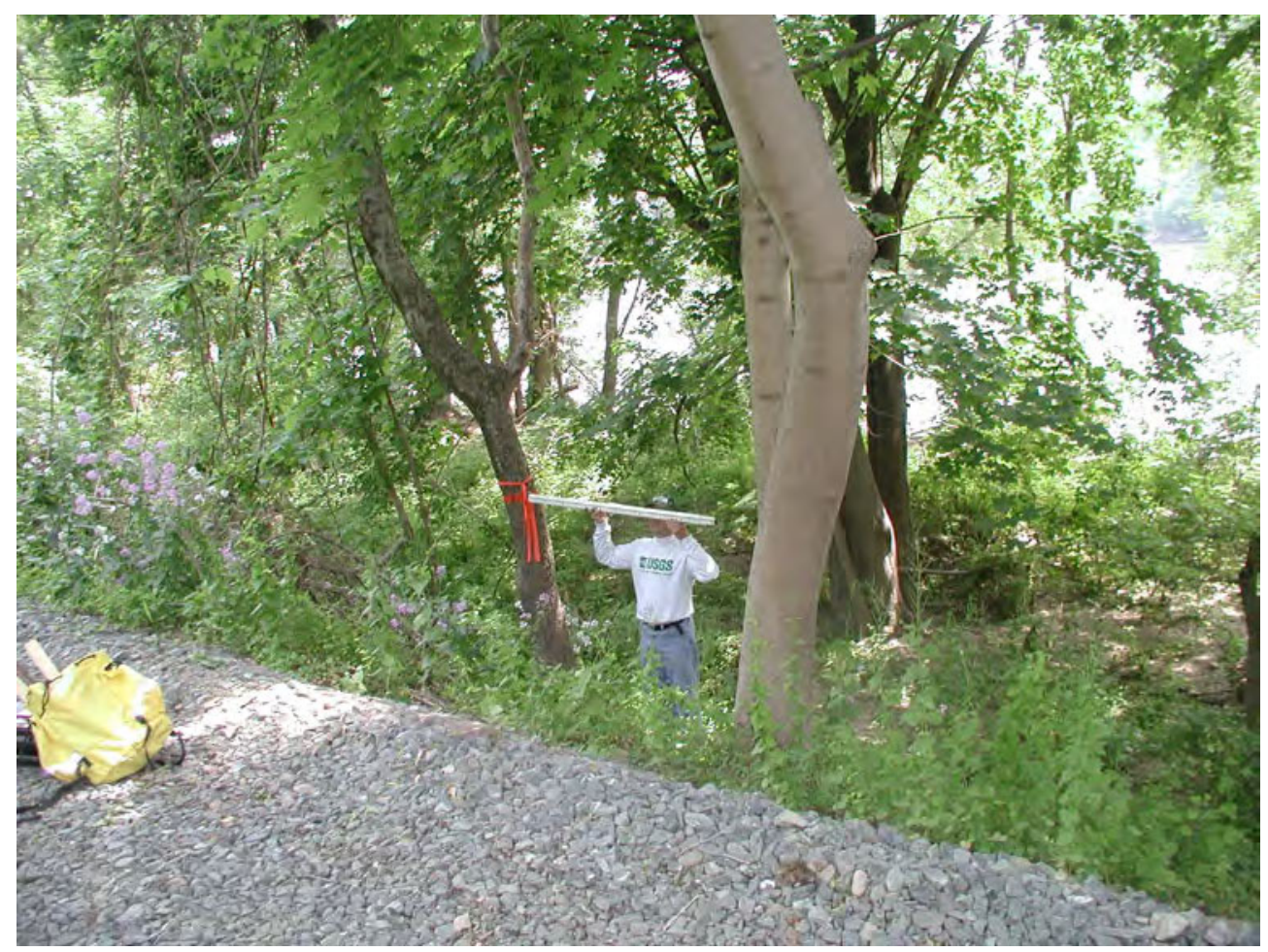

High-water mark NJ 19.1 for the Delaware River (lat $40^{\circ} 24^{\prime} 17.3^{\prime \prime}$, long $74^{\circ} 58^{\prime} 48.7^{\prime \prime}$ ), at an elevation of 80.2 feet above NGVD 29, is a fair wash line on a 1-foot diameter tree on the streamward side of the canal path, 5.6 feet above the ground, 478 feet upstream from the Bridge Street bridge, and was marked with a metal USGS washer and nail.

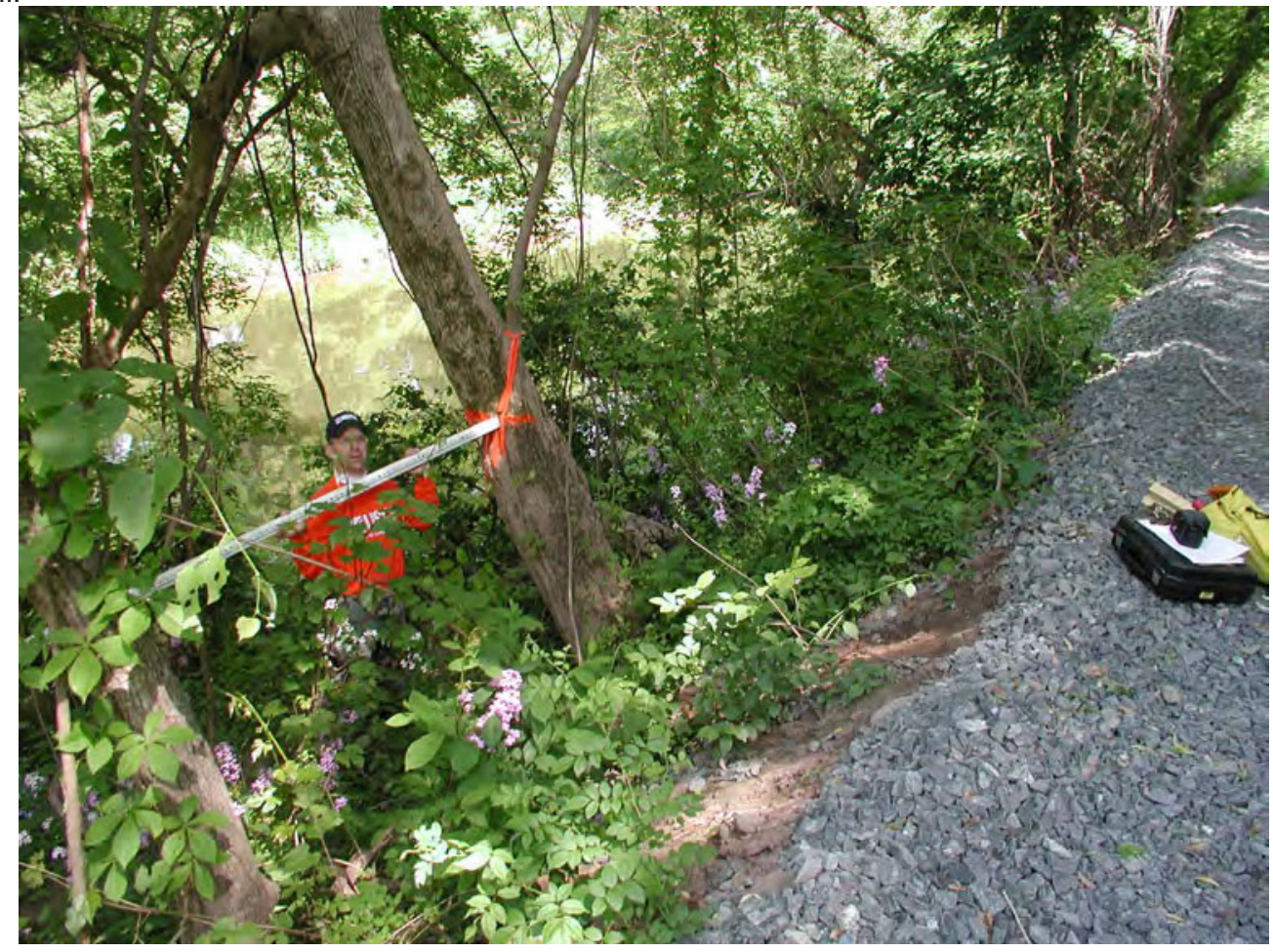

High-water mark NJ 19.2 for the Delaware and Raritan Canal (lat 40 $24^{\prime} 17.1^{\prime \prime}$, long $74^{\circ} 58^{\prime} 49.6^{\prime \prime}$ ), at an elevation of 79.5 feet above NGVD 29, is a good mud line on a 1.2-foot diameter tree, 5.1 feet above the ground, 579 feet upstream from the Bridge Street bridge, and was marked with a metal USGS washer and nail. 


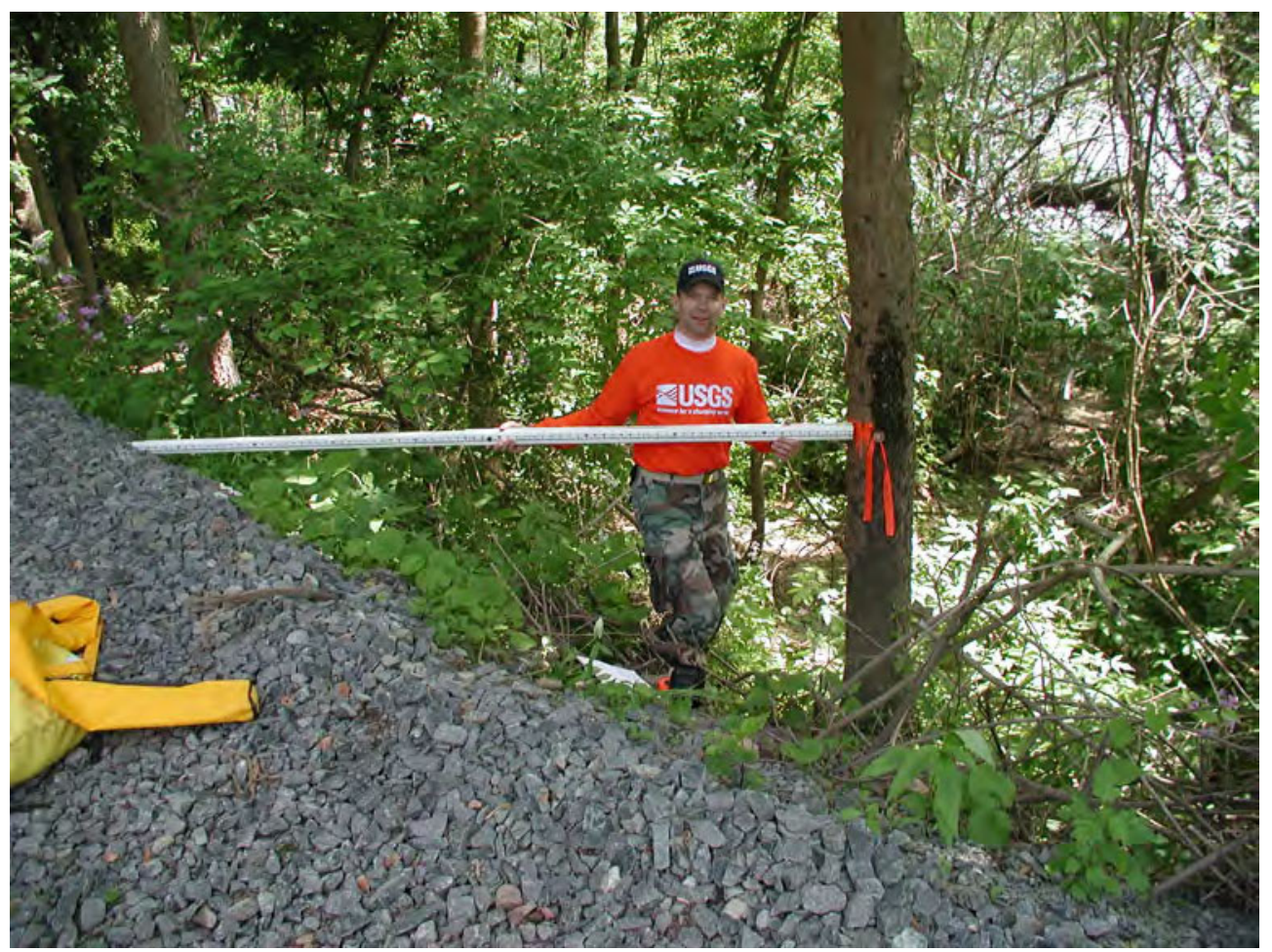

High-water mark NJ 19.3 for the Delaware River (lat $40^{\circ} 24^{\prime} 19.1^{\prime \prime}$, long $74^{\circ} 58^{\prime} 51.9^{\prime \prime}$ ), at an elevation of 80.2 feet above NGVD 29, is a good mud line on an 8-inch diameter tree, 4.1 -feet above the ground, 422 feet upstream from the Bridge Street bridge, and was marked with a metal USGS washer and nail.

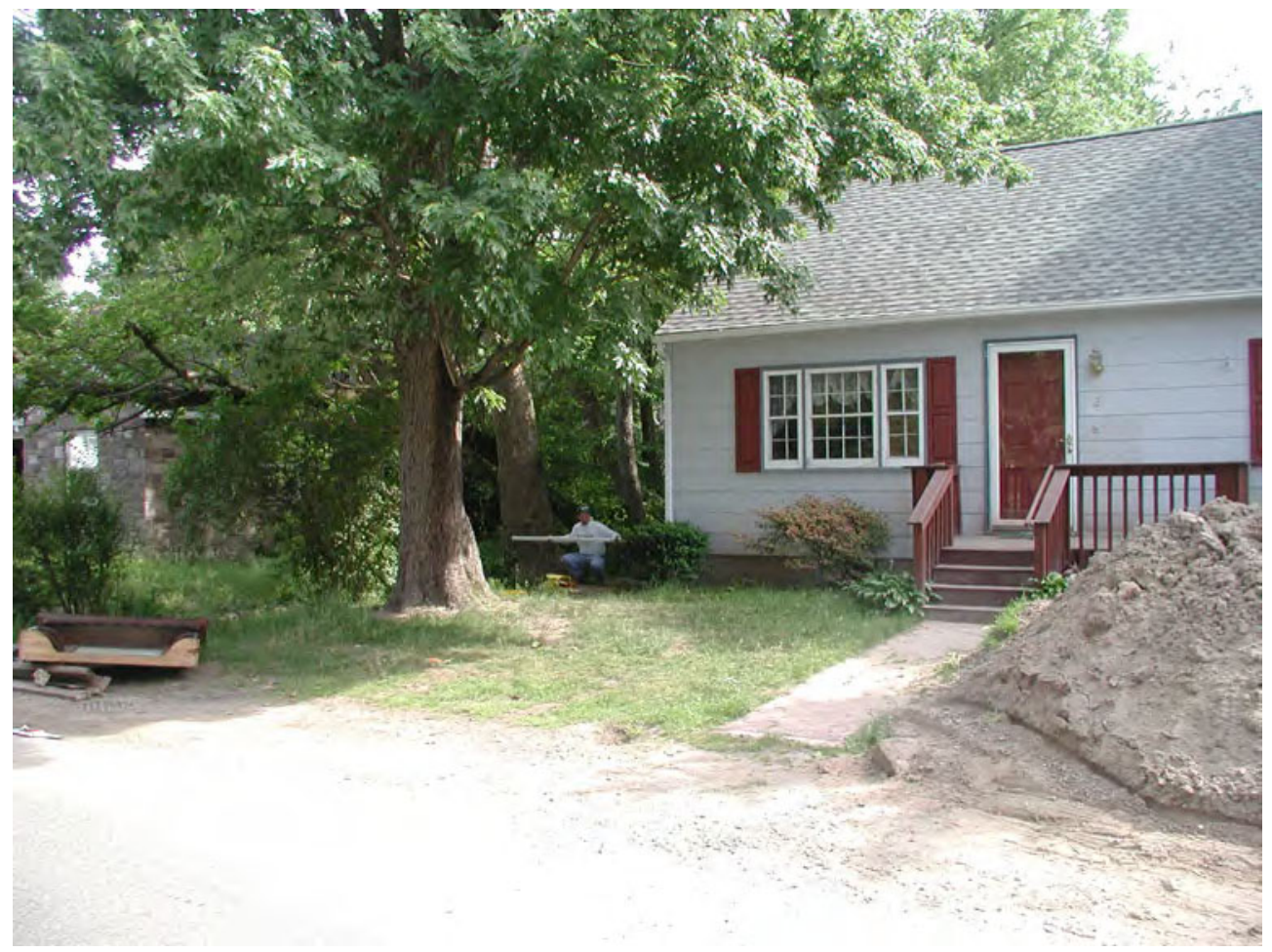

High-water mark NJ 19.4 for the Delaware and Raritan Canal (lat $40^{\circ} 24^{\prime} 16.4^{\prime \prime}$, long $74^{\circ} 58^{\prime} 39.3^{\prime \prime}$ ), at an elevation of 79.0 feet above NGVD 29, is a good mud line on a house, 2.3 feet above the ground, 191 feet downstream from the Bridge Street bridge, and was marked with a black marker line. 


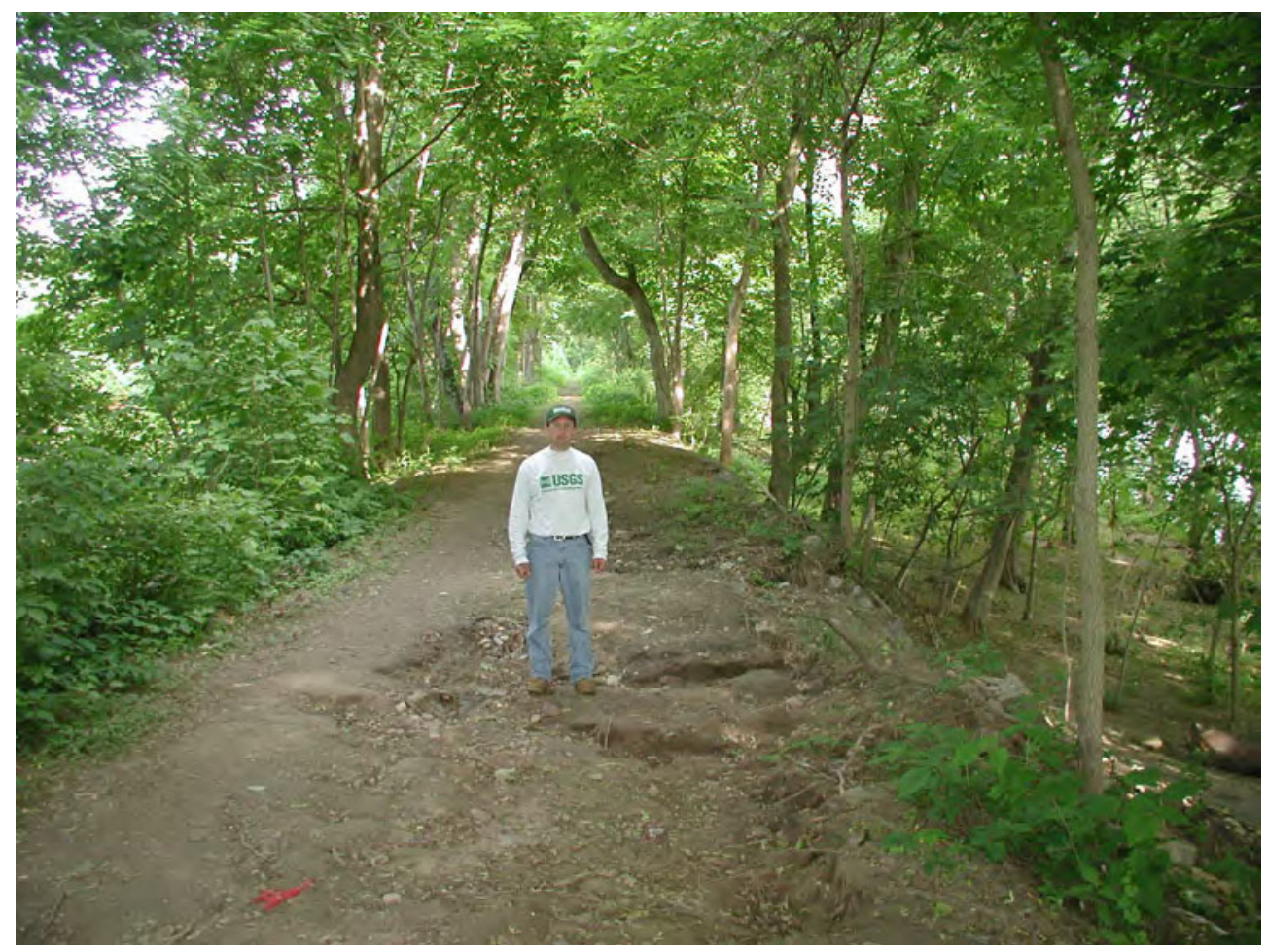

High-water mark NJ 19.5 for the Delaware River (lat $40^{\circ} 24^{\prime} 15.0^{\prime \prime}$, long $74^{\circ} 58^{\prime} 42.0^{\prime \prime}$ ), at an elevation of 80.0 feet above NGVD 29, is a poor debris line on the ground at the canal path, 44 feet downstream from the Bridge Street bridge, and was marked with a metal rebar. 


\section{SITE DESCRIPTION}

Site NJ 20: Delaware River at US Route 202 Bridge at Lambertville, NJ

Site Location: 0.3 mi reach in vicinity of lat $40^{\circ} 22^{\prime} 48^{\prime \prime}$, long $74^{\circ} 57^{\prime} 15^{\prime \prime}$

Delaware Township, Hunterdon County, NJ

Four high-water marks were surveyed: two debris lines, one seed line, and one wash line.

High-water mark elevations were determined using USGS reference mark 207 at lat $40^{\circ} 22^{\prime} 46.8^{\prime \prime}$, long $74^{\circ} 57^{\prime} 13.4^{\prime \prime}$ (elevation is 70.46 feet above NAVD 88).

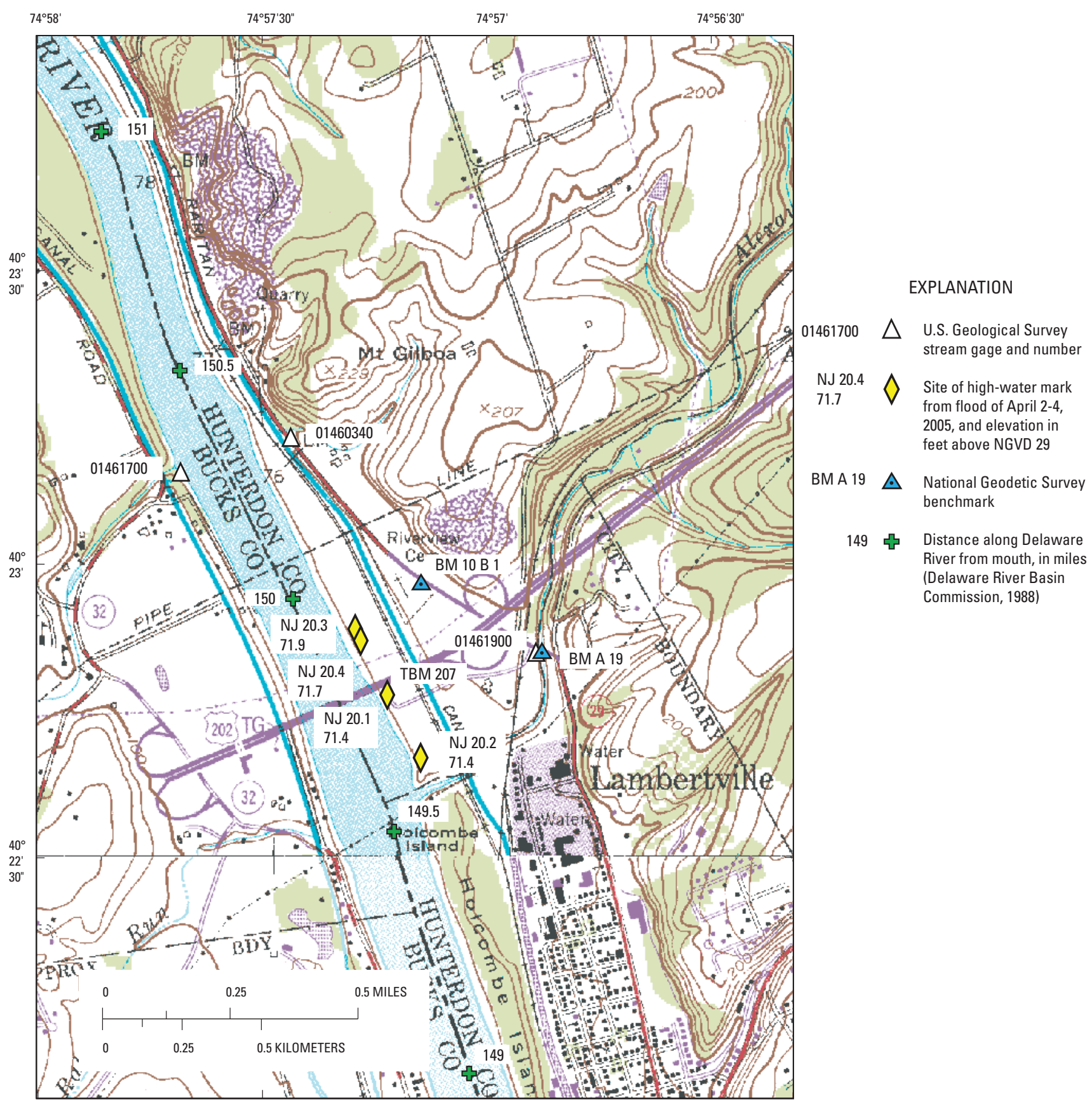

Stockton USGS 7.5' Topographic Quadrangle map showing location of site NJ 20, Delaware River at US Route 202 bridge at Lambertville, NJ. 


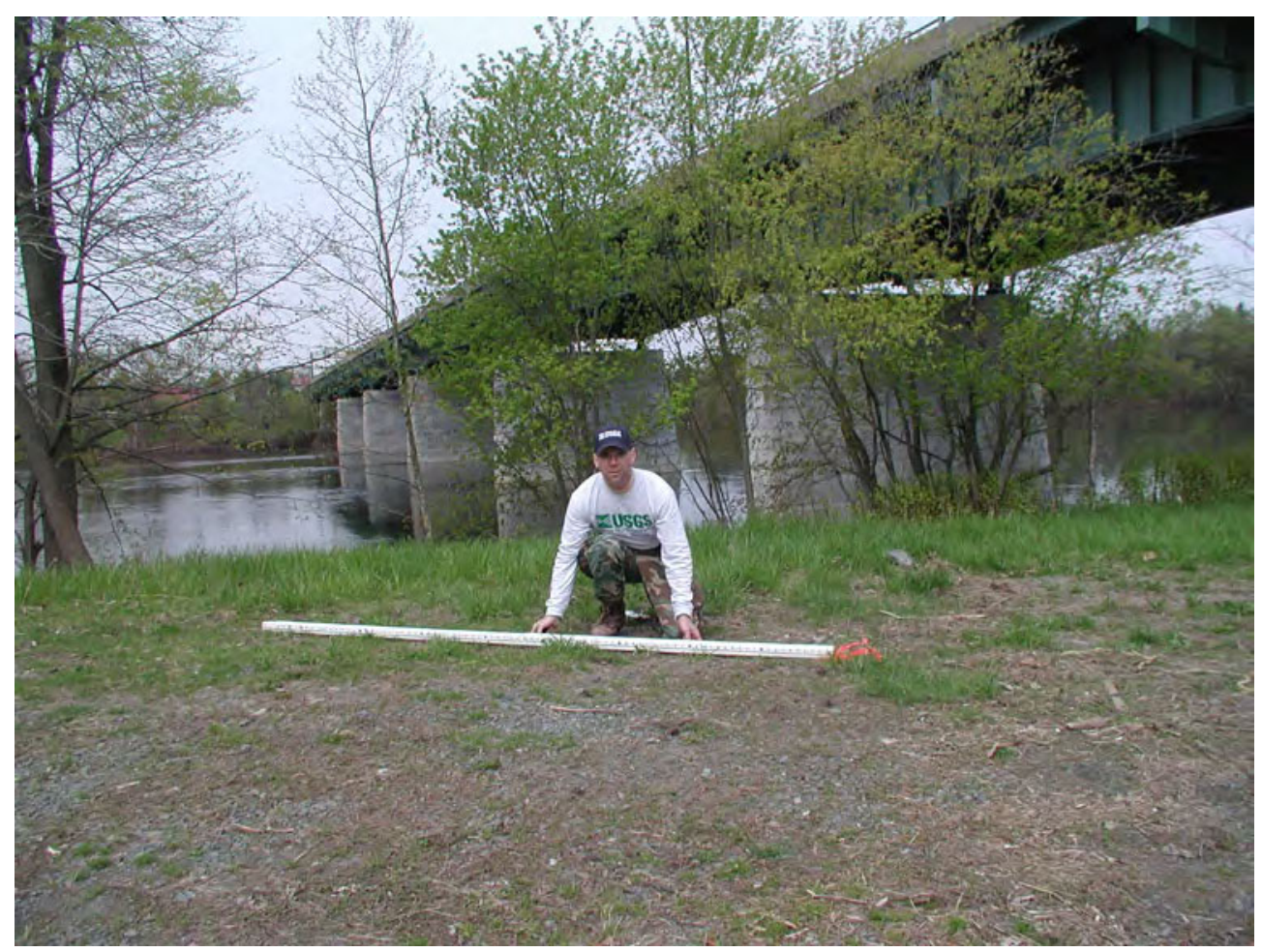

High-water mark NJ 20.1 (lat $40^{\circ} 22^{\prime} 46.7^{\prime \prime}$, long $74^{\circ} 57^{\prime} 13.5^{\prime \prime}$ ), at an elevation of 71.4 feet above NGVD 29, is a good debris line on the ground at top of bank, 65 feet downstream from the US Route 202 bridge, and was marked with a metal rebar.

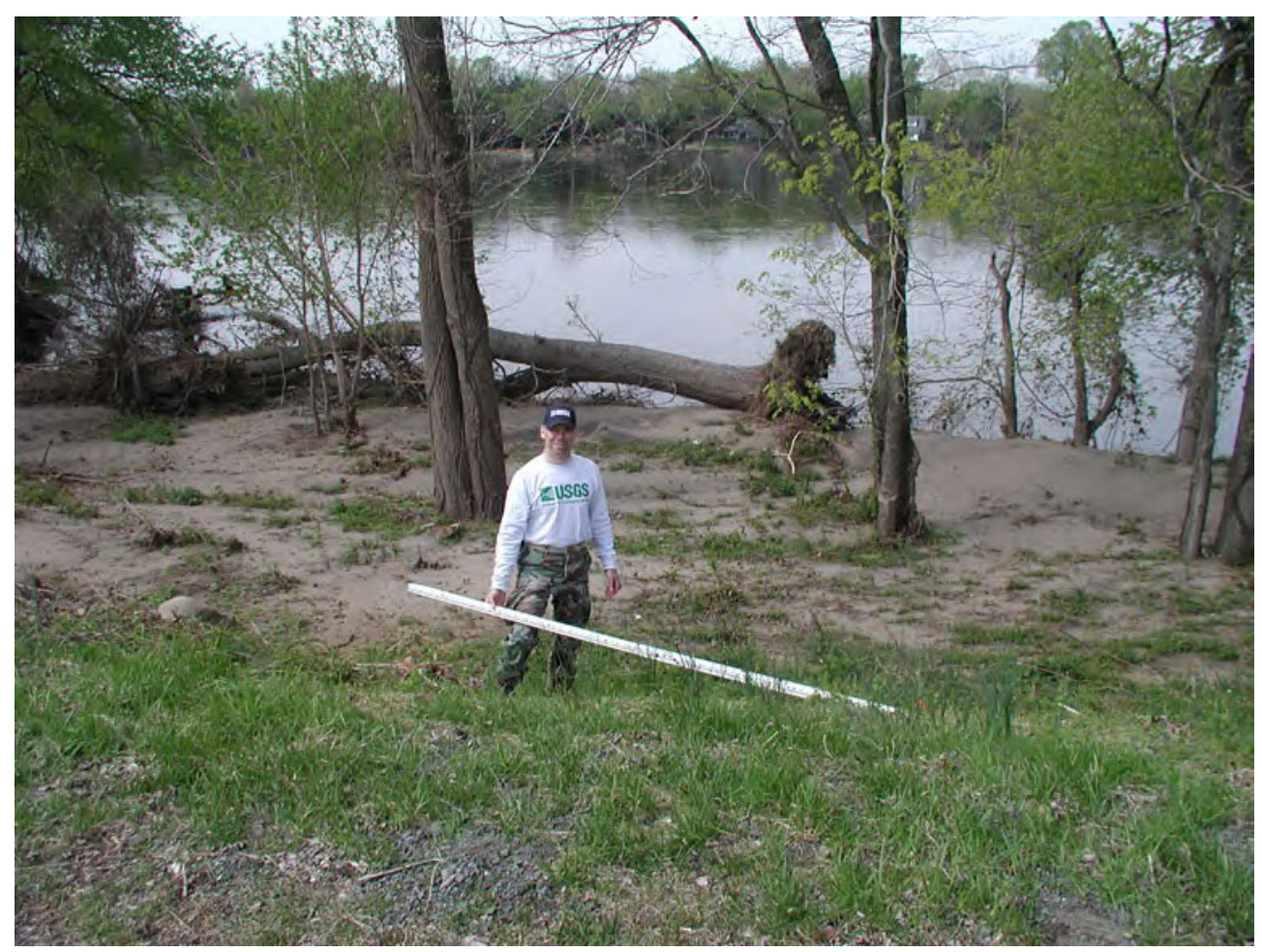

High-water mark NJ 20.2 (lat $40^{\circ} 22^{\prime} 40.6^{\prime \prime}$, long $74^{\circ} 57^{\prime} 09.2^{\prime \prime}$ ), at an elevation of 71.4 feet above NGVD 29 , is a fair wash line on embankment, 760 feet downstream from the US Route 202 bridge, and was marked with a metal rebar. 


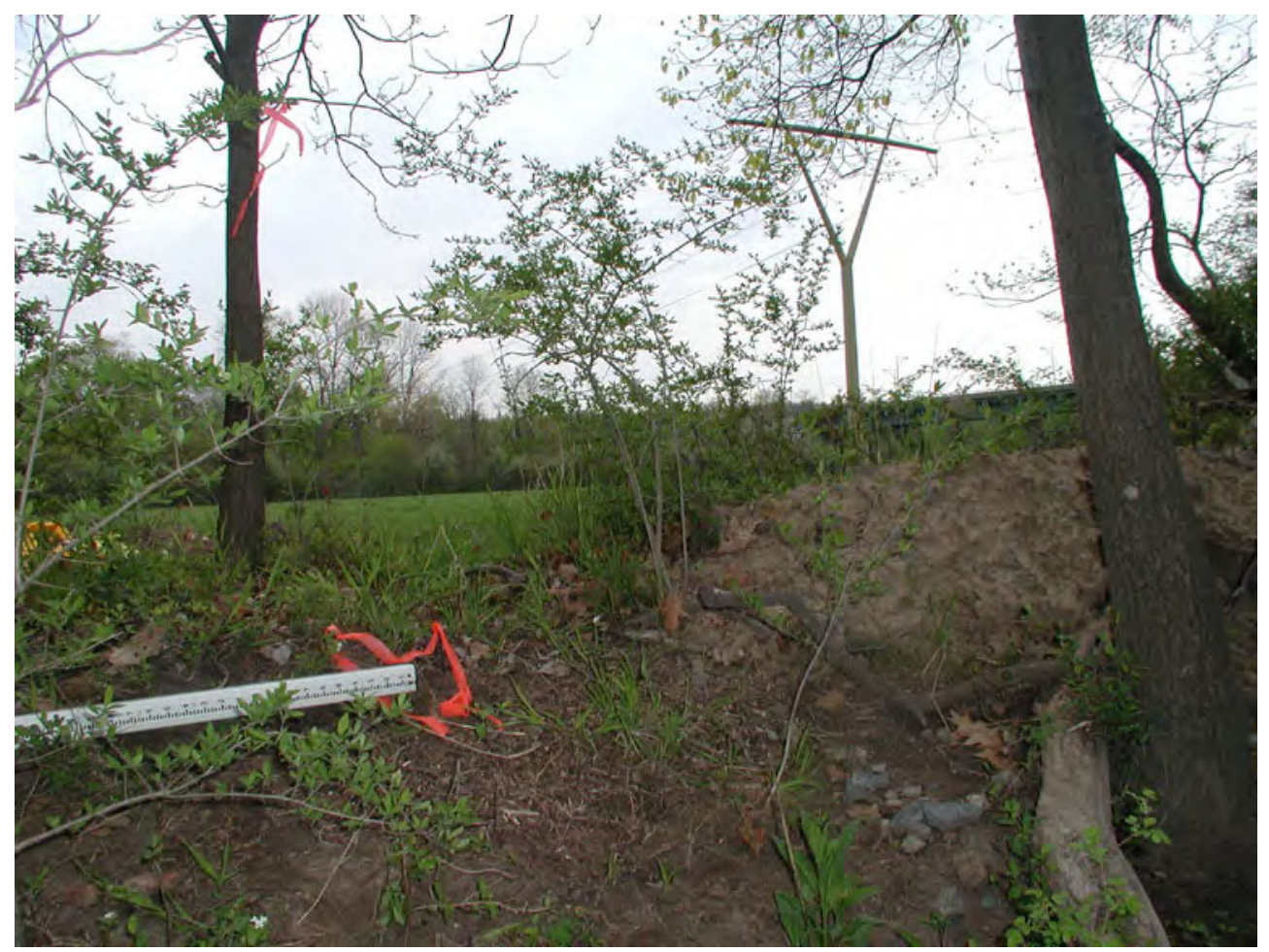

High-water mark NJ 20.3 (lat $40^{\circ} 22^{\prime} 53.3^{\prime \prime}$, long $74^{\circ} 57^{\prime} 17.7^{\prime \prime}$ ), at an elevation of 71.9 feet above NGVD 29 , is a fair debris line at the top of the bank, 600 feet upstream from the US Route 202 bridge, and was marked with a metal rebar.

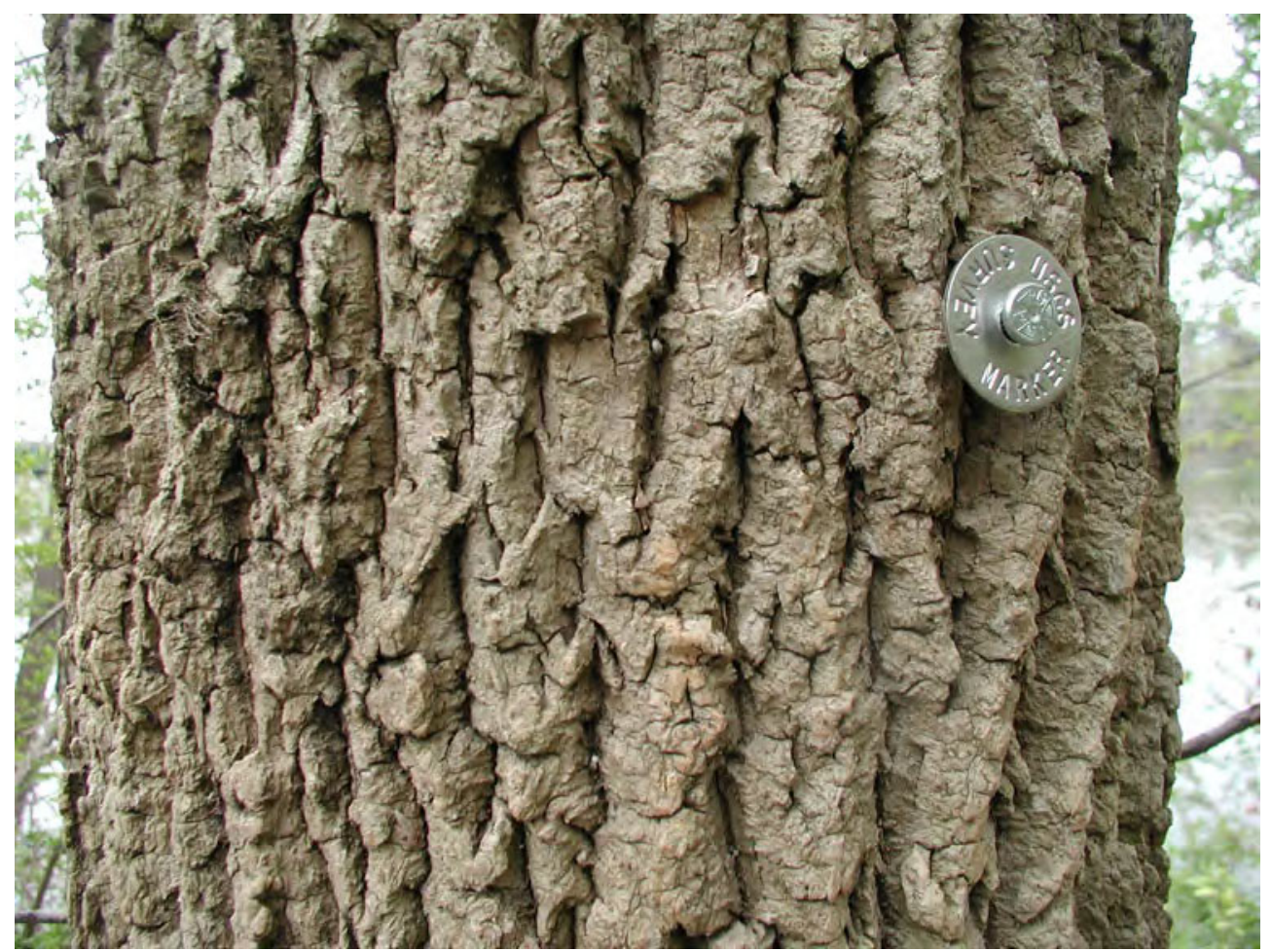

High-water mark NJ 20.4 (lat $40^{\circ} 22^{\prime} 52.5^{\prime \prime}$, long $74^{\circ} 57^{\prime} 17.1^{\prime \prime}$ ), at an elevation of 71.7 feet above NGVD 29 , is a fair seed line on a 1-foot diameter tree, 3.5 feet above the ground, 550 feet upstream from the US Route 202 bridge, and was marked with a metal USGS washer and nail. 


\begin{tabular}{|c|}
\hline SITE DESCRIPTION \\
\hline Site NJ 21: 01462000 Delaware River at Lambertville, NJ \\
\hline Site Location: $0.3 \mathrm{mi}$ reach in vicinity of lat $40^{\circ} 21^{\prime} 53^{\prime \prime}$, long $74^{\circ} 56^{\prime} 56^{\prime \prime}$ \\
\hline Lambertville City, Hunterdon County, NJ \\
\hline Four high-water marks were surveyed: four seed lines. \\
\hline $\begin{array}{l}\text { High-water mark elevations were determined using USGS reference mark } 206 \text { at lat } 40^{\circ} 21^{\prime} 51.7^{\prime \prime} \text {, } \\
\text { long } 74^{\circ} 56^{\prime} 47.6^{\prime \prime} \text { (elevation is } 58.96 \text { feet above NAVD 88). }\end{array}$ \\
\hline
\end{tabular}

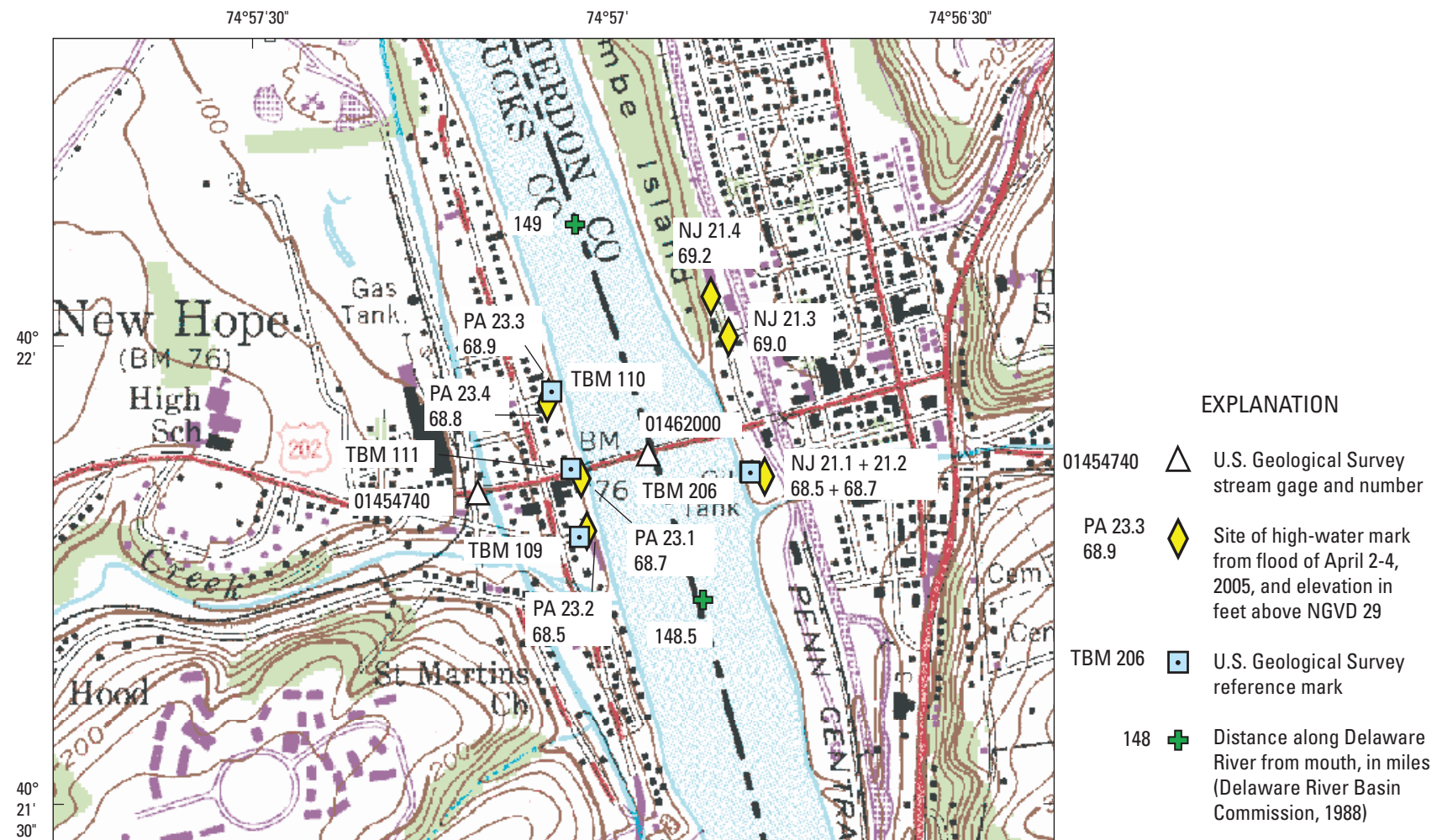

Lambertville USGS 7.5' Topographic Quadrangle map showing location of site NJ 21, Delaware River at Lambertville, NJ. 


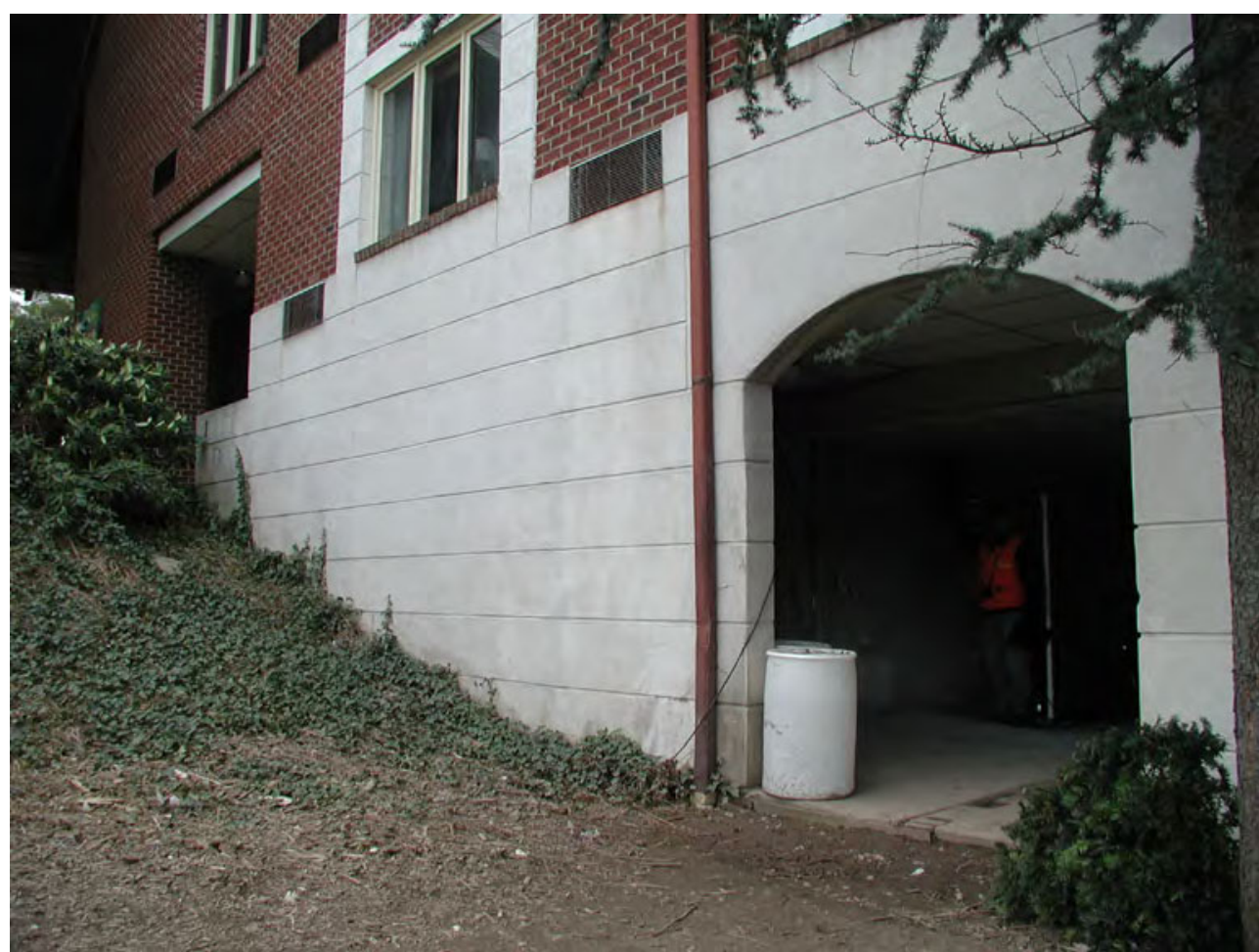

High-water mark NJ 21.1 (lat $40^{\circ} 21^{\prime} 51.7^{\prime \prime}$, long $74^{\circ} 56^{\prime} 46.4^{\prime \prime}$ ), at an elevation of 68.5 feet above NGVD 29 , is an excellent seed line on the Lambertville Inn, 5.7 feet above the ground, 473 feet downstream from the Bridge Street bridge, and was marked with a metal USGS washer and nail.

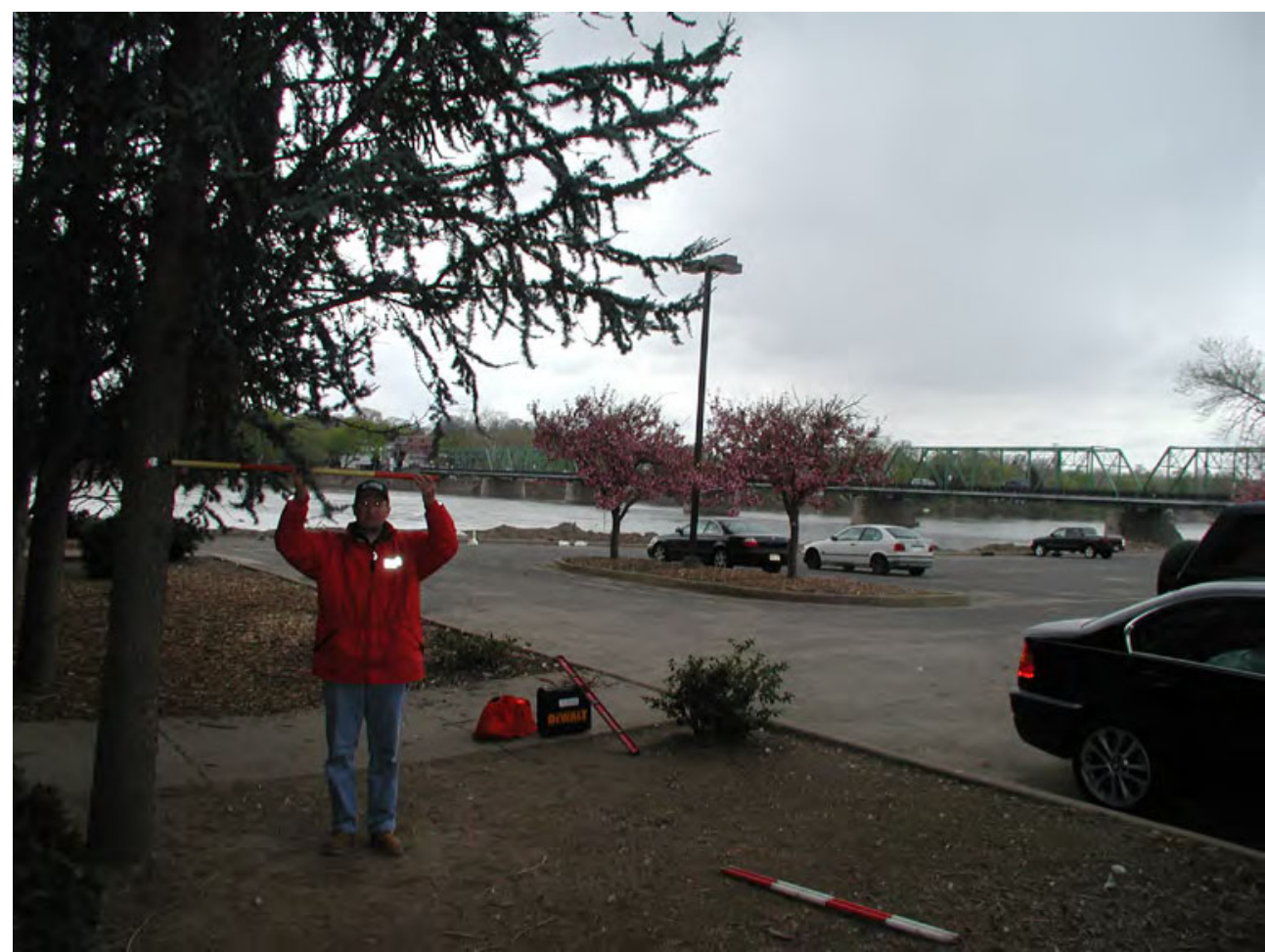

High-water mark NJ 21.2 (lat $40^{\circ} 21^{\prime} 51.7^{\prime \prime}$, long $74^{\circ} 56^{\prime} 46.4^{\prime \prime}$ ), at an elevation of 68.7 feet above NGVD 29 , is a good seed line on a tree between the Lambertville Inn and its parking lot, 457 feet downstream from the Bridge Street bridge, and was marked with a metal USGS washer and nail. 


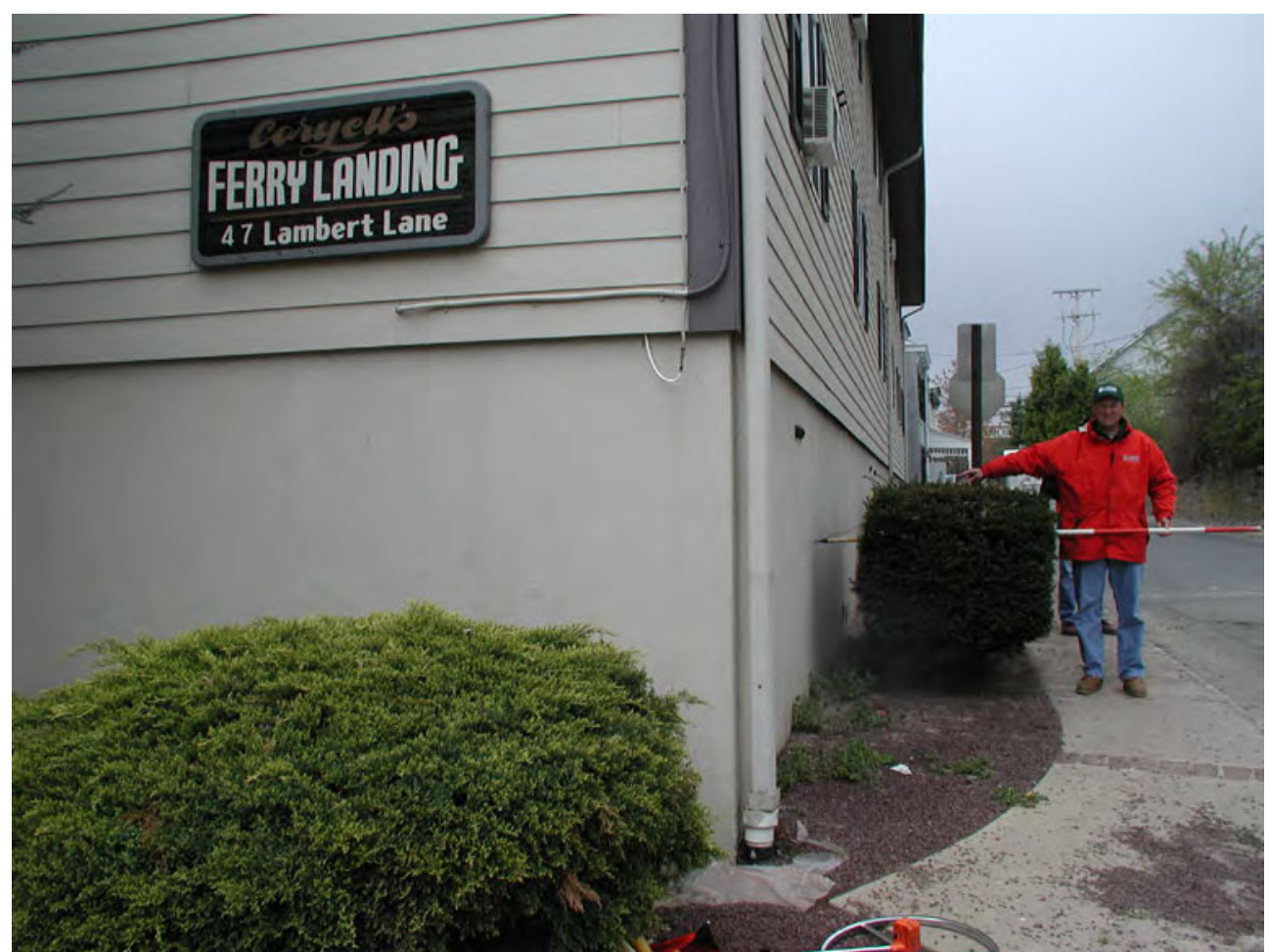

High-water mark NJ 21.3 (lat $40^{\circ} 22^{\prime} 00.8^{\prime \prime}$, long $74^{\circ} 56^{\prime} 49.5^{\prime \prime}$ ), at an elevation of 69.0 feet above NGVD 29, is an excellent seed line on a building, 569 feet upstream from the Bridge Street bridge, and was marked with a black marker line.

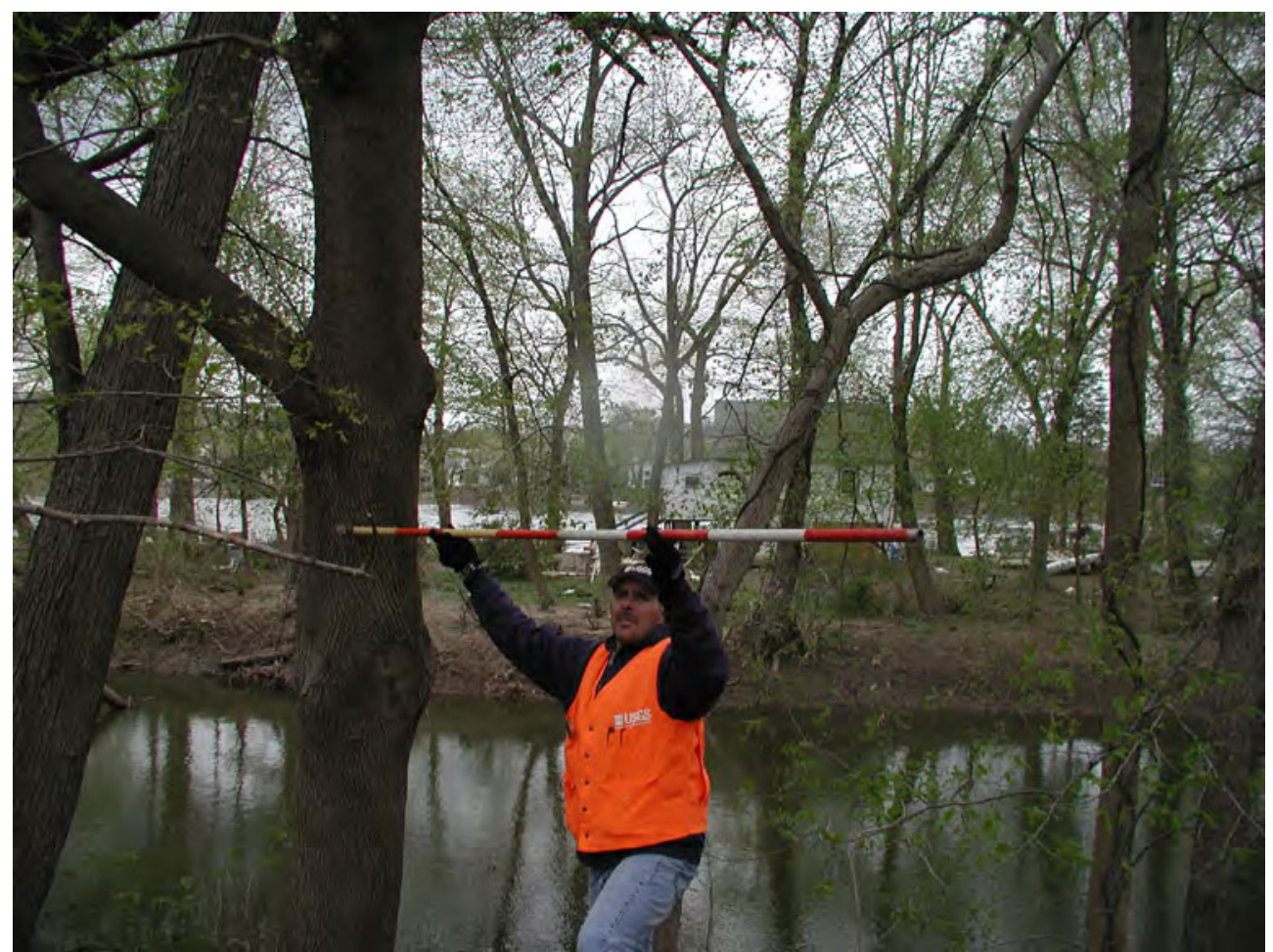

High-water mark NJ 21.4 (lat $40^{\circ} 22^{\prime} 03.4^{\prime \prime}$, long $74^{\circ} 56^{\prime} 51.0^{\prime \prime}$ ), at an elevation of 69.2 feet above NGVD 29, is a fair seed line on a 1.4-foot diameter tree, 7.1 feet above the ground, 885 feet upstream from the Bridge Street bridge, and was marked with a metal USGS washer and nail. 


\begin{tabular}{|l|}
\hline \multicolumn{1}{|c|}{ SITE DESCRIPTION } \\
\hline Site PA 23: Delaware River at New Hope, PA \\
\hline Site Location: 0.2 mile reach in vicinity of lat $40^{\circ} 21^{\prime} 52^{\prime \prime}$, long $74^{\circ} 57^{\prime} 07^{\prime \prime}$ \\
\hline New Hope Borough, Bucks County, PA \\
\hline Four high-water marks were surveyed: four mud lines. \\
\hline High-water mark elevations were determined using USGS reference mark 109 at lat $40^{\circ} 21^{\prime} 47.5^{\prime \prime}$, \\
long $74^{\circ} 57^{\prime} 2.3^{\prime \prime}$ (elevation is 62.83 feet above NAVD 88), USGS reference mark 210 at lat $40^{\circ} 21^{\prime}$ \\
$56.9^{\prime \prime}$, long $74^{\circ} 57^{\prime} 4.6^{\prime \prime}$ (elevation is 62.88 feet above NAVD 88 ), and USGS reference mark 111 at \\
lat $40^{\circ} 21^{\prime} 51.9^{\prime \prime}$, long $74^{\circ} 57^{\prime} 2.9^{\prime \prime}$ (elevation is 68.52 feet above NAVD 88 ). \\
\hline
\end{tabular}

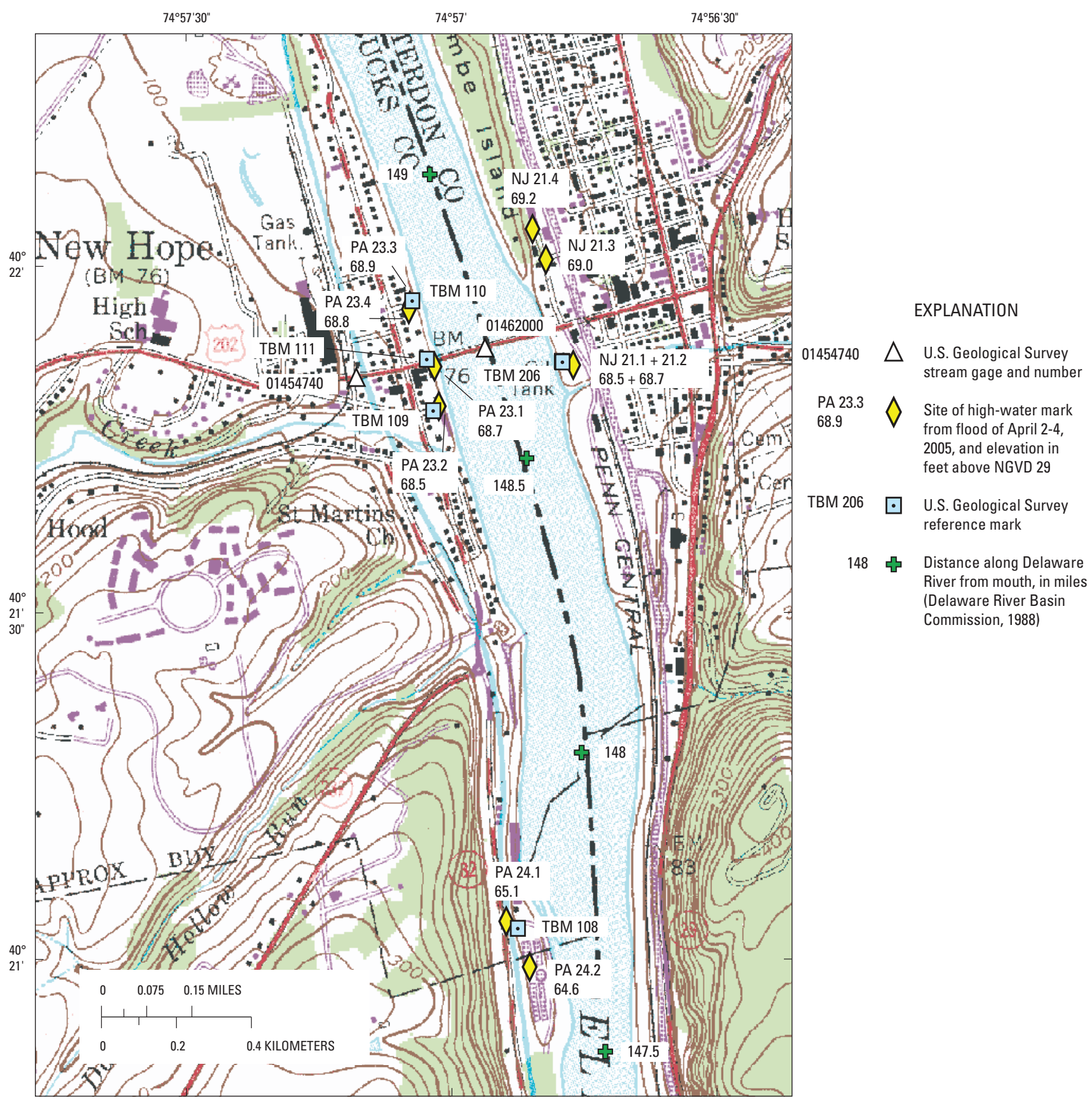

Lambertville USGS 7.5' Topographic Quadrangle map showing location of site PA 23, Delaware River at New Hope, PA. 


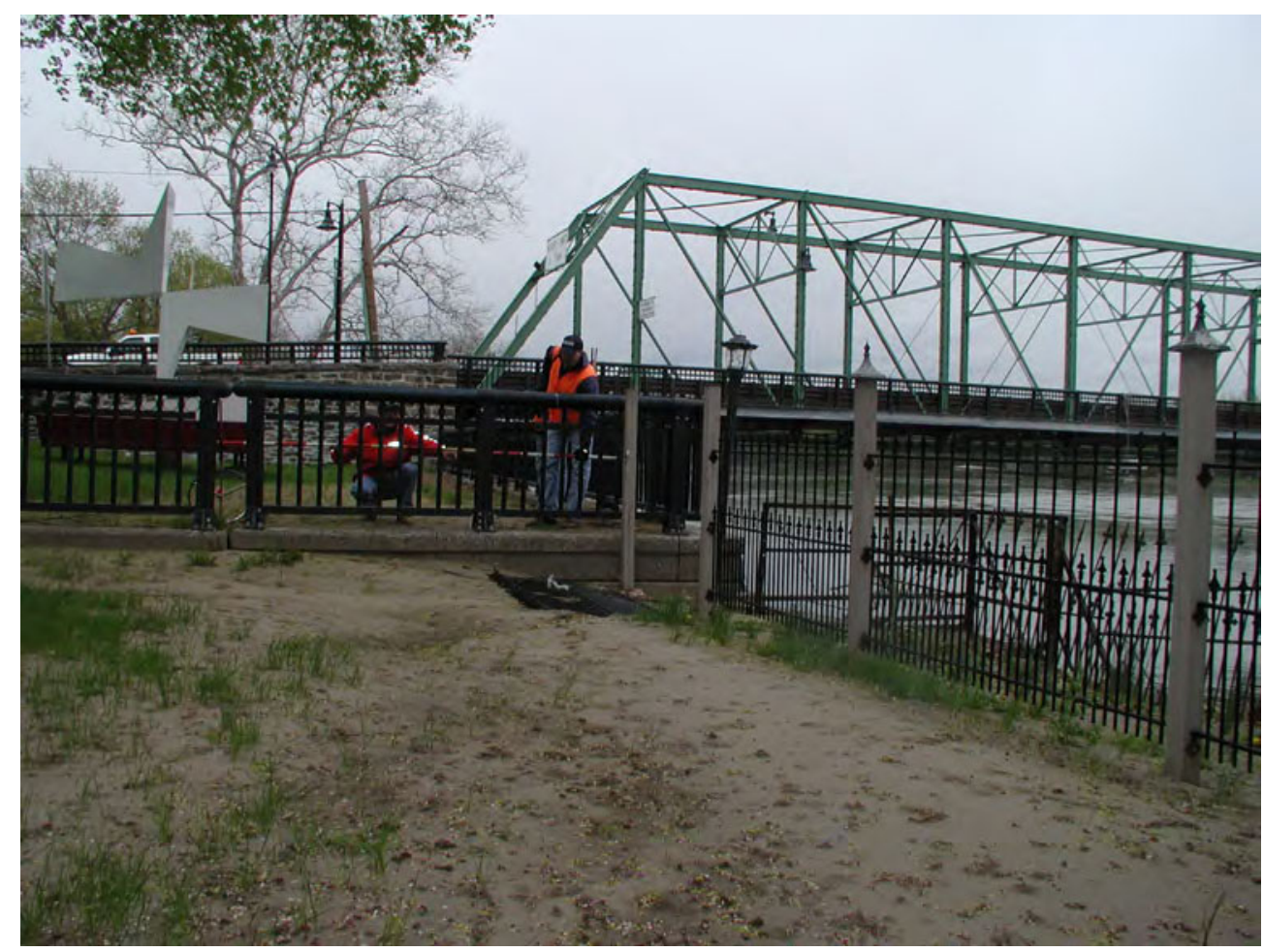

High-water mark PA 23.1 (lat $40^{\circ} 21^{\prime} 51.5^{\prime \prime}$, long $74^{\circ} 57^{\prime} 2.1^{\prime \prime}$ ), at an elevation of 68.7 feet above NGVD 29, is an excellent mud line on a railing, 2.1 feet above the ground, 50 feet downstream from the East Bridge Street bridge, and was marked with a yellow grease pencil line.

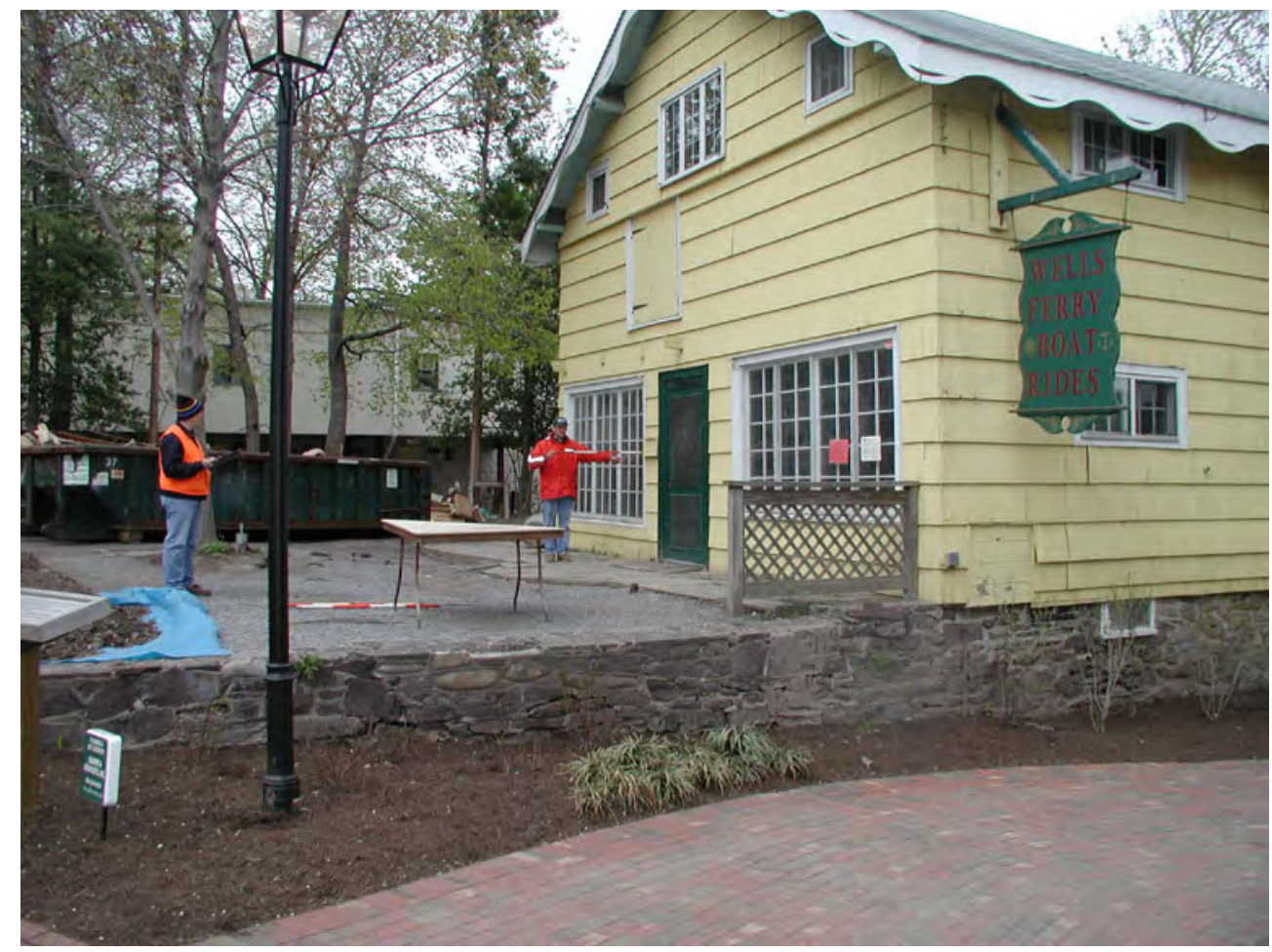

High-water mark PA 23.2 (lat $40^{\circ} 21^{\prime} 48.1^{\prime \prime}$, long $74^{\circ} 57^{\prime} 1.7^{\prime \prime}$ ), at an elevation of 68.5 feet above NGVD 29, is an excellent mud line on a building on Ferry Street, 4.5 feet above the ground, 0.1 miles downstream from the East Bridge Street bridge, and was marked with a black marker line. 


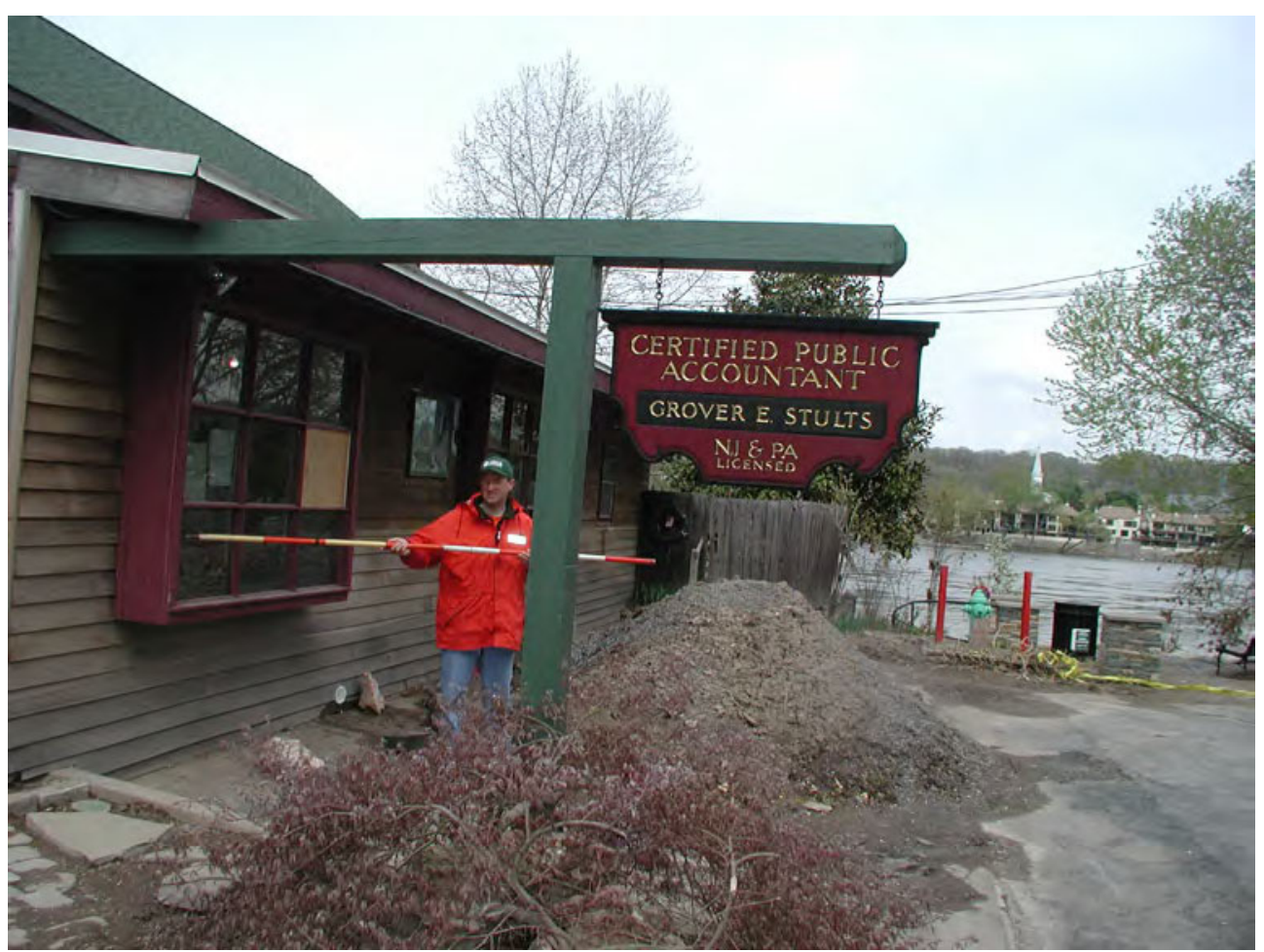

High-water mark PA 23.3 (lat $40^{\circ} 22^{\prime} 3.0^{\prime \prime}$, long $74^{\circ} 56^{\prime} 52.0^{\prime \prime}$ ), at an elevation of 68.9 feet above NGVD 29 , is an excellent mud line on a building on Randolph Street, 4.0 feet above the ground, 0.1 miles upstream from the East Bridge Street bridge, and was marked with a black marker line.

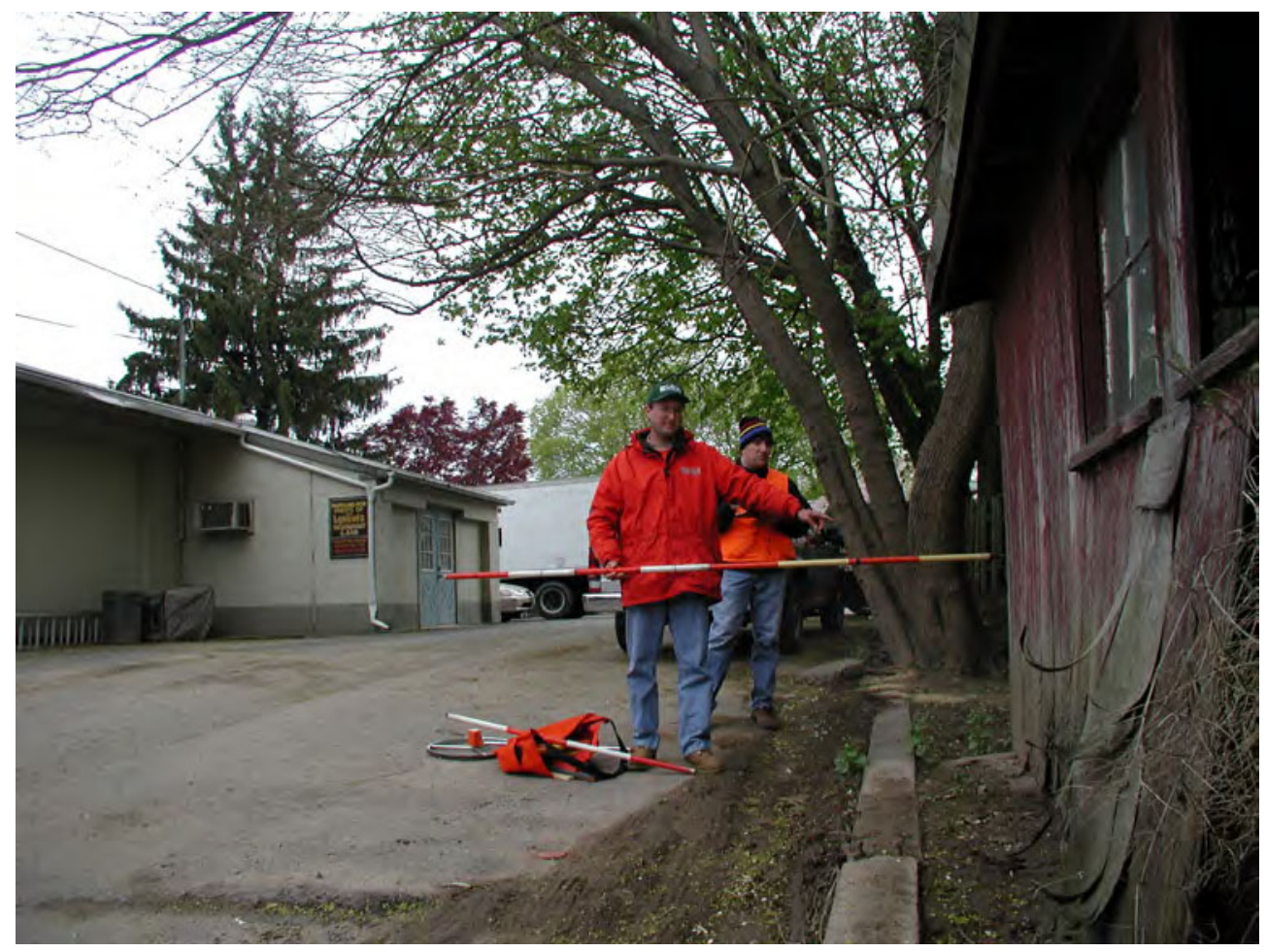

High-water mark PA 23.4 (lat $40^{\circ} 22^{\prime} 3.0^{\prime \prime}$, long $74^{\circ} 56^{\prime} 52.0^{\prime \prime}$ ), at an elevation of 68.8 feet above NGVD 29 , is an excellent mud line on a barn on Randolph Street, 3.9 feet above the ground, 0.1 miles upstream from the East Bridge Street bridge, and was marked with a black marker line. 


\section{SITE DESCRIPTION}

Site PA 24: Delaware River near New Hope, PA

Site Location: 400 foot reach in vicinity of lat $40^{\circ} 21^{\prime} 01^{\prime \prime}$, long $74^{\circ} 56^{\prime} 53^{\prime \prime}$

Solebury Township, Bucks County, PA

Two high-water marks were surveyed: two mud lines.

High-water mark elevations were determined using USGS reference mark 108 at lat $40^{\circ} 21^{\prime} 2.6^{\prime \prime}$, long

$74^{\circ} 56^{\prime} 52.8^{\prime \prime}$ (elevation is 56.54 feet above NAVD 88 ).

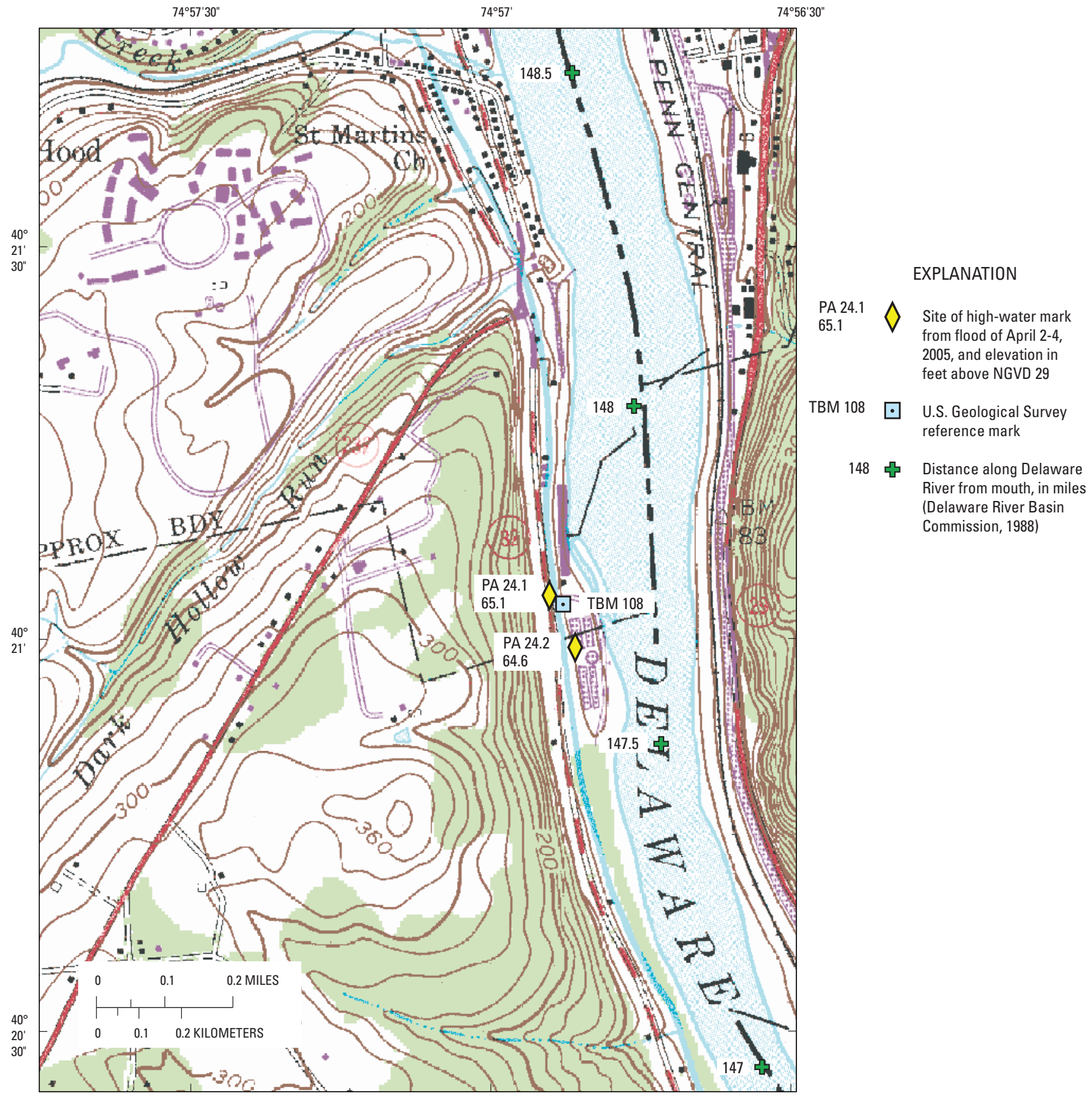

Lambertville USGS 7.5' Topographic Quadrangle map showing location of site PA 24, Delaware River near New Hope, PA. 


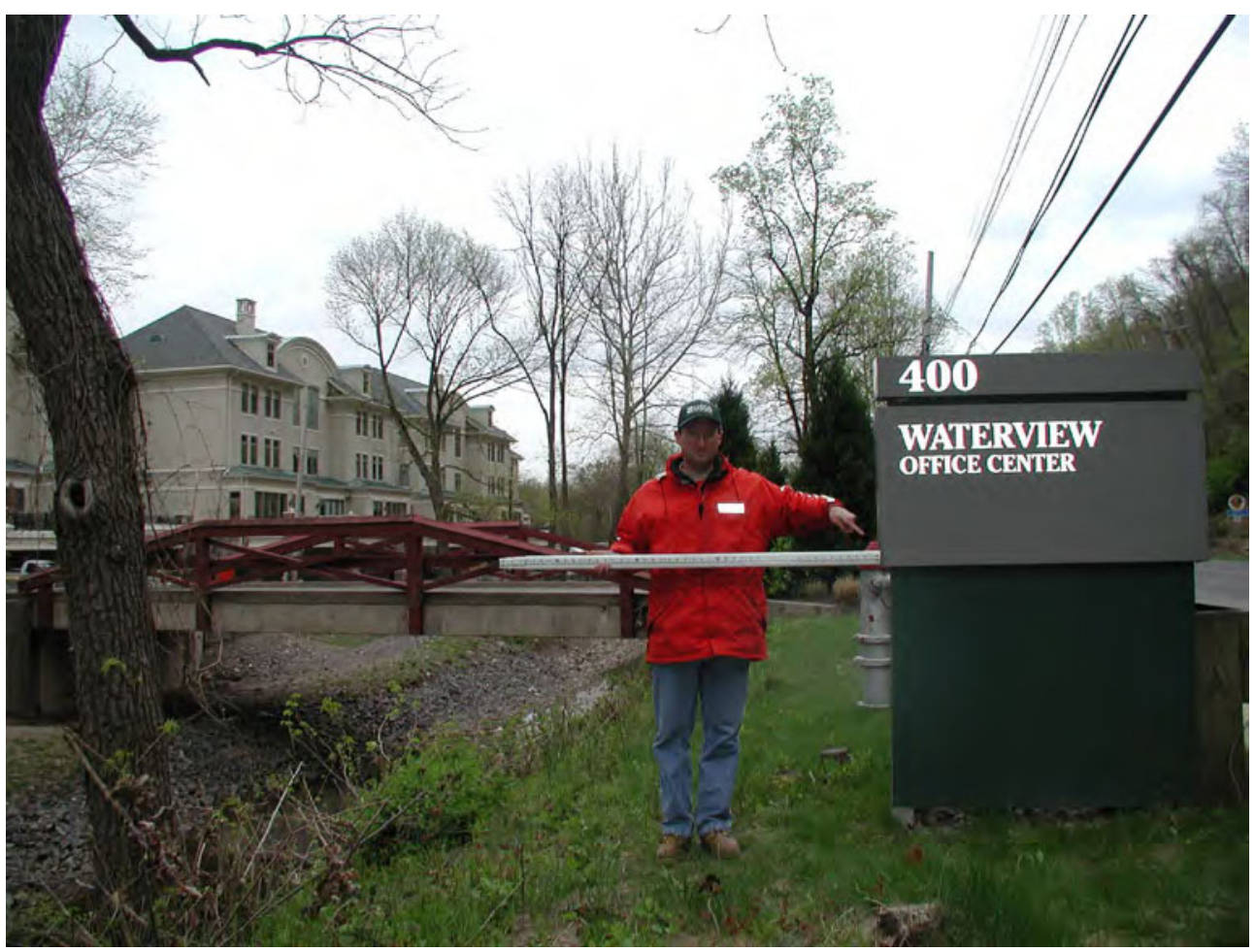

High-water mark PA 24.1 (lat $40^{\circ} 21^{\prime} 3.5^{\prime \prime}$, long $74^{\circ} 56^{\prime} 54.0^{\prime \prime}$ ), at an elevation of 65.1 feet above NGVD 29 , is an excellent mud line on a sign for an office park on State Route 32, 3.5 feet above the ground, 0.5 miles downstream from Dark Hollow Run, and was marked with a black marker line.

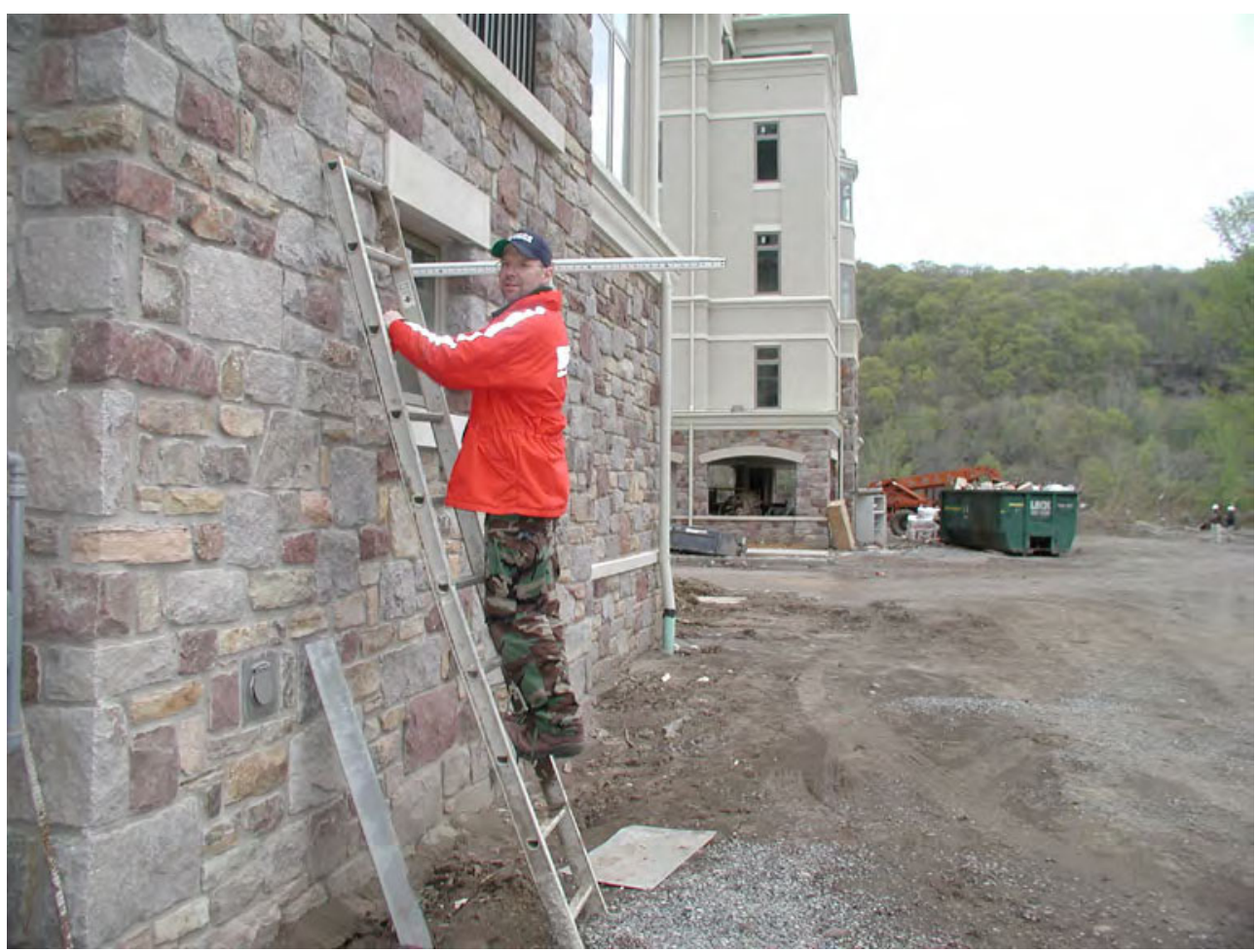

High-water mark PA 24.2 (lat $40^{\circ} 20^{\prime} 59.6^{\prime \prime}$, long $74^{\circ} 56^{\prime} 51.4^{\prime \prime}$ ), at an elevation of 64.8 feet above NGVD 29 , is an excellent mud line on a window frame of a building on State Route 32, 7.9 feet above the ground, 0.6 miles downstream from Dark Hollow Run, and was marked with a black marker line. 


\section{SITE DESCRIPTION}

Site NJ 22: 01462500 Delaware River at Washington Crossing, NJ

Site Location: 0.2 mi reach in vicinity of lat $40^{\circ} 17^{\prime} 42^{\prime \prime}$, long $74^{\circ} 52^{\prime} 05^{\prime \prime}$

Hopewell Township, Mercer County, NJ

Four high-water marks were surveyed: One debris line, two mud lines, and one seed line.

High-water mark elevations were determined using USGS reference mark 205 at lat $40^{\circ} 17^{\prime} 46.9^{\prime \prime}$,

long $74^{\circ} 52^{\prime} 01.9^{\prime \prime}$ (elevation is 50.29 feet above NAVD 88).

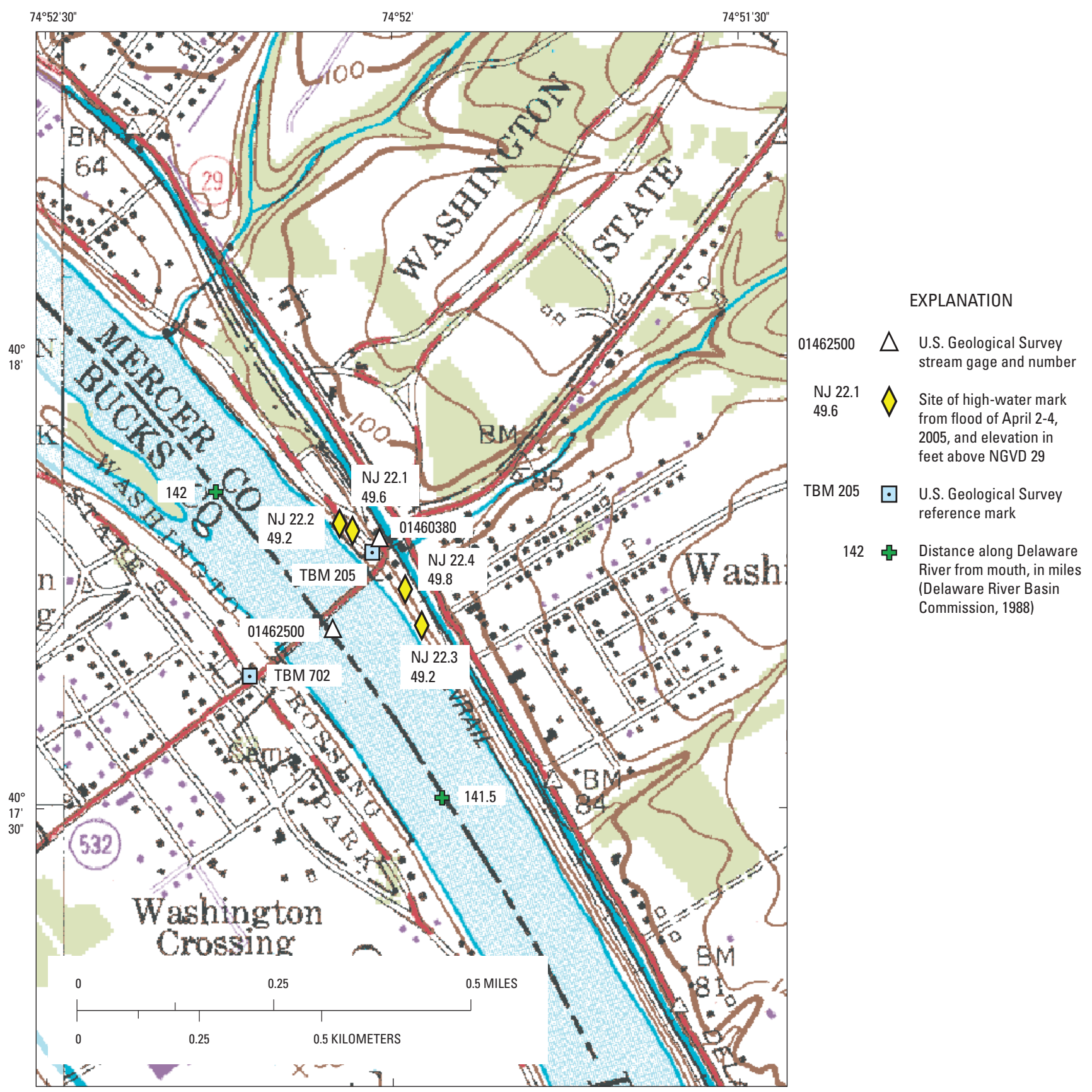

Pennington USGS 7.5' Topographic Quadrangle map showing location of site NJ 22, Delaware River at Washington Crossing, NJ. 


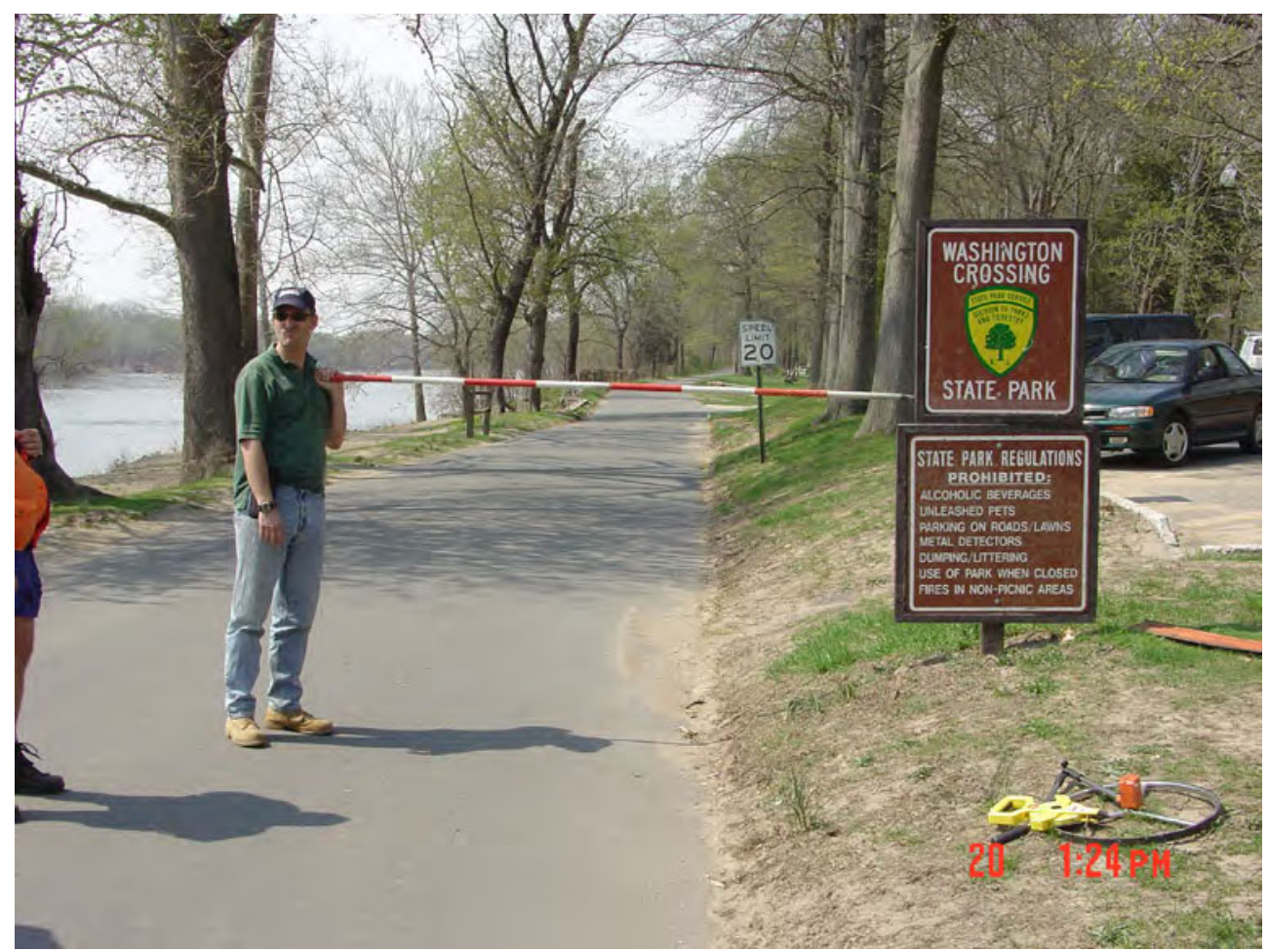

High-water mark NJ 22.1 (lat $40^{\circ} 17^{\prime} 48.7^{\prime \prime}$, long $74^{\circ} 52^{\prime} 03.6^{\prime \prime}$ ), at an elevation of 49.6 feet above NGVD 29 , is a good mud line on the Washington Crossing State Park sign, 3.9 feet above the ground, 308 feet upstream from the Washington Crossing bridge, and was marked with a black marker line.

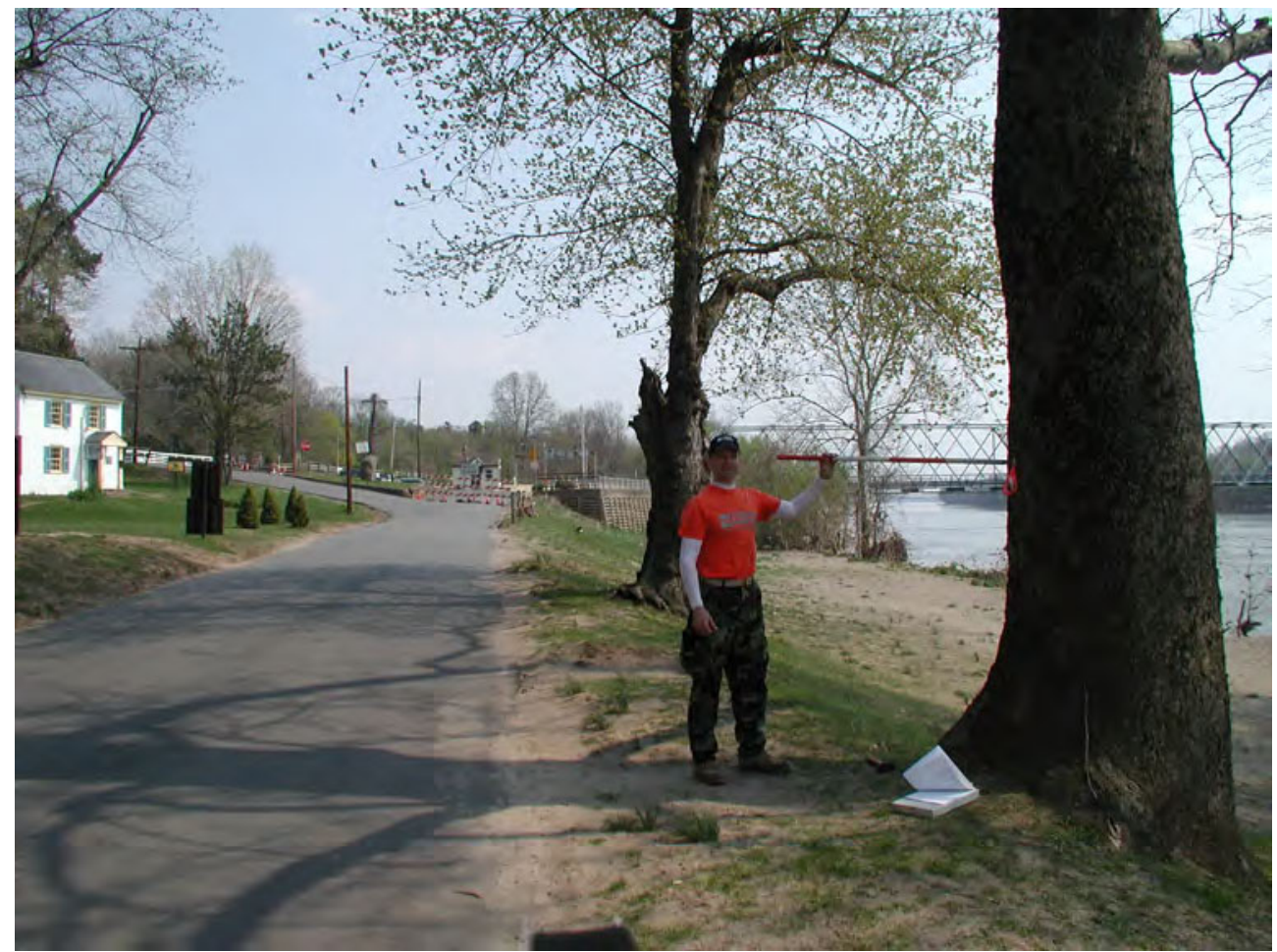

High-water mark NJ 22.2 (lat $40^{\circ} 17^{\prime} 49.1^{\prime \prime}$, long $74^{\circ} 52^{\prime} 04.6^{\prime \prime}$ ), at an elevation of 49.2 feet above NGVD 29 , is a fair mud line on a 40 -inch diameter tree, 375 feet upstream from the Washington Crossing bridge, and was marked with a metal USGS washer and nail. 


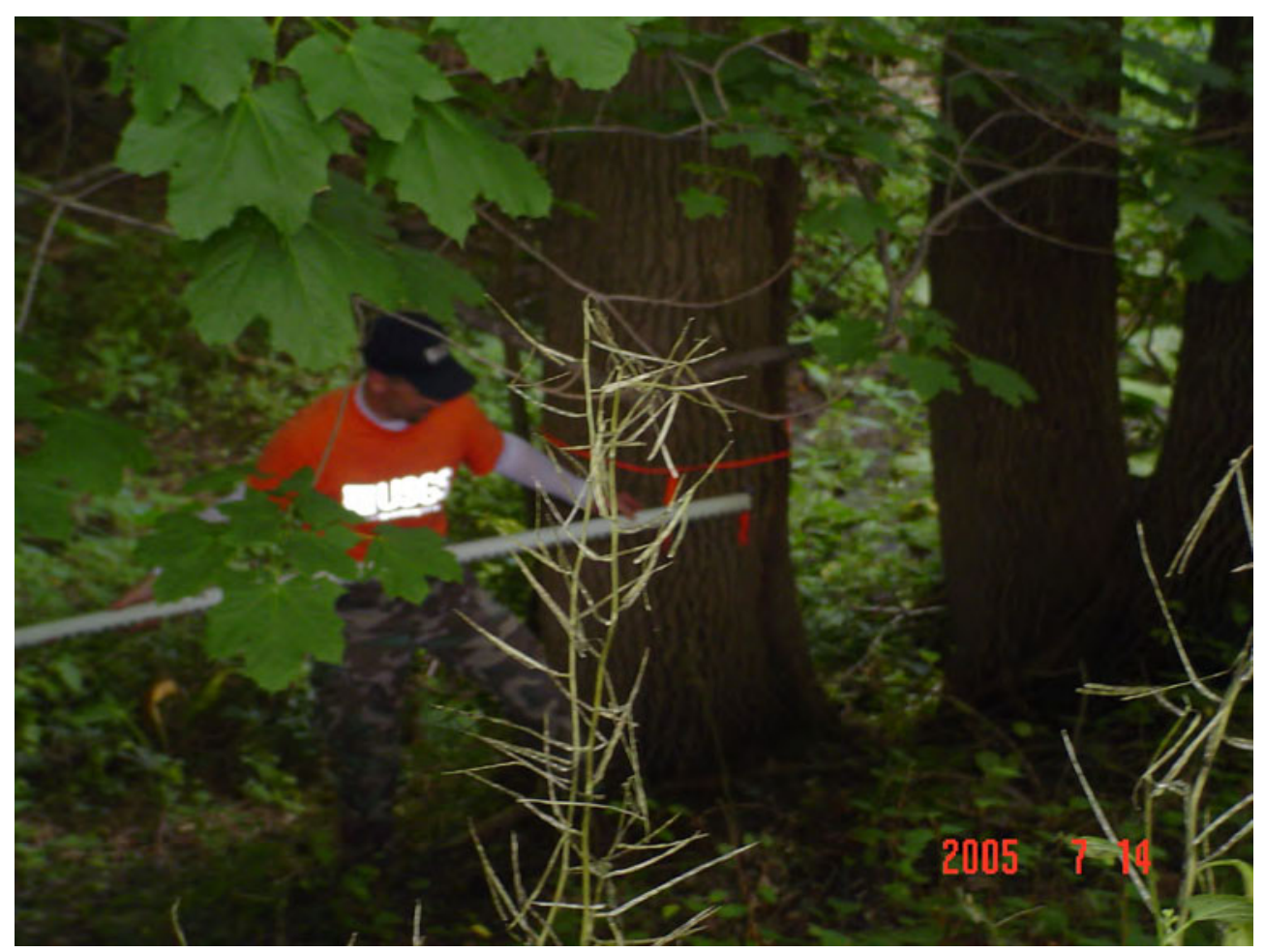

High-water mark NJ 22.3 (lat $40^{\circ} 17^{\prime} 42.4^{\prime \prime}$, long $74^{\circ} 51^{\prime} 57.5^{\prime \prime}$ ), at an elevation of 49.2 feet above NGVD 29 , is a fair seed line on a 26 -inch diameter tree, 529 feet downstream from the downstream towpath gate near the Washington Crossing bridge, and was marked with a metal USGS washer and nail.

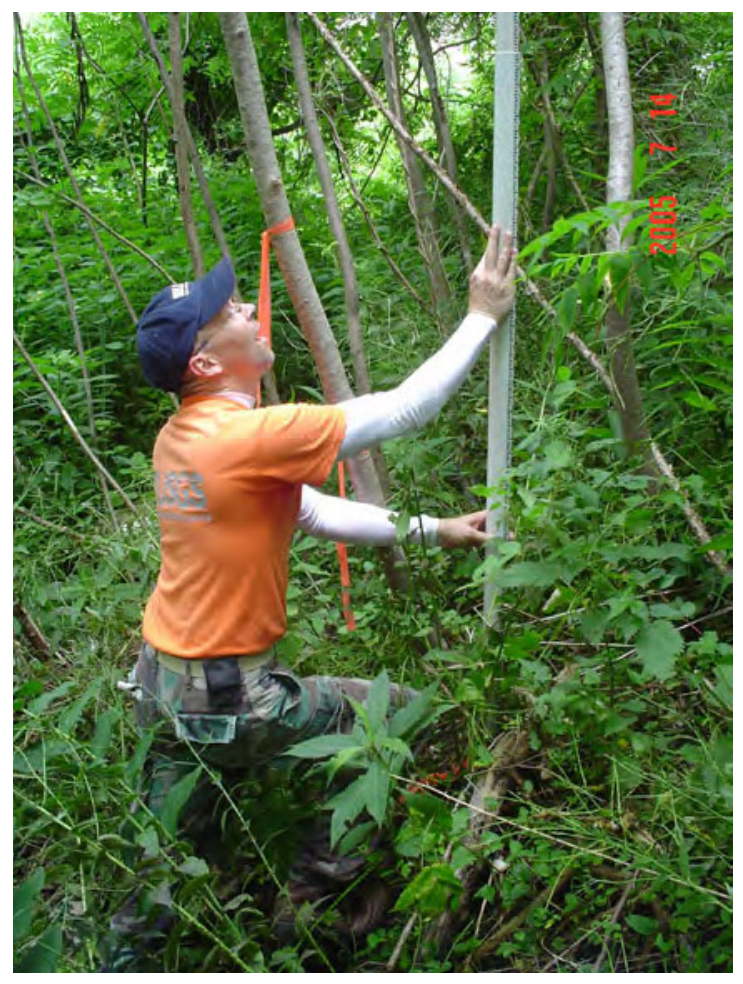

High-water mark NJ 22.4 (lat $40^{\circ} 17^{\prime} 44.7^{\prime \prime}$, long $74^{\circ} 51^{\prime} 59.0^{\prime \prime}$ ), at an elevation of 49.8 feet above NGVD 29 , is a good debris line on the ground, 283 feet downstream from the downstream towpath gate near the Washington Crossing bridge, and was marked with a metal USGS washer and nail. 


\begin{tabular}{|l|}
\hline SITE DESCRIPTION \\
\hline Site NJ 23: 01462900 Delaware River at Scudders Falls, NJ \\
\hline Site Location: 0.2 mi reach in vicinity of lat $40^{\circ} 15^{\prime} 33^{\prime \prime}$, long $74^{\circ} 50^{\prime} 48^{\prime \prime}$ \\
\hline Ewing Township, Mercer County, NJ \\
\hline Four high-water marks were surveyed: four debris lines. \\
\hline High-water mark elevations were determined using USGS reference mark 204 at lat $40^{\circ} 15^{\prime} 33.2^{\prime \prime}$, \\
long $74^{\circ} 50^{\prime} 42.8^{\prime \prime}$ (elevation is 44.16 feet above NAVD 88) and USGS reference mark 302 at lat \\
$40^{\circ} 15^{\prime} 40.8^{\prime \prime}$, long $74^{\circ} 50^{\prime} 46.4^{\prime \prime}$ (elevation is 64.01 feet above NAVD 88 ). \\
\hline
\end{tabular}

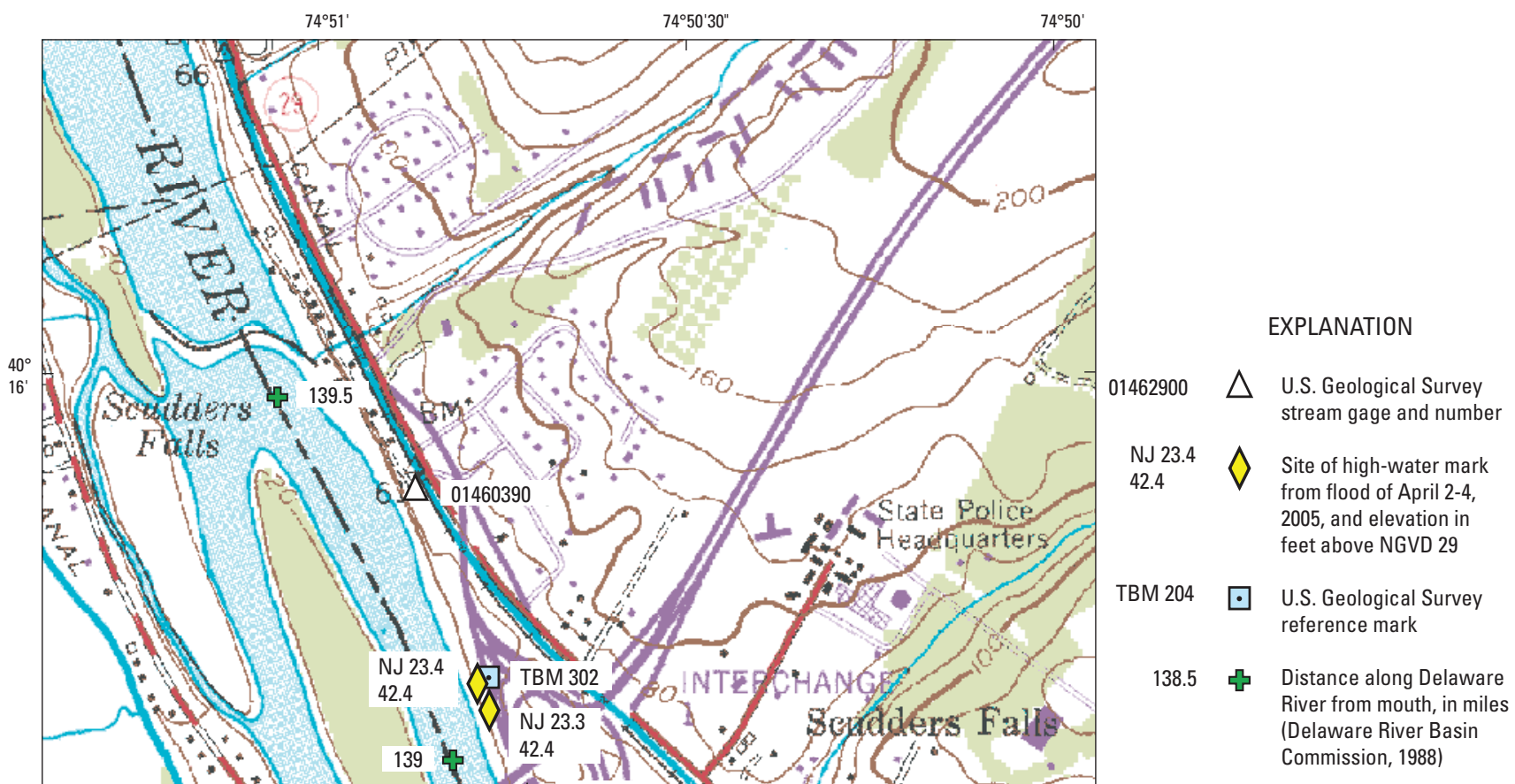

Pennington USGS 7.5' Topographic Quadrangle map showing location of site NJ 23, Delaware River at Scudders Falls, NJ. 


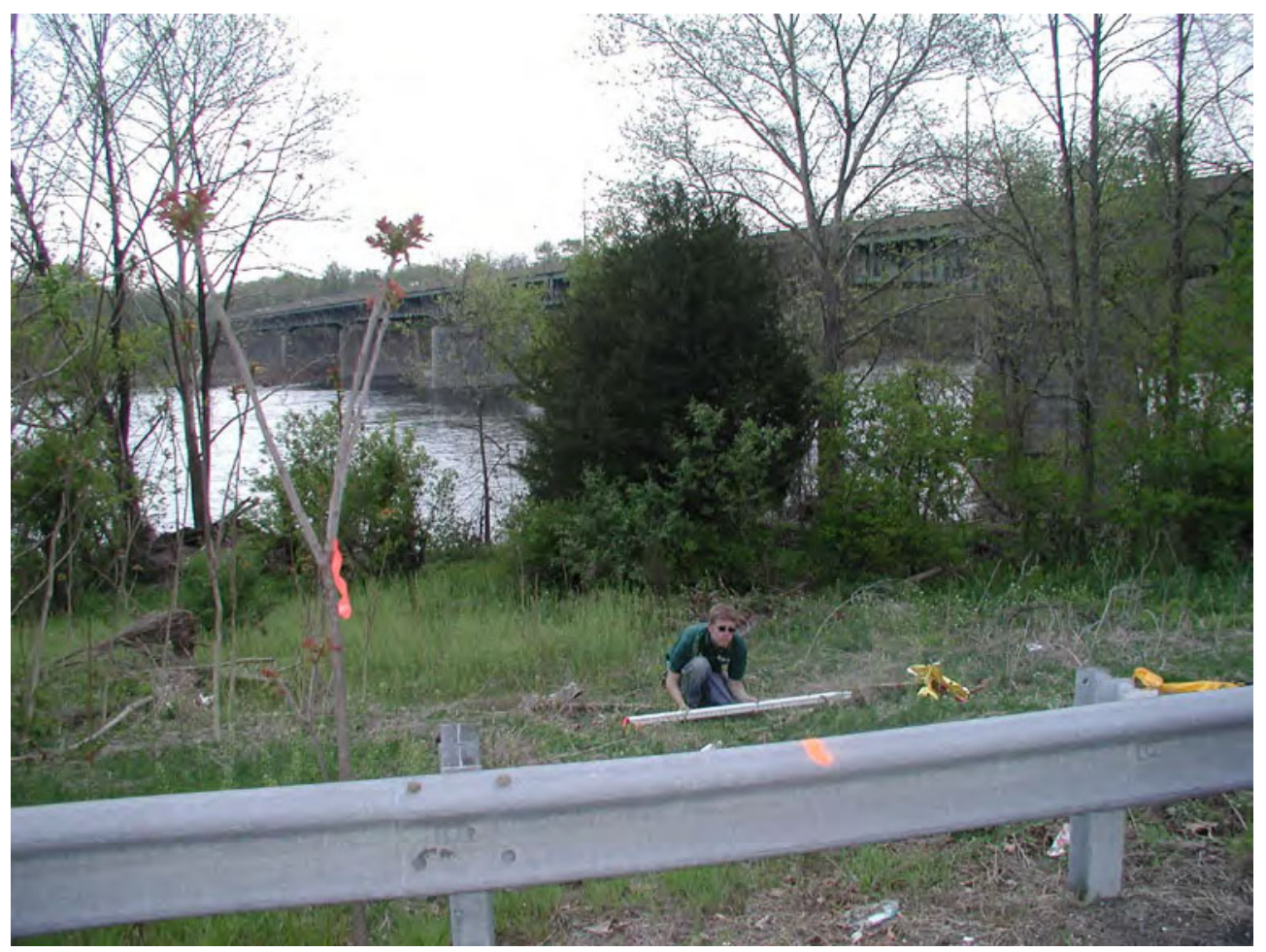

High-water mark NJ 23.1 (lat $40^{\circ} 15^{\prime} 33.2^{\prime \prime}$, long $74^{\circ} 50^{\prime} 43.1^{\prime \prime}$ ), at an elevation of 42.2 feet above NGVD 29 , is a fair debris line on the embankment, 177 feet downstream from the Interstate Route 95 bridge, and was marked with a metal rebar.

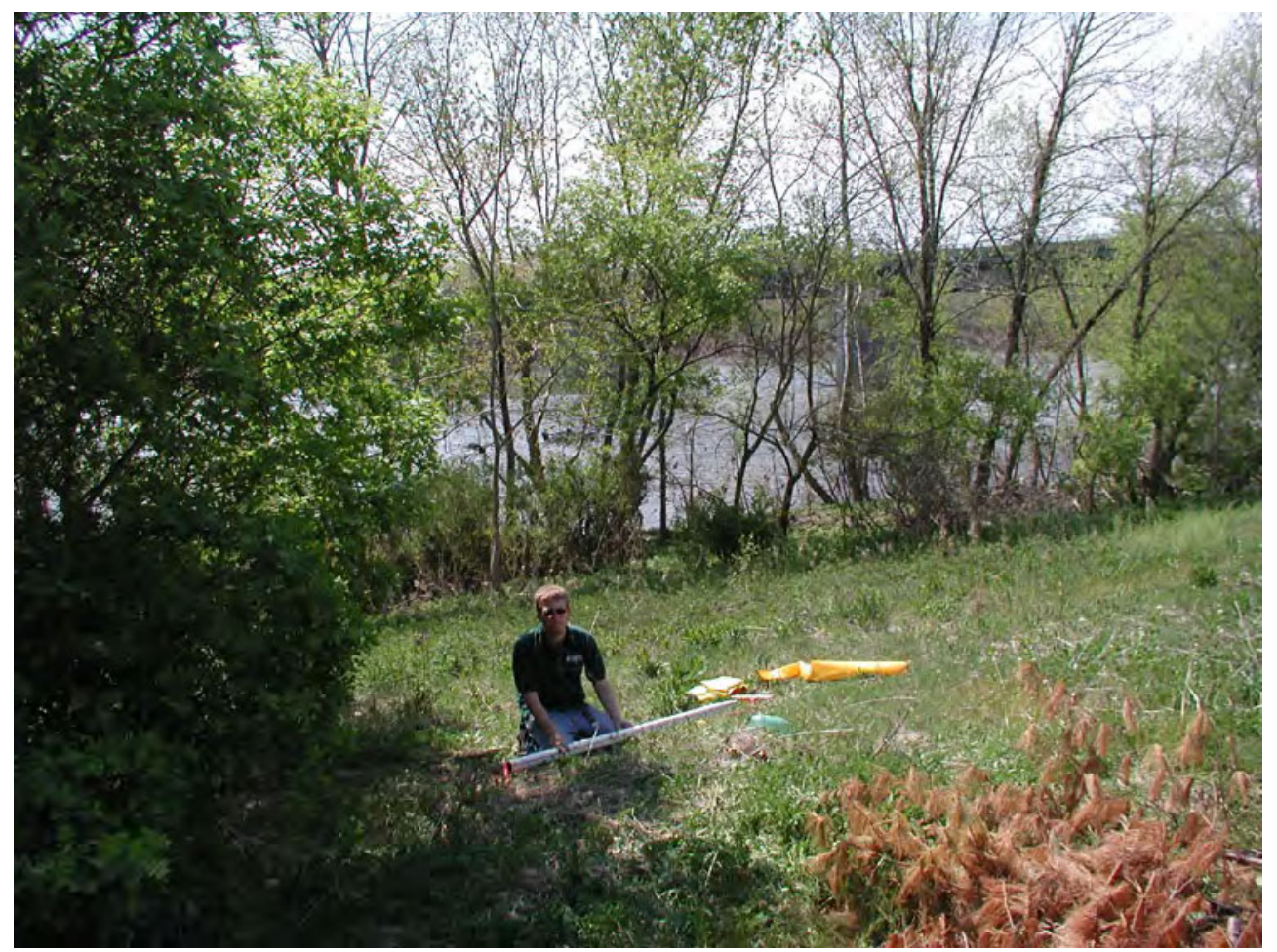

High-water mark NJ 23.2 (lat $40^{\circ} 15^{\prime} 31.6^{\prime \prime}$, long $74^{\circ} 50^{\prime} 42.0^{\prime \prime}$ ), at an elevation of 41.4 feet above NGVD 29 , is a fair debris line on the embankment, 367 feet downstream from the Interstate Route 95 bridge, and was marked with a metal rebar. 


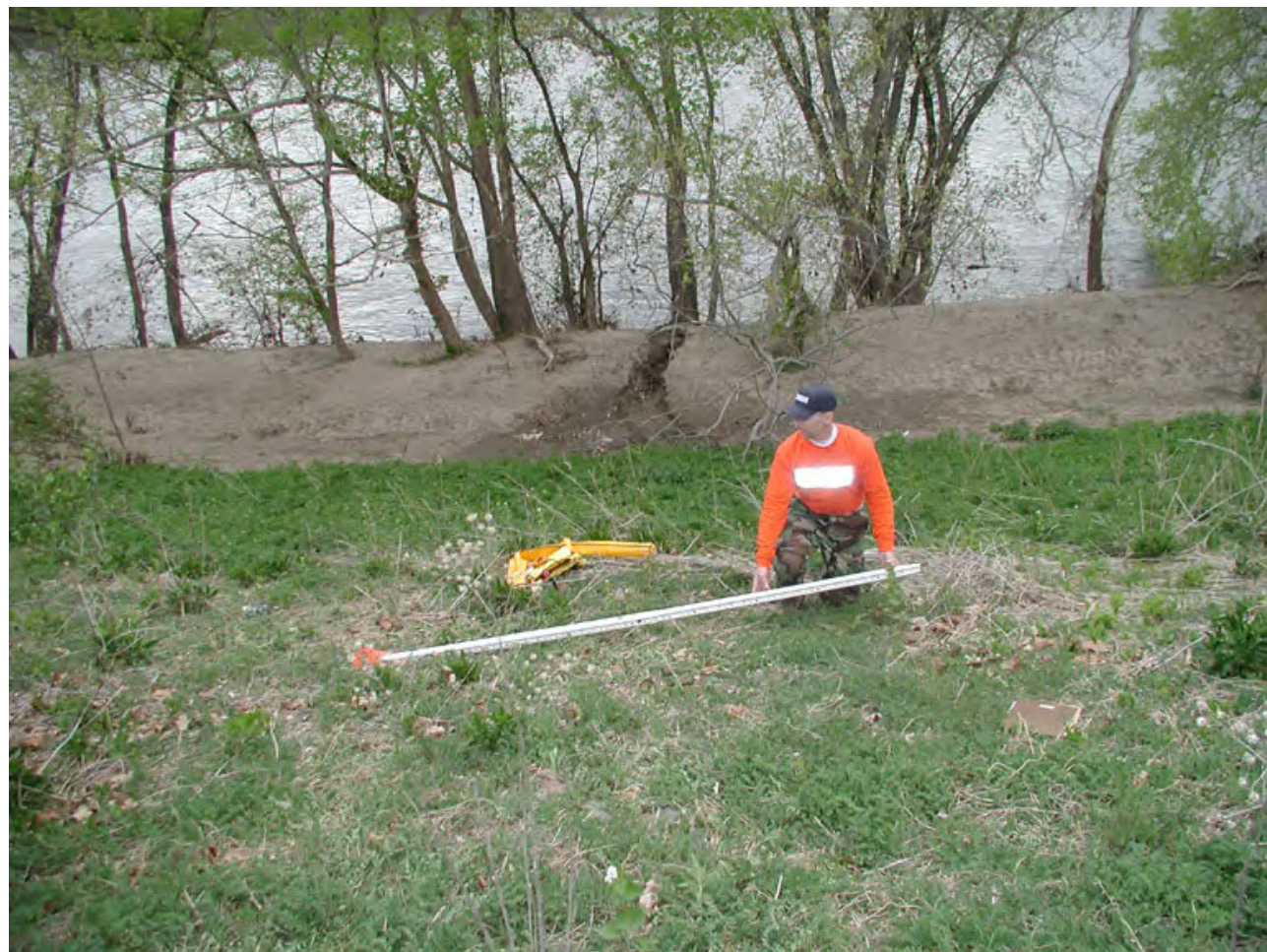

High-water mark NJ 23.3 (lat $40^{\circ} 15^{\prime} 39.1^{\prime \prime}$, long $74^{\circ} 50^{\prime} 46.3^{\prime \prime}$ ), at an elevation of 42.4 feet above NGVD 29 , is a fair debris line on the embankment, 409 feet upstream from the Interstate Route 95 bridge, and was marked with a metal rebar.

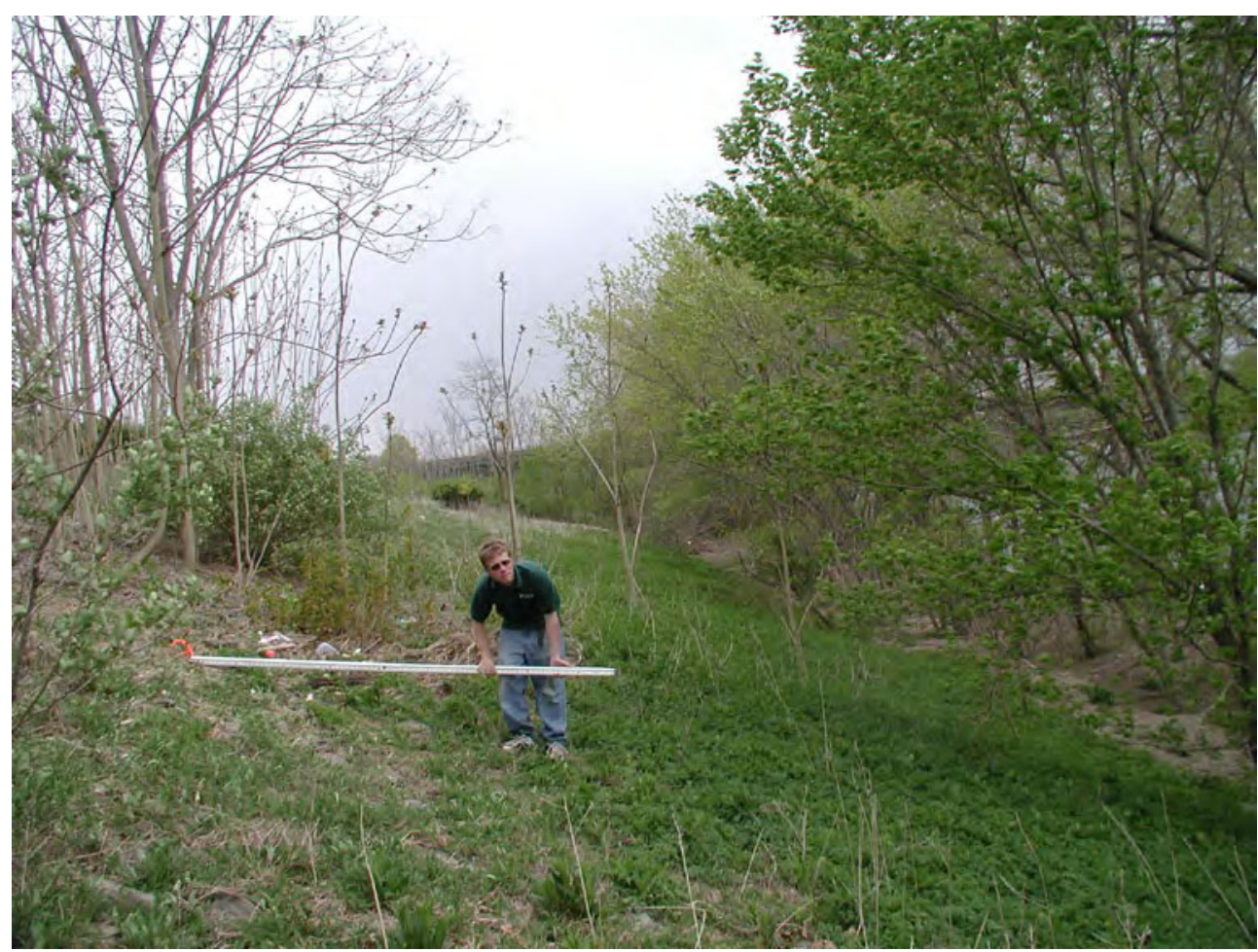

High-water mark NJ 23.4 (lat $40^{\circ} 15^{\prime} 40.8^{\prime \prime}$, long $74^{\circ} 50^{\prime} 47.2^{\prime \prime}$ ), at an elevation of 42.4 feet above NGVD 29 , is a fair debris line on the embankment, 590 feet upstream from the Interstate Route 95 bridge, and was marked with a metal rebar. 


\begin{tabular}{|l|}
\hline \multicolumn{1}{|c|}{ SITE DESCRIPTION } \\
\hline Site PA 27: 01463000 Delaware River at Yardley, PA \\
\hline Site Location: 0.2 mile reach in vicinity of lat $40^{\circ} 14^{\prime} 39^{\prime \prime}$, long $74^{\circ} 50^{\prime} 05^{\prime \prime}$ \\
\hline Yardley Borough, Bucks County, PA \\
\hline Three high-water marks were surveyed: three mud lines. \\
\hline $\begin{array}{l}\text { High-water mark elevations were determined using USGS reference mark } 107 \text { at lat } 40^{\circ} 14^{\prime} 41.6^{\prime \prime}, \\
\text { long } 74^{\circ} 50^{\prime} 10.4^{\prime \prime} \text { (elevation is } 35.2 \text { feet above NAVD 88). }\end{array}$ \\
\hline
\end{tabular}

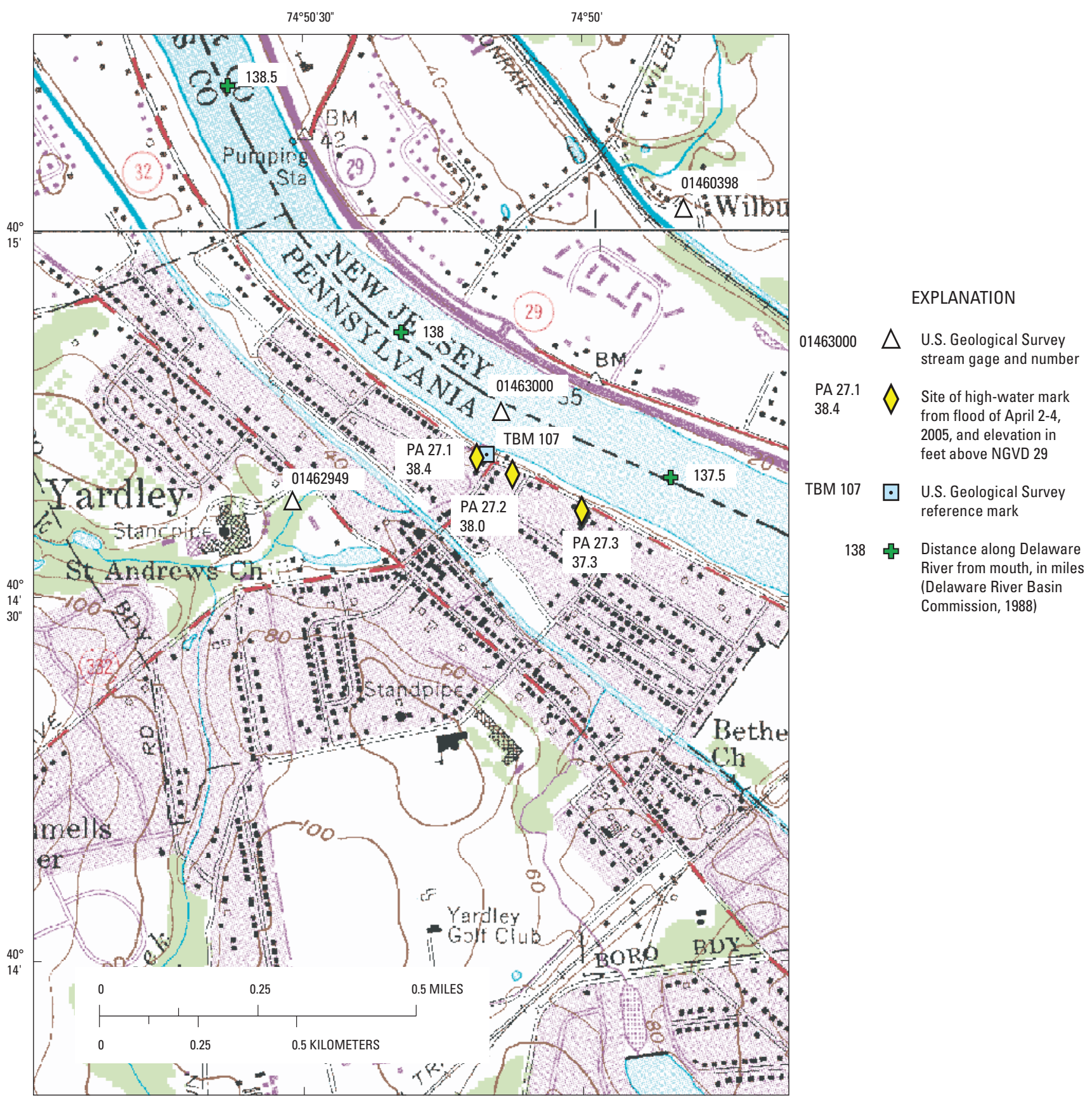

Trenton West USGS 7.5' Topographic Quadrangle map showing location of site PA 27, Delaware River at Yardley, PA. 


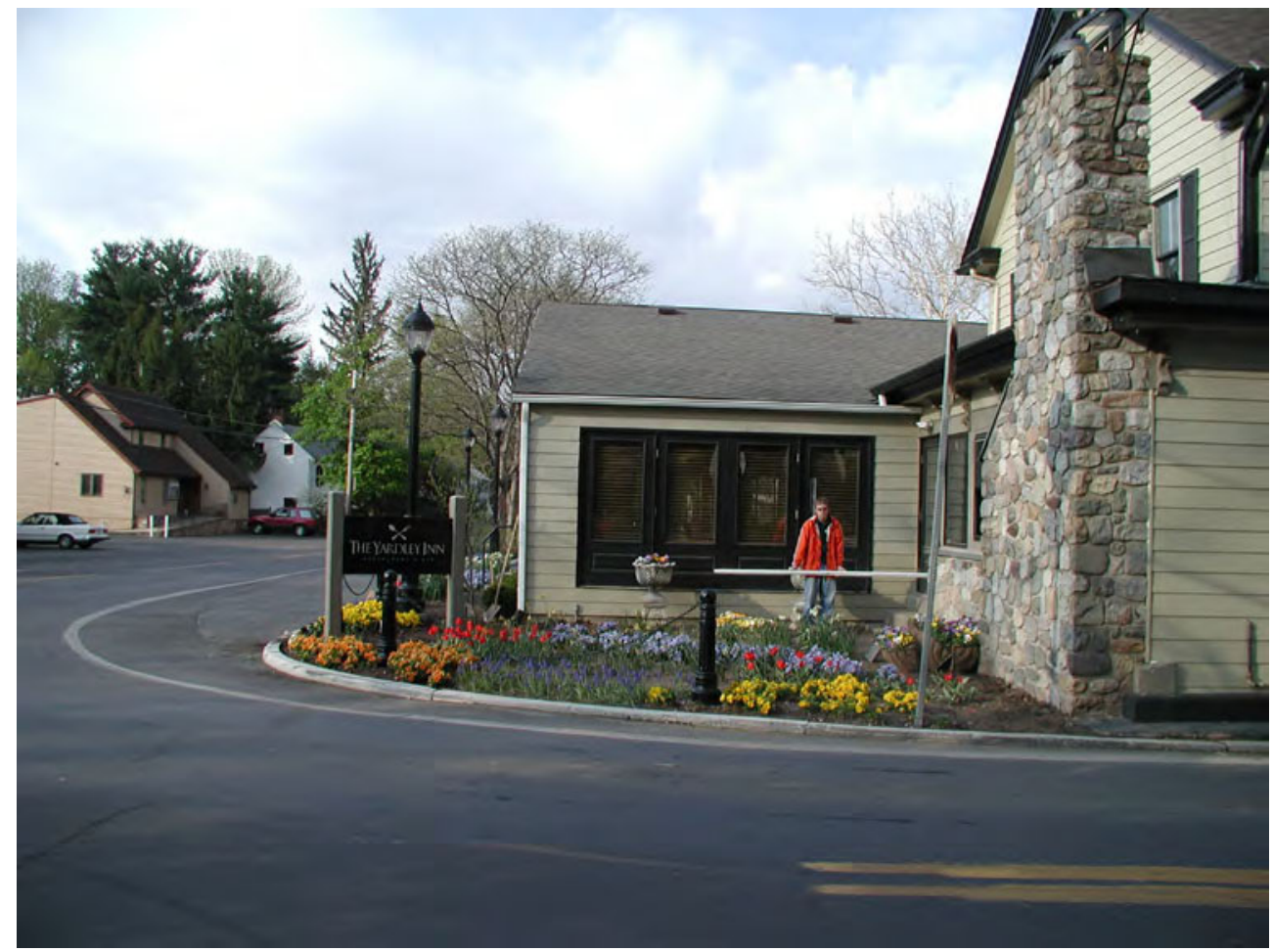

High-water mark PA 27.1 (lat $40^{\circ} 14^{\prime} 41.7^{\prime \prime}$, long $74^{\circ} 50^{\prime} 11.4^{\prime \prime}$ ), at an elevation of 38.4 feet above NGVD 29, is an excellent mud line on the door of a building (Yardley Inn) on East Afton Avenue, 2.4 feet above the ground, 1.1 miles downstream from the Interstate Route 95 bridge, and was marked with a black marker line.

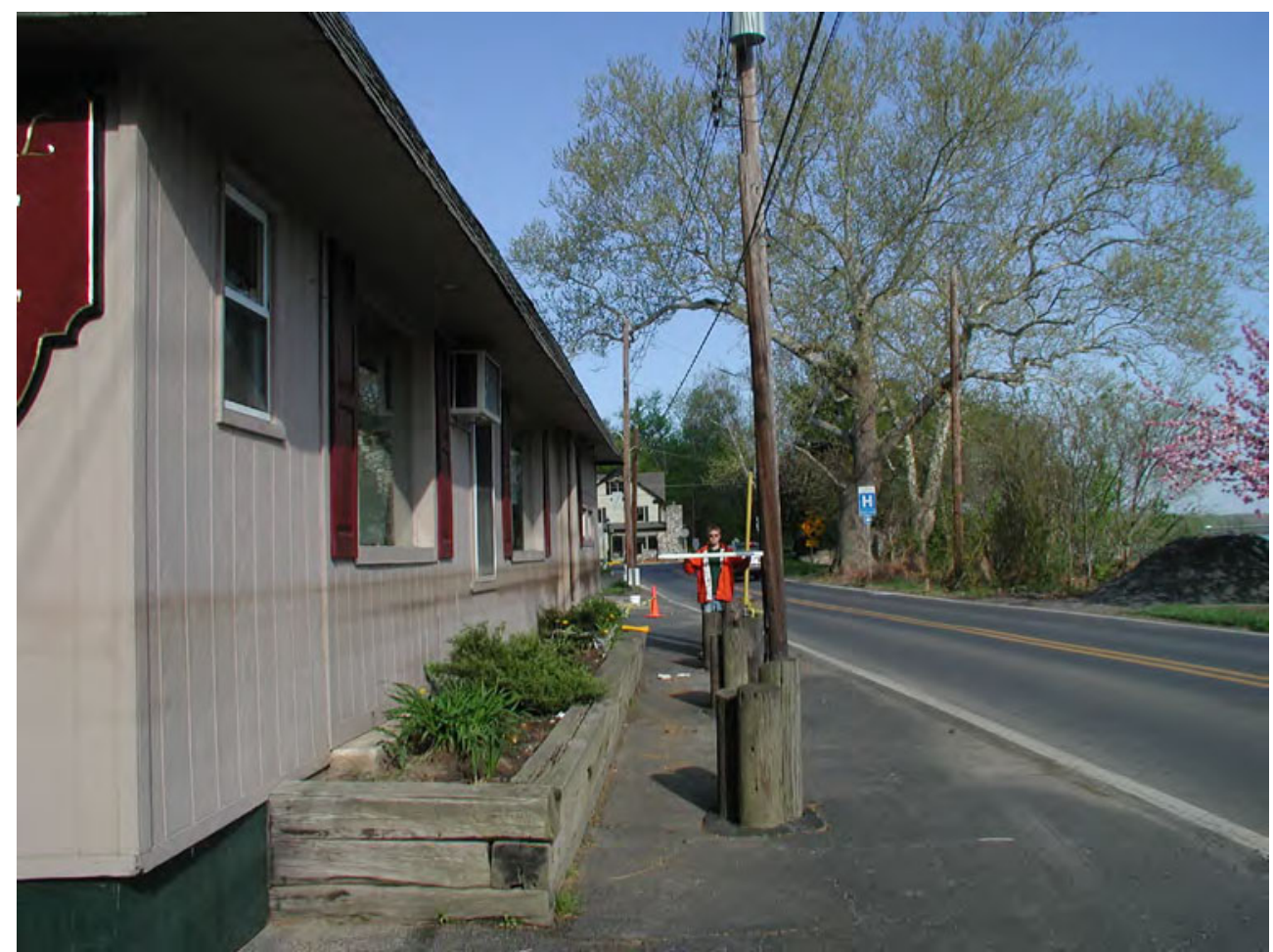

High-water mark PA 27.2 (lat $40^{\circ} 14^{\prime} 40.3^{\prime \prime}$, long $74^{\circ} 50^{\prime} 7.6^{\prime \prime}$ ), at an elevation of 38.0 feet above NGVD 29 , is an excellent mud line on a utility pole on State Route 32, 4.8 feet above the ground, 1.2 miles downstream from the Interstate Route 95 bridge, and was marked with a metal USGS washer and nail. 


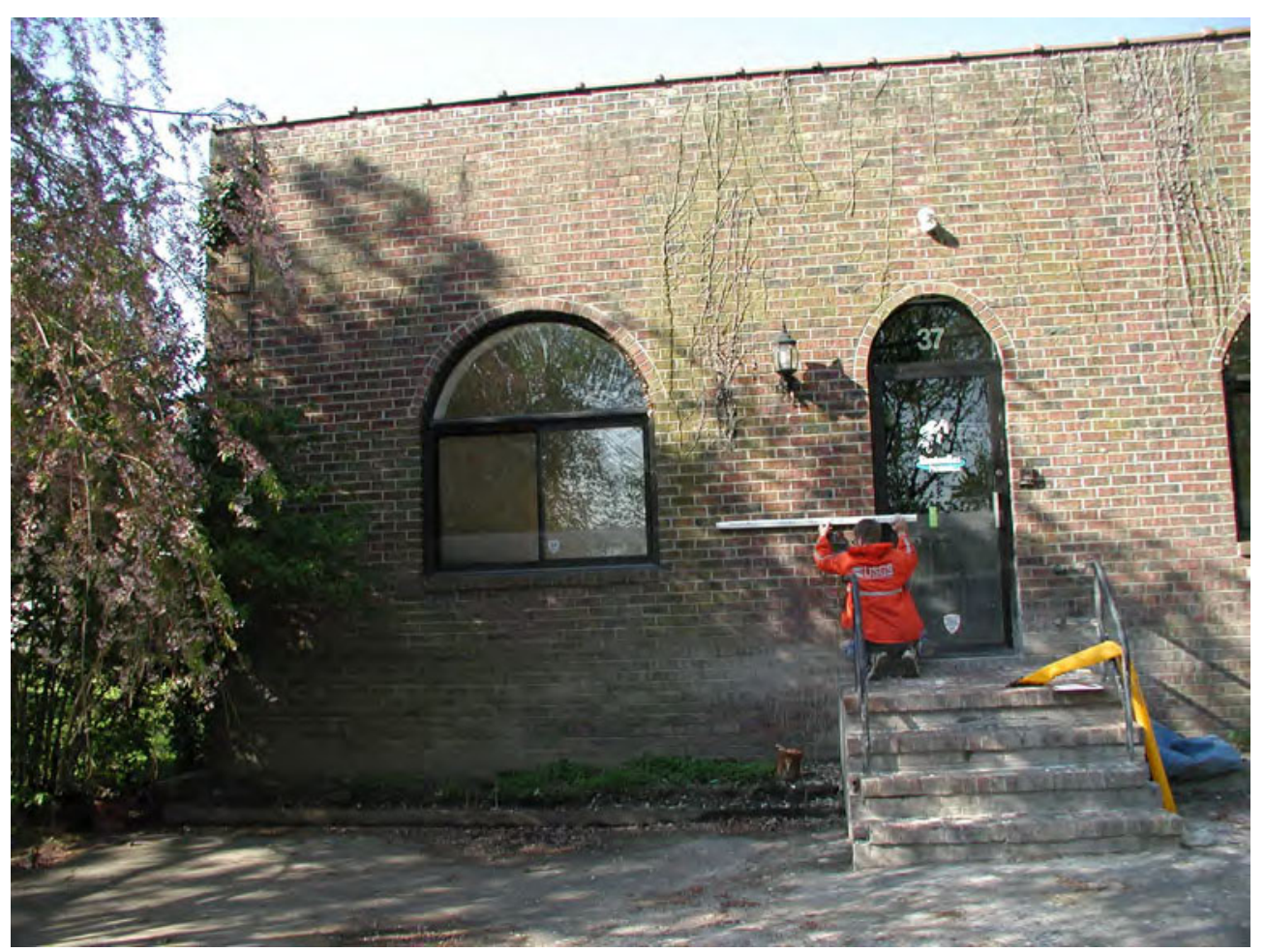

High-water mark PA 27.3 (lat $40^{\circ} 14^{\prime} 37.2^{\prime \prime}$, long $74^{\circ} 50^{\prime} 0.0^{\prime \prime}$ ), at an elevation of 37.3 feet above NGVD 29 , is an excellent mud line on the door of a building, 6 feet above the ground, 1.3 miles downstream from the Interstate Route 95 bridge, and was marked with a metal USGS washer and nail. 


\section{SITE DESCRIPTION}

Site NJ 24: Delaware River near intersection of State Route 29 and Sullivan Way at Trenton, NJ

Site Location: 0.2 mi reach in vicinity of lat $40^{\circ} 14^{\prime} 11^{\prime \prime}$, long $74^{\circ} 48^{\prime} 16^{\prime \prime}$

Trenton City, Mercer County, NJ

Two high-water marks were surveyed: two mud lines.

High-water mark elevations were determined using USGS reference mark 301 at lat $40^{\circ} 14^{\prime} 04.3^{\prime \prime}$, long $74^{\circ} 48^{\prime} 05.8^{\prime \prime}$ (elevation is 26.43 feet above NAVD 88).

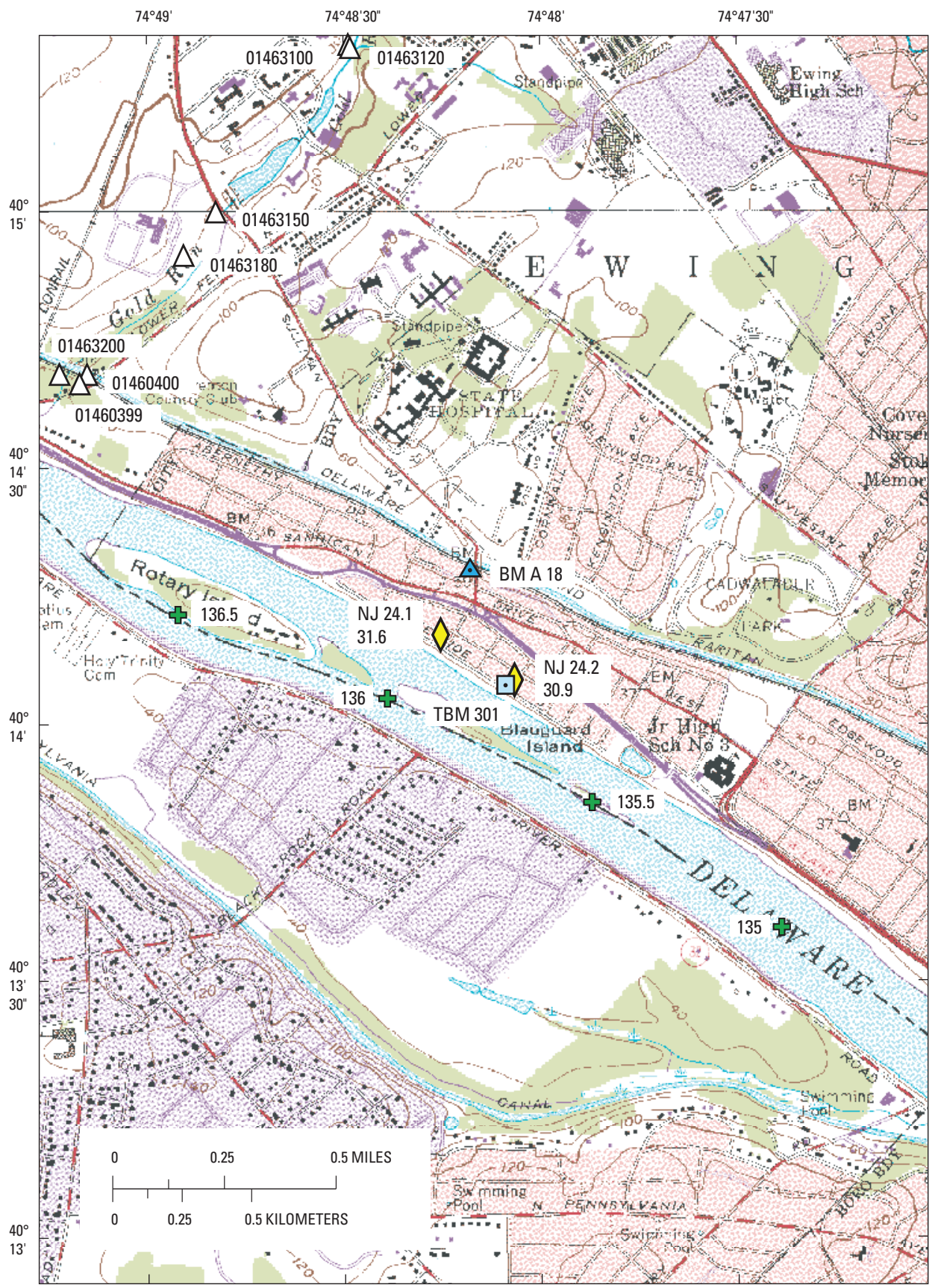

EXPLANATION

$01463100 \triangle$ U.S. Geological Survey stream gage and number

NJ 24.1 $\$ Site of high-water mark

$31.6 \quad$ from flood of April 2-4 2005 , and elevation in feet above NGVD 29

BM A $18 \triangle$ National Geodetic Survey benchmark

TBM 301 U.S. Geological Survey reference mark

136 Distance along Delaware River from mouth, in miles (Delaware River Basin

Commission, 1988)

Trenton West USGS 7.5' Topographic Quadrangle map showing location of site NJ 24, Delaware River near intersection of State Route 29 and Sullivan Way at Trenton, NJ. 


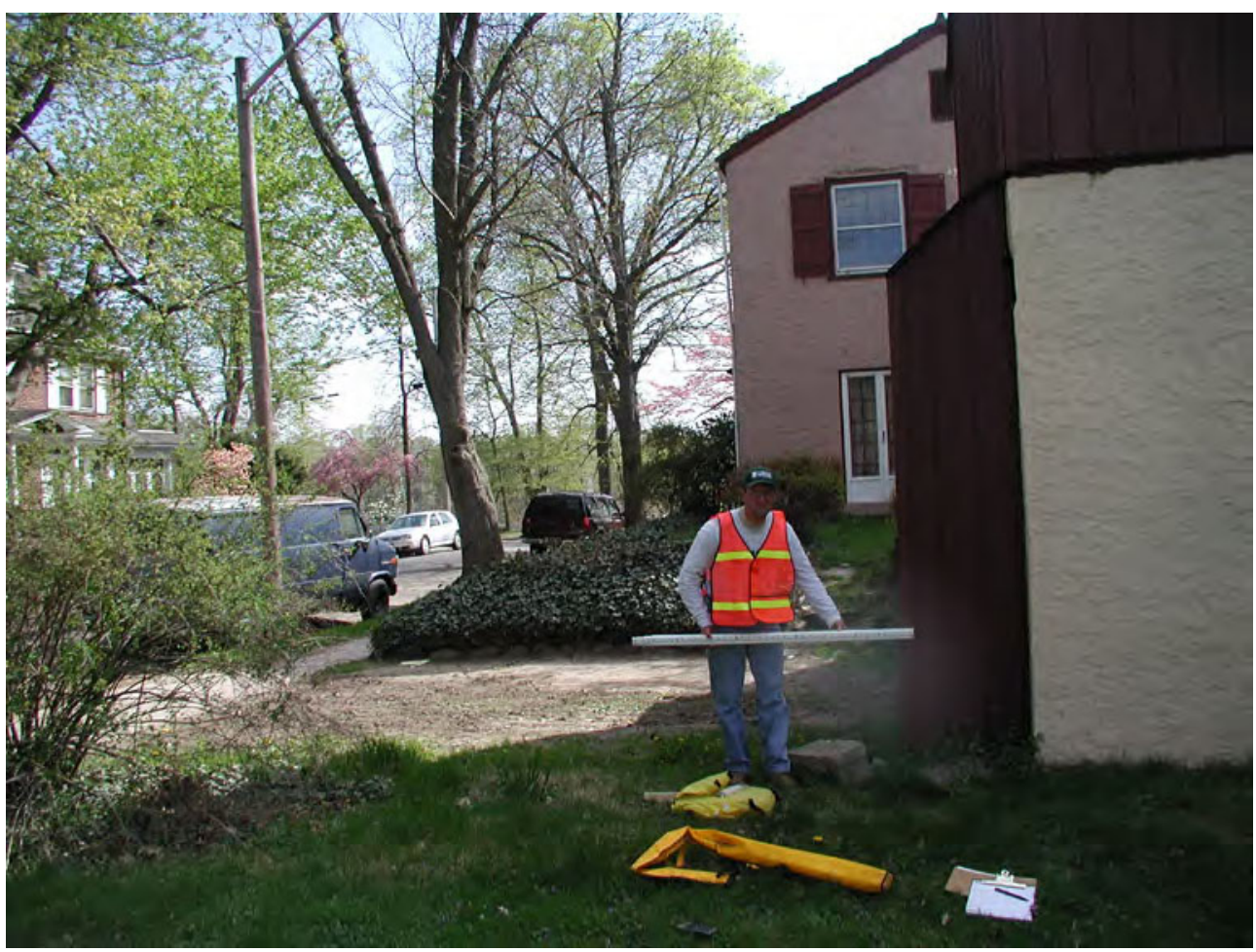

High-water mark NJ 24.1 (lat 40 $14^{\prime} 10.8^{\prime \prime}$, long $74^{\circ} 48^{\prime} 15.6^{\prime \prime}$ ), at an elevation of 31.6 feet above NGVD 29, is a good mud line on a garage at the intersection of Mount Vernon Avenue and Riverside Drive, 1.8 miles upstream from the Calhoun Street bridge, and was marked with a black marker line.

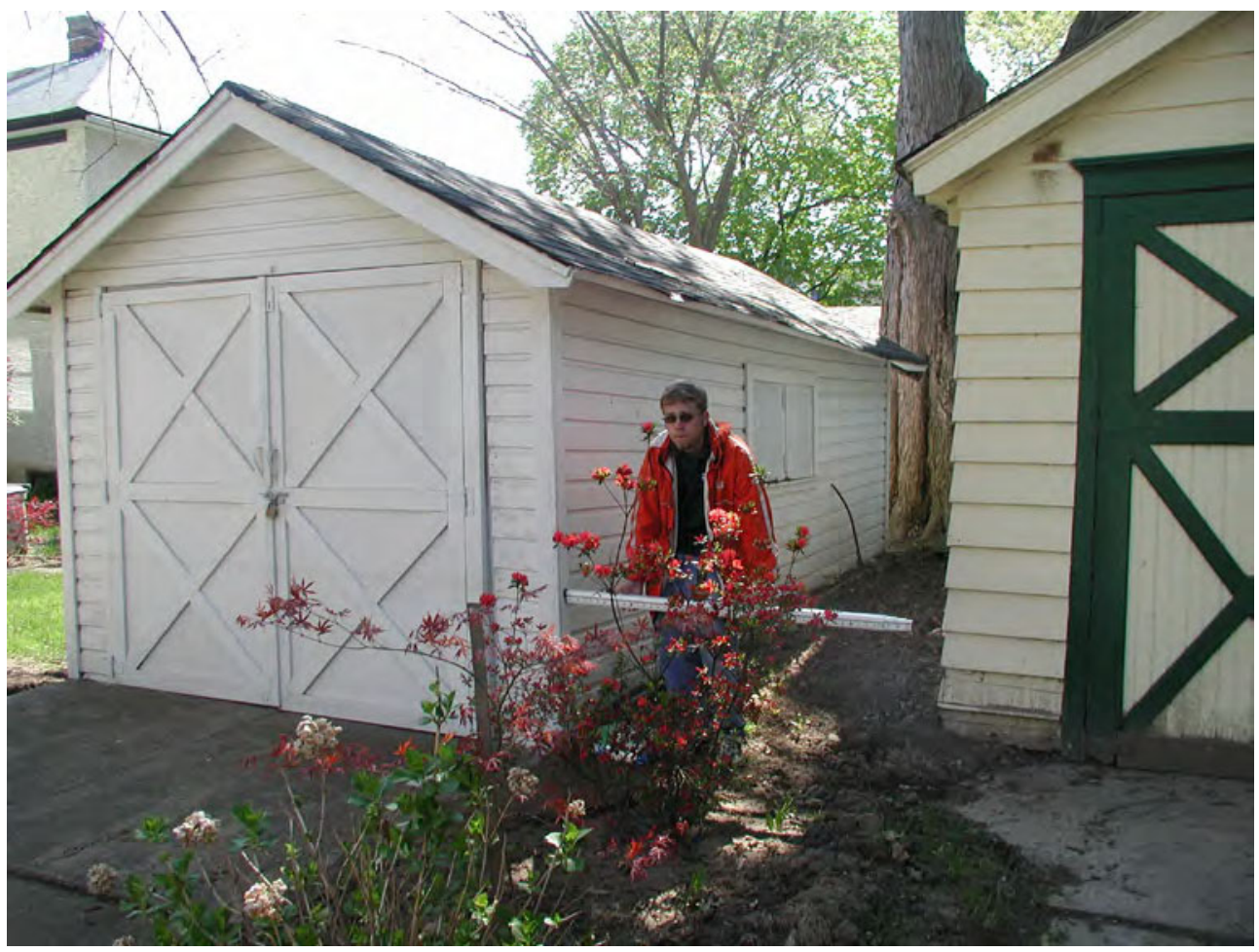

High-water mark NJ 24.2 (lat 40 $14^{\prime} 05.5^{\prime \prime}$, long $74^{\circ} 48^{\prime} 04.4^{\prime \prime}$ ), at an elevation of 30.9 feet above NGVD 29, is an excellent mud line on a garage at the intersection of Columbia Avenue and Bloomfield Avenue, 1.6 miles upstream from the Calhoun Street bridge, and was marked with a metal USGS washer and nail. 


\begin{tabular}{|l|}
\hline \multicolumn{1}{|c|}{ SITE DESCRIPTION } \\
\hline Site NJ 25: 01463500 Delaware River at Trenton, NJ \\
\hline Site Location: 0.4 mi reach in vicinity of lat $40^{\circ} 13^{\prime} 18^{\prime \prime}$, long $74^{\circ} 46^{\prime} 41^{\prime \prime}$ \\
\hline Trenton City, Mercer County, NJ \\
\hline Four high-water marks were surveyed: two seed lines, one mud line, and one debris line. \\
\hline $\begin{array}{l}\text { High-water mark elevations were determined using USGS reference mark } 202 \text { at lat } 40^{\circ} 13^{\prime} 23.2^{\prime \prime}, \\
\text { long } 74^{\circ} 46^{\prime} 46.1^{\prime \prime} \text { (elevation is } 25.76 \text { feet above NAVD } 88 \text { ). }\end{array}$ \\
\hline
\end{tabular}

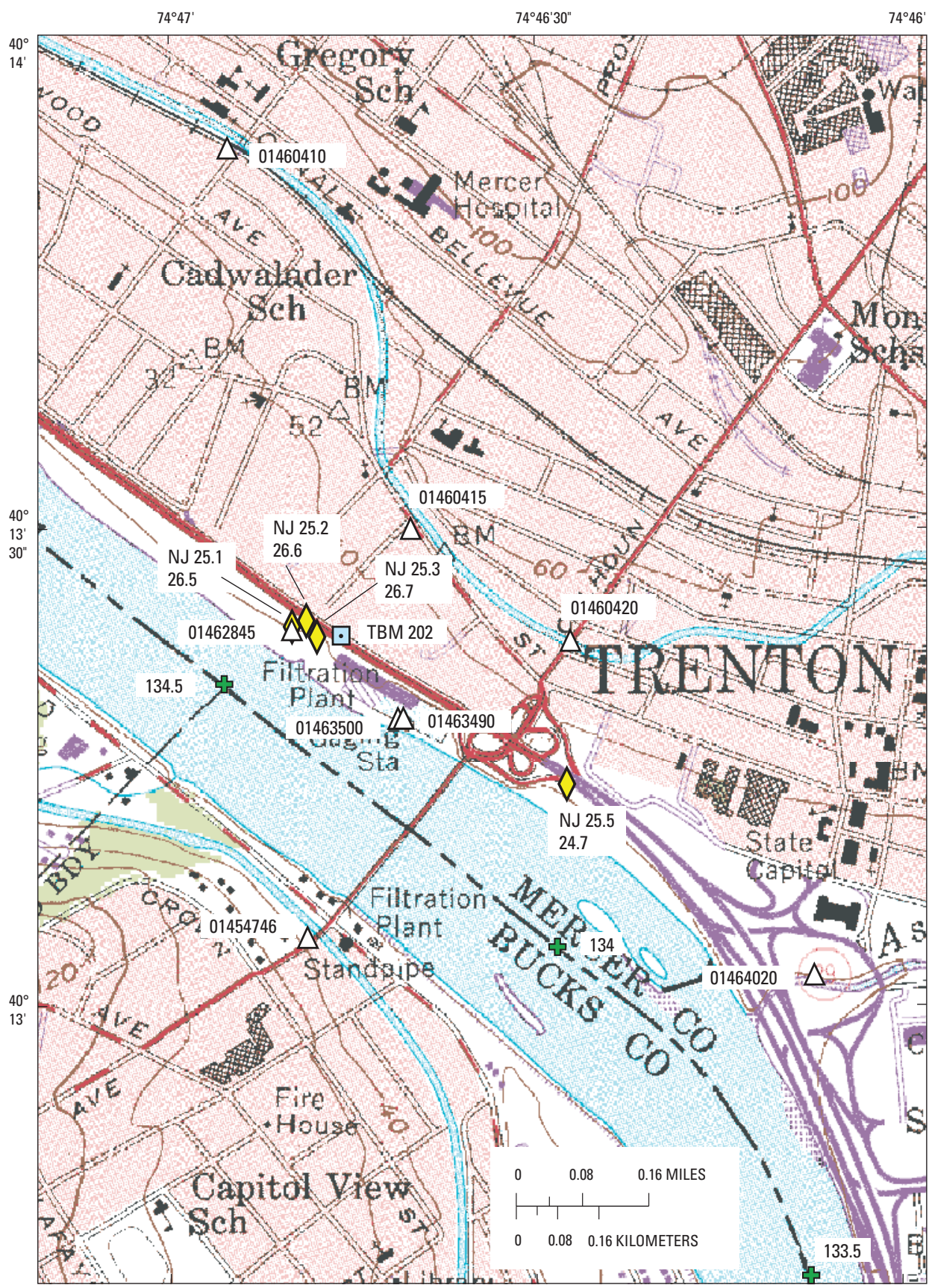

EXPLANATION

$01462845 \triangle$ U.S. Geological Survey stream gage and number

NJ $25.5 \bigcirc$ Site of high-water mark from flood of April 2-4, 2005, and elevation in feet above NGVD 29

TBM 202 U.S. Geological Survey reference mark

134.5 Ð Distance along Delaware River from mouth, in miles (Delaware River Basin Commission, 1988)

Trenton West USGS 7.5' Topographic Quadrangle map showing location of site NJ 25, Delaware River at Trenton, NJ. 


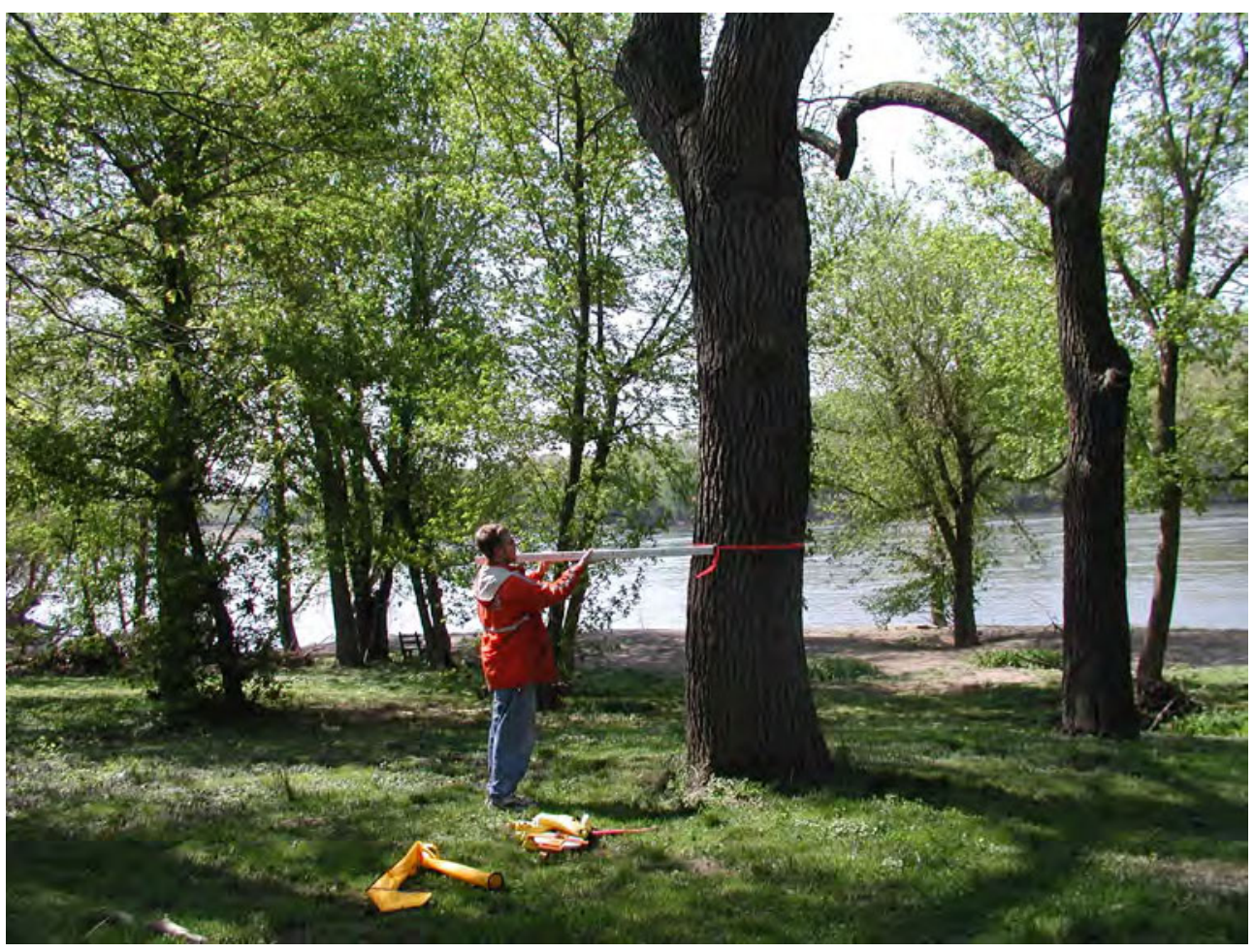

High-water mark NJ 25.1 (lat $40^{\circ} 13^{\prime} 24.0^{\prime \prime}$, long 74 46' 50.0"), at an elevation of 26.5 feet above NGVD 29, is a fair seed line on a 2.3-foot diameter tree, 1,300 feet upstream from the Calhoun Street bridge, and was marked with a metal USGS washer and nail.

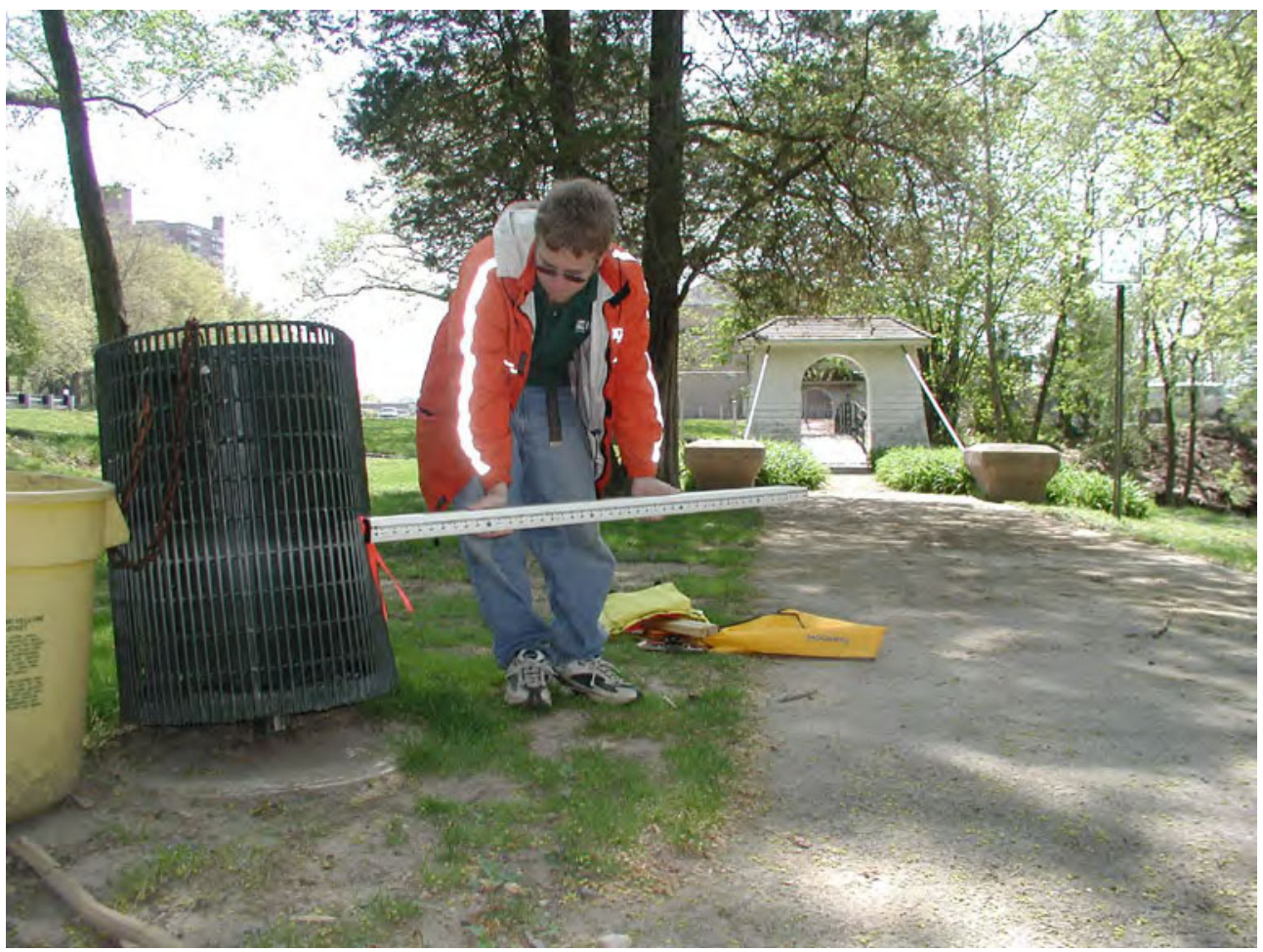

High-water mark NJ 25.2 (lat $40^{\circ} 13^{\prime} 24.4^{\prime \prime}$, long $74^{\circ} 46^{\prime} 48.8^{\prime \prime}$ ), at an elevation of 26.6 feet above NGVD 29, is an excellent mud line on an anchored garbage can holder, 1,330 feet upstream from the Calhoun Street bridge, and was marked with a black marker line. 


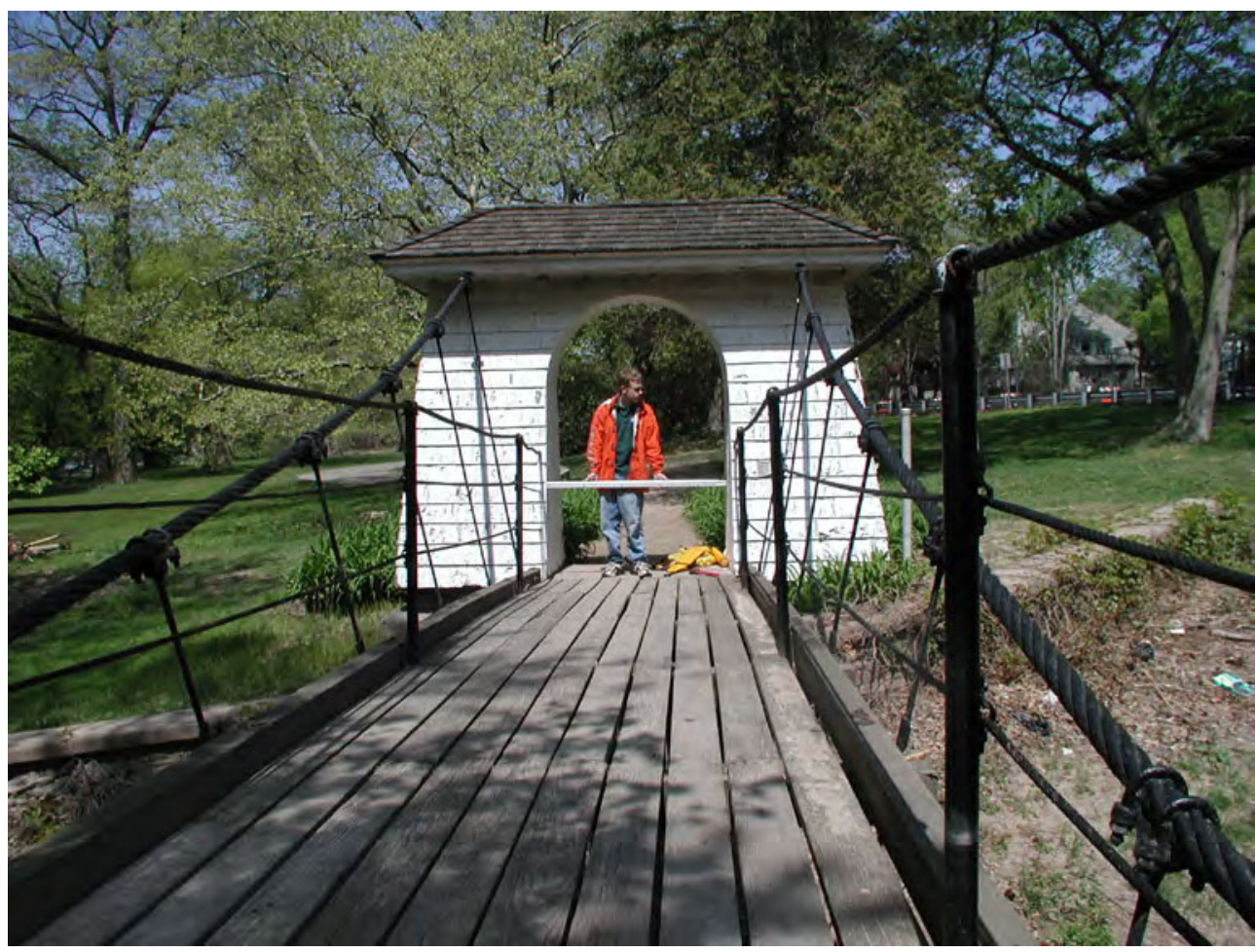

High-water mark NJ 25.3 (lat $40^{\circ} 13^{\prime} 23.4^{\prime \prime}$, long $74^{\circ} 46^{\prime} 48.0^{\prime \prime}$ ), at an elevation of 26.7 feet above NGVD 29, is an excellent seed line on the upstream archway for foot bridge, 1,230 feet upstream from the Calhoun Street bridge, and was marked with a metal USGS washer and nail.

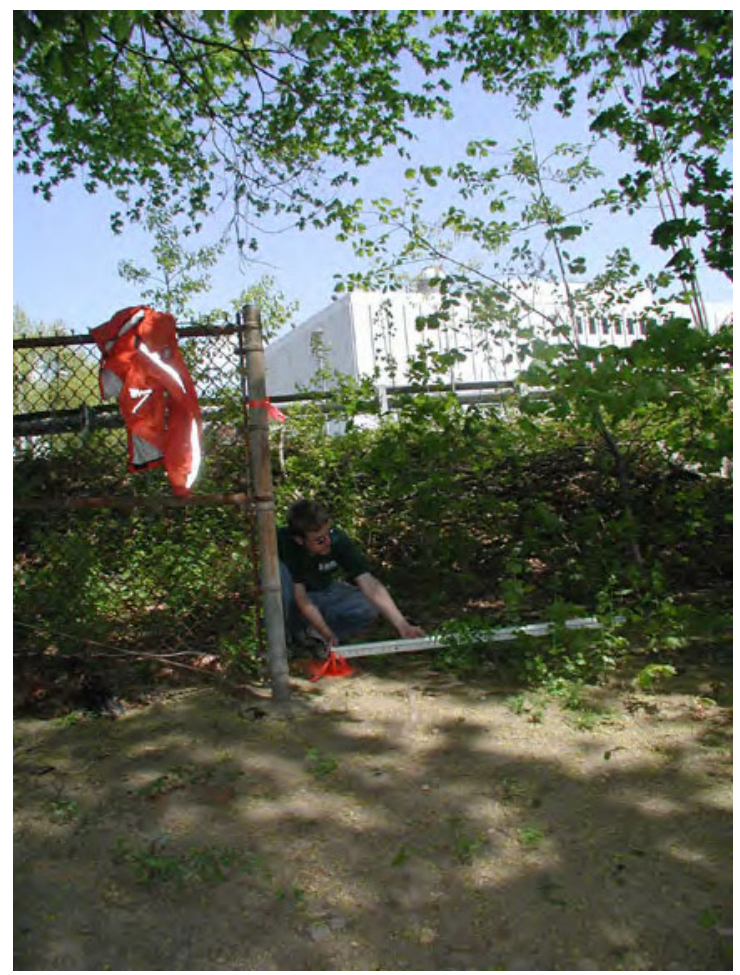

High-water mark NJ 25.5 (lat $40^{\circ} 13^{\prime} 14.1^{\prime \prime}$, long $74^{\circ} 46^{\prime} 27.6^{\prime \prime}$ ), at an elevation of 24.7 feet above NGVD 29 , is a good debris line on the embankment near State Route 29, 620 feet downstream from the Calhoun Street bridge, and was marked with a metal rebar. 


\begin{tabular}{|c|}
\hline SITE DESCRIPTION \\
\hline Site NJ 26: 01464030 Delaware River at US Route 1 Bridge at Trenton, NJ \\
\hline Site Location: 0.2 mi reach in vicinity of lat $40^{\circ} 12^{\prime} 32^{\prime \prime}$, long $74^{\circ} 46^{\prime} 03^{\prime \prime}$ \\
\hline Trenton City, Mercer County, NJ \\
\hline Three high-water marks were surveyed: three debris lines. \\
\hline $\begin{array}{l}\text { High-water mark elevations were determined using USGS reference mark } 203 \text { at lat } 40^{\circ} 12^{\prime} 33.0^{\prime \prime} \text {, } \\
\text { long } 74^{\circ} 45^{\prime} 59.6^{\prime \prime} \text { (elevation is } 16.18 \text { feet above NAVD 88). }\end{array}$ \\
\hline
\end{tabular}

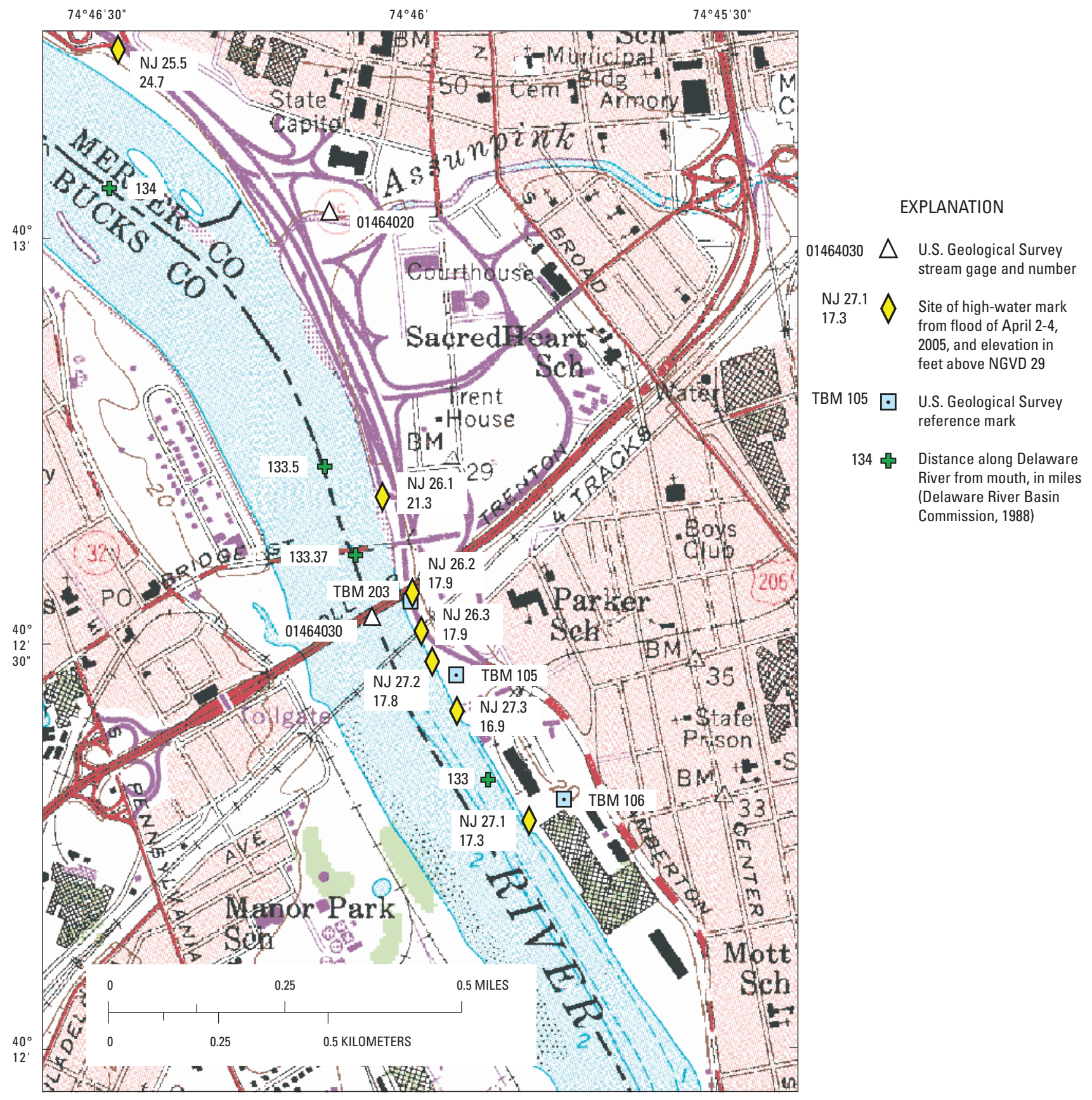

Trenton West USGS 7.5' Topographic Quadrangle map showing location of site NJ 26, Delaware River at US Route 1 Bridge at Trenton, NJ. 


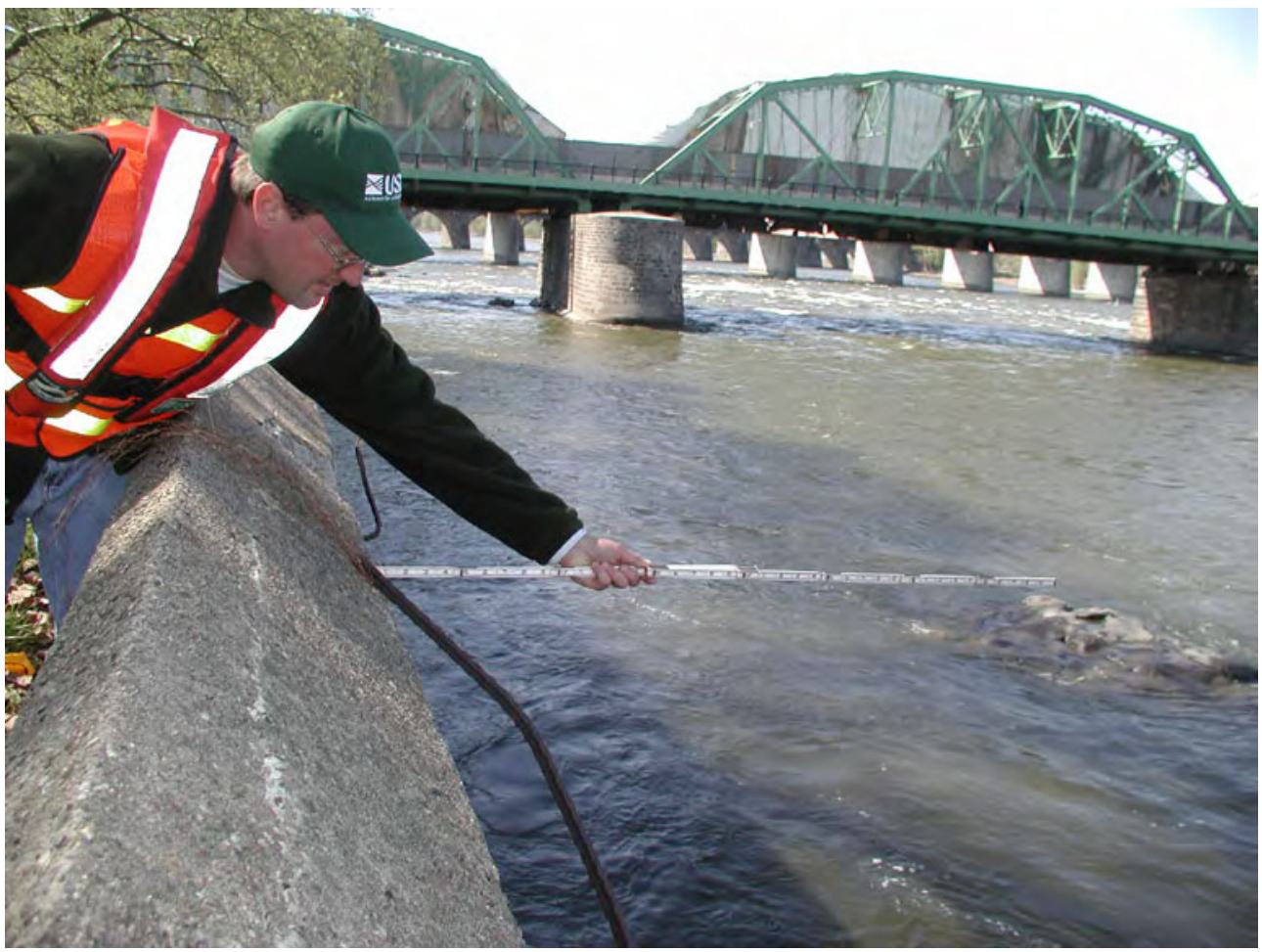

High-water mark NJ 26.1 (lat $40^{\circ} 12^{\prime} 41.0^{\prime \prime}$, long $74^{\circ} 46^{\prime} 02.2^{\prime \prime}$ ), at an elevation of 21.3 feet above NGVD 29 , is a poor debris line on a retaining wall, 680 feet upstream from the US Route 1 bridge, and was marked with a metal USGS washer and nail.

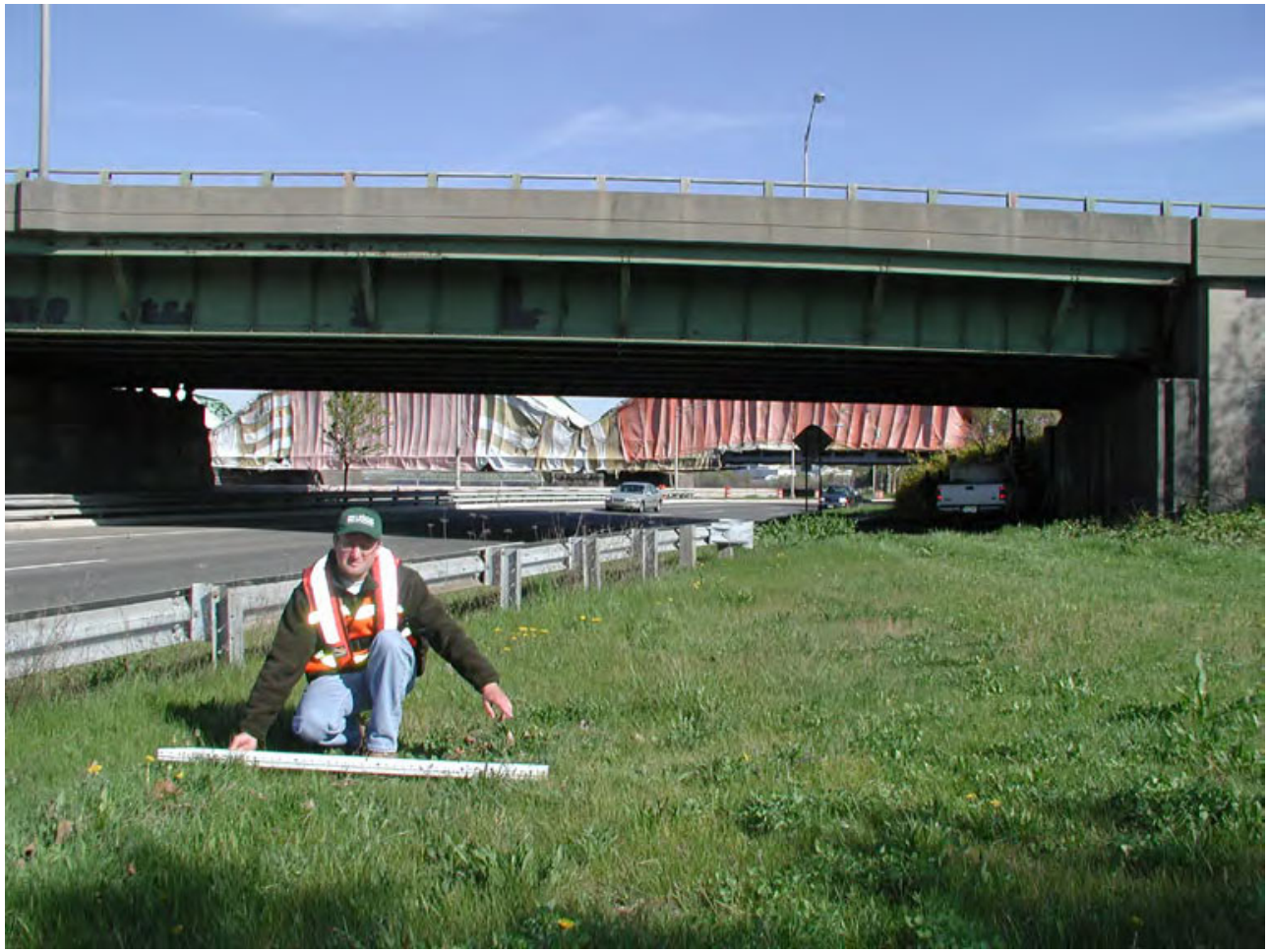

High-water mark NJ 26.2 (lat $40^{\circ} 12^{\prime} 33.9^{\prime \prime}$, long $74^{\circ} 45^{\prime} 59.3^{\prime \prime}$ ), at an elevation of 17.9 feet above NGVD 29 , is a fair debris line on the highway median, 81 feet upstream from the US Route 1 bridge, and was marked with a metal rebar. 


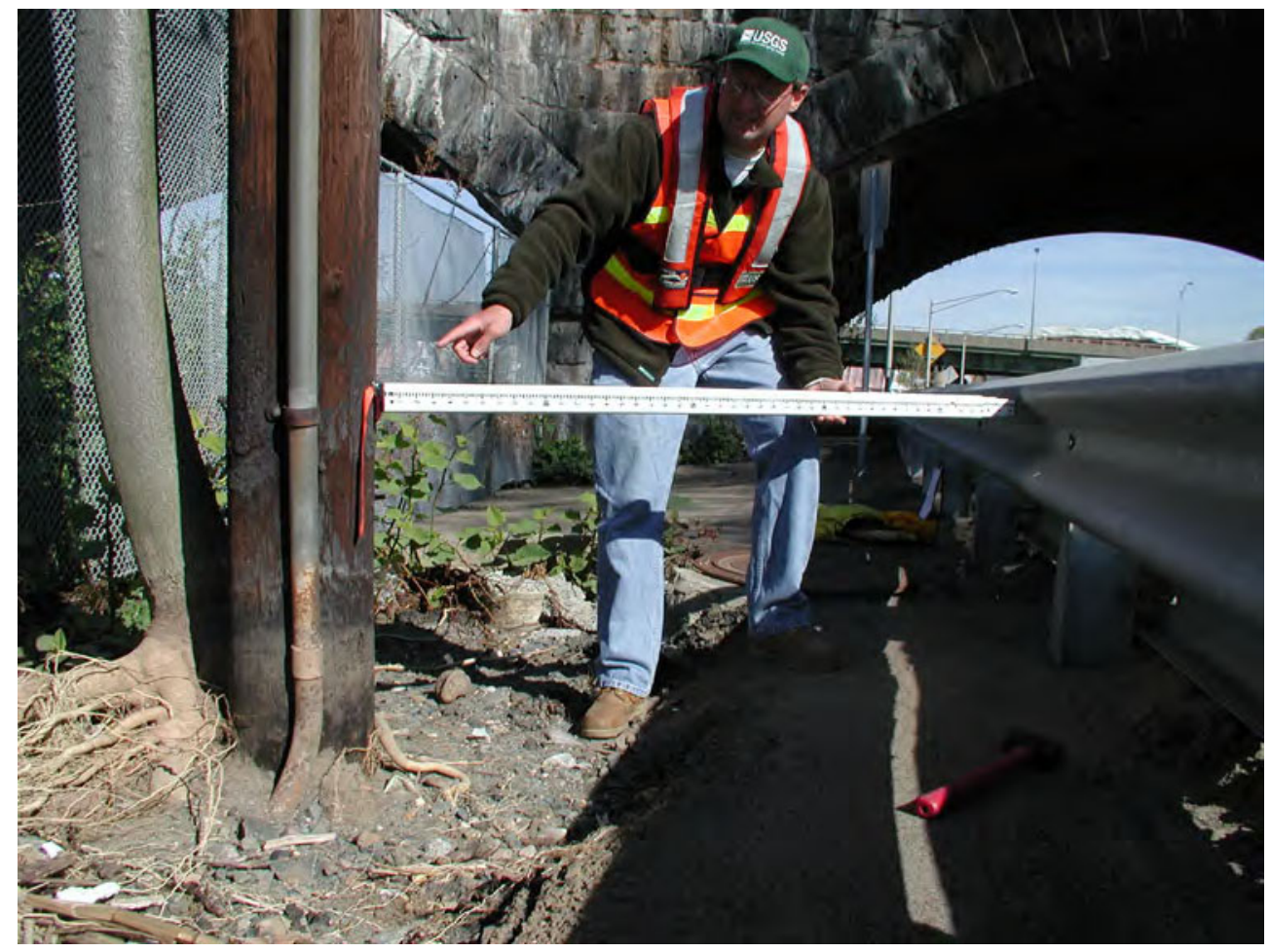

High-water mark NJ 26.3 (lat 40 $12^{\prime} 31.1^{\prime \prime}$, long $74^{\circ} 45^{\prime} 58.4^{\prime \prime}$ ), at an elevation of 17.9 feet above NGVD 29 , is a fair debris line on a fence just downstream from the Amtrak rail line, and 310 feet downstream from the US Route 1 bridge. NOTE: The mark was transferred from the fence to utility pole \# 12098TN and marked with a metal USGS washer and nail. 


\section{SITE DESCRIPTION}

Site NJ 27: Delaware River 1,000 feet downstream of US Route 1 Bridge at Trenton, NJ

Site Location: 0.3 mi reach in vicinity of lat $40^{\circ} 12^{\prime} 29^{\prime \prime}$, long $74^{\circ} 45^{\prime} 57^{\prime \prime}$

Trenton City, Mercer County, NJ

Three high-water marks were surveyed: one debris line, one seed line, and one wash line.

High-water mark elevations were determined using USGS reference 105 at lat $40^{\circ} 12^{\prime} 27.6^{\prime \prime}$,

long $74^{\circ} 45^{\prime} 55.2^{\prime \prime}$ (elevation is 15.99 feet above NAVD 88) and USGS reference mark 106 at

lat $40^{\circ} 12^{\prime} 18.4^{\prime \prime}$, long $74^{\circ} 45^{\prime} 44.8^{\prime \prime}$ (elevation is 20.25 feet above NAVD 88 ).

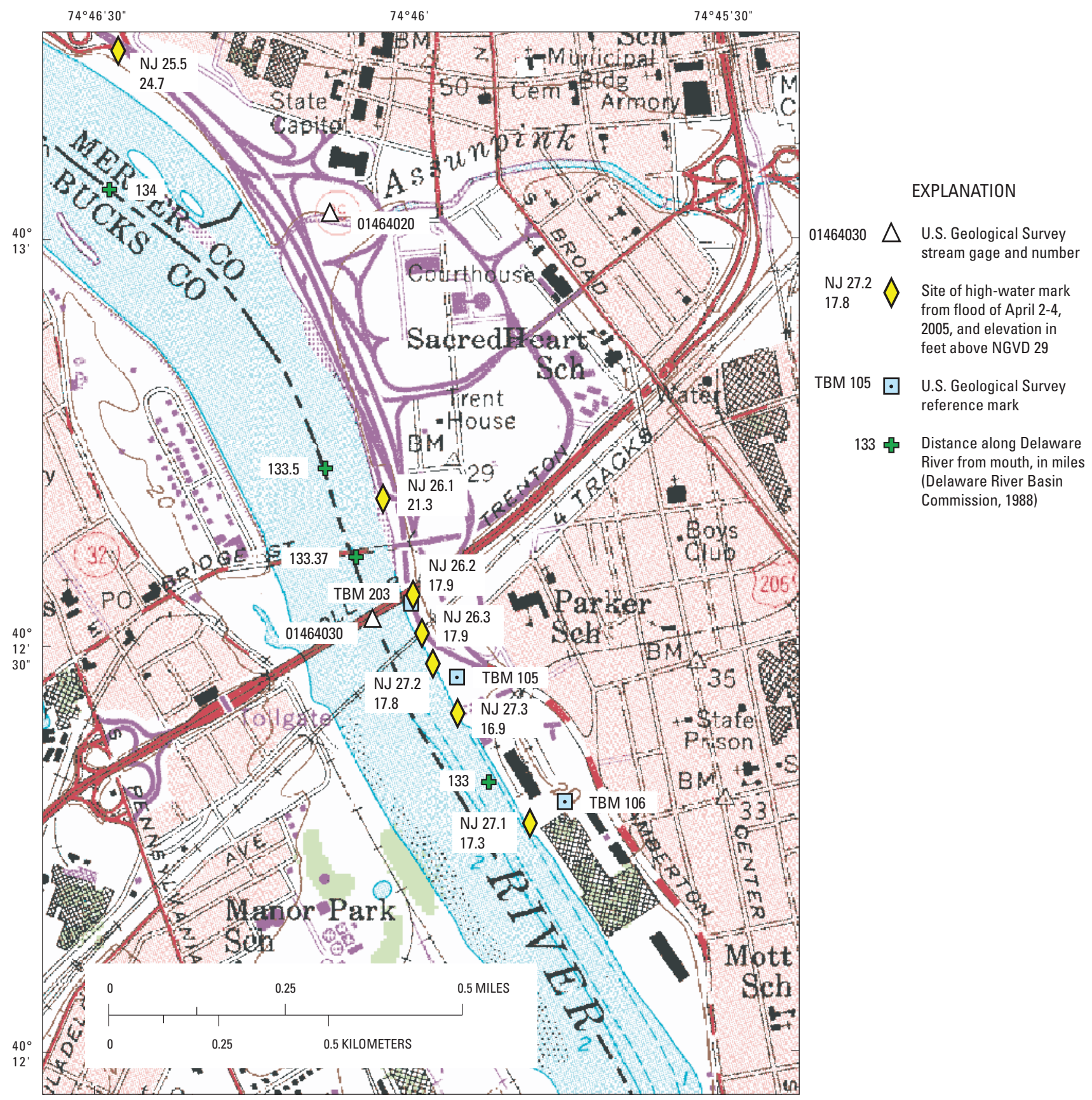

Trenton West USGS 7.5' Topographic Quadrangle map showing location of site NJ 27, Delaware River 1,000 feet downstream of US Route 1 Bridge at Trenton, NJ. 


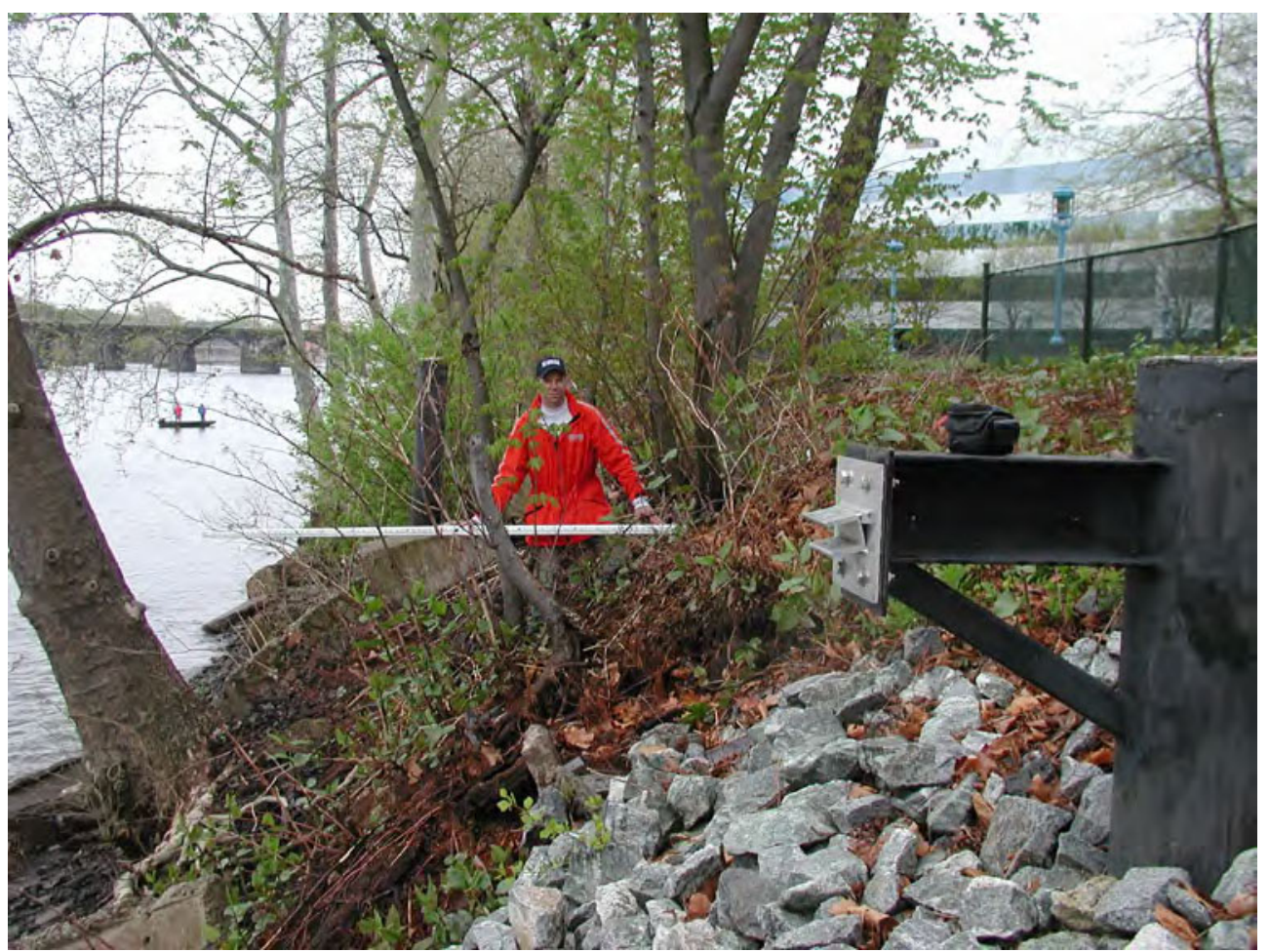

High-water mark NJ 27.1 (lat $40^{\circ} 12^{\prime} 17.1^{\prime \prime}$, long $74^{\circ} 45^{\prime} 48.1^{\prime \prime}$ ), at an elevation of 17.3 feet above NGVD 29, is a fair debris line at the base of a 1.0-foot diameter tree near top of bank, 1,800 feet downstream from the US Route 1 bridge, and was marked with a metal USGS washer and nail.

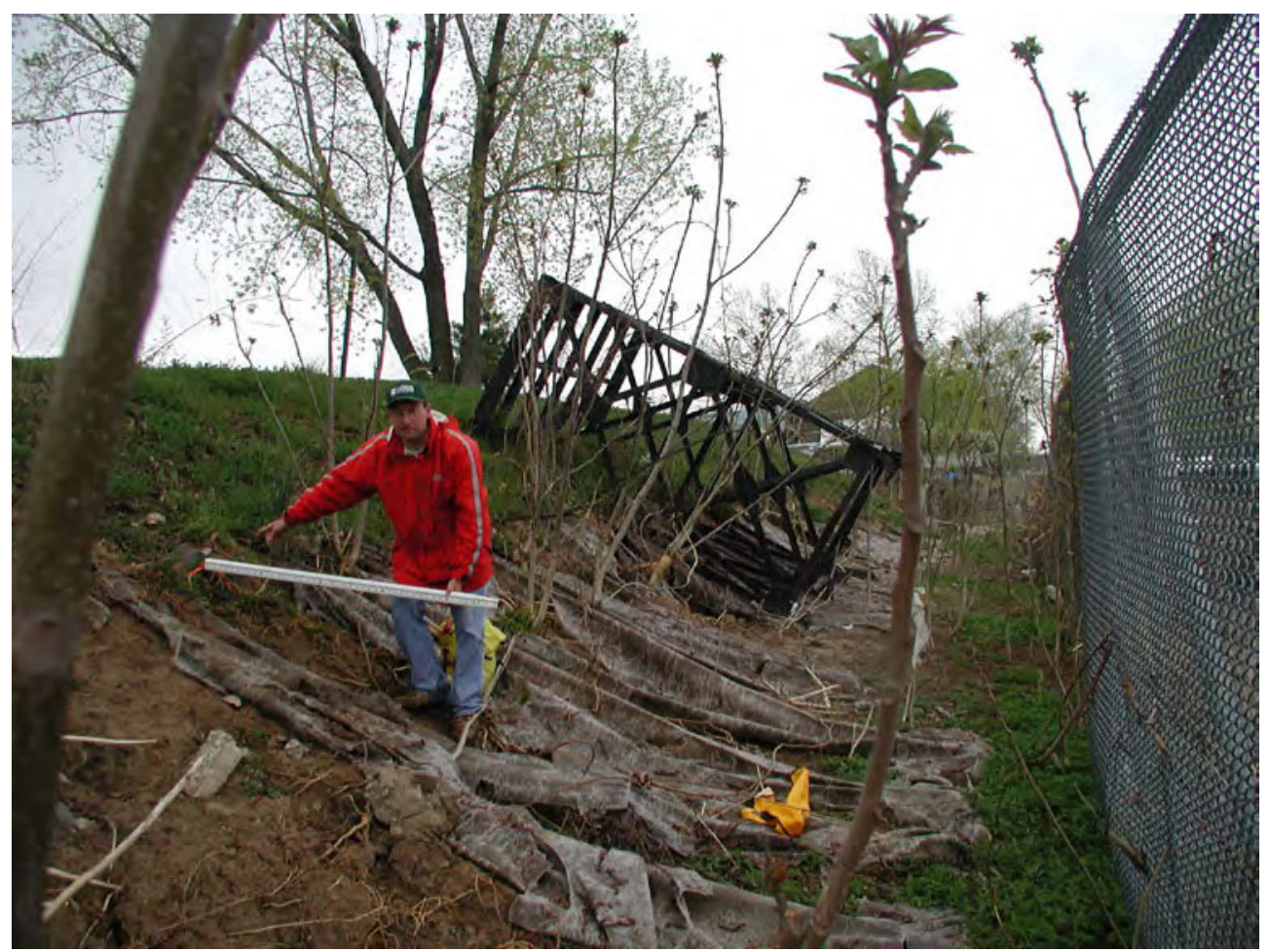

High-water mark NJ 27.2 (lat $40^{\circ} 12^{\prime} 28.9^{\prime \prime}$, long $74^{\circ} 45^{\prime} 57.4^{\prime \prime}$ ), at an elevation of 17.8 feet above NGVD 29, is a fair wash line on embankment, 500 feet downstream from the US Route 1 bridge, and was marked with a metal rebar. 


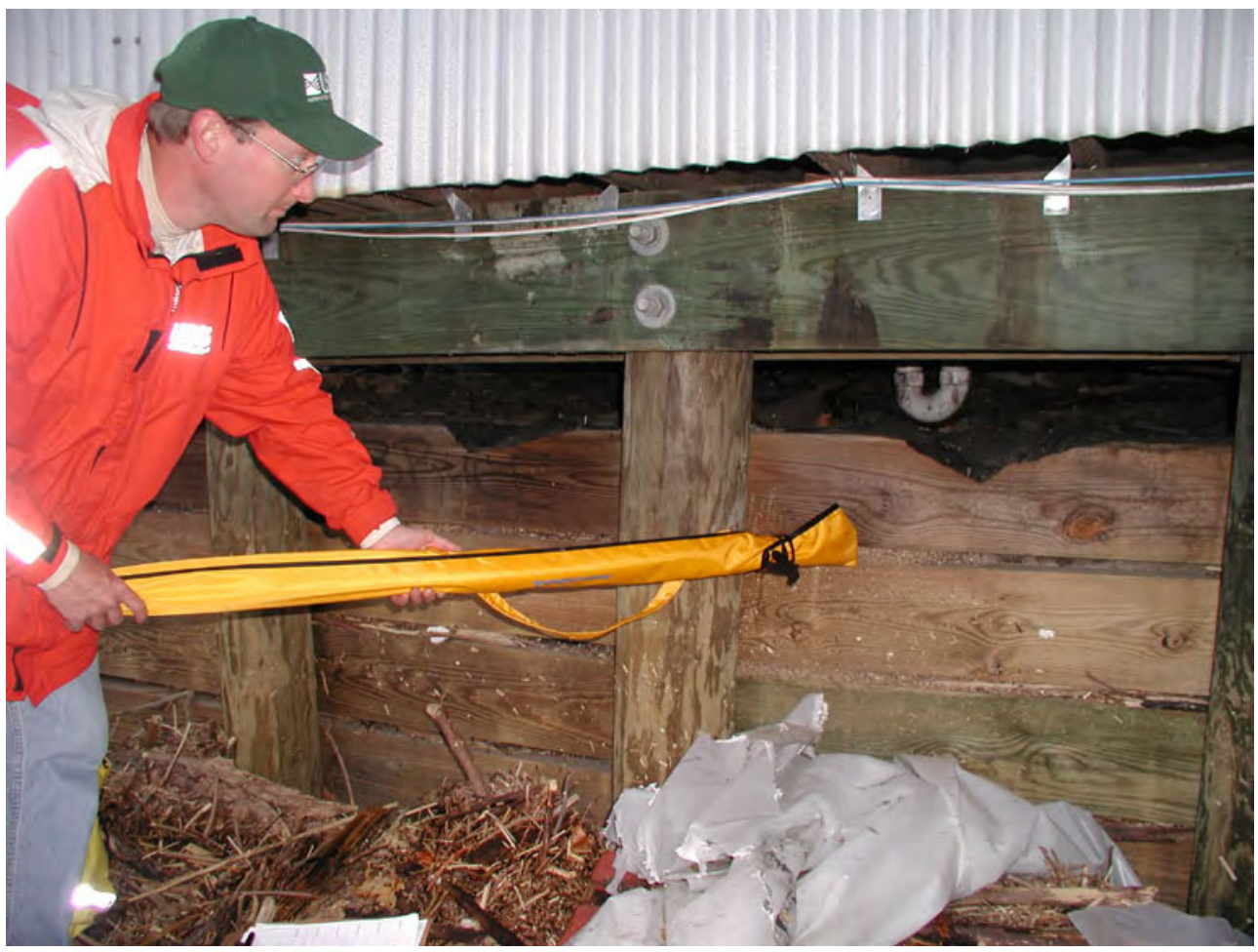

High-water mark NJ 27.3 (lat $40^{\circ} 12^{\prime} 25.2^{\prime \prime}$, long $74^{\circ} 45^{\prime} 55.1^{\prime \prime}$ ), at an elevation of 16.9 feet above NGVD 29, is a good seed line on the deck of a restaurant (Kat Man Du), 1,000 feet downstream from the US Route 1 bridge. NOTE: The mark was transferred from under the deck to a 2-foot diameter tree nearby and marked with a metal USGS washer and nail (transferred mark on tree is about 7 feet above the ground). 


\begin{tabular}{|l|}
\hline SITE DESCRIPTION \\
\hline Site NJ 28: 01464040 Delaware River at Marine Terminal at Trenton, NJ \\
\hline Site Location: in vicinity of lat $40^{\circ} 11^{\prime} 21^{\prime \prime}$, long $74^{\circ} 45^{\prime} 21^{\prime \prime}$ \\
\hline Trenton City, Mercer County, NJ \\
\hline One high-water mark was surveyed: a cork line on USGS crest-stage gage. \\
\hline High-water mark elevation was determined using gage datum. \\
\hline
\end{tabular}

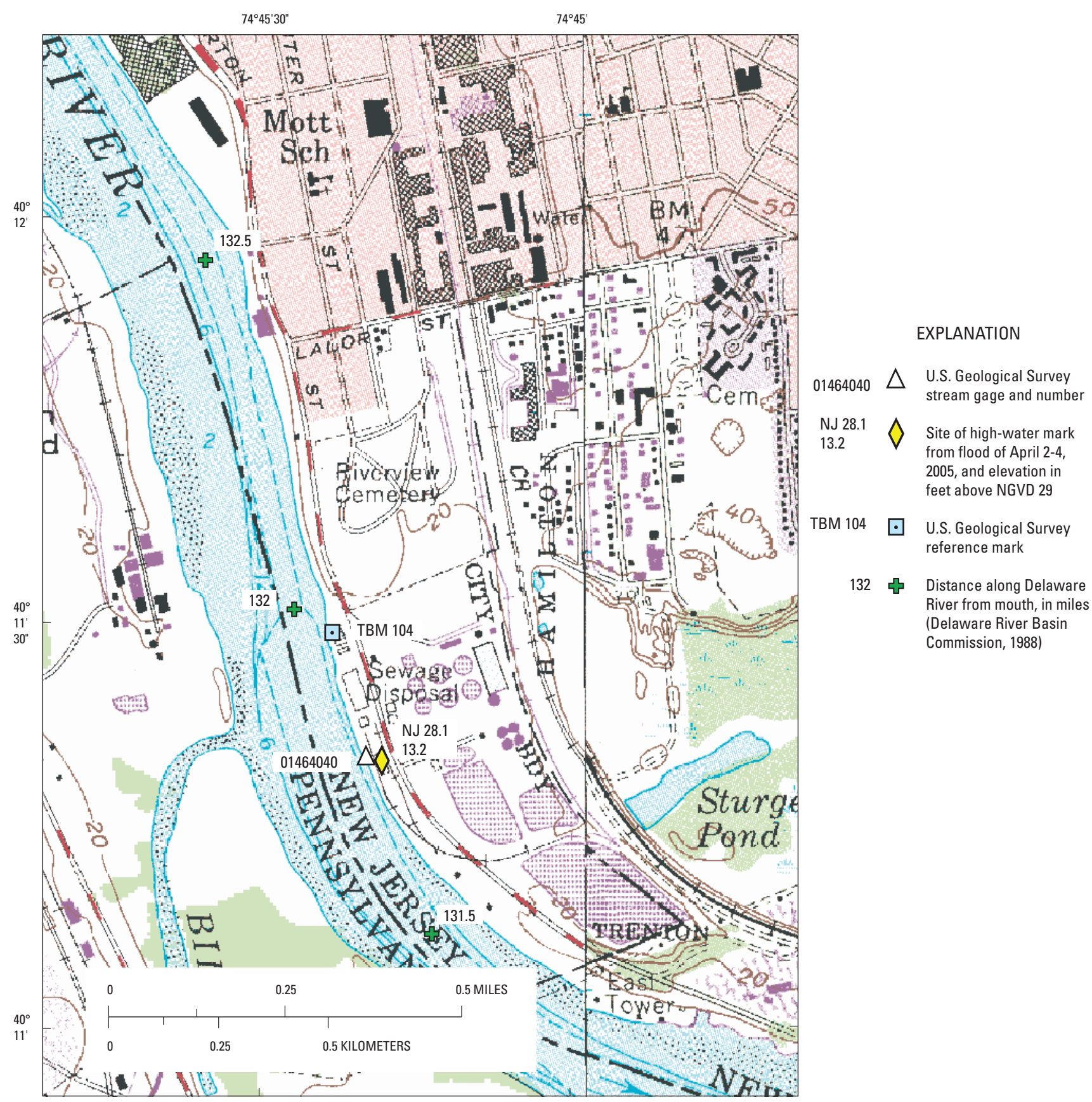

Trenton West USGS 7.5' Topographic Quadrangle map showing location of site NJ 28, Delaware River at Marine Terminal at Trenton, NJ. 


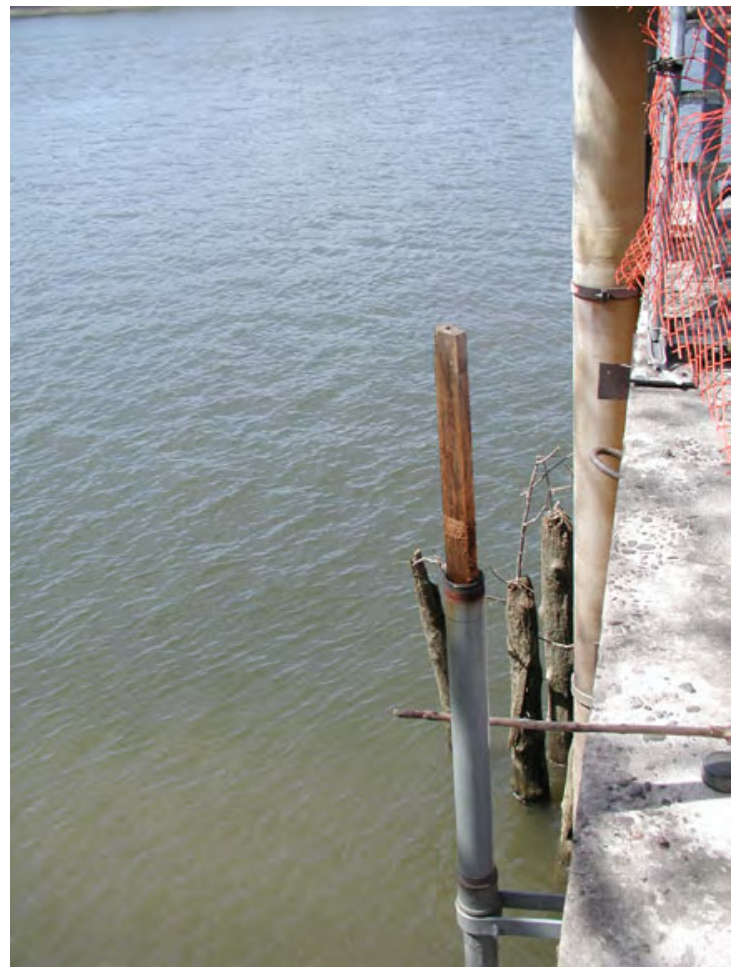

High-water mark NJ 28.1 (lat $40^{\circ} 11^{\prime} 21.4^{\prime \prime}$, long $74^{\circ} 45^{\prime} 20.6^{\prime \prime}$ ), at an elevation of 13.2 feet above NGVD 29, is an excellent cork line in the USGS crest-stage gage 01464040, on wall near Trenton Marine Terminal on Lamberton Road, 0.2 miles south from the intersection with State Route 29. 


\begin{tabular}{|c|}
\hline SITE DESCRIPTION \\
\hline Site NJ 29: Delaware River at mouth of Crosswicks Creek at Bordentown, NJ \\
\hline Site Location: 0.1 mi reach in vicinity of lat $40^{\circ} 09^{\prime} 04^{\prime \prime}$, long $74^{\circ} 42^{\prime} 56^{\prime \prime}$ \\
\hline Bordentown City, Burlington County, NJ \\
\hline Two high-water marks were surveyed: two mud lines. \\
\hline $\begin{array}{l}\text { High-water mark elevations were determined using USGS reference mark } 103 \text { at lat } 40^{\circ} 09^{\prime} 03.1^{\prime \prime} \text {, } \\
\text { long } 74^{\circ} 42^{\prime} 56.1^{\prime \prime} \text { (elevation is } 9.48 \text { feet above NAVD 88). }\end{array}$ \\
\hline
\end{tabular}

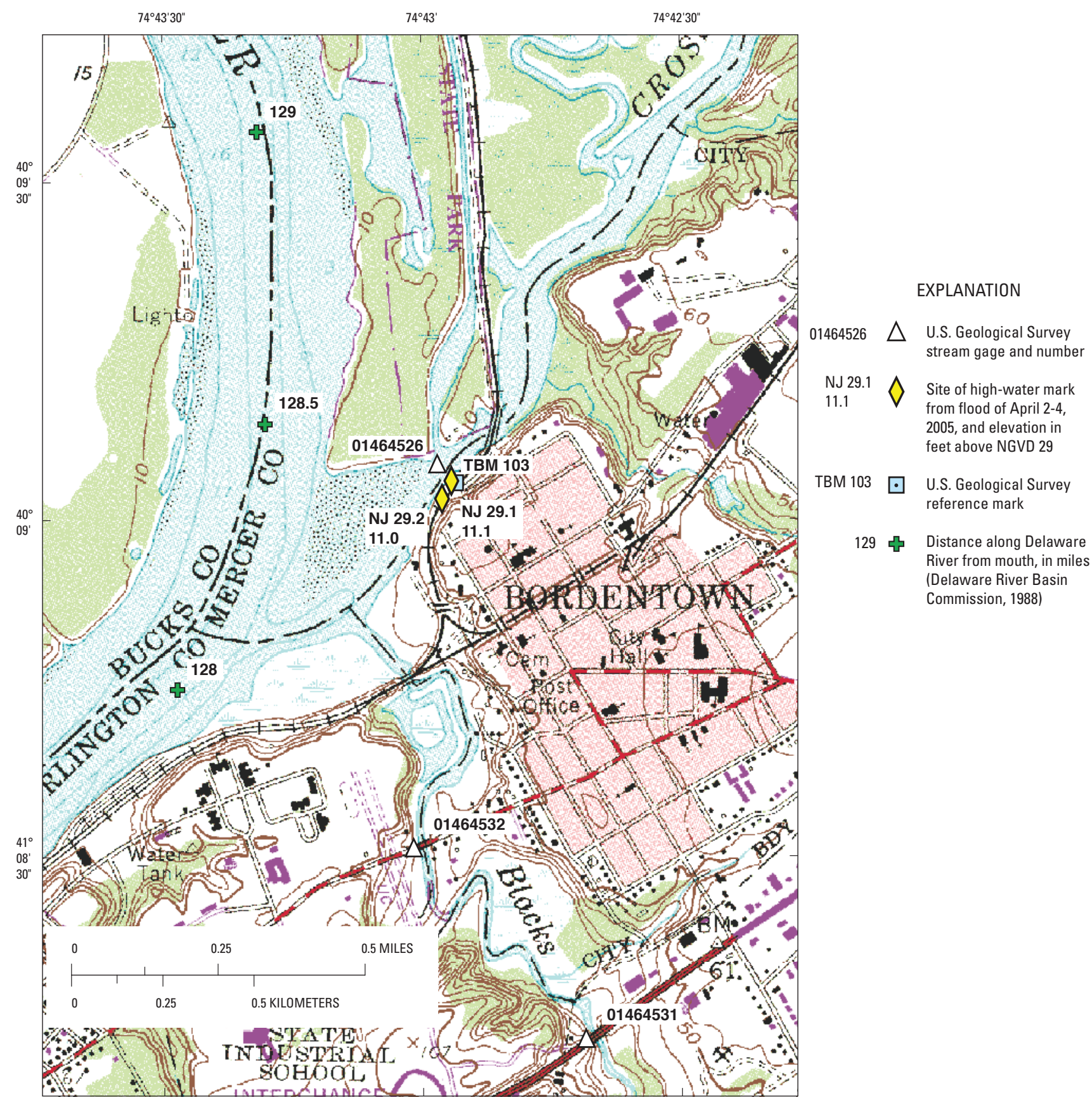

Trenton East USGS 7.5' Topographic Quadrangle map showing location of site NJ 29, Delaware River at mouth of Crosswicks creek at Bordentown, NJ. 


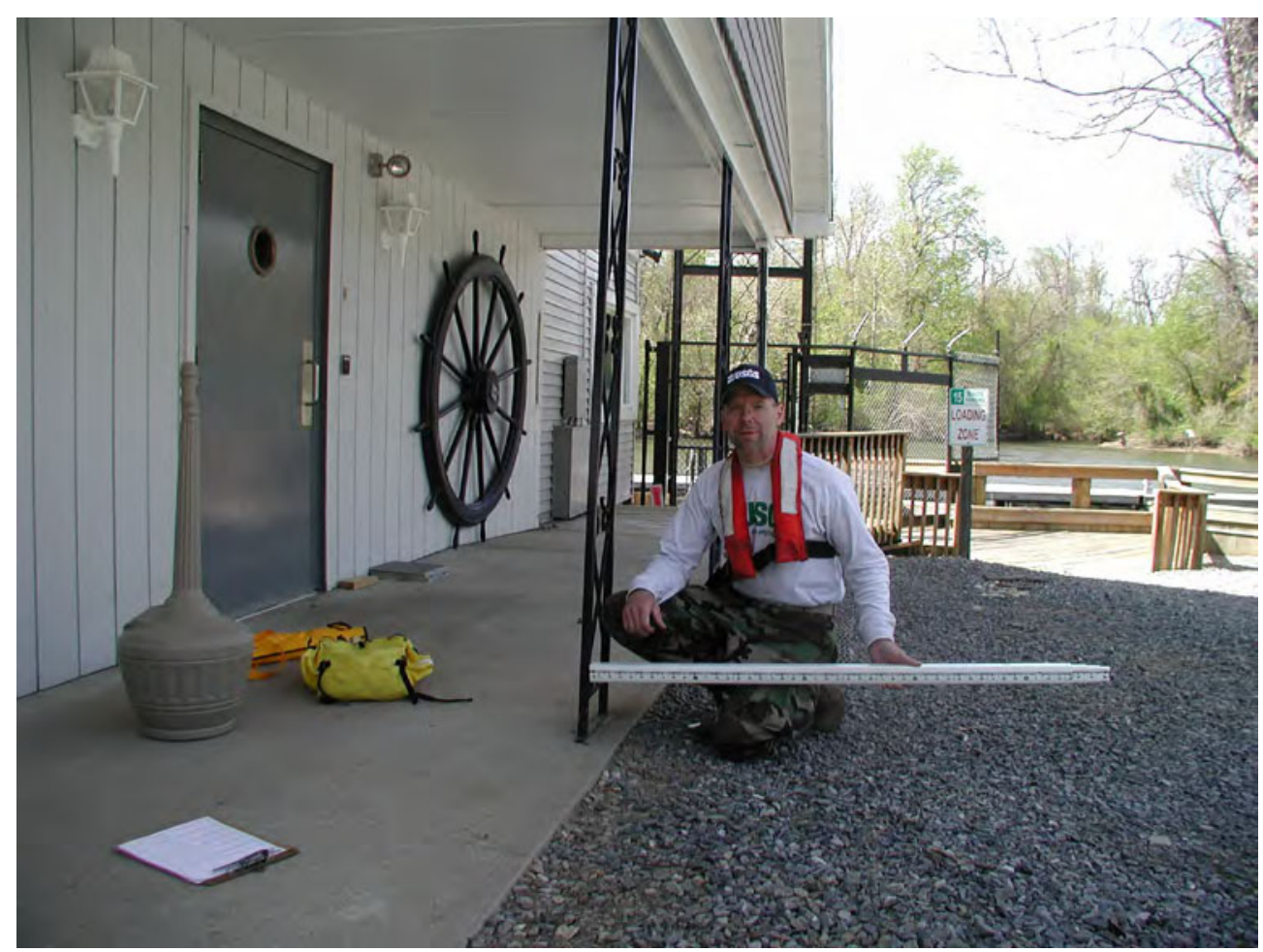

High-water mark NJ 29.1 (lat $40^{\circ} 09^{\prime} 03.7^{\prime \prime}$, long $74^{\circ} 42^{\prime} 56.0^{\prime \prime}$ ), at an elevation of 11.1 feet above NGVD 29, is an excellent mud line on the overhang support at the Bordentown Yacht Club, 0.7 feet above the ground, near the mouth of Crosswicks Creek, and was marked with a black marker line.

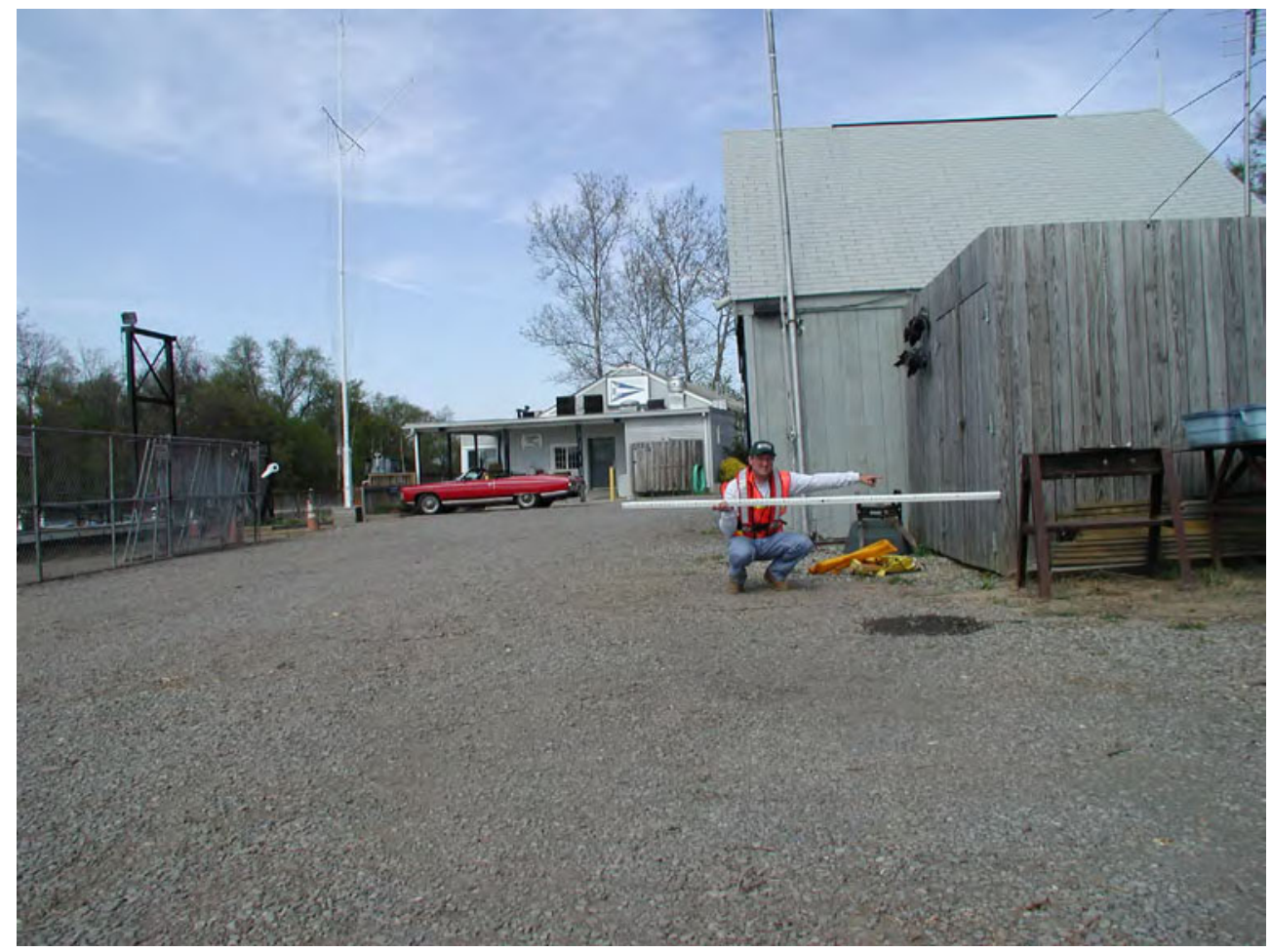

High-water mark NJ 29.2 (lat $40^{\circ} 09^{\prime} 02.0^{\prime \prime}$, long $74^{\circ} 42^{\prime} 57.8^{\prime \prime}$ ), at an elevation of 11.0 feet above NGVD 29 , is an excellent mud line on a storage facility at the Bordentown Yacht Club, 2.1 feet above the ground, across from the mouth of Crosswicks Creek, and was marked with a black marker line. 


\begin{tabular}{|c|}
\hline SITE DESCRIPTION \\
\hline Site NJ 30: 01464560 Delaware River at Florence, NJ \\
\hline Site Location: $0.3 \mathrm{mi}$ reach in vicinity of lat $40^{\circ} 07^{\prime} 34^{\prime \prime}$, long $74^{\circ} 48^{\prime} 58^{\prime \prime}$ \\
\hline Florence Township, Burlington County, NJ \\
\hline Two high-water marks were surveyed: two debris lines. \\
\hline $\begin{array}{l}\text { High-water mark elevations were determined using USGS reference mark } 101 \text { at lat } 40^{\circ} 07^{\prime} 31.9^{\prime \prime} \text {, } \\
\text { long } 74^{\circ} 48^{\prime} 48.7^{\prime \prime} \text { (elevation is } 13.38 \text { feet above NAVD } 88 \text { ) and USGS reference mark } 102 \text { at lat } \\
40^{\circ} 07^{\prime} 33.4^{\prime \prime} \text {, long } 74^{\circ} 49^{\prime} 03.9^{\prime \prime} \text { (elevation is } 11.05 \text { feet above NAVD } 88 \text { ). }\end{array}$ \\
\hline
\end{tabular}

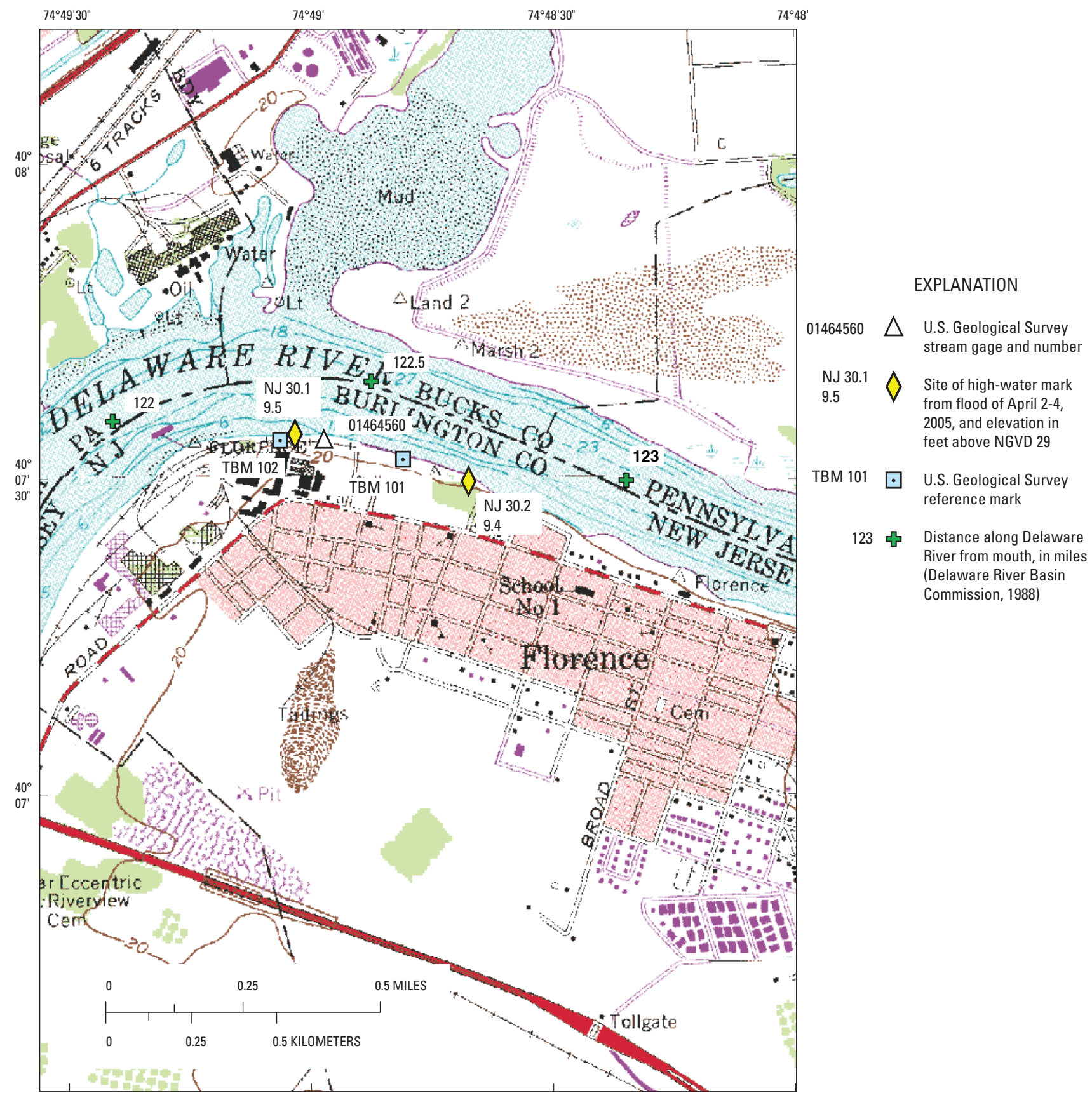

Trenton West and Bristol USGS 7.5' Topographic Quadrangle maps showing location of site NJ 30, Delaware River at Florence, NJ. 


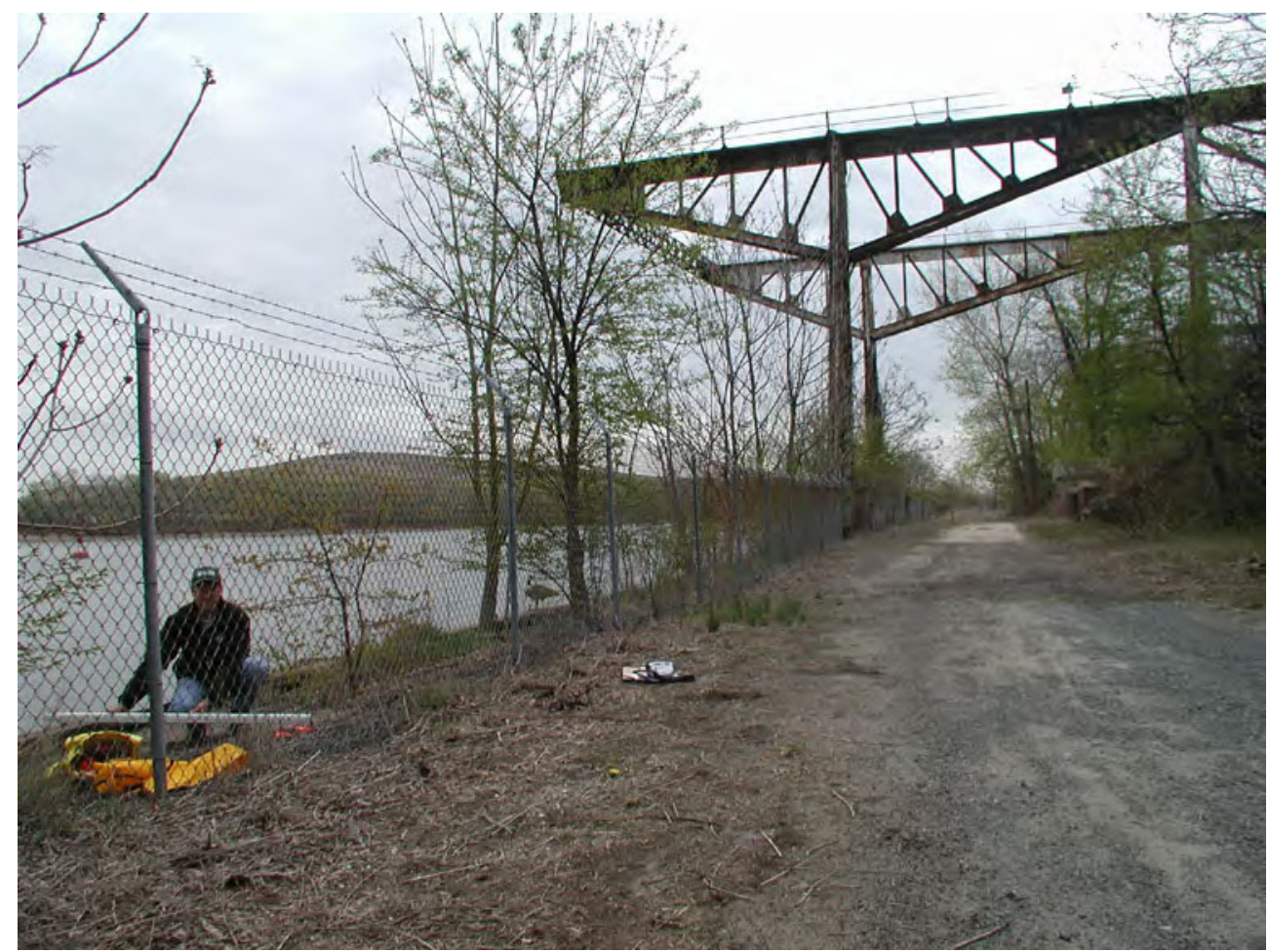

High-water mark NJ 30.1 (lat $40^{\circ} 07^{\prime} 34.4^{\prime \prime}$, long $74^{\circ} 49^{\prime} 02.0^{\prime \prime}$ ), at an elevation of 9.54 feet above NGVD 29 , is a good debris line on the ground just above the bulkhead at DC Fabricators, 1.0 miles upstream from the New Jersey Turnpike, and was marked with a metal rebar.

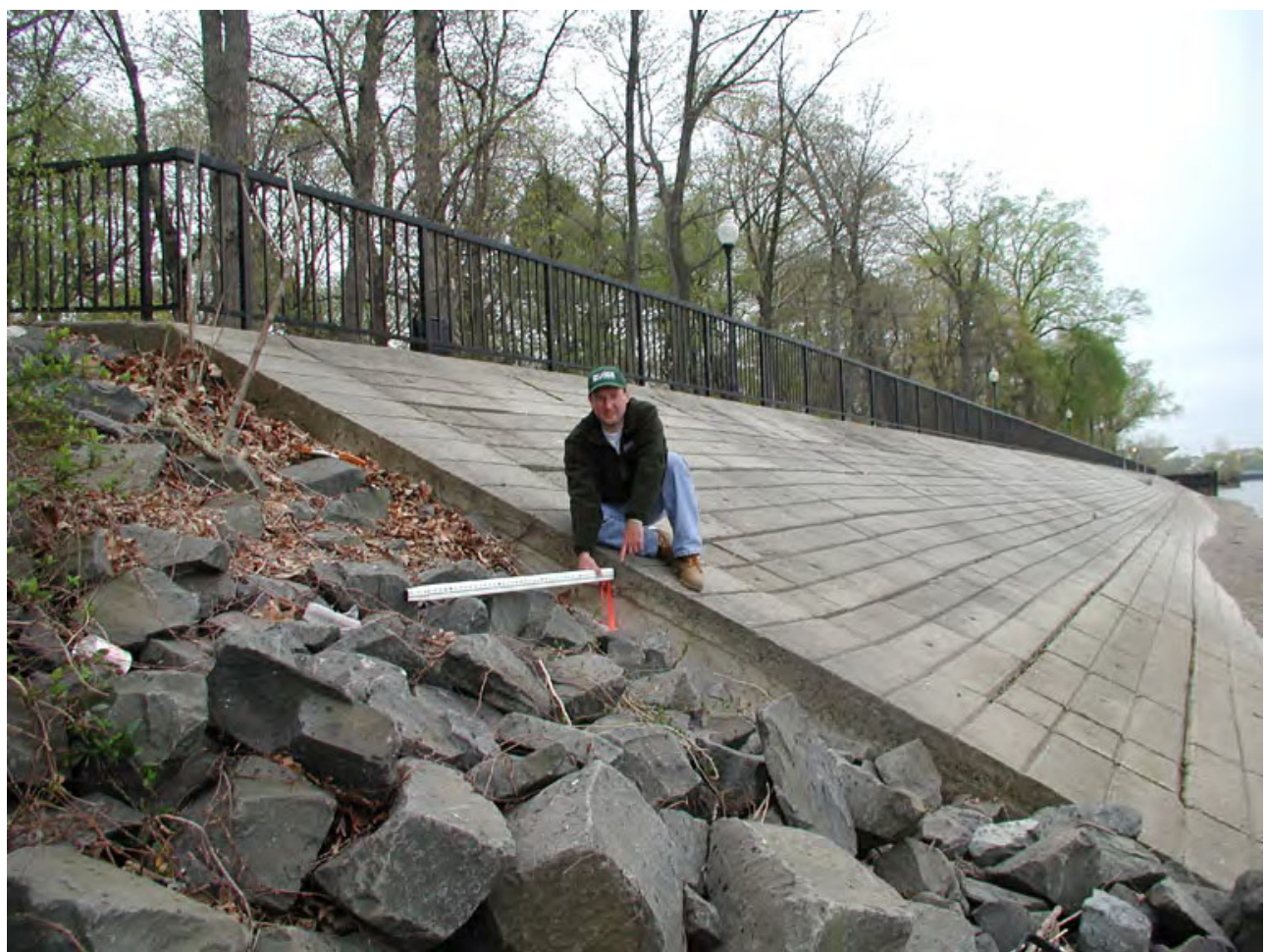

High-water mark NJ 30.2 (lat $40^{\circ} 07^{\prime} 30.0^{\prime \prime}$, long $74^{\circ} 48^{\prime} 40.5^{\prime \prime}$ ), at an elevation of 9.4 feet above NGVD 29, is a fair debris line on a sloped retaining wall at H. Kenneth Wilkie Memorial River's Edge Park, 1.4 miles upstream from the New Jersey Turnpike, and was marked with a metal USGS washer and nail. 


\section{SITE DESCRIPTION}

Site PA 32: 01463000 Delaware River at Bristol, PA

Site Location: lat $40^{\circ} 05^{\prime} 40.4^{\prime \prime}$, long $74^{\circ} 51^{\prime} 19.7^{\prime \prime}$

Bristol Borough, Bucks County, PA

One high-water mark was surveyed: one seed line.

High-water mark elevations were determined using USGS reference mark 201 at lat $40^{\circ} 05^{\prime} 38.3^{\prime \prime}$,

long $74^{\circ} 51^{\prime} 26.3^{\prime \prime}$ (elevation is 6.51 feet above NAVD 88).

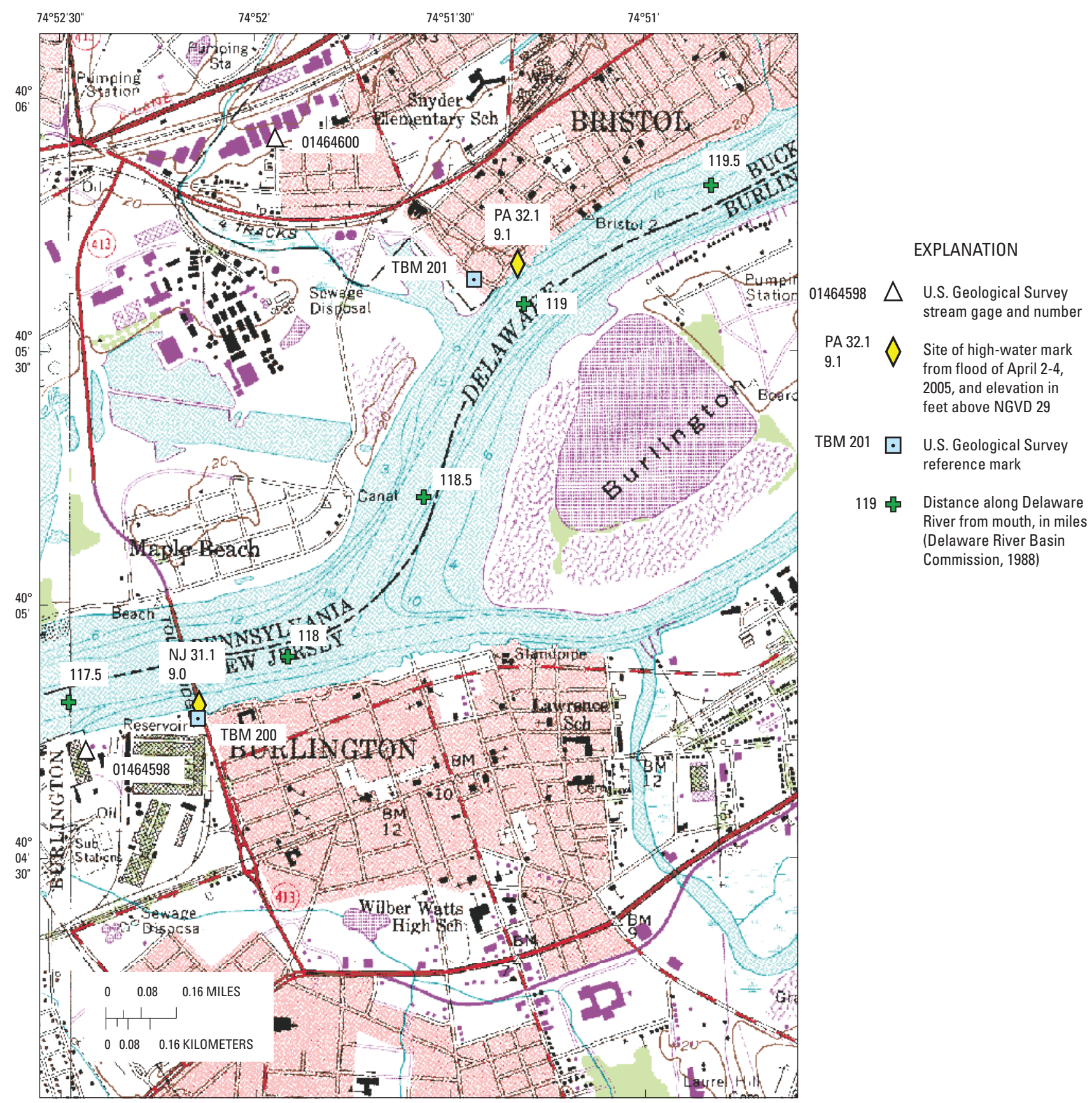

Bristol USGS 7.5' Topographic Quadrangle map showing location of site PA 32, Delaware River at Bristol, PA. 


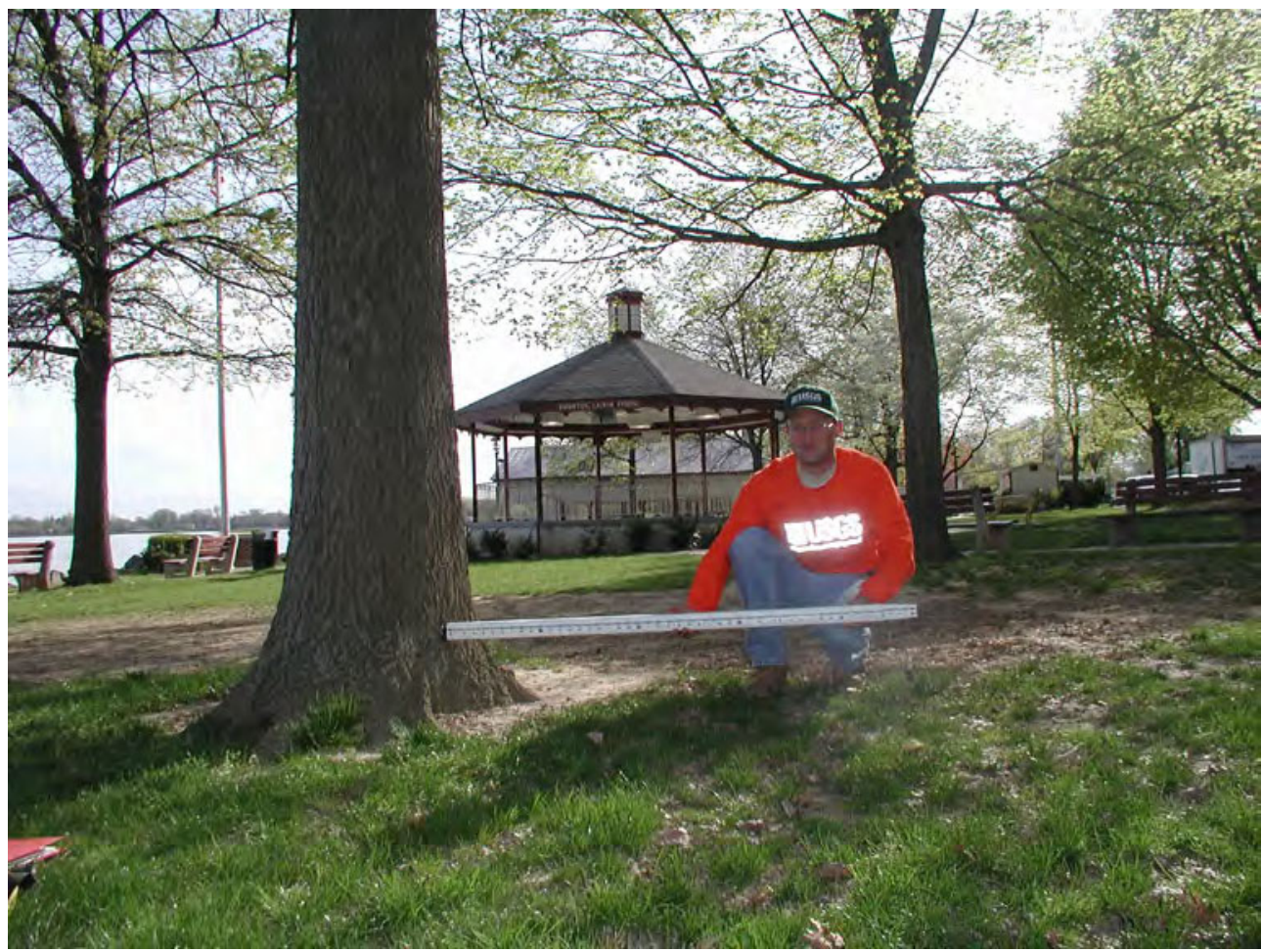

High-water mark PA 32.1 (lat $40^{\circ} 05^{\prime} 38.3^{\prime \prime}$, long $74^{\circ} 51^{\prime} 26.3^{\prime \prime}$ ) at an elevation of 9.1 feet above NGVD 29 , is a good seed line on a 2.3-foot diameter tree at Bristol Lions Park, 2.4 feet above the ground, 1.2 miles upstream from Burlington-Bristol Bridge, and was marked with a metal USGS washer and nail. 


\section{SITE DESCRIPTION}

Site NJ 31: 01464598 Delaware River at Burlington, NJ

Site Location: 0.2 mi reach in vicinity of lat $40^{\circ} 04^{\prime} 43^{\prime \prime}$, long $74^{\circ} 52^{\prime} 26^{\prime \prime}$

Burlington City, Burlington County, NJ

One high-water mark was surveyed: one seed lines.

High-water mark elevations were determined using USGS reference mark 200 at lat $40^{\circ} 04^{\prime} 46.6^{\prime \prime}$,

long $74^{\circ} 52^{\prime} 09.1^{\prime \prime}$ (elevation is 11.90 feet above NAVD 88).

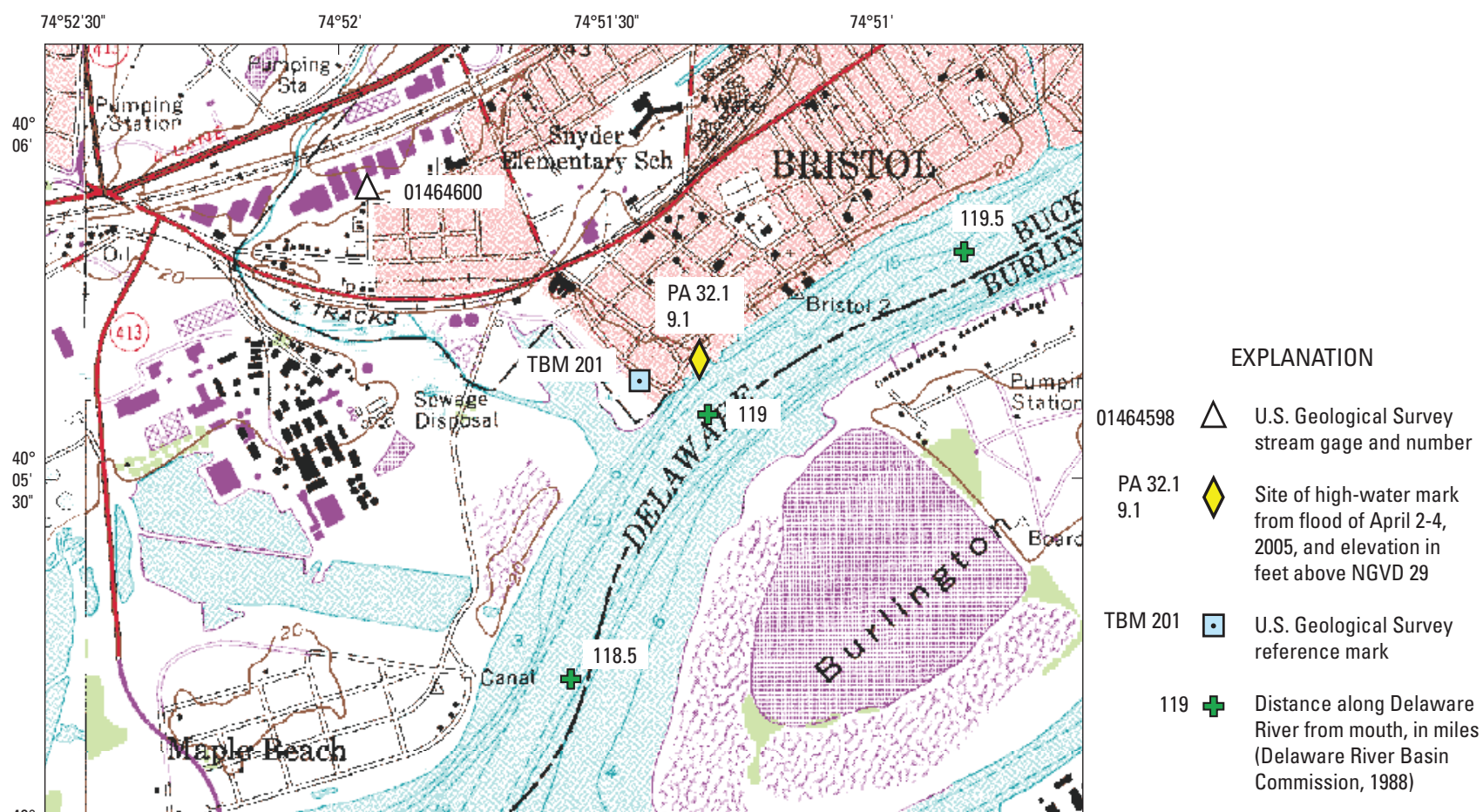

Bristol West USGS 7.5' Topographic Quadrangle map showing location of site NJ 31, Delaware River at Burlington, NJ. 


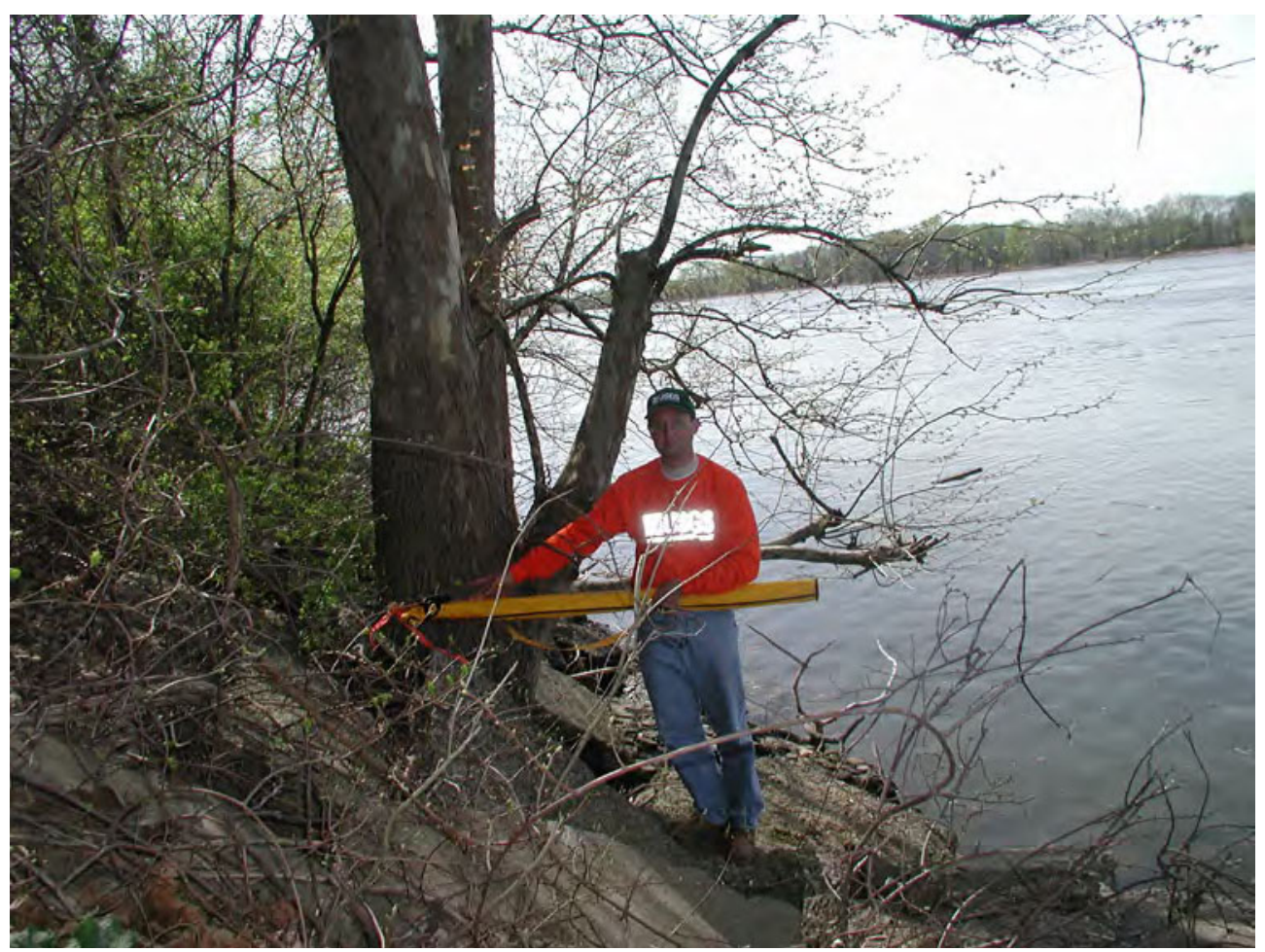

High-water mark NJ 31.1 (lat $40^{\circ} 04^{\prime} 48.4^{\prime \prime}$, long $74^{\circ} 52^{\prime} 08.8^{\prime \prime}$ ), at an elevation of 9.0 feet above NGVD 29, is a fair seed line on a 2.7-foot diameter tree, 1.2 feet above the ground, 45 feet downstream from the Burlington-Bristol Bridge, and was marked with a metal USGS washer and nail. NOTE: This site is tideaffected. The high-water mark is most likely from the high-tide which actually occurred on April 2, 2005, before the peak of the flood, as recorded at the USGS continuous-record tide-gaging station 01464598 , Delaware River at Burlington, $\mathrm{NJ}$, which is 0.3 miles downstream. 


\begin{tabular}{|c|}
\hline SITE DESCRIPTION \\
\hline Site NJ 32: Delaware River at Cinnaminson, NJ \\
\hline Site Location: 0.1 mi reach in vicinity of lat $40^{\circ} 01^{\prime} 48^{\prime \prime}$, long $74^{\circ} 59^{\prime} 36^{\prime \prime}$ \\
\hline Burlington City, Burlington County, NJ \\
\hline Beverly USGS 7.5' Topographic Quadrangle \\
\hline Two high-water marks were surveyed: one debris line and one seed lines. \\
\hline $\begin{array}{l}\text { High-water mark elevations were determined using USGS reference mark } 300 \text { at lat } 40^{\circ} 01^{\prime} 47.4^{\prime \prime} \text {, } \\
\text { long } 74^{\circ} 59^{\prime} 36.4^{\prime \prime} \text { (elevation is } 7.34 \text { feet above NAVD 88). }\end{array}$ \\
\hline
\end{tabular}

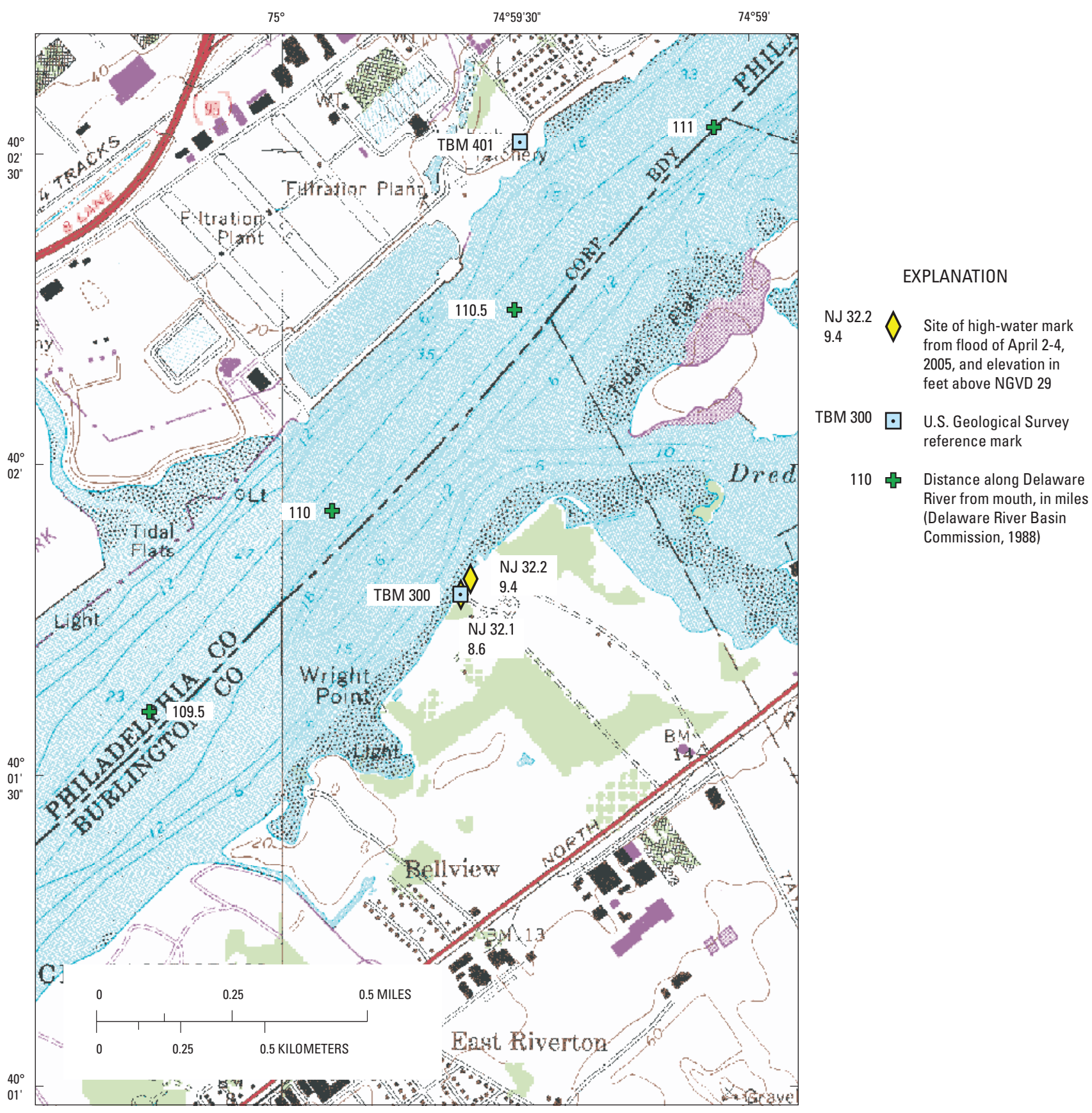

Beverly USGS 7.5' Topographic Quadrangle map showing location of site NJ 32, Delaware River at Cinnaminson, NJ. 


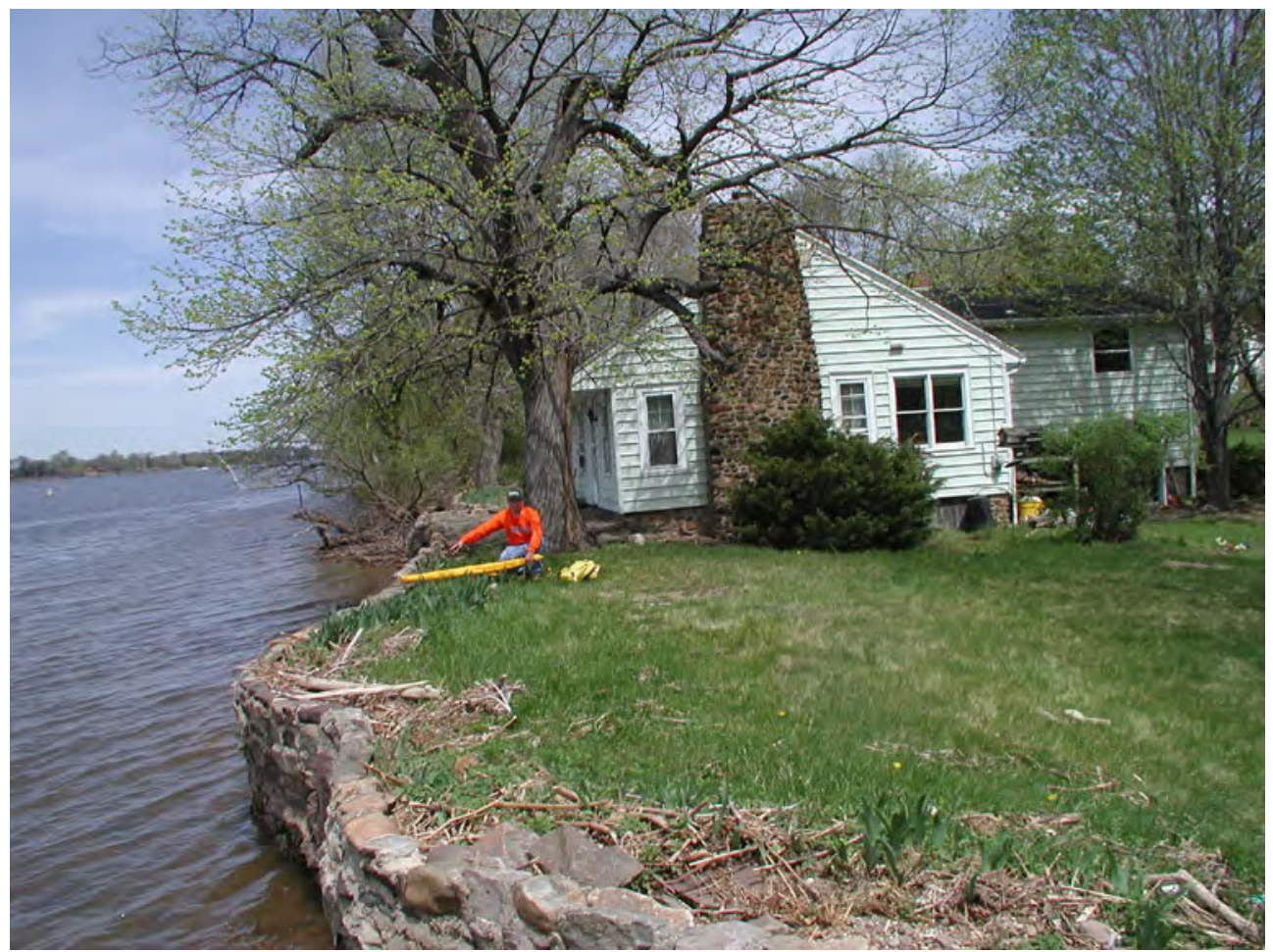

High-water mark NJ 32.1 (lat $40^{\circ} 01^{\prime} 47.8^{\prime \prime}$, long $74^{\circ} 59^{\prime} 36.2^{\prime \prime}$ ), at an elevation of 8.6 feet above NGVD 29 , is a good debris line on stone wall, next to house on Taylors Lane, and was marked with a black marker line.

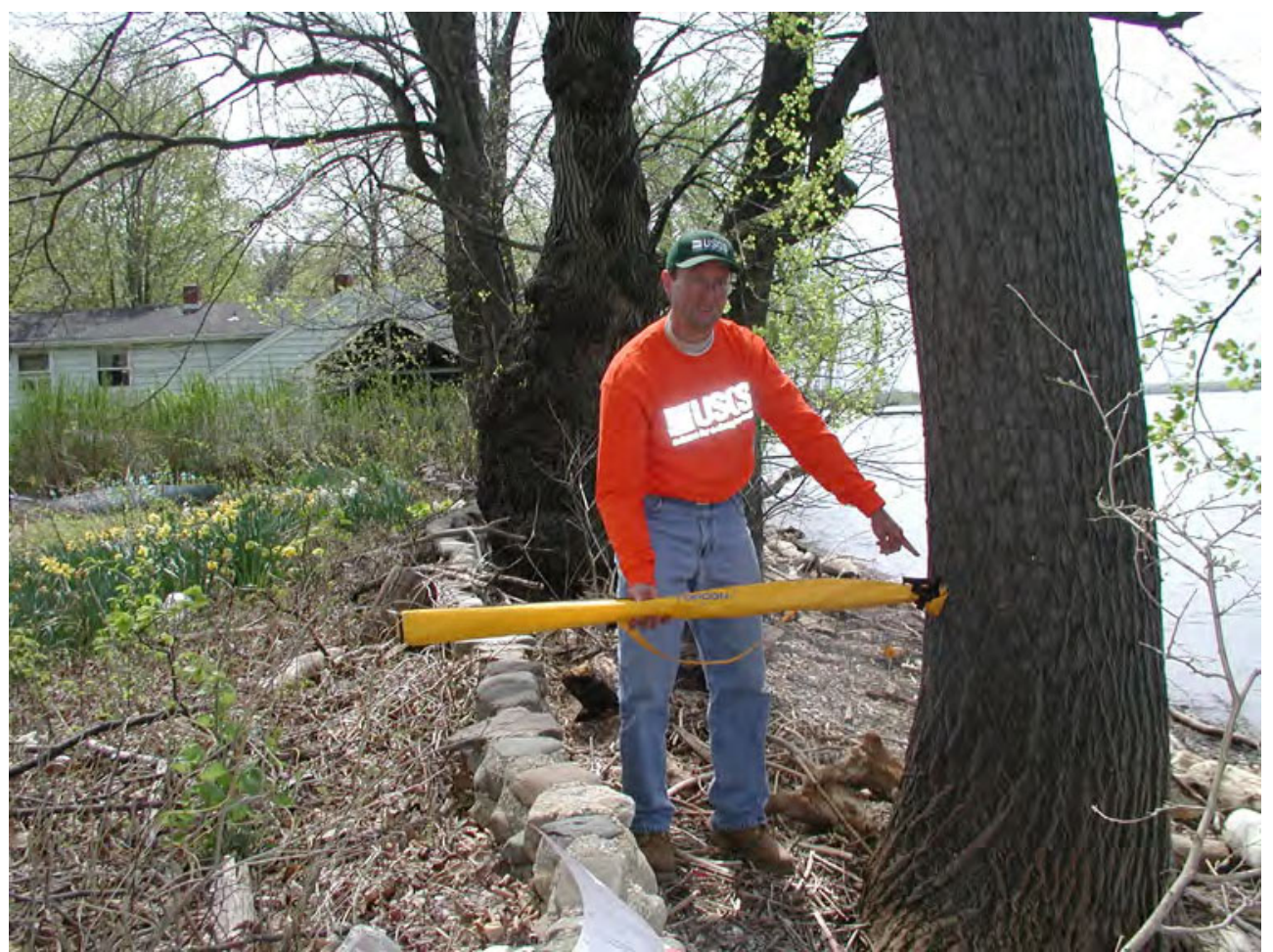

High-water mark NJ 32.2 (lat $40^{\circ} 01^{\prime} 49.3^{\prime \prime}$, long $74^{\circ} 59^{\prime} 35.1^{\prime \prime}$ ), at an elevation of 9.4 feet above NGVD 29 , is a fair seed line on a 2.9-foot diameter tree near house on Taylors Lane, and was marked with a metal USGS washer and nail. NOTE: This site is tide-affected. Marks are most likely from high tide, which occurred on April 2, 2005, before the peak of the flood. 